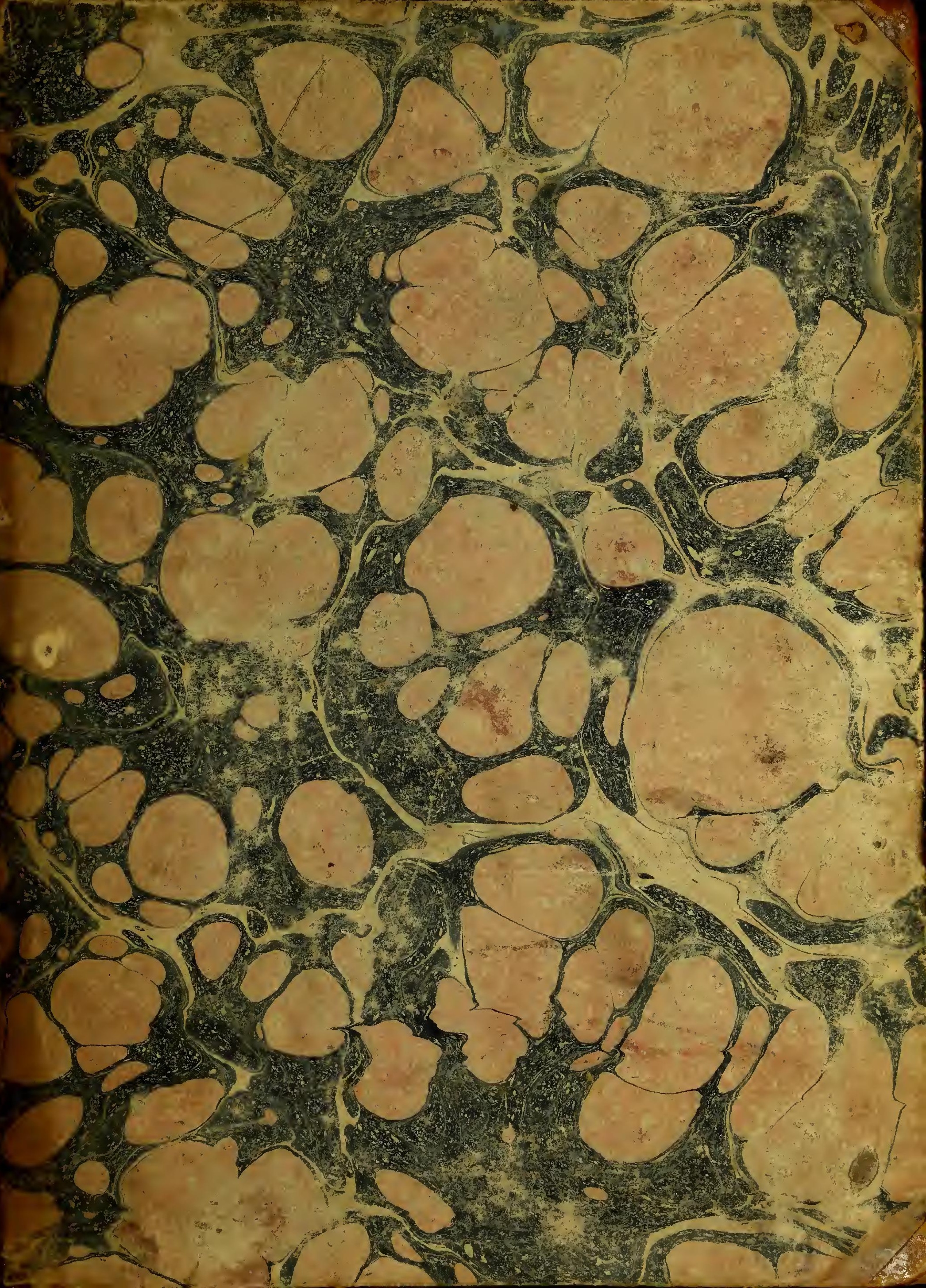




$$
\text { A.A. Ho. }
$$

$$
\text { an? }
$$

R2. 278 




\section{F U G I}

S I V E

\section{PLANTARUM FUCORUM GENERI

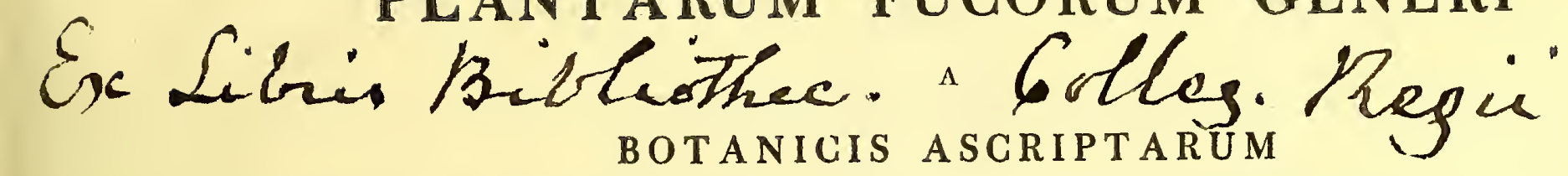

ICONES DESGRIPTIONES ET HISTORIA.

Medicor.

A UCTORE

DAWSON TURNER, M. A.

fodira.

REG. ANT. ET LINN. SOC. NECNON IMP. AC. NAT. CUR. REG. AC. HIB. ET ALIARUM SOCIETATUM SOCIO.

\section{LON DINI:}

TYPIS J. MR'CREERY.

IMPENSIS J. ET A. ARCH, IN VICO CORNHILL DICTO.

MDCCCIX.

\section{F U. C I ; \\ OB,}

GOLORED FIGURES AND DESGRIPTIONS

OF THE PLANTS

REFERRED BY BOTANISTS TO THE GENUS FUCUS.

By DAWSON TURNER, A. M. F.R.A. \& L.S.

HONORARY MEMBER OF THE IMPERIAL ACADEMY NATURE CURIOSORUM, OF THE ROYAL IRISH ACADEMY, OF THE HONORABLE DUBLIN SOCIETY, OF THE NATURAL HISTORY AND WERNERIAN SOCIETIES OF EDINBURGH, OF THE PHYSICAL SOCIETY OF GOTTINGEN, \&c. \&c.

$$
\text { VOL. II. }
$$

\section{LONDON :}

PRINTED BY J. M'CREERY, FLEET-STREET, FOR JOHN AND ARTHUR ARCH, 61, CORNHILL. 


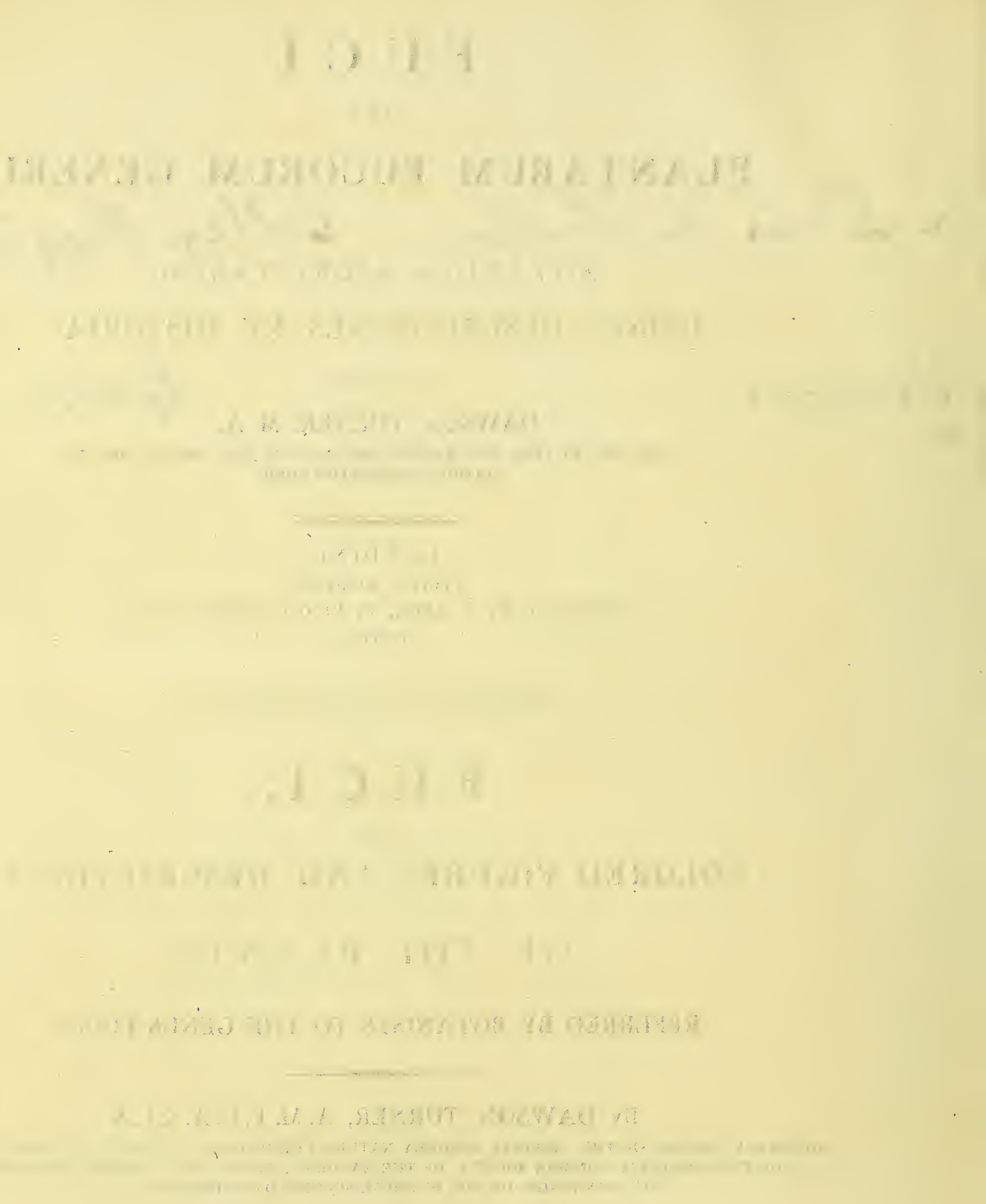

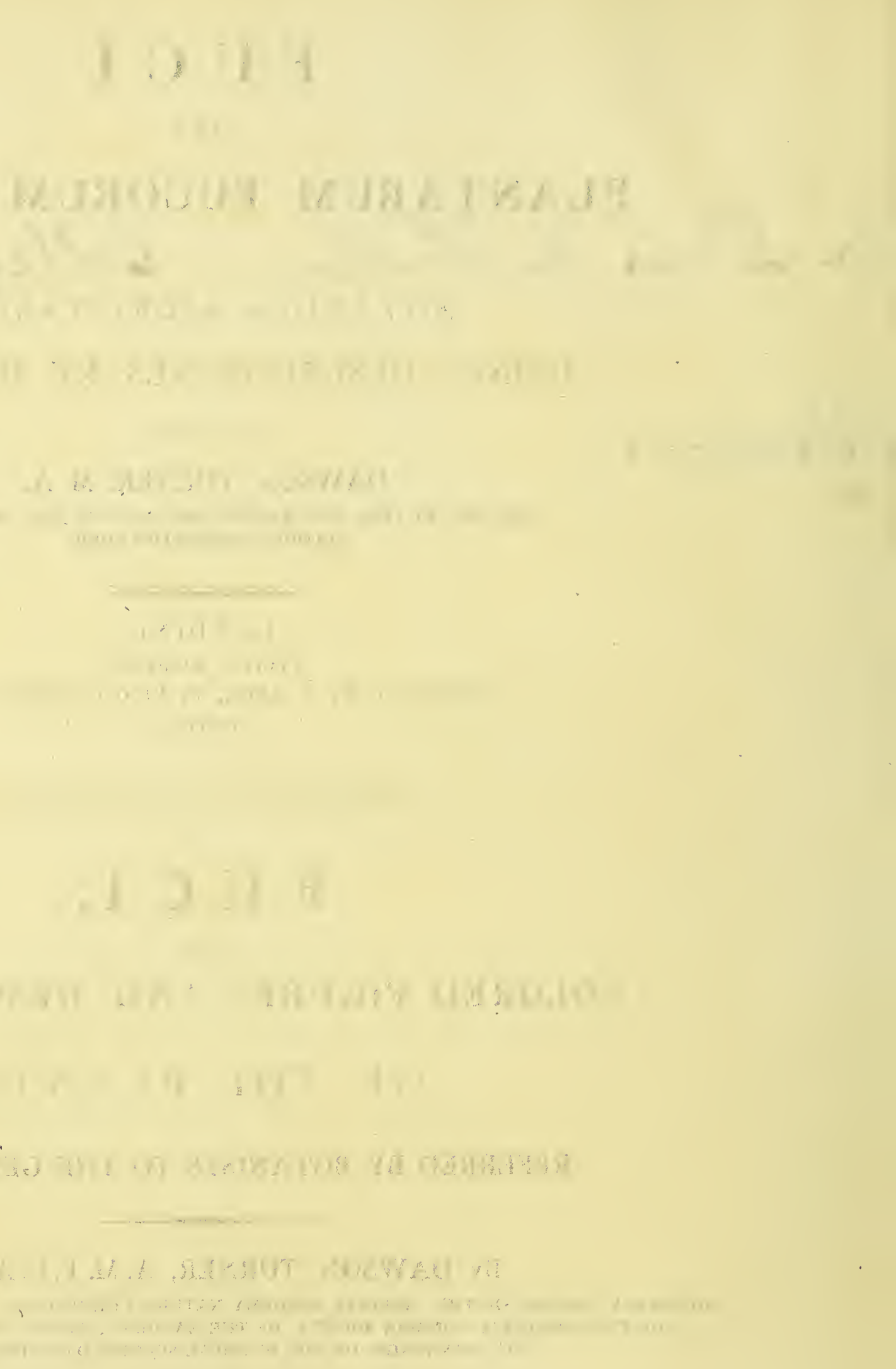

Wil

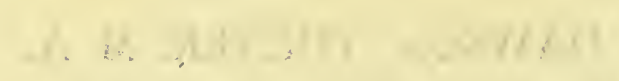

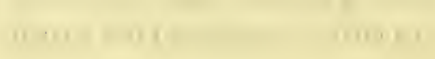

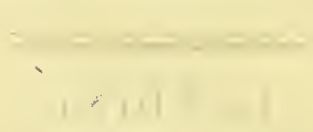

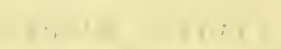

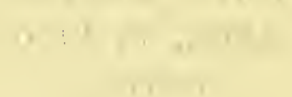

,

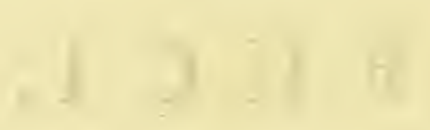

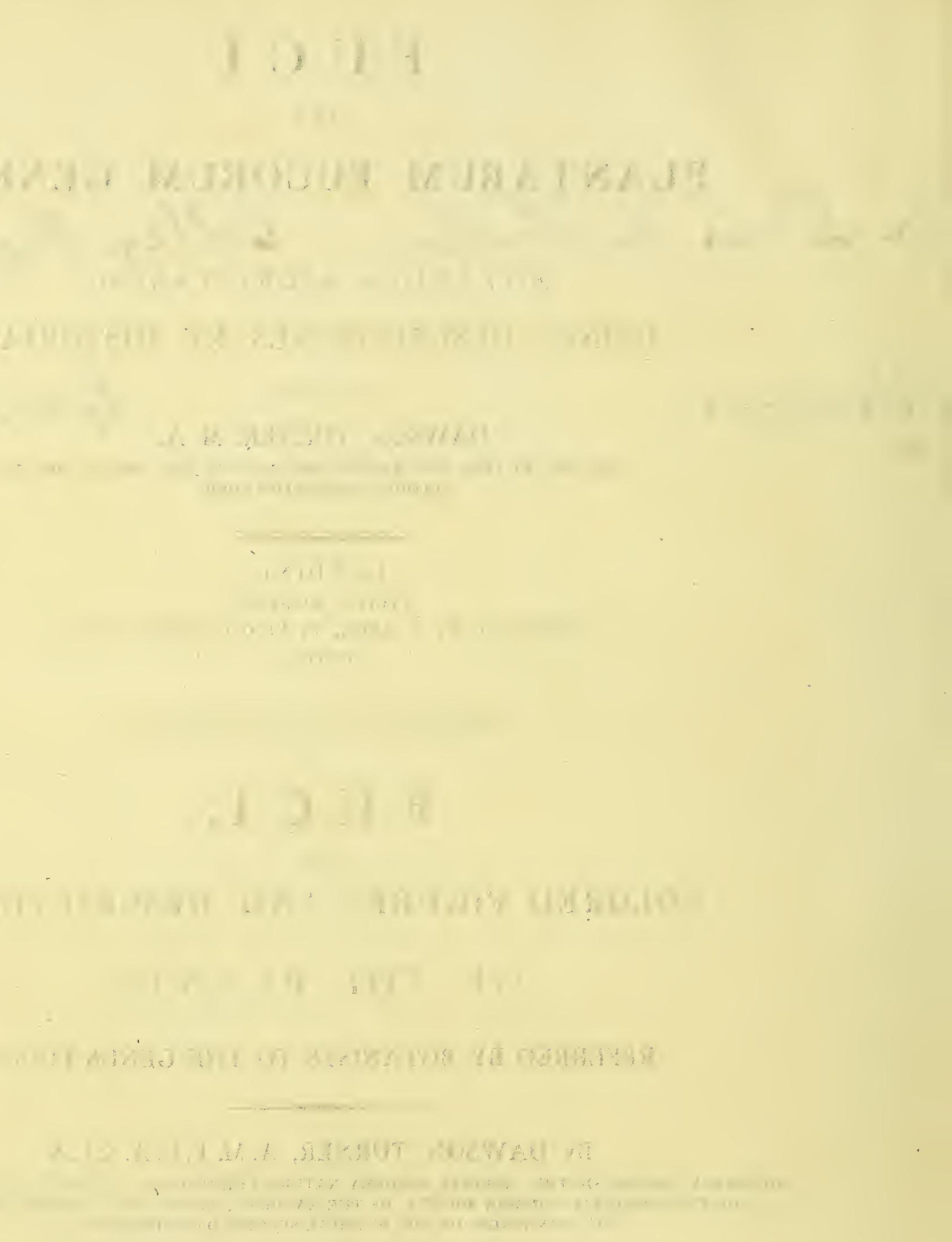

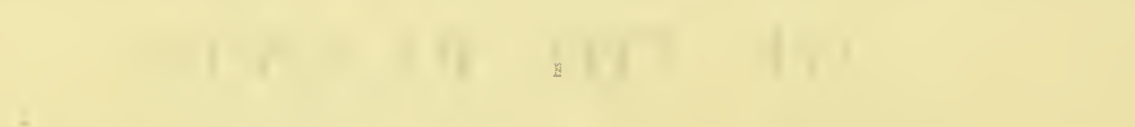

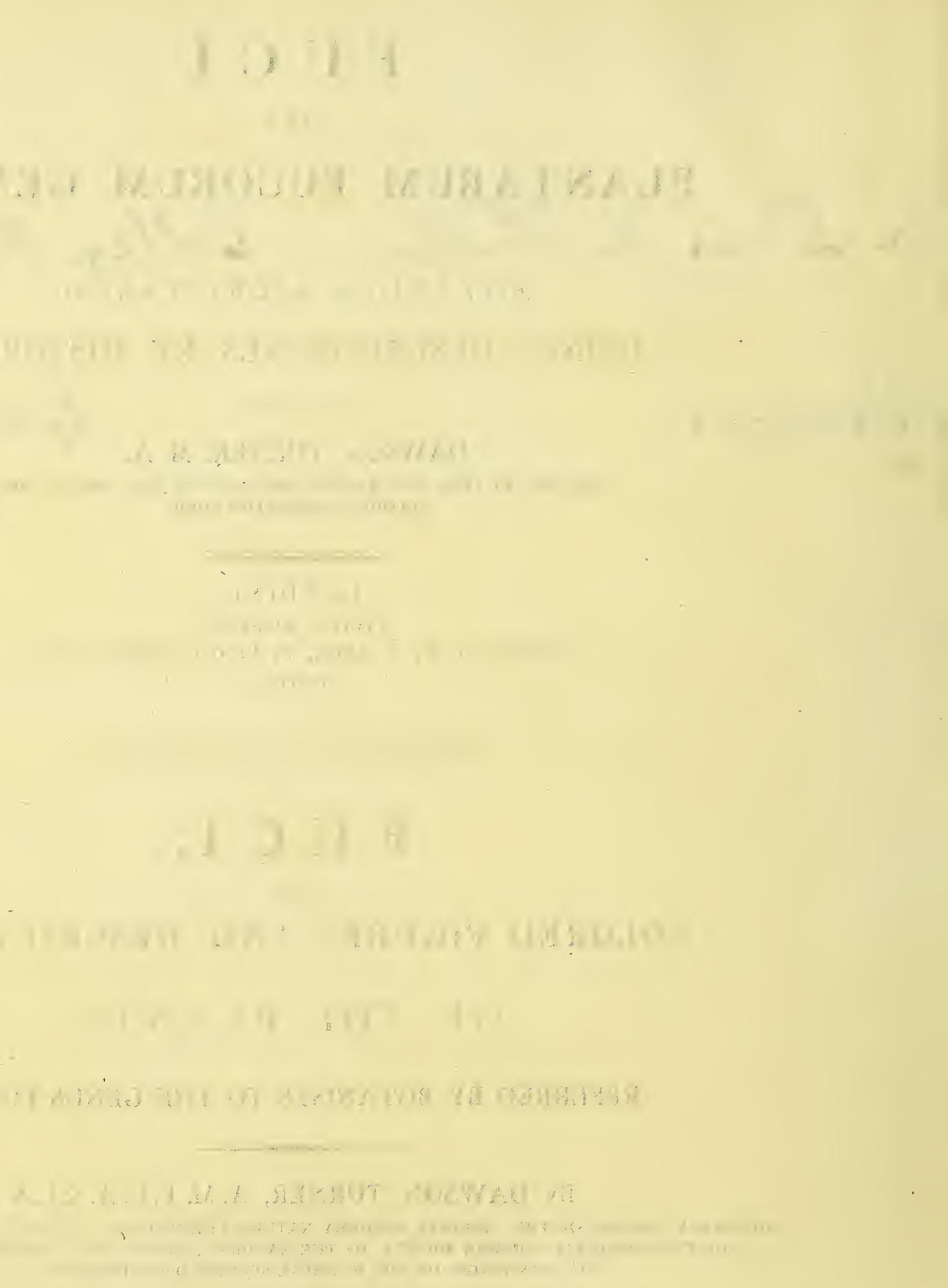

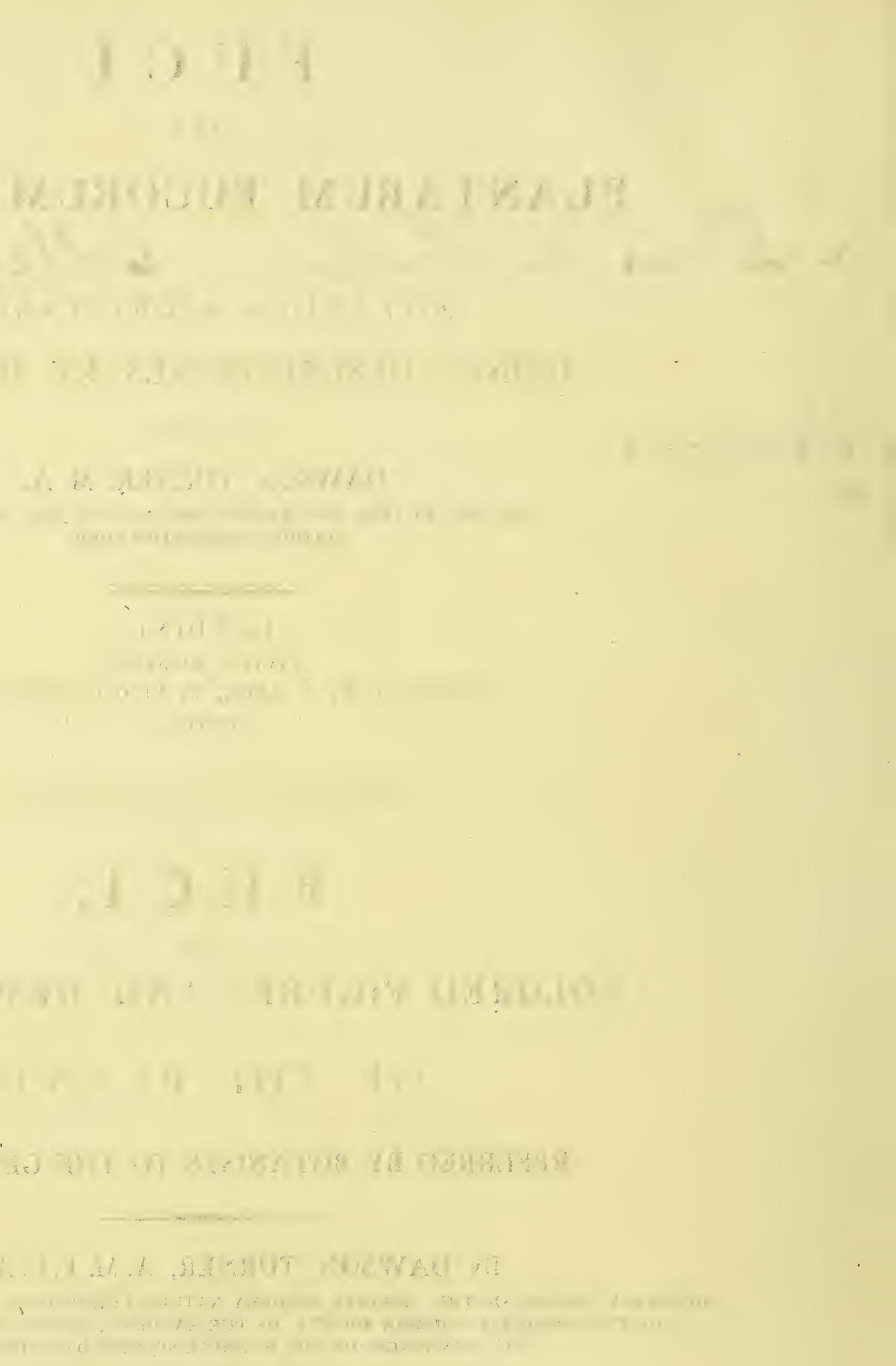

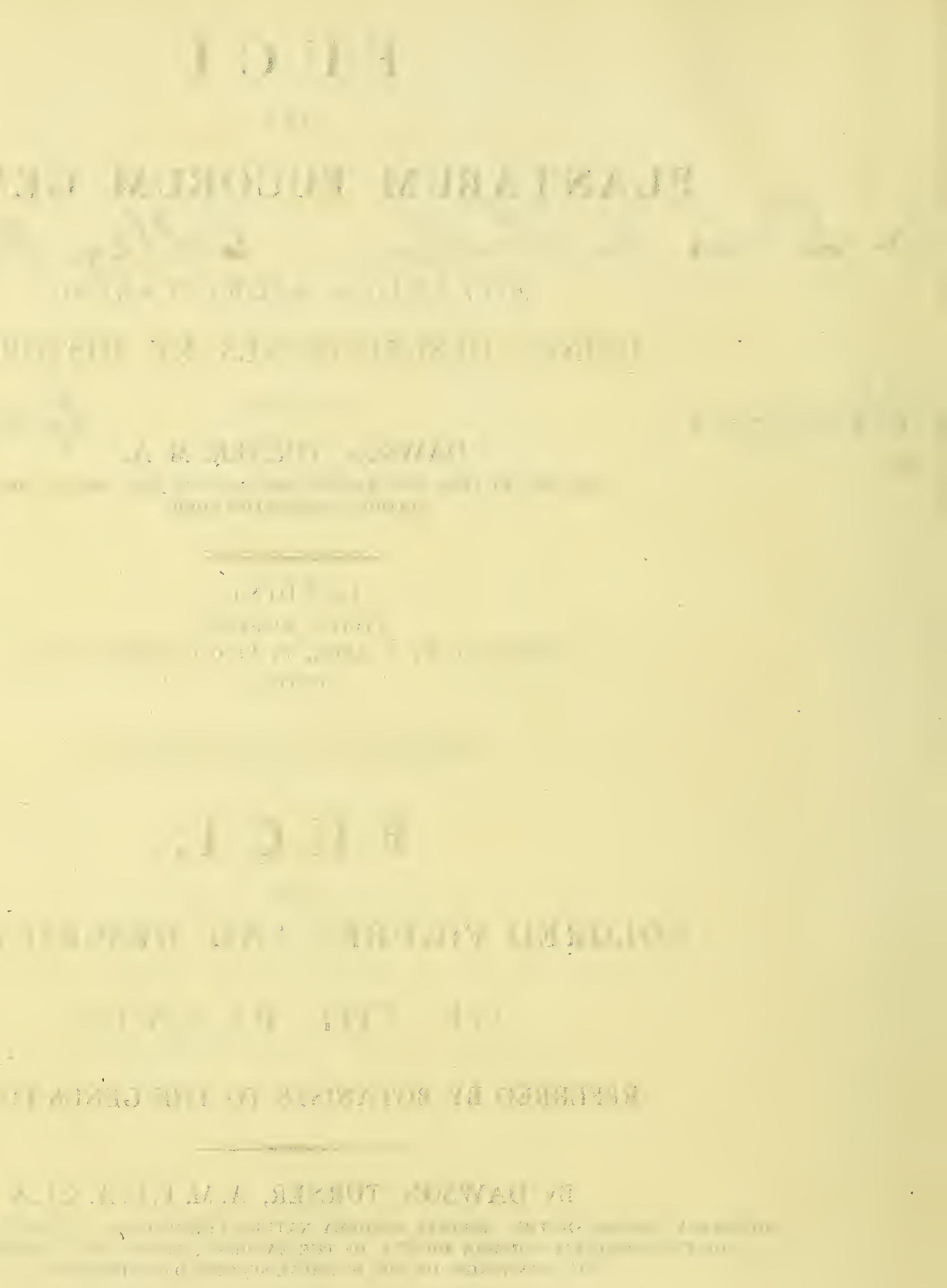

$\ldots$

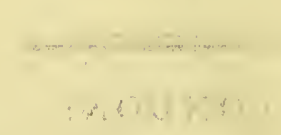

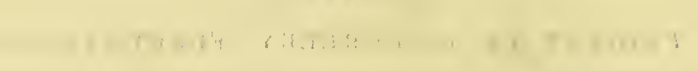

.

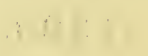




\section{HISTORIA FUGORUM.}

\section{2.-F U G U S B R O D I E I.}

frucus, stipite terete, ramoso, apice expanso in folium planum, membranaceo-cartilagineum, oblongum, simplex, bifurcumve, e margine proliferum ; tuberculis sphæricis, foliorum ad apices sessilibus.

Fucus membranifolius. Lamourovx, Diss. Fuc. p. 17. t. 21. f. 1, 2. (excl .syn.)

Habitat Bahusiæ. D. Wahlenberg.-In Mari Baltico. D. Prof. Mertens,-Apud Lossiemouth, in Scotiâ. D. Brodie.-In Galliæ oris, haud vulgaris. Lamouroux.

\section{Perennis?}

RADix callus exiguus discoideus.

Frondes ex eâdem basi plurimæ, 4- 6 pollices longæ, stipite instructæe terete, sub-palmari, pennæ passerinæ crassitie; ad mediam et ultrà longitudinem simplice, et inde vel vagè diviso, vel ramis aliquot sparsis distichis obsito, apices versus primùm compresso, mox plano, seque sensìm dilatante in folium planum elongato-cuneiforme, nervi expers, margine integerrimum, apice rotundatum, nunc indivisum, nunc bis ter dichotomum, duos tresve pollices longum, et latitudine, ubi maxima, propemodùm unguiculari, vel e marginibus, vel, ut sæepiùs accidit, ex apicibus proliferum, foliis aliis, primariorum similibus, attamen minoribus, nuic solitariis, nunc confertis, ortu ellipticis et simplicibus, adultis sub-cuneiformibus, nec rarò bifırcis, ipsisque quandoque iterùm simili ratione proliferis, semper apice rotundatis, et basi in petiolum brevissimum teretem attenuatis:-rami, quibus crescendi modus idem qui stipiti primario, non infrequentèr in longitudinem solito majorem sunt protensi, et ad apices usque (sicut in F. membranifolio accidere solet,) filiformes permanent.

Fructificatio tubercula exigua, sphærica, foliorum ad apices sessilia, hìc sólitaria, illìc duo vel tria singulis imposita, setâ brevissimâ plerumque septa, extrinsecùs pallidè rosea, et quasi spongiosa, membranâ nullâ obtecta, intùs e fibris parallelis, tenuissimis, dichotomis, articulatis, densè compactis, seminibus enormitèr subrotundis immixtis, constantia.

Co Lor intensè sanguineus, fusco perfusus, in foliis junioribus dilutior et diaphanus; in aquâ dulci servata aut soli objecta citò in sordidè luteo-virescentem et demùn in albicantem transit.

SuBSTANTIA in caule cartilaginea et tenax, in foliis cartilagineo-membranacea et tennis.

Oss. Exsiccata chartæ nequaquàm adhæret.

Cùm multa in se dulcissima habeat scientiæ naturalis cnltura, quæ non modo, quod de humanitatis artibus splendidè prædicat Cicero, adolescentiam alit, senectutem oblectat, secundas res ornat, adversis perfugium ac solatium prebet, verùm etian nos ad Dei Optimi Maximi summam sapientiam summamque bonitatem admirandan ducit, hortatur, suadet, cogit, tùm hoc quoque menti humanæ gratissimum efficit, quod, invidiâ vacua, viros iisdem studiis conjunctos anicitia conjungat, eorumque de se bene meritorum nomina plantis affigi sinendo, quasi in naturæ templum receptos ascribit. Inter dignissimos qui sic nominentur micat nomen Jacobi Brodie armig., de Brodie in sicotiâ, scientiarum omnium, et præsertìn Botanicæ, cultor indefessus, patronusque liberalis. Hic primus stirpem in hâc adumbratam tabulâ Britanniæe ad oras legit, plantamque, fructificatione detectâ, novam esse agnovit, quam olìm sterilem pro $F$. membranifolii varietate ad me miserant Mertensius Wahlenbergiusque. Sub eodem etiam nomine depinxit Lamourouxius, cujus icon nullam dubitationis ansam prabet, descriptio licet, præsertìm quod ad fructum attinet, partìm ex vero $F$. membranifolio deprompta utrumque commixtum prodat. Omme illud, quicquid hic de synonymiâ tradidit, est eâdem de causâ excludendum. In Fucorum systemate debetur $F$. Brodicai locus $F$. membranifolio proximus, et est stirps inter hunc et $F$. rubentem intermedia, sic duós a se invicem diversissimos Fucos quodammodò connectens. Consentit cum priore formâ habituque generali, cım posteriore substantiâ crescendique modo prolifero, qui rarissimè deest; ab utroque recedit colore et fructificatione, nec folia prolifera eâdem omnind ratione quâ ea $F$. rubentis oriuntur, quoniam semper ipsis frondis marginibus et nunquam superficiei imnascuntur,

a. F. Brodiai, magn. nat.

b. froudis apex, magn. auct. - - - $\quad 6$ - 6

c. tuberculum, seorsìm - $\quad$ - $\quad$ - $\quad$ - 4 .

d. tuberculum longitudinalitèr dissectum - - 3.

e. filamenta

f. semina

-1 .

-. 1. 


\title{
HISTORY OF THE FUGI.
}

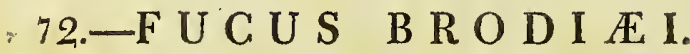

Fucus Brodiai, stipes cylindrical, branched, its apex expanded into a leaf between membranaceous and cartilaginous, oblong, simple, or forked, flat, nerveless, proliferous from its margin; tubercles spherical, sessile upon the apices of the leaves.

Fucus membranifolius. Lamouroux, Diss. Fuc. p. 17. t. 21. f. 1, 2. (excl. syn.)

At Bahus, in Sweden. Dr. Wahlenberg.-In the Baltic. Professor Mertens.-At Lossiemouth, in .Scotland. $M r$. Brodie.-On the shores of France, not common. Lamouroux.

\section{Perennial?}

Root, a small, expanded, callous disk.

FRONDs, numerous from the same base, from four to six inches long, furnished with a stipes about three inches in length, as thick as a sparrow's quill, and simple for more than half its height, where it is irregularly divided, or beset with a few scattered distichous branches, as it approaches its apices, it becomes at first compressed, and afterwards flat, when it gradually dilates into a flat leaf, of an elongated cuneiform shape, destitute of midrib and veins, entire at its margin, and rounded at its apex, undivided in some instances, in others twice or thrice dichotomous, about two or tliree inches long, and in its greatest width nearly equal to half an inch, proliferous, either from their margins, or, as is more commonly the case, from their apices, with other leaves similar to the primary ones, except in their smaller size, some solitary, others clustered, in their earliest stage elliptical and simple, when more advanced approaching to cuneiform, and not uncommonly forked, sometimes again proliferous in the same manner, their apices always rounded, their bases attenuated into an extremely short cylindrical petiolus:-it frequently happens that the branches, the mode of growth of which is the same as that of the primary stem, are extended to a greater leugth than usual, and, as is often the case with $F$.membranifolius, preserve their filiform shape to their very extremities.

Fructification, small, spherical tubercles, sessile upon the ends of the leaves, either solitary, or growing two or three together, generally bordered by an extremely sliort seta, externally pale-pink, with a spongy appearance, and not inclosed in any meinbrane, internally conıposed of very thin, dichotomous, jointed, parallel fibres, closely matted together, and mixed with irregularly roundish seeds.

Color, deep blood-red, tinged with brown, paler and diaphanous in the younger leaves; if kept in fresh water, or exposed to the sun, soon turning to a dirty yellowish green, and at last to whitish. thin.

Substance, cartilaginous and tough in the stem; in the leaves, between cartilaginous and membranaceous, and

OBs. It does not adhere in the least to paper after it is dried.

The study of natural history, independently of the advantages so nobly ascribed by Cicero to polite literature in general, that it nourishes our youth, deliglits our age, is an ornament in prosperity, and a comfort in adversity, may justly boast a still superior object, in leading, and, indeed, in forcing man to the admiration of the wisdom, and the goodness of his divine Creator, in the contemplation of the works of his almighty hand. In addition to this, it mixes itself also with the daily occurrences of social life, and gratifies the best feelings of our nature, by uniting in the bonds of friendship those whose pursuits were already the same; while, by permiting the names of its votaries to be affixed to plants, it records their zeal in its service, and touches one of the most powerful springs of human action. Among those who eminently deserve to be thus mentioned, stands forward the name of James Brodie, Esq., of Brodie, in Scotland, a man at once zealous in the pursuit, and liberal in the patronage of universal science, and especially of the Botany of Britain. Our native Flora is indebted to him for the discovery of several of her more hidden treasures, and among others, of the plant now before us, which had been gathered many years ago on the shores of Denmark and Swedeil, by Professor Mertens and Dr. Wahlenberg, but, till he fortunately discovered the fructification, and proved it to be an entirely new species, had always beell regarded as a variety of $\boldsymbol{F}$. membranifolius. It is even engraved under this title by Lamouroux, whose figure is such as to allow of no room for doubt, though parts of his description, and particularly sucl as refer to the fructification, are evidently taken from the true plant of that name. In an arrangement of the family $F$. Brodice $i$ must necessarily be placed next to that Fucus, between which and $F$. rubens it is nearly intermediate, thus tending to connect two species, which are by nature widely separated from each other. It agrees with the former in its shape and general habit, but with the latter in its substance and proliferous mode of growtlı: in point of color and fructification it differs from both, nor do its proliferous leaves originate in precisely the same manner as those of $F$. rubens, since they constantly arise from the very margin of the frond, and never from any part of its surface.

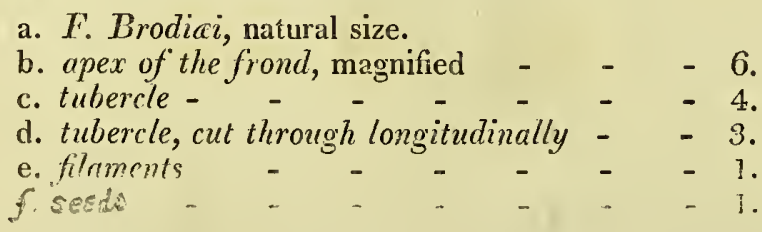



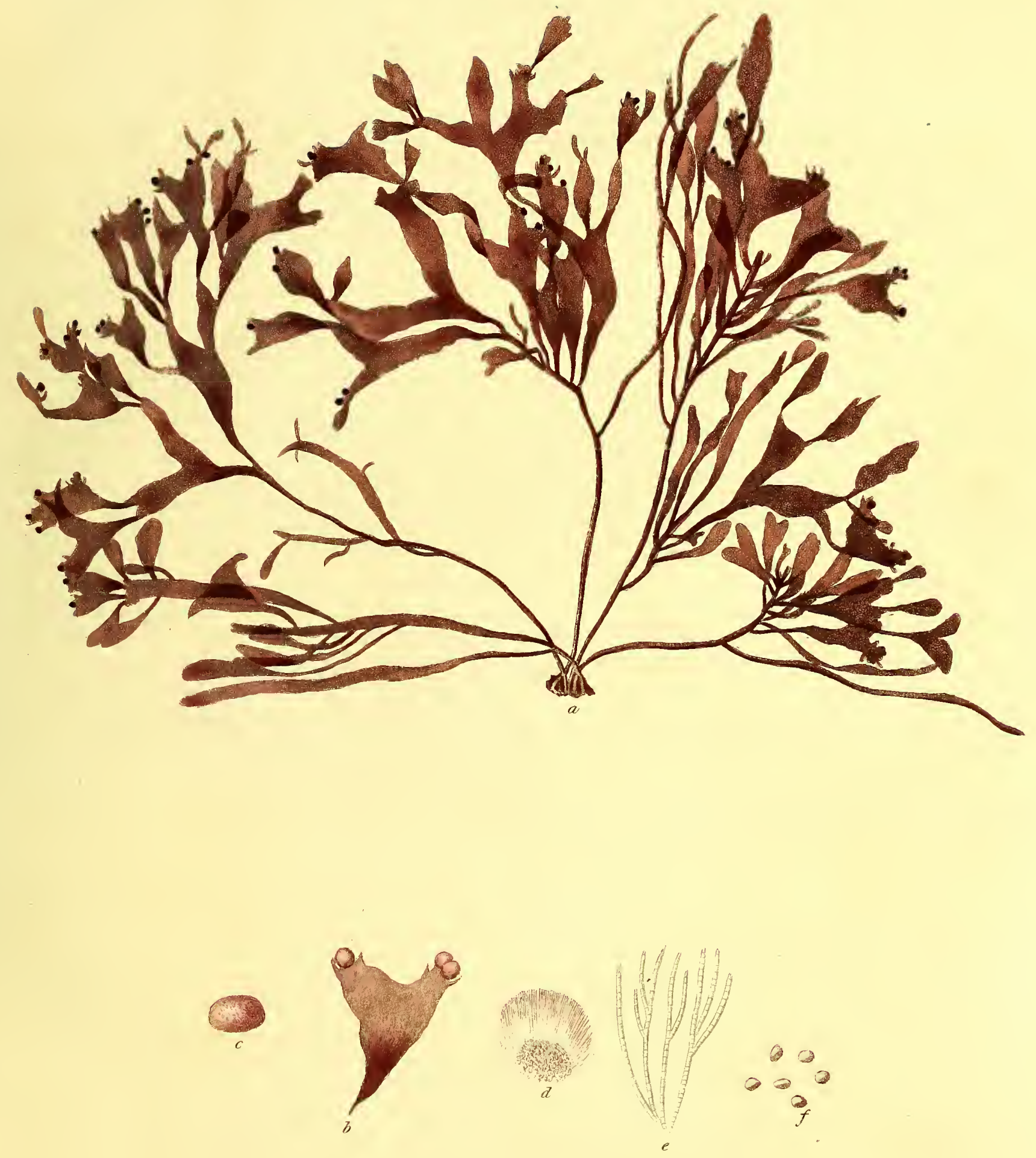

- Tucus Prodicei 


\section{Digitized by the Internet Archive in 2015}


Fucus, stipite terete, simpliciusculo, apice expanso in folium membranaceum, sub-cuneiforme, planum, enerve, palmatum; tuberculis hemisphæricis, in foliis sessilibus.

Fucus Palmetta. Syn. Fuc. I. p. 21. Ner. Brit. p. 102. t. 16. Eng. Bot. XVI. t. 1120. Esper, Ic. Fuc. I. p. 84. t. 40. (excl. syn. omn.)

F. Palmetta. var. B. La mounoux, Diss. Fuc. p. 12. t. 19. f. 3, 4.

ß. bifidus; stipite in folium sub-cuneiforme, plerumque simplex, vel bifidum, expanso.

F. bifidus. Fl. Ang. p. 581 .

\%. crassiusculus; stipite sub-nullo, segmentis linearibus, vagè divisis, apicibus multifidis acutiusculis.

8. linearis; stipite sub-nullo; segmentis elongatis, linearibus, simplicibus, vel bifurcis, apicibus rotundatis.

F. Palmetta. Lamouroux, Diss. Fuc. p. 11. t. 19. f. 1, 2.

Hавітат $\alpha$ in Cornubiæ littoribus. D. Stackhouse.-Apud Bantry Bay, F. digitati stipitibus semper insidens. $D^{n a}$ Hutchins. $-\beta$ in littore Hantoniensi, in saxis et rupibus submarinis, Hudson.- $\gamma$ in rupibus submarinis prope Plymoutlı. Da Hill. $-\delta$ in littore Sussexiano. D. Borrer.--Inter rejectamenta maris apud Yarmouth.

Annua? Jul.-Sept.

RADIX callus majusculus, expansus, discoideus, dilutè roseus, fibris aliquot repentibus instructus.

FrONDES ex eâdem basi plurimæ, (sexaginta vidi) longitudine bi- tri- pollicari, singulæ stipite assurgentes unico, plerumque indiviso, rariùs bifido, nunc sesquipollicem, nunc vix unguem alto, basi fili emporetici minoris crassitie, et terete, inde sensim compresso et dilatato, et demùm plano, apice expanso in folium planum, nervi venarumque expers, ambitu enormitèr cuneiforme, pollicem circitèr longum, latitudinisque, ubi maxima, ferè ejusdem, in his simpliciusculum, et margine tantummodo incisum, ut quasi ciliatum appareat, in illis multifido-palmatum bifurcumve, segmentis aut elongatis, linearibus, atque simplicibus, aut dilatatis, brevibus, atque iterum simili modo divisis; margines ubique integerrimi, apices ut plurimum rotundati, sæpe tamen acutiusculi aliquot in eâdem occurrunt fronde.

Fructificatio * tubercula hemisphærica, frondis nunc disco, nunc margini, præestim apices versus, imposita, sessilia, Brassica Rapa seminum magnitudine, ejusdem quo frons coloris, eâdemque epidermide obtecta, intùs seminum minutissimorum enormitèr sphæricorum intensè rubrorum congeriem foventia, sed fibris nullis, quantum vidi, immixtis.

CoLOR lætè ruber, sub-diaphanus, quandoque intensior et sanguineo tinctus; marcescentis vel soli objecta sordidè lutescenti-virescens.

SuBstantia in caule tenera et cartilaginea, in foliis membranacea et tenuis.

Var. $\beta$ in eo modd $\mathrm{ab}$ a discrepat, quòd sit folium vel indivisum vel bifidum, figuræ cuneiformis ad hemisphæricam accedentis; in ætate juniore folium oblongum simplex.

$\gamma$ est varietas perquàm singularis; stipite nullo, substantiâ cartilagineâ, crassiusculâ, ut quasdam $F$. crispi varietates propemodùm æequet, colore in exsiccatấ livido-purpurascente, fronde lineari, vagè divisâ, apicibus multifidis, segmentis angustatis acutiusculis, marginibus hic illic proliferis.

Var. $\delta$, inter $F$. Palmettam et $F$. rubentem media, radice gaudet latiùs quàm in reliquis repente, stipite vel brevissimo, vel nullo, substantiâ membranaceâ tenui, attamen tenace, et ad cartilagineam accedente, colore dillutè rubente, diaphano, segmentis linearibus, elongatis, bis ter dichotomis, apicibus indivisis rotundatis.

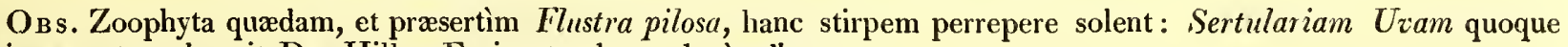
ei innascentem detexit Dna Hill.-_Exsiccata chartæ laxè adhæret.

Cùm nihil scientiæ Botanicæ processui magis obstet quàm nominum plantis inditorum quotidiana mutatio, talisque sit synonymorum inde exorta multiplicatio et confusio, ut studium in se suavissimum maximèque simplex verborum tenebris nunc obumbretur et difficillimum reddatur, summâ omnes ope niti decet, ne hæc innovandi prurigo latiùs quàm quod vitari nequit diffundatur. Hanc igitur ob causam non modò nomina primitùs imposita umninò servanda existimo, excepto si sint in se vitiosa, aut aliquid aliud repugnet, verùm etiam ea nolo rejicere, quæ, olim perperàm tributa, longo nunc inveteravere usu, et inter botanicos tam universè recipiuntur ut minus sit confusionis ex retinendis quàm ex delendis timendum. De Fuco hìc depicto ita se res lıabet; F. Palmettce enim nomen vix obtinuisset, nisi, ut jam sub $F$. sinuoso memoratur, mirè hallucinatus sit Esperus, quoniam satis, ut mihi videtur, liquet non esse stirpem quam sic nuncupare in animo habuit Ginelinus. Alterâ ex parte testantur exemplaria ab ipso Hudsono ad virum nob. T. Frankland missa, quorum unum hæc tabula ad lit. $g$, delineatum exhibet, esse revera ejus $F$. bifidum; unde, si nomina rectè disponere, et suum cuique restituere velimus, necesse erit ut $F$. noster Palmetta $F$. bifidus appellaretur, ut $F$. membranifolius in posterum $F$. Palmetta salutaretur, et ut pro Fuco qui nunc omnibus $F$. bifidus audit novus quæreretur titulus. Tali autem tantæque mutationi quis non adversaretur? Quis non potiùs sineret res vadere ut vadunt? Ipse saltèm ita censeo, et ita ergò relinquo. Pauci modò sunt inter Fucos Britannicos minùs noti quàm $F$. Palmetta, cùm quia est nostrorum littorum infrequens incola, tùm, quod fortasse magis valet, quia $F$. crispo et F. membranifolio arctissimè est affinis, et horum crescendi modus tam variabilis, ut limites inter sese et congeneres

agerrimè

* Hæc matura disrumpunt membranamque supcriorem perdunt, in quo statu Parmeliarum scutellas haud malè referunt, et semina quædam basi adhærentia plerumque sunt observanda. 
ægerrimè stabiliantur. F. rubenti quoque est propinquus, per var. $\delta$ cum eo connexus, quæ aded usque inter utrumque ambigit, ut diu dubitaverim annon sit rectiùs ad illum referenda. Fructificatio notam speciei certissimam præbet, quæ ab his omnibus distinguit; sed, præter hanc, inest in substantiâ tenui et in foliis palmatim fissis peculiare quiddam, per quod vel sterilis satis facilè dignoscitur.

a. et b. F. Palmetta, magn. nat.

c. frondis pars cum fructu, magn. auct. - $\quad-6$.

d. tuberculum - $\quad-\quad-\quad-\quad-5$.

e. idem longitudinalitèr dissectum - $\quad-\quad-3$.

f. semina - - - - - - 1 .

g. var. $\beta$, magn. nat.

h. var. $\gamma$.

\section{3.-F U G US PA L M E T TA.}

Fucus Palmetta, stipes cylindrical, mostly simple, its apex expanded into a membranaceous, flat, nerveless, subcuneiform, palmate leaf; tubercles hemispherical, sessile upon the leaves.

Fucus Palmetta. Syn. Fuc. I. p. 21. Ner. Brit. p. 102. t. 16. Eng. Bot. XVI. t. 1120. EsPer, Ic. Fuc. I. p. 84. t. 40. (excl. syn. omn.)

F. Palmetta, var. B. Lamouroux, Diss. Fuc. p. 12. t. 19. f. 3, 4.

B. bifidus; stem expanded into a sub-cuneiform leaf, generally simple, or only bifid. F. bifidus. Fl. Ang. p. 581 .

\%. crassiusculus; stem, scarcely any; frond linear, irregularly divided, with multifid, sharpish apices.

8. linearis; stem, scarcely any; frond linear, with long, simple, or forked segments, and rounded apices. F. Palmetta. Lamouroux, Diss. Fuc. p. 11. t. 19. f. 1, 2.

On the shores of Cornwall. Mr. Stackhouse.-At Bantry Bay, always found growing upon the stems of $F$. digitatus. Miss Hutchins. $-\beta$ on the stones and submersed rocks of the Hampshire coast. Hudson.- $\gamma$ on rocks near Plymouth. Miss Hill. $-\delta$ on the Sussex Coast. Mr. Borrer.-Among the rejectamenta of the sea at Yarmouth.

\section{Annual? July-September.}

Root, a largish, expanded, callous disk, of a pale pink color, provided with a few creeping fibres.

FRONDS, numerous from the same base (I have counted sixty) two or three inclies long, each rising with a single stem, generally undivided, sometimes bifid, varying in height from an inch and half to scarcely half an inch, cylindrical at its base, and about the thickness of small twine, thence gradually becoming compressed and dilated, expanding at its apex into a flat leaf, destitute of veins or midrib, of an irregularly cuneiform outline, about an inch in length, and the same in width at its widest part, in some specimens nearly simple, and only gashed at its margin, in others forked, or multifid in a palmate manner, with segments either elongated, linear, and simple, or short, dilated, and again divided in a similar manner; the margins are every where enture, the apices in general rounded, but occasionally some sharpish ones are observable.

Fructification, * hemispherical tubercles, placed both upon the disk and margin of the frond, especially towards the extremities, sessile, of the size of turnip-seed, of the same color as the frond, and covered with the same epidermis, containing a mass of extremely minute, irregularly roundish, deep-red seeds, but unnixed, as far as I have seen, with any fibres.

CoLOR, a bright purplish red, almost transparent, sometimes more dark, and almost crimson ; turning in decay, or from exposure to the sun, to a dirty yellowish green.

SUBSTANCE, tender and cartilaginous in the stem, membranaceous and thin in the leaves.

$\beta$ differs from $\alpha$ only in its leaf being either undivided or merely two-lobed, of a cuneiform figure, approaching to hemisplerical : in its younger state it is oblong and simple.

- These in an advanced state burst, and lose their upper half, so as to take, in some measure, the appearance of the shields of the Parmelia, at the bottom of which the seeds may be observed. 


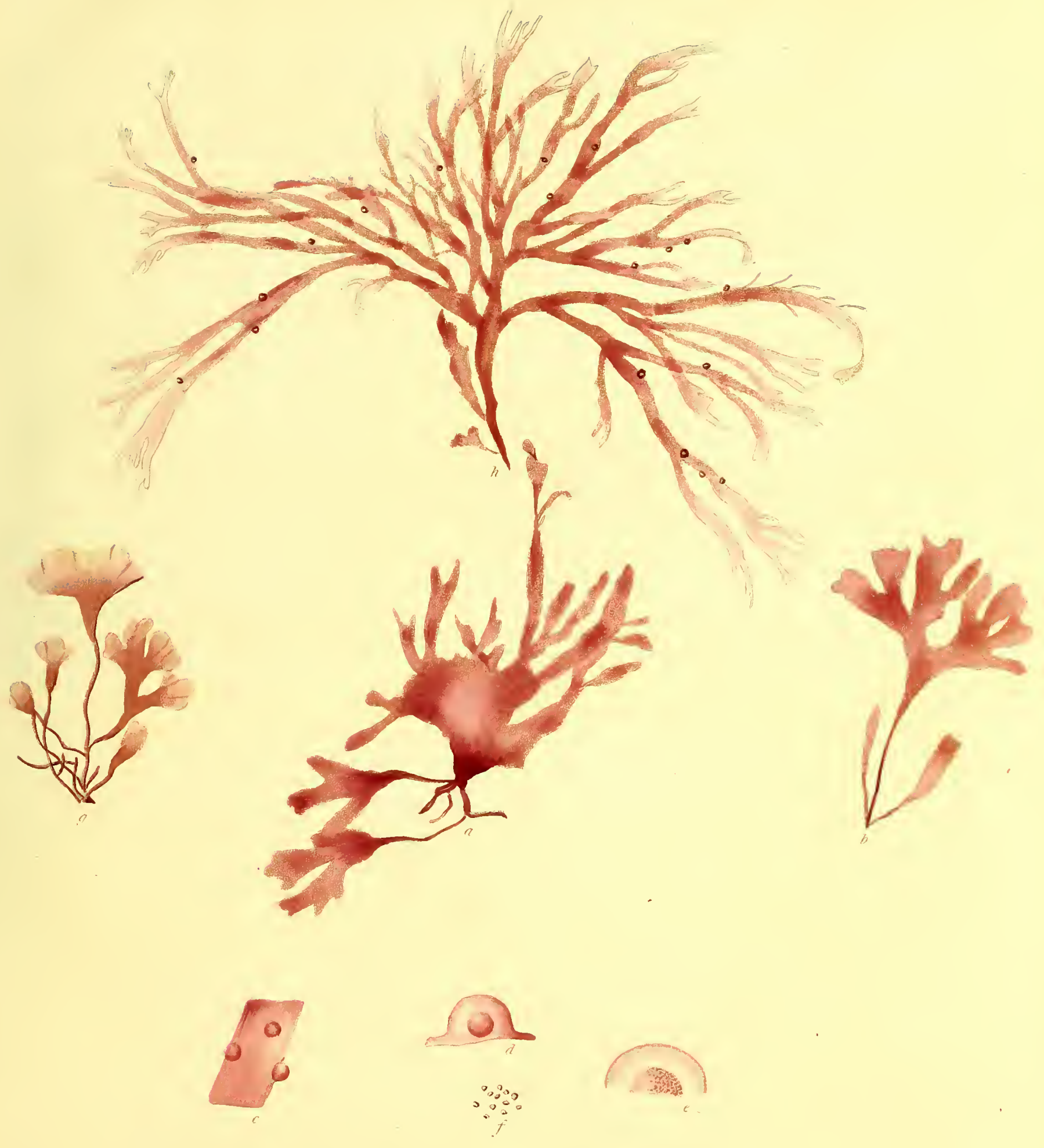

- Hucies. Patrectlo. 

$y$ is a very singular variety; it has no stipes; its substance is cartilaginous and thickish, so as to be almost equal to that of some of the varieties of $F$. crispus; its color, in a dried state, is a livid purple; its frond is linear, irregularly divided, the apices being multifid with narrow sharpish segments; the margins are here and there proliferous.

$\delta$ is intermediate between $F$. Palmetta and F. rubens; its root creeps more remarkably than that of the other varieties; it has either no stipes, or only a very short one; its substance is membranaceous and thin, but tough and approaching to cartilaginous; its color a pale transparent red; its segments linear, long, twice or thrice dichotomous, with undivided rounded apices.

Овл. Several species of Zoophytes, and particularly Flustra pilosa, frequently infest this Fucus: Miss Hill has also found the scarce Sertularia Uva creeping over it.-In a dried state it adheres, but loosely, to paper.

Since there is no more effectual obstacle to the progress of the study of Natural History than that constant and arbitrary changing of the names affixed to plants, which has introduced such a confusion and multiplication of synonyms, as tends to render most obscure and intricate a science in itself eminently attractive and simple, it appears to me to be highly incumbent upon every Botanist to strive, as far as lies in his power, to check this spreading rage for innovation. I would upon this account not only wish to see retained all the names at present in use, excepting those to which there exists any important objection, but I even feel reluctant to consent to the alteration of such others, as, though primarily founded on error, are now so generally received among Botanists, that the changing of them would be the means of causing fresh perplexity. The Fucus here figured stands in this predicament: it originally obtained the name of $\boldsymbol{F}$. Palmetta from a very extraordinary, and indeed almost unaccountable error of Professor Esper's, already noticed under $F$. sinuosus, and it admits, I think, of little doubt, that it is not the plant which was intended to be so called by Gmelin. On the other hand, it seems still more clear, from original specimens sent by Hudson to Sir Thomas Frankland, one of which is, by his kindness, represented at the letter $g$, that it is the real $F$. bifidus of that author; so that, to set the names right upon the score of priority, the only just criterion, it would be necessary that the appellation of $F$. bifidus should be transferred to the plant before us, that $F$.membranifolius should be called F.Palmetta, and that the species at present universally known under the denomination of $F$. bifidus should be distinguished in future by a fresh title. This, however, would be an alteration so violent, that I apprehend but few, if any, Naturalists would be disposed to assent to it, and $I$ therefore consider it best to leave the matter in its present state. F. Palmetta is one of the least understood among the British Fuci ; a circumstance arising, probably, not so much from its unfrequent occurrence, as from its close affinity to $F$.crispus and $F$. membranifolius, two plants so extremely variable, that it is in the highest degree difficult to define their limits. It is also, by means of its var $\delta$, very nearly allied to $F$. rubens, indeed so much so, that I had long been in the habit of regarding this appearance as belonging to that species. The most certain mark, by which to distinguish it from all these, lies in the fructification, independently of which, the thin substance and palmate mode of growth are so peculiar, that it is in general not difficult to know it even in a barren state.

a. \& b. F. Palmetta, natural size.

c. part of frond, with fructification, magnified - 6 .

d. tubercle - - - - - - - 5.

e. ditto, cut through longitudinally - - $\quad 3$.

f. seeds - - - - - - - 1 .

g. var. $\beta$, natural size.

h. var. $\gamma_{0}$ 
Fucus membranifolius, stipes cylindrical, branched, its apex expanded into a sub-cuneiform leaf, between membranaceous and cartilaginous, flat, nerveless, bilobed, or dichotomous; tubercles oblong, pedunculated, growing on the stem.

Fucus membranifolius. Linn. Trans. III. p. 120. t. 16. f. 1. Syn. Fuc. I. p. 25. Esper, Ic. Fuc. II. p. 5. t. 115. Lamouroux, Diss. Fuc. (quoad ic.) t. 21 . f. 3.

F. Palmetta. Fl. Dan. t. 827. (excl. syn. Limn.)

F. Palmetta. var. C. La mo uroux, Diss. Fuc. p. 12. t. 20.

B. lacer; leaves dichotomous, segments linear, apices acute.

F. membranifolius. B. Syn. Fuc. I. p. 25.

F. membranifolius. $\gamma$. Linn. Trans. III. p. 120.

F. ceranoides. $\gamma$. Fl. Ang. p. 583. Fl. Scot. II. p. 915.

F. pseudo-ceranoides. Gmelin, Hist. Fuc. p. 119. t. 7. f. 4. Syst. Nat. Ed. Gmel. II. p. 1389.

F. parrus, cauliculis teretibus, summitatibus membranaceis dilatatis et laceris. RaII Syn. p. 44. n. 19. (excl. syn. Moris.)

F. firutescens, foliis angustis, se sensim ad extrema dilatantibus. Mo r Is. Hist. Ox. III. p. 648. s. 15. t. 9. f. 2.

$\gamma$. stellatus; apices of the leaves cleft into very numerous narrow segments.

F. membranifolius. $\gamma$. Syn. Fuc. I. p. 25.

8. fimbriatus; leaves fringed at the margin.

F. membranifolius. 8. Linn. Trans. III. p. 121. t. 16. f. 2. Syn. Fuc. I. 26.

F. fimbriatus. Fl. Ang. p. 574. (excl. syn. Gmel.) Wıтн. IV. p. 105. (excl. syn. Gmel.)

F. ceranoides. \&. Fl. Scot. II. p. 916.

є. latifolius; leaves membranaceous, seniorbicular, multifid in a palmate manner, segments shortish, rounded at the apices.

F. Palmetta. Gmelin, Hist. Fuc. p. 183. t. 22. f. 3. \& t. 23.? Syst. Nat.Ed. Gmel. II. p. 1388.?

२. roseus; stipes simple, expanded at its apex into a single, oblong, simple leaf.

n. angustissimus; leaves very narrow, nearly linear, irregularly divided, proliferous from the margin.

$\alpha$ and $\beta$ are not unfrequent on the shores of the British Isles.-In the Bays of Norway, every where. Muiller.$\gamma$ on the Southern coast of England.- $\delta$ at the Isle of Anglesea. Rev. H. Davies.-At Cromer, in Norfolk.Among the rejectamenta of the sea at Brighton. Mr. Borrer. ${ }_{\varepsilon}$ on the shores of the Northern Ocean and the Mediterranean. Gmelin.-At Bantry Bay. Miss Hutchins.- $\zeta$ on the Devonshire coast. Mrs. Griffiths. — $n$ in the Baltic. Professor Mertens.

Perennial. October-January.

Roor, an expanded, callous disk.

FroNDS, numerous from the same base, from nine to twelve inclies long, furnished with a cylindrical filiform stipes, of the thickness of a blackbird's quill, half a foot or more long, generally undivided, and naked for about lialf its length, and there irregularly branched; branches either simple, or repeatedly divided without any order, the upper ones not uncommonly clustered, all of them sub-distichous, and nearly of equal height, in their lower part completely resembling the stem, and sometimes continuing so to their extremities, but in general becoming gradually compressed as they rise, and at their apices expanding into flat leaves, destitute of midrib or veins, of a wide cuneiform shape, either bilobed, or dichotomous, or palmate, almost an inch long, and of nearly the same width in their widest part, their margins entire, their apices in some instances rounded, in others notched, with sharp segments :-other leaves, like the terminal ones, but attenuated at their base into an extremely short petiolus, grow upon the sides of the upper shoots.

Fructification, small ovate tubercles, nearly sessile, or supported upon short peduncles, growing upon the branches, especially near the extremities, and sometimes, but not commonly, also upon the leaves, containing a cluster of most minute roundish seeds:- besides these are frequently observable, on both sides of the leaves, deep blood-red cuneiform spots, of a substance different from that of the leaves themselves, and thicker than they are, which, if carefully dissected, will be found to be wholly composed of jointed parallel fibres, closely matted together, and exactly resembling the tubercles of $F$. Griffithsia, for which reason I look upon them as belonging to the fructification.

Co Lok, dark brown, tinged with purple in the stem, paler in the leaves, and more or less approaching to red, often pink towards the apices; in a state of decay, or from exposure to the sun, it turns to a dirty greenish hue, and at last to white.

Substance, cartilaginous in the stem, in the leaves between cartilaginous and membranaceous, tough, flexible, and, though thin, inclining to horny.

$\beta$, which I have made a distinct variety, upon the authority of Dr. Goodenough and Mr. Woodward, las its leaves and the divisions of its terminal membrane more thin and sharpish : it is also of somewhat taller growth:-in other respects it agrees with $\alpha$.

The var. $y$ differs from $\alpha$ only in the apices of the leaves being cut into very numerous narrow segments, like the stellated variety of $F$. crispus; the stem is mostly simple, and the leaves dichotomous, with linear segments.

The margins of the leaves in \&, especially near the apices, are beautifully fringed with small oblong processes, placed 

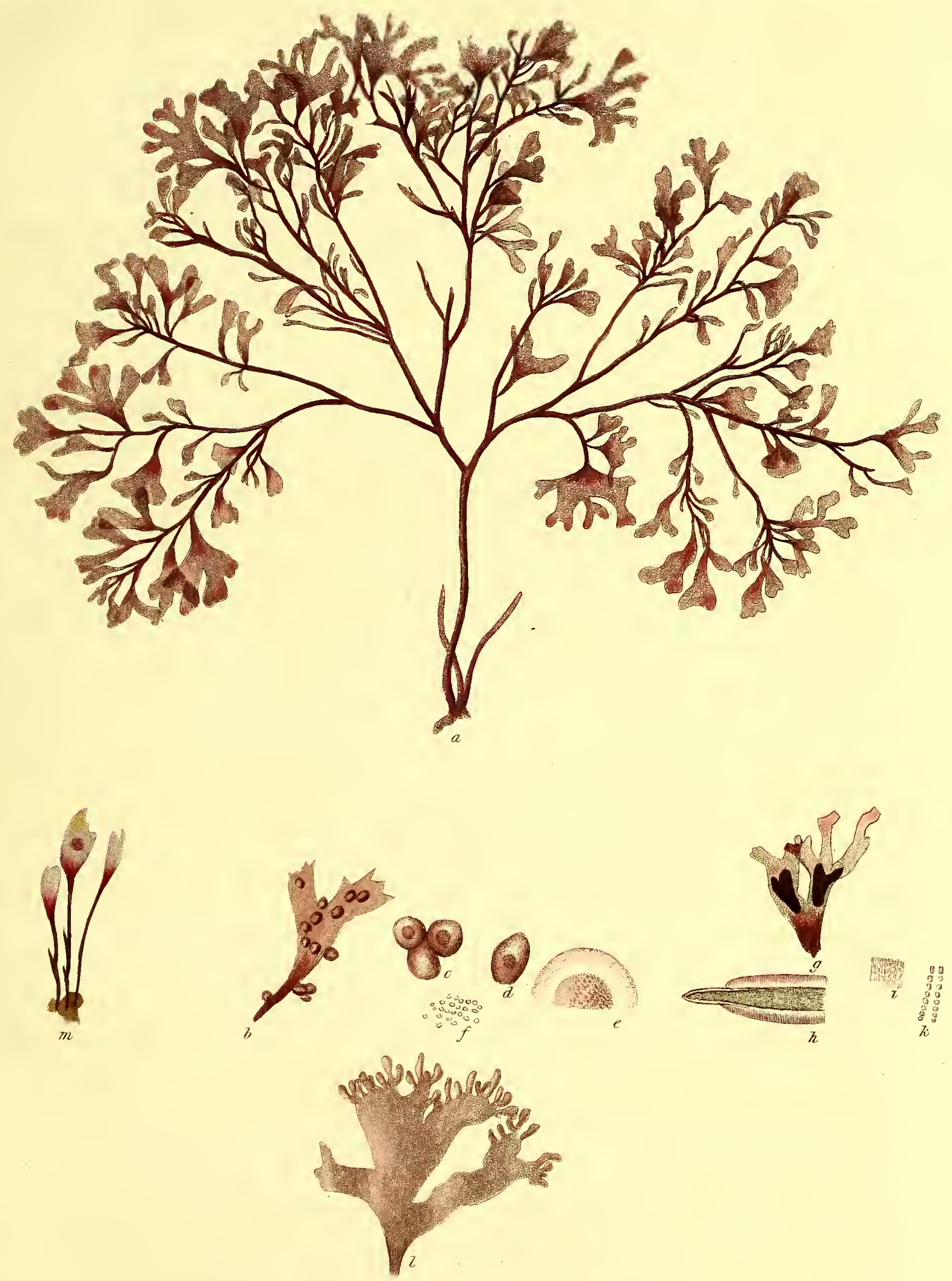

placed close to each other, mostly simple, but sometimes forked, considerably thicker than the leaves, and of a different substance:-I have never seen any seeds in these, nor are they like the tubercles, but I should still rather incline to suppose them the rudiments of imperfect capsules than of leaves:- this variety agrees in other respects with $\beta$.

$\varepsilon$ is a very pretty plant, nearly intermediate between $F$. membranifolius and F. Palmetta, but undoubtedly belonging to the former:-it has leaves twice as wide, and considerably more thin than those of the other varieties, its color is a paler, brighter red, its segments more rounded.

I have at present seen only one specimen of var. $\zeta$, the fronds of which were scarcely above an inch long, the stems simple, lateral leaves none, terminal ones solitary, oblong, undivided, all marked in their centres with a dark-red spot, had it not been for which, I slıould rather lave referred this plant to $F$. Palmetta than to $F$. membranifolius.

In $\eta$ the leaves are an inch and half or two inches long, and so narrow as scarcely any where to exceed a line in width, not bilobed or dichotomous as in $\alpha$, but divided quite irregularly, with acute apices, and proliferous margins: - the color, substance, and size are the same as in $\alpha$ and $\beta$.

Oвs. The habit of $F$. membranifolius is twisted, when fresh, and it has then in general a scent like violets:-in drying, it does not adhere to paper.

The whole of what has been written by various authors respecting the changeable nature of $F$. crispus, may be considered as applicable, though in an inferior degree, to the greater part of the Fuci most nearly allied to it, and to few more justly than to the subject of the present plate. That these two plants are in reality completely distinct, is a point which can admit of no question, and yet it must be allowed that the difference between them is far from being so observable as might be wished in every specimen; for, though the dissimilarity of their fructification, and the cylindrical stem of $F$. membranifolius afford the strongest and surest marks, yet individuals of this species are occasionally met with in a barren state, which are compressed from the very base, and expand almost immediately into a nembranous leaf, while, on the other hand, there are not wanting varieties of $\boldsymbol{F}$. crispus, in which the part nearest the root wears the appearance of a stipes. On this account Hudson and Lightfoot were of opinion that the two plants should be united, and this has also been the cause of the inestricable confusion that prevails in the synonymy of $F$. membranifolius; since no Botanist ever attended to the Fuci, without acknowledging the justice of the remark made by Dr. Goodenough and Mr. Woodward, "that whatever approaches to F. crispus is the same," and all have consequently feared lest they should be led to adopt as distinct species what are in reality mere varieties of this marine Proteus. The close affinity which $F$. membranifolius bears to $F$. Palmetta and $F$. Brodici has already been noticed under those Fuci, from both which it is sufficiently distinguished by the fructification alone. The dark-red spots above described upon the leaves are of a very peculiar nature, and, I believe, confined to this single Fucus. I had formerly suspected that they might possibly originate from the puncture of some insect, but I now rather incline to the opinion that they are connected with the fructification, their internal structure being completely uniform, and similar to that of the tubercles of F. Griffithsia, and some other species. Upon these Dr. Goodenough and Mr. Woodward founded their var. $\beta$, respecting which I am obliged, however reluctantly, to dissent from those able $\mathrm{Na-}$ turalists, as, from their being equally present upon all the forms of the leaves of this Fucus, it does not appear to me that they can be a fit basis for any variety. With regard to the synonyms it is necessary to say a few words. A mark of doubt is subjoined above to the quotation of Gmelin's F. Palmetta, because he describes the stem as flat, and his figures seem designed to represent a plant in some degree different from F. membranifolius; and yet the specimens received from Miss Hutchins approach so nearly to his species, that there can be little doubt of their being the same. Withering's $\boldsymbol{F}$. membranifolius is only $\boldsymbol{F}$. crispus, and his account of his second variety is little more than a translation of Gmelin's description of F. Palmetta. In the Synopsis of the British Fuci I had suggested a question, whether the $F$. ovinus of Gunner might not possibly be the same as the plant before us, but, according to the figure in the Acta Nidrosensia, it is our $F$. palmatus, and Ray's $N^{\sim} 16, \mathrm{p} .44$, quoted by the reverend author, is either $F$. crispus or F. manmillosus. The figure in the Flora Danica is excellent, but those of Gmelin and Morison are so extremely bad, that it is far from wonderful that they should have been by different authors referred to different species, or that Esper should have been led to figure, nnder the name of $F$. pseudo-ceranoides, a plant altogether dissimilar to F. memlranifolius, wlich, from the descriptions of those Naturalists, is clearly the plant intended by them.

a. F. membranifolius, natural size.

b. summit of the frond, with fiructification.

c. clustered tubercles, magnified - - $\quad-\quad$ - 6 .

d. tubercle separate - $-\quad-\quad-\quad-\quad-\quad-6$.

e. portion of the same cut through longitudinally - - 3.

f. seeds - - - - - - - - 1 .

g. summit of the frond with dark spots, natural size.

h. horizontal section of the same, magnified - - $\quad-6$.

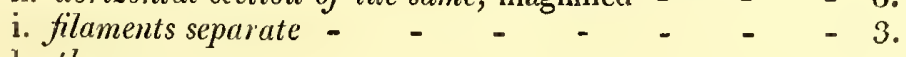

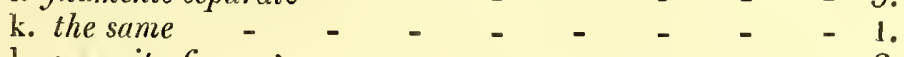

l. summit of var. $\delta$ - $-\quad-\quad-\quad-6$.

m. $\approx u r . \zeta$, natural size. 
Fucus, stipite terete, ramoso, apice expanso in folium membranaceo-cartilagineum, sub-cuneiforme, planuin, enerve, bilobum, dichotomumve; tuberculis oblongis, e caule pedunculatis.

Fucus membranifolius. Linn. Trans. III. p. 120. t. 16. f. 1. Syn. Fuc. I. p. 25. Esper, Ic. Fuc. II. p. 5. t. 115. Lamouroux, Diss. Fuc. (quoad ic.) t. 21. f. 3.

F. Palmetta. Fl. Dan. t. 827 . (excl. syn. Linn.)

F. Palmetta. vat. C. Lamourovx, Diss. Fuc. p. 12. t. 20.

B. lacer; foliis dichotomis, segmentis linearibus, apicibus acutis:

F. membranifolius. $\beta$. Syn. Fuc. I. p. 25.

F. membranifolius. $\gamma$. Linn. Trans. III. p. 120.

F. ceranoides. r. Fl. Ang. p. 583. Fl. Scot. II. p. 915.

F. psendo-ceranoides. Gi ELIN, Hist. Fuc. p. 119 . t. 7. f. 4. Syst. Nat. Ed. Gmel. II. p. 1383.

F. parvus; cauliculis teretibus, summitati busmembranaceis dilatatis et laceris. RaI1 Syn. p. 44. n. 19. (excl. syn. Moris.)

F. frutescens, foliis angustis, se sensim ad extrema dilatantibus Monıs. Hist. Ox. III. p. 648. s. 15. t. 9. f. ․o

$\gamma$. stellatus; foliorum apicibus tenuissimè divisis, numerosissimis.

F. nembranifolius. $\gamma$. Syn. Fuc. 1. p. 25.

S. fimbriatus; foliis margine ciliatis.

F. membranifolius. \&. Linn. Trans. III. p. 121. t. 16. f. 2. Syn. Fuc. I. p. 26.

F. fimbriatus. Fl. Ang. p. 574. (excl. syn. Gmel.) W Iтн. IV. p. 105. excl. syn. Gmel.)

F. ceranoides. 8. Fl. Scot. II. p. 916.

є. latifolius; foliis membranaceis, semiorbicularibus, multifido-palmatis, segmentis breviusculis, apice rotundatis.

F. Palnetta. GuElin, Hist. Fuc. p. 183. t. 22. f. 3. et t. 23.? Syst. Nat. Ed. Gmel. II. p. 1388.?

5. rosens; stipite simplice, in folium unicum oblongum simplex apice expanso.

ท. angustissimus; foliis angustis, sub-linearibus, vagè divisis, e nargine proliferis.

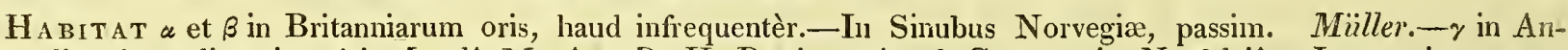
gliæ Australis oris.- $\delta$ in Insulâ Monâ. D. H. Davies.-Apud Cromer, in Norfolciâ.-Inter rejectamenta maris apud Brighton. D. Borrer.- $\varepsilon$ ad littora Oceani Septentrionalis et Maris Mediterranei. Gmelin.In Sinu, "Bantry Bay" dicto. Dna Hutchins. $-\zeta$ in Devoniæ oris. Dna Griffiths. $\rightarrow$ in Mari Baltico. D. Prof. Mertens.

Perennis. Oct.-Jan.

Ra Dix callus expansus, discoideus.

Frondes ex eâden basi plurimæe, dodrantales, vel pedales, stipite instructæ terete, filiformi, Merulæ pennæ crassitie, semipedali, et ultrà, ad dimidiam circitèr longitudinem plerumque indiviso nudoque, et ibi vagè ramoso ; rami nunc simplices, nunc iterum atque iterum absque nornâ divisi, summis haud rarò fasciculatis, omnes subdistichi, et sub-fastigiati, basin versus caulis omnino similes, eodemqne aliquandò modo ad apices usque excurrentes, sæpiùs tamen sursùm sensim compressi, et apice expansi in folia plana, nervi venarumque expertia, latè cuneiformia, biloba, aut dichotoma, aut etiam palmata, longitudine ferè pollicaria, latitudinisque, ubi maxima, propemodùm ejusdem, margine integerrima, apicibus in his rotundatis, in illis emarginatis, segmentis acutis:- -alia quoque folia, termnnalium similia, sed basi in petiolum brevissinum attenuata, ramorum superiorum ad latera producuntur.

FRUCT1FICATIO tubercula exigua, ovata, brevissimè pedunculata, vel sub-sessilia, ramis, prasertim apices versus, imposita, et interdùm, sed rariùs, foliis quoque insidentia, seminum minutissimorum subrotundorum congeriem includentia:- præter hæc haud infrequentèr occurrunt in foliis maculæ atro-sanguineæ, cuneiformes, substantiæ a foliis diversæ, ipsisque crassiores, utramque paginam occupantes, quæ, si cautè dissecentur, e fibris articulatis parallelis densissimè compactis constare reperientur, et sunt $F$. Griffithsice tuberculorum ad amussim similes, unde ad fructificationem pertinere credo.

Color in caule intensè fuscus, purpurascente tinctus, in foliis dilutior, et ad rubrum plùs minùs accedens, sæpe juxta apices roseus; marcescentis vel soli din objectc sordidè virescit, et demùm evanescit in album.

SubSTANTia caulis cartilaginea, foliorum cartilagineo-membranacen, lenta, tenax, et, quantumvis tenuis, subcornea.

Var. $\beta$, quam Goodenovii Woodwardiique auctoritati obtemperans pro varietate distinctâ enumeravi, folia et membranæ terminalis divisuras tenuiores et acutiusculas habet, et paullò altiùs crescî : -in cæteris cum $\alpha$ convenit.

Var. $\gamma$ in eo modd ab a liscrepat, quod foliorum apices in segmenta numerosissima angusta, F. crispi varietatis stellata instar, secentur; stipes quoque sinpliciusculus, et folia dichotoma, segmentis linearibus.

Foliorum margines in var. $\delta$, præsertim apices versus, sult pulchrè fimbriati, processubus exiguis, oblongis, approximatis, plerumque simplicibus, aliquandd tamen bifurcis, foliis multo crassioribus, substantiæque diversæ:nulla in his semina unquam vidi, neque sunt tuberculorum similes, potiùs tamen capsularum sterilium quàm foliorum rudimenta crederem :-. hæc varietas in reliquis cum $\beta$ consentit.

Var. : est stirps perpulchra, inter $F$. membranifolinm et $F$. Palmettam ferè intermedia, sed ad illum certè peltinens:-folia habet duplò latiora et tenuiora quam ea reliquarum varietatum, colorem pallidiorem lætiùsque rubentem, segmenta magis rotundata. 


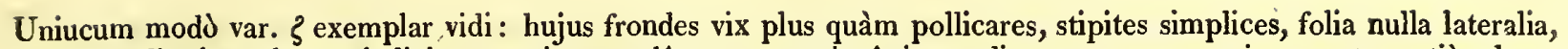
terminalia solitaria, oblonga, indivisa, omnia maculâ atro-sanguineâ in medio notata, quæ ni vetaret, potiùs hanc plantam ad F. Palmettam quam ad F. membranifolium retulissem.

Var. n folia habet elongata, ut sesquipollicem vel duos pollices æquent, angusta, ut nullibi ferè sint lineâ latiora, haud, sicut in $\alpha$, biloba aut dichotoma, sed vagè, absque normâ, divisa, margine prolifera, apicibus acutis :-colore substantiâ, et magnitudine cum $a$ et $\beta$ convenit.

OBs. Habitus in plantâ recente crispatus :-odorem violaceum sæpiùs spirat:-exsiccata chartæ nequaquàm adhæret.

Omne illud quicquid est de F. crispi indole crescendique modo summoperè mutabili ab auctoribus memoratum, jure vix minùs æquo ad Fucos plurimos ei affines et præsertìm ad illum hìc depictum referre licet. Discrimen etiam inter hasce duas species, licet certissimè sint reapse distinctæe, nequaquàm in omnibus individuis ita dilucidè ut velles discernitur: Quamvis enim utriusque fructificatio notas cuivis satis obvias suppeditet, et stipes sit in unâ elongatus in alterâ nullus, occurrunt tamen aliquando $F$. membranifolii exemplaria sterilia et manca, quod præsertìm in junioribus accidit, quorum frondes sunt $\mathrm{ab}$ ipsâ basi compressæ, et ferè statìm in membranam expansæ, dum contrà $F$. crispi pars radici proxima non raro est teretiuscula, et stipitem quandoque simulat. Hanc igitur ob rem ambas conjungendas censuerunt Hudsonus Lightfootiusque, et hæc causa extitit quodd de $F$. membranifolii synonymis tantum sint hallucinati auctores; quoniam nemo unquam botanicus animum ad Fucos advertit, quin fateretur justissimum esse illud Goodenovii Woodwardiique de F. crispo dictum, "quod tangit esse idem;" omnesque igitur sunt veriti ne varietates pro speciebus venditare crederentur. Est quoque F. membranifolius, quod sub Fuco præcedente memoratur, ei maximè affinis, sed ab hoc quoque dignoscendus per fructum, qui $F$. Brodiai quoque nunquam non distinguere sufficit. Maculæ in foliis atro-sanguineæ, quibus Goodenovii Woodwardiique var. $\beta$ nititur, quæ vero neutiquàm, me judice, ad varietatem distinctam stabiliendam sunt idoneæ, quoniam in omnibus frondis formis occurrunt, sunt valdè singulares, et in nullo alio, quod scio, Fuco observantur. Has ab insecti cujusdam puncturâ pendere olim sum suspicatus, sed nunc magis propendeo ut crederem esse aliquo modo cum fructificatione connexas, quoniam structura interna omnibus eadem ejus in $F$. Griffithsia aliorumque Fucorum tuberculis observandæe similis conspicitur. De synonymis pauca sunt dicenda. Gmelini $F$. Pulmettam dubitantèr modò suprà citavi, quia caulem in descriptione planum dicit, et icones plantam a nostrâ alienam designare videntur. Exemplaria tamen a Dna Hutchins accepta nimium ad hanc ejus quadrant ut specie distincta crederem. Fucus ille, qui Witheringio $F$. membranifolius audit, est tantummodò F. crispus, et de varietate 2 dâ nihil ferè nisi $F$. Palmetta descriptionem a Gmelino datam repetit. Gunneri $F$. ovinus, quem in Fucorum Britannicorum Synopsi ad F. membranifolium fortè referendum dixi, est, fide iconis in Act. Nidros., idem qui $\boldsymbol{F}$. noster palmatus, et Raii n. 16. p. 44., sub illo citatus, vel $\boldsymbol{F}$. crispi vel $\boldsymbol{F}$. mammillosi synonymon habendus. Flore Danica icon est optima; contrà iis Gmelini et Morisoni nihil pejus, quamobrem nequaquàm mirum si sint ad diversas species ab auctoribus relatæ, aut si erraverit Esperus, qui plantam ab hâc nostrâ toto cælo diversam sub $F$. pseudo-ceranoidis nomine in Iconibus Fucorum p. 15\%. t. 80. depinxit. Eorüm tamen descriptiones perpendenti dubium restabit nullum quin $F$. membranifolius sit stirf i: designata.

a. F. membranifolius magn. nat.

b. frondis apex cum fructu.

c. tubercula congesta, magn. auct. - - $\quad-\quad 6$.

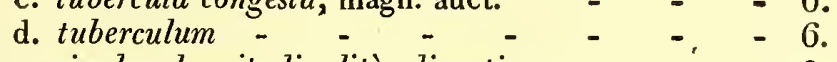

e. ejusdem longitudinalitèr dissecti pars - - $\quad$ - $\quad 3$.

f. semina

g. frondis maculata apex, magn. nat.

l. ejusdem horizontalitèr dissecta pars, magn. auct. 6.

i. filamenta, seorsùm - $\quad-\quad-\quad-\quad-3$.

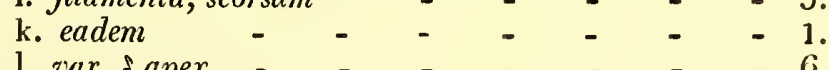

1. var. sapex - - - - - - - 6.

m. var. $\zeta$, magn. nat. 
Fucus Agarum, stipes almost cylindrical, short, terminated by a membranaceous, flat, simple, roundish, midribbed leaf, perforated with sub-orbicular cavities; seeds naked, collected into spherical spots, scattered all over the frond. Fucus Agarum. Gmelin, Hist. Fuc. p. 210. t. 32. Syst. Nat. Ed. Gmel. II. p. 1390.

F. Clathrus. Esper, Ic. Fuc. II. p. 37. t. 128. (excl. syn.)

In the Indian Ocean, and the sea near Kamtschatka. Gmelin.-On the coast of Nova Scotia. Mr. Menzies. -Hudson's Bay. Dr. Macnab.

\section{Perennial?}

Root, composed of several woody, incurved, narrow, flat, branching fibres.

FroND, a single, simple leaf, of an orbicular, or irregularly oblong shape, one or two feet long, and nearly of the same width, or somewhat less, supported upon a stipes scarcely three lines in length, almost cylindrical at its base, and as thick as a small goose-quill, afterwards flat, longitudinally furrowed, and passing through the leaf like a midrib; it sends out no lateral nerves, and preserves throughout its whole length, as far as I have seen, a nearly equal width of about two lines: the frond is every where perforated, like a sieve, with numerous holes, placed, apparently, without any order, in general orbicular, or "roundish, but occasionally elliptical, and sometimes, though seldom, angular, their diameter varying from almost half an inch to scarcely a line, and greater and smaller mixed together: the margin of the frond, according to Gmelin, is toothed, with unfrequent, simple, erect, crooked teeth : upon this subject I am unable to say any thing, as the specimens which I have seen were so much torn at their margins, that it was impossible to determine whether they were entire or not: I should have thought, however, that they were entire.

* FrUCtification, small, roundish, brown, naked seeds, collected into circular spots, scattered all over the frond: the seeds, I believe, are mixed with fibres, but, if so, these are so minute that the highest powers of the microscope are inadequate to the discovery of their shape.

Co LOR, in the stem a blackish, in the leaf a yellowish brown, and semitransparent, blackish when dry; if long kept in fresh water, turning pale, and at length quite white.

SUBSTANCE, coriaceous and thick in the stem, thin, and between membranaceous and cartilaginous in the leaves.

Oss. In a dried state it does not in the least adhere to paper.

Gmelin, who first described this very extraordinary Fucus, appears from his account of it to have had an opportunity of examining specimens far more perfect than those which I have been fortunate enough to meet witl, and it is therefore greatly to be lamented that lie should have taken his figure from one peculiarly injured and imperfect. The nature of this plant is so singular, that he was induced to form from it a separate order of Fuci, which he called Agara, and to which, besides the present, he referred only $+F$. bracteatus, already figured in this work, I. t. 25., aud $\$ F$. Clathrus, of which $I$ have hitherto seen no specimens, the one represented under that name in Professor Esper's Icones Fucorum, and sent to him by me, being, as I have subsequently found, only a mutilated fragment of F. Agarum. Of this order the leading character consisted in the perforated frond, which, from the constancy and the regularity of the cavities, he was inclined to regard as by no means the effect of accident, but as innate in the nature of the plant, and I must confess, that what I have seen of the species before us induces me to be of the same opinion. At the same time, I can form no idea what purpose these cavities can be intended to answer in the economy of vegetation. They appear in their origin to be black dots, resembling the pores of F. serratus, or, more nearly, those of the leaves of $F$. natans and its affinities, which gradually widen, leaving the edges always stained with black, and so smooth and even as to take away the idea of their being merely casual. Very nearly allied to these is the Ulica reticulata of Forskal, an extraordinary vegetable, of which no figure has yet been published, consisting altogether of linear membranous segments, about one or two lines wide, and every where anastomosing, and still more nearly allied to them is another at present noudescript Ulva, brought by Lord Valentia from the Red Sea, the frond of which is linear and narrow, and formed like that of Ulva rcticilata, but the meshes all round. Perhaps the whole of these ought to be carried to the genus, Ulva, with several of the species of which F. Agarum agrees in fructification; but, as it is provided with a root and stem so different from those plants hitherto referred to that family, I have thought it best to leave it among the Fuci, till the system of the submersed Algæ shall be modelled afresh, and cast into new genera more consistent with nature and botanical arrangement. The specimen of $F$. Agarum here figured exhibits a curious peculiarity, which, though I have seen it in no other, I apprehend to be natural to the piant. The upper part of the frond is quite hard and corriaceous, while the lower part is thin, membranous, and apparently much younger. In this respect it agrees curiously with what has been observed in the Synopsis of the British Fuci respecting the mode of growth of $F$. saccharinus, and tends to strengthen the conjecture originally made by Mr. Dillwyn, and subsequently confirmed in a great measure by the observations of Mr. Borrer, that the old frond,

\footnotetext{
- This account of the fructification is very different from that given by Dr. Weber and Dr. Mohr, in their Ncue Beiträge, p. 284; but I have the authority of those Botanists to say, that the plant which thcy have there called $F$. Agarum is a different specics from the true one. + It appears to me that $F$. bracteatus has little or no natural affinity with $F$. Agarum. The substance of the two plants is quite different, the fructification equally untike, and in the specimens which $I$ havc seen of $F$. bracteatus there were no cavities; so that, though I regard these as natural in the onc, I cannot but consider them as accidental in the othcr.

$\ddagger$ Of this also it is to be regretted tirat Gmelin's figure is taken from a mutilated specimen, and by no means agrees with his description, which refers to a plant with a stem one or two feet long, terminated by an orbicular frond about a foot in diameter; but whether with a mid. rib, or not, he docs not say. Many Botanists have supposed $F$. Clathrus to be a variety of $F$. Agurum.
} 


frond, having discharged its office, is gradually supplanted by a new one, which rises from the base, and thus the plant acquires a perennial growth, and, as Tibullus beautifully says of the serpent, " novus exuit annos."

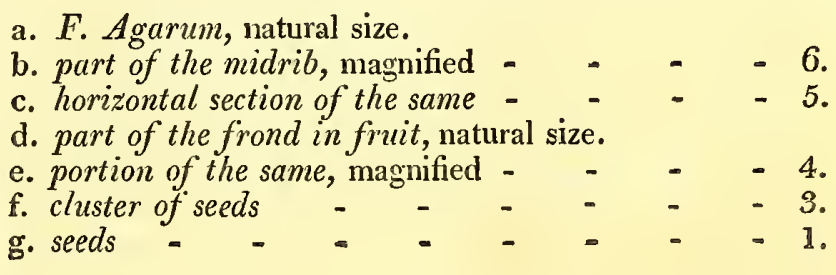

\section{5.-F U G US A G A R U M.}

Fucus, stipite teretiusculo, brevi, terminato folio simplice, plano, membranaceo, elliptico-subrotundo, costato, pertuso foraminibus sub-orbicularibus; seminibus nudis, in maculas sphæricas per totam frondem sparsas congestis.

Fucus Agarum. Gmelin, Hist. Fuc. p. 210. t. 32. Linn. Syst. Nat. Ed. Gmel. II. p. 1390.

F. Clathrus. Es PER, Ic. Fuc. II. p. 37. t. 128. (excl. syn.)

Haвıтат in Oceano Indiæ orientalis, et Mari Kantschatico. Gmelin.-In Novæ Scotiæ oris. D. Menzies.In Sinu, "Hudson's Bay" dicto. D. Macnab.

Perennis.?

RADIX fibrosa, fibris plurimis, lignosis, incurvis, angustis, planis, ramosis.

Frons folium unicum, simplex, orbiculare, vel enormitèr oblongum, pedem unum alterumve longum, et latitudinis ferè ejusdem, aut aliquantùm minoris, stipiti insidens vix trium linearum longitudine, basi teretiusculo, et pennæe anserinæ minoris crassitie, mox plano, longitudinalitèr sulcato, folii medium costæ loco percurrente, nervos nullos laterales emittente, duarum circitèr linearum latitudine, et per totam longitudinem, quantum ego vidi, æequali; frons ubique, cribri ad instar, pertusa foraminibus crebris, nullo, ut videtur, ordine dispositis, ut plurimum orbicularibus, subrotundisve, interdùm ellipticis, et quandoque, sed rariùs, angulatis, diametro nunc ferè unguem, nunc vix lineans superantibus, majoribus minoribus senıer imnixtis; frondis margines, teste Gmelino, dentati, dentibus raris, simplicibus, erectis, aduncis, de quo tamen nihil proferre possum, cùm nulla exemplaria viderim, nisi margine ita lacerata, ut an integra sint necne nequaquàm constaret: certè verò integra milhi apparuerunt.

* Fructificatio semina exigua, subrotunda, fusca, nuda, in maculas orbiculares congesta, fibrisque, ut videtur, immixta, sed aded exiguis, ut silngulæ visum effugerent, per frondem ubicunque sparsa.

Co lor in caule nigricanti, in foliis flavescenti, fuscus, et sub-diaphanus; exsiccatce nigricans; in aquâ dulci diu servata fit dilutior, et demùm albicans.

Substantia caulis coriacea, et crassa; folii membranaceo-cartilaginea, tenuis.

OBs. Exsiccata chartæ nequaquàm adhæret.

Ex descriptione Gmelini, qui primus lıunc Fucum maximè singularem memoravit, constat facultates illi esse oblatas observandi exemplaria iis longè perfectiona quæe ego vidi, idedque magis est dolendum quòd tabula sua insignitèr mancum delineatum exhibeat. Movit hunc stirpis indoles peculiaris suique solius ferè propria ut novum ex illâ Fucorum ordinem strueret, quem Agara appellavit, et cui, preter speciem hìc depictam, tantummodò ascribendos novit $+F$. bracteatum, janı olim in loc opere adumbratum, I. t. 25, et $\$ F$. Clathrum, mihi adhuc incognitun ;

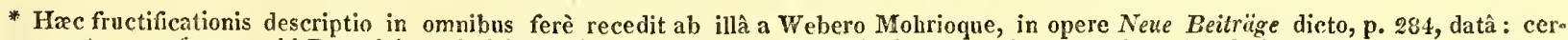
tiorcm autem me fecerunt hi Botanici nlaximè ingenui se plantam a Gmelinianâ diversaun sub $F$. Agari noınine designavisse.

+ Mili qnidem videtur perpaullum esse affinitatis inter $\boldsymbol{F}$. Agarum et $\boldsymbol{F}$. bracteatum, quoniam substantiâ fructuque prorsus dissimili gaudent neque in iis F. bructeati exemplaribus qua ego vidi ulla unquam foramina apparuerunt; quamobrem frondem pertusam, quam in illo nativam, in hoc fortuitanı suspicor.

† Piget etiam quod hujus quoque Fuci exemplar mancum depinxerit Gmelinus, et quod vix descriptioni quadrat, e qu’ stirpem caule pedali biperlalive instructam, et folio orbiculari, cujus diameter pedem aquat, intelligeres. An sit hoc folium costatum necne non memorat. Multi cledidere Botanici esse $F$. Clathum tantummodò $F$. Agari varietatem.
} 
situm; quoniam planta sub illo nomine ad Esperum a me missa, et ab ipso in Fucorum Iconibus sculpta, nihil est uti posteræ observationes edocuerunt, nisi $F$. Agari læsi laceratique frustum. Notam hujus sui ordinis essentialem in fronde pertusâ posuit Grmelinus, quod nequaquàm e casu aliquo pendere, sed in ipsâ stirpis indole inseri credidit, quia foramina semper adesse, et semper aliquid in se peculiare habere observavit; cui ut ipse opinioni faveam cuncta specimina a me in præsens visa suadent, licet conjicere prorsùs nequeam ad quem sint finem a Naturâ comparata. Ortu puncta atra referunt, et similia sunt pororum in $F$. serrati fronde, aut potiùs eorum in $F$. natantis foliis observandorum. Etate progrediente se sensim magis magisque dilatant, ita tamen ut margines semper nigricantes servent, quasi inustos, nimiumque glabros et æquales ut fortuitd orta crederes. His plantis summoperè est affinis Forskalii Ulva reticulata, vegetabile singulare, cujus nulla hactenus extat icon, totumque constans e membranâ lineari, lineam unum alteramve latấ, ubique anastomosante. Alia quoque datur Ulva, nondunı a Botanicis descripta, quam secum e Mari Rubro reportavit nobilissimus Vicecomes de Valentia, et quæ $F$. Agaro et congeneribus magis adhuc accedit; frons enim huic linearis angusta, crescendique modus idem qui Ulve reticulate, sed foramina omnia rotundata. Dicet forsitan aliquis omnes has stirpes rectiùs Ulvis fore associatas, neque is ego sum qui tali sententiæe obsisterem, quoniam $F$. Agari fructificatio ab illâ quarundam Ulvarum nequaquàm abludit: nihilominùs tamen, ob radicem fibrosam stipitemque diversæ a fronde substantiæ, quibus reliquæ hujus generis species carent, inter Fucos reliquendum putavi, donec Algarum submersarum de novo recudatur systema. $F$. Agari exemplar hic depictum quiddam in se peculiare habet, quod, licet in nullo alio hactenùs viderim, plantæe esse proprium suspicor. Frondis pars superior est dura et coriacea, inferior verò tenuis, membranacea, et, ut videtur, junior evadit. Consentit in hoc cum illo quod est in Fucorum Britannicorum Synopsi de F. saccharino animadversum, firmatque conjecturam, quam, olìm a Dillwynio factam, mox Borreri observationes magnâ ex parte stabiliverunt, novam frondem a radice ortam sensim depellere veterem munere suo perfunctam, unde Fucus per annos durans recenti semper honore viget, et, ut pulcherrimè de serpente dicit Tibullus, " novus exuit annos."

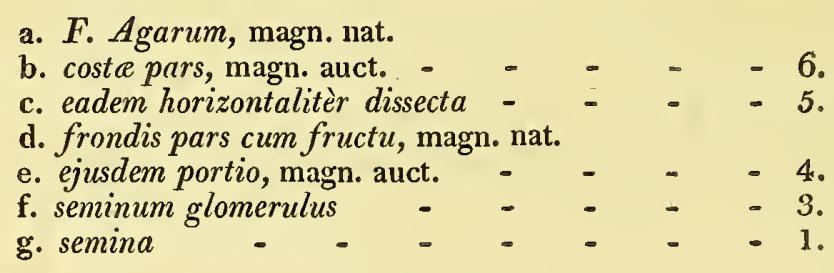

\section{6.-F U C US SPERMOPHORUS.}

is spermophorus, frond cartilaginous, flat, linear, nerveless, dichotomous, of equal height; apices narrow, multifid, very numerous; tubercles hemispherical, externally wrinkled, lateral.

Fucus spermophorus. LIN . Syst. Nat. II. p. 719. Syst. Nat. Ed. Gmel. II. p. 1386. Fl. Norv. II. p. 26. Es PER, Ic. Fuc. II. p. 91. t. 154.

Ceramium spermophorum. Rотн, Cat. Bot. III. p. 113.

In the sea near Norway, as at Hameröen in Nordland. Gunner.-Sent from Ceylon to Linnaus.

\section{Perenniai.}

Root, a small, callous disk.

Fron D, three or four inches, or more, long, at its base cylindrical, and about the thickness of a sparrow's quill, but before it acquires the height of six or seven lines becoming compressed, and soon afterwards flat, when it preserves every where, except at the extremities, an equal width of a line, or a line and half; it is quite destitute of veins or midrib, and towards its base simple and naked, but in general forked a little below the middle, and afterwards repeatedly dichotomous, the space between each division being uncertain, though mostly it is rather long in the lower branches, and short in the upper ones; the angles of the divisions are acute, the segments of equal height; it sometimes, though not commonly, happens that the frond is dichotomous to its very extremities, with branches all of the same width, or even that the upper ones are wider than the rest, in general, however, the apices are multifid, with extremely short, irregularly divided segments, some of them acute, others obtuse, and almost truncated, all three or four times as narrołi as the rest of the plant, so that they look capillary; the margins are entire, but occasionally, especially near the apices, proliferous with numerous, short, narrow, horizontal shoots. 

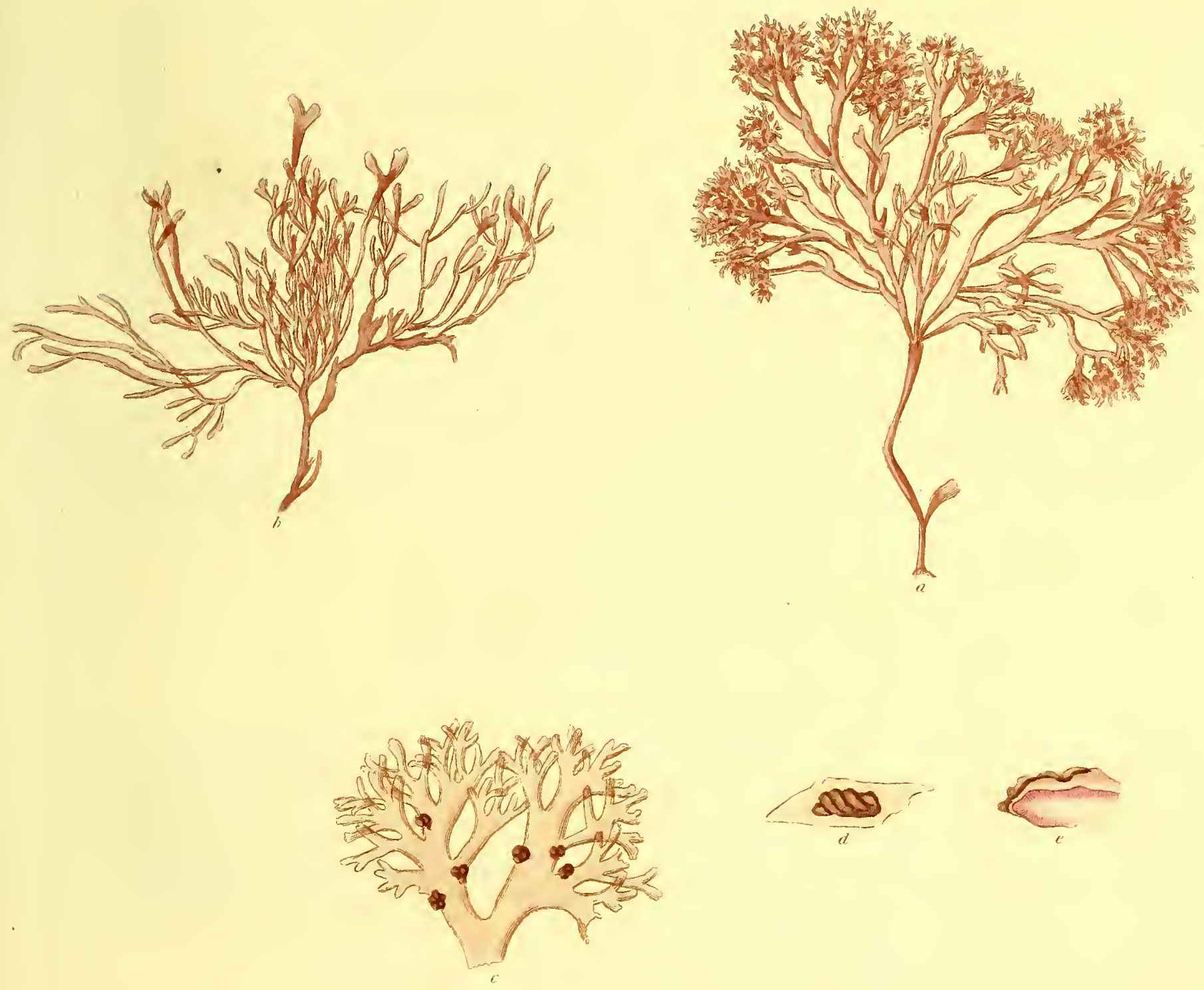

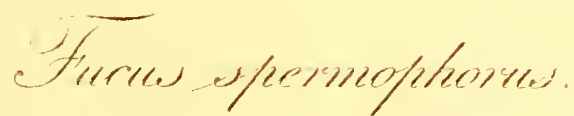



Fructification, small orbicular tubercles, of a darker color than the frond; externally furrowed and wrinkled, * sessile near the margins of the upper branches:- with respect to the internal structure of these I can say nothing, as in my specimens they are not sufficiently advanced.

Color, a pleasant, but pale red, transparent, very fugitive; in a dried state darker, and mixed with brown; in decay, turning to a yellowish green, and at last to white.

SUBSTANCE, between membranaceous and cartilaginous, thin, flexible, tough ; somewhat stiff after it is dried.

Oвs. Sertularia anguina is found growing upon this Fucus :-I apprehend its habit to be twisted when recent:in drying it does not adhere to paper.

In its mode of growth, this Fucus is liable to considerable changes, and, ttwo strikingly dissinilar appearances are represented in the plate before us. These, however, seem to me to run too much into each other to justify the regarding of them as distinct varieties; the one figured at $b$ I apprehend to be by far the least common, and probably to be in a young state, or the effect of accident, nor does the other by any means represent the plant with apices so much clustered as I have frequently seen; on the contrary, in many specimens, the upper parts form a thick tuft of extremely narrow shoots, so numerous, and so much confused, that the whole constitute a mass of which it is impossible to discover the natural form. Of these narrow shoots the origin is most uncertain: in some instances they appear to be the natural result of the frequently repeated divisions of the frond; in others they seem to arise from a proliferous mode of increase, being disposed along the margins and apices, and springing in clusters from the same point; while again, in others, it might be considered that they were merely occasioned by some injury, which the plant had received, and was striving vigorously to repair. This latter, however, I am persuaded would be an erroneous supposition, and $\ddagger$ they appear to me not only to belong naturally to the species, but to constitute its most striking character. In a dry state they are almost altogether capillary, and make the branches look as if terminated by bundles of short hairs. When destitute of these, $F$. spermophorus bears some resemblance, in form and general habit, to the smallest narrow varieties of $F$. crispus, while its color and texture approach more nearly to those of $F$. coronopifolius. The fructification, too, described by Dr. Roth, is like that of this latter species, but the tubercles here figured, the only ones that I have seen, are in their exterior so similar to the remarkable ones of $F$. rubens, that there can be little doubt of their resembling them internally also. Respecting the synonym of Gunner, above quoted, I feel it necessary to make the same remark as has already been made relative to his $\S \vec{F}$. vittatus. No more is said upon the one plant than upon the other, and both rest upon the same authority, which I can scarcely think in itself sufficient to justify the regarding a native of Ceylon as an inhabitant of the shores of Norway. On the contrary, it is surely more probable that Gunner and Tonning, by mistake, referred the Linnæan character of $F$. spermophorus to some other species.

a. et b. F. spermophorus, natural size.

c. apex of frond, with fruit, magnified - $\quad-6$.

d. tubercle - - - - - - 4 .

e. longitudinal section of the same - $\quad-3$.

* Koenig says they are peduneulate, whieh $I$ lıave never seen ; and Roth mentions the same thing. This latter author also describes the capsules of a form different from mine, and seems to have reeeived the fruit in a more perfect state, on which aecount I think it right to tran. scribe what he has written upon the subject:- "Capsula globosæ, acumine brevi terminatæ, sub-pellueidæ, granulis minutissimis, flavescen. tibus farctæ, laterales, sparsæ, tamen eopiosæ, pedunculatæ, demum infra apicem Iatere transversim dehiscentes, magnitudine seminis Papaveris. Pedunculi tertiam lineæ partem vix superantes, nudi, teretiusculi."-Probably the plant las a two-fold fructification.

+ Dr. Roth had also observed two modes of growth in this Fucus, but his remarks upon the subject are far from aceording with my spe. cimens : he says, "Ramuli in sterilibus speciminibus, quæ maseula salutare audeo, densissimi ; terminales dilatati, palmato-multifidi, apieibus sub-inerassatis, obtusis : in capsuliferis laxiores; terminales bifidi, furcati, aenminati."

$\ddagger$ Professor Esper’s opinion respeeting them is eurious: he thinks that they originate from the fructification; the seeds vegetating while in the capsules, and thus producing a new progeny parasitic upon the parent plaut.

$\$$ See Vol. Y, p. 144. 
Fucus, fronde cartilagineâ, planâ, lineari, enervi, dichotomâ, fastigiatâ; apicibus attenuatis, multifidis, numero= sissimis ; tuberculis hemisphæricis, extrinsecùs rugosis, lateralibus.

Fucus spermophorus. Linn. Syst. Nat. II. p. 719. Syst. Nat. Ed. Gmel. II. p. 13s6. Fl. Norv. II. p. \&6. EsPer, Ic. Fuc. II. p. 91. t. 154.

Ceramium spermophorum. Roтн, Cat. Bot. III. p. 113.

Ha bita in Mari Norvegico, e.g. ad Hamerüen Nordlandiæ. Gunner.-Ex Insulâ Ceylon accepit Linnaus.

Perennis?

RADIX callus exiguus.

FBON palmaris, et ultrà, basi teres, et pennæ passerinæ crassitie, sed priusquàm sex septemve linearum altitudinem attigit compressa, et inde sensim plana, linean vel sesquilineam lata, et ubique, nisi juxta apices, linearis, nervi venarunıque prorsùs expers, basin versus simplex et nıda, it plurimum paullùm infra medium bifurca, et mox divisa dichotomiis pluries repetitis, spatio inter singuias incerto, sed sæpiùs in inferioribus longiusculo, in superioribus perbrevi, angulis acutis, segmentis fastigiatis; aliquandò, rariùs tamen, accidit specimina ad apices usque dichotoma evadere, ramis latitudine ubique æqualibus, vel summis etiam dilatatis, apices vero plerumque sunt multifiai, segmentis brevissimis, variè divisis, nunc acutis, nunc obtusis, et quasi truncatis, reliquâ fronde triplo quadruplove angustioribus, ut ferè capillares videantur ; frondis margines integerrimi, sed interdùm surculis plurimis, brevibus, angustis, horizontalibus, præsertìm apices versus, pullulant.

Fructificatro tubercula exigua, orbicularia, superficie variè rugulosa, coloris fronde intensioris, satis frequentia, ramorum superiorum juxta margines * sessilia :- de internâ horum structurâ nihil est quod dicam, quoniam in exemplaribus nostris nondùm satis adoleverunt.

Co Lor amøè̀, dilutè tamen, ruber, diaphanus, fugacissimus; exsiccata intensior, et fusco immixtus ; marcescentis in flavicanti-viridem transiens, et demùm albicans.

Substantra membranaceo-cartilaginea, tenuis, lenta, tenax; siccitate rigidiuscula.

Ов. Sertularia anguina huіс Fuco imnascens est reperta:-recentis habitum tortilem esse suspicor :-exsiccatus charte non adhæret.

Qualitèr $F$. spermophorus crescendi modo variare solet per hanc tabulam liquet, quæ †duo a se invicem formâ longè recedentia exemplaria exhibet. Vix tamen, me judice, fieri potest ut hæc, quantumvis primo aspectu dissimilia, pro varietatibus distinctis censerentur, quoniam utrumque in alterunı nunquam non transiens limites nullos, vel ninimos, certè definiendos relinquit. Illud ad lit. $b$ depictum non modò infrequentiùs occurrere, sed forsan ab æatate minùs provectâ aut a casu aliquo pendere suspicor; neque altera figura ostendit plautam apicibus tàm confertis instructan quàm sæpe occurrunt; in multis enim exemplaribus hi congeriem effingunt surculorum adeò densè stipatorum inplexorumque ut formam indolemve veram æagerrimè detegas. Origo etiam his admodùm incertus et dubius: nunc a frondis repetito-divisæ segmentis necessariè multiplicatis procedere apparent; nunc ramorum marginem apicesque densè obsidentes, nec rarò plurimi ab eodem puncto orti, ad incrementum proliferum tribuendi videntur; et nunc in eo tantùm disponuntur modo ut primordium ducere crederes a vi illâ regenerandi, quæ in multis innata Fucis ad damnum aliquid casu acceptum resarciendum vires subministrat. Persuasum tamen mihi habeo posteriorem hanc opinionem, quanvis in quibusdam individuis verisimillima appareat, in errore esse positam; hosque apices non modò ad stirpem łnaturâ pertinere credo, verùm etiam characterem ejus maximè essentialem suppeditare arbitror. In plantâ exsiccatâ prorsùs capillares evadunt, efficiuntque ut aliquis obitèr inspiciens ramorum apices brevitèr cincinıatos dicat. $F$. spermophori exemplaria his destituta formâ habituque generali non adeò longè recedunt ab $F$. crispi varietatibus minimis angustissimisque; dum colore et texturâ $F$. coronopifolium magis referunt. Fructificatio quoque, qualem descripsit Rothius, similis est illius in posteriore hoc Fuco notatæ; tubercula vero in hâc nostrâ depicta tabulâ, quæ sola in præsens vidi, ab iis $F$.rubentis facie externâ tàm nullo modo discrepant, ut dubitari nequeat quilı maturorum structura interior quoque sit eadem. De Gunneri synonymo suprd citato necesse est ut illud jam sub $\S F$. vittato memoratun repetam; characterem enim specificum Linnæanum, quem de uno, de altero quoque profert, nihilo mutato adjectove, ut ex eâdem uterque prorsùs auctoritate pendeat; neque hæc mih: videtur satis per se valere, ut plantam Zeylonæ orarum Oceanique Indici certè incolam in Norvegiæ vegetabilium ascribanus numerum. Nonne potiùs est verisimile Gunnerum Tonningiumque ad aliam quandam per errorem transtulisse speciem characterem $F$. spermophoro a Linnæo impositum?

\begin{tabular}{|c|c|}
\hline c. frondis apex, cum fiuctu, magr & a. auct. \\
\hline d. tuberculium - - - & - $\quad-$ \\
\hline e. idem longitudinalitèr sectum & - \\
\hline
\end{tabular}

* Pedunculata dicit Koenigins quod tamen ego certè nunquam vidi : idem quoque memorat Rothius, qui capsnlas nostris quoad formam abludentes describit, et qui fructum nostro perfectiorem accepit, quanobrem exscribendum puto quod de hoc tradit. Stirps fortc̀ fructificatione duplici gaudet.- "Capsula globosæ, acumine brevi terminatæ, sub-pellucidæ, granulis minutissinis, flavescentibus farctæ, laterales, sparsæ, tamen copiosæ, pedunculatæ, denum infra apicem laterc transversim dehiscentes, magnitudine seninis Papareris. Pedunculi tertiam lineæ partcm vix superantes, nudi, teretinsculi."

$\dagger$ Duplicem etiam crescendi modum in hoc Fuco memorat Rothius, cujns tamen de hâc re observationes nequaquàm cum meis conveniunt. Dicit illc: "Rumuli in sterilibus specininibus; quæ mascula salutare audeo, numerosissimi ; terminales dilatati, palmato-multifidi, apicibus sub inerassatis, obtusis : in capsuliferis laxiores; terminalcs bifidi, furcati, acuminati."

$\ddagger$ Singulari, uti milhi videtur, modo de his sentit Esperus, qui e fructu natos autumat; nempe seminibus dum in capsulis adhuc includuntur germinantibus, atqune ita progeniem novan parenti parasiticè adnatam ferentibus.

§ Confer Ton:, I. p. 144. 
Fucus, fronde sub-cartilaginể, terete, filiformi, dichotomâ, fastigiata ; ramis patentibus, summis divaricatis ; apicibus obtusis, sterilibus sub-incrassatis, fructiferis rotundis.

Fucus Forsteri. Mertens, M. SS.

HaBıtat in Novâ Selandiâ. Thunberg.-In Novæ Hollandiæ oris, aliis plantis marinis innascens.

Annua?

RADIX callus minutissimus.

Frons teres, filiformis, longitudine bi- tri- pollicaris, fili emporetici minoris crasside, furcis juxta basin incipientibus, et mox decies pluriesve repetitis dichotoma, spatio inter inferiores longiusculo, inde sensim magis magisque abbreviato, ut sit in summis brevissimum; rami omnes sub-fastigiati; dichotomiarum anguli patentes, supremarum tamen divaricato-patentes; apices breves, obtusi, ut propemodùm truncati appareant.

Fructificatio frondis ad apices sita, qui tunc intumescunt, et tuberculorum subrotundorum faciem præ se ferunt: intra hos latent semina plurima, intensè rubra, sphærica, limbo pellucido cincta, dissepimentisque pellucidis in tres quatuorve partes intùs distincta; sunt quoque præter hæc in tuberculis alia corpuscula his multoties minora, coloris et formæ ejusdem, sed limbo dissepimentisque carentia.

Co Lor pallidissimè ruber, propemodùm carneus; exsiccata aurantiacus.

SuBst ANTI A tenera, cartilaginea, ad gelatinosam tamen accedens.

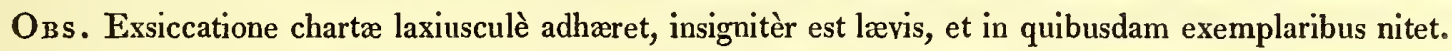

Exemplar hujus Fuci, ab illust. Equite C. P. Thunberg olìm acceptum, multos abhìnc annos ad me misit D. Prof. Mertens, F. Forsteri nomine adjecto, unde conjicere licet esse primùm ab J. R. Forstero filioque suo, dum orbem circumnavigarent, detectum. Plantam, quam hæc tabula exhibet, Menziesii amicitiæ sæpe jam in hoc opere memoratæ debeo, qui nuperiùs Novæ Hollandiæ ad oras copiosè legit. Pulchella est stirps, et quæ magnitudine, texturâ, atque colore propiùs ad $\boldsymbol{F}$. obtusum quàm ad alium quemlibet mihi in præsens notum accedit. Fieri etiam potest ut, illius instar speciei, ferat quoque in tuberculis ovatis semina pyriformia : neque tamen est negandum qudd nulla ex iis quæ hactenus vidi speciminibus tale aliquid arguant; neque Botanicum aliquem latebit quantùm sint semina formâ et facie illorum in $F$. obtusi apicibus occurrentium dissimilia, aut quanto magis quàm in illâ stirpe frondis extremitates capsulas referant. Memorantur suprà in descriptione et in tabulâ delineantur duo seminum genera in his extremitatibus reperta, quorum forsàn minima nihil sunt aliud nisi majorum diffractorum reliquiæ. Illud jam notandum restat ut, quamvis frondis totius divisurâ dichotomâ plerumque gaudeat hic Fucus, reperiantur tamen interdùm exemplaria quæ potiùs caule indiviso ramis alternis repetito-dichotomis obsito præedita diceres: horum peripleria sub-pyramidalis, minusque in hoc statu quàm in sueto interest inter hunc Fucum et $F$. obtusum primo aspectu discrimen; F. Forsteri vero ramorum apices bifurci segmentis sub-divaricatis nunquam non ad distinguendum sufficient.

a. F. Forsteri, magn. nat.

b. frondis pars, magn. auct. $\quad-\quad-\quad-6$.

c. ejusdem apex - - - $\quad-\quad-5$.

d. unum e segmentis jam diruptum - $\quad$ - 3 .

e. semina - - - - - - 1 . 
Fucus Forsteri, frond sub-cartilaginous, cylindrical, filiform, dichotomous; branches patent, the upper ones divaricated, all of equal height ; apices obtuse, the barren ones slightly incrassated, the fructifying ones globular. Fucus Forsteri. Mertens, M.SS.

New Zealand. Sir C. P. Thunberg.-Coast of New Holland, parasitical upon other Fuci. Mr. Menzies.

Annual?

Root, an extremely small callous disk.

FroND, cylindrical, filiform, two or three inches long, and not thicker than a pack-thread, forked near its base, and afterwards ten times, or more frequently, dichotomous, the distance between the lower divisions being rather long, and thence gradually shortening, so that in the upper ones it is very small; the branches are all of nearly equal height; the angles of the dichotomies are patent, excepting the extreme ones, which are between divaricated and patent, the apices are short, and so blunt, as to appear almost truncated.

Fructification, placed in the ends of the frond, which then swell, and resemble small roundish tubercles, containing numerous dark-red spherical seeds, surrounded by a pellucid limbus, and internally divided by pellucid lines into three or four parts: besides these, there are also in the tubercles other granules, of the same color and form, but many times smaller, and destitute both of the pellucid limbus and the dissepiments.

CoLOR, an exceedingly pale red, almost carnation, in a dried state approaching to orange.

SUBSTANCE, tender and cartilaginous, but inclining to gelatinous.

Oвs. When dried it adheres loosely to paper, is particularly smooth, and in some cases shines.

I received many years ago, from Professor Mertens, a specimen of this Fucus, which was communicated to him by Sir C. P. Thunberg, and was marked with the same name as is here given to it, from which I apprehend that it was originally gathered by John Reinhold Forster and George Forster, in the course of their voyage round the world. Mr. Menzies has since found it growing in considerable plenty upon the coast of New Holland, and it is to him that I am indebted for the individual figured in the present plate. It is a pretty Fucus, approaching in size, texture, and color, more nearly to $F$. obtusus than to any other species with which I am acquainted. Probably, too, like that plant, it bears also pyriform seeds in ovate tubercles, though in none of the specimens that $I$ have at present seen, either from Professor Mertens or Mr. Menzies, is there any vestige of the kind; and it will be observed, that the seeds are, both in shape and appearance, very different from those found in the extremities of $F$. obtusus, and that the apices wear more the look of capsules. Of the two-fold granules, above noticed as occurring in these, the smaller ones may possibly be the contents of some of the larger that have burst. Though the dichotomous ramification of this plant is alone mentioned in the description, it deserves to be remarked, that specimens are occasionally met with, which seem rather to rise with an undivided stem beset with alternate, repeatedly dichotomous branches, in which case the outline of the whole approaches to pyramidal, and its general appearance is then still more like that of $F$. obtusus than in its more common form, but it is at all times distinguishable by the forked nearly divaricated exiremities of the shoots.

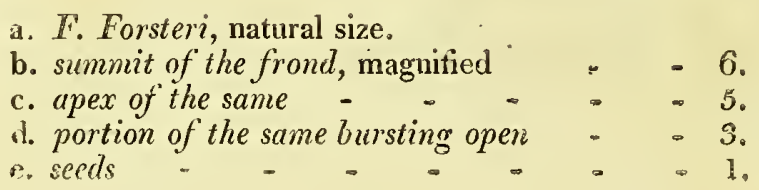



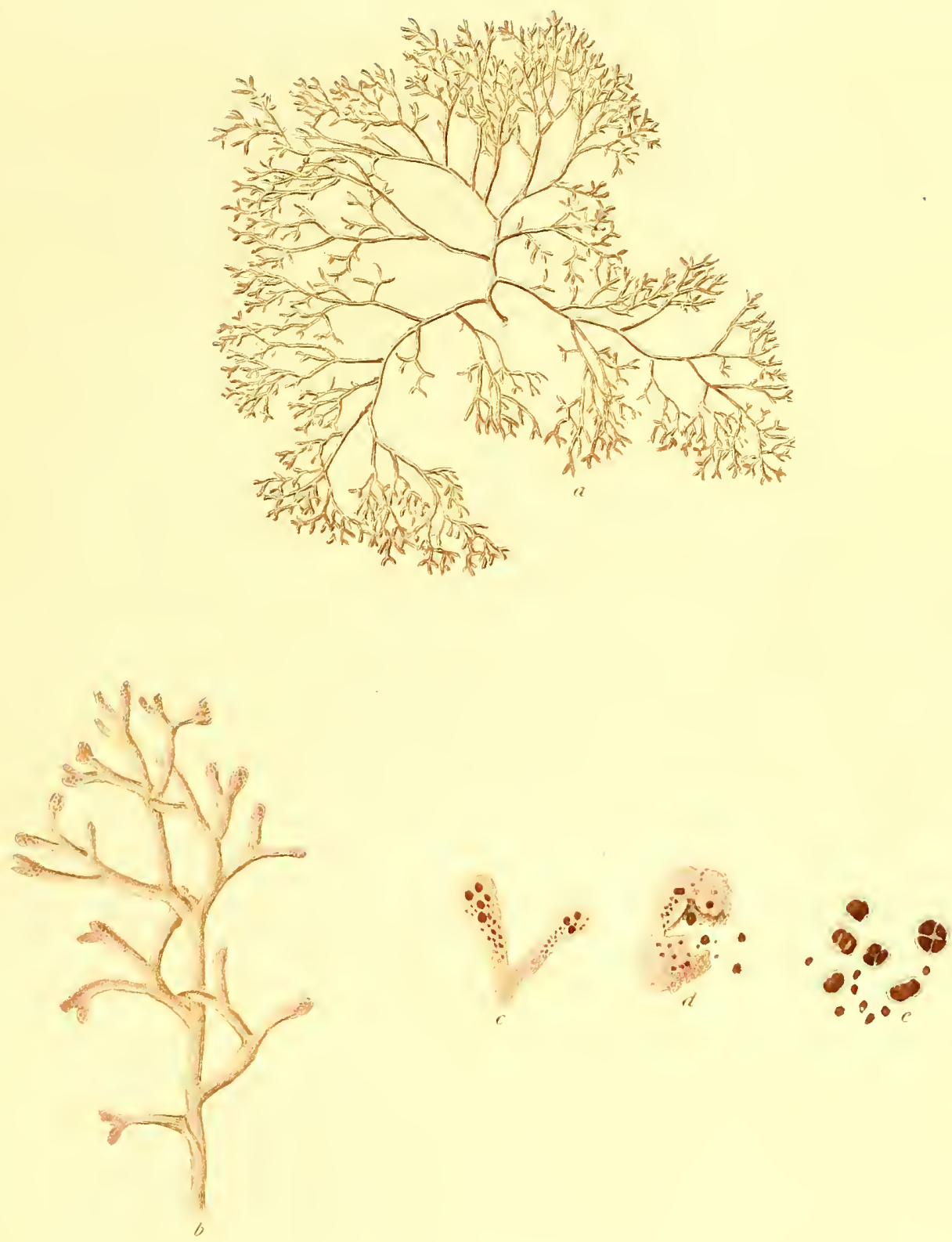

- fucues Sinsters: 

Fucus, fronde cartilagineâ, terete, filiformi, sub-dichotomâ, laxè vestitâ ramulis horizontalibus, sparsis, subulatis, simpliciusculis, brevibus : tuberculis sphæricis, in ramulis sessilibus.

Habitatin Mari Rubro. Vicecomes de Valentia.

Annua?

RADrX.callus exiguus, discoideus, fibris aliquot crassiusculis, incurvis, repentibus, et mox in-novas frondes assurgentibus instructus.

FroN DEs ex eâdem basi plurimæ, teretes, filiformes, flexuosæ, quatuor pollices longæ, pennæ passerinæ crassitie, apices versus acuminatæ, instructæ caule, nunc indiviso, nunc bis ter dichotomo, furcis patentibus, a basi usque ad extremitates laxè obsito ramis vagis sub-horizontalibus, his duos pollices, illis vix unguem longis, majoribus minoribus immixtis, ipsis vel simplicibus, vel caulis ad instar divisis, vel ramos alios minores sustentantibus, et omnibus, sicut est caulis, ubique obsitis ramulis sparsis, horizontalibus, lenitèr incurvis, aculeiformibus, lineam, sesqulineamve longis, simplicibus, bifurcisque, et sese aliquandd in novos ramos producentibus.

Fructificatro tubercula sphærica, Silenes anglica seminibus vix majora, rubra, ramulorum ad latera sessilia, unum vel duo in singulis, seminum oblongorum rubrorum congeriem intùs foventia.

COLOR ærugineus, violaceo, et quandoque fusco tinctus, diaphanus; exsiccata intensior; marcescentis dilutễ virescens, et demùm albicans.

Substantia sub-cartilaginea, tenera, mollis, debilis.

OBs. Exsiccata chartæe non adhæret.

Quanto studio in scientias omnigenas promovendas incubuit nobilissimus Vicecomes de Valentia, qui, harum ingenti percussus amore, iter per Indiæ Orientalis plagas primus nostratium hanc tantùm ob causam confecit, satis omnibus jam notum; supervacaneumque prorsùs' foret, si. plaribus demonstrare conarer, quàm justè, nomen suum stirpi pulchellæ hìc depictæ indendo, tributum meritis debitum (minimum id quidèm, sed unicum quod penes me est) pendo. Magnis illi Historia Naturalis, maximisque hoc opus beneficiis astringitur, ad quod auxiliandum, uti jam suprà plus unâ vice menıoravi, Fucorum in Mari Rubro lectorum ditissimum thesaurum, species multas nondùm descriptas et plures antehàc paullum cognitas includentem, summâ cum benevolentiâ communicavit. Paucas modò jactat Algarum submersarum catalogus stirpes quibus $F$. Valentice elegantiâ cedit, presertìm si frondis colorem spectes, qui ab illo plurimarum aliarum abludit, et in recente pulchritudinem majorem a tuberculis superimpositis coccineis trahit. Hæc res sola sufficit per quam $F$. Valentice a congeneribus distinguatur; sed et alia eaque maximè insignis nota a ramulis horizontalibus ducitur, qui caulem ramosque vestiunt, atque ita densè in quibusdam disponuntur exemplaribus ut tota ferè cooperiant. Hi faciunt ut appropinquet hæc planta ad $F$. acicularem Wulf. cujus color intensè ruber, et substantia tenax est atque cartilaginea; arctiùs verd ad $F$. muscoidem Wulf. ramorum apicibus incurvis cirrhiformibus insignem; et ad $F$. Nootkanum Esp. cujus in colore dissimili præcipuum ponitur discrimen. Neque tamen silentio est prætereundum specierum trium jam memoratarum fructificationem in præsens latere, quæ forsan characteres certiores magisque manifestos suppeditabit. Quamdiu verò hæc latere perget, nollem sententiæ meæ impensiùs instare, licet enim persuasum mihi habeam hos omnes Fucos esse inter se revera distinctos, expertus tamen scio quatenus hæ plantæ formâ ludere solent, ut de Britannicorum, nedùm exoticorum, discriminibus specificis sæpe sit difficile aliquid pro certo dicere.

a. F. Valentia, magn. nat.

b. ramus, magn. auct. - $\quad-\quad-\quad-6$.

c. ejusdem pars - - - - $\quad-\quad-4$

d. tuberculum longitudinalitèr dissectum - 3.

e. semina (fibris immixta?) - - - - 2.

f. semina - - - - - - - 1. 
Fucus Valentia, frond cartilaginous, cylindrical, filiform, mostly dichotomous, beset with horizontal, scattered, subulate, short, generally simple ramuli: tubercles spherical, sessile on the ramuli.

In the Red Sea. Viscount Valentia.

\section{Annual?}

Rooт, a small, callous disk, furnished with a few, thickish, incurved, creeping fibres, which afterwards grow up into new plants.

Fronds, numerous from the same base, cylindrical, filiform, flexuose, four inches long, of the thickness of a sparrow's quill, acuminated at the apices, furnished with a stem, either undivided, or two or three times dichotomous, with patent segments, beset from base to summit with loosely scattered, nearly horizontal branches, of various lengths, from half an incl to two inches, long and short being mixed without any regularity; these also are in some instances simple, in others, divided in the same manner as the stem, and again, in others, produce a series of still smaller branches; the whole of them, as well as the stem, are every where beset with horizontal, slightly incurved, spiniform ramuli, more closely arranged in some specimens than in others, and least so towards the apices, a line, or a line and half long, some simple, some forked, and some occasionally lengthening into new branches.

Fructification, spherical tubercles, about the size of the seeds of Silene Anglica, of a bright red color, sessile on the sides of branches, and one or two on each, containing a mass of minute, oblong, red seeds.

CoLOR, a deep verdigris green, tinged with purple, and occasionally with brown, transparent, turning in decay to a paler green, and at length to white.

SUBSTANCE, sub-cartilaginous, tender, soft, and weak.

Oвs. In drying it does not adhere to paper.

The services rendered by Lord Valentia to every department of science, and not least to that of Natural History, are too well known to the world in general, for it to be necessary here to offer any observations on the subject, for the purpose of shewing the propriety of making the insignificant return, the only one in my power, of aftixing his name to the elegant little plant figured in the plate before us. I may, however, be allowed once more to express the particular obligations that I feel myself under to him, for the assistance which he has given to this work, by communicating to me most liberally, for the sake of promoting it, the whole of the beautiful collection of submersed Algax, nuade by himself in the Red Sea, and not only containing many nondescript species, but throwing great light upon several others previously described, though imperfectly known. In this collection, and indeed in the whole catalogue of the Fuci, there are few plants more elegant than F. Valentia, particularly in point of its color, which is very unlike that of the greater part of the marine Algæ, and is, when moist, especially if observed under a microscope, beautifully relieved by the red tubercles of the fructification. This single circumstance is alone sufficient to distinguish F.Valentice from its congeners, but it has also another strong character in the horizontal ramuli that clothe the stem and branches, resembling spines in their form, and being in some specimens so numerous as nearly to cover the whole frond. By means of these, it approaches to F. acicularis of Wulfen, a plant of a deep-red color, and stiff cartilaginous texture; but much more nearly to $F$. muscoides of Wulfen, remarkable for the incurved tendril-shaped ends of its branches; and to $F$. Nootkanus of Esper, in the different color of which consists the principal dissimilarity between them. Of these three latter the fruit remains at present unpublished. I should be sorry to speak with any thing like the positiveness of confidence upon a point which is so little understood as the specific characters of exotic Fuci, and where our opportunities of deciding are necessarily so few and so imperfect; it is, however, my opinion, that $F, V$ alentia is really distinct from those just mentioned, and from all others at present described.

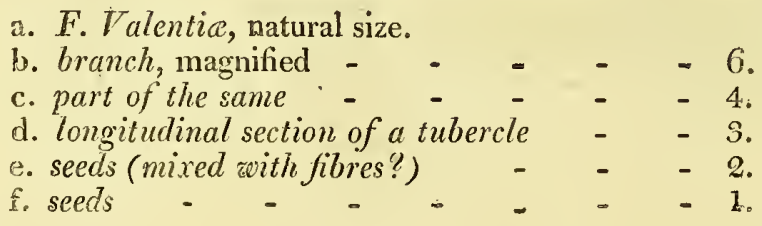




$$
\underbrace{2}
$$



Fucus, fronde membranaceâ, teretiusculâ, filiformi, ramosissimâ, laxè vestitâ ramulis horizontalibus, subulatis, bi- tri- furcis, apice in siliquas lanceolatas intumescentibus.

Fucus hamulosus. EsPER, Ic. Fuc. I. p. 129. t. 89.

Ha вiтar in Mari Rubro. Vicecomes de Valentia.-Ex Indiæ Orientalis littoribus, Corallina Opuntic adnatam, accepit Esperus.

\section{Annua?}

RADIX, quam ego nondùm vidi, est, teste Espero, callus aded exiguus ut visum ferè fugiat.

Frons teretiuscula, vel levitèr compressa, filiforınis, longitudine circitèr palmaris, Motacilla troglodytis pennæ crassitie, variè flexuosa, a basi usque ramosissima, ramis laxiusculè sparsis, implexis, horizontalibus, his elongatis et duos pollices, illis brevioribus et vix unguem longis, majoribus minoribus immixtis; sunt etiam nunc simplices, nunc bis ter dichotomi, furcis patenti-divaricatis, nunc aliis minoribus, ipsis quoque horizontalibus, laxè dispositis, et longitudinis incertæ, obsiti : frondem totam a radice ad apices occupant ramuli plùs minùs densè locati, lineam sesquilineamve longi, bifurci, aut iterùm atque iterùm dichotomi, segmentis minutissimis, acuminatis.

FRUCTIFICATIO ramulorum ad apices sita, qui tunc intumescentes siliquarum perquàm exiguarum, lanceolatarum, compressarum, coloris dilutè rosei, speciem præ se ferunt, seminaque includunt plurima, rubra, oblonga, enormitèr tamen angulosa.

CoLOR pallidè miniatus, fusco perfusus, diaphanus, marcescentis albicans.

Substantia membranacea, succosa, mollis, tenerrima, flexilis, perquàm debilis.

Oвs. Habitus variè implexus, et substantia ita flaccida, ut post siccitatem madefacta ægrè in pristinam revocetus: formam :- exsiccata chartæ adhæret.

Dubitabit, uti credo, nemo Botanicus, qui crescendi modum in hoc Fuco perquàm singularem respicit, quin sit onninò eadem stirps quam sub $F$. hamulosi nomine descripsit et delineavit Esperus, ejus licet icon ab hâc nostrâ insignitèr in eo discrepet, quòd plantam colore intensè fusco non sine purpurascentiâ aliquâ donatam exhibeat. Exemplaria quoque ab illo visa fructificatione caruerunt, et non modo nostris minora fuerunt, verùm etiam hanc forsan ob causam quodammodò imperfecta, quia Corallina Opuntice ramis implicita iis aded arctè hæserant, ut difficile, imò impossibile, fuerit integritate salvâ extricare. Character hujus speciei essentialis, quod statìm cuivis patebit, in ramulis ponitur; quorum forma singularis non modo valet ad distinguendam stirpem ab omnibus aliis mihi hucusque notis, sed facit ut ægrè dicamus cuinam inter omnes maximè sit affinis. E frondis tenuitate totiusque facie delicatâ $F$. hamulosus primo aspectu Confervam simulat, nec desunt huic generi multæe species quarum filamenta cjus ramos magnitudine superant.

a. F. hamulosus, magn. nat.

b. ramus, magn. auct. - - - - - 5.

c. ejusdem pars - - - - $\quad$ - 4 .

d. apices seminiferi - $\quad-\quad=3$.

e. semina - + - - + - $3_{3}$ 
F'ucus hamulosus, frond membranaceous, nearly cylindrical, filiform, much and irregularly branched, beset with horizontal, subulate, repeatedly forked ramuli, the apices of which swell into lanceolate pods.

Fucus hamulosus. EsPer, Ic. Fuc. I. p. 129. t. 89.

In the Red Sea. Viscount Valentia.-Sent from the Malabar Coast, growing upon Corallina Opuntia, to Professor Esper.

\section{Annual?}

RooT, which I have not yet seen, is, according to Esper, a small, scarcely visible, callous disk.

FroND, nearly cylindrical, or slightly compressed, filiform, three or four inches long, of the thickness of a wren's quill, flexuose, much and irregularly branched from the very base upwards; branches scattered loosely and withous order, entangled, horizontal, some in length equal to two inches, others to scarcely half an inch, great and small mixed together, they are also in some instances simple, in others, twice or thrice dichotomous, with segments between patent and divaricated, and again, in others, beset with a series of smaller ones, which also are horizontal, loosely scattered, and of various length: the whole frond from base to summit is clothed with ramuli, more or less closely arranged, a line or a line and half long, either forked, or twice or thrice dichotomous, with extremely minute acuminated segments.

Fructification, situated at the extremities of the ramuli, which then swell into the form of very minute, compressed, lanceolate siliquu, of a pale pink color, and contain numerous, red, irregularly oblong seeds.'

Color, a pale, transparent, bright red, slightly tinged with brown, turning to white in decay.

SuBstaNCE, membranaceous, juicy, soft, very tender, flexible, and flaccid.

Oвs. The growth of this species is variously entangled, and the substance so flaccid, that, after it has been dried, it can with difficulty be brought back to its proper shape.-In drying it adheres to paper.

From the peculiar mode of growth of this plant, no doubt, I think, can be entertained of its being the same Fucus as is intended by Professor Esper under the name of $F$. hamulosus, though his figure differs very materially from mine in point of the color, which he represents a dark and purplish brown. His specimens also are destitute of fructification, and, besides being smaller than the subject of the present plate, are also rendered in some degree less perfect from the circumstance of their having grown so entangled among the branches of Corallina Opuntia, that it was difficult, if not impossible, to separate them without injury. It will immediately be observed that the ramuli constitute the leading character of this species, and these are in point of form so remarkable, as not only to distinguish it from all others, with which I am at present acquainted, but even to render it difficult to point out the one to which it is most nearly allied. The exceeding tenuity of the frond, and delicate appearance of the whole plant, make it look at first sight like a Conferva, in which genus there are many individuals of larger size.

a. F. hamulosus, natural size.

b. branch, magnified - $-{ }^{-}-5$.

c. part of the same - - - - 4 .

d. fruil-bearing apices - $\quad$ - $\quad-3$.

e. seeds - - - - . - 2. 

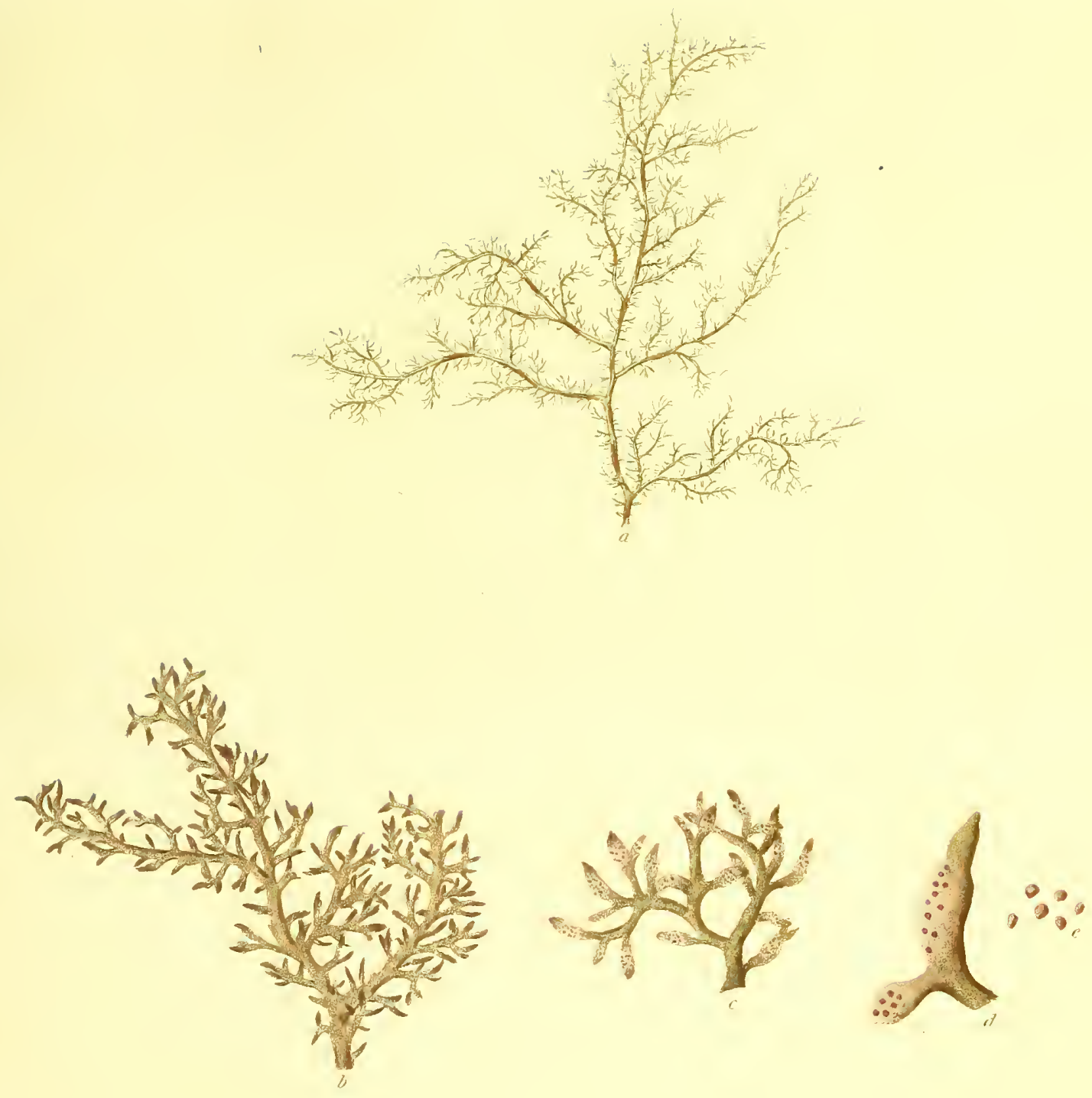

Fuces hermulons. 
Fucus fronde membranaceâ, tenerrima, planâ, enervi, lobatâ; lobis obtusis, margine planis integerrimisque : tuberculis hemispliæricis, umbonatis, immersis, ubique sparsis.

Hав гт Aт in Sinu, "Bantry Bay" dicto, haud infrequens. Dra Hutchins.

Annua? Junio, Julio.

RADrx callus exiguus.

Frons plana, nervi venarumque prorsùs expers, longitudine tri- quadri- pollicaris, a basi angustissimâ statim dilatata, seque sensim magis magisque amplians, ut peripheria sit propemodùm subrotunda, plerumque ad medium circitèr fissa in duas tresve lacinias sub-æquales, omnes sursùm dilatatas, omnesque, cùm ad margines tùm ad apices, lobatas, lobis numerosis, plùs minùs profundè incisis, ut plurimum unguem lougis semiunguemque latis, simplicibus, blifurcisve, linearibus, lenitèr rotundatis, vel sub-truncatis : margines plani, integerrimi, nunquam crispati, crenative.

FRUCTIFICATIO tubercula hemisphærica, apice in recentibus brevitèr mucronata, ubique per frondem sparsa, et in ejus substantiâ immersa, Brassica Rapa seminum magnitudine, diaphana, ut semina, quæ inclıdunt, enormitèr subrotunda, saturatè rubra transluceant :- - semina in fronde nuda nulla vidi.

Co Lo R dilutè, sed amœenè, roseus; marcescentis vel soli objecta sordidè albescens.

Su bstantia membranacea, tenuissima, et tenerrima.

OBs. Frons sub lente pulcherrimè reticulata :-exsiccata chartæ arctè adhæret.

Summâ uon sine dubitatione lìc pro novâ distinctâque specie exhibeo Fucum, cui talis est cum $\mathbb{F}$. punctato et $F$. lacerato, jam in hoc opere depictis, affinitas, ut sedem inter eos prorsùs intermediam teneat, consentiatque cum hoc, colore habituque, quod aiunt, generali, margines verò integerrimos planos fructumque per totam frondem enormitèr sparsum cum illo communes habeat; dum substantiâ uno tenuiore altero crassiore gaudet, recentisque tubercula, teste Dna Hutchins, magis quàm in utroque mucronata prominent. Omnes has tres stirpes in littoribus apud Bantry Bay reperire solet lectissima hæc virgo, quæ specie inter se revera differre arbitratur, et cujus sententiæ, summi semper ponderis, ed nunc libentiùs in hoc assentior, quod ipse $\boldsymbol{F}$. ulvoidem nunquam nisi exsiccatum viderim, neque sit exsiccatis impensiùs in re dubiâ instandum. Quamvis igitur characteres qui mihi satisfaciunt hucusque detegere nequiverim, haud igitur illud impedivit quo minus hanc plantam publici juris facerem, cùm Botanicorum aliorum animos hùc alliciendo rem tandem dijudicandam sperem, et, si huic demùm negetur Fuco speciei genuina gradus, saltèm nos cognituros confido cuinam sit in posterum rectè associandus. Præter exemplaria a Dnâ Hutchins missa, ad quæ descriptio nostra et icon sunt confectæe, alia quoque nuper communicavit Dna Hill, ab ispâ juxta Plymouth anno proximo lecta, quæ ad $\mathcal{F}$. ulvoidem fortè pertinent, substantia licet firmior et color intensior dubitationem injiciant. Altera etiam est mihi stirps, sed sterilis, cùm a Dná Hutchins tùm a D. Brodie accepta, cujus frons linearis et ubique dichotoma longitudine vix palmum latitudine vix quatuor lineas æequat. Hanc quoque ob colorem texturam et habitum $F$. ulvoidi conjungendam autumo, sed non est ut de re incertâ certè loquar. Nomen ducitur a similitudine quæ interest inter $F$, ulvoidem plurimasque plantas Ulva generi jam associatas.

a. F. ulvoides, magn. nat.

b. frondis pars, magn. auct. - $\quad-\quad-5$.

c. ejusdem portio - - - - $\quad$ - 3.

d. $\operatorname{semina}-\quad-\quad-\quad-1$. 
Fucus ulvoides, frond membranaceous, very tender, flat, nerveless, lobed; lobes obtuse, flat, and quite entire at their margins : tubercles hemispherical, umbonated, immersed in the frond, and scattered all over it.

In Bantry Bay, not uncommon. Miss Hutchins.

Annual? June, July.

Root, a small, callous disk.

FroND, flat, quite destitute of veins or midrib, three or four inches long, at its base very narrow, but immediately widening, and gradually expanding more and more, till its outline becomes nearly orbicular, in general entire for about half its height, and thence divided into two or three segments of nearly equal size, all of them expanded upwards, and all lobed both at their margins and apices with numerons lobes, of uncertain depth, but for the most part half an inch long, and a quarter of one wide, either simple or forked, linear, slightly rounded at their extremities, or sub-truncated: the margin of the frond is every where flat, and quite entire, never either curled or crenated.

Fructification, hemispherical tubercles, tipped, when recent, with a minute mucro, scattered all over the frond, and immersed in the substance of it, as large as turnip-seed, and transparent, so as to shew the roundish darkred seeds that it contains:-I have seen no naked scattered seeds upon the frond.

Color, a pale, but pleasant, pink, turning in decay, or from exposure to the sun, to a dirty white.

SUBSTANCE, membranaceous, extremely thin and tender.

OBs. When viewed through a microscope, the frond appears most beautifully reticulated:-in drying it adheres firmly to paper.

It is not without the greatest hesitation, that I venture upon proposing the present plant as essentially distinct from $F$. laceratus and $F$. punctatus, already published in the first volume of this work; since it is altogether intermediate between them, agreeing with some of the varieties of the former, especially the var. $\gamma$, in its color and general habit, and with the latter in its want of veins, in its flat entire margins, and in having its fructification indifferently scattered over all parts of the frond: while its substance is neither so thick as the one, nor so thin as the other, and its tubercles, according to Miss Hutchins, are, in fresh specimens, considerably more prominent and pointed than in either. I have also the opinion of this highly accomplished lady, who is in the laabit of gathering all the three plants recent upon the shores of Bantry Bay, in favour of their being specifically distinct; but I must nevertheless frankly confess, that, having examined only dried specimens, I feel myself unable satisfactorily to discover, and still more so to describe, the characters that separate them; and that $I$ am rather induced here to figure $F$.ulvoides, in the hopes, that, by so doing, the attention of other Botanists may be called to it, than in the certain expectation that it will be allowed to retain its place as a permanent species, though, if it be not so, I am at loss to which other it would most properly be referred. Besides the specimens collected by Miss Hutchins, from which the present figure and description are taken, I have lately been favoured by Miss Hill with the sight of some others, gathered by her last year in the neighborhood of Plymouth, which, though they differed in their darker colour and firmer texture, appeared to me to belong to the sanıe species, and to bring it nearer to $F$. laceratus. I have also received, both from Miss Hutchins and Mr. Brodie, another plant, but without fructification, of which the whole frond is not above three inches long, and every where dichotomous, with linear segments about four lines wide. This too, from its color, texture, and habit, I am inclined to refer to $F$. ulvoides, but, in a matter of so much difficulty, I feel it impossible to speak with any thing approaching to positiveness. The name of $F$. ulvoides is derived from its being in appearance no less allied to the Ulve than the Fuci.

a. F. ulvoides, natural size.

b. part of the frond, magnified - - 5.

c. smaller part of the same - $\quad$ - 3.

d. seeds - - - - -1 .

\footnotetext{
* It was my original intention that this plant should have immediately followed $F$. punctatus, and been the last plate of the first volume, under which idea, it is included in the Index, and is referred to in the description of $\boldsymbol{F}$. punctatus, where it is observed how nearly that plant is allied to the followin one. This design was, however, frustrated by the necessity of clesing the volume with the 71st figure, contrary to my expectation; and I therefore feel it necessary to apologize to my readers on the subject, trusting they will excuse an inaccuracy that has arisen fiom the distance of my residence from wy publishers.
} 

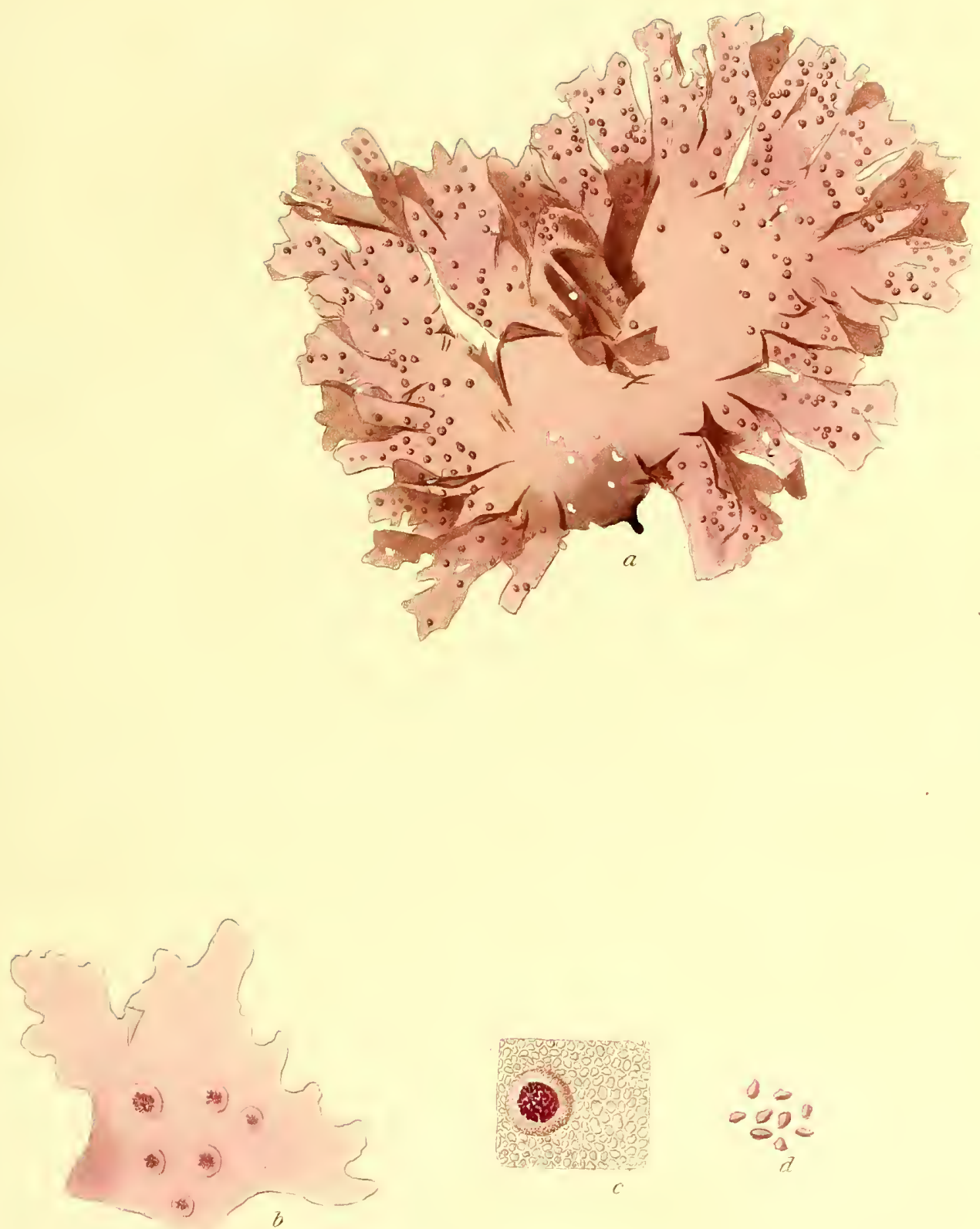

Sucus utronides 

Ficus, fronde sub-gelatinosâ, teretiusculâ, filiformi, vagè dichotomâ, infernè nudâ, supernè ramulis ellipticis, simplicibus, undique imbricatis obtectâ; seminibus sparsis, nudis, tuberculisque in ramulis hemisphæricis.

Fucus ovalis. Fl. Ang. p. 573. Wiтн. IV. p. 112. Linn. Trans. IIl.p. 116. Eng. Bot. X.t.711. Syn. Fuc. I. p. 30.

F. sedoides. Linn. Trans. III. p. 117. Ner. Brit. p. 67. t. 12.

F. vermicularis. Gmelin, Hist. Fuc. p. 16.. t. 18. f. 4. Syst. Nat. Ed. Gmel. II. p. 1386. Fl. Scot.II. p. 958. Fl. Fr. Ed. 2 da. II. p. 27.

F. polypodioides. Gmelin, Hist. Fuc. p. 186. Syst. Nat. Ed. Gmel. II. p. 1388.

F. uvarius. EsPer, Ic. Fuc. I. p. 153. t. 78. (excl. syn. Linn.)

F. mollis candicans foliis vermiculatis. REAMU R, in Act. Gall. 1712. p. 40. t. 4. f. 8.

$\beta$ botryoides; ramulis abbreviatis, sub-globosis.

F. botryoides. Wulfen, in Jacqu. Coll. III. p. 146. t. 13. f. 1. Fl. Fr. Ed. 2da. II. p. \&6.

F. uvarius. Wulfen, Crypt. Aquat. n. 3. (excl. syn. Linn.)

y. sub-articulatus; ramulis elongatis, linearibus, articulato-contractis.

Навгтат in Angliæ, præsertìm Australis, oris.-In Hiberniâ septentrionali. D. Templeton.-In Sinu Bantry Bay, copiosissimè. Dna Hutchins.-In Galliæ Australis oris. Decandolle. - $\beta$ in Fucorum majorum caudicibus Tergesti. Baron de Wulfen.-Inter rejectamenta maris apud Yarmouth, F. lorei radici innascens, rarissimè.- $\gamma$ in Devoniæ littoribus. Dna Griffiths._A pud Nootka Sound. D. Menzies.

Annua. Jun.-Aug.

RADIx callus exiguus, discoideus, fibris aliquot instructus brevibus, repentibus, sese hìc illic in discos callosos explanantibus, et in novas frondes assurgentibus.

FroNDES ex eâdem basi plurimæ, densè cæspitosæ, singulæe instructæ caule 3-7 pollicari, teretiusculo, Merulæx pennæ crassitie, flexuosè erecto, nunc simplice, nunc bis terve, præsertìm apices versus, vagè dichotomo, et. nunc ramis aliquot brevibus, his horizontalibus, illis patentibus, aut etian erectis, sparsìm instructo, semper quà basi proximus et plerumque ad mediam et ultrà longitudinem nudo, exinde obsito ramulis, infernè remotiusculis, sed quò magis ad apices accedis ed densiùs dispositis, et ad extremitates confertis; * ramuli (folia si mavis cum plurimis auctoribus dicas,) undique imbricati, horizontales, ortu sub-globosi, adulti ovales, aut ex ovali cylindrici, apice rotundati, basi attenuati, ut per punctum tenuissimum ramis adhæreant, et, licet revera sint sessiles, exsiccatione brevitèr petiolati videantur, simplices, aut, quod raro accidit, alio minore proliferi; longitudo his plerumque bi- tri- linearis, crassities Corvi Merulæve pemnæ, solent tamen magnitudo et forma in eodem individuo ludere, ita ut inferiores unguem superiores vix lineam æquantes, et hos ovatos illos cylindraceos haud raro cernas.

FrUCTIFICATIo duplex, in diversis individuis, utraque ramulis imposita, hac e tuberculis constans hemisphæricis, papaveris semine dıplo minoribus, sessilibus, seminum pyriformium intensè rubrorum congeriem includentibus; illa e seminibus sparsis, nudis, sub-rotundis, in tres partes dehiscentibus.

Color diaphanus, ruber, nunc fusco, nunc purpurascente, et nunc gramineo tinctus, in caule obscurior, et aliquandò juxta basin ferè nigricans; marcescentis aut soli diu objecta in sordidè virentem, et demùm in albicantem transit.

Substanta in caule cartilaginea, et recentis rigidiuscula, quæ tamen citissimè fit lenta et flaccida, in ramulis pulposa, tenerrima, et gelatinosa.

Var. $\beta$ in eo discrepat qudd ramuli omnes insignitèr conferti formæ sint ferè splæricæ, et diametro vix lineam superent: totius quoque stirpis statura est minor, et color intensior.

y ramulos habet propemodùm pollicem longos, et, quod maximè est singulare, evidentèr constrictos, ut primo aspectu verè articulati appareant, articulis brevibus, ellipticis: hìc illic etiam, ubi contrahuntur, proliferi sunt aliis ramulis minoribus sparsis:-in exemplare hìc depicto, quod e Nootka Sound allatum sub $\boldsymbol{F}$. sedifolii nomine in Herbario Banksiano servatur, facies articulata minùs est manifesta quàm in. Britannicis, et ramuli sunt breviores, sed inter hos non desunt qui sunt bifidi, et ramulorum dispositio disticha et totius stirpis color inter viridem et aquosè lilacinum a nostris aded recedunt ut delineandum crederem.

Ов. Tota planta insignitèr lævis :--exsiccata chartæ arctè ad̉æret

Cùm plurimi Botanici, iique quorum judicio maximè obsequendum existimo, F. ovalem in duas dispertiverint: species, invitè admodùm in contrariâ ipse sententiấ persto, neque facerem, nisi cogeret omne illud quicquid de hâc stirpe in loco natali observavi. Ad secùs sentientium numerum accessit jam Mertensius, qui, collatis exemplaribus $F$. nostri ovalis cum iis $F$. botryoidis Wulf. in ipsius herbario servatis, multa et ea magni momenti inter lias stirpes discrimina intercedere perhibet. Quænam sint lææc, præsens orbis terrarum status prohibet ne quæramus; licet autem mihi alterâ ex parte memorare, quòd ipse quoque F. botryoidem a Wulfenio missum sedulò lustraverim, et neque in hoc nec in descriptione et icone ab illo datis aliquid repererim quod ad speciem a Britannicâ distrinctam constituendaun

sufficeret.

\footnotetext{
* Hos ramulos vesiculas dicit Wulfenius, mcmoratque esse "inflatas, tumentcs, inanes, acris plenas;" quotquot autem ipse dissecui semper muco aquoso pellueido compleri reperi. De horum statu exsiceato optimè habet idem: " extra aquam seriùs per desiecationem in scuta fornieata introlabentes, nec per rcimmersionem pristinæe porro restituenda figura. Ita siquidem infera vesieularum mcmbranula versus superioren introlabitur, cjusdemque eoneavitati apprimitur, ut, lieet aquæ rursum immergas, excluso jam aere, hand amplius sese restituat aut ab eâdem avellatır: desiccatum ideirco si quis fucum hune intueatur, nullas in eo conspiciet vesieulas; subtilia duntaxat iu eo se videre eredat folioli cochleariformia, aquosè flaveseentia, diapliana, sessilia, sub-ovata, concavo-convcxa, clypei seu scuti-formia, supernè convexa, sıbtus fornicato-concava, margine integerrima,"-Crypt. Aquat. p. 52.
} 
sufficeret. Immo etiam necesse est ut fatear nagis in dubio esse animum, utrùm rectè fecerim stirpem in dua varietates dividendo. Multo longiùs a vulgari plantæ facie recedit varietas y suprà descripta, quæ $F$. ovalem cum F. kaliformi quodammodd connectit; et quam, si unum modd e ramulis inferioribus abruptum inspiceres, facilè hujus fragmen crederes. Hanc, ab omnibus, quod scio, Botanicis antehàc prætermissam, prima et nuperrimè in nostris littoribus detexit Dna Griffiths. F. uvarius Linn., a multis auctoribus cum $F$. ovali commixtus, illum formâ tantum refert, ut, nisi nobis fuerit data facultas phytophylacium Linnæanum adeundi, error verisimillè in hunc usque diem indeprehensus permansisset. Nunc autem hujus ope compertum habemus horum indolem texturam et habitum summoperè discrepare, et forsitan est $F$. uvarius ad Zoophyta, quibuscum substantiâ siccâ corneâ et colore pallidè stramineo convenit, rectiùs relegandus. Credideram figuras, in Esperi icone suprà citat $\hat{n}$, 2-6 hunc tàm re quànı nomine exhibere, de quo tamen me in errore esse versatum edoceor; neque ulteriùs opus est ut utrumque a Wulfenio confusum putarem, quoniam specimina pressuræ nullæ vel minimæ subjecta satis illud explicant, quod de stirpis exsiccatæ facie memorat. Profitetur palàm Gmelinus se pro $F$. polypodioide suo totum e Martynii auctoritate pendere; neque mirum si plantam, quam tantunmodd in statu exsiccato et forsitàn haud etiam in illo viderat, Fucis membranaceis annumeraverit, aut si in systemate longè disjunxerit $a b F$. vermiculari, quamvis sint revera aliusque et idem. Optimè, pro more, de F. ovali dixit Wulfenius, " elegans si quis alius, rubro simillimus botro;" pigetque quodd nomen ab hâc similitudine depromptum mutare sim coactus. Inter Fucos nulli tàm arctè naturâ accedit hæc stirps quàm $F$. dasyphyllo, jam in hoc opere delineato, I. t. 22., quocum, et simùl cum $F$. tenuissimo et $F$. obtuso, segreganda est in posterum a Fucis folizs distinctis præditis, et in illorum fronde tereti donatorum numerum recipiendus.

a. F. ovalis, magn. nat.

b. frondis pars superior, cum seminibus sparsis, magn. auct. 6.

c. ramulus - - - - - - - - - 4 .

d. semina - - - - $\quad$ - $\quad-\quad-\quad-1$.

e. frondis pars, cum tuberculis - $\quad-\quad-\quad-\quad-6$.

f. ramulus - - - - - - - - -4 .

g. semina - - - - - - - - - 1 .

h. var. $\gamma$, magn. nat.

i. ranulus, magn. auct. $\quad$ - $\quad \ldots \quad-\quad-40$

\section{1.-F U C U S O V A L I S.}

Fucus ovalis, frond sub-gelatinous, nearly cylindrical, filiform, irregularly dichotomous, naked below, in its upper part clothed with elliptical simple ramuli, imbricated on all sides, bearing naked scattered seeds, and hemispherical sessile tubercles.

Fucus ovalis. Fl. Ang. p. 573. Wrтн. IV. p. 112. Linn. Trans. III. p. 116. Eng. Bot. X. t. 711. Syn. Fuc. I. p. 30.

F. sedoides. Linn. Trans. III. p. 117. Ner. Brit. p. 67. t. 12.

F. rermicularis. Gmelin, Hist. Fuc. p. 162. t. 18. f. 4. Syst. Nat. Ed. Gmel. II. :386. Fl. Scot. II. p. 958. Fl. Fr. Ed. $2 d a$. II. p. 27.

F. polypodioides. Gmelin, Hist. Fuc. p. 186. Syst. Nat. Ed. Gmel. II. p. 1388.

F. uvarius. ESPER, Ic. Fuc. I. p. 153. t. 78. (excl. syn. Linn.)

F. mollis candicans foliis vermiculatis. Re A $\mathrm{u}$ U R, in Act. Gall. 1712. p. 40. t. 4. f. 8.

B. botryoides; ramuli short, nearly globular.

F. botryoides. WU LFen, in Jacqu. Coll. III. p. 146. t. 13. f. 1. Fl. Fr. Ed. 2da. II. p. 26.

F. uvarius. Wulfes, Crypt. Aquat. n. 3. (excl. syn. Linn.)

r. sub-articulatus; ramuli long, linear, contracted as if jointed.

On the shores of England, especially the Southern Counties.-North of Ireland. Mr. Templeton.-Very plentiful in Bantry Bay. Miss Itutchins. - South of France. Decandolle. $-\beta$ on the stems of the larger Fuci at

Trieste. Baron Wulfen.-Found, but very seldom, upon the roots of $F$. loreus, among the rejectamenta of the sea at Yarmouth.— $\gamma$ on the Devonshire coast. Mrs. Griffiths.-At Nootka Sound. Mr. Mienzies.

Annual. June-August.

Root, a small, discoid, callous base, furnished with a few short creeping fibres, which here and there expand into similar bases, and give rise to numerous

FRONDS, growing in thick tufts, each furnished with a stem from three to seven inches in length, nearly cylindrical, as thick as a blackbird's quill, slightly flexuose, either simple, or twice or thrice dichotomous in an irregular manner, especially near the summits, or else beset with a few slort scattered branches, mostly horizontal, but occasionally patent, or even erect; the stem is always naked in the part nearest the root, and in general continues so for more than half its length, after which it is clothed with ramuli, at first rather remote, but placed nearer and near to each 

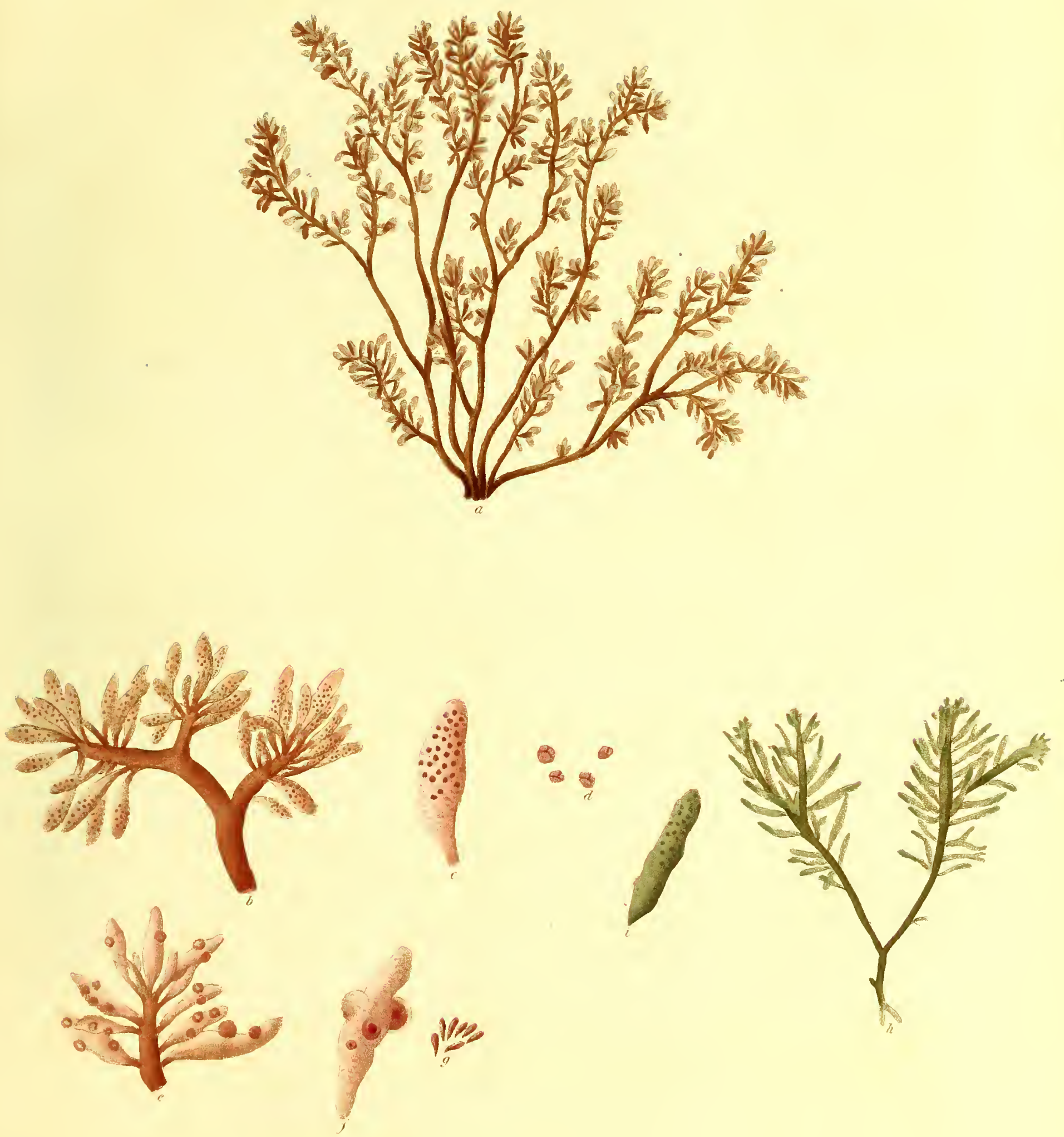

- Fierer analis. 

other as they approach the ends of the branches, where they are quite clustered; the * ramuli, or leaves, as they have been termed by most authors, are horizontal, imbricated on all sides, nearly spherical at their origin, at maturity elliptical, or between elliptical and cylindrical, rounded at the apex, and at the base attenuated, so that they adhere to the branches by a very small point, and, though really sessile, appear in a dry state petiolated; they are simple, but occasionally, though very rarely, proliferous with one or two smaller ones; their common length is from two to three lines, their thickness that of a crow's or blackbird's quill, but their size and shape are so variable, even in the same individual, that it is not unusual to see the lower ones cylindrical and half an inch long, while the upper ones are ovate and hardly a line in length.

Fructification, of two kinds, placed upon different individuals, both growing upon the ramuli, the one composed of sessile hemispherical tubercles, twice as small as poppy-seed, containing a mass of dark-red pyriform seeds: the other, of naked, scattered, roundish seeds, which, under the microscope, appear divided into three parts.

CoLOR, transparent, red, tinged in some instances with brown, in others with purplish, and in otlers with grassgreen, darker in the stem, and occasionally blackish towards the root, turning in decay, or from long exposure to the sun, first to a dull dirty green, and at last to white.

Substance, in the stem cartilaginous, and rather stiff when quite fresh, but very soon becoming flaccid, in the leaves, soft, juicy, tender, and gelatinous.

$\beta$ differs in having all its ramuli remarkably clustered, of nearly a globular form, and scarcely a line in diameter; the whole plant too is of humbler growth, and the color a deep vinons red.

In $\gamma$ the lower ramuli are almost an inch long, and, what is most singular, are evidently contracted, so as to appear at first sight composed of a series of short oblong joints: at some of the contractions too they are proliferous with other smaller scattered ramuli:- the specimen of this variety here figured was brought from Nootka Sound, and is preserved as a new species in the Banksian Herbarium, under the name of $F$.sedifolius; its jointed appearance is less striking than in the British specimens, and its ramuli are shorter, but, from the distichous disposition of the whole, front the circumstance of some of them being bifid, and from the color of the plant, I thought it right to represent it.

Oвs. The whole plant is remarkably smooth, and in drying adheres closely to paper.

It is not without extreme reluctance, nor at the same time without the strongest conviction, that I differ from the numerous Botanists who have given their opinions in favour of dividing F. ovalis into two species; and, especially; as to those already mentioned in the Synopsis of the British Fuci must now be added the authority of Professor Mertens, who, from an actual comparison of our English F.ovalis with $F$. botryoides of Wulfen, in the noble author's own herbarium, does not hesitate to pronounce them essentially different in several particulars. What these particulars are, we have unfortunately at present no means of knowing, but I must be allowed to say, that I also have examined plants sent me by Wulfen himself, without finding in them any character whatever to distinguish them from our own. Indeed I feel much more inclined to doubt whether there are sufficient grounds to separate them as varieties, than whether they have any claim to be regarded as species. The variety $\gamma$ above described, which, I believe, wvas never noticed till it recently attracted the attention of Mrs. Griffiths, is a far more singular appearance. It tends to draw $\boldsymbol{F}$. ovalis near to $\boldsymbol{F}$. kaliformis, for a fragnent of which, one of the larger ramuli, if detached, might easily be mistaken. F. uvarius of Linnæus, for which the species before us has by many authors been mistaken, is so similar in its form, that without the assistance of the original Linnæan specimens it would have been difficult to detect the error, though by means of these we now know it to be quite unlike in its nature and habit. It is possible also, but upon this point I speak with the greatest doubt, that it may belong to the Zoophytes, to which its thin dry horny substance and pale straw color indicate a close affinity. I am assured that $I$ was mistaken in the opinion that the lower part of Professor Esper's figure actually represents this latter plant; and, without supposing, as I had done, that Wulfen had confounded the two, I can now satisfactorily account for his observation upon the appearance of the ramuli of $\boldsymbol{F}$. ovalis after they are dry, from the knowledge that his specimens were subjected to little, if any, pressure. Gmelin, who relies upon the authority of Martyn for his $F$. polypodioides, and who had certainly seen it only in a dried state, if at all, was naturally led to place it among the membranaceous Fuci, and to remove it far from his $F$. vermicularis, though in reality the same species. The observation of Wulfen is excellent, that the plant bears a resemblance in miniature to a bunch of red grapes, and the name drawn from this resemblance is so appropriate, that it is impossible not to regret the necessity of changing it. The nearest natural affinity of $F$. ovalis is with $F$.dasyphyllus, already figured in this work, I. t. 22., together with which, and F. tenuissimus, and F. obtusus, it must in future be removed from the division of Fuci with distinct leaves, to that of those with cylindrical frond.

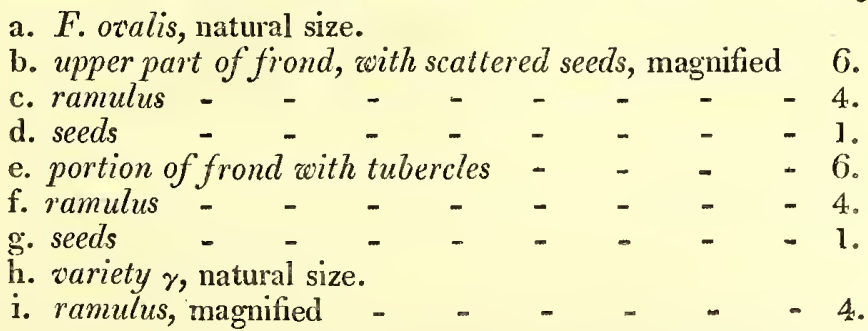

* Wulfen calls these ramuli vesicles, and says they are internally hollow and empty, excepting air: all those, however, which I have dissectcd, I have found full of a pellucid watery mucus. The same learned author observes of their appearance in a dry state; "extra aquam seriùs per desiccationem in scuta fornicata introlabentes, nec per reinımersionem pristinæ porro restituendæ figuræ. Ita siquidem infera vesi. eularum membranula versus supcriorem introlabitur, cjusdemque concavitati apprimitur, ut, licet aqua rursum immergas, excluso jam arie, hand amplius sese restituat aut ab eâdem avcllatur: desiccatum idcirco si quis fucum hunc intueatur, nullas in eo conspiciet vesiculas ; subtilią duntaxat in co sc videre credat foliola cochleariformia, aquosè flavescentia, diaphana, sessilia, sub-ovata, concavo-convexa, clypei-seu scuti. formia, supernè convexa, subtus fornicato-concava, margine integerrima."-Crypt. Aquat. p. 3\%.

VoL. II. 
Fucus Siliquastrum, stem three-sided, filiform, bipinnate: branches mostly alternate : leaves linear, very narrow, entire and toothed: vesicles obovate, petiolated: receptacles oblong, compressed, solitary.

In the Harbour at Nangasaki. Dr. Horner.

Perennial?

Roот, at present unknown to me.

FroND, furnished with a stem, about the length of which I am unable to say any thing, having seen only broken pieces of one, nearly as thick as a crow's quill, three-sided, with sharp angles, slightly flexuose, always, as far as I have seen, undivided, but furnished with branches at intervals of about half an inch, in other respects naked; branches placed round the stem in nearly a spiral manner, and altogether similar to it, except in being more thin, between horizontal and patent, a foot and half, or more, long, undivided, and, like the stem, naked, except that they are beset with other branches, of not above half their thickness, two or three inches long, simple, patent, some alternate, others opposite, separated by short, but uncertain spaces, and bearing both leaves, vesicles, and fructification; leaves scattered loosely over the smaller branches, between erect and patent, sessile, distichous, alternate, linear, an inch long, and scarcely a single line wide, provided with an extremely narrow dark midrib, some of them entire at their margins, others here and there toothed; vesicles generally placed upon the lower parts of the youngest shoots, and, apparently, only one upon each, of a widely obovate form, not unlike the pods of Alyssum utriculatum, except in being soniewhat smaller, externally smooth, internally quite hollow, supported upon a petiolus about a line in length, and tipped at their apices with an extremely short and thin mucro.

FRUCTIFICATION, compressed receptacles, oblong, or between oblong and cuneiform, three lines long, rounded" at their apices, at their base attenuated into a very short petiolus, scattered plentifully over the branches, and generally situated either at the axillæ of the leaves, or upon them near their bases, alternate, distichous, unequal in their exterior, and perforated with most minute pores, under which lie small, globular, innate tubercles, each containing a single, roundish, dark-brown seed, surrounded by a pellucid limbus.

CoLor, most probably an olive-green in the fresh plant, but in my specimens a very deep brown, yet paler in the vesicles, and blackish in the receptacles: when dry, the whole is an unvaried black.

SU BSTANCE, coriaceous, flexible, weak, approaching in the stem to woody, and in the vesicles to membranaceous.

OBs. In a dry state it does not in the least adhere to paper.

The name here given to the present Fucus is the same under which I received it from Professor Mertens, who communicated it to me, together with the others collected by Dr.Horner in his expedition round the world. It is an elegant species in point of its form and mode of growth, and from the size of its single branches I should apprehend? that it attains to considerable magnitude, but upon this point I am necessarily precluded from speaking with any certainty, as all that I have at present seen have been merely fragments of larger specimens. It evidently belongs to the family of $F$.natans, among which it agrees with $F$. Acinaria, and one or two others, in the remarkable circumstance of the tubercles producing only single seeds : its nearest afinity, however, is with $F$. pilulifer, already figured in this work, I. t. 65, and with the following species, from both which, as well as from all others already known, if is readily distinguished by the singular shape of the vesicles, and the extraordinarily narrow leaves.

a. branch of $\boldsymbol{F}$. Siliquastrum, natural size.

b. small branch, magnified - - - - 6

c. receptacle - - - - - - 5 .

d. horizontal section of the same - $\quad-\quad 3$.

e. seeds - . - - - - 1 . 


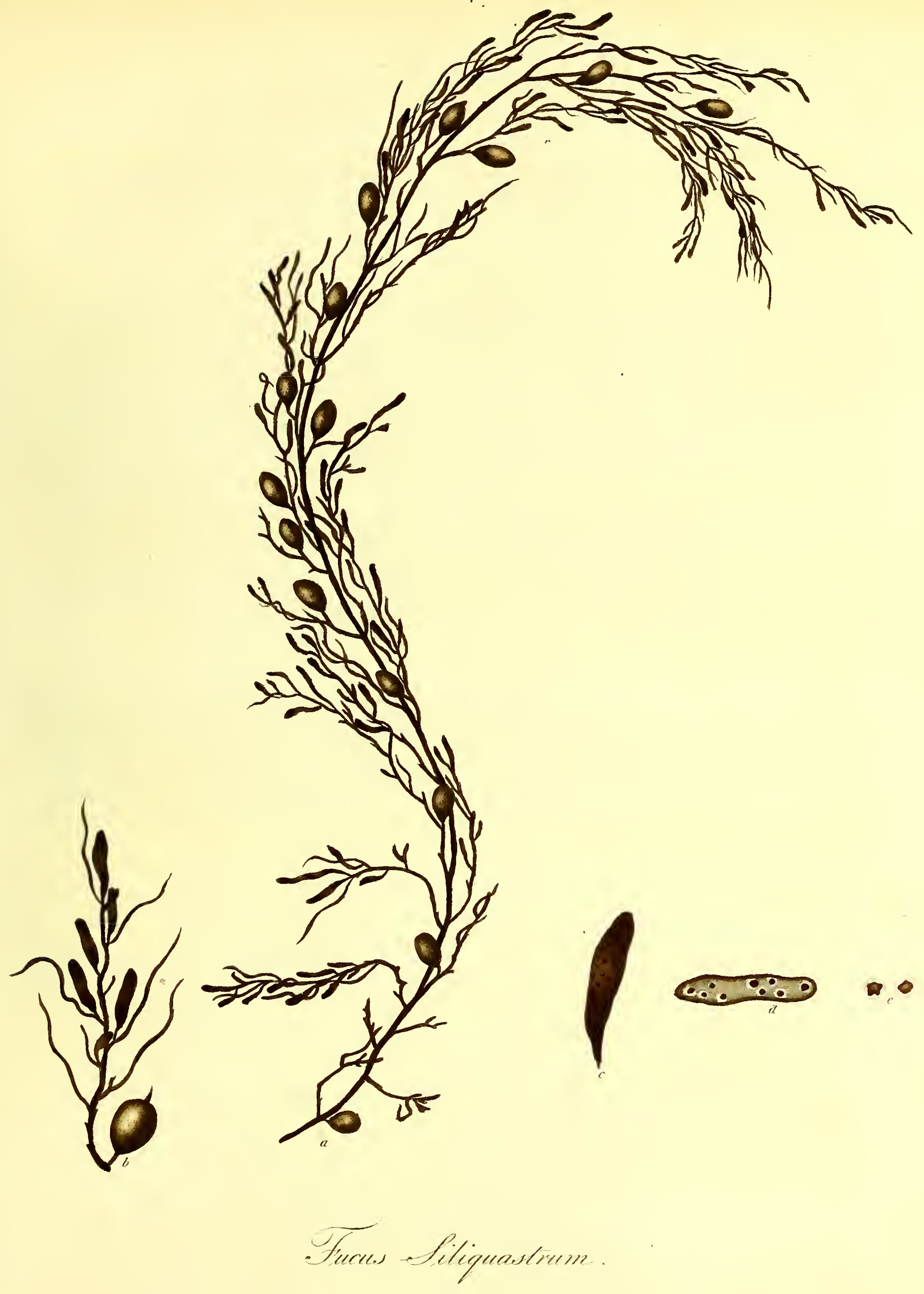



Fucus, caule triquetro, filiformi, bipinnato: ramis sub-alternis: foliis linearibus, angustissimis, integerrimis dentatisque : vesiculis obovatis, petiolatis : receptaculis oblongis, compressis, solitariis.

Habitat in Portu Nangasaki. D. Horner.

\section{Perennis?}

RADIX nondùm a me visa.

FroNs instructa caule, de cujus longitudine nihil est quod dicam, cùm frustulum modò viderim, penuæ corvinæ ferè crassitie, acutè triquetro, lenitèr flexuoso, semper, quatenus vidi, indiviso, sed intervallis circitèr unguicularibus ramos emittente, cætera nudo; rami circa caulem ordine sub-spirali dispositi, ejusque omninò similes, nisi quòd sint tenuiores, horizontalitèr patuli, sesquipedales et ultrà, indivisi, et caulis instar nudi, nisi quòd instructi sint aliis duplò tenuioribus, duos tresve pollices longis, simplicibus, patentibus, nunc alternis, nunc oppositis, spatio inter singulos brevi, attamen incerto, folia, vesiculas, fructumque sustentantibus: folia in ramis minoribus laxè sparsa, erectopatula, sessilia, disticha, alterna, linearia, longitudine pollicem latitudine vix semilineam requantia, nervo tenuissimo obscuro percursa, margine nunc integerrima, nunc hìc illìc denticulata; vesicula ramis junioribus, præsertìm basin versus, impositæ, atque, uti videtur, una in singulis, figuræe latè obovatæ, vel brevitèr pyriformis, ejus Alyssi utriculati silicularum, quibus aliquantùm sunt minores, haud absimilis, extrinsecùs læves, intùs omninò cavæ, petiolo lineam circitèr longo fultæe, atque apice mucrone tenui brevissimo aristatæ.

FRUCTi Ficatio receptacula compressa, oblonga, vel oblongo-cuneiformia, trium linearum longitudine, apice rotundata, basi in pedunculum per-brevem attenuata, per ramos satis copiosè disposita, alterna, disticha, sæpiùs foliorum ad alas, vel supra illa juxta basin nata, extrinsecùs torulosa, porisque minutissimis pertusa, sub quibus latent tnbercula exigua, sphærica, innata, singula semen unicum, subrotundum, fuscum, limbo pellucido cinctum, includentia.

CoLOR, qui recentis est verisimillimè olivaceus, in meis est exemplaribus intensè fuscus, vesicularum dilutior, receptaculorum nigricans; tota stirps exsiccata est atra.

SubstanTra coriacea, lenta, debilis, in caule ad lignosam, in vesiculis ad membranaceam accedens.

OBs. Exsiccata chartæ nequaquàm adhæret.

F. Siliquastri nomen primitùs huic Fuco imposuit amicissimus Mertensius, qui, unà cùm plurimis aliis a D. Hor。 nero cùm orbem circumnavigaret lectis, benevolè ad me misit. Stirps est quoad formam crescendique modum elegans, et quam, quatenus e ramorum magnitudine conjicere licet, in magnam molem excrescere solere hariolarer. Fieri tamen nequit ut aliquid de hàc re pro certo dijudicare auderem, cùm nihil in presens nisi mancum, stirpium majorum modd fragmina, conspiciendi sit data facultas. In Fucorum $F$. natanti congenerum numerum liquidd est recipi-* endus, et inter hos convenit in eo cum $F$. Acinariâ atque uno alterove alio, quodd singula tubercula semen tantùm. unicum includant. Nequaquàm verò vel liis vel ulli alii in præsens descripto tam arctè est naturâa affinis quàm $F$. pilulifero, jam olìm in hoc opere delineato, I. t. 65., et speciei insequenti, a quibus, sicut a reliquis omnibus, sese per vesicularum formam et folia angustissima nunquam non facilè dignoscendum præstat.

a. F. Siliquastri ramus, magn. nat.

b. ramus minor, magn. auct. $\quad-\quad-6$.

c. receptaculum - - - - - $\quad-5$.

d. idem horizontalitèr dissectum - $\quad$ - $\quad$ - 3.

е. semina - - - - - - - 1 . 
Fucus myagroides, stem compressed, bipinnate : branches alternate, simple : leaves linear, thickened at their apices, toothed at their margins, with scattered, thickened, sub-clavate teeth : vesicles between elliptical and spherical, petiolated, growing on the leaves.

In the Harbor at Nangasaki. Dr. Horner.

Perennial?

Roот, I have not yet seen.

FROND, furnished with a compressed, two-edged, linear stem, nearly a line wide, but of what length, or whether divided or not, I have no means of judging, as I have at present only seen it in a broken state, sending out branches at intervals of about an incl each, in other respects naked; branches distichous, horizontal, alternate, similar to the stem, except in being more narrow, two or three feet long, slightly flexuose, leafy ; leaves (or perhaps they would more properly be called secondary branches) disposed along the branches from their bases to their summits, with the distance of about half an inch between them, between erect and patent, alternate, distichous, flat, linear, two inches, or more, long, and not above half a line wide, provided with an extremely narrow dark midrib, at their apices blackish, slightly dilated, and of a thicker substance than the rest, at their margins quite entire, but beset with alternate, patent, clavate processes, separated by short intervals, and also thickest at their ends, which in all probability, if the duration of the plant permitted, would lengthen into new leaves; vesicles situated upon the leaves near their bases, two or three upon each, alternate, remote, in shape between elliptical and spherical, of the size of the seeds of Vicia sativa, externally smooth, and internally quite hollow, except a solitary fibre, which passes through their centre, being the continuation of the flat petiolus, about two inches long, that supports them; at their apices they are tipped with a leaf like the rest, but in general short, and not unfrequently broken.

Fructification, hitherto unknown:--there can, however, be no doubt of its being situated in the processes observable upon the sides and ends of the leaves.

CoLOR, olive green, semitransparent, opaque and blackish in the stem, and darker when the plant is dry.

SUBSTANCE, cartilaginous, approaching in the stem to coriaceous, and in the leaves to membranaceous, everywhere flexible, and tough.

OBs. The habit of the plant is twisted:- having nothing in its nature either viscid or juicy, but being, on the contrary, remarkably hard and dry, it does not in the least adhere to paper.

The fructification of this Fucus being at present undetected, it is impossible to say any thing with certainty either upon that subject, or upon the tribe to which it properly belongs; but at the same time, with regard to the first of these points, $\bar{I}$ apprehend that scarcely any Botanist, judging from analogy and appearances, would hesitate in acceding to the opinion, expressed above, that the receptacles are to be sought for in the tooth-like processes at the sides and ends of the leaves, the dark color, thick substance, and peculiar shape of which point them out as designed for a purpose of this nature, and, in respect to the place of the plant in the system, it seems to me no less clear that it must be classed among the congeners of $F$. natans. It must, however, be remarked, that, if such be really the case, $F$. myagroides is a very interesting plant, as constituting a link which immediately connects this peculiar family with that of the division, termed by Botanists, Fuci foliis unitis; for the leaves are far from being so distinct in shape as those of most others, and seem unquestionably intended to form new branches, many of them, even in the specimen here figured, having at their bases already begun to thicken, and become compressed rather than flat. The substance and color both of these leaves, and of the whole plant, and its general habit, also agree strikingly with $F$. aculeatus, thus indicating an affinity that would very little be expected between the Fuci provided with vesicles and that extraordinary plant, the nature of which is at present most imperfectly known to Naturalists. The name of $F$. Myagroides was given by Professor Mertens, and is expressive of the form of the vesicles, which considerably resemble in shape the pods of Myagrum sativum, and, still more so, those of Myagrum paniculatum.

a. branch of $F$. Myagroides, natural size.

b. leaf, magnified $-\div-5$ - $-\quad-6$.
co vesicle, cut open $-\quad-4$.




Fucus, caule compresso, bipinnato : ramis alternis, simplicibus: foliis linearibus, apice incrassatis, margine dentatis, dentibus sparsis, incrassatis, sub-clavatis : vessiçulis elliptiço-sphæricis, in foliis petiolatis.

Ha is a in Portu Nangasaki. D. Horner.

\section{Perennis?}

RADIX nondùm a me visa.

Frons instructa caule compresso, ancipite, lineari, et lineam ferè lato, de cujus longitudine et an divisus sit necne nihil est quod dicam, quoniam diffractum modd in præsens vidi, ramos intervallis sub-pollicaribus emittente, cæetera nudo ; rami distichi, horizontales, alterni, caulis similes, nisi qudd sint tenuiores, bi- tri- pedales, lenitèr flexuosi, indivisi, foliosi ; folia (ramos juniores, si malis, dicas) per totam ramorum longitudinem disposita, spatio inter singula sub-unguiculari, erecto-patula, alterna, disticha, plana, linearia, longitudine duos pollices et ultrà, latitudine semilineam æquantia, nervo angustissimo obscuro percursa, apice nigricantia, paullùm dilatata, substantiæque crassioris, margine integerrima, sed obsita processubus vix lineam longis, claviformibus, apice incrassatis, alternis, patentibus, remotiusculis, qui, si plantæ pateretur ætas, verisimilitèr sese in nova folia producerent; vesicula foliis juxta basin imposita, duæ tresve in singulis, alternæ, remotæ, formæ inter ellipticam et sphæricam, Vicia sativa seminum magnitudine, extrinsecùs læves, intùs fibrâ unicâ e petioli nervo constante percursæ, petiolo circitèr bilineari plano uninervi fultæ, apice coronatæ folio reliquorum simili, sed plerumque breviore, et haud raro diffracto.

Fructificatio hactenus ignota: dubitandum tamen non est quin sit posita in processubus foliorum ad margines et apices observatis.

Color olivaceus, sub-diaphanus; in caule obscurus et nigricans; exsiccata intensior.

SuBSTANTIA cartilaginea, in caule ad coriaceam, in foliis ad membranaceam accedens, ubique lenta et tenax.

OBs. Stirpis habitus tortilis :-planta nihil in se viscidi succosive habens, sed contrà insignitèr dura et sicca, exsiccatione chartæ nequaquàm adhæret.

Quamvis, tandiù quàm hujus Fuci fructificatio Botanicorum notitiam effugere perget, necesse est ut, cùm de ejus naturâ, tùm de loco qui stirpi in systemate debetur, scrupuli nonnihil restet, pauci tamen sunt, uti credo, qui, dummodò ad plantæ indolem analogiamve advertant animum, dubitabunt quin sit ad $F$. natantis adscribenda familiam, paucioresque adhuc qui conjecturæ suprà de fructu habitæ assentire nolent, scilicet verisimillimè esse quærendum in processubus illis dentiformibus, foliorum ad margines apicesque observandis, quorum color nigricans, substantia in crassata, et forma peculiaris sese ad simile aliquid a Naturâ comparari testantur. Sin equidem ita se res habeat, notatione est dignissimum quàm sit $\boldsymbol{F}$. myagroides in algarum submersarum catenâ summi momenti annulus, utpote qui Fucos $F$. natanti congeneres, foliis, si qui alii, verè distinctis præditos, cum illorum tribu, quibus folia sunt, quod dicunt, unita, connectit; hujus enim stirpis folia formâ a reliquis frondis partibus nequaquàm tantum abludunt quantum ea plurimorum affinium, neque dubium est quin, si plantæ pateretur ætas, in novos tandem mutarentur ramos, quoniam vel in exemplare hìc depicto non desunt quorum bases jam crassiores redditæ compressæ potiùs quàm planæ evadunt. E totius plantæe et præsertìm horum foliorum colore et substantiâ multum inter hanc speciem et $F$. aculeatum affinitatis intercedere liquet. Habitu etiam generali hi duo Fuci plurimùm conveniunt, adeò ut, quod vix suspicari esset in promptu, $F$. aculeatus, cujus indolem imperfectissimè modò in præsens perspexerunt Botanici, quódammodò per hanc stirpem Fucis vesiculiferis comnexus videtur. F. myagroidis nomen indidit Mertensius, a similitudine depromptum, quam habent vesiculæ quoad figuram, cum Myagri sativi aut potius cum Myagri paniculati siliculis.

2. F. myagroidis ramus, magn. nat.

b. folium, magn. auct. - - - - 6.

c. vesicula dissecta $=-\infty=4$ 
Fucus confervoides, frond cartilaginous, cylindrical, filiform, much and irregularly branched; branches long, mostly simple, beset with setaceous scattered ramuli, attenuated at each end: tubercles hemispherical, sessile, scattered all over the frond.

Fucus confervoides. Linn. Sp. Pl. II. p. 1629. Syst. Nat. II. p. 719. Syst. Nat. Ed. Gmel. II. p. 1384. Linn. Trans. III. p. 208. (excl. syn. Fl. Dan. et Lightf.) Wiтн. IV. p. 114. Syn. Fuc. II. p. 328. Eng. Bot. XXIV. t. 1668. Fl. Fr. Ed. 2da. II. p. 36. (excl. syn. Lightf.) *Wulfen, in Jacq. Coll. III. p. 151. t. 14. f. 1. Wulfen, Crypt. Aquat. n. 20. (excl. syn. Huds.) Esper, Ic. Fuc. I. p. 136. t. 68. Fl. Norv. II. p. 92. (excl. syn. Huds.)

F. longissimus. Gmelin, Hist. Fuc. p. 134. t. 13. Syst. Nat. Ed. Gmel. II. p. 1384.

F. verrucosus. Fl. Ang. p. 588. Ner. Brit. p. 26. t. 8. Fl. Fr. Ed. 2da. II. p. 36. Fl. Ped. II. p. 331. +F. scorpioides. OEDER, Enum. Fl. Dan. p. 17.? Fl. Dan. t. 887.?

F. uniformis. EsPer, Ic. Fuc. I. p. 196. t. 108.?

F. marinus purpurascens parvus, caule et ramulis seu foliolis teretibus. RAII Syn. p. 50. n. 50.

F. teres ramosissimus. Reaumur, in Act. Gall. 1712 . p. 40. t. 5. f. 9.

Ceramium longissimum. $\beta$. Roтн, Cat. Bot. III. p. 116.

B. procerrimus; branches very long, generally simple, and almost naked.

F. confervoides. $\beta$. Syn. Fuc. II. p. 328.

F. procerrimus. Es PER, Ic. Fuc. I. p. 133. t. 92.

F. longissimuis. Wulfen, in Jacq. Coll. I. p. 361. Wulfen, Crypt. Aquat. 11. 24. (excl. syn. Esp. et Fl. Dan.) Ner. Brit. p. 99. t. 16. Fl. Ped. II. p. $331 . \quad$ Fl. Lus. p. 436.

F. teres rubens minus ramosus in longum protensus. RAII Syn. p. 51. n.'53.

F. sive Alga lenta capillacea pallida, flagellis ramosis chordas musicas referentibus. Monrs. Hist. Ox. III. p. 649. n. 11.

Ceramium longissimam. Roтн, Fl. Germ. IIT. p. 460. (excl. syn. Esp. Fl. Dan, et Lightf.) Cat. Bot. II. p. 172. (excl. syn. iisdem.) Cat. Bot. III. p. 116.

Conferva dichotoma. Fl. Dan. t. 358 .

\%. implexus; frond intangled; branches and ramnli very numerous, crowded, twisted.

F. confervoides. \%. Syn. Fuc. II. p. 329.

8. gracilis; frond filiform; fruit lateral, clustered, minute, placed near the apices.

F. confervoides. 8. Syn. Fuc. II. p. 329.

F. gracilis. Ner. Brit. p. 100. t. 16.

E. albidus; frond slightly compressed, mostly dichotomous; ramuli subulate.

F. confervoides. E. Syn. Fuc. II. p. 329.

F. albidus. Fl. Ang. p. 588. (excl. syn. Raii.) Linn. Trans. III. p. 210. Esper, Ic. Fuc. I. p. $14 \%$ t. 100. Wiтн. IV. p. 118.

F. verrucosus. Guelin, Hist. Fuc. p. 136. t. 14. f. 1.

F. flagellaris. Esper, Ic. Fuc. I. p. 193. t. 105. Wulfen, Crypt. Aquat. n. 51.

F. albus. Wúfen, Crypt. Aquat. n. 25. (excl. syn. Esp. et. Fl. Dan.)

Ceramiantemo ramosissimo, basso, trasparente, rosso. Don a ti, Hist. Mar. Adr. p. 28. t. 1.

५. inflatus; frond incurved towards the apices, swollen here and there with lanceolate pod-shaped tumors.

$\eta^{\circ}$ geniculatus; frond bent, as if broken, at the tubercles.

$\alpha, \beta$, and $s$ are found not unfrequently upon the coasts of the British Isles, and upon those of all Europe, as well those exposed to the Ocean, as those to the Mediterranean and Adriatic.-West India Islands. Dr. Wright.$\gamma$ among the rejectamenta of the sea at Yarmouth. $-\delta$ in Cornwall. Stackhouse. $\zeta$ coast of Devonshire. Mrs. Griffiths. - $n$ at Swansea. Mr. Dillwyn.

Perennial. August-September.

Root, a small, callous $\ddagger$ disk.

FroNDS, numerous from the same base, cylindrical, filiform, flexuose, generally about half a foot, but sometimes extending to two feet, in length, as thick a \$blackbird's quill, acuminated at the apices, in point of ramification very variable, some specimens being divided near the root into a few sub-distichous branches of nearly equal height, while others preserve throughont their whole length an undivided stem, irregularly beset with scattered branches: the branches are always long, patent, and attenuated at both extremities, clustered in some individuals, in others remote,

and

\footnotetext{
- In the Synopsis of the British Fuci I expressed my opinion that the synonyms of Wulfen and Esper ought to be omitted; but now upon a more careful examination of their descriptions and figures, $I$ feel fully persuaded that they really belong to this plant; nor am $I$ deterred by the observation in the Allgemeine Litieratur-Zeitung (A. D. 1805, III. p. 451.) that Walfen himself considered a specimen of our British $F$. conferroides to be different from his ; for, highly as I respect his knowledge, and appreciate his services in this department of Botany, I cannot but feel that he was not sufficiently cautious in distinguishing species, and that so variable a Fucus miglit easily mislead him.

+ A mark of doubt is subjoined to this and the following synonym, not because $I$ feel myself any doubt respecting them, but because $I$ have at present seen no authentic specimens, and I know how easily any Botanist may be misled by representations of plants, of which the structure is so simple and uniform, especially if they be destitute of fructification.

$\mp$ Dr. Goodenough and Mr. Woodward call the root fibrous, but, in all the specimens that $I$ have seen, it is completely solid, and even destitute of any lateral fibres.

$\oint$ Some specimens collected by Dr. Wright in the West Indies are in thickness not equal to a sparrow's quilI.
} 


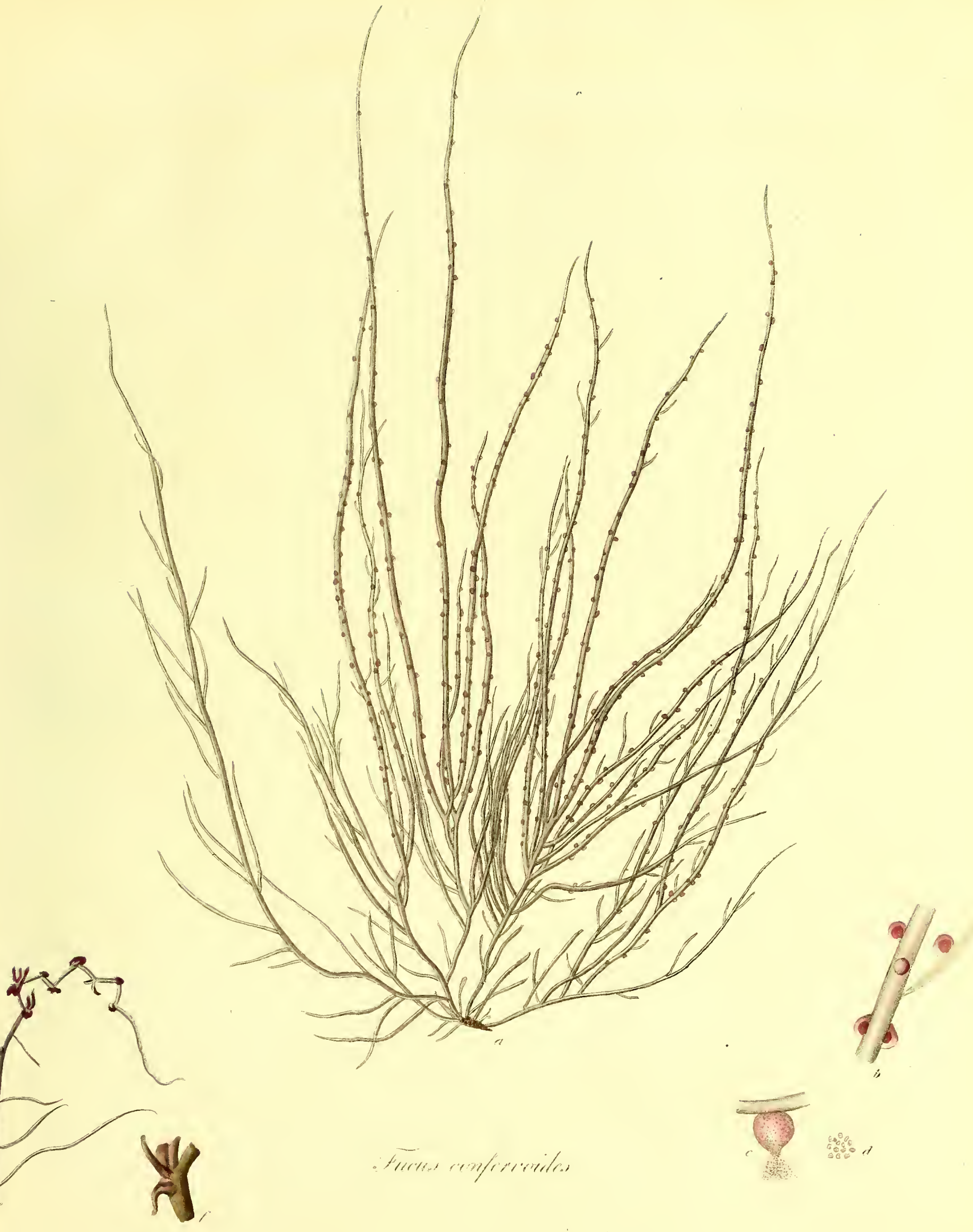



and in others placed principally on one side, some of them also are undivided, others twice or thrice dichotomous, and some are furnished with a series of smaller ones disposed in the same manner, while others are quite naked, except that the whole of them produce a greater or less quantity of ramuli, which, like the branches, are either crowded or remote, or, what more frequently happens, disposed in alternate parcels on different sides of the frond, remarkably attenuated at both ends, between horizontal and patent, simple, and two or three lines long, but sometimes much longer, and extending into new branches.

FRUCTIFICATION, sessile tubercles, somewhat smaller than turnip-seed, scattered plentifully over all parts of the branches, hemispherical in their early state, when ripe mammilliform, and at length pouring out, through a natural perforation at their apex, a quantity of extremely minute, irregularly oblong, red seeds, mixed with a pellucid mucus : having discharged their contents, they become depressed, urceolate, or, like the fructification of the Parmelia, scutelliform.

CoLor, a more or less deep purplish, mixed in some specimens with red, in others with brown, and in others with green, semitransparent; in a state of decay, or from exposure to the air, it turns green, and at last white.

Substance, cartilaginous, soft, and flexible.

The variety $\beta$ is in general about a foot and half long, and somewhat thicker than $\alpha$ : it is divided almost immediately by the root into a few branches, of nearly equal height, generally simple, but sometimes once or twice dichotomous, and either quite naked, or only furnished towards their bases with a few, very short, scattered, horizontal ramuli: the fructification, color, and substance are the same as in $\alpha$.

$\gamma$ has at present been seen only in a barren state;-the root is most minute; the frond always solitary, much and irregularly branched, remarkably curled and twisted, that the branches, which are both numerous and crowded, are with difficulty separated; the ramuli are long, and often produce other smaller ones; the substance is more tender than in the other varieties, and approaches to gelatinous; the color in a recent state is generally pale red, and in decay turns to a dirty orange.

I venture upon introducing as a distinct variety only upon the authority of Mr. Stackhouse :-the frond is slender, two or three inches long; the mode of growth similar to that of $\alpha$; the tubercles, according to Stackhouse, are so minute as scarcely to be visible, nor are there any ramuli at the sides of the branches, but neither of these observations holds good in specimens sent me by himself.

The appearance of $\varepsilon$ is so different, that Gmelin, Hudson, Wulfen, Esper, Goodenough, and Woodward, names of the greatest authority in these matters, have all considered it a distinct species ; -I have, however, seen so manry specimens intermediate between this and the most common appearance of the plant, that $I$ am constrained to differ from them.-In color, length, substance, and fructification, it agrees with $\alpha$, but the frond is somewhat thicker, and compressed rather than cylindrical; the branches are mostly dichotomous, and both these and the ramuli are thickest at their origin, from which they gradually taper to the extremities.

With regard to \&, Mrs. Griffiths suspects it is the true $\boldsymbol{F}$. gracilis of Stackhouse, and such would also be my opinion, but for the specimens sent me by himself, and for his neglecting to mention the singular swellings, peculiar to this variety.-Its length is from two to four inches; its frond twisted; its apices and ramuli generally recurved; its fructification tubercles far smaller than those of the other varieties, but of uncertain size; its color orange, when fresh ; the upper part of its branches, and occasionally its ramuli, here and there inflated with swellings of a lanceolate form, four or five lines long, twice as thick as the rest of the frond, and hollow within.

$\eta$ might perhaps more properly be accounted a lusus natura than a variety.-It agrees wholly with $\alpha$, except that the tubercles, which are most abundant, are of an irregular oblong, instead of an hemisplierical, form, of uncertain size and figure, and more frequently placed upon the ramuli than the branches; wheresoever these occur the frond is bent, as if broken, which gives the whole plant a very singular appearance.

Oвs. This Fucus is smooth and glossy, and on drying adkeres slightly to paper.'

With regard to this Fucus, as with $F$. ovalis, I am obliged to differ from the majority of botanical writers, who have given their opinions in favour of dividing it, some into two species, others into more, and I do so with considerable diffidence, as well as reluctance, because in plants, of which the structure is so simple, it is difficult, if not impossible, to define the limits between species and varieties, and the broader appearances of the present, after having been subjected to heavy pressure, seldom recover their cylindrical figure, so that there is a danger of being misled from the examination of any specimens, excepting those which are completely fresh. The discovery of the fruit of the variety $\beta$, of which the ramification is most remarkable, fortunately removes all doubt as to its identity with the more common form of the plant; and specimens of $\varepsilon$ also, which has still more generally been looked upon as distinict, may so often be traced into the same, that I know no certain limits between them, those pointed out by Dr. Goodenough and Mr. Woodward, though well defined, being, I am sorry to say, far from constant. It is not a little extraordinary, that, while so many naturalists have concurred in separating $F$. confervoides into different species, all should have equally concurred in confounding F. flagelliformis with it, an error, which, as is observed under that Fucus, never could have lappened, had not authors been in the habit of relying upon dried specimens alone. The various forms of the tubercles of this plant are well figured by Donati, but, besides these, I once observed at Cromer, a singular lusus naturæ in a specimen, all the capsules of which were of their natural shape, except one, which was 
much elongated, and in form resembled a pear. It is upon these capsules, and upon the short setaceous ramuli scattered over the branches, that $\boldsymbol{F}$. confervoides depends for its most certain specific characters. The bases of the ramuli are, at their insertion, so much attenuated, and so apt to lose their color, that in a recent state the plant often appears nearly allied to $F$.dasyphyllus, and $F$. tenuissimus, from which, in ramification and substance, it is for the most part so far removed. Specimens also are occasionally met with of a very dwarfish size, which, from exposure to the sun, have acquired the subdiaphanous yellowish tint, and wiry substance of $F$.plicaius, but this latter always wants the lateral ramuli, and its tubercles, as well as its ramification, are different.

a. F. confervoides, natural size.

b. part of a branch, magnified - $\quad-6$.

c. tubercle, discharging its seeds - $\quad$ - 5.

d. seeds - - - - - - 2 .

e. part of var. n, natural size.

f. portion of the same, magnified - $\quad 6$.

\section{4.-F U G S CONFER VOI D E.}

Fucus, fronde cartilagineâ, terete, filiformi, ramosissimâ; ramis elongatis simpliciusculis, obsitis ramulis setaceis, sparsis, utrinque attenuatis : tuberculis hemisphæricis, sessilibus, ubique per frondem sparsis.

Fucus confervoides. Linn. Sp. Pl. II. p. 1629. Syst. Nat. II. p. 719. Syst. Nat. Ed. Gmel. II. p. 1384. Linn. Trans. III. p. 208. (excl, syn. Fl. Dan. et Lightf.) WIтн. IV. p. 114. Syn. Fuc. II. p. 328. Eng. Bot. XXIV. t. 1668. Fl. Fr. Ed. 2da. II. p. 36. (excl. syn. Lightf.) *Wulfen, in Jacqu. Coll. III. p. 151. t. 14. f. 1. Wulfen, Crypt. Aquat, n. 20. (excl. syn. Huds.) Esper, Ic. Fuc. I. p. 136. t. 68. $F l$. Norv. II. p. 92. (excl. syn. Huds.)

F. longissimus. Gmedn, Hist. Fuc. p. 134. t. 13. Syst. Nat. Ed. Gmel. II, p. 1384.

F. verrucosus. Fl. Ang. p. 588. Ner. Brit. p. 26. t. 8. Fl. Fr. Ed.2da. II. p. 36. Fl. Ped. II. p. 331. †F. scorpioides. OE DER, Enum. Fl. Dan. p. 17.; (excl. syn. Raii.) Fl. Dan. t. 887?

F. uniformis. Es Pe R, Ic. Fuc. I. p. 196. t. 108 ?

F. marinus purpurascens parvus, caule et ramulis seu foliolis teretibus. RAI Syn. p. 50. n. 50.

F. teres ramosissimus. Reaumur, in Act. Gall. 1712. p. 40. t. 5. f. 9.

Ceranizum longissimum. $\beta$. Roтн, Cat. Bot. III. p. 116.

$\beta$. procerrimus; ramis in longum protensis, sub-simplicibus, sub-nudis.

F. confervoides. $\beta$. Syn. Fuc. II. p. 328.

F. procerrimus. Esper, Ic. Fuc. I. p. 133. t. 92.

F. longissimus. Wulfen, in Jacq. Coll. I. p. 361. Wulfen, Crypt. Aquat. n. 24. (excl. syn. Esp. et Fl。 Dan.) Ner. Brit. p. 99, t. 16. Fl. Ped. II. p. 331. Fl. Lus. p. 436.

F. teres rubens minus ramosas in longum protensus. $\mathbf{R}_{\mathrm{AII}}$ Syn. p. 51. n. 53.

F. sive Alga lenta capillacea pallida, flagellis ramosis chordas nusicas referentibus. Moris. Hist. Ox. III. p. 649 . n. 11.

Ceramium longissimum. Roтn, Fl. Germ. III. p. 460. (excl. syn. Esp. Fl. Dan. et Lightf.) Cat. Bot. II. p. 172. (excl. syn. iisdem.) Cat. Bot. III. p. 116.

Conferva diclotoma. Fl. Dan. t. 358.

y. implexus; fronde implicatâ; ranis ramulisque numerosissimis, confertis, contortis.

F. confervoides. \%. Syn. Fuc: II. p. 329.

8. gracilis; fronde filiformi, confertim prodeunte; fructu laterali, glomerato, minuto, juxta apices.

F. confervoides. \&. Syn. Fuc. II. p. 329.

F. gracilis.

- Wulfenii Esperique synonyma, cum Fucorum Britannicorum Synopsin scriberem, omninò prætermittenda duxi, nunc verò, descriptionibus et iconibus at tentiùs perpensis, ad hunc nostrum Fucum pertinere mili est persuasissimum; neque multum obstat illud quod Criticus in Allg. Litt. Zeit. (A. D. 1805. IIL p. 451.) memoret, scilicet ipsum Wulfenium stirpis Britannicæe exemplar a suâ diversum habuisse, quoniam planta insignitèr variabilis virum optimum et optimè de Fucologiâ meritum, in speciebus tamen discriminandis vix satis cautum, facillimè in errorem induxerit.

$\uparrow$ Dubitationis signum huic synonymo et insequenti subjeci, non quia ipse de iis dubito, sed quia exemplaria nulla, anctoritate, quod aiunt, rata, in præsens vidi, et facilè decipitur aliquis de stirpibus, quarum structura adeo simplex est et uniformis, præsertim si fructı careant. 
F. gracilis. Ner. Brit. p. 100. t. 16.

s. albidus; fronde sub-compressâ, sub-dichotomâ, ramulis subulatis.

F. confervoides. \&. Syn. Fuc. II. p. 329.

F. albidus. Fl. Ang. p.588. (excl. syn. Raii.) Linn. Trans. III. p. 210. Esper, Ic. Fuc. I. p. 147. t. 100.

WITH. IV. p. 118.

F. verrucosus. GMELIN, Hist. Fuc. p. 136. t. 14. f. 1.

F. flagellaris. Es PER, Ic. Fuc. I. p. 193. t. 105. Wulfen, Crypt. Aquat. n. 51.

F. albus. Wulfen, Crypt. Aquat. n. 25. (excl. syn. Esp. et Fl. Dan.)

Ceramiantemo ramosissimo, basso, trasparente, rosso. Don a t, Hist. Mar. Adr. p. 28. t. 1.

5. inflatus; fronde apices versus falcatâ, hìc illìc in tumores lanceolatos, siliquiformes inflatâ.

n. geniculatus; fronde ad tubercula geniculatâ.

Habitant $\alpha, \beta$, et $\varepsilon$ in Insularum Britannicarum, nec non in totius Europæ oris, cùm Oceano, tum Mari Mediterraneo aut Adriatico allutis, haud infrequentèr.-In Indiâ Occidentali. D. Wright.-r inter rejectannenta maris apud Yarmouth.- 8 in Cornubià. Stackhouse.- $\mathcal{\zeta}$ in Devoniæ littoribus. Dra Griffiths. $\rightarrow$ apud Swansea. D. Dillwyn.

Perennis. Aug.-Dec.

RADIX * callus exiguus, discoideus.

FrONDES ex eâdem basi plurimæ, teretes, filiformes, flexuosæ, longitudine plerumque circitèr semipedali, aliquando et ad bipedalem excurrentes, + Merula pennæ crassitie, apices versus in acunıen longum productæ, quoad ramificationem incertissimæ, nunc enim prope basin in ramos aliquot elougatos, sub-distichos, sub-fastigiatos dividuntur, nunc caulem unicum ramis sparsim obsitum per totam longitudinem servant; rami semper elongati, patentes, ortu apiceque paritèr attenuati, in his conferti, in illis sparsi remotique, in aliis subsecundi, nunc indivisi, nunc bis ter quaterve dichotomi, nunc aliis simili ratione dispositis instructi, et nunc nudi, excepto quòd omnes copiâ majore minorve ferant ramulos sparsos setaceos, ramorum ad instar vel confertos, vel dissitos, vel, quod sæpiùs accidit, alternatìm subsecundos, eodem modo utrinque attenuatos, horizontalitèr patulos, simplices, et bi- tri- lineares, sed quandoque multoties longiores, seque in novos ramos producentes.

Fructi ficatio tubercula sessilia, Brassica Rapa seminibus aliquantùm minora, copiosè ramis imposita, juniora hemisphærica, adulta mammilliformia, et demùm ex apice naturalitèr pertuso effundentia congeriem seminum minutissimorum, difformitèr oblongorum, rubrorum, muco pellucido immixtorum ; effota fiunt depressa, urceolata, aut etiam, Parmeliarum fructûs ad instar, scutelliformia.

CoLor nunc intensè, nunc dilutè, purpurascens, et in his rubro, in illis fusco, in aliis viridi plùs minùs tinctus, diaphanus, contra lucem elegantèr hyacinthino-rubens; soli objecta aut marcescentis virescit, et tandem in albicantem transit.

Su Bst Antı cartilaginea, mollis, flexilis.

Var. $\beta$ longitudinem habet sesquipedalem, et crassitiem plerumque aliquantùm majorem quàm $\alpha$ : ad ipsam ferè basin dividitur in ramos aliquot sub-fastigiatos, ut plurimum simplices, interdum tamen semel aut bis dichotomos, et vel omnind nudos, vel tantummodò ramulis paucis, sparsis, brevissimis, horizontalibus, basin versus obsitos :- fructificationem habet eandem quem $\alpha$, eundemque colorem et substantiam.

y nondùm nisi sterilis est detecta :-radix minutissima; frons semper solitaria, ramosissima, insignitèr tortilis, atque ita implicata, ut rami, qui numerosissimi sunt et conferti, ægrè se disjungi patiantur; ramuli elongati sæpe alios minores ferunt; substantia tenerior quàm in reliquis varietatibus ad gelatinosain accedit; color recentis plerumque dilutè ruber, marcescentis in sordidè aurantiacum transit.

$\delta$ vix pro distinctâ varietate hìc recensere sustinuissem, nisi ut Stackhousii auctoritati obtemperarem:-frons gracilis, longitudine bi- tri- pollicaris; crescendi modus idem qui in $\alpha$; tubercula, secundum Stackhousium, sunt minutissima, et vix visibilia, quod tamen in exemplaribus ab ipso missis haud valet, ramulosque, ejusdem fide, nullos ad latera ramorum, ut in præcedentibus, cernere est.

Facie a reliquis aded discrepante gandet $\_$ut pro specie diversâ habuerint Gmelinus, Hudsonus, Wulfenius, Esperus, Goodenovius et Woodwardius, a quibus invitissimè dissentio, coactus a speciminibus quæ vidi multis inter hanc plantæ formam eamque maximè vulgarem ambiguis.-Colorem, longitudinen, substantiam, et fructum eosdem habet quos $\alpha$, sed frons aliquantùm crassior, compressa potiùs quàm teres; rami sub-dichotomi, et hi ramulique omnes ortu sunt incrassati, atque exinde ad apices usque sensim attenuati.

De var. $\zeta$ suspicata est Dna Griffiths verum esse $F$. gracilem Stackh., idemque ipse crederem, nisi repugnarent exemplaria ab ipso missa, et nisi silentio præteriret et tumores illos singulares, hujus varietatis proprios.-Longitudo huic bi- quadri- pollicaris, frons tortilis; apices atque ramuli plerumque recurvi ; fructificatio tubercula iis cæaterarum Vol. II.

\footnotetext{
Radicem fibrosam dicunt Goodenovius Woodwardinsque, sed, in omnibus qua ego vidi exemplaribus, est ompinò solida, atque etiam fibrarum lateralium expers.

t Exemplaria ex Iudiâ Occidentali accepta pennâ passerinâ sunt tenuiora.
} 
varietatum longè minora, magnitudinis tamen incertæ ; recentis color aurantiacus ; ramorum pars superior, quod in ramulis quoque aliquando occurrit, hìc illìc inflata, tumoribus lanceolatis, quatuor vel quinque lineas longis, reliquâ fronde dupld crassioribus, intùs cavis.

Forsitàn rectiùs pro naturæe lusu memoraretur, quàm pro varietate censeretur.-Consentit in omnibus cum $\alpha$ nisi quòd fructificatio, quæ frequentissimè occurrit, haud sit tubercula hemisphærica, sed potiùs enormitèr oblonga, figuræe magnitudinisque incertæ, sæpiùsque ramulos quàm ramos occupet: ubicunque hæc occurrunt frons geniculata evadit, unde toti stirpi facies perquàm singularis.

OBs. Planta lævis, nitida, et quæ exsiccatione chartæ lenitèr adhæret.

Sub hujus etiam Fuci, sicut et sub $F$. ovalis nomine, plus quàm unam includi speciem censent Botanici plerique, quorum hi in duas, illi in plures, dispertiendum edocent. Ab his tamen omnibus invitè, et simùl diffidentissimè, dissentio, expertus enim scio quàm sit difficilè, immò potiùs impossibile, in stirpibus structurâ tam simplice atque uniformi præeditis varietates a speciebus probè distinguere; acceditque alia in plantâ hìc depictâ difficultas, quod exemplaria solito crassiora, si sint in exsiccando gravitèr pressata, rarò postea figuram teretem recuperent, quamobrem cavendum est ne per talia in errorem inducamur, et nullis, nisi recentibus, est omnind fidendum. Ramorum in var. $\beta$ dispositio multùm recedit $a b$ eâ stirpis faciei maximè vulgaris, sed prohibet fructificatio nupèr detecta quo minus pro distinctis haberentur; neque infrequentèr occurrunt ipsius var. $\varepsilon$ ( $F$. albidi auctorum) specimina, quæ talitèr inter hanc et $\alpha$ ambigunt ut characteres ad utramque certè dignoscendam sufficientes frustrà quærantur. Optimos quidenı, si modò semper ex æquo valerent, suppeditant Goodenovius Woodwardiusque, sed vel hi non stabiles. Mirabitur jure aliquis, quodd, dum tot Botanici $F$. confervoidem sic dividendum censuerunt, ne unus ex illis $F$. flagelliformem diversum putaverit; quæ tamen nunquam extitisset hallucinatio, nisi individuis exsiccatis, recentium loco, ad descriptiones conficiendas sint confisi. Formas, quas $F$. confervoidis capsulæ, variis atatis gradibus induere solet bene delineavit Donatius; sed, præeter hos, aliquandò natura in his effingendis ludit, et semèl apud Cromer in Norfolciâ exemplar legi, in quo unum e tuberculis, (reliqua figuræ erant vulgaris,) elongatum et pyriforme evasit. Hæ capsulæ et ramuli breves, setacei, ubique per ramos sparsi, plantæe characteres certissimos subministrant. Ramuli, basi nunquam non insignitèr attenuati, colorem ibi non rard perdunt, efficiuntque ut inter stirpem recentem atque $F$. dasyphyllum et $F$. tenuissimum, a quibus substantiâ et ramorum dispositione longè recedit, affinitas quædam intercedat. Occurrunt etiam quandoque specimina pumila, quæ soli diu objecta colore subdiaphano flavicante et substanti $\hat{\not}$ corneâ $F$. plicatum referunt, sed hic semper ramulis lateralibus caret, neque ramos liabet nec tubercula eorum $F$ 。 confervoidis similes.

a. F. confervoides, magn. nat.

b. rami pars, magn. auct. - 6 .

c. tuberculum, semina effundens - - - 5 .

d. semina - - - - - - 2 .

e. var. n portio, magn. nat.

f. ejusdem portio, magn. auct. - 6 . 
Fucus, fronde cartilagineâ, lubricâ, terete, filiformi, ramosâ ; ramis sub-distichis, elongatis, simpliciusculis, nudis, truncatis : seminibus nudis, in fronde immersis, fibris immixtis.

Fucus flagelliformis. Fl. Dan. t. 650. Fl. Scot. II. p. 928. (excl. syn. Gmel.) Syn. Fuc. II. p. 335. Eng. Bot. XVII. t. 1222.

ß. tortilis; fronde tenui, tortuosa ; caule ramis sparsis brevibus obsito.

Hавітат in Britanniarum oris, haud ita infrequens.-In Oceano Norvegico. Müller.-Ad Caput Bonæ Spei. D. C. Brand, in Herb Banks.-Ad littora Kamtschatkica legit D. Horner. — $\beta$ apud Sidmouth. Dna Griffiths.-In Scotiæ oris. D. Brodie.-Prope Belfast. D. Templeton.-Inter rejectamenta maris apud Yarmouth, F. nodoso innascens.

Annua. Junio.

RADIX callus perquàm exiguus, discoideus.

Frons, nunc solitaria, nunc bina, teres, filiformis, longitudine a semipedali ad tripedalem variabilis, passeris aut aliquandd Merulæ pennæ crassitie, et ubique a basi ad apices æquali instructa caule obsito ramis sub-distichis, sparsis, nunc dissitis, nunc confertis, plerumque ad duorum triumve pollicum altitudinen indiviso, atque ibi subito deficiente, quasi truncato, interdùm longiùs progrediente, et repetito-bifurco, donec sensìm evanescit in ramos illorum ad latera sua dispositorum similes; rami omnes elongati, stricti, sub-fastigiati, erecto-patentes, hi per totam longitudinem simplices, illi bis terve dichotomi, sinubus levitèr rotundatis ; apices cunctis obtusi ; ramuli, in $F$. confervoide insignes, in F. flagelliformi penitùs desunt.

FRUCTIFICATIO semina oblongo-pyriformia, intensè fusca, in ipsâ frondis substantiâ immersa, juxta peripheriam sita, et immixta fibris, e quibus tota stirps tunc constare videtur.

CoLOR recentis olivaceo-viridis, nitidus, contra lucem propemodùm flavicans; exsiccate nigricans, marcescentis aterrimus, et nitoris expers.

Su BSTANT1A sub-cartilaginea, lubrica, tenera, et mollis; in marcescente fragilis.

Var. $\beta$ longitudine vix palmum, crassitie filum tenuius vix superat:-habitus crispatus et tortilis:-caulis haud deficit infra dimidiam longitudinem, sicut in $\alpha$, sed per totam frondem porrigitur, ramisque est obsitus horizontalibus, sparsis, circiter unguem longis, simplicibus, bifurcisque.

Ors. Fuci hujus frons in loco natali observata ubique tomento denso albicante obducta apparet, quod, si lenti objiciatur, totum e fibris brevibus articulatis constare reperitur ; in fronde tamen, utcunque dissectâ, nihil quod tex. turam fibrosam argueret detegere potui, sed omnino solida et uniformis est visa, excepto fructificationis tempore, quando Rivularia structuram exhibuit:-exsiccata chartæ, quam colore fusco-flavicante tingit, satis arctè adhæret.

Si parva synonymorum suprà citatorum copia adducat aliquem ut credat $F$. flagelliformem in Fucorum rariorum numerum recipi debere, is certè errabit; nequaquàm enim infrequentèr in nostris saltèm maribus occurrit, sed tantam habet cum specie præcedente, et præsertim cum ejus var. $\beta$, similitudinem, ut in hunc usque diem sit ab omnibus ferè botanicis cum illâ commixtus, paucæque admodùm descriptiones extent, quæ non partìm ad hanc et partìm ad illam conficiuntur. Quicquid igitur auctores de his stirpibus tradiderunt cautè est recipiendum, visumque est, quò meliùs hujusmodi erroribus tandem finem imponeremus, synonyma ad $F$. confervoidem, ut optimè notum maximèque vulgarem, omnia referre, iis modò exceptis F. flagelliformem liquidò designantibus. Ex his tamen duo tantùm postrema dubio omni vacant; Lightfootius enim pravam reddidit descriptionem magnâ ex parte optimam, fructificationem et colorem ab $F$. confervoide depromptum adjiciendo; neque Flora Danice iconem omnind pro certâ habui, ex quo ejusdem exemplar, cui idem singularis crescendi modus hìc illic fasciculatus, Dna Griffiths misit. Quantumvis vero fuerit hic Fucus hanc ob causam preternissus, puto neminem unquam vidisse recentem, qui mecum assentiri nollet esse ab $F$. confervoide toto cælo diversum, et primo statìm aspectu dignoscendum. Magnitudo quidem utrique est eadem, idemque crescendi modus $F$.flagelliformi et $F$. confervoidis var. $\beta$, ramis scilicet prope radicem ortis, elongatis, simpliciusculis, flagelli Romani (unde nomen ducitur) formam referentibus; sed, utut in his conveniant, satis distinguuntur, cùm per fructificationem, tùm per $F$.flagelliformis ramos obtusos, crassitie ubique aquali, ramulisque setaceis nunquam non carentes, neque minùs evidentèr per hujus colorem, substantiam, superficiemque lubricam, in quibus consentit cum F. Filo, cui arctiùs quàn alii cuivis inter algas submarinas naturâ est affinis, ita ut etiam particeps sit structuræ illius propriæ, marcescensque in duas laminas æquales circa se invicem spiralitèr tortas solvatur. Fructificationem a nemine antehàc visam prima anno proximo juxta Plymouth detexit Dna Hill, quæ hâc donatum exemplar benevolè mecum communicavit; a quo tamen, utpote quod diu fuit pritsquàm accepi exsiccatum, non datur tan certè quam vellem de fructu loqui, qui, quatenùs ego perspicere possum, ejus est similis ab amicissimo Borrero in Rivulariâ vermiculatâ observati. Quis non mirabitur frondem in hoc statu prorsùs fibrosam evadere, atque, omni epidermidis specie depositâ, Rivulariarım, a quibus sterilis multùm abludit, formam induere?

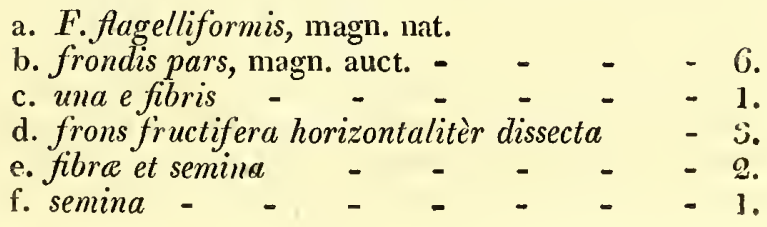


Fucus flagelliformis, frond cartilaginous, slimy, cylindrical, filiform, branched; branches long, mostly simple and distichous, naked, truncated: seeds naked, immersed in the frond, mixed with fibres.

Fucus flagelliformis. Fl. Dan. t. 650. Fl. Scot. II. p. 928. (excl. syn. Gmel.) Syn. Fuc. Il. p. 335. Eng. Bot. XVII. t. 1222.

B. tortilis; frond thin, twisted, stem beset with short scattered branches.

On the shores of the British Isles, not very uncommon.-In the Ocean about Norway. Müller.-Cape of Good Hope. Mr. C. Brand, in the Banksian Herbarium. - Shores of Kamtschatka. Dr. Horner. - $\beta$ at Sidmouth. Mrs. Griffiths.-Coast of Scotland. Mr. Brodie.-Near Belfast. Mr. Templeton._On F.nodosus, among the rejectamenta of the sea at Yarmouth.

Annual. June.

Root, a very small, callous disk.

FROND, generally solitary, but sometimes two together, cylindrical, filiform, from half a foot to three feet long, as thick as a sparrow's, or sometimes as a blackbird's quill, and uniform from base to summit, furnished with a stem, beset with scattered, sub-distichous branches, clustered in some specimens, in others remote; the stem mostly contimues undivided to the height of two or three inches, and there suddenly ceases, as if cut off, sometimes, however, is extends farther, and is repeatedly forked, till it gradually changes into branches similar to those arranged along its sides; branches all along, straight, nearly of equal height; between erect and patent, some simple throughout the whole of their length, others twice or thrice dichotomous, with angles slightly rounded; the apices of all are blunt:the ramuli, so remarkable in $F$. confervoides, are in this species altogether wanting.

Fructification, seeds between oblong and pyriform, of a dark-brown color, immersed in the substance of the frond, near the circumference, and mixed with fibres, of which, at that time, the whole plant appears to consist.

CoLOR, olive-green in a recent state, when held to the light nearly yellow, glossy; in drying it turns blackish, and: in decay is a deep dull black.

SUBSTANCE, nearly cartilaginous, slippery, tender, and soft, brittle as it decays.

The variety $\beta$ is not more than three or four inches long, nor thicker than a small packthread:-its habit is curled and twisted :- the stem does not disappear at a short distance from the root, as in $\alpha$, but extends throughout the whole length of the frond, and is beset on all sides with scattered, horizontal branches, about half an inch long, some simple, others forked.

Oвs. If this Fucus be observed while growing, it appears every where covered with a thick whitish woolly down; which, examined under the microscope, is found entirely composed of short jointed fibres : the examination, however, of various sections of the frond has not led me to the discovery of any thing that proved an internal fibrous structure, but the whole seemed quite solid and uniform, except at the time of the fructification, when it wore altogether the look of a Rivularia :-in drying it adheres with tolerable firmness to paper, and stains it of a dirty brownishyellow color.

From the very small number of synonyms, quoted above, it might be apprehended that $F$. flagelliformis is a plànt of unfrequent occurrence, which, however, is far from being the case, at least upon the shores of Britain; but the extreme resemblance that it bears, when dry, to the subject of the preceding plate, and particnlarly to its var. $\beta$, has been the cause of its being so constantly confounded with that species, that there are few descriptions which are not in part composed both of the one and the other. In consequence of this circumstance, whatever has been written by the older authors respecting either of them must be read with a degree of caution, and it has appeared best, for the purpose of avoiding all farther ambiguity upon the subject, to leave to $F$. confervoides, as the inore common and the best understood plant, the whole of the synonyms, excepting those which seem clearly to refer to $F$. fiagelliformis; though, even of these, only the two last can be considered altogether free from doubt, for it is evident that Lightfoot, whose description is for the greater part excellent, borrowed his account of the fruit, and a part of what he says of the color, from F. confervoides, and, since Mrs. Griffiths sent me a specimen of this Fucus, bearing in different parts of its branches a clustered mode of growth, similar to what is represented in the Flora Danica, the figure in that work, however generally characteristic, has always appeared to me in some degree uncertain. Yet still, though these Fuci have been so frequently confused, no botanist, who has ever had an opportunity of seeing them growing, or even recent, can entertain a question of their being truly and specifically distinct. The size, indeed, of the two plants is alike, and the inode of growth of $F$. flagelliformis, which is very constant, and resembles the form of a Roman flagellum, whence it derives its name, is similar to that of the var. $\beta$ of $F$. confervoides, but the branches are always obtuse, and of equal thickness throughout, and are altogether destitute of setaceous ramuli; the fructification too, the color, the substance, and the slimy exterior, afford certain marks of distinction. In the three latter respects $F$. flagelliformis agrees with $F$. Filum, to which it is more naturally allied than to any other species, partaking even of the strong peculiarity of that Fucus, the separating into two spiral filaments in a state of decay. For the only specimen that $I$ have seen in fruit $I$ am indebted to Miss Hill, who gathered it at Plymouth, and first discovered the fructification, which seems to be the same as that observed by my friend, Mr. Borrer, in Rivularia vermiculata. I think it, however, necessary to mention, that the plant had been dried before I had an opportunity of examining it. It is not a little extraordinary that the frond in this state has so evident a fibrous structure, and is apparently quite destitute of any epidermis, so that no one 


would hesitate about referring it to the Rivularia, yet that nothing similar has ever been observed of it when barren.

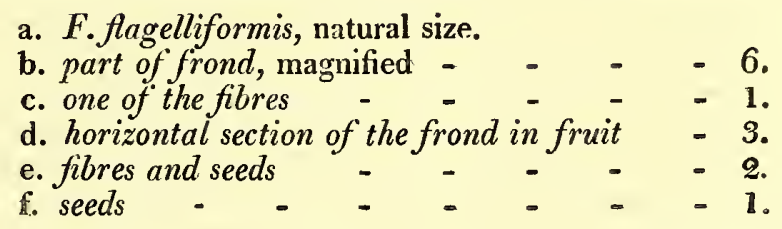

\section{6.-F U G U F I L U M.}

Fucus, fronde cartilagineâ, lubricâ, terete, utrinque attenuatâ, simplicissimâ, intùs geniculatâ, senectute spirali.

Fucus Filum. Sp. Pl. II. p. 1631. (excl. syn. Alsæn. Acad.) Syst. Nat. I1. p. 717. Syst. Nat. Ed. Gmel. II. p. 1384. Fl. Lapp. p. 363. Fl. Suec. p. 432. Fl. Alig. p. 587. Fl. Scot. II. p. 963. With. IV. p. 108. Gmelin, Hist. Fuc. p. 131. Fl. Dan. t. 821. Fl. Norv. II. p. 10. Fl. Monsp. p. 458. Ner. Brit. p. 40. t. 10. Linn. Trans. III. p. 193. Syn. Fuc. II, p. 339.

F. Tendo. Es Per, Ic. Fuc. I. p. 47. t. 22. (excl. syn. Linn.)

F. filiformis. Fl. Fr. Ed. 1mu. I. p. 97.

Ceramium Filum. Fl. Germ. III. p. 478. Cat. Bot. I. p. 147. Fl. Fr. Ed. 2da. II. p. 47.

Fucus chordam referens teres pralongus. Ra11 Syn. p. 40. n. 3.

F. setaceus niger longissimus non ramosus. Moris. Hist. Ox. p. 649.

Ha вітAт in Britanniarum oris, vulgaris.-In Oceano Septentrionali et Atlantico, et in Mari Baltico. Gmelin.-.. Lapponiæ ad oras. Linneus.

Annua?-

RA DIX callus perquàm exiguus, discoidèus, sub-conicus.

Fro NDES vel solitariæ, vel ex eâdem basi tres quatuor aut quinque confertæ, teretes, simplicissimæ, nunc uniuss nunc quindecim aut viginti pedum longitudine, basi vix pennâ passerinât crassiores, et inde sensìm magis magisque auctæ, ut corvinam, aut aliquando anserinam, æquent, quum eandem ubique crassitiem servant, donec, ad apicem appropinquantes, iterùm gradatìm attenuantur, et in acumen longum producuntur; intùs ${ }^{*}$ geniculis, aut annulis, geniculorum, ut videtur, rudimentis, per totam longitudinem sunt interceptæ, spatio inter singula brevi, attamen incerto, nunc vix semiunguiculari, nunc pollicari, et ultrà ; neque tamen hæc impediunt quominùs stirps extrinsecùs omnind æqualis appareat, in exsiccatâ longè magis manfesta evadunt, sed haud paritèr in omnibus exemplaribus, et in quibusdam, nisi fallor, penitùs desunt: spatium inter genicula plerumque occupat mucus pellucidus, fibris intertextus, sed aliquandò vacuum relinquitur : in exemplaribus vetustis aut aliquo modo læsis frons spiralitèr torta reperitur.

Fructificatio ignota.

CoLor recentis olivaceo-viridis; fusco tinctus, contra lucem propemodùm flavicans, nitidus ; exsiccate nigrescens; in littore diu exposite stramineus, et demùm albescens; marcescentis nigerrimus, omnisque nitoris expers.

+ Su вSTA NTı cartilaginea, lubrica, tenax, insignitèr elastica, ex aquầ vero extractæ citò fít flaccida; exsiccatione rigidiuscula, sub-cornea, et quodamımodò fragilis evadit.

Oss. Hujus, sicut præcedentis, Fuci frons in loco natali observata tomento denso brevi obducta conspicitur, quod, lenti subjectum, totam e łfibris pellucidis articulatis constare reperitur:-undarum cursui obsequens, Sparganii

\footnotetext{
- In optimo tractatu de Algarum submersarum dissepimentis, lıæc genicula intergerina dicit Rothius, memoratque adeò rarò in Algarum filiformium cotu occurrere, nt duo tantùm sibi bucusque prostent eorum exempla, in Fuco scilicet Filo, et in Confervâ scruposá. Addit quoque, " quando in hisce Algis articuli utrinque juxta genicula traisversın dissecentur, tunc eo in loco, ubi externè visui sese otferunt, microscopii ope modicè angentis, prasertim in exsiccaio plantæ statu, septum membranaccum evidentissimè in conspectum veniet, tubıli cavum trans. versim occludens, ut ita hisce septis totus plantæe tubulus in tot loculos dividatur, quot articuli intra genicula numerantur. Sub microscopio optimæ notæ septa hæc e fibris parallelis cum interjectâ telâ cellulosâ conflata constructa milhi videbautur. Loculi in lisce Algis a dissepimentis ntrinque occlusi in vivo statu neutiquàm inanes sunt, sed succo mucoso repleti, hivc septa succi nutritii ascensum lıad parùm relevare apparent."-Cat. Bot. III. p. 85.

$\uparrow$ Singulare admodum est illud q"od Esperus de hâc plantâ dicit, multùm, ut videtnr, a substantiâ ductus : “ Nach allen Eigenschaften und Kennzeichen gelı̈rt dieses Product zu dem Geschlecht der Tubularia. Es est gerundet, inwendig liolıl, und durclı Scheidewande untersclieden, uberdiss von einer häutigen Substanz: im trockenen Stand hingegell, hat es ganz das ansehen eines Tangs."-Ic. Fuc. I. p. 49.

$\ddagger$ Aperturas in frondis epidermide nullas detegere potui, per quas ha. fbra excunt, neque fasciculatin disponuvtur, illaruni in $F$. serrato et aliis notatarum ad instar.
} 
natantis aut Zosterce marina ad instar fluitat, nec tamen, uti observavit Linnæus, supra aquam, sed sub ipsâ superficie aquæ :- exsiccatione chartæ laxiusculè adhæret.

Ulvarum structuram simplicem atque uniformem, Fucorum substantiam, et Confervarum diaphragmata F. Filum in se unus includit, ideoque inter hæc tria genera quodammodo ambigit. Fructificatio hanc dirimere potest litem, sed hæc in præsens indetecta latet; quicquid enim de hâc disseruit * Stackhousius paucis, nisi fallor, satisfaciet, minùsque adhuc arridet Rothii sententia, qui, exemplare detecto unico, apice casu aliquo inflato, hoc nisus plantam Ceramiis suis adscripsit, et capsulâ solitariâ terminali glandiformi instructam prædicat. Postulat contrà analogia, ut, cùm inter $\boldsymbol{F}$. Filum atque F. flagelliformem colore texturâ et habitu arctissima intercedat afinitas, eundem in utroque quæreremus fructum, nec quos natura conjunxit distrahere conaremur, quare verisimilius videtur illud quod paucis abhìnc annis ad me scripsit D. Pigott, se mense Augusto vidisse seminum myriadas ab $\boldsymbol{F}$. Fili superficie ablutas effugere. Adjecit vero, se tale nequaquàm in omnibus individuis observâsse, et nihil unquam postea de eâdem re memoravit, quamobrem, priusquàm hoc pro rato habemus, expectanda sunt vel ejus vel aliorum Botanicorum judicia. Ipse pro me fateor, me, sedulò quærentem, ejusmodi nihil hactenus detexisse, neque vidisse aliquid in $F$. Fïl $i$ fronde, quod ad texturam fibrosam in $F$. flagelliformi fructifero notabilem appropinquabat. E contrario, substantia semper uniformis apparuit, ex epidermide constans crassâ, cui annectitur fibrarum rete, maculis rotundis, centro in quibusdam individuis vacuo, in aliis muco aquoso repletis, fibris aliquot albis articulatis interjectis. De dissepimentorum internorum in stirpis oecononiầ usu, ingeniosè memorant Goodenovius Woodwardiusque, esse forsan a naturâ cơmparata ut frondem roborent, figuramque teretem servent; cui etiam conjecturæ favet Ulva fistulosa, quæ, talibus destituta, semper hìc illìc variè articulato-contracta reperitur. Ab hâc plantâ, cui magis quàm ulli alii inter Algas submersas F. Filum est extrinsecùs affinis, dignoscitur, præter dissepimenta, fronde lubricâ, utrinque attenuatâ. A reliquis forma simplicissima distinguit. Botanicis omnibus Historiæ Naturalis philosophiam spectantibus frondis conformatio in F. Filo notatu est dignissima. Hanc primùm in Nereide Britannicấ Stackhousius, et in Fucorum Britannicorum Synopsi Dillwynius observavit. Tota frons investigationi cautæ subjecta per totam longitudinem constare reperitur e duabus laminis æqualibus, circa se invicem spiralitèr convolutis, sed ita firmitèr cohærentibus ut connexus ibi modd appareat, ubi ætas aut casus patefacit; senectute enim appropinquante, aut injuriâ aliquâ acceptâ, solvuntur laminæ, et stirps figuram spiralem, in tabulâ nostrâ delineatam et a pluribus auctoribus memoratam, induit. Ad $F$. Fìli et F. Tendinis synonyma ritè disponenda, multùm in primo Iconum Fucorum tomo elaboravit Esperus, qui, deceptus ab ipso Linnæo citante sub illo iconem in Amanitatibus Academicis (IV. p. 259. t. 3. f. 2.) ad hunc certè pertinentem, verum $\boldsymbol{F}$. Filum sub $\boldsymbol{F}$. Tendinis nomine depingendum curavit, indiditque $\boldsymbol{F}$. Fili titulum Tillandsia usneoidis caulibus denudatis. Est autem $\uparrow F$. Tendo Linnæanus substantia animalis, in Angliâ haud infrequentèr sub Graminis Indici nomine venditata, quâ pro linis piscatoriis nostrates utuntur. Ex regno quoque vegetabili verisimilitèr est excludendus Plukenetii $\boldsymbol{F}$. Indicus teres setam piscatoriam referens, et forsitan alia quædam ab auctoribus vetustioribus pro Fucis habita. Gunnerus de $F$. Filo memorat, esse in Norvegiâ pabulo bobus gratissimo et salutari.
a. F. Filum, magn. nat.
b. frondis pars, magn. auct. - $\quad-\quad-6$.
c. una e fibris - - - -1 .
d. frons longitudinalitèr dissecta $\quad-\quad-6$.
e. eadem horizontaliter dissecta - - 4 .
f. stirpis vetusta frons, magn. nat.

\footnotetext{
- De fructu dicit Stackhousius; " fructificatio gelatina, pellucida, tubulis flexuosis, bullisque aereis intùs ; semina, sine granulis, minutissima, glomerata, interiori cutis superficiei affixa."-Ner. Brit. p. 40.

+ Hujus quoque in tomo secundo iconem dat Esperus, t. $15 \%$.
} 
<smiles></smiles> 

Fucus Filum, frond cartilaginous, slimy, cylindrical, filiform, attenuated at both ends, jointed internally, spirally twisted when old.

Fucus Filum. Linn. Sp. Pl. II. p. 1631. (excl. syn. Amœn. Acad.) Syst. Nat. II. p. 717. Syst. Nat. Ed. Gmel. II. p. 1384. Fl. Lapp. p. 363. Fl. Suec. p. 432. Fl. Ang. p. 587. Fl. Scot. II. p. 963. With. IV. p. 108. GMeliN, Hist. Fuc. p. 131. Fl. Dan. t. 821. Fl. Norv. II. p. 10. Fl. Monsp. p. 458. Ner. Brit. p. 40. t. 10. Linn. Trans. III. p. 193. Syn. Fuc. II. p. 339.

F. Tendo. Es Per, Ic. Fuc. I. p. 47. t. 22. (excl. syn. Linn.)

F. filiformis. Fl. Fr. Ed. 1ma. I. p. 97.

Ceramium Filum. Fl. Germ. III. p. 478. Cat. Bot. I. p. 147. Fl. Fr. Ed.2da. II. p. 47.

Fucus Chordam referens teres pralongus. Ra11 Syn. p. 40. n. 3.

F. setaceus niger longissimus non ramosus. Moris. Hist. Ox. p. 649.

Common upon the shores of the British Islands.-In the Northern and Atlantic Oceans, and in the Baltic. Gimelin.-Coast of Lapland. Linnæus.

\section{Annual?}

Rooт, a very small, sub-conical, callous disk.

FRONDS, either solitary, or growing three, four, or five together, cylindrical, quite simple, varying in length from one to twenty feet, at their base scarcely exceeding in thickness a sparrow's quill, and thence gradually swelling to the size of a crow's or goose's, after which they regularly preserve the same size, till, as they approach the apices, they again gradually decrease, and end in a long acuminated point ; internally they are divided throughout their whole length, at short, but uncertain distances, by * septa, or rings, which appear to be the rudiments of septa, but these do not prevent the exterior of the plant from being completely even, they are by far most evident in a dried state, and more so in some individuals than in others; indeed, in some, if I am not mistaken, they are wholly wanting: the space between the joints is generally filled with a pellucid watery mucus, but is occasionally quite empty : in old or injured specimens the frond is found twisted in a spiral manner.

Fructification, unknown.

Color, in the fresh plant, a glossy olive-green, tinged with brown, nearly orange if held to a strong light; blackish when dry; from exposure on the beach turning to a pale yellow, and at last to white; in a state of decay completely black, and destitute of gloss.

† SuBSTANCE, cartilaginous, slippery and tough, very elastic when recent, but, if taken out of the water, soon growing flaccid; in a dry state rather rigid and brittle, and inclining to horny.

Oвs. The frond of this Fucus, as of the preceding one, appears, if examined in a growing state, covered with a very short woolly down, which the microscope proves to consist entirely of pellucid, jointed $\ddagger$ fibres :-it floats about, like Sparganium natans or Zostera marina, following the course of the waves, but, as is observed by Linnæus, lies immediately under the surface of the water, instead of lying upon it:-in drying it adheres slightly to paper.

From the union in F. Filum of the simple structure of an Ulva, the texture of a Fucus, and the diaphragms of a Conferva, there can be no wonder, if, constituted as those genera now are, its proper situation among them has been regarded as in a measure uncertain. The fructification, which alone can determine this point, is at present far from bẹing clearly understood, for what $\$$ Mr. Stackhouse has written upon this subject can scarcely be considered by any one as satisfactory, and still less so is the account given of it by Dr. Roth, who, relying altogether upon a specimen, of which the apex was accidentally swollen, has described it as a terminal, solitary, glandiform capsule, and classed the plant with his genus Ceramium. A remark made to me many years ago by Mr. Pigott is far more conformable to analogy, which would lead us to expect that the fruit of $F$. flagelliformis and F. Filum is the same, the similarity between the two Fuci being, as is already remarked under the former of these species, llost striking in point of color, texture, and habit. This gentleman says that, in the month of August, he has seen what he supposed to be the fructification wash off in myriads of minute brown grains. At the same time, however, he added, that this was discoverable only in certain specimens, nor did he afterwards favor me with farther particulars, so that I cannot but look upon his opinion as still requiring the support of a confirnation,' which no otlier botanist has at present, to my knowledge, given it; nor, though I have attended myself closely to the subject, have $I$ ever been fortunate enough to

meet

- Dr. Roth, in his excellent treatise upon the different kinds of dissepinents in the submersed algx, calis these genicula intergerina, and says that they are of so unfrequent occurrence, that lie knows but two instances of them, viz. in Fucus Filum, and in Conferva scruposa. He adds, “ quando in lisce Algis articuli utrinque juxta genicula transversim dissecentur, tunc eo in loco, ubi externè visni sese offerunt, microscopii ope morlicè augentis, præsertim in exsiccato plantæ statu, septum membranaceum evidentissimè in conspectum veniet, tubuli cavum transversim occludens, ut ita lisce septis totus plantæ tubulns in tot loculos dividatur, qnot articuli intra genicula numerantur. Sub microscopio optimæ notæ septa hæe e fibris parallelis cum interjectâ telâ cellulosâ conflata constructa milii videbantur. Loculi in lisce algis a dissepimentis utrinque occlusi in vivo statu neutiquàm inanes sunt, sed sncco mucoso rcpleti, hinc septa succi nutritii ascensum haud parùm relevare apparent."-Cat. Bot. III. p. 85.

+ It is not a little singular that Esper should have been induced, in great measure, by the substance, to consider this plant as having, when moist, all the appearance of a Tubularia; but, after it is dry, he says, it looks like a Fucus.

† There is no aperture visible in the epidermis through which these fibrcs issue, nor do they grow in clusters, like those observable upon the rond of $F$. serratus, \&c.

$\$$ Mr. Stackhonse's description of the fruit is, " a transparent mucus with tubes wreathed, and twisted with numerous imbedded air.bubbles, seds extremely minu's, naked, clustered, adhering to the inner coat."-Ncr. Brit. p. 41. 
meet with a similar appearance, or with any approach to that fibrous texture, peculiar at such time to $F$. flagelliformis. On the contrary, I have found the substance of $F$. Filum always uniform, consisting of a remarkably thick outer coat, next to which is a net-work of fibres, forming circular meshes, and the centre is either empty, or full of a colorless mucus, with a few white jointed fibres passing here and there through it. With regard to the use of the internal dissepiments in the economy of the plant, it is ingeniously suggested by Dr. Goodenough and Mr. Woodward, that they may perhaps be intended to strengthen the frond, and enable it to preserve its tubular form; a conjecture that seems highly probable, since, from being destitute of these, the Ulva fistulosa, of which the form is very similar, is always found irregularly broken and contracted at intervals. There is no other submersed Alga, to which in external appearance $\boldsymbol{F}$. Filum is so much allied, its simple structure affording the means of immediately distinguishing it from most others, and from this, besides the dissepiments, it differs in its attenuated extremities and slimy surface. The extraordinary conformation of this plant, originally noticed by Mr. Stackhouse and Mr. Dillwyn, constitutes its most striking peculiarity, and is a circumstance well deserving the attention of every philosophical Botanist. The whole frond appears, if carefully examined, to be composed of two equal strips, coiled spirally round each other, but so closely united, as to be discernible only in those parts where time or accident has caused a separation; for they gradually loosen, as the plant advances in age, or if it receives any injury, and thus occasion the spiral appearance represented in the plate before us, and noticed by various authors. Professor Esper, who, in the first volume of his work, has figured $\boldsymbol{F}$. Filum under the name of $\boldsymbol{F}$. Tendo, and has transferred the name of $\boldsymbol{F}$. Filum to some naked stems of Tillandsia usneoides, has been at considerable pains in his endeavors to settle the synonymy of these two species; having been misled by the circumstance of Linnæus' referring in the Species Plantarum under $\boldsymbol{F}$. Filum to the figure in the Amanitates Academica (IV.p. 259. t. 3. f. 2.) which is evidently intended to represent his own * F. Tendo, which latter is in reality an animal substance, cornmonly used in this country for fishing lines, and known by the name of Indian Grass. There can also be little doubt but Plukenet's $F$. indicus teres setam piscatoriam referens, and perhaps some other supposed Fuci of the older Botanists, ought consequently to be expunged from the list of vegetables. Gunner relates of $F$. Filum, that it constitutes in Norway a most acceptable and salutary food for cattle.
a. F. Filum, natural size.
b. part of the frond, magnified $\quad-\quad-6$.
c. one of the fibres $-\overline{-}-1$.
d. longitudinal section of the frond $\quad 6$.
e. horizontal section of the same - $\quad 4$.
f. frond of an old plant, natural size.

Of this also a figure is given by Esper in his secoud volume, $t .157$. 
Fuscus, fronde inembranaceâ, planâ, costatâ, lineari, dichotomâ, integerrimâ, e costâ proliferâ: seminibus nudis, in maculas hemisphæricas utrinque juxta costam congestis.

Fucus membranaceus. Ner. Brit. p. 13. t.6. Syn. Fuc. I. p. 141. Wiтн. IV. p. 93. Eng. Bot. XXV. t. 1758.

F. polypodioides. Fl. Atl. II. p. 421.

Ulva polypodioides. Fl. Fr. Ed. 2 da. II. p. 15.

H нвгтат in rupibus submarimis apud Sidmouth. Dna Griffiths.-In Cornubiâ, in Sinu, "St. Austell's Bay". dicto. D. Rashleigh.-Galliæ ad oras, cùm Oceano, tum Mari Mediterraneo allutas. Decandolle.-In Mari Numidico. Desfontaines.-E Zeylonâ accepit Linnaus.-In Insulâ Minorcâ.

Perennis. Jun.-Nov.

RADrX callus planiusculus, oblongus, vel orbicularis, diametro sæpe sesquipollicaris, tomento fulvo, e fibris articulatis ramosis densissimè compactis constante, ubique vestitus, et repens, ut primo aspectu spongiam simulet.

Frondes ex eâdem basi plurimæ, unaquæque tamen ortu non modò distincta, sed intervallo brevi a reliquis separata, longitudine dodrantales, pedales, et ultra, planæ, circiter unguem latæ, lineares, dichotomiis juxta basin incipientibus, et inde sæpe repetitis, spatio inter singulas brevi, divisæ, furcarum sinubus acutis, percursæ costâ radicem versus pennæ passerinæ crassitie et nigricante, sed sensìm tenuiore $\epsilon$ dilutiore, ut juxta apices propemodùm evanescat, non rarò hìc illìc proliferâ, foliis ortu oblongis simplicibusque, nox bifurcis et lincaribus; frons superficie sparsim pertusa, poris fibrarum brevium articulatarum albarum fasciculos emittentibus, apice bifida, segmentis brevibus, patenti-divaricatis, obttsis, margine lenitèr undulata et integerrima, excepto in exemplaribus vetustis, et præsertìm fructiferis, quæ plerumque junioribus teneriora, variè corrosa atque laciniata evadunt, et haud infrequentèr sunt junioribus duplo angustiora :- basin versus membrana vi fluctuum sæpiùs deteritur, unde planta stipiti tereti insidere videtur; aliquando etiam hoc per totam longitudinem accidit, et costa, vel omninò denudata, vel hìc illìc prolifera, stirpi dat faciem a vulgari longè alienam.

- FRuctificatio frondis apices versus sita, e seminibus constat subrotundis, majusculis, fuscis, †limbo lato, pellucido cinctis, prope costam utrique frondis paginæ insidentibus, in niaculas ellipticas, aut hemisphæricas, lineam sesquilineamve longas, et semilineam latas, alternas, oppositasque, congestis, ortu, teste Dna Griffiths, pelliculâ tenuissimâ obtectis, quæ citò perditur, et nuda jacent.-Frondis ea pars, cui imponuntur semina, incrassata apparet, et, sub acri lente observata, granulis fuscis, adeò minutis ut singulorum forma visum effugiat, cooperta reperitur; hisce immixta jacent semina.

Co lo R dilutè olivaceo-viridis, non sine flavedine, nitidus; exsiccata obscurior, et fuscescens.

Substantia inter cartilagineam et membranaceam, tenuis, in recente elastica, sed, vel in aquâ dulci, vel extra aquam servatæ, cito fit flaccida, et tenerrima.

OBs. Planta exsiccata chartæ nequaquàm adhæret, viscidique nihil in se labere videtur, sin absque curâ et pressurß̂̊ siccetur, frondis partes, ubicunque tangunt, adeò tenacitèr sibi invicem adhærent ut nullâ arte postea evolvantur:frons sub lente lineis nigricantibus, parallelis e costâ ad margines excurrentibus notata conspicitur.

Quamvis, uti jam ¥suprâ in hoc opere memoratur, Limnæum non omninò latuerit $F$. membranaceus, tresque ejus iconas, fructificatione adjectâ, æri olìm insculpi curaverit acutissimus Michelius, nihilo tamen secius, cùm ille ab $F$. disticho non distingueret, et cùm hic suas plantarum marinarum zoopliytorumque figuras nunquam publici juris fecerit, planta diu indescripta restitit, donec, paucis abhinc annis, Stackhousius, specimine unico illoque sterili inter maris rejectamenta apud Sidmouth lecto, pro specie novâ agnovit, et in primo Nereidis Britannica fasciculo delineatum exhibuit. E Mari Mediterraneo iteratis vicibus accepi, et ibi non infrequentèr reperiri verisimile videtur, in Wulfenii licet scriptis frustrà quæratur; sed australium forsan plagarum incola Britannixe ad littora rarò occurrit, neque ullum inter botanicos nostrates unquam in loco natali detexisse constat, prater Dnam Griffiths et $\S D$. Gulielmum Rashleigh, quorum prior exemplar hìc depictum, unà cùm multis aliis diversarum ætatum individuis, ut descriptio et icon a recentibus conficerentur, benevolè, pro more, communicavit. Fructificationem \| primi ex auctoribus ritè VoL. II.

* De fructificatione dicit Dna Griffiths, cui optima fuit observandi facultas, "when the seeds are first formcd in young plants they appear to be contained in a thin pellicle, a little prominent on either side, or rather immersed in the substance, and covered with a transparent skin a little elevated, which in plants more advanced disappears, and the secds only remain. The substance at length decays, and leaves a sort of oval perforation, like those so common in $\boldsymbol{F}$. crispus."

† Hic limbus est adco latus et conspicuus, ut senina non tàm margine albo scpta, quàm sacco albo inclusa videantır; et hoc verisimilius apparet, quia scmina, si aciculâ tangas, statim granulorum minutissimorum congeriem effundunt, et tegmell vacuum relinquunt.-rectiusne semina an capsulæ dicuntur?

$\neq$ I. p. 8 .

Hujus benevolentiæ $F$. membranacei adumbrationes debeo, cùm ad stirpes juniores in vere, tùm ard fiuctiferas citòque perituras in auctumno paratas, formâ inter se multùm absimiles. Hre quoque in epistolis adjecit:- " the reason of its bcing so seldom found, is from its inhabiting pools at considerable distance from the shore, wherc it is only to be met with at the lowest tide: the fructification, though most visible when recent, soon becomes less so from the seeds dropping out; and the plant has, when fresh, a stronger odor than any other marine alga that $I$ am acquainted with ; cqual in strength to that of onions, and not more agreeable."

|| Stackhousius, qui poros modò in fionde, illorum $r$. serrati et aliorum omninò similes sed magis conspicuos, viderat, hune Fucum inter specics Sructificatione anomalâ relinquit. Desfontainius vero, cùm niliil aliud, ut videtur, repererit, hos pro fructu habet, et dicit; " folia tuberculis parvis, distinctis, subrotundis conspersa, ut in Polypodio. Hoc charactere distingnitur a $F$. spirali, cujus siuilitudinem omnino refert." In elndem errorem in opere, English Botany dicto, incidit optimus Smithius. Decandollii descriptio nimis brevis quid designare vellet incertum relinquit. 
intellexerunt et explicârunt Weberus Mohriusque, qui, in * tractatu sæpe jam laudato, fusè de hâc disserunt, indoleque ejus singulari perpensâ, novum e $F$. membranaceo genus, quod + Neurocarpum appellant, construendum censent. Huic autem sententix ut multi assentiant metuo, quoniam radix tomentosa spongiosa, frons lineata, et semina nuda arillata talem cum Zonarïs Draparnaudii affinitatem indicant, ut non nisi invitissimâ naturâ divellantur. Fructûs descriptionis exquisitæ ab his botanicis traditæ pars magna $\neq$ infra exscribitur; monendus tamen est lector seminum fasciculos in nostris speciminibus nequaquàm tàm constantèr quàm illi memorant nunc in hâc nunc in illâ frondis paginâ ordine certo alterno disponi. Per formam, texturam, et fructificationem, $\boldsymbol{F}$. membranaceus statim ab omnibus aliis hactenus detectis distinguitur, neque ullum multùm refert, nisi quòd obitèr inspicienti frons junior aliquam primo aspectu $F$. vesiculosi similitudinem exhibeat.

a. F. membranaceus, magn. nat.
b. stirpis fructiferce pars
c. ejusdem portio, magn. auct.
d. semina -

* Beiträge zur Naturkunde. I. p. 204.

† Character hujus generis est; "Semina (arillata) in punctis subrotundis ad utrumque vence frondis latus, alternatim in utrdque pagina, congesta, nuda."

$\ddagger$ "Der F. membranaceus hat dieselben Körper, die wir bei der Familie der Fuci Stackh. Saamen genannt. Sie sind indess hier in keinem warzenförmigen Receptaculo eingeschlossen. Sie liegen vielmehr nackt auf der Frons. Aber in welcher bewunderns würdigen ordnung thun sie das. Der Tang is aus der festgesetzten Abtheilung der Alati. Nun gelın wir die Mittelrippe hinauf. Gegen cinander iber liegen auf jeder Seite derselben in einem halbrunden Punct versammelt, vielleicht auf 20 oder mchr der angeführtell mit ihren Limbus umgebnen Saamen. Die beiden halbrunden Puncte zu der beiden Seiten der Mittelrippe bilden zusammen einen vö̈lig runden Fructificationspunct, zwischen den nur die Mittelrippe selbst durclıgeht. Nun aber das Sonderbarste. Der nächstfolgende Fructificationspunct, der sich sofort an den ersten anzuschliessen scheint, liegt anf der pagina aversa der frons. Der dritter liegt wieder vorn, der vierte hinten, und so in regelmassiger Abwech. slung immer fort. Die fructification der einer Seite hat roh betrachtet so ungefähr das Ansehn der Fructification der Farrenkrautgattung Woodwardia (doch dass die Saamen nackt liegen ;) mit der Rückscite sieht cs ans wie einc doppelte Woodwardia, wo aber die Puncte der einen zwischen die der andern (alternirend) fallen. Von den, den Moosparaphysen ähnlichen, Fäden, die sich beim Fucus Stackh. überall zeigten, sind wir in den Fruchtpuncten des $F$. membranaceus nichts gewahr geworden. Dass man sie sonst auch hier wohl hätte vermuthen dïrfen beweist ilıre jüngst erst entdeckte Gegenwart zwischen den jungen Sporangien mehrerer Filiccs."-Beitrüge zur Naturkunde. I. p. 243.

\section{7.-F U C U S M E M B R N A G E US.}

Fucus membranaceus, frond membranaceous, flat, midribbed, linear, dichotomous, quite entire, proliferous from the midrib : seéds naked, collected into hemispherical spots on each side of the frond near the midrib.

Fucus nembranaceus. Ner. Brit. p. 13. t.6. Syn. Fuc. I. p. 141. Wiтн. IV. p. 93. Eng. Bot. XXV. t. 1758.

F. polypodioides. Fl. Atl. II. p. 421.

Ulva polypodioides. Fl. Fr. Ed.2da. II. p. 15.

Rocks at Sidmouth. Mrs. Griffiths.-St. Austell's Bay, Cornwall. Mr.W. Rashleigh.-Coasts of France, both opposite to the Ocean and the Mediterranean Sea. Decandolle.-Numidian Sea. Desfontaines. - Sent from Ceylon to Linnaus.-Island of Minorca.

Perennial. June-November.

Rоот, a flattish, callous disk, of an oblong or orbicular shape, often an inch and half in diameter, every where covered with a woolly coat, of a tawny color, consisting of jointed branching fibres, most closely matted together, so that at first sight it looks like a sponge. 


Fronds, numerous from the same root, yet not only distinct at their origin, but each separated from the others by a short space, varying in length from nine to twelve inches, or more, about half an inch wide, quite linear, branched with dichotomies that begin near the base, and are then frequently repeated at short intervals, their angles acute: throughout the whole frond passes a midrib, as large as a sparrow's quill and blackish towards the root, but gradually growing more thin and pale, so as scarcely to be visible at the apices, not. unfrequently proliferous in various parts with leaves, at first oblong and simple, but afterwards forked and linear: the surface of the frond is spotted with minute scattered pores, more numerous in some individuals than in others, from which issue small tufts of short, white, jointed fibres; the apices are bifid, with short obtuse segments, between patent and divaricated; the margins are slightly undulated, and quite entire, excepting in old, and particularly in fruit-bearing, specimens, which are mostly very thin and tender, and irregularly worn away, and torn, and not uncommonly twice as narrow as the younger ones:-towards the root the membranous part is generally destroyed by the action of the waves, and the midrib remaining naked has the appearance of a cylindrical stem; the same is also sometimes the case throughout the whole length, and the midrib is either quite naked, or only proliferous here and there, so that the plant looks very differently from what it usually does.

* Fructification, situated near the apices, consisting of largish, roundish, dark-brown seeds, bordered by a wide pellucid †limbus, lying upon each side of the frond, adjoining the midrib, collected into elliptical or hemispherical clusters, a line, or a line and half long, and about half a line wide, either alternate or opposite, at first, according to Mrs. Griffiths, covered with a very thin pellicle, which soon vanishes, and they are quite naked:--the part of the frond, on which they are placed, appears thicker than the rest, and, if examined with a powerful microscope, is found covered with brown granules, so nimute, that their individual form is not to be detected.

Color, pale olive-green, with a tinge of yellow, glossy; darker, and brownish in a dry state.

Substancr, between cartilaginous and membranaceous, thin, elastic when quite recent, but, if kept in fresh water, or exposed to the air, soon turning flaccid, and extremely tender.

Oвs. In drying it does not in the least adhere to paper, and scems to lave no viscidity whatever in it; but, if it be dried without care or pressure, all those parts of the frond, which touch each other, adhere together, and can never afterwards be separated:- -under the microscope the frond is seen to be marked with fine, blackish, parallel lines, running from the midrib to the margins.

Although, as has been $\ddagger$ already observed in this work, $F$. memlranaceus was not altogether unknown to Linnæus, and although three figures of it, with a portion of the fructification annexed, have long existed in a collection of engravings of marine plants and zoophytes, made under the care of the celebrated Micheli, yet, as these engravings were never published, and as Limmeus did not distinguish it from $F$. distichus, the plant remained undescribed till a few years ago, when Mr. Stackhouse fortunately met with a single barren specimen upon the beach at Sidmouth, and, justly regarding it as new, inserted it in the first number of his Nereis Britannica. There is reason to believe that it is not uncommon upon the shores of the Mediterranean, but, being probably confined to sourthen latitudes, few British species are of less frequent occurrence, nor does it appear that any of our botanists have been fortunate enough to detect it in its places of growth, excepting Mrs. Griffiths and $\S$ Mr. William Rashleigh, to the former of whom I am indebted, as well for the individual here figured, as for the opportunity of writing a description from a large collection of others in a recent state, and in different stages of their existence. The fructification of $F$. membranaceus was \|| first well understood and explained by Dr. Weber and Dr. Mohr, who, in their ** treatise, already often referred to; dwell much at large upon the subject, and, from its singular nature, consider the plant entitled to form a new genus, which thcy call +f Neurocarpus. In this latter point, however, I apprehend that few botanists will be willing to coincide with them, since, both in its woolly spongy root, its lineated frond, and its naked arillatcd seeds, it shews so strong a natural affinity to the Zonaria of Draparnaud, as makes it scarcely possible to separate it from that tribe. The description given by those botanists is so accurate and curious, that I have been led to transcribe a considerable

portion

- Upon the subject of the fructification, Mrs. Griffiths, who lias had the best opportunities of observing, says, "when the secds are first I formed in young plants they appear to be contained in a thin pellicle, a little prominent on eicher side, or rather immersed in the substance, and covered with a transparent skin a little elevated, which in plants more advanced disappcars, and the seeds only remain. The substance at length decays, and leaves a sort of oval perforation, like those so common in $F$. crispus."

+ This limbus is so large and conspicuous that the seeds seem rather to be inclosed in a white bag, than merely surrounded with a pcllucid margin, and such appears more probable, because, if touched with a pin, they instantly pour out a cluster of most minute grauules, and lcave their covering empty,-Are they more properly to be called seeds or capsulcs?

$\ddagger$ I. p. 8 .

$\$$ This gentleman very kindly commnnicated to me drawings of vigorous plants in spring, and of old oncs in autumn, of wlich, as observed in the description, the appearance is so different. He added, that the reason of its being so seldom found is from its inhabiting pools at considerable distance from the shore, where it is only to be net with at the lowest tides: that the fructification, thongh most visible when recent; soon becomes less so, from the seeds dropping out; and that the plant has, when fresh, a stronger odor than any other marine alga that he is acquainted with; equal in strength to that of onions, and not more agreeable.

II Mr. Stackhouse, who had seen only the pores upon the frond, which appear to me precisely similar to those of $F$. serratus, though more remarkable, has left this plant among the species with anomalous fructification; but Desfontaines, who also seems to have met with nothing
clse, describes these as the fruit, and says, "Folia tuberculis parvis, distinctis, subrotundis conspersa, ut in Polypodio. Hoc charactere distinguitur a $F$, spirali, cujns similitudinem omnino refert.". The same is the case in English Botuny. 'The description of the fructification given in the Flore Française is so short, as to leave it uncertain what it alludes to.

* Beiträge zur Naturkunde. I. p. 204.

t+ The character of this genus is "Semina (arillata) in punctis subrotundis ad utrumque vena frondis latus, alternatim in ulrâgue pagina, congesta, nudu." 
portion of it * below, though I must observe, that my own remarks have not precisely coincided with theirs, as to the regular situation of the clusters of seeds alternately upon the opposite surfaces of the frond. There is no other marine plant at present known from which $F$. membranaceus is not immediately distinguishable, except that the youngest shoots are at first sight not unlike those of $F$. vesiculosus.
a. F. membranaceus, natural size.
b. part of a specimen in fruit.
c. portion of the same, magnified
$=-5$
e. seed discharging its contents - $\quad-\quad-\quad-\quad-1$.
f. portion of frond, to shew the lineated structure 3.
g. pore, with a cluster of fibres - - - 2 .
h. fibres - - - - - - - - 1 .
i. fibres of the root - $\quad-\quad+\quad-\quad+\quad 2$.

\begin{abstract}
* "Der F. membranaceus hat dieselben Körper, die wir bei der. Familie der Fuci Stackh. Saumen genannt haben. Sie sind indess hier in kcineın warzenförmigen Receptaculo eingeschlossen. Sie lieg $\mathbf{n}$ vielmehr wackt auf der Fıons. Aber in welcher bewunderns wïrdigen ordnung thun sie das. Der Tang is aus der festgesetzten Abtheilung der Alati. Nun gein wir die Mittelrippe hinauf. Gegen einander über liegen auf jeder Seite derselb ${ }^{\prime}$ in einem halbrunden Punct versammelt, vielleicht auf 20 oder nehr der angeführten mit ilıren L.mbus umgebnen Saanien. Dic beiden talbrunden Puncte zu der beiden Seiten der Mittelrippe bilden zusammen einen völlig runden Fructificationspunct, zwischen den nur die Mittelrippe selbst durchgeht. Nun aber das Sonderbarste. Der , ächstfolgende Fructificationspunct, der sich sofort an den ersten anzuschliessen scheint, liegt auf der pagina aversa der frons. Der dritter liegt wieder vorn, der vierte hinten, und so in regelmussiger Abwechslung immer fort. Die Fructification der einer Seitc hat roh betrachtet so ungerähr das Ansehn der Fructification der Farrenkrautgattung $\mathbf{W o o d w a r d i a}$ (doch dass die Saamen nackt liegen;) mit der Rückseite sieht cs aus wie eine doppelte Woodwardia, wo aber die Puncte der einen zwischen die der andern (alternirend) fallen. Von den, den Moosparaphysen ähnlichen, Fäden, die sich beim Fucus Stackh. überall zeigten, sind wir in den Fruchtpuncten des $F$. membranaceus nichts gewahr geworden. Dass man sie sonst auch hier wohl hätte vermutheı dürfen beweist ihrc jüngst erst entdeckte Gegenwart zwischen den jungen Sporangien mehrerer Filice日:"-Beitrüge zur Naturkunde. I. p. 243.
\end{abstract}

\title{
88.-F U G US VES I G U O S US.
}

Fucus vesiculosus, frond coriaceous, flat, midribbed, linear, dichotomous, quite entire: vesicles spherical, innate in the membrane of the frond: receptacles solitary, terminal, compressed, turgid, mostly elliptical.

Fucus vesiculosus. Linn. Sp. Pl. 11. p. 1626. Syst. Nat. II. p. 715. Syst. Nat. Ed. Gmel. II. p. 1380. Fl. Lapp. p. 366. Fl. Suec. p. 430. Fl. Ang. p. 576. Fl. Scot. II. p. 904. Iinn. Trans. III. p. 144. ... In. IV. p. 84. Ner. Brit. p.3. t. 2. Syn. Fuc. I. p. 117. Eng. Bot. XV. t. 1066. Fl. Cant. p. 479. Fl.Carn. II. p. 403 . Velley. t. 1. f. 1-7. Fl. Monsp. p. 457. Fl. Ped. II. p. 528. Fl. Lus. II. p. 434. Fl. Norv. I. p. 48. Fl. Germ. III. p. 442. Fl. Atl. II. p. 422. EsPe , Ic. Fuc. I. p. 33. t. 12. Fl. Fr. Ed. $2 d a$. II. p. 18.

F. Quercus maina. Gmelin, Hist. Fuc. p. 60.

F. vesiculosi varietates. EsPER, Ic. Fuc. I. p. 35 . t. 13. p. 160. t. 83, 84.

F. mamillaris. Esper, Ic. Fuc. II. p. 14. t. 118.

F. sive Alga marina latifolia vulgatissima. Rain Syn. p. 40. n. 4.

Alga sive Fucus, Quercus Marina dictus. Basten, Op. Subs. II. p. 116. t. 11. f. 2.

F. marinus vulgatissimus latifolius foliis quercinis vesiculis donatis. Mon s. Hist. Ox. III. p. $64 \%$.

Quercus marina herbacea et varietas. PARKINSON. p. 1293. t. 11.

F. divaricatus. Linn. Sp. Pl. II. p. 1627. Syst. Nat. II. p. 715. Syst. Nat. Ed. Gmel. II. p. 1380. Fl. Scot. II. p. 909. Fl. Norv. II. p. 143. Esper, Ic. Fuc. I. p. 31. t. 11. Fl. Luss. II. p. 434. F. vesiculosus. $\beta$. Linn. Trans. III. p. 144. Fl. Germ. III. p. 443. Fl. Fr. Ed.2da. II. p. 18.

F. vesiculosus. $\gamma$. Fl. Ang. p. 577.

F. Quercus marina. จ. GaLLIN, Hist. Fuc. p. 62. 


F. bullatus fructicescens caule nudo foliis rectis compressis bifidis. MoRıs. Hist. Ox. III. p. 647. s. 15. t.8. f. 5 .

F. inflatus. Linn. Sp. Pl. II. p. 162\%. Syst. Nat. II. p. 715. Syst. Nat. Ed. Gmel. II. p. 1380. Fl. Lupp. p. 367. Fl. Suec. p. 431 . Fl. Scot. II. p. 910 . Fl. Lus. II. p. 435. Fl. Norv. II. p. $38 . \quad F l$. Dan. t. 1127 . EsPer, Ic. Fuc. I. p. 30. t. 10. SмIтH, Ic. t. 75.

F. vesiculosus. $\beta$. Syn. Fuc. I. p. 118.

F. vesiculosus. $\gamma$. Linn. Trans. III. p. 144.

F. Quercus nearina. :G Gewn, Hist. Fuc. p. 63.

F. ceranoides. \&. Fl. Ang. p. 583.

F. palmaris platyphyllus bidigitatus in vesiculas longas ventricosas conjunctas se terminans. Moris. Hist. Ox. HI. p. 647 .

F. undulatus. Ner. Brit.p. 103. t. 16.

F. vesiculosus. \&. Lim. Trans. III. p. 144.

F. vesiculosus. d: Syn. Fuc. I. p. 119.

B. spiralis; frond twisted in a spiral manner; vesicles none; receptacles ronndish.

F. vesiculosus. \&. Syn. Fuc. I. p. 119.

F. spiralis: Lin N. Sp. Pl. II. p. 1627. Syst. Nat. II. p. 715. Syst. Nat. Ed. Gnel. II. p. 1380. F\%, Lapp. p. 366. Fl. Suec. p. 431 . Fl. Ang. p. 577. Fl. Scot. II. p. 911 . Linn. Trans. III. p. 147. With. IV. p. 92. Ner. Brit. p. 10. t. 5. Fl. Norv. II. p. 64. Fl. Ped. Il. p. 333. Fl. Dan. t. 286. Fl. Atl. II. p. 422. Fl. Fr. Ed. $2 d a$. II. p. 19. BAster, Op. Subs. t. 11. f. 1. Eng. Bot. XXIV。 t. 1685.

F. vesiculosus. r. Fl. Gërn. p. 443 .

F. Quercus marina. E. Gmelin, Hist. Fuc. p. 62.

F. spiralis maritinus major. RaII Syn. p. 41. n. 5.

F. palmaris latioribus foliis in binas ternasve vesiculas verrucosas terninatis. Moris. Hist. Ox. III. p. $64 \%$ s 15. t. 8. f: 10 .

\%. volubilis; frond spirally twisted; vesicles generally wanting; apices long, elliptical.

F. vesiculosus. ל. Linn. Trans. 11L. p. 144. Syn. Fuc. I. p. 120.

F. volubilis. Fl. Ang. p. 577. (excl. syn. omn. preter Raii.)

F. spiralis muritimus minor. RA1 万 Syn. p. 42. n. 6.

£. acutus; frond narrow, producing vesicles; apices long, lanceolate.

F. vesiculosus. \&. Linn. Trans. 111. p. 144:

F. vesiculosus. $\gamma$. Syn. Fuc. I. p. 119.

F. vesiculosus. var. $\beta$. Ner. Brit. p. 12. t. 6 .

F. spiralis. EsPER, Ic. Fuc. I. p. 36. t. 14.

F. spiralis. var. ESPER, Ic. Fuc. I. p. 143. t. 72.

s. angustifolius; frond narrow; vesicles mostly wanting; receptacles sub-pedunculated, long, between linear and lanceolate, acuminated.

F. vesiculosus. ?. Syn. Fuc I. p. 120.

F. angustifolius. Wiтn. IV. p. 92.

F. lorgifructus. Fl. Fr. Ed. 2da. II. p. 19.

F. Quercus marina. \&. Gmein, Hist. Fuc. p. 62.

F. seu Quercus marina angustiore folio raro vesiculas habens. Monis. Hist. Ox. III. p. 647.

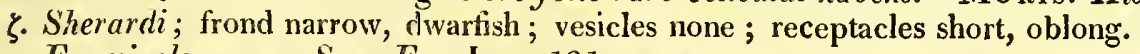

F. vesiculosus. ¿. Syn. Fuc. I. p. 121.

F. Sherardi. Ner. Brit. p. 72. t. 13.

F. vesiculosus. Wulfen, in Jarq. Coll. IV. p. 343. Crypt. Aquat. n. 6.

Virsoide con caule terete, con rami piatti, ed equali, e con sommitic bifide, o trifide, turgide. Donatr. p. 33. t. 3.

Quercia marina che ha vesiche. GiNANN1. p. 21. t. 20. n. 39.

Quercia marina di foglie anguste, eflorida. Ginanni. p. 21. t. 20. n. 40.

n. livearis; frond narrow, dwarfish; vesicles none; receptacles long, between linear and lanceolate.

F. vesiculosus. n. Syn. Fuc. p. 120.

F. linearis. Fl. Ang. p. 578. (excl. syn. Gmel.)

F. distichus. Fl. Scot. II. 912. (excl. syn. Linn. Gmel. et Fl. Dan.)

F. ceranoides. EsPER, Ic. Fuc. II. p. 76 t. 146. (excl. syn. omn.)

F. Quercus marina n. G melin, Hist. Fuc. p. 62.

F. sive Quercus marina minima angustifolia. Monis. Hist. Ox. III. p. 647.

$\approx, \beta, \gamma$, and $\delta$ are found upon the shores of the British Isles, and of all the North of Europe, plentifully.- $-\alpha$ I have received from the coast of North $\Lambda$ merica.-At Newfoundland. Herb. Banks. $\alpha$ and $\beta$ in the Mediterranen. Decandolle.-Shores of Spain, near Cadiz. Don Simon de Roxas Clemente. $-\varepsilon$ and $\zeta$ in Cornwall. 
$M r$ Stackhouse._- in the Ocean, near Brest. Decandolle.-North of Scotland. MLr. Brodie.- $\zeta$ ins the Adriatic. Wulfen.— $n$ in Cornwall. Mr. Stackhouse.-Ireland. Dr. Scott.

Perennial. Spring.

Rоот, an expanded, black, woody, callous disk.

FRON D, flat, winged, from one to four feet long, and from half an inch to an inch and half wide, every where linear, forked near the root, and afterwards repeatedly dichotomous, the intervals between each division being uncertain, but mostly rather long in the lower ones, and very short in the upper ones; the angles of the upper dichotomies are remarkably acute, those of the others generally also acute, except where a vesicle is placed at the axilla, in which case the segments are patent, or even * divaricated ; all the branches are of nearly equal height; the apices are rounded, and not unfrequently notched; the margins quite entire; throughout the whole length of the frond runs a midrib, of a blackish color, and as thick as a goose-quill at the base, but gradually growing more pale and thin, yet so as to remain every where thicker and darker than the rest of the frond: the surface, especially in young plants, is perforated with minute, scattered pores, from which issue small tufts of short, white, jointed fibres; in the membranous part of the frond, throughout its whole length, are found immersed spherical vesicles, varying in size from that of a pea to that of a hazel-nut, much more numerous in some individuals than in others, mostly opposite along the sides of the midrib, and solitary at the base of the dichotomies, constantly placed close to the midrib, in some instances occupying the whole of the membrane, in others leaving a part flat, so that they appear bordered with a small margin, externally smooth, internally empty, excepting a net-work of pellucid, jointed, anastomosing fibres; besides these, particularly in spring, almost always near the apices, but never, I believe, reaching completely to them, are often observable elliptical $\uparrow$ swellings, an inch or two long, generally confined to the membrane on each side of the midrib, but sometimes taking in the midrib itself, so that the whole branch becomes infated, and nearly cylindrical; their color is a pale yellowish green, their substance necessarily thin, because they originate from air generated between the double membrane of which the frond consists, separating the two coats from each other.- Towards the root, the leafy part of the frond is most frequently worn away by the action of the waves, and the naked midrib looks like a stipes: the sanıe is also sometimes, but very rarely, the case throughout the whole length of the frond.

Fructification, compressed, turgid receptacles, placed at the ends of the branches, solitary, or in pairs, varying in form through all the gradations from roundish to linear, or occasionally obcordate, by no means constant even in the same specimen, but mostly elliptical, from a quarter of an inch to two inches long, generally wider than the branches, externally uneven, and perforated with very minute pores, under which lie imbedded spherical tubercles, composed of short jointed fibres, mixed with seeds of an elliptical form, surrounded with a pellucid limbus, and appearing under a powerful microscope to contain six or seven roundish grains : the centre of the receptacles is filled with a colorless and tasteless pellucid mucus, through which passes a net-work of anastomosing fibres.

CoLor, dark olive-green, paler towvards the apices, smooth, and glossy; when dry black and dull.

SUBSTANCE, coriaceous, flexible and tough, but brittle after it is dried.

The variety $\beta$, which most authors look upon as distinct, seldom rises beyond nine inclies in height:-its frond is spirally twisted, but the same is observable also in the following variety, and sometimes in $\alpha$ : it has seldom vesicles; and its receptacles, which is the strongest mark, are short, and sub-globose; even this, however, is not constant, and I have seen specimens with both globular receptacles and vesicles. In the Linnæan specimen of F. spiralis most of the receptacles are oblong, some are spherical, and one is ovate and emarginate.

$\gamma$ is by no means of frequent occurrence, and is more remarkably twisted in a spiral manner than $\beta$ : its length i\$ usually three or four inches, seldom above a foot, its width about three lines: the smaller plants are destitute of vesicles, the larger ones produce them in abundance; the barren apices are long and sub-acuminated ; the receptacles, which are scarce, are large, and oblongo-ovate. Ray and Hudson, who never found this with vesicles,' considered it distinct from $F$. vesiculosus, and the latter, taking it for the Linnæan $F$. volubilis, already figured in this work, described it under that name in the Flora Anglica.-It often grows in muddy places, where it is under water only at high tides, and there it is always dwarfish.

$\delta$ extends to three feet or more in length, and is about four lines wide; its frond is remarkably flat, even, and glossy; it has always vesicles, but seldom any near the ends; its receptacles are nearly an inch long, between linear and lanceolate, acute, compressed, but little wider than the branches:- the form of the fruit causes this variety, which is the liandsomest perbaps of all, to approach near to $F$. serratus.

$\varepsilon$ resembles $\delta$ in most respects, but is more narrow, and has no vesicles: the apices, even when barren, are in some specimens acute: the receptacles are solitary, and grow at the ends of long shoots, so that they appear pedunculated; their length is an inch or more; their form lanceolate and acuminated, but sometimes bifid.-Decandolle's $F$. longi-

\footnotetext{
* This is the sole character of the Linnæan $F$. ditaricatus, which I did not consider it possible to admit, even as a varicty, since the samc circumstance is occasionally observable in every form of the frond, and never constant in any.

+ Upon these Linnæus depends for his $F$. inflalus, which, for the same reason as is already given in the preceding note, is not here enumerated, even as a variety. Similar intiations are also occasionally to be seen in $F$. servatus and $F$. ceranoides. Mr. Drummond, a very intelligent marine botanist, observes, in a letter to me, that these, fron their nature cannot be formed from a casual adnission of air, but he is rather inclined to attribute them to weakness in the plant, which he has never seen growing in this state, except at the mouths of rivers, and has always found the luest specimens in situations, where at cbb tide thcy were washed by fresh or brackish water.
} 
fructus, though quoted above under this variety, appears from his description to be intermediate between this and the preceding, agreeing with the one in its lineari-lanceolate receptacles, and with the other in its narrow frond devoid of vesicles.

Though Stackhouse's $F$. Sherardi and the only appearance of $F$. vesiculosus found by Wulfen in the Adriatic, appear to be just the same, I wish the var. $\zeta$ to be regarded as depending principally upon the latter of these. 'The frond is fiat, without vesicles, from two to six inches high, and two or three lines wide; the receptacles are short, oblong, and scarcely wider than the branches :-it connects $n$ and $\alpha$.

In $\eta$ the frond is equally narrow as in $\varepsilon$, and not taller than in $\zeta$ : it is flat, without vesicles, and has lineari-lanceolate, acute receptacles, an inch long, but hardly wider than the branches. Most botanists have confounded this with $F$. distichus, to which it is certainly nearly allied, as is mentioned in the account of that species.

Oвs. The frond of $F$. vesiculosus possesses so strong a * power of repairing any injury it may receive, that, if torn in the branches, it immediately throws out from the place a profusion of new shoots, if in the fructification, an equal number of small receptacles, which sometimes give the plant so singular an. appearance as may easily mislead a young botanist:-in drying it does not adhere to paper.

The Fucus here figured, though the most common perhaps of all our European species, and at the same time the most generally known, has still been but imperfectly understood among botanists, the greater part of whom, considering. its vesicles as its most essential, as well as its most obvious, character, have been led, by the different situations, or total absence, of these, to separate into distinct species appearances which in reality have no claim to be regarded even as varieties. Such is particularly the case with $F$. inflatus and $F$. divaricatus of Linnæus, $F$. undulatus of Stackhouse, and F. mamilaris of Esper, of which the first owes its origin probably to disease, the second and thurd certainly to accident, and the fourth is merely a fragment; and I therefore hesitated whether, with regard to them, it would be best to follow the example of preceding authors, and keep them apart as varieties, so as to leave the synonymy less intricate, or whether, joining them all under the most common form of the plant, to enumerate such of its appearances as seem most remarkable and most permanent, and, by arranging these according to their natural affinities, thus at length put a stop to the confusion that has so long prevailed. The latter plan I have followed, and trust I have done right in so doing; and as, by means of the varieties above described, the frond may be traced from three inches to four feet in length, from two lines to an inch and half in width, from flat to spiral, and from being covered with vesicles to being quite destitute of them, the reader will easily conceive the intermediate gradations; to have attempted to enumerate all which would have been an endless and useless task, as the plant in this respect yields only to $F$. crispus. Upon the various uses made of $F$. vesiculosus, in different countries, Gmelin and Lightfoot have treated much at length, and a considerable portion of what they have written on the subject will be found t below.

a. F. vesiculosus, an intermediate specimen between a and
8, natural size.
b. upper part of the frond of another specimen, inflated.
c. part of the midrib, quite stripped of its membrane;

c. part of the midrib, quite stripped of its ment.
from a drawing by Sir T. Frankland.

d. portion of var. $\beta$.

e. part of the outside of a receptacle, magnified - $\quad 6$.

f. horizontal section of a receptacle - - - -6 .

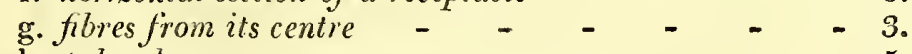

h. tubercle - - - - - - - -5 .

i. fibres of which the tubercle is composed - - $\quad 1$.

k. seeds - - - - - - - - - 3.

1. contents of a seed - $\quad-\quad-\quad-\quad-\quad-\quad-2$.

m. some of the same - $\quad$ - $\quad$ - $\quad$ - $\quad$ - $\quad$ - $\quad$ - 1 .

n. longitudinal section of a vesicle - _ - $\quad$ - 6 .

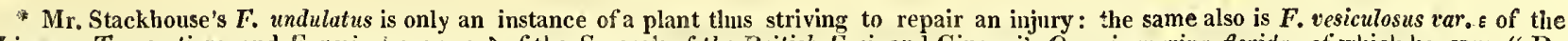
Linnaren Transactions, and F. vesicuiosus rar. $\delta$ of the Synopsis of the British Fuci, and Ginanni's Quercia marina florida, of which he says, "Da alcui i de suoi rani escano a mazzetto molte foglie, che la fanio comparire florida, e queste piccole foglie, che formano il mazzetto nella loro sommità, sono toulde."

+ "It is well known to be an excellent manure for land, to which purpose it is often applied in the maritime parts of Scotland, and other countries. In the islands of Jura and Skye it frequently serves as a winter food for cattle, whicli regularly come down to the shores at the recess of the tides to seek for it. Aud sometimes even the stays have beell obscrved, after a storm, to descend from the mountans to the sea sides, to feed upon this plaut. Linnæus informs us that the inliabitants of Gothland, in Sweden, boil this Fucus in water, and mixing therewith a little coarse meal or flour, feed their ho:s with it ; for which reason they call it Swintzng. And, in Scania, he says, the poor people cover their cottages with it, and sometimes uie it for fuel. In Jura, and some other of the Hebrides, the inliabitants dry their clieeses without salt, by covering them with the asbes of this plant, wlich abounds with such quantity of saits, that from five ounces of the ashes may be procured two ounces and a half of fixed alkaline salts. Its virtues in the medical way liave been mich celebrated by Dr. Russel, in his Dissertalion concerning the use of Sea-water in the Diseases of the Glands. He found the saponaceous liquor or mucts in the vesicles of this plant to be an excellent resolvent, extremely serviceable in dispersing all scorbutic and scrophulous swellings of the glands; and by calcining the plant in the open air, lie made a very black salt powder, which he called $V$ getable Ethio, s, a medicine much in use as a resolvent and deolstruent, and recommended also, as an excelleut dentrifice, to correct the scorbutic laxity of the gums, and take of the fonlness off the moutl." - Fl. Scot. p. 905.-The most important nse, however, of $F$. vesiculesus is in the manufacture of kelp, for an account of which the reader is referred to the general dissertation on the Fuci inteuded to accompany this volume. 
Trucus, fronde coriaceâ, planâ, costatâ, lineari, dichotomâ, integerrimâ: vesiculis sphæricis, frondis membrahne innatis : receptaculis solitariis, terminalibus, compressis, turgidis, sub-ellipticis.

Fucres vesiculosus. Linn. Sp. Pl. II. p. 1626. Syst. Nat. II. p. 715. Syst. Nat. Ed. Gmel. II. p. 1380. Fl. Lapp. p. 366. . Fl. Suec. p. 430. Fl. Ang. p. 576 . Fl. Scot. II. p. 904. Limn. Trans. III. p. 144. Wiтн. IV. p. 84. Ner. Brit. p. 3. t. 2. Syn. Fuc. I. p. 117. Eng. Bot. XV. t. 1066. Fl. Cant. p. 479. Fl. Carn. II. p. 403 . Veldey. t. 1. f. 1-7. Fl. Monsp. p. 45\%. Fl. Ped. II. p. 328. Fl. Lus. II. p. 434. Fl. Norv. I. p. 48. Fl. Germ. III. p. 442. Fl. Atl. II. p. 422. EsPer, Ic. Fuc. I. p. 33. t. 12. Fl. Fr. Ed. 2da. II. p. 18.

F. Quercus marina. GMELIN, Hist. Fuc. p. 60.

F. vesiculosi varietates. EsPER, Ic. Fuc. I. p. 35. t. 13. p. 160. t. 83, 84.

F. mamillaris. EsPER, Ic. Fuc. II. p. 14. t. 118.

F. sive Alga marina latifolia vulgatissima. RaII Syn. p. 40. n. 4.

Alga sive Fucus, Quercus Marina dictus. Baste R, Op. Subs. II. p. 116. t. 11. f. 2.

F. marinus vulgatissimus latifolius foliis quercinis vesiculis donatis. Mor Is. Hist. Ox. III. p. 647.

Quercus marina herbacea et varietas. PARKInson. p. 1293. t. 11.

F. divaricatus. Linn. Sp. Pl. II. p. 1627. Syst. Nat. II. p. 715. Syst. Nat. Ed. Gmel. II. p. 1380 Fl. Scot. II. p. 909. Fl. Norv. II. p. 143. EsPer, Ic. Fuc. I. p. 31. t. 11 . Fl. Lus. II. p. 434.

F. vesiculosus. B. Linn. Trans. III. p. 144. Fl. Germ. III. p. 443. Fl. Fr. Ed. 2da. II. p. 18.

F. vesiculosus. \%. Fl. Ang. p. 577.

F. Quercus marina. 9. Guetin, IHist. Fuc. p. 62.

F. bullatus fruticescens caule nudo foliis rectis compressis bifidis. Moris. Hist. Ox. III. p. 647. s. 15. t. 8. f. 5 .

F. inflaius. Linn. Sp. Pl. II. p. 162\%. Syst. Nat. II. p.715. Syst. Nat. Ed. Gmel. II. p. 1380. Ft.

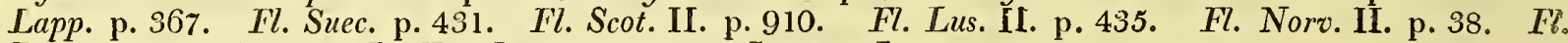
Dan. t. 1127 . Esper, Ic. Fuc. I. p. 30. t. 10. Sмiтr, Ic. t. 75.

F. vesiculosus. ß. Syn. Fuc. I. p. 118.

F. vesiculosus. $\gamma$. Linn. Trans. III. p. 144.

F. Quercus marina. .. GMeLin, Hist. Fuc. p. 63.

F. ceranoides. d. Fl. Ang. p. 583.

F. palmaris platyphyllus bidigitatus in vesiculas longas ventricosas conjuncias se terminans. Mo Ris. Hist. Ox。 III. p. 647.

F. undulatus. Ner. Brit. p. 103. t. 16.

F. vesiculosus. в. Lim. Trans. III. p. 144.

F. vesiculosus. 8. Syn. Fuc. I. p. 119.

B. spiralis; fronde spiralitèr tortâ; vesiculis nullis : receptaculis subrotundis.

F. vesiculosus. \&. Syn. Fuc. I. p. 119.

F. spiralis. Linn. Sp. Pl. II. p. 1627. Syst. Nat. II. p. 715. Syst. Nat. Ed. Gmel. II. p. $1380 . \quad F$. Lapp. p. 366. Fl. Sazec. p. 431. Fl. Ang. p. 577. Fl. Scot. II. p. 911. Linn. Trans. III. p. 147. With. IV. p. 92. Ner. Brit. p. 10..t. 5.. Fl. Norv. II. p. 64. Fl. Ped. II. p. $333 . \quad F l$. Dan. t. 286: Fl. Atl. II. p. 422. Fl. Fr. Ed. 2da. II. p. 19. Baster, Op. Subs. t. 11. f. 1. Eng. Bot. XXIV. t. 1685 .

F. vesiculosus. r. F. Germ. p. 443.

F. Quercus marina. є. GMEL1N, Hist. Fuc. p. 62.

F. spiralis maritimus major. RaII. Syn. p. 41 . n. 5 .

F. palmaris latioribus foliis in binas ternasve vesiculas verrucosas terminatis. MonIs. Hist. Ox. III. p. 647. s. 15. t. 8. f. 10.

ช. volubilis; fronde spiralitèr tortâ; vesiculis plerumque millis : apicibus oblongis, elongatis.

F. vesiculosus. ?. Limn. Trans. III. p. 144. Syn. Fuc. I. p. 120.

F. volubilis. F. Ang. p. 577 . (excl. syn. omn. præter Raii.)

F. spiralis maritimus minor. RA11 Syn.p. 42. n. 6.

ঠ. acutus; fronde angustâ, vesiculiferâ; apicibus productis lanceolatis.

F. vesiculosus. \&. Limn. Trans. III. p. 144.

F. vesiculosus. r. Syn. Fuc. I. p. 119.

F. vesiculosus. var. $\beta$. Ner. Brit. p. 12. t. 6.

F. spiralis. EsPer, Ic. Fuc. T. p. 36. t. 14.

F. spiralis. var. Es PE R, Ic. Fuc. I. p. 143. t. 72.

s. an gustifolius; fronde angustâ; vesiculis plerumque nullis: receptaculis sub-pedunculatis, elongatis, lineari-lanceolatis, acuminatis.

F. vesiculosus. भ. Syn. Fuc. 1. p. 120 .

F. angustifolius. Wıтн. IV. p. 92. 
F. longifructus. Fl. Fr. Ed. 2da. II. p. 19.

F. Quercus narina. 8. Guelin, Hist. Fuc. p. 62.

F. seu quercus marina angustiore folio raro vesiculas habens. Moris. Hist. Ox. III. p. 647.

३. Sherardi; fronde angustâ, humili ; vesiculis nullis: receptaculis brevibus, oblongis.

F. vesiculosus. ". Syn. Fuc. I. p. 121.

F. Sherardi. Ner. Brit. p. 72. t. 13 ,

F. vesiculosus. WulfeN, in Jacq. Coll. IV. p. 343. Crypt. Aquat. n. 6.

Virsoide con caule terete, con rami piatti, ed eguali, e con sommità bifide, o trifide, turgide. Donatr. p. 33.

t. 3.

Quercia marina che ha vesiche. GinanNı. p. 21. t. 20. n. 39.

Quercia marina di foglie anguste, e florida. GinanNi. p. 21. t. 20. n. 40.

ท. linearis; fronde angustâ humili : vesiculis nullis: receptaculis elongatis, lineari-lanceolatis.

F. vesiculosus. n. Syn. Fuc. p. 120.

F. linearis. Fl. Ang. p. 578. (excl. syn. Gmel.)

F. distichus. Fl. Scot. II. p. 912 . (excl. syn. Linn. Gmel. et Fl. Dan.)

F. ceranoides. EsPer, Ic. Fuc. II. p. 76. t. 146. (excl. syn. omn.)

F. Quercus marina. n. Gmelin, Hist. Fuc. p. 62.

$F$. sive quercus marina minima angustifolia. Moris. Hist. Ox. III. p. 647.

Habitant $\alpha, \beta, \gamma$, et $\delta$ in Britanniarum et in totius Europæ Septentrionalis oris, vulgares.- $\alpha$ ex Americâ Septentrionali accepi.-Apud Newfoundland. Herb. Banks. $-\alpha$ et $\beta$ in Mari Mediterraneo. Decandolle.-In Hispaniæ littoribus, prope Gades. D. S. de Roxas Clemente.- $\varepsilon$ et $\zeta$ in Cornubiâ. D. Stackhouse.- ${ }_{\varepsilon}$ in Oceano propre Brest. Decandolle.-In Scotia Borealis oris. D. Brodie.—Z in Mari Adriatico. Wulfen. 一 in Cornubiâ. D. Stackhouse.-In Hibernix oris. D. Scott.

Perennis. Vere.

RADrX callus expansus, discoideus, lignosus, ater.

FroN s plana, alata, longitudine a pedali ad quadripedalem et ultrà, latitudine a semiunguiculari ad pollicarem aut sesquipollicarem variabilis, ubique linearis, prope radicem bifurca, atque exinde dichotomiis pluries repetitis divisa, intervallis inter singulas incertis, sed plerumque inter inferiores longiusculis, inter summas brevissimis; furcarum supremarum anguli insignitèr acuti, reliquarum ut plurimum acuti, nisi fortè vesicula ad sinum ponatur, quando segmenta patentia, aut * divaricata evadunt; rami omnes sub-fastigiati; apices rotundati, obtusi, nec raro emarginati ; margines integerrimi ; frondem totam longitudinalitèr percurrit costa, basi nigricans, et pennæ anserinæ crassitie, sed sensim, ut progreditur, tenuior et dilutior, ubique tamen magis obscura et magis crassa quàm reliqua frons ; superficies, quod maximè in juniore evenit, poris minutis fibrarum albarum articulatarum brevium fasciculos emittentibus hic illị̀ pertusa ; in frondis membranâ per totam longitudinem immersæ reperiuntur vesicula sphæricæ, nunc $P$ isi sativi nunc Coryli Avellana seminum magnitudine, multò frequentiores in quibusdam individuis quàm iu aliis, plerumque oppositæ ad costæ latera, et solitariæ ad dichotomiarum sinus, semper juxta costam positæ, in his totam membranæ latitudinem occupantes, in illis partem relinquentes planam, ut marginatæ appareant, extrinsecùs glabræ, intùs cavæ, et vacuæ, nisi quòd fibras aliquot pellucidas, anastomosantes, articulatas ferant: præter has, præsertìm in vere, et ferè semper frondis juxta apices, nunquam vero, uti credo, ad ipsos, sæpe observantur ftumores elliptici, pollicem et ultrà longi, plerumque in membranâ modò positi, interdùm tamen ipsam quoque costam complecteutes, ut ramus integer inflatus et sub-cylindricus evadat, color his dilutè virens, aut flavicans, substantia necessario tenuis quonian ortum debent aeri intra membranam duplicem, e quâ tota constat planta, admisso, aut ibidèm generato.--Membrana frondis ad basin sæpiùs vi fluctuum atteritur, et costa denudata stipitem mentitur: reperitur hrec quoque aliquandò, sed rarissimè, et non uisi fortuitò, per totam longitudinem nuda.

FrUCtificatio receptacula compressa, turgida, frondis ad apices sita, solitaria, vel bina, figurae subrotundæ, aut ovatæ, aut ellipticæ, aut lanceolatæ, aut linearis, aut demùm ob-cordatæ, aut aliûs qualiscunque ex his compositæ, et variabilis in eodem individuo, sæpiùs tamen ellipticæ, nunc semiunguem, nunc duos pollices longa, ramis plerumque latiora, extrinsecùs ubique torulosa, et poris minutissimis pertusa, sub quibus latent tubercula sphærica, $\mathrm{c}$ fibris brevibus articulatis constantia, immixtis seminibus ellipticis, limbo pellucido cinctis, ipsis sub lente acerrimâ sex septemve granula subrotunda includentibus : mediam receptaculorum partem implet mucus pellucidus, albus, fibris anastomosantibus intertextus.

Co Lo R intensè olivaceus, apices versus dilutior, lævis, uitidus; exsiccate nigricans, nitoris expers.

Su bstanti a coriacea, lenta, tenax, desiccatione fragilis.

Var. $\beta$, quam pro specie distinctâ plerique auctores habuerunt, rarò ad altitudinem ultra dodrantaien attingit:frons huic spiralitèr torta, sed idem in aliis quoque varietatibus, atque interdùm in a observatur: vesiculæ plerımque desunt; et receptacula, quod magis valet, abbreviata sunt et sub-globosa : loc verò non constans; et vidi etiam exem-

VOL. II.

plaria

* Ex hoc umninò pendet $F$. divaricatus Linnæi, quem, cùm sit in omnibus $F$. vesiculosi formis aliquando conspiciendum, et in nullo coustans, non potui vel varietatis loco admittere.

$\dagger$ Ex lis pendet $F$. inflatus Linuæi, quem, ob eandem in notâ pracedente nemoratam causam, nequeo hìc vel pro varietate, nedùm pro specie distinctâ, habere. Tales sunt quoque, sed rariùs, in $F$. ceranoide et in $F$. serrato conspiciendi. Ex aere intùs formato originem ducere, et in plantis modò debilibus reperiri, suspicatur D. Drummond, acer liarun stirpium investigator, qui me nuper per literas certiorem fecit, se nun. gram, nisi in individuis fluviorum ad ostia natis, observâsse. 
plaria receptaculis sub-globosis et simùl vesiculis donata. F. spiralis exemplar linnæanum receptacula habet plurima oblonga, quædam sphærica, atque unum ovatum emarginatum.

Var. $\gamma$ infrequentèr occurrit, frondemque habet insigniùs spiralem quàm $\beta$ :-longitudo plerumque palmaris, rarò plus quàm pedalis, latitudo circitèr trilinearis : stirpes minores vesicularum sunt expertes, majores satis copiosè ferunt: apices in sterilibus oblongi sub-acuminati ; receptacula visu perrara, oblongo-ovata, majuscula.-Hanc semper absque vesiculis viderunt Raius et Hudsonus, et hic sub $F$. volubilis nomine in Florâ Anglicâ edidit, eandem esse credens quam planta ejus nominis Linnæana, jam in hoc opere vulgata, a quâ toto cælo discrepat.-In cœnosis, ubi æstu fervente modò alluitur, nasci solet, ibique semper est humilis.

\& ad longitudinem tripedalem et ultrà producitur, latitudine quadrilineari; frons præ cæteris plana, nitidissima; vesiculæ, quæ semper adsunt, rard apices versus conspiciuntur; receptacula pollicem ferè longa, lineari-lanceolata, acuta, compressa, ramis vix latiora:- - fructûs forma efficit ut hæc varietas, omnium forsan pulcherrima, ad $F$. serratum accedat.

$\varepsilon$, varietatis præcedentis in plurimis simillima, illâ est angustior, vesiculisque caret; apices sunt, vel steriles, in quibusdam individuis acuti: receptacula segmentorum elongatorum ad apices solitaria nascuntur, et sub-pedunculata apparent; longitudo his pollicaris et ultrà, figura lanceolata, acuminata; quandoque bifida occurrunt:-Decandollii F. longifructus, sub hâc suprà citatus, inter lianc et var. \& intermedia ex descriptione videtur, fronde angustissimâ et vesicularum absentiâ cum unâ, receptaculis lineari-lanceolatis cum alterâ conveniens.

Per var. $\zeta$ non tàm Stackhousii $F$. Sherardi quàm Wulfenii $F$. vesiculosum designare mihi est in animo, uterque licet mihi idem videatur. Hanc unicam in Mari Adriatico reperit Wulfenius: frons plana, vesicularum expers, altitudine $\mathrm{ab}$ uno duobusve pollicibus ad semialteram variat spithamam, latitudine duas tresve lineas æequat; receptacula abbreviata, ovali-oblonga, ramis vix latiora.-Var. $\eta$ cum $a$ hæc connectit.

In $n$ frons est æquè angusta atque in $\varepsilon$, et æquè humilis atque in $\zeta:$ est plana, sine vesiculis, receptaculaque habet lineari-lanceolata, acuta, pollicem longa, ramis vix latiora.-Hanc, $F$. disticho certè maximè affinem, cum illo commiscuerunt botanici plerique, de quo consulenda est ejus stirpis historia.

Oвs. F. resiculosi frons, * ubicunque læditur, si in ramis, magnam ramorum novorum, folia simulantium, emittit copiam, si in vesiculis, vesicularum parvarum copiam non minorem, unde plantæ facies aliquando longè a vulgari aliena, et quæ tyronem facilè decipiat:- - exsiccata chartæ non adhæret.

Inter Fucos Europreos omnium forsan est vulgatissimus $F$. vesiculosus, neque ullus alius magis in universum innotuit; quod tamen non prohibuit quominus ejus fuerit historia errorum nebulis involuta; quia botanici plerique plantæ characterem essentialem, paritèr ac maximè obvium, in vesiculis quærendum existimaverunt, et, earum dispositione aut absentiâ nisi, in plures distraxerunt species. Harum multas, si rectè perpendas, haud etiam pro varietatibus, nedum pro speciebus distinctis, habendas censebis; præsertìm $\boldsymbol{F}$. inflatum et $\boldsymbol{F}$. divaricatum Iinnei, $\boldsymbol{F}$. undulatum Stackh., et F. mamillarem Esp., quorum primus verisimilitèr a morbo, alter certè a casu aliquo foriuito, tertius ab injuriâ acceptâ ortum ducit, quartus verò nihil est nisi stirpis majoris apex diffractus. De his igitur dubitavi quid facerem; all satius foret auctorum præcedelitium vestigiis insistere, et in varietates dispertire, ut synonymia minus iniplicita evaderet; an; omnibus ad plantæ faciem vulgatissimam relatis, illas stirpis formas, quæ notatu dignissimæ et simul maximè stabiles apparent, de integro secundum naturam disponere. In posteriorem denique sententiam ivi, ut errori tandem ponatur modus; et per varietates suprà descriptas perspicere poterit lector, quàm longitudine a palmari ad quadripedalem, latitudine a bilineari ad sesquipollicarem, figurâ a planâ ad spiralem, ludere solet frons, vesiculis nunc tota ferè cooperta, nunc illarum prorsùs expers. Plus præstare tentavisse, et omnes stirpis, quâ, præter $F$. crispum, nulla magis variabilis, formas enumeravisse, vanum fuisset conamen. De usibus neconomicis et medicis, quibus inservire solet $F$. vesiculosus, multis verbis disserit Gmelinius, e quo non pauca † infrà exscripsi.

\author{
a $F$. vesiculosus, formá inter a et $\delta$, magn. nat. \\ b. frondis pars superior, inflata \\ c. costa pars, membranâ totâ deperditâ, ad iconem \\ a nob. T. Frankland missam.
}

d. vass

\footnotetext{
- Stackhousii F. undulatus est nihil nisi planta sic læesa; et ex eâdem omninò causâ pendent $F$, vesicuilosi rar. E, Act. Soc. Linn.; F. vesiculosi

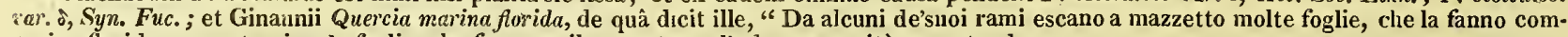
parire florida, e queste piccole foglie, che formano il mazzetto nella loro sommità, sono tonde.

† " Cel, v. Linnè, in Itinere Oelundico habet, uti hoc finco incolas ad conficienda domorum tecta, et ad fiugalitatem terræ conferendam : conjici propterea ut bene cxuratur, in acervos, quos pecora ob salem amant. Hominibus insulas Scillii inhabitantibus utraque hæc utilitas non incognita est. In Itinere Gothico refert, vocari Quercum ab incolis Sweintang, quod in aqua cocta, et in illa per aliquod tempus maccrata, bonum suibus pabulum præbere soleat. In Norlandia eundem in finem cum farina commiscetur. Singularem attentionem meretır præstantissina medicata virtus qua Quercum natura instruxit, primo a Richardo Russell observata, et postea a Gaubio et Bastero multis experimentis comprobata. Vis scilicet huic inest potenter resolvens, durissinis schirris non impar. Russelius, in libro, Dissertation concerning the use of Sea-water in the Discases of the Glunds iuscripto, refert, quod vesicnlis quercus pitvitoso et saponaceo lumore justo tempore repletis si partes induratæ perfricentur, detumescere eædein solent. Idem auctor folia in aere siccanda cremandaque suadet producitur inde pulvis subsalsus et ater quem Aethiopem vegetabilem appellat, atque summa cum utilitate ad strumas induratas aliosque norbos adhibet. Plinii quoque tempore cognitæ quercus virtutes medicatæe erant."-Gmelin, Hist. Fuc. p. 67, - Maxino tamen $F$. vesiculosus est usui in sale alcalino, nostratibus kelp Jicto, faciendo, de quo consulenda est dissertatio de Fucis hnic operi, uti spero, adjungenda.
} 


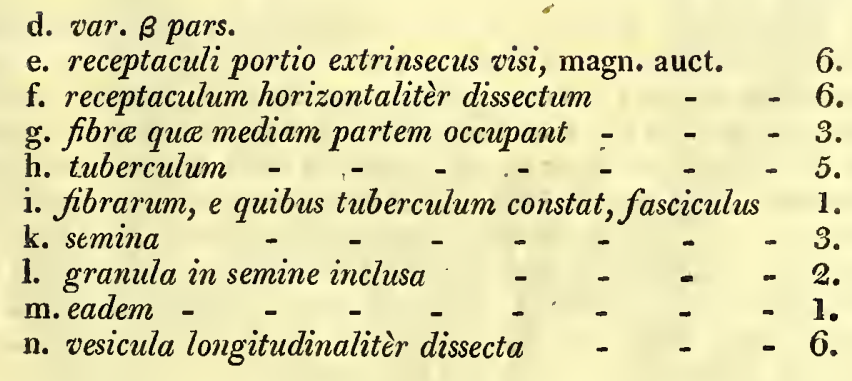

\section{9.-F U G U S G E A N O I D E S.}

Fucus, fronde coriaceo-membranaceâ, planâ, costatâ, lineari, sub-dichotomâ, integerrimâ, ramis lateralibus, angustioribus, multifidis, fructiferis sparsìm pinnatâ: receptaculis solitarïs, terminalibus, teretiusculis, lineari-acuminatis.

Fucus ceranoides. Linn. Sp. Pl. II. p. 1626. (excl. syn. Moris.) Syst. Nat. II. p. 715. Syst. Nat. Ed. Gmel. II. p. 1380. (excl. syn. Moris. et var. B.) Fl. Lapp. p. 366. Fl. Suec. p. 430. Ner. Brit. p. 71. t. 13. Linn. Trans. III. p. 149. (excl. syn. Fl. Ang. Fl. Scot. Gmel, et With.) Syn. Fuc. I. p. 136. Fl. Fr. Ed. 2da. II. p. $19 . \quad$ Fl. Carn. II. p. 403.

F. distichus. Es Per, Ic. Fuc. II. p. 62. t. 139. (excl. syn.)

Habitat in Britanniarum oris, haud ita frequens.-Lapponiæ et Sueciæ ad littora. Linnaus.-In Galliæ oyis, ubi oceano alluitur. Decandolle.

Perennis. Vere.

RA DIX callus exiguus, discoideus, nigricans.

Frons plana, alata, longitudine pedalis, vel sesquipedalis, latitudine tri- quadri- linearis, sub-dichotoma, scilicet divisa dichotomiis haud procul a radice incipientibus, atque exinde ter quaterve repetitis, spatio inter singulas incertissimo, ramis fastigiatis, ubique a basi usque ad apices linearibus, furcarum angulis acutis, apicibus bifidis, segmentis perquàm brevibus, rotundatis, patentibus, ipsis haud rarò emarginatis, præter quod stirps hìc illìc, præsertìm apices versus, ramos emittit laterales, horizontalitèr patulos, alternos, renıotiusculos, inferiores pollicem unum alterumve longos, cæteros, quò magis plantæ ad summitates appropinquant, eò sensìm breviores, omnes ortu simplices, mox bifurci, aut palmati segmentis tribus vel quatuor, et his quoque iterùm atque iterùm simili ratione divisis, utrâque serie præcedente tenuiore, ut ultimi vix sint lineam lati ; margines ubique integerrimi, lenitèr undulati; superficies sparsìm pertusa punctis exiguis, fibras emittentibus; frondem totam percurrit costa nigricans, basi Merulæ pennæ crassitie, inde pedetentim tenuior et pallidior, ita tamen ut ad ipsos sit apices, fructiferis modo exceptis, semper manifesta; frons fastigium versus interdùm, sed infrequentèr inflata occurrit, * tumoribus ellipticis, circiter pollicem longis, ad utrumque costæe latus dispositis, coloris pallidè lutei, et substantiæe tenuis.-Membrana costam cingens plerumque juxta radicem vi fluctuum deperditur, et costa ibi denudata stipitem brevem refert.

Fructificatio receptacula lineari-lanceolata, acuminata, longitudine unguem aut propemodìm pollicem æquantia, ramorum lateralium angustorum, nunquarn termiualium, ad apices sita, turgida, e tereti compressa, ramis neutiquàm latiora, extrinsecùs ubique torulosa, et poris minutissimis pertusa, sub quibus latent tubercula exigua, sphærica, immersa, e fibris pellucidis articulatis constantia, immixtis seminibus subrotundis, fuscis, limbo pellucido cinctis : receptaculorum partem interiorem occupat mucus albus aquosus, interjectis fibris pellucidis, tenuissimis, articulatis, retis in formam anastomosantibus.

Color olivaceus, flavicante sæe tinctus, sub-diaphanus; exsiccatce intensior.

Substantia inter coriaceam et cartilagineam, tenuis.

Oвs. Frons, ubicunque læditur, vi eâdem proliferâ, quâ $F$. vesiculosus, donatùr; - habitus lenitèr tortilis :-eXsiccata chartæe non adhæret.

Si nihil esset, preter vesicularum in fronde innatarum absentiam, per quod $F$. ceranoides ab $F$. vesiculoso dignosceretur, pauci, uti credo, auderent botanici, hâc solâ nisi, pro verè distinctis venditare; quonian non desunt huic etiamn

varietates, * Ex his pendet $F$. ceranoides var. B in Fusorum Britannicorum Synopsi memorata, quam, ob eandem jam suo $F$. vesiculoso prolatam causam,
hic repetere destiti. 
varietates, quæ harum, maximâ saltèm sunt ex parte, si non semper, expertes. Receptacula quoque, quantumvis aliquid in se peculiare primo aspectu ostendant, formâ haud ita multùm recedunt ab is $F$. vesiculosi var. $\delta$, ut ad duas stirpes naturâ arctissimè connexas distinguendas valerent ; neque majoris sunt momenti notæ, quæ a colore, substantiâ, aut habitu dissimili eruuntur, singulæ licet $\mathrm{ex}$ his discrimen cuivis statim manifestum prodant. Talibus igitur posthabitis, aliunde est quærendus $F$. ceranoidis character specificus, et hunc frondis forma crescendique modus inter dichotomum et pinnatum intermedius suppeditant. Planta per hæc sese a cæteris omnibus Fucis dignoscendam præstat, manseruntque hæc in cunctis, quæ ego vidi, exemplaribus constantèr stabilia et manifesta, quamvis magis in his quàm in illis conspicua. Aliæ quoque sunt observandæ notæ in ramis brevibus lateralibus, qui, radiatìm dispositi, circulum ferè dimidiatum peripheriâ suâ describunt, cùm quia reliquâ fronde, quæ ubique est in $F$. vesiculoso linearis, multoties sunt angustiores, tùm quia semper ad horum, et nunquam ad segmentorum dichotomorum latiorum, apices receptacula sunt sita. Botanicorum hodiernorum cupido Linnæi summi vestigiis insistendi causæ extitit, quare $F$. ceranoidis nomen, antehac a Raio, Morisono, Gmelino, * omnibusque botanicis F. crispo suo impositum, huic stirpi inditum servaretur; quod ille primitùs fecerat, deceptus ab icone in Plantarum Historiâ Oxoniensi semper sub $F$. ceranoide ab antiquis citatâ, et liquidò referente $F$. mammillosum, tunc cum $F$. crispo commixtum, et ipsi forsitan incognitum. Titulus quidem, a similitudine inter frondis figuram et cornua depromptus, aptiùs ad Gmelinianam quàm ad Linnæanam speciem quadrat, hujus licet exemplaria interdùm a cervorum quorundam cornibus, apices versus, formâ non ita multum abludunt. Talem hallucinationem, in re ubi nullus hallucinationi locus apertus videbatur, nemo unquam est † suspicatus, donec exemplaribus in ipsius Linnæi herbario lustratis, detexerunt Goodenovius Woodwardiusque, a quibus dissentire cogor de Gmelini Hudsoni et Lightfootii synonymis, ad F. ceranoidem in Societatis Linnaana Actis relatis, quorum primum in hoc opere sub $F$. disticho, alterum et tertium snb $F$. vesiculoso citantur, ad quem $F$. linearem $F l$. Ang. pertinere pro certo scio, edoctus exemplaribus, quæ cum amicissimo H. Davies Hudsonus communicavit. Ad Fucorum rariorum numerum F. ceranoidem ascribendum existimo, quoniam nullam descriptionem quæ ejus formam peculiarem exprimit reperio, et hæc nimis est singularis ut anctoris alicujus, cui planta reapse innotuit, observationes effugeret. Hanc ob causam Flore Gallica synonymon non omni dubio vacare credo, quamvis Nereidis Britannica iconem citat Decandollius. Summam laudem meretur figura ab Espero data; infaustis autem avibus cel. Professor mutavit nomina $F$. ceranoidis et $F$. distichi Lightf. exemplaribus a me missis imposita, unde factunı est ut, utrâque sub alterius titulo editâ stirpe, nihil ad plantarum diu. vexatarum historiam illustrandam contulerit.

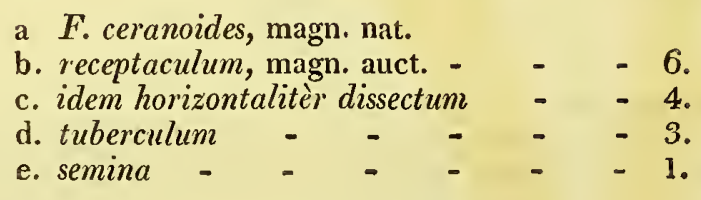

\footnotetext{
* Ex horum numero Scopolins unus est excipiendus, crijus tamen synonymon nequaquàm est pro indubio habendum, quoniam tantummodò characterem Linnæanun specificum repetit, adjecto plantam snam esse $F$. resiculose latioren et majorem.

† Si ulla unquam de hâc re extitisset suspicio, botanicorum forte oculos aperuisset, et Linnæi $F$. cerunoidem ab eo Gmelini diversum docuisset, animadversio in Systemate Natura, ubi de hoc traditur " Pracedenti $(F$. inflato) affinis, sed angustior magisque ramosus, utrinque punctis impressis adspersus." Hâc observatione motus Hudsonıs $F$, inflatum (quod mireris) sub $F$. suo ceranoide, qui noster $F$. crispus, pro varietate d recersuit.
} 

Fucus ceranoides, frond between coriaceous and membranaceous, midribbed, linear, sub-dichotomous, pinnated with narrow, lateral, scattered, multifid, fruit-bearing branches : receptacles solitary, terminal, sub-cylindrical, linear, acuminated.

Fucus ceranoides. Lin N. Sp. Pl. II. p. 1626. (excl. syn. Moris.) Syst. Nat. II. p. 715. Syst. Nat. Ed. Gmel. II. p. 1380. (excl. syn. Moris. et var. B.) Fl. Lapp. p. $366 . \quad$ Fl. Suec. p. 430. Ner. Brit. p. 71. t. 13. Linn. Trans. III. p. 149. (excl. syn. Fl. Ang. Fl. Scot. Gmel. et With.) Syn. Fuc. I. p. $136 . \quad F l$. Fr. Ed. 2da. II. p. 19. Fl. Carn. II. p. 403.

F. distichus. Es PER, Ic. Fuc. II. p. 62. t. 139. (excl. syn. omn.)

On the shores of the British Isles, not very common.-Coasts of Lapland and Sweden. Linnceus.-In the Atlantic Ocean, on the coast of France. Decandolle.

Pereniial. Spring.

Roот, a small, blackish, callous disk.

Fron D, flat, winged, a foot or a foot and half long, and three or four lines wide, sub-dichotomous, that is to say, divided by dichotomies, beginning near the root, and afterwards about thrice repeated, at very uncertain intervals, with branches of equal height, linear from base to summit, the angles of the divisions being acute, the apices bifid, with short, patent, rounded segments, themselves also not uncommonly notched, in addition io which, the plant here and there sends out lateral shoots, between horizontal and patent, alternate, rather remote, the lowest an inch or two long, the rest gradually shortening as they approach the summits of the frond, all simple at their origin, but almost immediately either forked or palmate, with three or four segments, which also are repeatedly divided in a similar manner, each series being more narrow than the preceding one, so that the extreme ones are not above a line wide; the margins are every where quite entire and slightly undulated; the surface is dotted with small holes, from which issue short tufts of white fibres; throughout the whole frond runs a blackish midrib, as thick at its base as a blackbird's quill, but gradually growing more thin and pale, yet so as constantly to continue visible to the very apices, except in a state of fructification : the frond, towards the top is occasionally, but by no means frequently, found * inflated, with elliptical swellings, about an inch long, placed along both sides of the midrib, of a pale yellow color, and thin substance.-The membranous part of the frond is generally worn away near the base by the action of the waves, and the naked midrib there resembles a short stipes.

Fructification, receptacles between linear and lanceolate, acuminated, from half an inch to nearly an inch in length, situated at the extremities of the narrow lateral branches, but never of the terminal ones, between cylindrical and compressed, not wider than the branches, externally uneven, and perforated with very minute pores, under which lie small, spherical, immersed tubercles, composed of pellucid jointed fibres, mixed with roundish brown seeds, surrounded by a transparent limbus: the internal part of the receptacles is filled with a colorless watery mucus, through which passes a net-work of extremely thin, pellucid, jointed, anastomosing fibres.

CoLOR, an olive-green, often inclining to yellow, semitransparent; darker when dry.

SUBSTANCE, thin, between coriaceous and membranaceous.

Oвs. The frond, wherever it receives an injury, is found to be provided with the sane proliferons tendency as $F$. vesiculosus; the naked part of the midrib, at the base, is also generally fringed with small shoots:-the habit is slightly twisted:-in drying it does not adhere to paper.

Were the absence of air-bladders in the frond the only mark of distinction that separated $F$. ceranoides from $F$. vesiculosus, few botanists, I believe, would venture so fully to rely upon this circumstance, as to regard it in itself sufficient to constitute a certain specific difference; since there are also varieties of the latter species, in which these are generally, if not always, wanting. The form too of the receptacles of the Fucus before us, though peculiar, is not very dissimilar to that of those of $\boldsymbol{F}$. vesiculosus var. $\delta$; so that both these marks, though highly characteristic, as well as obvious, are inadequate to the purpose of permanently distinguishing the two plants. Other characters are afforded by the dissimilarity of habit, color, and substance, but none of these would be satisfactory, were it not for the mode of growth of $F$. ceranoides, upon which alone implicit reliance is to be placed, and which is sufficiently striking and constant to entitle it to the place of a species. This, though more remarkable in some individuals than in others, appears to be enough so in all, immediately to distinguish this Fucus from every other at present known, rendering the form of the plant intermediate between dichotomous and pinnated. The short lateral shoots are disposed in a radiated manner, and their outline makes the segment of a circle. In these, also, additional proofs may be found of the difference between $\boldsymbol{F}$. ceranoides and $\boldsymbol{F}$. vesiculosus, from the circumstances of their being always considerably more narrow than the rest of the frond, which in $F$. vesiculosus is regularly linear throughout, and of their bearing at their extremities the receptacles, which are never to be met with in the broader branches that terminate the dichotomies. Nothing, but the desire of treading exactly in the foosteps of the great Linnæus, could have induced the modern botanists to continue, after his example, to the plant here tigured, the name of $F$. ceranoides, which had, by Ray, Mo-

\footnotetext{
- Upon this circunstance depends the variety $\beta$, described in the Synopsis of the British Fuci, which is here omitted, for the reasons men. tioned under $F$. vesiculosus.
} 
rison, Gmelin, and indeed by * every other author, been applied to what he has called $F$. crispus, to which it is also more appropriate, though many specimens of the present species are at their apices not unlike the horns of some kinds of deer. The error originated in his mistaking the Fucus intended by Morison in the Historia Oxoniensis, III. s. 15. t. 8. f. 13 , which unquestionably belongs to $F$. mamillosus, then confounded under the name of $F$. ceranoides; but, so little room did there seem for error in the case, that no + suspicion was entertained of the existence of any, previously to the arrival of the Linnæan Herbarium in England, when Dr. Goodenough and Mr. Woodward discovered it, by means of the original specimens there preserved. From these gentlemen I have been under the necessity of differing, with respect to the synonyms quoted by them from Gmelin, Hudson, and Lightfoot, the first of which is already referred to in the first volume of this work under $F$. distichus, and the two latter under the preceding species, to which I know, from authentic specimens communicated to the Rev. H. Davies by Hudson himself, that $F$. linearis of the Flora Anglica belongs. Indeed no botanist could well mention $F$. ceranoides without noticing the particular manner of its growth, and I therefore apprehend it to be a plant of unfrequent occurrence, and even feel a doubt as to the synonym of the Flore Française, though reference is there made to the plate in the Nereis Britannica. Professor Esper's figure of this Fucus is excellent, but is, unfortunately, not qualified to remove the doubts that existed upon the subject, as, by some most unlucky accident, he has reversed the names attached to the specimens which I sent him of $F$. ceranoides and $F$ a distichus, Lightf., and has represented each under the appellation of the other.

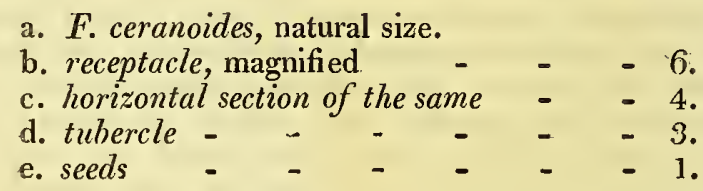

\footnotetext{
* To this observation Scopoli furnishes a solitary exception, but his $F$. ceranoides is far from a certain synonym, as he merely repeats the Linuxan specific character, and adds that his plant is longer and wider than $F$. vesiculosus.

+ Had such a suspicion arisen, the observation in the Systema Natura could scarcely have failed to satisfy botanists that the Linnæan $F$. ceranoides was not the same as Gmelin's plant of that name; for it is there said of it, "Pracedenti, (F. inflaio) affinis, sed angastior magisque ramosus, utrinque punctis impressis adspersus."-This remark did not essape Hudson, who, in consequence of it, described $F$. inflatus as the var. \& of his $F$. ceranoides, which is our $F$. crispus,
}

\section{0.-F U C US SER R A T US.}

Fucus serratus, frond coriaceous, flat, midribbed, linear, dichotomous, serrated at the margins : receptacles solitary, terminal, flat, linear, serrated, sharpish.

Fucus serratus. LinN. Sp. Pl. II. p. 1626. Syst. Nat. II. p. 715. Syst. Nat. Ed. Gmel. II. p. 1380. Fl. Lapp. p. $365 . \quad$ H. Suec. p. 430. Fl. Ang. p. 576. Fl. Scot. II. p. 902. Linn. Trans. III. p. 143. Ner. Brit. p. 2. t. 1. Syu. Fuc. I. p. 110. Wiтн. IV. p. 91. Eng. Bot. XVII. t. 1221. Fl. Cant. p. 478. Velley. t. 1. f. a-c. Fl. Ped. II. p. 328. Fl. Norv. I. p. 28. Fl. Germ. III. p. 441. GMELIN, Hist. Fuc. p. 5\%. EsPer, Ic. Fuc.I. p. 23. t. 5. p. 25, t.6. Fl. Fr. Ed.2da. II. p. 20. Baster, Op. Subs. II. p. 120. t. 11. f. 3.

F. sive Alga latifolia major dentata. Reaumur, in Act. Gall. 1711. p. 285. t. 9. f. 1. 1712. partie 2de. t.3. f. 1,2, 3, 4, 5, 7. RaII Syn. p. 42. n. 7. Moris. Hist. Ox. III. p. 648. s. 15. t. 9. f. 1.

B. latifolius; upper branches widened upwards, of an ovate-lanceolate shape.

F. serratus. B. Fl. Ang. p. 576. Grelin, Hist. Fuc. p. 57. Syn. Fuc. I. p. 111.

Quercus marina humilis, latifolice serrata similis. RAII Syn. p. 42. n. 8.

$\gamma$. integer; margins nearly entire.

F. serratus. $\gamma$. Syn. Fuc. I. p. 117 .

On the shores of the British Isles, and throughout the Northern Ocean, abundantly.-Coast of Piedmont. Allioni.

Perennial. December-March.

Root, a thick, orbicular, sub-conical disk, about half an inch in diameter, of a substance between spongy and? woody, sometimes appearing, in consequence of prominent nerves upon its surface, as if wholly. composed of clustered fibres. 


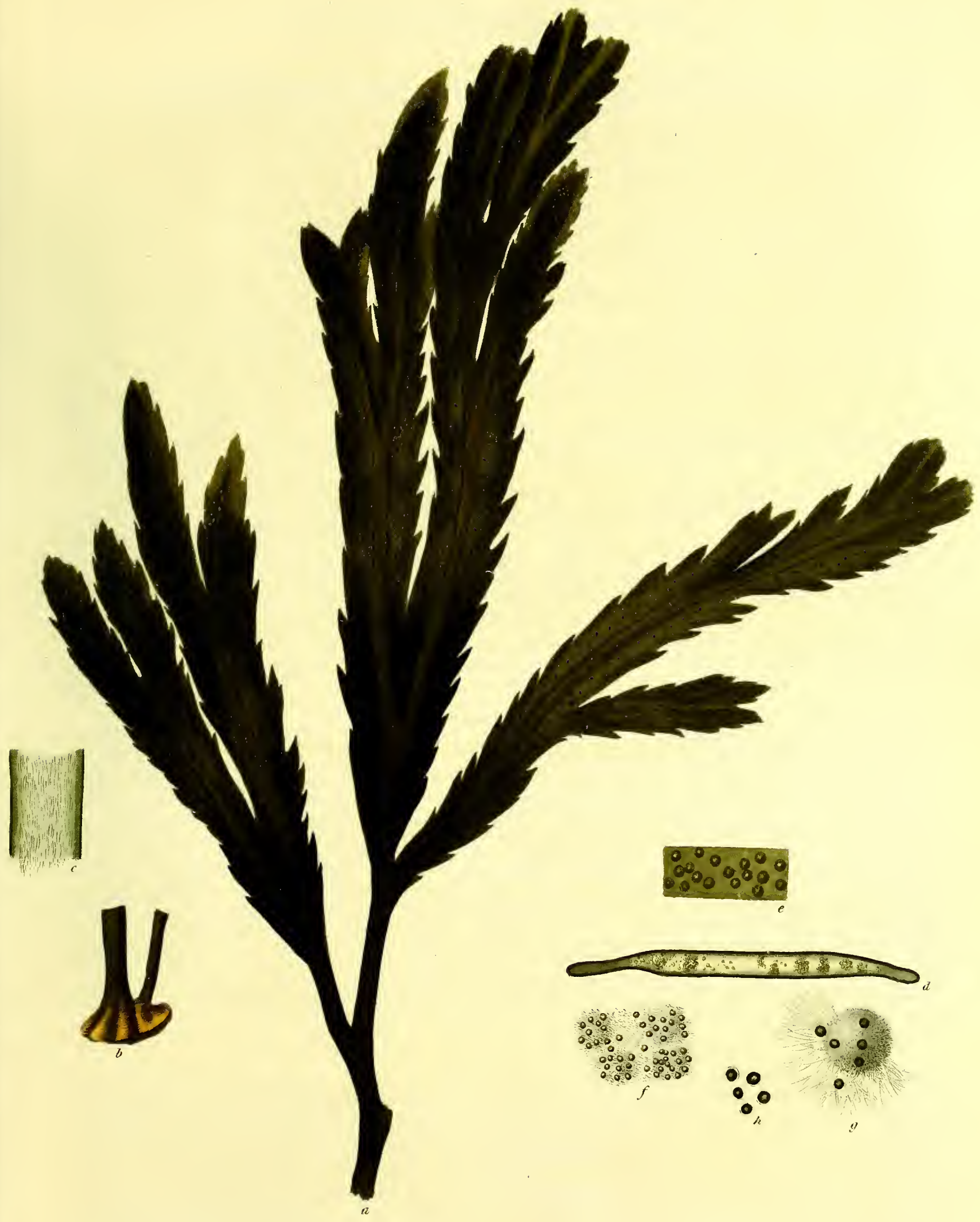

Sucus serralius. 

FROND, mostly solitary, flat, winged, from two to six feet long, and from half to three quarters of an inch wide, constantly linear throughout, divided with dichotomies that begin near the root, and are afterwards frequently repeated, the intervals between each being uncertain, but generally long between the lower ones, and very short in the upper ones; the angles of the divisions are acute; the surface is spotted all over with small, rather prominent, dark-colored, scattered perforations, out of which issue pencils of most minute white fibres; through the whole frond passes a blackish midrib, nearly as thick as a goose-quill at its base, and there sub-cylindrical, but almost immediately becoming compressed, and soon quite flat, gradually growing more thin and pale as it advances, yet constantly visible to the very extremities, excepting those in fructification, in which it terminates where the tubercles begin; the apices, in barren specimens, are rounded, blunt, and bifid, with segments of various lengths; the margins are every where serrated, or rather serrato-dentate, with teeth of the same substance as the branches, in some instances placed near to each other, in others remote, in some two or three lines long, in others not exceeding a single one, in some simple, in others forked, always slightly incurved, and pointing upwards.-The leafy part of the frond is generally worn away towards the base by the action of the waves, and the naked midrib resembles a stipes, varying in length from an incla to a foot in different individuals.

Fructification, flat * receptacles, an inch, or more, long, placed at the ends of the branches, which scarcely swell in the least, or change their appearance in consequence of them, except that they are elongated, and sharpish, and externally uneven, and perforated with very minute pores, under which lie imbedded spherical tubercles, composed of short, pellucid, branching, jointed fibres, closely matted together, mixed with brown, reundish seeds, surrounded by a transparent limbus.

CoLOR, olive-green, in some specimens dark and tinged with brown, with a still deeper-colored midrib, in others pale, and with a midrib even more pale; yellow in the fruit-bearing apices; when dry constantly black throughout.

SUBSTANCE, between coriaceous and cartilaginous, flexible, tough.

In $\beta$ the frond is by no means linear, but the upper branches are twice as wide as the lower ones, and are undivided, and rounded at the ends, so that their shape is between elliptical and ovate; the pla!t is dwarfish ; the color pale; the teeth rather remote and large.

The variety $\gamma$, of which I have seen only a single specimen, communicated by Mr. Stackhouse, agrees in almost every point with $\alpha$, but has its margins nearly entire, and quite destitute of serratures, though far from smooth or even : it appears at first sight as if it belonged to $F$. vesiculosus, between which and $F$. serratus it is intermediate, but the fructified apices leave no room to doubt of the species to which it ought to be referred.

Oвs. The habit of $F$. serratus never inclines to twisted, and the branches always grow in the same plane :- Sertularia pumila and Serpula spirorbis and spirillum are frequently found upon this plant:--in drying it does not adhere to paper.

The serratures of the Fucus before us, and the constant absence of air-bladders upon the frond, furnish two so striking and obvious characters as can scarcely fail, at any time, immediately to distinguish it from all the varieties of $F$. vesiculosus, with which alone there is reason to fear its being confounded. In addition, however, to these, a t third, and still more certain mark of difference is to be found in the receptacles, which, far from being swollen, as in that species, so as to be almost cylindrical, are but very little thicker than the rest of the branches, down which they extend for a considerable length, withont materially altering their form. Specinens are occasionally, though very rarely, to be met with, $\mp$ inflated in a manner similar to what has been described at length under the two preceding Fuci, and instances of the same remarkable proliferous tendency, as is there also noticed, not unf:equently occur in $F$ serratus, though in a smaller degree. On the other hand, the punctures upon the frond are far more numerous and striking than in those species, so that Réaumur, who regarded the tufts of fibres, that issued from these, as the male fructification, selected the § present as the most favourable instance for elucidating his theory of the generation of the Fuci, a point which has been so repeatedly discussed, that I may be well excused from here dwelling upon it. Respecting the uses of $\boldsymbol{F}$. serratus, we learn from Gunner, that it is employed in some parts of Norway, sprinkled over with meal, for the food of cattle; and Baster observes, that the Dutch fishermen use it for packing their lobsters in preference to $F$. vesiculosus, because the mucus contained in the receptacles of this latter causes the fish to rot. It serves also the same purpose in England, and is cultivated upon the Western coast of Scotland for the manu-

facture

* How far these can properly be termed receptacles appears to me doubtful: their nature, indecd, is precisely the same as that of those observable in $F$. vesiculosus and its congeners, but they do not cause the ends of the shoots to change their appearance, and they look only like scattered tubercles immersed in the substanee of the frond.

$t$ Dr. Roth, who does not notice this latter character, makes a third distinction to depend npon the pedunculate fruit, in which $\mathbf{I}$ really do not at all comprehend his meaning. He mentions it repeatedly in lis description, donbts whether Esper or Gmelin had ever seen the fruit, and and says, "Fruetifieationes plerumque geminæ, peduneulo eommuni eompresso, fronde paullo erassiore, diehotomo, ala foliacea destituto in.
sidentes." Fl. Germ. III. p. 441.

Upon this eireumstance depends the var. $\delta$, deseribed in the Synopsis of the British Fuci, but here omitted for the reasons mentioned under F. vesiculosus. I found the plant growing in this state, at Fresh-water, at the Isle of Wight, the swellings being quite at the extremities, and

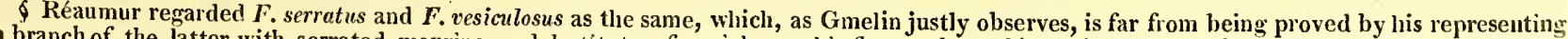
a branch of the latter with serrated margins, and destitute of vesicles, as his figure show this to be a plant of $F$, scrratus, growing upon the other, instances similar to which are far from uncommon among the maine algæ. 
facture of * kelp, but more frequently for manure. According to Gmelin it yields but a small quantity of lixivial salt in comparison of $F$. vesiculosus, and six ounces only can be procured from sixteen ounces of the ashes.

a. F. serratus, natural size.

b. root.

c. longitudinal section of the midrib, magnified 3.

d. horizontal section of a receptacle - $\quad 6$.

e. part of the coat of the same, viewed internally 3.

f. tubercles - - - - $-{ }_{-}$- 3 .

g. single tubercle $\quad-\quad-\quad-\quad-\quad 2$.

h. seeds - - - - - - - 1 .

\footnotetext{
- In the island of Mull, I was told that F. serratus goes by the name of black:wrack, and is but little used in making kelp, because it shrinks so much in drying, and contains so little marine salt.
}

\section{0.-F U G U S E R R T US.}

Fucus, fronde coriaceâ, planâ, costatâ, lineari, dichotomâ, margine serrato-dentatâ: receptaculis solitariis, termínalibus, planis, linearibus, serratis, acutiusculis.

Fucus serratus. Linn. Sp. Pl. II. p. 1626. Syst. Nat. II. p. $715 . \quad$ Syst. Nat. Ed. Gmel. II. p. 1380. Fl. Lapp. p. 365. Fl. Suec. p. 430. Fl. Ang. p. $576 . \quad$ Fl. Scot. II. p. $902 . \quad$ Linn. Trans. III. p. 143. Ner. Brit. p. 2. t. 1. Syn. Fuc. I. p. 110. Wiтн. IV. p. 91. Eng. Bot. XVII. t. 1221. Fl. Cant. p. 478. Velley. t. 1. f. a-c. Fl. Ped. II. p. 328. Fl. Norv. I. p. $28 . \quad F l . G e r m$. III. p. 441. GMEliN, Hist. Fuc. p. 57. EsPer, Ic. Fuc. I. p. 23. t. 5. p. 25. t.6. Fl. Fr. Ed. 2da. II. p. 20. Baster, Op. Subs. II. p. 120. t. 11. f. 3.

F. sive Alga latifolia major dentata. Re u u un, in Act. Gall. 1711. p. 285. t. 9. f. 1. 1712. partie 2 de t. 3. f. 1, 2, 3, 4, 5, 7. RAII Syn. p. 42. n. 7. Moris. Hist. Ox. III. p. 648. s. 15. t. 9. f. 1.

ß. latifolius; ramis superioribus sursùm dilatatis, ovato-lanceolatis.

F. serratus. B. Fl. Ang. p. 576. Gmelin, Hist. Fuc. p. 57. Syn. Fuc. I. p. 111.

Quercus marina humilis, latifolia serrata similis. RAII Syn. p. 42. n.8.

\%. integer; ramorum marginibus sub-integerrimis.

F. serratus. r. Syn. Fuc. I. p. 111 .

Ha вıтат in Britanniarum oris, et ubique in Oceano Septentrionali, copiose.-In Mari Nicæensi et Uneliensi. Allioni.

Perennis. Dec.-Maium.

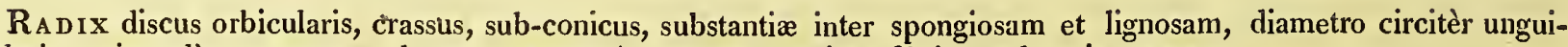
cularis, et interdùm apparens, ob nervos supernè extantes, quasi ex fibris coadunatis constaret.

Frons solitaria, vel bina, plana, alata, longitudine a bipedali ad orgyalem, latitudine ab unguiculari ad sesquiunguicularem variabilis, ubique semper linearis, divisa dichotomiis haud procul a radice incipientibus, atque exinde sexies pluriesve repetitis, intervallo inter singulas incerto, sed plerumique inter inferiores longiusculo, et inter supremos perbrevi; furcarum anguli acuti ; superficies passim pertusa punctis prominulis, exiguis, nigricantibus, sparsis, fibrarum albarum minutissimarum fasciculos emittentibus; frondem totam percurrit costa nigricans, basi pennæ anserinæ propemodùm crassitie, et teretiuscula, mox compressa, et citò plana, quæ sensìn fit, ut progreditur, tenuior et dilutior, sese tamen semper manifestam prestat, excepto in apicibus fructiferis, ubi tuberculis incipientibus desinit; apices, in stirpe sterili, rotundati, obtusi, bifidi, segmentis, quoad longitudinem, incertissimis; margines- ubique serrati, vel potiùs serrato-dentati, dentibus homogeneis, nunc approximatis, nunc remotiusculis, nunc unam, nunc duas tresve lineas longis, nunc simplicibus, et nunc bi- tri- furcis, semper lenitèr incurvis, et sursùm spectantibus.-Membrana frondis basin versus vi fluctuum sæepiùs deteritur, et costa, ibi denudata, stipitem, in his pedalem, in illis vix pollicarem, refert. 
Fructificat 10 * receptacula plana, pollicem, et ultrà, longa, ramorum ad apices sita, qui tunc vix, aut ne vix, intumescunt, formamve mutant, nisi quod elongati et acutiusculi fiant, atque extrinsecùs sint torulosi, et poris minutissimis pertusi, sub quibus latent tubercula sphærica, immersa, e fibris pellucidis, brevibus, densè compactis, ramosis, articulatis constantia, immixtis seminibus subrotundis, fuscis, limbo diaphano cinctis.

Color olivaceus, nunc obscurus, et fusco tinctus, cum nervo intensiore, nunc pallidus, nervo magis diluto; in receptaculis flavicans; exsiccata nunquam non ubique nigrescit.

SU B ST A N I A coriaceo-cartilaginea, lenta, tenax.

In var. $\beta$ froıs nequaquàm est linearis, sed rami superiores sunt inferioribus dupld latiores, indivisi, et apice rotundati, ut figuræ sint elliptico-ovatæ: statura humilis; color dilutus; dentes remotiusculi, magni.

Var. $\gamma$, cujus unicum modd adhuc exemplar a Stackhousio missum vidi, in omnibus feré cum a convenit, sed margines habet sub-integerrimos, dentium expertes, non tamen læves, aut æquales : hæc primo aspectu ad $F$. vesiculosum referenda videtur, inter quem et $F$. serratım quasi intermedia anbigit, sed apices fructiferi non sinunt ut dubitemus ad quemnam horum rectiùs pertinet.

Oвs. F. serrati habitus nunquam tortilis, et rami semper in eodem plano sunt positi:-Sertularia pumila et Serpula spirorbis et Spirillum huic innasci solent:--exsiccatus chartæ non adhæret.

Frons serrata vesicularum nunquam non expers duos cuivis satis manifestos characteres suppeditant, per quos Fucus hìc depictus ab omnibus $F$. vesiculosi, quocum uno ne commisceatur est timendum, varietatibus statìm dignoscitur. $\uparrow$ Tertium etiam, et cui non minùs quàm præcedentibus fidere licet, discrimen in receptaculis ponitur, quæ nunquam sunt, sicut in illâ stirpe, turgida et sub-cylindracea, sed contrà̀ ramis vix crassiora evadunt, horumque figurâ levissimè mutatâ, per multum longitudinis porriguntur. Occurrunt $F$. serrati interdùm, sed perrard, exemplaria, fronde $\ddagger$ tumoribus insdem jam sub $F$. vesiculoso et $F$. ceranoide descriptis hìc illic inflatâ, neque deest aliquando vis eadem prolifera in illis maximè conspicua. In fronde etiam punctatâ hæ tres plantæ conveniunt, sed frequentiores magisque manifesti sunt pori in $F$. serrato quàm in aliis, unde Reaumurius, qui fibrarum penicillos ex his exeuntes pro fructu masculo habuit, ad theoriam suam de Fucorum generatione §hoc usus est exemplo; quam cùm multi fusè tractaverint botanici, rem in præsens indelibatam relinquo. Tradit Gunnerus, $\boldsymbol{F}$. serratum, adspersâ farinâ, boum pabulum esse in Norlandiâ ; memoratque Basterus, "Astacos, qui Zirizœa in reliquas Belgii fæderati provincias devehuntur, hoc fuco obvolvi, ut humidi permaneant. $F$. vesiculosus autem, varietasque illius rard vesiculas habens, ob multum in vesiculis contentum mucum facilè putrescunt, adeoque hunc in finem rarò adhibentur." Eidem etiam usui in Britanniæ maritimis hæc planta inservit; et in Scotiæ oris occidentalibus cùm ad salem alcalinum, quem || kelp vocant, conficiendum, tùm ad frugalitatem terræ conferendam colitur. Gmelino teste, " cremata salis lixiviosi quantitatem F. vesiculoso multo habet minorem, ut ex sedecim cinerum unciis non nisi sex illius eliciantur."

a. F. serratus, magn. nat. -
b. radix.
c. costa pars longitudinalitèr dissecta, magn. auct.
d. receptaculum horizontalitèr dissectum
e. ejusdem epidermidis pars, intus visa
f. tubercula

* An jure receptacula dicenda?-dubito quidem-ejusdem sumt omninò naturæe quâ ea $F$. vesiculosi et congenernm, sed ramorum apices non, ut in illis, faciem ob hæe mutant, quare fructificatio nihil aliud videtur nisi tubercula sparsa in frondis substantiâ immersæ.

+ Rothius, hoc posthabito, tertium inter $\boldsymbol{F}$. vesiculosum et $\boldsymbol{F}$. serratum discrimen ex lujus fructu pedunculato ducit, in quo fateor me non bene capere quid exprimere vellet. Hunc fructûs pedunculum evidentissimum ter quaterve in descriptione memorat, dubitare se profitens utrum Gmelinus Esperusve unquam fructificationem viderit, et de hâc dicit, "Fructificationes plerumque geminæ, pedunculo comnuni compresso, fronde paullo crassiore, dichotomo, ala foliacea destituto, insidentes."-Fl. Germ. III. p. 441.

‡ Ex his pendet $F$. serrati var. Sin Fucorum Britannicorum Synopsi descripta, sed hic ob causas jam sub $F$. vesiculoso traditas prætermissa. Plantam sic inflatam in mari, apud Fresh-water, in Insulâ Vecti, cum amicissimo Borrero, in mense Junio 1806, nascentem detexi. Tumores ab iis $F$. vesiculosi in hoc discrepabant, quod ad ipsos apices erant positi, longitudinis vix unguicularis, et totam frondis latitudinem occupantes. $F$. serratum pro $F$. vesiculosi varietate habuit Reamurius; quod tamen, ut optimè monet Gmelinus, haud est ex illo inferendum " quòd lıujus repraesentaverit ramum, dentatâ fronde, memoratisque vesicnlis destitutum, cùm ex iconis contemplatione pateat, esse eum verum ser. ratum fucum, quercui adcretum, familiare enim est plantis marinis, ut distinctæ species in distinctis crescant."-Gmelin, Hist, Fuc. p. 58.

|| In Insulâ Mull $F$. serratus "black-wrack" nuncupatur; incolæeque hoc rarồ utuntur in "kelp" faciendo, nou ninùs quia exsiccatione multum coltrahitur, quàm quia paullùm in se salis marimis includit. 
Fucus nodosus, frond coriaceous, compressed, reinless, sub-dichotomous, branched in a pinnated manner : receptacles distichous, pedunculated, roundish, mostly solitary.

Fncus nodosus. Linn. Sp. Pl. II."p. 1628. Syst. Nat. II. p. 716. Syst. Nat. Ed. Gmel. II. p. 1381. Fl. Lapp. p. $366 . \quad$ Fl. Suec. p. 431 . Fl. Ang. p. 584. Fl. Scot. 1I. p. 918. Linn. Trans. III. p. 190. Ner. Brit. p. 35. t. 10. Syn. Fuc. II. p. 252. Wiтн. IV. p. 84, Eng. Bot. VIII, t. 570. Fl. Cant. p. 479. Fl. Monsp. p. 458. Fl. Ped.II. p. 329. Fl. Norv. I. p. 83. Fl. Dan. t. 146. Fl. Germ. III. p. 454. Gmel1N, Hist. Fuc. p. 78. t. 1. B. f. 1. EsPer, Ic. Fuc. 1. p. 25. t. 7. Fl. Fr. Ed. $2 d a$. II. p. 22. Baster, Op. Subs. II. p. 121. t. 11 . f. 5.

F. maritimus nodosus. Reaumur, in Act. Gall. 1712. t. 26. t. 2. f. 3. RaII Syn. p. 48. n. 41.

F. maritimus vesiculis majoribus singularibus per intervalla dispositis. MoRrs. Hist. Ox. III. p. 647. s. 15 t. 8. f. 2.

ß. minor; receptacles ovate, scarcely wider than the peduncle.,

F. nodosus. B. Syn. Fuc. II. p. 253.

F. nodosus. var. Es PER, Ic. Fuc. I. p. 118. t. 60.

$\%$ siliquatus; receptacles lineari-lanceolate.

F. nodosus. \%. Syn. Fuc. II. p. 253.

8. serratus; frond much and irregularly branched, toothed at the margins.

F. nodosus, var. GMELIN, Hist. Fuc. t. 1. B. f. 2. (no description.)

F. nodosus. ß. Fl. Germ. III. p. 454.

On the shores of the British Isles, and throughout the Northern Ocean, abundantly: I have also rcceived it from North America. - Shores of Piedmont. Allioni. $\beta$ in the South of England.-Newfoundland. Herl. Banks. $\sim_{\gamma}$ at Dover. Mr. Dillayn.

Perennial. November-May.

Roот, a large, shapeless, hard, woody mass, inclining generally to conical or roundish.

Fronds, numerous from the same base, compressed, or between flat and compressed, destitute of midrib or veins, from two to four, or even six feet long, about three lines wide, and everywhere linear, except that they are here and there swollen into vesicles, whence the plant derives its knotty appearance and name; they rise to the height of some inches undivided, and are there forked, after which they are generally twice or thrice dichotomous, with patent segments, and, besides this, furnished with lateral, horizontal branches, more or less plentiful in different specimens, some crowded, others remote, some a foot or two long, others not above as many inches, some simple, others forked; all the branches are remarkably attenuated at their bases, so as to be attached only by very slender points, and are along their margins serrated with extremely minute, alternate, distant teeth, from the axillæ of which would arise new branches if the age of the plant permitted it, at their apices they are blunt, and often terminated by minute vesicles, the smaller ones look like linear leaves, and it not unfrequently happens that specimens are found with a simple stem, merely lined with these, the appearance of which is quite pinnated; the vesicles are innate in the frond, of which they occupy the whole substance, and are considerably wider than it; in size they vary from that of a hazel-nut to that of a * walnut, they are always solitary, and mostly separated by intervals of some inches, externally they are smooth, internally hollow, and quite empty, except that their sides are lined by a coat of white jointed fibres.

Fructification, spherical or elliptico-spherical receptacles, some not larger than a pea, others as large as an acorn, scattered along the sides of the branches, and coming out of the axilla of the serratures, generally solitary, but sometimes two or three together, supported upon compressed peduncles, that gradually widen from very narrow bases, and are half an inch or an inch long; the exterior of the receptacles is slightly uneven, and perforater all over with minute pores, under which lie imbedded spherical tubercles, composed of short, simple, jointed fibres, mixed with roundish brown seeds, which have a transparent limbus, and with pellucid elliptical granules, many times smaller than the seeds, similar to those observable in $F$. tuberculatus and some other species of Fuci: the internal part of the receptacles is filled with a colorless mucus, through which passes a net-work of white jointed fibres, with irregular meshes.

CoLOR, olive-green, glossy when fresh, not in the least transparent, yellow in the receptacles, but everywhere black after it is dried.

SubstancE, coriaceous, flexible, extremely tough, a line or a line and half thick in the primary parts of the frond.

$\beta$, which is a pretty variety, is no where more than half the size of $\alpha$, and bears numerous elliptical receptacles, about as large as the seeds of Vicia sativa, and scarcely wider than the peduncle.

Of $\gamma, \mathrm{I}$ have seen only a single specimen gathered by Mr. Dillwyn; it agrees in size with $\alpha$, but has lineari-lanceolate receptacles, three quarters of an inch or an inch long, and not more than a line and half in width, at first sight not unlike the vesicles of $F$. siliquosus.

$\delta$ is taken up altogether upon the authority of Gmelin, who has given a figure, but no description, of it: the frond is irregularly branched in a pinnated manner with long simple branches, some linear throughout, others remarkably serrated, with largish teeth, placed close to each other:- does it really belong to $F$. nodosus?

* Mr. Stackhouse mentions, that in old plants they are sometimes four inches long, a size far exceeding that of any I ever saw. 


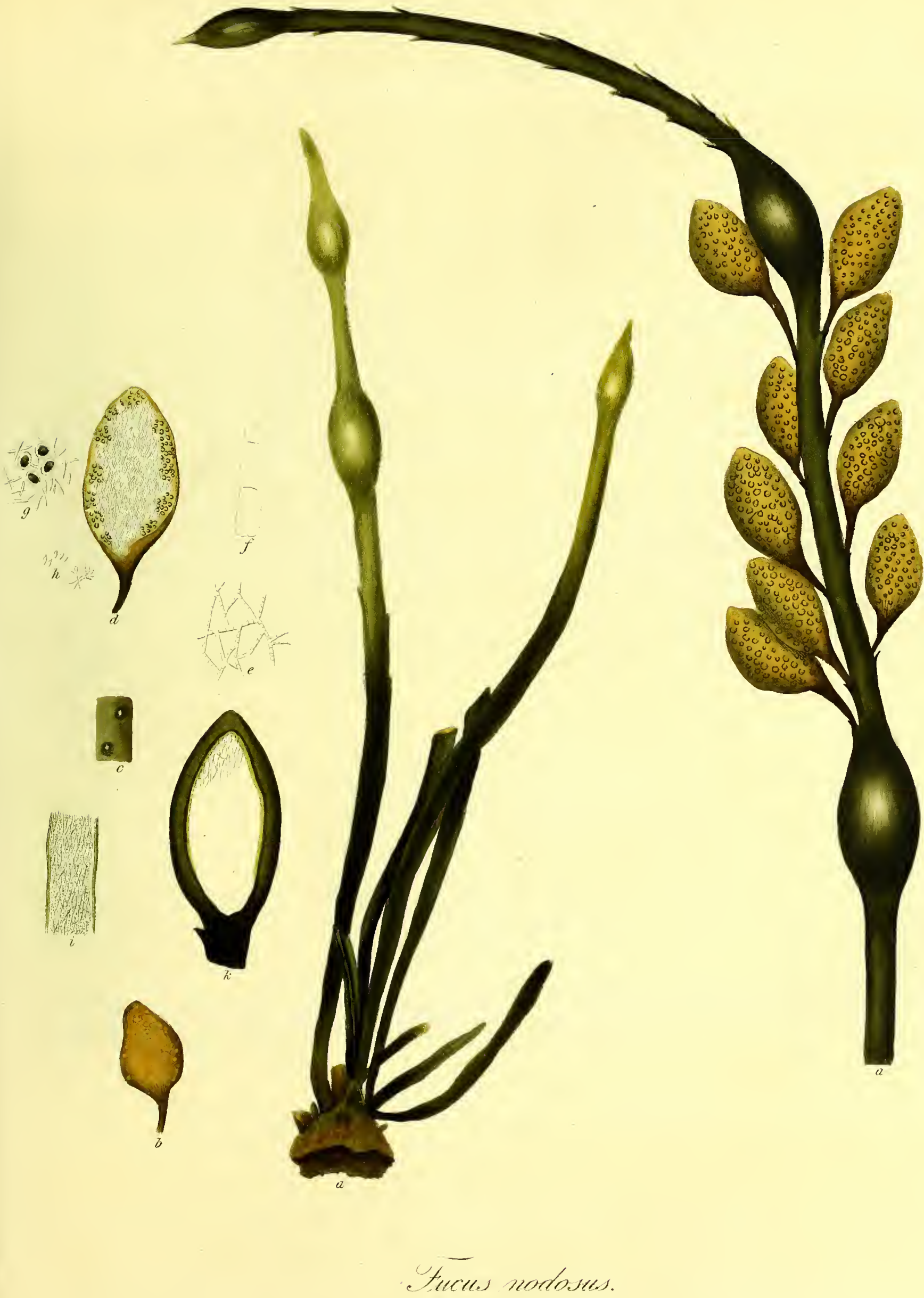



Oвs. Very few Zoophytes are ever found attached to the frond of this Fucus, which, on the contrary, is generally tufted here and there with branches of Conferva polymorpha, which grows on nothing else:-in drying it does not adhere to paper.

The vesicles innate in the frond of this Fucus are so remarkable in their figure, their texture, and their situation, and afford so strong and obvious a character of the species, that there is seldom any difficulty in distinguishing it, however disguised under varying appearances. On this account, few of our more common Fuci have been less perfectly described, and any botanist, who formed his judgement of the plant before us only from what he found written respecting it, would be led to conclude that, in point of form, it is subject to few, if any, deviations. Such a conclusion, however, would be altogether unwarranted by fact, for it is no less changeable than $F$. vesiculosus, though its varieties are far less defined or permanent, so that it is not equally easy to describe them, and none of them are destitute of vesicles, so that they are not equally likely to mislead. The leading stem of the frond, though most frequently dichotomous, is sometimes undivided, and, though almost always provided with lateral branclies, is occasionally altogether naked; these branches, also, are generally short, simple, and placed at distances of half an inch, or an inch, from each other, but some specimens have them clustered from the same point, and in others they throw out a profusion of smaller ones, which are again and again divided in the same manner; instances also occur of their being very long, narrow, subcylindrical, and nearly entire, of their being fringed with others so as to resemble in miniature the beak of a saw-fish, and of their being themselves so small as to look only like short blunt teeth. Their situation varies from patent to horizontal. In all these changes, liowever, in the shape of the frond, not only the vesicles but the receptacles remain constant, and both these, though liable to some alteration in size and * form, are always unlike those of every other Fucus. The coat of the vesicles is so tough that pressure between the fingers is insufficient to break them, but, if stamped upon, or put into the fire, they explode with a considerable report. The receptacles, I think, undoubtedly fall off after they have fulfilled their office, and thus afford an additional proof in opposition to the opinion entertained by Professor Mertens, that it is a law in the economy of this tribe for them to turn into air-bladders. The root, too, of $\boldsymbol{F}$. nodosus is very remarkable, not being, like those of its congeners, a wide, expanded, flat disk or cone, but rather a shapeless mass, either solid, or composed of a few thick shoots, as in $\boldsymbol{F}$. tuberculatus, the power of which, to preserve, by mere adhesion, so great a mass unmoved against the force of the waves, is truly wonderful. There are no pores or capillary fibres visible upon the surface of the frond in any stage of its growtlh. This Fucus is in the Hebrides preferred to all others in the manufacturing of kelp, and passes there under the name of kelp-wrack.

a, a. F. nodosus, natural size.

b. receptacle.

c. portion of the exterior of the same, magnified 6 .

d. Tongitudinal section of the same - $-\quad-6$.

e. fibres from the interior of the receptacle - 3 .

f. part of the same - $\quad-\quad-\quad-1$.

g. seeds and fibres from the tubercles - - 1 .

h. pellucid granules - $-{ }_{-}-1$ -

i. longitudinal section of a part of the frond - 3 .

k. vesicle cut open - - - - 6.

\footnotetext{
* The only remarkable instance $I$ ever saw of clange of form in the vesicles of $F$. nodosus is in a specimen gathered at Yarmouth, in which many of those situated at the ends of the smaller branches are of a narrow lanceolate shape, some of them almost an inch long, and not more than a line and half wide, looking like siliquæ, others, however, are of the common shape and size.
} 
Fucus, fronde coriaceâ, compressâ, aveniâ, sub-dichotomâ, pinnato-ramosâa: receptaculis distichis, pedunculatis, sub-globosis, plerumque solitariis.

Fucus nodosus. LinN. Sp. Pl. II. p. 1628. Syst. Nat. II. p. 716. Syst. Nat. Ed. Gmel. II. p. 1381. Fl. Lapp. p. $366 . \quad$ Fl. Suec. p. 431. Fl. Ang. p. 584. Fl. Scot.II. p.918. Linn. Trans. III. p. 190. Ner. Brit. p. 35. t. 10. Syn. Fuc. II. p. 252. W1тн. IV. p. 84. Eng. Bot. VIII. t. 570. Fl. Cant. p. 479. Fl. Monsp. p. 458. Fl. Ped. II. p. 329. Fl. Norv. I. p. 83. Fl. Dan. t. $146 . \quad$ Fl. Germ. III. p. 454. Gmelin, Hist. Fuc. p. 78. t. 1. B. f. 1. Esper, Ic. Fuc. I. p. 25. t. 7. Fl. Fr. Ed. 2da. II. p. 22. Baster, Op. Subs. II. p. 121. t. 11. f. 5.

F. maritimus nodosus. Reaumur, in Act. Gall. 1712. p. 26. t. 2. f. 3. RaI1 Syn. p. 48. n. 41.

F. maritimus vesiculis majoribus singularibus per intercalla dispositis. Monis. Hist. Ox. p. 647. s. 15. t. 8. f. 2 .

B. minor; receptaculis ovatis, pedunculo vix latioribus.

F. nodosus. $\beta$. Syn. Fuc. II. p. 253.

F. nodosus var. EsPer, Ic. Fuc. I. p. 118. t. 60.

\%. siliquatus; receptaculis lineari-lanceolatis.

F. nodosus. $\gamma$. Syn. Fuc. II. p. 253.

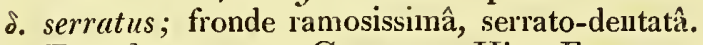

F. nodosus. var. GMELIN, Hist. Fuc. t. I. B. f. 2. (sine descriptione.)

F. nodosus. ß. Fl. Germ. III. p. 454.

Ha в Iт a Britanniarum ad oras, et ubique in Oceano Septentrionali, copiosè ; ex Americâ Septentriouali quoque accepi.-Ad mare Nicæense, et Uneliæ. Allioni._ $\beta$ in Angliâ Australi._Apud Newfoundland. Herb. Banks. - $\gamma$ apud Dubrem. D. Dilläyn.

Perennis. Nov.-Maium.

RADIX callus majusculus, infornis, nunc enormitèr conicus, nunc subrotundus, durus, lignosus.

FroNDEs ex eâdem basi plurimæ, compressæ, aut e plano compressæ, nervi venarumque expertes, longitudine bi- quadri-pedales, aut etiam orgyales, latitudine circitèr trilineares, et ubique æquales, nisi quod hìc illìc in vesiculas sint inflatæ, unde stirpi facies nodosa, ad pollicum aliquot altitudinem indivisæ, atque ibi bifurcæ, exinde bis ter dichotomæ, segmentis patentibus, ramis præter hoc instructæ lateralibus, distichis, horizontalibus, majore minoreve copiâ, his confertis, illis remotis, his ad unius alteriusve pedis, illis ad totidem modo pollicum longitudinem productis, lis demùm simplicibus, illis bifurcis, majoribus minoribus inmixtis; rami omnes basi sunt insignitèr attenuati, ut per punctum tenuissimum frondi adhæreant, margine per totam longitudinem intervallis exiguis minutissimè denticulati, denticulis alternis, quorum ex alis, si plantæ pateretur ætas, novi rami exirent, apice sunt obtusi, et vesiculâ exiguấ sæpe terminati ; minores simplices folia linearia referunt, neque infrequentèr occurrunt exemplaria, caule simplice talibus tantùm obsito, quorum facies omninò pinnata; vesicula in fronde innatæ, illâ multò latiores, totam ejus substantiam occupantes, ellipticæ, nunc Coryli Avellance nunc * Juglantis regice nucum magnitudine, semper solitariæ, et plerumque pollicum aliquot spatio distinctæ, extrinsecùs læves, intùs cavæ, et vacuæ, excepto juxta latera, quæ fibrarum albarum articulatarum tegmine sunt obducta.

Fr U CTIF1 CA'TI o receptacula sphærica, aut elliptico-sphærica, a Pisi ad glandis magnitudinem variabilia, ramorum ad latera sparsa, et e denticulorum suprà memoratorum alis exeuntia, plerumque solitaria, quandòque autem bina vel terna, pedunculis fulta compressis, e basi tenuissimâ sensìm dilatatis, unguem pollicemve longis, extrinsecùs lenitèr torulosa, et poris minutissimis pertusa, sub quibus latent tubercula immersa, sphærica, e fibris brevibus simplicibus articulatis constantia, immixtis seminibus subrotundis, fuscis, limbo pellucido cinctis, granulisque iisdem ellipticis, diaphanis, seminibus multoties minoribus, in $F$. tuberculato aliisque aliquot observandis : receptaculorum mediam partem occupat mucus pellucidus, intertextus fibris albis, articulatis, retis in modum anastomosantibus, maculis figuræ incertæ.

COLOR olivaceus, ne minimùm diaphanus, nitidus, receptaculorum flavicans, exsiccata ubique niger.

Substantia coriacea, lenta, tenacissina, adeơque crassa, ut in fronde primariâ sæpiùs lineam sesquilineamve zquet.

Var. $\beta$ ubique est duplo tenuior quàm $\alpha$, receptaculis frequentibus, ellipticis, Vicia sativa seminum circitèr magnitudine, pedunculo vix latioribus: stirps est pulchella.

\%, cujus unicum modd exemplar. Dillwynius legit, staturâ cum $\beta$ convenit, sed receptacula habet lineari-lanceolata, sesquiunguem aut pollicem longa, latitudine vix sesquilineari, $F$. siliquosi vesiculis primo aspectu haud absimilia.

$\grave{\jmath}$, a me nunquam visam, Gmelini auctoritati obtemperans hìc receuseo: íconem ille dedit, sed descriptionem omisit : frons vagè pinnatìm ramosa, ramis simplicibus, lis ubique linearibus, illis ob vesiculas innatas nodosis, omnibus insignitèr serratis, dentibus approximatis, majusculis.-An verè ad $F$. nodosum pertinet ?

Oвs.

"Ad quatuor pollicum longitudinem in plantis vetustis excrescere perhibet Stackhousius, sed ego nihil tale unquam vidi. 
OBs. Rarò accidit Zoophyta aliqua hujus stirpis frondi innasci, quam contrà densi Conferve polymorpha fasciculi, in nullo alio uuquam detegendæ Fuco, sæpiùs hìc illìc occupant:- exsiccata chartæ nequaquàm adhæret.

Vesicularum in $F$. nodosi fronde innatarum forma, textura, et situs adeò sunt insignes, ut speciei characterem evidentissimum maximèque stabilem hæ solæ subministrent, tantumque per se valent ut rarissimè sit ulla in stirpe discriminandâ difficultas. Hanc ob causam accidit ut vix unus sit inter Fucos qui nobiscum vulgatissimè occurrunt in quo describendo minus operæ posuerunt auctores, tyroque aliquis, cui plantam ipsan in loco natali inspiciendi nunquam est oblata facultas, facilè adduceretur ut crederet, mutationibus, vel nullis, vel levissimis modo, esse obnoxium. Talis tamen sententia longè a vero abhorreret, quoniam formâ non minus quàm $\boldsymbol{F}$. vesiculosus ludere solet, varietates licet nequaquàm characteres ita firmos per quos describantur suppeditant. Frons primaria, in plurimis individuis dichotoma et ramis lateralibus per totam longitudinem sparsim obsita, in quibusdam indivisa et omninò nuda occurrit, hi quoque rami, qui plerumque breviusculi simplices et intervallis pollicaribus vel sesquipollicaribus sejuncti reperiuntur, nunc ex eodem puncto bini terni vel plures unà oriuntur, nunc variè sunt divisi, nunc alios minores simili ratione iterùm atque iterùm divisos copiâ majore minoreve ferunt, nunc elongati sunt, angusti, sub-cylindracei, et sub-integerrimi, nunc brevissimorum serie piunati Squali Pristis rostri (si parva licet componere magnis) similitudinem aliquam præ se ferunt, et nunc ipsi sunt aded exigui ut tantummodo dentes breves obtusos referant. Neque minùs horum situs inter horizontalem et patentem incertus fluctuat. Utut verd in talibus aliisve frondis forma ludat, non solùm vesiculæ, sed receptacula etiam, stabiles manent; suique nunquam non similes, quanvis neque magnitudo neque * figura semper unicuique est eadem, ab iis aliorum Fucorum discrepant. Substanciâa aded tenace vesiculæ gaudent ut digitorum pressura rumpere nequeat, sin pedibus conculcentur, aut in ignem injiciantur claro cum strepitu dissiliunt. Receptacula jam effoeta decidere indubium mihi videtur, et hìnc novum ducitur argumentum contra Mertensii sententiam, legem esse in harum stirpium oeconomiâ ratam fructum demùm in vesiculas mutari. $\boldsymbol{F}$. nodosi radix iis congenerum est absimilis, cùm non sit discus orbicularis planus aut conicus, sed potiùs callus informis, nunc solidus, nunc totus e fibris aliquot crassis compactis constans. Quis autem non mirabitur Summi Numinis potentiam, quæ tali hanc donavit adhæsionis vi, ut per hanc solam tantæ molis planta fluctuum minantium iræ obsistere valeat! Nullum vel pororum vel fibrarun capillarium vestigium in quolibet æatis gradu $\boldsymbol{F}$. nodosi superficies exhibet. Hebridum incolæ hunc Fucum omnibus aliis in kelp conficiendo præponunt, et nomine "kelp-zerack" appellant.
a, a. F. nodosus, magn. nat.
b. receptaculum.
c. ejusdem pars extrinsecùs visi, magn. auct. - 6.
d. idem longitudinalitèr dissectum - $\quad 6$.
e. fibra e receptaculi parte interiore deprompta 3.
f. una ex iisdem - $\quad$ - $\quad$ - $-\mathrm{J}$.
g. semina et fibra e tuberculis - $\quad-\quad$ -.
h. granula pellucida ex iisdem - $\quad$ - $\quad$ - 1 .
i. frondis pars longitudinalitèr dissecte - $\quad 3$.
k. vesicula longitudinalitèr dissecta $\quad-\quad-6$.

\footnotetext{
- Sernel quidem in littore apnd Yarmouth exemplar legi, in quo vesicularum forma multùm ab usitatâ ablusit. Ex his plurimæe ramorum minorum ad apices sitæ angustè erant lanceolatæ, longitudine pollicem latitudine vix sesquilineam æquantes, ut siliquas simularent. Relig̨ure formam et magnitudinem vulgarem habuerunt.
} 
Fucus heterophyllus, stem quadrangular, irregularly pinnated: leaves sessile, entire, the lower ones elliptical, the upper ones linear and almost setaceous: vesicles petiolated, spherical; mucronated: receptacles cylindrical, minute, mostly solitary.

\section{Coast of Japan. Sir C. P. Thunberg.-Coast of New Holland. Mr. R. Brown.}

\section{Perennial.}

Root, a black, woody, callous disk.

Fro N D, furnished with a stem, a foot, or a foot and half long, as thick as a crow's quill at the base, and thence gradually narrowing, quadrangular, with acute angles winged with an extremely short membrane, slightly flexuose, undivided, but beset throughout its whole length, except immediately near the base, with branches, in other respects naked; branches between horizontal and patent, similar to the stem, but smaller, originating from the flat sides, disposed in a sub-spiral direction, with an interval of three or four lines between each, the lower ones four inches or more in length, and furnished with others still smaller, arranged in the same manner, the upper ones scarcely an inch in length, all of them producing leaves, vesicles and fructification; the lower leaves, which are situated so near the base of the stem, that they may almost be called radical, are of an eliiptical form, an inch or more long, and a quarter of an inch wide, those on the branches are linear, in length equal to three quarters of an inch, or an inch, but in width scarcely to a line, distichous, alternate, and separated by short intervals, all of them are rounded at their apices, entire at their margins, provided with a very thin blackish midrib, and attenuated at their bases into so short a petiolus that they appear nearly sessile; a single leaf, similar in size and shape to the lower ones, is not unfrequently placed at the bases of the branches, nor are all the others of the same size, but some are considerably larger than others; vesicles situated on the branches, and mostly near their bases, generally only one, but sometimes two or three on each, while in others they are altogether wanting, the lower ones spherical, and as large the seeds of Lathyrus odoratus, the upper ones much smaller, and between elliptical and spherical, the whole of them supported upon sub-cylindrical petioli, hardly a line long, and tipped with a setaceous mucro of uncertain length.

Fructification, abundant in the branches, arising from the axilla of the leaves, or occasionally placed upon their petioli, consisting of cylindrical receptacles, about a line long, standing on peduncles barely a third of their length, some solitary, others growing two or three together, and others, but this is not common, collected into racemi, all slightly uneven in their surface, and perforated all over with most ninute pores, under which lie immersed spherical tubercles, each containing a single brown globular seed, surrounded by a pellucid margin.

Color, in the fresh plant undoubtedly olive, when dried quite black, and if again wetted a dark olive brown.

SUBSTANCE, coriaceous in the stem, woody near the base, in the leaves and vesicles cartilaginous and thin; everywhere pliant and tough while moist, but rigid and brittle after it is dried.

\section{Oвs. In drying it does not in the least adhere to paper.}

I have been unable to find in any author a description of the Fucus here figured, though $I$ am led to conclude that it is a species of by no means unfrequent occurrence, from specimens of it being preserved in the Linnæan and Banksian Herbaria, as well as in Mr. Brown's splendid collection of the plants of New Holland, and from niy having received others, through the kindness of Professor Mertens, gathered in Japan by Sir C. P. Thunberg. It had pro bably been confounded, like many of its affinities, under the comprehensive name of $F$. natans, to the tribe of which it unquestionably belongs, and is distinguished from its congeners by its minute mostly solitary receptacles, by the entire margin of its leaves, and by the singular circumstance of some of these, particularly the lower ones, being seven or eight times wider than those which grow towards the ends of the branches. The name of $F$. heterophyllus, which is given to it in the Banksian Herbarium, is derived from this peculiarity, which, however, is by no means equally remarkable in every individual, nor even in every branch of the same. - In some specimens nothing whatever intermediate is observable between the largest and the smallest leaves, so that the plant really seems provided with two sets, of different kinds, as the name implies; while in others there is a regular and almost imperceptible gradation from the widest, that grow at the base of the stem, to the narrowest that are found at the extremities of the youngest shoots. The nearest affinity of $F$. heterophyllus is with $F$. lendigerus, from which, however, and from all. others already described, the characters above pointed out distinguish it.

a. F. heterophyllus, natural size.

b. part of a branch, magnified - - - 6 .

c. receptacles, disposed in a racemose manner 4 .

d. horizontal section of a recepiacle - $\quad 3$.

e, e. seeds - - - - - - - 2 .

f. granules contained in the seeds - - - 1 . 

Fucus, caule quadrangulo, vagè pinnato : foliis sessilibus, integerrimis, costatis, inferioribus ellipticis, superioribus lineari-setaceis: vesiculis petiolatis, sphæricis, mucronatis: receptaculis cylindraceis, exiguis, plerumque solitariis.

Нав Ітат in Japoniâ. Thunberg.--Novæ Hollandiæ ad oras. D. Brozon.

Perenuis.

RADIX callus discoideus, lignosus, ater.

FroN's instructa caule pedali, vel sesquipedali, basi pennæ corvinæ crassitie, exinde sensìm attenuato, acutè quadrangulo, angulis membranâ brevissimâ alatis, lenitèr flexuoso, indiviso, sed ramis per totam longitudinem, nisi ipsam ad basin, obsito, cætera nudo ; rami caulis similes, sed minores, ejus e lateribus planis orti, sub-spiralitèr dispositi, spatio inter singulos tri-quadri-lineari, horizontalitèr patuli, inferiores palınares, et ultrà, aliisque minoribus simili ratione dispositis instructi, summi vix pollicares, omnes folia, vesiculas, et fructum ferentes; folia inferiora, quæ caulis juxta basin nascuntur, elliptica, pollicem et ultrà longa, et semiunguem lata, ramea linearia, longitudine sesquiunguem vel pollicem, latitudine vix lineam æquantia, disticha, alterna, spatio inter singula brevi, omnia apice rotundata, margine integerrima, nervo tenuissimo nigricante percursa, basi in petiolum brevissimum attenuata; folium unicum, inferiorum simile, sæpe ramorum ad basin ponitur, neque cunctis rameis inagnitudo eadem, sed hæc illis sunt majora; vesicula in ramis, et plerumque juxta basin, sitæ, in his una, in illis duæ aut tres, in pluribus nulæ, inferiores sphæricæ, et Lathyri odorati seminum magnitudine, superiores elliptico-sphæricæ, et multo minores, omnes petiolo insidentes teretiusculo, vix lineam longo, et terminatæ mucrone setaceo, longitudinis incertæ.

Fructificatro in ramis copiosa, foliorum ex alis orta, vel aliquando eorum petiolo imposita, e receptaculis constat cylindraceis, circiter lineam longis, pedunculo triplo breviore fultis, his solitariis, illis binis aut ternis, aliis, sed hoc rariùs, in racemos congestis, omnibus extrinsecùs lenitèr tortlosis, superficie ubique poris minutissimis pertusâ, sub quibus latent tubercula immersa, sphærica, singula semen unicum sphæricum fuscum limbo pellucido cinctum includentia.

Co LOR, recentis absque dubio olivaceus; exsiccata nigerrimus; rursus madefacte intensè olivaceo-fuscus.

Substantia in caule coriacea, juxta basin lignosa; in foliis et vesiculis cartilaginea, tenuis; madefacte lenta et tenax, exsiccatce ubique rigida et fragilis.

Овs. Exsiccatione chartæ nequaquàm adhæret.

Extant, cùm in Herbario Limnæano Banksianoque, locis tamen natalibus nullis adjectis, tum in splendido plantarum thesauro quem secum ex Australasiâ redux attulit D. Brown, hujus Fuci exemplaria; et alia etiam Japoniæ ad oras a Thunbergo lecta olìm ad me nisit Mertensii benevolentia. Adducor hìnc ut credam in Oceano Asiatico non rarò provenire, ejus licet descriptionem quærens frustrà auctorum botanicorum opera evolverim. Forsan sub $F$. natantis nomine cum multis aliis commixtus, horum instar, latuit; neque dubium est quin ad hanc tribum pertineat. A reliquis autem ejusdem familiæ stirpibus dignoscitur per receptacula minuta plerumque solitaria, per foliorum margines integerrimos, et potissimùm quod quædam ex his, præsertìm inferiora, latitudine octies noviesve illa exuperent quæ in ramis nascuntur. F. heterophylli nomen, in Herbario Banksiano primum inditum, hunc innuit characterem, qui tamen nequaquàm in omnibus individuis, neque in omnibus ejusdem individui ramis, sese ex æequo observandun præstat. Dantur quidem exemplaria in quibus inter folia maxima et minima nihil est intermedii detegendum, sed planta foliorun diversorum serie duplice, ut videtur, prædita reverà heterophylla evadit; dum, contrà non desunt alia, in quibus, a foliis latissimis caulis juxta basin sitis ad angustissima quæ surculorum juniorum apices vestiunt, horum magnitudo pedetentìm et quasi lege certâ immiuuitur. Affinitatem cum nullo Fuco tàm arctam quàm cum $F$ : lendigero habet $F$. heterophyllus, a quo verò, et paritèr ab omnibus aliis in præsens detectis, notæ suprà expositæ distinguunt.

a. F. heterophyllus, magn. nat.

b. rami pars, magn. auct. - $\quad-\quad-\quad-6$.

c. receptacula in racemum congesta - $\quad$ - 4 .

d. receptaculum horizontalitèr dissectum - 3.

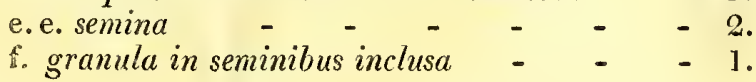


Fucus dentifolius, stem obsoletely quadrangular, filiform, pinnated: branches alternate, simple: leaves linear, serrated at their magins and midrib : vesicles spherical, petiolated; petioli cylindrical : receptacles nearly cylindrical, mostly solitary, toothed.

In the Red Sea. Lord Valentia.

\section{Perennial.}

Root, at present unknown.

FroN D, furnished with a stem a foot and half or more long, thicker than a sparrow's quill, filiform, obsoletely quadrangular, slightly flexuose, either undivided, or only cleft near the base, beset throughout its whole length witlı branches, in other respects naked; branches distichous, alternate, patent, similar to the stem, but not so thick, separated by intervals of about half an inch, simple, the lower ones two or three inches long, the upper ones very short, all of them bearing leaves, vesicles, and fruit; leaves placed rather loosely upon the branches, distichous, alternate, linear, sessile, nearly an inch long, and not a line wide, blunt at their àpices, serrated at their margins with very acute teeth, and provided with a thick blackish midrib, which is also serrated like the margins; vesicles scattered upon the branches, especially the upper ones, seldom more than one or two on each, spherical, of the size of the seeds of $L a$ thyrus odoratus, supported upon a cylindrical petiolus a line and lialf long, externally smooth, internally quite empty, not uncommonly tipped at their apices with a minute point.

FrUCTIFICATION, sessile at the axillæ of the leaves, consisting of oblong, blunt, spinous receptacles, one or two lines in length, and half a line in diameter, either solitary, or, what is more common, growing three or four together in a racemose manner, externally uneven all over, and perforated with extremely minute pores, under which lie imbedded spherical receptacles, each containing a few roundish brown seeds, surrounded by a pellucid limbus.

CoLor, most probably an olive-green in the recent plant, but blackish when dry, and if again moistened turning to a dark brown.

SUBSTANCE, coriaceous in the stem, cartilaginous in the vesicles, everywhere flexible and tough while the plant is wet, but stiff and brittle after it is dried.

Oвs. Sertularia quadridentata is found upon this Fucus :-in drying it does not in the least adhere to paper.

Having seen no more of the Fucus before us than a single specimen, which is preserved in the collection of Lord Valentia, I am able to say nothing of its history, and to add but very little to the description above given. On the contrary, I feel it rather incumbent upon me to apologize for the necessary imperfections of a description so written, and to assure my readers I would not have ventured upon introducing, as distinct, a plant belonging to so numerous and intricate a tribe of Fuci, without more satisfactory means of judging, had it not appeared so strongly characterized by nature as to remove all suspicions upon the subject. The habit of $F$. dentifolius most resembles that of some of the varieties of $F$. natans, while in the shape of its leaves it approaches far more nearly to $F$. bacciferus, and in its receptacles to $F$. ilicifolius, though it must at the same time be observed, that, however spinous the exterior of these may be, there is still no appearance of their being about to turn into leaves, as in that species. Of these three Fuci, the second is the only one for which $\boldsymbol{F}$. dentifolius can well be mistaken; and from this it is particularly distinguished by its flexible substance, its soft vesicles that yield to the tonch, the obtuse apices of its leaves, and, above all, their toothed midrib, from which latter circumstance it derives its name, as well as its leading specific character.

a. F. dentifolius, natural size.

b. barren branch.

c. fruit-bearing branch, magnified $\quad-\quad-6$.

d. leaf; and cluster of receptacles - $\quad$ - $\quad$ - 4 .

e. horizontal section of a receptacle $\quad-\quad-3$.

f. seeds - - - - - 1 . 

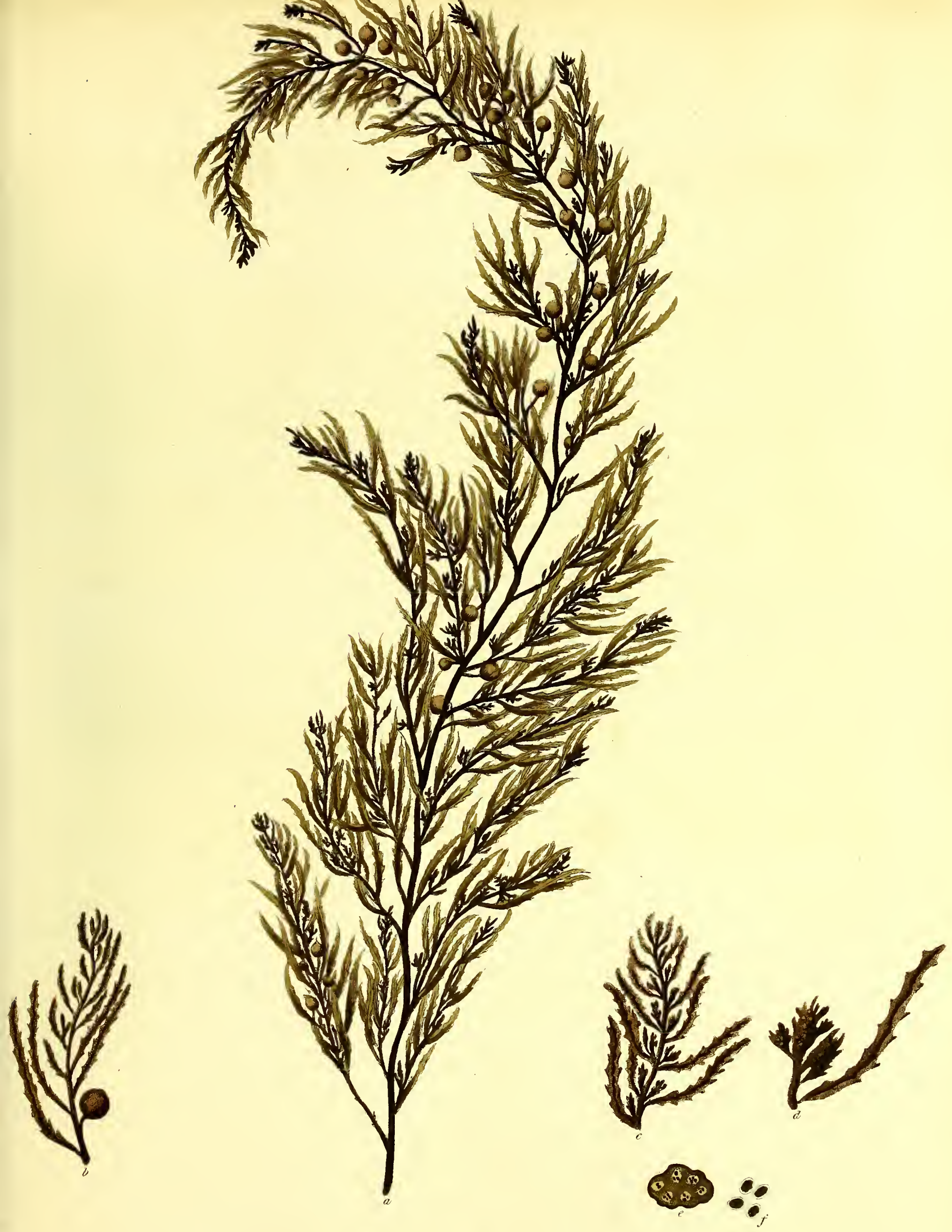

- Hecers dentifólines. 

Fucus, caule sub-tetragono, filiformi, pinnato : ramis alternis, simplicibus : foliis linearibus; margine costâque serratis : vesiculis sphæricis, petiolatis; petiolis teretibus : receptaculis teretiusculis, sub-solitariis, dentatis.

Habitat in Mari Rubro. Vicecomes de Valentia.

Perennis.

RADIX nondùm a me visa.

Frons instructa caule longitudine sesquipedali et ultrà, crassitie pennam passerinam superante, filiformi, anguloso, obsoletè tetragono, lenitèr flexuoso, indiviso, vel tantummodò juxta basin fisso, ramis per totam longitudinem obsito, cætera nudo; rami distichi, alterni, patentes, caulis similes, sed tenuiores, intervallis sub-unguicularibus sejuncti, simplices, inferiores bi- tri- pollicares, summi abbreviati, omnes folia, vesiculas, et fructum ferentes; folia in ramis laxiusculè posita, disticha, alterna, linearia, sessilia, pollicem ferè longa, nec lineam lata, apice obtusa, margine acutissimè serrato-dentata, nervo crasso nigricante (hoc quoque serrato-dentato) percursa; vesicula in ramis, præsertim superioribus, sparsæ, rard plures quàm una aut duæ in singulis, sphæricæ, Lathyri odorati seminum magnitudine, petiolo sesquilineari tereti fultæ, extrinsecùs læves, intùs omnino vacuæ, apicibus non rard minutè aristatæ.

Fructificatio foliorum ad alas sessilis, e receptaculis constat oblongis, obtusis, spinosis, longitudine lineam unam alteramve, diametro semilineam æquantibus, nunc solitariis, nunc, quod sæpiùs accidere solet, tribus aut quatuor in racemum conjunctis, extrinsecùs torulosis, et poris minutissimis pertusis, sub quibus latent tubercula immersa, sphærica, singula semina aliquot fusca subrotunda limbo pellucido cincta includentia.

CoLOR, qui recentis verisimillimè est olivaceus, exsiccata nigrescit, et rursus madefacta intensè fit fuscus.

SubSTANTIA in caule coriacea, in foliis et vesiculis cartilaginea, madentis ubique lenta et tenax, exsiccato rigidiuscula et fragilis.

OBS. Copiosè huic Fuco innascitur Sertularia quadridentata.-planta exsicrata chartæe non adhæret.

Cùm Fuci hìc depicti exemplar modò unicum, quod in nobilissimi Vicecomitis de Valentia, animadversionibus nullis adjectis, herbario servatur, viderim, nihil de ejus historiâ proferre valeo, et perpauca modò sunt quæ descriptioni suprà datæ adjicienda sese præstant. E contrario planè scio quàm necessariè sit manca descriptio talitèr conflata, neque auderem in Fucorum tribu ditissimâ specierum, earumque arctissimê Naturâ connexarum, aliquam pro novâ et distinctâ proponere, specimine uno nisus, nisi forsan insiguiri videretur characteribus satis manifestis ut ab aliis primo aspectu distinguerent. Crescendi modo habituque, quod aiunt, generali $F$. dentifolius cum quibusdam $F$. natantis varietatibus consentit; foliorum vero figurâ ad $F$. bacciferum accedit; et receptacula habet eorum $F$. ilicifolii multùm similia, quamvis hæc, utcunque sint extrinsecùs spinosa, nihil tamen in se habeant per quod in folia transitura conjicias. E tribus hisce speciebus fieri nequit ut cum aliquâ præter secundam commisceatur, et ab hâc dignoscitur, cùm substantiâ flexili, vesiculis tactu mollibus, et foliorum apicibus obtusis, tùm, ante omnia, costâ dentatâ, a quâ nomen ducitur, et quæ notam in specie discriminandâ maximè essentialem suppeditat.

a. F. dentifolius, magn. nat.

b. ramus sterilis.

c. ramus cum fructu, magn. auct. - - - 6.

d. folium et receptaculorum racemus. - $\quad$ - 4.

e. receptaculum horizontalitèr dissectum - -3 .

VoL. II. 
Fucus latifolius, stem compressed, filiform, bipinnate: branches alternate, mostly simple : leaves lineari-elliptical, repando-dentate: vesicles spherical, petiolated; petioli cylindrical.

In the Red Sea. Lord Valentia.

\section{Perennial.}

Root, I have not yet seen.

Frow D, consisting of a compressed, obsoletely two-edged, flexuose stem, three or four feet or more long, as thick as a crow's quill, as far as I have seen, undivided, but beset from base to summit with branches, in other respects naked; branches horizontal, distichous, alternate, separated by intervals of one or two inches, the lower ones nine inches, the upper ones scarcely a single one in length, these simple, those pinnated with a series of other smaller ones arranged in the same manner, all of them producing leaves and vesicles; leaves alternate along the branches, rather remote, except towards the ends, where they are crowded, horizontal, sessile, of a shape between linear and elliptical, about an inch and half long, and a quarter of an inch wide, rounded at their apices, and crenato-dentate at their margins, with largish teeth, provided with a thin dark-colored midrib that disappears near the apex, and perforated in their surface with small scattered pores; vesicles situated at the axillæ of the leaves, and mostly towards the lower part of the branches, three or four or more upon each branch, spherical, as large as sloes, supported upon short cylindrical petioli, externally smooth, internally quite empty.

Fructification, at present unknown.

CoLOR, most probably an olive-green when fresh, blackish when dry, and turning, if again wetted, to a rich brown in the leaves and vesicles, but still continuing black in the stem.

SUBSTANCF, of the stem coriaceous, of the leaves cartilaginous, every where flexible and tough.

OBs. In drying it does not in the least adhere to paper.

I must confess that I feel still more unwilling to publish, as a distinct species, the Fucus here figured than the preceding one, nor would I do so, were I less anxious to contribute what may be in my. power towards the elucidation of the beautiful and interesting tribe of which it is an individual. In point of external appearance it looks, indeed, at first sight, considerably farther removed from its congeners than many others, and especially than $F$. dentifolius, but, unfortunately, it has no leading character of distinction, like that species, and I must frankly own that I have sought in vain for some specific mark, which might fully satisfy. me of its being truly different from $F$. bacciferus, though, at the same time, its extraordinary size, and the shape of its leaves seem to forbid the entertaining of a doubt upon the subject. There is in the Banksian Herbarium a specimen of $F$. natans, with leaves of nearly similar shape, and both these and the vesicles almost equally large, but of considerably thinner substance, as well as paler color, and with the footstalks of the vesicles Alat and dilated upwards, as is always the case in that species. From $F$. aquifolius, to which F. latifolius is also in some degree allied, the color of the whole frond, and the form of the leaves and vesicles, which latter shew no tendency to be mucronated, immediately distinguish it. According to what Forskal says of his $F$. subrepandus, particularly with regard to its size, it is by no means impossible that the present plant is what he may really have intended under that name, though the shortness and imperfection of his * description of that species in the Flora Egyptiacn-Arabica led me to quote it above as a probable synonym of $F$. natans, to which Dr. Weber and Dr. Mohr, who have had an opportunity of examining the original specimens in his Herbarium, †observe that it is nearly allied, if not altogether the same.

a. branch of F. latifolius, uatural size.

* "Fucus suBrePandus ; caule compresso, ramis alternis ; foliis lineari-lanceolatis, subrepando dentatis, vesiculis pedunculal is.

"DFscr. Caulis cubitalis, compressus, flavescens. Rami alterni, ex marginibits canlis, non e latere, sesquipoll. Folia alterna, conferta, obtusa, quæedam integra, alia subrepanda, alia serrato-dentata. Vesicula axillares, globoso-ovatæ. P'uncta excavata, sparsa in utrâque foliorum paginâ.

"OEs. Fucus hic prope accedit ad Fucum natantem, sed foliis gaudet dentatis, non serratis, neque sunt vesicæ aristatæ." p. 192.

+ Archir: für die systematische Naturgeschichte. I. p. 136. 


Fucus, caule compresso, filiformi, bipimato : ramis alternis, simpliciusculis : foliis lineari-ellipticis, repando-dentatis : vesiculis sphæricis, petiolatis; petiolis teretibus.

Haвitat in Mari Rubro. Vicecomes de Valentia.

\section{Perennis.}

RADIX nondùm a me visa.

Fron $\mathrm{S}$ e caule constans compresso, levitèr ancipite, flexuoso, longitudine tri- quadri-pedali et ultrà, pennæ corvinæ crassitie, quantum ego vidi indiviso, sed ramis a basi ad apices obsito, cætera nudo; rami horizontales, distichi, alterni, spatio inter singulos pollicari vel bipollicari, inferiores dodrantales, summi vix pollicares, hi simplices, illi minorum simili ratione dispositorum serie pinnati, omnes folia vesiculasque ferentes; folia, in ramis laxè alterna, juxta apices modò conferta, horizontalia, sessilia, lineari-elliptica, pollicem sesquipollicemve longa, et circiter unguem lata, apice rotundata, margine crenato-dentata, dentibus majusculis, nervo tenui obscuro juxta apices evanescente instructa, superficie poris exiguis sparsìm pertusa ; vesicula foliorum ad alas et plerumque ramorum basin versus sitæ, tres, quatuor, aut plures in singulis ramis, sphæricæ, Pruni spinos๔ druparum magnitudine, brevitèr petiolatæ, petiolis teretibus, extrinsecùs læves, intùs omnind vacuæ.

Fructificatio hactenùs latet.

Co Lo recentis verisimillimè olivaceus; exsiccata nigricans; rursùs madefacta fuscus in foliis et vesiculis, in caule niger.

Su BSTA N TiA caulis coriacea, foliorum cartilaginea, ubique lenta et tenax.

Oвs. Exsiccata chartæ nequaquàm adhæret.

Fateri necesse est in dubio esse animum an Fucus in hâc tabulâ depictus sit reapse a congeneribus distinctus; quamobrem invitè admodùm hìc delineatam exhibui, neque fecissem si minore desiderio flagrarem conferendi quicquid in me est ad tribûs pulcherrimæ cui liquido annumerari debet historiam illustrandam. Facies quidem externa facilè duceret alıquem qui obitèr modò inspiceret ut crederet primo aspectu rectiùs quàm multos alios, et præsertìm quàm $F$. dentifolium, in specierum genuinarum numerum esse recipiendum; sed, quantumvis a reliquis extrinsecùs abludat, eget tamen tali charactere essentiali qualis illum distinguit, et frustrà aliquam conquisivi notam quæ scrupulos statìm omnes eximeret, annon fieri posset ut sit mera $F$. bacciferi varietas; tantoperè licet discrepent hæ stirpes omnium partium magnitudine et foliorum figurâ, ut talis conjectura forsan paucis verisimilis videbitur. Servatur in Herbario Banksiano F. natantis exemplar, cujus vesiculæ et folia formâ ea $F$. latifolii referunt, et vix sunt iis minora, sed substantiâ gaudent longè tenuiore, colore dilutiore, et vesicularum petiolis (quod semper in $F$. natante valet) planis et sursùm dilatatis. Ab $F$. aquifolio, cui etiam $F$. latifolius est multùm affinis, dignoscitur cùm per totius frondis colorem, tùm per foliorum vesicularumque formam, et quod hæ nullum unquàm mucronis vestigium ostendant. F. subrepandum Forskalii, dubiè suprà sub $F$. natante pro synonymo citatum, multi forsan censebunt botanici esse rectiùs ad hanc speciem referendum, præsertìm si spectent quod de magnitudine dicitur; sed * descriptio in Florâ AEgyptiaco-Arabicâ nimis brevis et manca prohibet quo minus aliquid certi de hoc proferatur, et perhibent + Weberus Mohriusque, quibus Herbarium Forskalianum adeundi est data facultas, "Fucus subrepandus Fuco baccifero Turn. vel ejus natanti valdè affinis videtur secundum specimina in Herbar. Forsk."

\section{a. F. latifolii ramus, magn. nat.}

\footnotetext{
* "FucUs SUBREPandus; caule compresso, ramis alternis; foliis lineari-lanceolatis, subrepando-dentat is, vesiculis pedunculat is

"Descr. Caulis cubitalis, compressus, flavescens. Rami alterni, ex marginibus caulis, non e latere, sesquipoil. Folia altena, conferta, obtusa, quædam integra, alia subrepanda, alia serrato.dentata. Vesicula axillares, globoso-ovatæ. Puncta excavata, sparsa in utrâque foliorum paginâ.

“OBS. Fucus hic prope accedit ad Fucum natantem, sed foliis gaudet dentatis, non serratis, neque sunt vesicæ aristatæ."-Fl. $\mathbb{E}$ grypt-Airci p. 192.

$\dagger$ Archiv. für die systematische Nuturgeschichte. I. p. $13 \xi_{.}$
} 
Fucus telephifolius, stem cylindrical, filiform, mostly simple, beset with alternate leaves, between elliptical and roundish, crenated at their margins: vesicles spherical, petiolated: petioli cylindrical: receptacles cylindrical, racemose : racemi compound.

In the Red Sea. Lord Valentia.

Perennial.

Root, a small, blackish, callous disk.

Fronds, two or three from the same base, each rising with a cylindrical, filiform, erect stem, from nine inches to a foot long, and as thick as a sparrow's quill, generally undivided and simple, but sometimes forked, and furnished in its lower part with one or two short, scattered, horizontal branches; it produces both leaves, vesicles, and fructification : leaves occupying the whole length of the younger stems, but in the older ones seldom to be seen below the centre, distichous, horizontal, generally disposed alternately, and with an interval of three or four lines between each, but sometimes growing two or three together, sessile, between elliptical and roundish, provided with a thin dark-coloured midrib, that disappears near the apex, their margins slightly undulated, and minutely crenated; vesicles of very uncommon occurrence, so that out of several specimens $I$ have seen them only in a single one, situated at the axillæ of the leaves, spherical, as large as the seeds of Vicia sativa, in some instances solitary, in others placed in a sub-racemose manner, supported upon short cylindrical petioli, externally smootl, internally quite hollow.

FRUCT1FICATION, abundant upon the stem and branches, consisting of cylindrical receptacles, disposed in irregular racemi, two or three lines, or more, long, slightly uneven in their surfaces all over, and perforated with extremely minute pores, under which lie imbedded spherical tubercles, each containing a single brown roundish seed surrounded by a pellucid limbus.

CoLOR, of the leaves in a dry state pale-brown and semitransparent, of the stem blackish and opaque; the same when again moistened; but $I$ am at a loss to conjecture what it was when fresh.

SubSTANCE, coriaceous in the stem, cartilaginous and thin in the leaves, every where flexible and tough, but, after it is dried, rigid and brittle.

Овь. The frond is generally found much infested with small zoophytes, and calcareous incrustations; towards the base it is rough with what appear to be the remains of broken branches.-In drying it does not adhere to paper.

After having been under the necessity of observing, with respect to the two preceding Fuci, that the one might easily be overlooked as a variety of some of its congeners, and that the other, though far more different in exterior, is probably much less so in reality, it is pleasant to meet in that here figured with an individual of the same family upon the specific differences of which no botanist, however sceptical, will entertain a doubt. This plant, like $F$. dentifolius and $F$. latifolius, I have seen only in the collection of Lord Valentia, but, from the number of specimens that he has preserved of it, I should apprehend that it is not uncommon in the Red Sea, though there is no description in Forskal's Flora AEgyptiaco-Arabica which can be considered as designed for it. Its texture is peculiar, having a degree of stiffness and rigidity, even in a moist state. Its general want of vesicles is another peculiarity; and there is in no specimen that $\mathbb{I}$ have met with any appearance of its being considerably branched, excepting the roughness of the lower part of the stem, already observed above, which may, however, possibly be the consequence of broken leaves. In point of size it seems liable to very little variation. Upon the color, though remarkable, I should be unwilling to place too great a confidence, as the plants gathered by Lord Valentia are far from being in a good state, and it is well known that long exposure to repeated changes of sun-shine and moisture will produce, even in $F$. vesiculosus, such an alteration fron an olive-green to a brownish-red as may mislead a hasty observer. The name of $F$. telephifolins is derived from the resemblance of the leaves in size, shape, and mode of growth, to those of Sedum Telephium.

a. F. telephifolius, natural size.

b. cluster of receptacles, magnified - - 6.

c. horizontal section of a receptacle - - 3.

d. seeds - - - - 1 . 


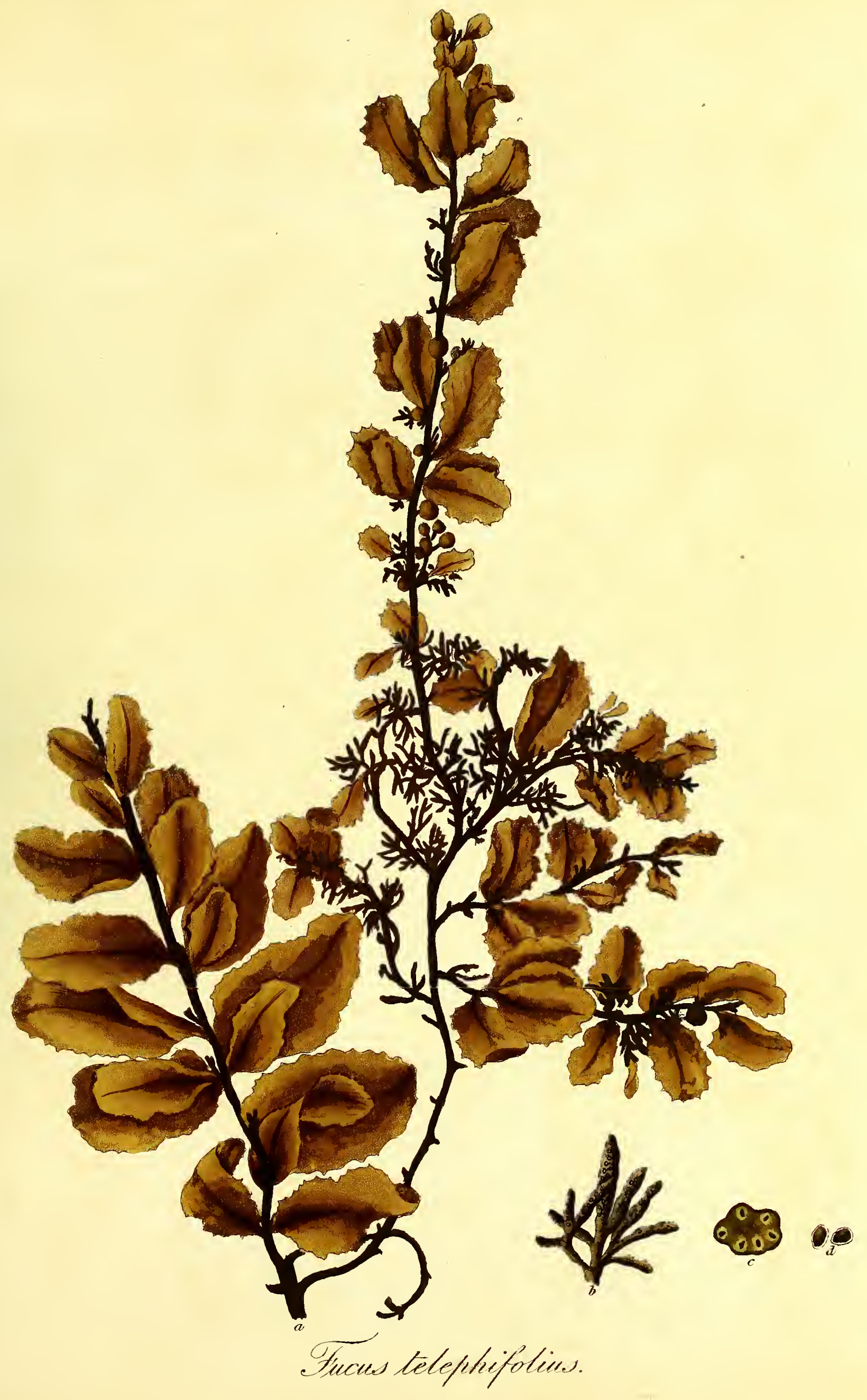



Fucus, caule terete, filiformi, simpliciusculo, foliis obsito alternis, elliptico-subrotundis, crenatis : vesiculis sphæricis, petiolatis ; petiolis teretibus : receptaculis cylindraceis, racemosis; racemis compositis.

Habıтат in Mari Rubro. Vicecomes de Valentia.

Perennis.

RADIX callus discoideus, exiguus, nigricans.

FroN DES ex eâdem basi binæ vel ternæ, instructæ caule terete, filiformi, erecto, longitudine dodrantali vel pedali, pennæ passerinæ crassitie, plerumque indiviso, et simplice, sed aliquando bifurco, aut ramo uno alterove horizontali sparso brevi basin versus obsito, folia, vesiculas, et fructum ferente; folia, quæ caules juniores per totam longitudinem vestiunt, in adultioribus non nisi supra medium locantur, disticha, horizontalia, ut plurimum laxè alterna, spatio inter singula tri- quadri- lineari, interdùm tamen bina vel terna, sessilia, figuræ ex elliptico subrotundæ, nervo tenui obscuro infra apicem evanescente instructa, margine lenitèr undulata, et enormitèr crenata; vesicula visu perraræe, ut e multis exemplaribus in uno modd viderim, foliorum ex alis ortæ, sphæricæ, Vicia sativa seminum magnitudine, nunc solitariæ, nunc sub-racemosæ, petiolis brevibus teretibus insidentes, extrinsecùs læves, intùs omnind vacuæ.

FrUCTIFICATIO in caule et ramis copiosè proveniens, e receptaculis constat cylindraceis, variè racemosim divisis, duas tresve lineas et ultrà longis, superficie ubique lenitèr torulosâ, et poris minutissimis pertusâ, sub quibus latent tubercula sphærica, immersa, singula semen unicum subrotundum fuscum limbo pellucido cinctum includentia.

CoLor qualis fuerit in recente planè nescio; exsiccatæe dilutè fuscus et subdiaphanus in foliis, in caule nigricans opacus; iterùm madefacte manet idem.

Substantra caulis coriacea, foliorum cartilaginea et lenuis, ubique lenta et tenax, sed exsiccatione rigida fragilisque evadit.

Oвs. Frons plerumque zoophytis exiguis crustâque calcareâ hìc illìc obducta reperitur :-basin versus exasperata occurrit, quasi ramorum diffractorum reliquiis :-exsiccatione chartæ non adhæret.

Dolebam, dum Fucos duos præcedentes describerem, quòd horum unus adeò quosdam ex affinibus primo aspectu referret, ut quivis obitèr intuens facilè pro eorum varietate præteriret, et quòd alter, quamvis facie externâ multo magis a congeneribus abluderet, forsan revera minùs erat dissimilis; ideòque noll sine aliquo gaudio in hâc tabulâa adumbratam exhibeo ejusdem familiæ plantam, de quâ nemo, quantumvis scepticus, dubitabit, quali sit jure inter species recensenda distinctas. Hanc stirpem, sicut $F$. dentifolium et $F$. latifolium, nullibi nisi in nobilissimi Vicecomitis de Valentia herbario adhuc vidi ; sin judicare liceat a multis ibi servatis exemplaribus, certè crederem nequaquàm infrequentèr in Mari Rubro provenire. Descriptionem tamen in Forskalii Florâ Egyptiaco-Arabicâ frustrà quæsivi. F. telephifolius texturâ gaudet singulari, cui durum quiddam et rigidiusculum vel in stirpe madefactâ inest. Consentit etiam in hoc cum paucissimis ex $\boldsymbol{F}$. natantis familiâ quòd vesiculis plerumque careat; neque aliquid in ullo individuo vidi, quod plantam naturâ multùm ramosam argueret, si excipias caulem prope basin exasperatum, quod forsan potiùs e foliorum quàm e ramorum rudimentis pendet. Quoad magnitudinem perpaullùm variare videtur. Colore, quantumvis insigni, nollem in specie discriminandâ nimium niti, quoniam suspicor specimina omnia a Vicecomite de Valentia lecta esse olìm aliquo modo læsa, aut in tali loco natali inventa qualis interdùm exsiccata relinqueret; et satis est botanicis cognitum Fucos plurimos colore olivaceo præditos, si nunc aeri nunc madori iteratis vicibus objiciantur, rufo-fuscos fieri; et ipsum $\boldsymbol{F}$. vesiculosum interdùm sic tantum mutari ut facilè tyronem decipiat. Nomen F. telephifolius ducit a similitudine, quæ, formâ, magnitudine, et crescendi ıodo, iṇter hụjus folia atque ea Sedi Telephii interest maxima.

a. F. telephifolius, magn. nat.

$\mathrm{b}$, receptaculorim racemus. 
Fucus Corallorhiza, root fibrous : frond cartilagimous, flat, nerveless, linear, dichotomous, sinuated at the margin: capsules cylindrical, bifid or trifid, collected into spherical clusters, placed both on the surface and the margin * SEB A, Thes. III. p. 191. t. 102. n. 10.? III. p. 192. t. 103. n. 4. (bene.)

At the Cape of Good Hope. Mr. Lind, in the Banksian Herbarium.

\section{Perennial?}

Rоoт, consisting of numerous, subcylindrical, repeatedly branched fibres, thicker than a sparrow's quill, of the same color and substance as the frond, loosely collected into a globular mass, an inch or more in diameter, creeping, and at length rising into new fronds.

FroNDS, numerous from the same base, flat, quite destitute of midrib or veins, from nine inches to a foot long, and about half an inch wide, every where linear, divided by dichotomies that begin near the base, and are afterwards frequently repeated at very uncertain distances, with segments between erect and patent; the apices are rounded; the margins sinuated, with sinuses generally slight, but sometimes rather deep, especially near the extremities.

Fructification, pale pink-colored, cylindrical, very thin capsules, almost a line in length, twice or thrice irregularly dichotomous, growing, both upon the margin and surface of the frond, in small globular clusters, each containing near its apex a few minute, roundish, deep-red seeds, most frequently disposed in a two-fold series.

CoLor, a dull brick-red, inclining to orange, destitute of gloss, and semitransparent.

SUBSTANCE, cartilaginous, thickish, tough.

Oвs. The habit of the frond is twisted and inclining to spiral :-in drying it does not in the least adhere to paper.

From the particular care which Grmelin has bestowed upon investigating the synonyms of different botanical authors respecting the Fuci, and from his having subjoined to his work a list of those which remained to him still doubtful, among which are a few from Seba's Thesaurus, it might reasonably have been expected that, since the figures above referred to are not to be met with in this number, they would be included in the body of his work. Under such an idea I have more than once examined his Historia Fucorum with attention, but, I am sorry to add, without success. He seems altogether to have left thein unnoticed, though their singular appearance could scarcely fail to have attracted observation. That the first of these applies to the plant before us, there can be little or no question; for it is provided both with the fructification and the root, which are the distinguishing characteristic of the species. The second, from wanting the one as well as the other of these peculiarities, may with justice be looked upon as more doubtful; and it is possible that it may have been rather designed to represent a small specimen of $\boldsymbol{F}$. venosus, which is the nearest affinity of the subject of the present plate. These two Fuci agree in their color, substance, size, and general habit, but $+F$. Corallorhiza is distinguished by wanting those singular veins that give the name to the other, by its linear frond, and by its sinuated margin, the sinuses of which are of various depth and form, sometimes horizontal and rounded, sometimes pointing upwards, and sometimes quite acute. Its fructification is very curious, resembling that of scarcely any other Fucus at present known, excepting $F$. cirrhosus, $\ddagger$ already figured in this work. It is, however, possible, though scarcely probable, that both these plants may also produce globular capsules; in which case they would, in point of fruit, be altogether analogous to $\boldsymbol{F}$. coccineus, and, through the medium of this species, connected with a very extensive tribe of Fuci. Such connections and gradations it is most gratifying to the scientific naturalist to trace; but, unfortunately, the nature and abode of the marine Algæ have always been hitherto, and seem likely long to continue to be, a material obstacle to our success in similar investigations. The root of $F$. Corallorhiza is so remarkably like that of the Ophrys which bears the same name, that 1 was induced to derive the appellation from the resemblance. I have at present seen only a single specimen of this plant, which is preserved in the Banksian Herbarium.

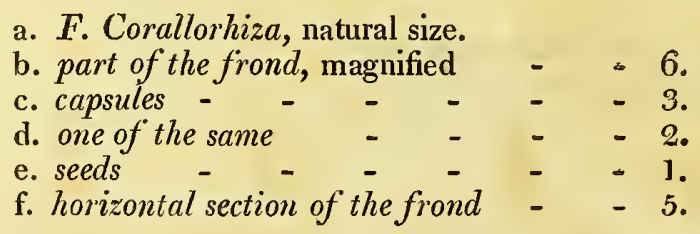

"Seba has given no name to eithcr of these figures, the former of which he includes under "Fucor"um maritimorum species differentes," toge. ther with three other Fuci, all apparently distinct from it, though he observes they differ principally in color, which is perhaps owing to their different ages. All he says about them is,

t. 10\%. n. 10. " Rufi est coloris, obscurioris tamen in medio foliorum."

t. 103. n. 4. "Eandeı, quæ præcedente tabulâ ad Num. 10 habctır, alganı marinanı sistit, sed quæ lutei est coloris, nonnullisque sparsim verruculis consita."

+ I have said notluing here respccting the fructification of $F$. venosus, not having at present sccn it myself: Weber aud Mohr describe it in their Beiträge, I. p. 275, as similar to that of $F$. crispus, but it is far from clear that they mcan the true Linnaean species. What is observed upon this subject in the Synopsis of the British Fuci, J. p. 160, is certainly erroneous, for the supposed seeds, hike those of the Ulva, appear to be accidental extraneous granules.

†. t. 63 . 


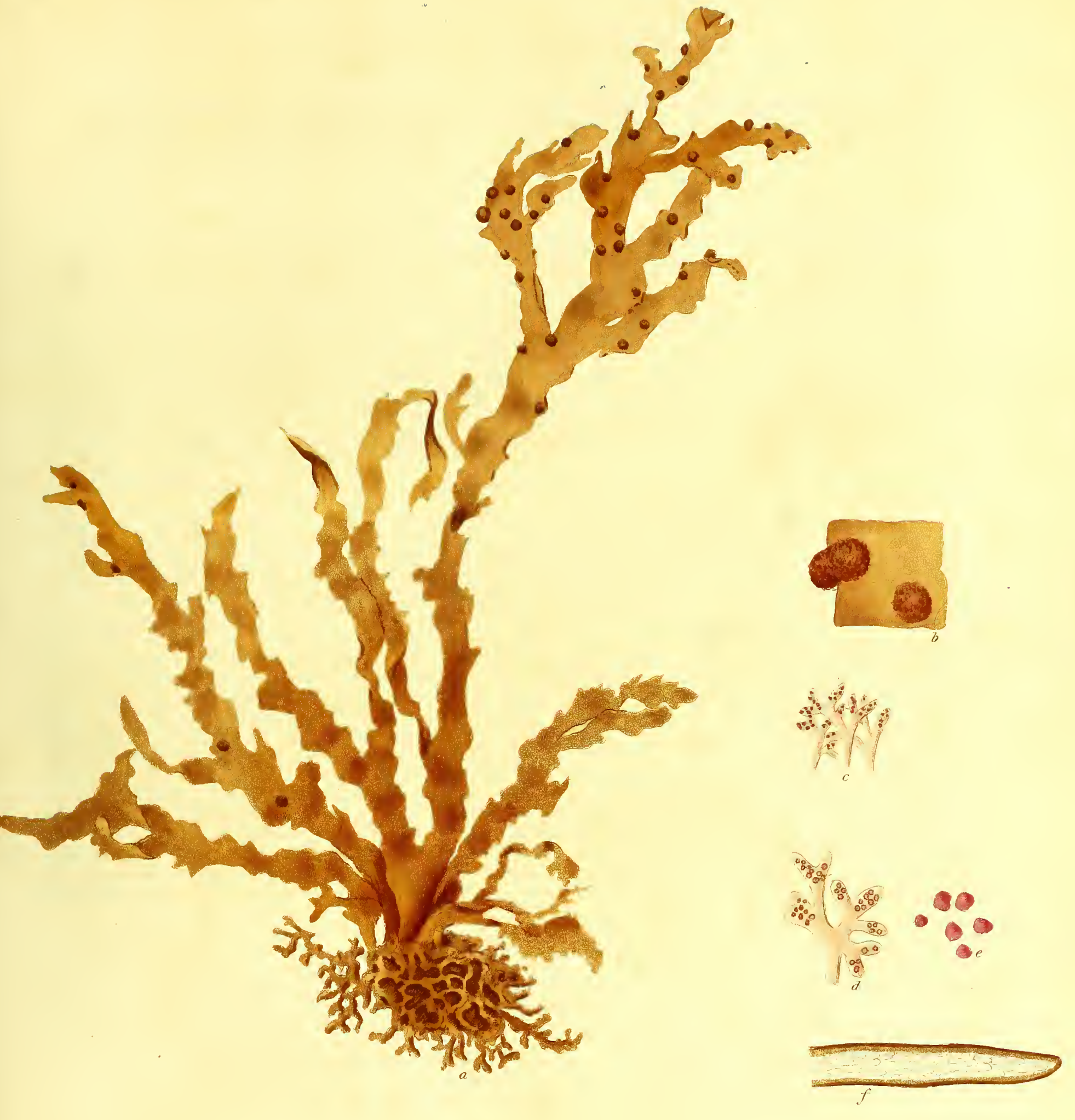

Surcus Comallortica. 

Fucus, radice fibrosâ: fronde cartilagineâ, planâ, enervi, lineari, dichotomâ, margine sinuatâ: capsulis teretibus, bi- tri- fidis, in sphærulas congestis, marginalibus superficialibusque. * SEBA, Thes. III. p. 191. t. 102. n, 10.? III. p. 192. t. 103, n. 4. (bene.)

Ha Bitat ad Caput Bonæ Spei. D. Lind, in Herb. Banks.

\section{Perennis?}

RADIX e fibris constans plurimis, iterùm atque iterùm vagè ramosis, teretiusculis, pennâ passerinâ crassioribus, ejusdem cum fronde coloris et substantiæ, in glomerulum laxum diametro pollicarem et ultrà compactis, repentibus, et demùm in novas frondes assurgentibus.

FRONDEs ex eâdem basi plurimæ, planæ, nervi venarumque prorsùs expertes, longitudine dodrantales vel pedales, latitudine circitèr unguiculares, ubique lineares, divisæ dichotomiis juxta basin incipientibus et exinde pluries repetitis, intervallo inter singulas incertissimo, segmentis erecto-patnlis; apices rotundati; margines abnormitèr sinuati, sinubus plerunque levibus, aliquando tamen, præsertìm apices versus, profundiusculis.

FruCTificatjo capsulæ dilutè roseæ, teretes, pertenues, propemodùm lineam longæ, bis terve vagè dichotomæ, plurimæ in rosulam densam sphæricam congestæ, et frondis superficiei vel margini impositæ, singulæ juxta apices semina aliquot minuta sub-globosa intensè coccinea serie duplice ut plurimum disposita includentes.

CoLOR aurantiacus lateritio immixtus, absque nitore, subdiaphanus.

Su bstantra cartilaginea, crassiuscula, tenax.

OBs. Plantæ habitus contortus et subspiralis :- exsiccata chartæ nequaquàm adhæret.

Fucum hìc depictum et in Sebæ Thesauro haud malè delineatum frustrà in Gmelini Historiâ Fucorum quæsivi ; quamvis plurimam, sicut et ipse perhibet, in synonymis auctorum, qui de Fucis tractaverunt, eruendis operam ille dedit, librique sui ad calcem apposuit eorum catalogum quæ pro incertis habuit. Horum in numero recensentur species aliquot Sebanæ, sed prætermittitur hæc nostra; neque liquet quamobrem ita est factum, quoniam una saltèm ex jconibus suprà citatis stirpem exhibet satis a reliquis omnibus formâ abludentem, et cui neque fructificatio nec radix, atraque maximè singularis, deest. De alterâ, utpote his destitutâ, nemo auderet botanicus ex cathedrâ loqui ; forsan enim tantummodò $F$. venosi, cui summa est cum $F$. Corallorhizâ affinitas, exemplar parvulum sistit. Colore substantiâ, magnitudine, habituque, quod aiunt, generali, hæ duæe species inter se consentiunt; sed distinguitur $+F$. Corallorhiza per venarum illarum, a quibus, ipsius propriis, $F$. venosus nomen ducit, absentiam, et 11011 minùs per frondis linearis margines ubique sinuatos, sinubus nunc horizontalibus, nunc sursùm spectantibus, nunc profundis, nunc levibus, nunc rotundatis, et nunc acutissimis. Fructificatione quoque tali gaudet, qualem vix ullus habet alius inter Fucos hactenus notos, $F$. cirrhosum $\Varangle$ jam in hoc opere delineatum si excipias. Fieri quidem potest, neque tamen verisimile videtur, utrasque has stirpes capsulis sphæricis quoque esse præditas; quod si ita sit, fatendum est habere tantum, quoad fructum, cum $F$. coccineo convenientiæ, ut sint per hanc speciem magnæ Fucorum familiæ annumerandæ. Tales nexus atque annulos in magnâ rerum catenâ dum indagat summam voluptatem percipit quivis verus naturæ amator ejusque historia cultor; sed dolendum est qudd hisce de algis submersis indagationibus semper adliuc obstiterint et diu forsan obstare pergant earum indoles locusque sub undâ natalis. Inter Fuci hìc depicti atque Ophryos Corallorhiza radices summa primo aspectu similitudo interest, quamobrem nomen ab hâc similitudine depromptum plantæ indidi. Unicum modd hujus stirpis exemplar, quod in Herbario Banksiano servatum hæc tabula exhibet, in præsens vidi.

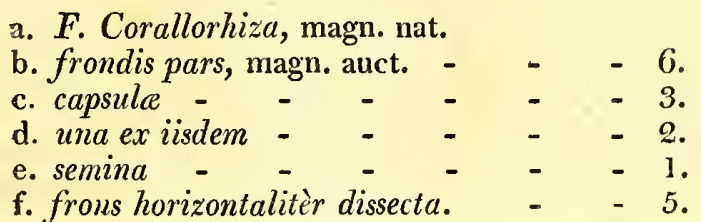

\footnotetext{
- Nullum nomen stirpilus quas hæ exhibent icones indidit Seba. Priorem jungit inter "Fucornm maritimorum species differentes" tribus aliis, quæ omnes, nti videtur, revera ab illa discrepant, quamvis censeat colore „potissimum inter sesc differie, quod forsan diversæ eorundem rtati debetur."-Hoc modò de lis dicit.

t. 102. n. 10. "Rufi cst coloris, obscurioris tamen in medio foliorum."

t. 103. n. 4. " Eandem, quæ præcedente Tabula ad Num. 10 habctur, Algam marinam sistit, sed quæ lutei est colorıs, nonnullisque sparsim verruculis consita."

+ Nihil hic de $\boldsymbol{F}$. venosi fructificatione, utpotc nondùm a me visa, discere sustinui. Hanc in operc suo, Beiträge dicto, I. p. 275 , describunt Weberus Mohriusque sicut ejus $\boldsymbol{F}$. crispi similem, scd nequaquàm liquet hos vcram stirpem Linnæanam respicere. Quicquid de hâc in Fucorım Britannicorum Synopsi, I. p. 160, memoratur ex elrore pendet; scmina eniu ibi descripta, quæ ea Ulvarum referre credidi, extranelım quiddam et fortuitum videntur.

\$ I. t. 63 .
} 
Fucus viridis, frond cartilaginous, filiform, cylindrical, repeatedly pinnated; branches and ramuli all opposite and capillary.

Fucus viridis. Fl. Dan. t. 886. Linn. Syst. Nat. Ed. Gmel. II. p. 1383. Syn. Fuc. II. p. 397. Eng. Bot. XXIV. t. 1669. Ner. Brit. p. 112. t. 17. EsPer, Ic. Fuc. II. p. 4. t. 114. Fl. Fr. Ed. $2 d$. II. p. 35 .

In the Bay of Dröback, scarce. Müller.-Rocks at Scarborough. Sir Thomas Frankland.-Among the rejectamenta of the sea at Yarmouth. Mr. Wigg.-On the beach at Brighton, very scarce. Mr. Borrer.-At Budleigh. Mrs. Griffiths.-Bantry Bay. Miss Hutchins.-Abundant upon F. vesiculosus and F. serratus at Dieppe. Decandolle.

\section{Annual.}

Root, a whitish, opaque, shapeless knob, almost the size of the seeds of Vicia sativa.

FroN Ds, sometimes solitary, sometimes two or three from the same base, from two to three feet long, cylindrical, varying in size near the root from that of a crow's to that of a sparrow's quill, and thence gradually, but almost imperfectly, diminishing, furnished with a single undivided stem, which is throughout its whole length pinnated with branches altogether similar to it, excepting their smaller size; branches patent, or between horizontal and patent, capillary, most uncertain in point of length, some of them extending to nine inches, others scarcely to one, the lowest generally, but by no means always, longest, all of them constantly opposite, separated by intervals of three or four lines, and pimnated with others still smaller, disposed in the same manner, which in their turns bear a third series, and the plant thus, not unfrequently, reaches a fourth or a fifth, each being less than the one before it.

Fructification, at present unknown.

* CoLOR, in the fresh plant, a deep rich orange, tinged with brown, which is so fugitive that, from only a few minutes exposure to the air, it becomes a light verdigris green, and if kept some time in fresh-water turns to a pale reddish brown : in decay it is whitish.-It is constantly destitute of gloss, and semitransparent.

SUBSTANCE, cartilaginous, rather stiff to the touch, and without the least sliminess.

Oвs. The whole appearance of this plant is most beautifully feathery and capillary:-in drying it does not adhere to paper.

Objectionable as is the name of $F$. viridis, if considered with a reference to the real color of the Fucus before us, I should nevertheless be sorry to see it changed, because it marks so strong a peculiarity in the nature of the species as is sufficient immediately to distinguish it from all its congeners; since no botanist can have gathered it in a recent state without being struck by the circumstance, that, before he had conveyed it home, whether exposed to the air in his hand, or shut up in his vasculum, it had changed its original golden hue to a bright verdigris green. At the same time, it also undergoes a change in its substance, less remarkable indeed, but not less rapid, turning from a peculiar stiffness and elasticity, such as would scarcely be expected in so delicate a plant, to the being completely flaccid. In drying, it again loses its green color, and becomes a pale greenish yellow; or, in case it has been kept too long in fresh-water, retains the dull brown tinge which it has acquired from that circumstance. Its habit is altogether that of a beautiful Conferva, and Sir Thomas Frankland, who first added it to the British Flora, knew it, long before it was published, by the manuscript name of Conferva auricoma. The branches, however, even when most highly magnified, seldom slow any traces of dissepiments; nor did I ever meet witl specimens by any means so clearly jointed, as the branch represented in the present plate at $f$; for which, as well as for the other uncolored figures, I am indebted to the kindness of Sir Thomas Frankland, who drew thein in a recent state. Respecting the fructification of $F$. viridis +nothing is known, nor is it easy to form a conjecture from analogy as to what it is likely to be, as the plant does not bear a sufficiently strong resemblance to any other to justify the hazarding of an opinion upon the subject. In point of its variation of color, it agrees principally with $F$. ligulatus, from which it is widely different in its form, and in many other respects. Its appearance at first sight might lead to the supposition that it belongs to an interesting tribe of submersed algæ, not yet separated by any writer upon the subject, comprising Conferva villosa, Huds. Conferva verrucosa, Eng. Bot., and probably Fucus pedunculatus, and F. aculeatus, together with a few others; but the total absence of jointed hairs upon any part of the frond seems to forbid such a conclusion.
a. F. viridis, natural size.
b. part of a branch, magnified
c. summit of "the same -
$-\quad 5$
$-\quad-3$

\footnotetext{
- Mr. Stackhouse is certainly mistaken as to the color of this Fucus, when he says of it, "variat respectu ratis : in junioribus listeo-viridis, ad lucem mutabilis; in adultioribus subfuscus, sed tamen diaphanus." Decandolle, who had seen the plant fresh, says, "sa couleur est d'un verd jaunâtre."

+ Mr. Stackhouse, indeed, both describes and figures in his Nereis Britannica what he considers as the fructification of this Fucus, which he calls " terminal, consisting of oval vesicles, but with no visible seeds within."-Few botauists, however, will doubt but that lie was in this instance misled by some casual inflations at the apices of the frond.
} 


Fucus, fronde cartilagineâ, filiformi, terete, supra-decomposito-pinnatâ :" ramis ramulisque omnibus oppositis, capillaceis.

Fucus viridis. Fl. Dan. t. 896. Linn. Syst. Nat. Gmel. II. p. 1383. Syn. Fuc. II. p. 397. Eng. Bot. XXIV.t. 1669. Ner. Brit. p. 112. t. 17. Esper, Ic. Fuc. II. p.4. t. 114. Fl. Fr. Ed. 2da. 1I. p. 35.

На вгтат in sinu Drobachiensi, rarò. Muller.-In rupibus submarinis apud Scarborough. D. T. Frankland, Inter rejectamenta maris apud Yarmouth.- Inter rejectamenta maris apud Brighton, perraro. D. Borrer.Apud Budleigh. Dna Griffiths. In sinu, Bantry Bay dicto. Dna Hutchins-Galliæad oras, apud Dieppen, copiose, $F$. vesiculoso et $F$. serrato inuascens Decandolle.

\section{Annua?}

RA DIX callus sub-globosus, informis, albicans, Vicia sativa seminum ferè magnitudine.

FroNDES nunc solitariæ, nunc ex eâdem basi duæ vel tres, longitudine bi-tri-pedales, teretes, basi pennæ interdùm corvinæ interdùm vix passerinæ crassitie, exinde sensìm, sed lenissimè, attenuatæ, caule assurgentes unico, indiviso, ramis homogeneis per totam longitudinem obsito ; rami caulis omninò similes, nisi quòd minores sint, patentes, aut horizontaliter patentis capillacei, longitudinis quàm maximè incertæ, hi dodrantales, illi vix pollicares, inferiores plerumque, sed nequaquàm semper, longissimi, omnes oppositi, intervallis tri- quadri-linearibus sejuncti, aliis minoribus simili ratione dispositis pinnati, atque ita aliquandò quartâ quintâve serie instructi, utrâque præcedentibus breviore, et tenuiore.

Fructificatio hactenus latet.

* Color in stirpe recente intensè aurantiacus, non sine fuscedine quâdam; luci tantililùm objectoe ærugineo-viridis; in aquâ dulci diu servata dilutè rufo-fuscus; marcescentis albescens; nitoris semper expers.

Substantia cartilaginea, tactu rigidiuscula, et quæ nihil in se lubrici habet.

OBs. Planta pulcherrimè plumosa et capillacea : exsiccata chartæ levitèr adhæret.

Utcunque colorem longè a vero abludentem exprimat nomen olìm huic Fuco a Mullero impositum et postea ab omnibus auctoribus servatum, tale tamen est quale mutatum nollem, speciei enim characterem denotat per quem statìm a congeneribus dignoscitur; quoniam nemo unquam botanicus lujus stirpis exemplar recens legit, qui non animadveret, priusquam domum reportaverat, sive in vasculo inclusam, seu apertam in manu, colorem nativum aureum in viridem transivisse. Eodem quoque tempore plantæ indoles aliam mutationem patitur, quæ, quantumvis minús est evidens, non minùs est subita, et vix minoris notationis meretur, substantia enim in vivâ elastica et rigidiuscula statìm omnem firnitatem amittet et fit insignitèr flaccida. Exsiccatione colorem viridem rursùs exuit, et dilutè flavescit non sine viredine; nisi forsan in iis exemplaribus quæ in aquâ dulci diutiùs æquo servata colorem fuscum ita ascitum nunquam deponunt. F. viridis facies est omnind ea Confervæ cujusdam pulcherrimæ, et vir nobilissimus D. T. Frankland, qui in oris nostris primus detexit, et Flore Britannica annumerandum docuit, sub Conferve auricome titulo multos annos priusquam publici juris est factus pro novâ specie in herbario suo servaverat. Rami tamen, lentibus acerrimis subjecti, rarò ulla geniculorum vestigia ostenduat, neque ego unquam individuum vidi, in quo structura articulata æquè dilucidè apparuit ac in ramulo quem ad lit. $f$ delineatum nostra tabula exhibet. Hanc et reliquas adumbrationes ad lit. $d$, $e$, et $g$, ommes in plantæ statu vivo delineatas, benevolè communicavit Dni. Frankland amicitia. De $F$ : viridis fructificatione† nihil hactenùs est notum, neque botanicus aliquis facilè conjiceret qualis sit hujus natura, quoniam plantæ peculiari et sui modò simili affinitas arcta cum nullâ aliâ intercedit. Quod ad colorem attinet multùm cum $F$. ligulato consentit, a quo formâ et habitu toto coelo discrepat. Nisi frondi ubique deessent fibræ illæ articulatæ capilliformes in Confervî villos $\hat{a}$ et verrucos $\hat{a}$ conspicuæ, suspicarer $F$. viridem ad algarum tribum pertinere, nondum ab ullo segregatam auctore, sed quæ naturæ, nisi fallor, est conveniens, et stirpes jam memoratas unà cum $F$. pedunculato et fortassis $F$. aculeato et aliquot aliis includit.

a. F. viridis, magn. nat.

b. rami pars, magn. auct. - $\quad-\quad-6$.

c. ejusdem apex - - - - - 3.

d. $e, f, g$, rami, magn. auct.

"De colore dicit Stackhonsins, "variat respectu $x$ tatis : in juniorilus lnteo-viridis ad lucem mutabilis; in adultioribus subfuscus, sed tamen diaphanus:"-in hoc verò certè errat.-Decandollius, qui plantam nascentem videt, dicit " sa conleur est d'un verd jaunâtre."

† Stackhonsius quidem credidit se hujns Fuci verum detexisse fructum, crijus iconem unà cum descriptione in Nereide Britannicå tradit me. moratque esse terminalem, e vcsiculis ovalibus constantem, seminibus nullis visibilibus intùs. Pauci tamen, uti credo, dubitabunt quin fiondis
apices casu aliquo intlati virun clarissimum in errorem induxerint. 
Fucus ligulatus, frond cartilaginous, flat, almost nerveless, doubly pinnate; segments lineari-lanceolate, serrated at their margins with spinous teeth.

Fucus ligulatus. Fl. Scot. p. 946. t. 29. W1 Wu. IV. p. 101. Linn. Trans. III. p. 123. Syn. Fuc. I. p. 99. Eng. Bot. XXIII. t. 1636. Fl. Fr. Ed. 2da. II. p. 34. Ner. Brit. App.

F. herbaceus. Fl. Ang. p. $58 \%$.

B. angustior; frond more narrow, trebly pinnated; ramuli nearly entire.

$\gamma$. dilatatus; ramuli sub-elliptical, attenuated at their bases into a very short petiolus.

On the shores of the British Isles, not very common.--Among the rejectamenta of the sea near Hastings, and in Northumberland. Hudson.-Firth of Forth, near Newhaven. Lightfoot. Thrown on the coast of the County of Antrim. * Dr. Scott._-Bantry Bay, plentifully. Miss Hutchins._Coast of Cornwall. Miss Hill.Coast of France, where exposed to the ocean, in deep water. Decandolle. $-\alpha$ and $\beta$ among the rejectamenta of the sea at Yarmouth, but scarce.- $-\gamma$ near Bayonne. Professor Mertens.

\section{Annual?}

Root, a blackish, callous knob, of irregular form, not uncommonly equal in size to the seeds of $\boldsymbol{F}$ isum sativum.

Fronds, sometimes solitary, sometimes many from the same base, each rising with a single undivided stem, from two to six feet long, nearly cylindrical in the part nearest the root, and as thick as a blackbird's quill, but immediately becoming compressed, and, before it attains to the height of an inch, flat, after which it preserves throughout an equal width of about two lines, till it approaches the apices, when it again grows more narrow, and ends in a long point; it is destitute both of + midrib and veins, and pinnated throughout its whole length with branches of the same nature and substance as itself; branches, distichous, arising from the edges of the stem, and precisely like it, except that they are smaller, attenuated at their base and apices, patent, separated by intervals of two or three lines, of very different length in different individuals, reaching in some to one or two feet, in others, scarcely to four inches; the lowest \$ generally longest, the upper ones regularly shortest, but long and short mostly mixed together, all opposite and undivided, but pinnated with others still smaller, arranged in the same manner, and these occasionally with a third series; the extreme branches, or ramuli, or as they are called by most authors, leaves, are of a lineari-lanceolate shape, and serrated along their margins with short teeth standing close to each other, which, if the age of the plant permitted it, would most probably grow out into new branches :-in very vigorous individuals, the margins are generally found fringed with extremely minute fibres of the same color as the frond, which give the plant a most elegant feathered appearance.

$\$$ FRUCTICATION, at present unknown.

II CoLOR, in the plant, when growing, an olive-brown, very glossy, but, from exposure to the air, it becomes im. mediately a deep orange, and soon afterwards turns to a verdigris green: in decay, or from being kept too long in fresh water, it changes to a dirty white.

Sunstance, intermediate between cartilaginous and membranaceous, approaching to the former in the stem, which is thickish and full of moisture, and to the latter in the ramuli. In drying, it becomes every where thin and membranous.

$\beta$ has its frond trebly pinnated, and no where above two lines wide: the teeth of its ramuli are so small and obsolete as to be scarcely obses vable without a glass, whence the whole plant has a naked appearance.

$\gamma$, which is a native of more southern seas, is distinguished from the specimens of our coasts by the width of its branches, extending to four lines or more; its ramuli are nearly elliptical, and remarkably attenuated at their base, so that they seem to be supported upon very short petioli.

Oвs. This Fucus, when recent, is endowed with considerable elasticity, which, however, it loses sooner than almost any other marine alga, and becomes so flaccid, that the finer parts are with difficulty expanded:-in drying it adheres slightly to paper.

Fucus

- Dr. Scott some time since informed me that $F$. ligulatus grows upon the rocks near the Giant's Causeway, where he las discovered im. pressions of it upon siliceous basalt, a curious circumstance which no preceding naturalist liad ever noticed.

+ Such is the appearance to the naked eye, but, if examined under a powerful microscope, a very thin blackislı nerve will be found to run through all the brauches, being most visible in the younger ones. This nerve, in vigorous individuals, according to Miss Hutchins, is visible to the naked eye in the stem and primary shoots, and is thicker than the rest of the frond.

¥ Hence, it necessary follows, tbat the outline of the frond, which Hudson calls ovate, is uncertain. Lightfoot, whose description is in other respects excellent, is very wrong, when le says, that specimens with their branches, fairly expanded, are six or eiglt inches wide, for most of then are twice or thrice as wide.

$\checkmark \mathrm{Mr}$. Stackhouse is of opinion that he has disc $\delta$ vered the fructification, and says upon this subject, in the Nereis Britannica, "Fructification circular flat warts on the branclies, near the setting out of the leaves;" and he farther ailds, "I liave likewise found iu some large specinens, flatted orbicular excrescences on the sten, which I take to be seniniferous,"-For my own part, I have seen notling similar to what lie describes, bnt I cannot help suspecting that lie has been misled by some warts of the same nature, as those observable in $F$. subfuscus, \& c.

II For this description of the color I am indebted to Miss Hutchins and Miss Hill, who have found the plant growing, which I never did, and who have most obligingly communicated to me some interesting particulars respecting it, which I will here transcribe.-" $F$. ligulatus grows apon all the rocks at Bantry Bay, in deep water, but never, that I have seen, lcft bare by 'the tide: its color, in the water, is a dark olive brown, and no plant can look more beautiful. When fully expanded, the delicate fringe at the edge is very conspicuous. When exposed to the air, it soon changes to orange, and in a fev minutes to bright grass green, but loses it color, and closes so entirely in fresh water, that it is extremely difficult to preserve or display it properly. Both it and $\boldsymbol{F}$. viridis have a strange quality, that of causing other marine plants which are kept with them to decay. They particulary affect $F$. kaliformis, $F$. clavellosus, $F$. ovalis, and Conferva rubra, turning them to a purple, and, where they press upon them, making them to dissolve, A beautiful green colferva, that preserves well in drying, was changed by them to a dirty white. They themselves remained unhurt," 

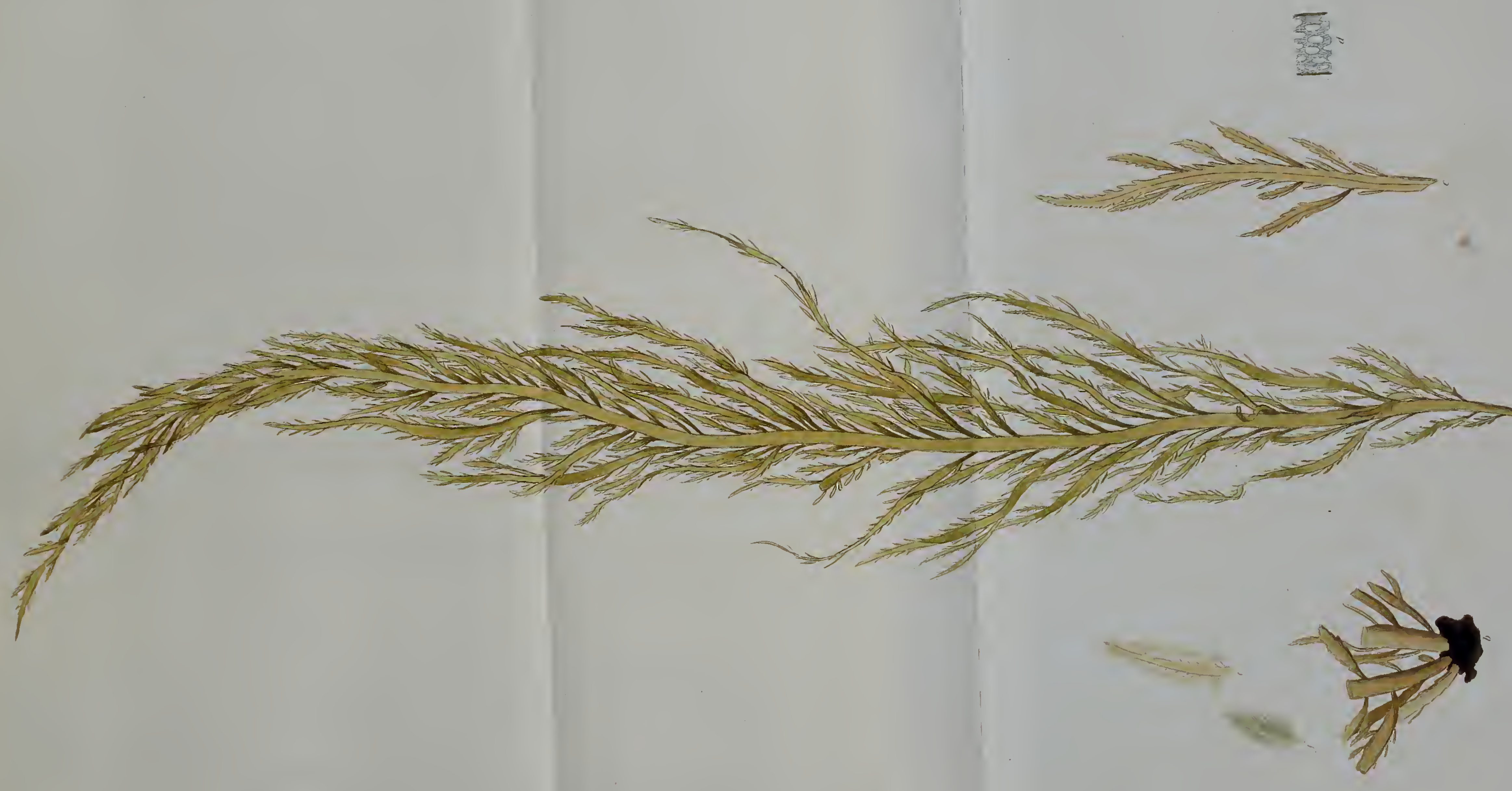

Fucus ligulatus, though occasionally found upon almost every part of the British shores, was never secu upon its native rocks till very lately, when it was discovered by Miss Hutchins and Miss Hill ; and, though inmediately distinguishable from all other Fuci, by its form, which is marked with a peculiar elegance and delicacy, it appears to have escaped the observation of all the older authors upon the subject, and not to have been noticed previously to the publication of the Flora Siotica, in which Mr. Lighttfoot has given an excellent description of it, accompanied by a figure that cannot be mistaken. In consequence of this, the name there assigned to it has, notwithstanding its having been already applied by Gmelin to one of the appearances of $F$. ciliatus, been universally adopted, in preference to Hudson's appellation of $F$. herbaceus, derived from the green color, which he, in common with most other authors, has considered natural to the plant. Upon this subject, it has already been observed, under the preceding species, how difficult it is to escape from error, and how extraordinarily these two plants agree, not only in their natural color, but in the remarkable changes to which this color is liable. * They agree also in the circumstance of the fructification of neither having been discovered, nor is it in this respect more easy to form from analogy a probable conjecture relative to the one than to the other. Mr. Hudson has marked the duration of $\boldsymbol{F}$. ligulatus as perenmial, but I must own that there seems to me to be little or no donbt of its being only anmual; as, though I never saw it in its place of growth, still, in those years when it is found at Yarmouth, it is regular in the period of its appearance; being confined almost exclusively to the months of June, July, and August, in the course of which its growth may be traced; and afterwards, if any remains of it be seen, it is almost always a mere fragment, which serves but to indicate that its time is over. In conformity with the opinion of Dr. Goodenough and Mr. Woodward, it was arranged in the Synopsis of the British Fuci, among the species foliis unitis, but in a future distribution of the species I should wish to see it placed among those with a flat frond, next to $F$. dentatus, of which, as of $F$. ligulatus, it is difficult to say if it may most properly be considered as provided with, or destitute of, a midrib.
a. F. ligulatus, natural size.
b. root.
c. small branch, magnified - $\quad-\quad$ - 6 .
d. longitudinal section of the frond - $\quad-2$.
e. end of ramulus fringed with fibres - $\quad 5$.
f. portion of the same. $\quad-\quad-\quad-3$.

* Completely as these two spceies differ in their shape, yet, as has been observed in the Synopsis of the British Fuci, if seen only lying upon the beach, or floaling in the water together, in a case where the general effect can alone be distinguished, it would require a keen eye to discriminate them at first sight. Mrs. Griffiths bas lately sent me a specimen of $F$. viridis, with a small plant of $F$. ligulatus, growing from the same root.

\section{8.-F U G U S L G U L A T US.}

Fucus, fronde cartilagineâ, planâ, sub-enervi, bipinnatâ ; segmentis oppositis, lineari-lanceolatis, margine spinosodentatis.

Fucus ligulatus. Fl. Scot. II. p. 946. t. 29. Wıтн. IV. p. 101. Linn. Trans. III. p. 123. Syn. Fuc. I. p. 99. Eng. Bot. XXIII. t. 1636. F7. Fr. Ed.2da. II. p. 34. Ner. Brit. App.

F. herbaceus. Fl. Ang. p. 582.

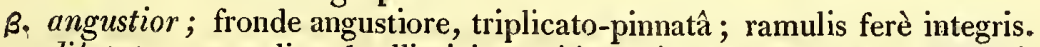

$\gamma$. dilatatus; ramulis sub-ellipticis, basi in petiolum perbrevem attenuatis.

HА ВIтAт in Britanniarum oris, hand ita frequens. - Inter rejectamenta maris prope Hastings in Sussexiâ, et in Northumbriâ. Hudson.-In sinu "Frith of Forth," dicto, prope Newhaven. Lightfoot.- In oris Comitatùs Antrim. * D. Scott.-In sinu, "Bantry Bay," copiosè. Dna Hutchins. Cornubiæ ad oras. Dna Hill.Galliæ ad oras in oceani locis profundioribus. Decandolle. $\gamma$ in Mari Aquitanico, propre Lapurdum. $D$. Prof. Mertens. $-\beta$ inter rejectamenta maris apud Yarmouth una cum $\alpha$, raro.

Annua?.

RADIX callus informis, planiusculus, nigricans, magnitudine Pisi sativi semina haud rard æquans.

Frondes nunc solitariæ, nunc ex eâdem basi plurimæ, singulæ caule assurgentes unico, indiviso, longitudine bisex-pedali,

\footnotetext{
* Per litteras me certiorem feeit vir optimus D. Scott, “ F. ligulatus grows upon the roeks near the Giant's Causeway, where I discovered impressions of it on siliceous basalt, a eurious circumstance which no preceding naturalist had noticed."
} 
sex-pedali, quà radici est prosimus teretiusculo, et merulæ peniæ crassitie, exinde statìm conipresso, et priusquàme pollicis unius altitudinen attigit plano, quum latitudinem eandem circitèr bilinearem ubique servat, donec ad apices appropinquaus rurstis angustatur, et in acumen longum producitur; caulis †nervi venarumqne expers, per totam longitudinem ramis lomogeneis est pinnatus; rami distichi, caulis e marginibus orti, ejusque omninò similes nisi quòd minores sint, ad basin apicesque attenuati, patentes, intervallis bi-tri- linearibus sejuncti, longitudinis in diversis individuis diversissimæ, in his pedales bipedales et ultrà, in illis vix palmares, inferiores t plerumque, sed nequaquàm semper, longissimi, summi numquan non abbreviati, breviores longioribus non rarò immixti, omnes oppositi et indivisi, sed aliis ninoribus simili ratione dispositis pinnati, qui seriem tertiam interdùn ferunt; rami ultimi, (ramulos, si mavis, aut folia cum plurimis dicas,) figuræ sunt ineari-lanceolate, et margine serrati, dentibus approximatis, brevibus, qui, si' plantæ pateretur ætas, verisimillimè in novos ramos excrescerent.-Stirpium vegetarum. margines ut plurimùm fibris minutissimis concoloribus ciliati reperiuntur, unde plantæ facies elegantissimè plumulosa.

S Fructificatio hodie latet.

If COLOR in stirpe nascente olivaceo-fuscus, nitidissimus, sed aeri objecta statìm fit intensè aurantiacus, et paullo post in æerugineo-viridem mutatur; marcescentis aut aquâ dulci diu serzate sordidè albescit.

Substa NTIA inter cartilagineam et inembranaceam ambigit; in caule, qui crassiusculus est et succosus, magis ad illam, in ramulis magis ad hanc accedens. Exsiccatione ubique membranacea fit et tenuis.

Var. $\beta$ frondem habet triplicato-pinuatam, latitudine nullibi plusquam bilineari; ramulorum dentes aded sunt exigui et obsoleti ut oculum inernen lateant, unde stirpi toti facies denudata.

Var. $\gamma$, mariım australium incola, per ramorum latitudinem ferè quadrilinearem ab exemplaribus nostralibus distinguitur: ramuli lıuic propemodùn elliptici, basi insignitèr attenuati, ut petiolo brevissimo insidere videantur.

OBs. Planta recens vim multam elasticam in se habet, quam tamen citiùs quàm alia ferè quælibet species amittit, et fit ita flaccida ut ramuli sese ægerrimè explicari patiantur :-exsiccata chartæ levitèr adhæret.

Ubique ferè per insularum Britannicarum oras inter alia maris rejectamenta subinde projicitur $F$. ligulatus, qui tamen nuperrimè morłò est in rupibus nativis a Duầ Hutchins et Dnâ Hill detectus; nec, licet sit species primo aspectu a reliquis distinctissima, formâ singủlari eâque perelegante et delicatissimâ prædita, ulli illum inter auctores vetustiores recensuerunt, sed primus in Florâ Scoticấ descripsit Lightfootius, adjectâ icone per quam satìm dignoscitur. Hæc causa extitit quare nomen ibi datum, quantumvis olìm fuerit a Gmelino F. ciliato impositum, sit nihilominùs inter omnes botanicos receptum; prætermisso illo Hudsoni, qui, credens unà cum plurimis auctoribus plantæ colorem verum esse viridem, $F$. herbaceum appellaverat. Quàm difficile sit in hoc errorem vitare, et quàm mirè consentiat $F$. viridis et $\boldsymbol{F}$.ligulatus, non modd colore proprio, verùm etiam mutationibus quibus ille color est obnoxius, jam sub præcedente memoratur stirpe. ** Consentiunt quoque in illo, qudd neque unius neque ulterius sit in præesens detecta fructificatio, et quòd impossibile sit aliquid de hâc certi ex analogiâ augurari. Vitam $F$. ligulato perennem ascribit Hudsonus, in quo dubito ut rectè fecerit, potiùsque credo vix ultra unius anni terminum produci, quamvis enim plantam nascentem ipse nunquam viderim, singulis tamen annis occurrit inter maris rejectamenta apud Yarmouth ïsdem mensibus, nempe Junio, Julio, et Augusto, inter quos gradatim crescere pergit, et si fortè exemplar unum alternumve seriùs reperiatur, sunt semper manca, et quæ plantam deficientem citòque perituram arguunt. Goodenovii Woodwardiique summæ auctoritati cedens hanc stirpem in Fucorum Britannicorum Synopsi inter eos foliis unitis præditos recensui; sed meliùs, me judice, in posterum iis fronde planấ annumeraretur, sedemque haberet $F$. dentato proximam, de quo, ut et de $\boldsymbol{F}$. ligulato, difficile sit dictu an rectius uninerves enervesve dicerentur.

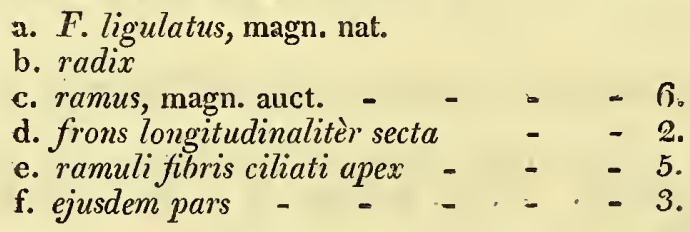

† Tta quidem oculo inermi apparet, sin sub melioris notæ microscopio observetur, nervus tenuissimus nigricans ramos omues percurrere repcritur, in junioribus maximè conspicuus. In individuis vegetis hic nervus, teste Dnâ Hutchiras, se nudo oculo in caule et raunis primariis manifestum prestat, est reliquâ fronde crassior.

† Stirpis peripheria, quam ovatam dicit Fadsonus, hìnc necessariò incerta evadit. Lightfootius, cujus descriptio cæeteroquin optima, multùm hallucinatur, quum exemplaria ramis expansis sex octove pollices lata dicit, plurima enim dnplo triplove sunt latiora.

$\S$ Se fructum detexissc crcdit Stacklousius, qui de hoc iu Nereide Britannicâ dicit: "Fructification, circular flat warts on the branches, near the setting out of the leaves;" cui mox adjungit, "I lave likewise found, in some large specimens, flatted orbicular excrescenccs on the stem, whiclı I take to be seminiferous." I pse quidem nihil lujusmodi unquam vidi, suspicor tamen virum cl. erravisse, deceptus forsan a verrucis eorum in $\boldsymbol{F}$. subfusco plurimisque aliis Fucis observandis similibus.

II Hanc coloris descriptionem Dıa Hutchins et Dua Hill debeo, plantam in loco natali ego nunquam vidi. Hæe mul ta de lâc stirpe mecum benevolc̀ per literas communicaverunt, quæ memoratu dignissima hic suis verbis exscribam. " $F$. ligulatus grows upon all the rocks at Bantry Bay, in decp water, but never, that $I$ have seen, left bare by the tide : its color in the water is a dark olive brown, and no plant can look more beantifin. When fully expanded, the delicate fringe at the edge is very conspicuous. When exposed to the air, it soon changes to orange, and in a few minutes to bright grass green, but loses its color, and closes so entirely in fresh water, that it is extremely difficult to preserve or display it properly. Both it and $F$, rividis have a strange quality, that of causing other marine plants which are kept with them to decay. They particularly affect $F$. kaliformis, $F$. clavellosus, $F$. oralis, and Conferva rubra, turning them to a purple, and, where they press upon them, making them to dissolve. A beautiful green conferva, that preserves well in drying, was changed by them to a dirty white. They themselves remained unlurt.

** Quamvis in omnium frondis partium formâ li Fuci discrepant, nihilominus, si tantummodo obitèr inspiciantur, sive in littore projecti, seus în aquâ fluitantes, tanta intcr ntrunque similitudo interest ut facilè unum pro altcro prætereas, $-F$, viridis exemplar, quod ex eâdem radice F. ligulatum quoque ferret, nuper ad me misit Dna Grifiths. 
Fucus, fronde membranaceâ, planâ, obsoletè costâ, bipinnatâ ; segmentis oppositis, ellipticis, basi attenuatis, apice obtusis, margine spinoso-dentatis.

Ha вітат in Americæ Septentrionalis oris occidentalibus, D. Menzies.

\section{Annua?}

RADIX callus exiguus, discoideus.

Frons plana, longitudine bipedalis, et ultrà, caule assurgens unico, indiviso, ad basin teretiusculo, pennæque corvinæ cassitie, sed ferè statìm plano, et sese sensìm ad aliquot pollicum altitudinem dilatante, ubi latitudinem unguicularem aut sesquiunguicularem adeptus fit exinde linearis, donec ad apicem appropinquans iterùm lenitèr attenuatur, et in extremitatem rotundatam desinit ; margines per totam longitudinem serrati, dentibus exiguis, spiniformibus, remotiusculis ; caulis a basi ad apicem pinnatus ramis homogeneis, oppositis, distichis, horizontalitèr patulis, spatio inter singulos sub-unguiculari, pedalibus aut sesquipedalibus, mediisque, aut videtur, longissimis, latitudine, ubi latissimi, ferè pollicari, ipsis basi in petiolum brevissimum teretiusculum attenuatis, apice rotundatis, margine spinoso-dentatis, ramorumque minorum sui cæeteroquin formâ et dispositione similium serie pinnatis :- frondem totam percurrit nervus in caule incrassatus et latiusculus, in ramis tenuis, ut vix, nisi planta luci objiciatur, sit manifestus, et tantummodd linea nigricaṇs videatur.

Fructificatio hactenus latet.

Color in iis qua ego vidi exemplaribus gramineo-viridis, non sine fuscedine, diaphanus.

Substantia membranacea, tenuissima, et tenerrima, sed caulis juxta basin aliquantùm incrassata.

Oвs. Exsiccatione chartæ lenitèr adhæret.

Eadem ferè similitudo quæ inter $F$. bacciferum et $F$. latifolium interest paritèr est inter $F$. ligulatum et $F$. her baceum reperienda, quare licet idem de his repetere quod jamjam est in hoc opere de illis memoratum, scilicet, quamvis sint primâ facie dissimilimi, aded ut vix ullus sit quæsiturus Botanicus quali sunt jure inter species recensendæ distinctas, nihilominùs esse difficillimum et forsan impossibile characteres exponere e quibus differentiæ specificiæ pendent. Si modo nobis algarum submersarum omnium fructificatio pateret, id quod Historiæ Naturalis cuivis Cultori debet quàm maximè esse in votis, nil dubium est quin rectè de omnibus hisce statuere et tales in posterum lites dirimere daretur; sed donec se res ita habet necesse est ut rectè judicandi viam cæcè quærentes incertè admodùm loquamur, et forsan in errorem incidamus. Quatenus autem perspicere licet, differt $F$. herbaceus ab $F$. ligulato frondis substantiâ longò tenuiore, et quidem ita tenui ut exsiccata vix sese tangi patiatur integritate salvà, mole majore, ramorum formâ basi attenuatorum apicibusque rotundatorum, et præsertìm colore, quo tamen (quantumvis manifesto) nollem in specie discriminandâ nimium niti, quoniam plantam recentem ego nunquam vidi, et non nisi per recentem scire potest aliquis quantis qualibusve mutationibus est obnoxia. Nervus quoque qui frondem percurrit magis est in $F$. herbaceo quam in $F$. ligulato conspicuus, sed in stirpe majore hoc non mirum.

a. F. herbaceus, magn. nat. 
Fucus herbaceus, frond membranaceous, flat, obsoletely midribbed, bipinnate; segments opposite, elliptical, attenuated at their bases, blunt at their apices, toothed as if with spines at their margins.

On the North-west coast of America. Mr. Menzies.

\section{Annual?}

RooT, a small callous disk.

Fronn, flat, two feet or more long, rising with a single undivided stem, at its base nearly cylindrical, and as thick as a crow's quill, but almost immediately becoming flat, and gradually widening to the height of a few inches, where it acquires a widtl of half an inch, or three quarters of an inch, after which it continues linear, till, on approaching the extrenity, it is again slightly narrowed, and terminates in a rounded apex; the margins are throughout the whole length serrated, with small, spiniform, rather remote teeth; the stem, from root to summit, is pinnated witl opposite, distichous branches, of the same substance as itself, between horizontal and patent, separated by intervals of about half an inch, a foot or a foot and half long, and the middle ones, apparently, longest, their greatest width nearly an inch, attenuated at their bases into very short sub-cylindrical petioli, rounded at their apices, toothed at their margins, and in their turns pinnated with a series of others, similar to them in every particular, except their small size :throughout the whole frond runs a midrib, thick, and rather wide in the stem, but in the branches thin and faint, so as scarcely to be visible, unless the plant is held to the light, and appearing only like a dark line.

Fructification, at present unknown.

COLOR, in the specimens which I have seen, grass-green, with a faint tinge of brown, transparent.

SubSTANCE, inembranaceous, extremely thin snd tender, but somewhat thickened in the stem, near the root.

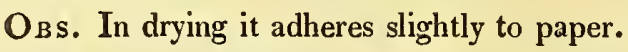

The same observations as have been made upon the probable identity of $F$. bacciferus and $F$. latifolius are equally applicable to the subjects of the present and the preceding plate. Scarcely any botanist will entertain a doubt of their being essentially distinct, and yet it is difficult to point out the character in which the specific difference between them may satisfactorily be sought. When the fructification of both is discovered, if such should fortunately ever be the case, there can be no doubt of an easy solution, as well to this question, as to many others of a sinilar nature, connected with the Fuci, but, till then, we must content ourselves with making the best use we can of the imperfect materials at present afforded us; and with observing that $F$. herbaceus differs from $F$. ligulatus in the extreme tenuity of its substance, which is such, that, after it has been dried, it is impossible to handle it without injury; in its greater size; in the shape of its branches, which are remarkably attenuated at their bases, and rounded at their apices; and, above all, in its color; upon which, however, though far more striking than the rest, I should be least willing to place dependence, as it is impossible for any one who has not seen it recent to form an idea what the changes are to which it is liable. The midrib, too, is much most visible in $F$. herbaceus, but this is no more than might naturally be expected from its greater size.

a. F. herbaceus, natural size. 


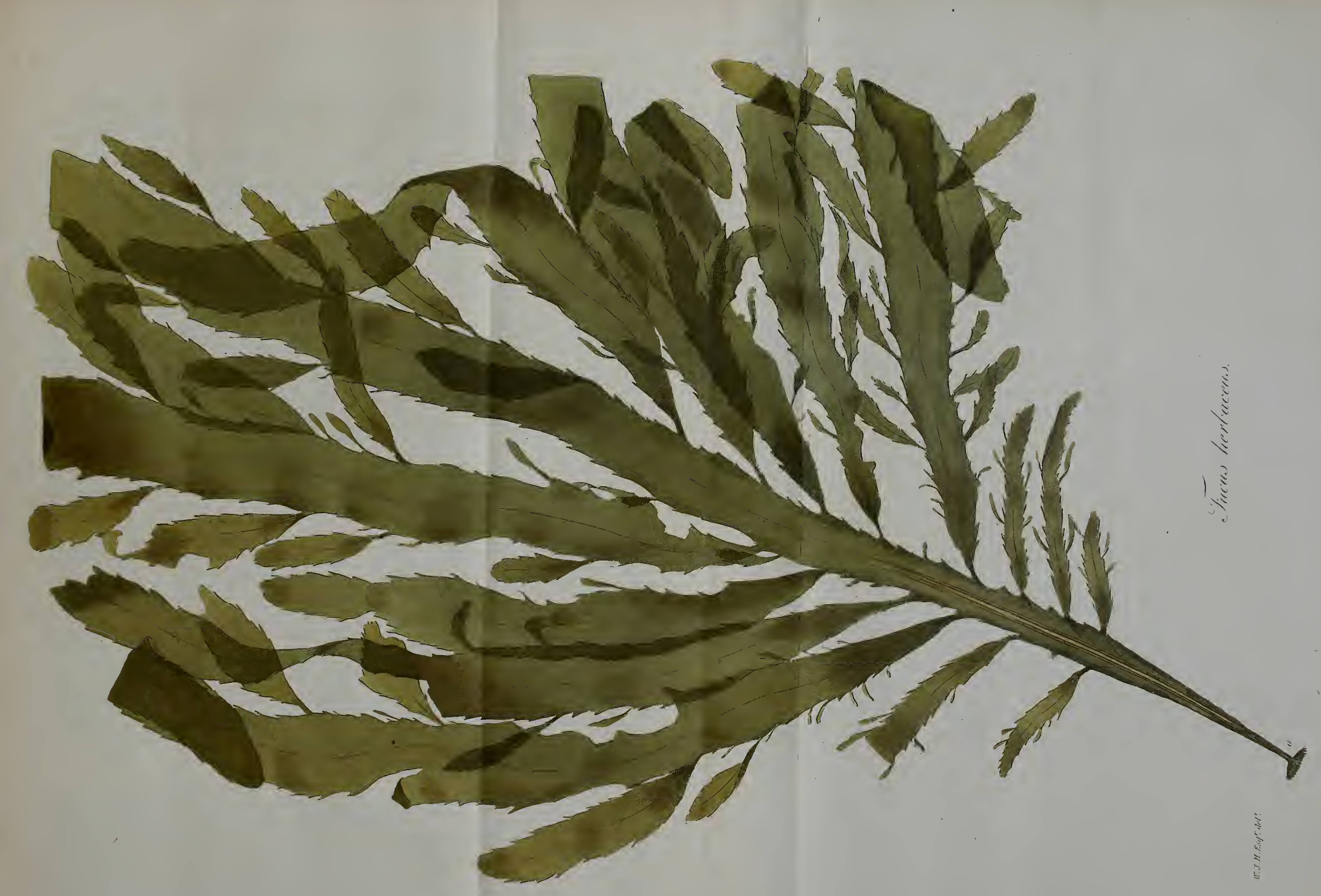



Fucus, fronde sub-gelatinosâ, filiformi, terete, pinnatím ramosâ; ramis alternis, horizontalitèr patulis, simpliciusculis : ramulis cylindraceis, sparsis, simplic ibus, utrinque acuminatis: capsulis, ovatis, sessilibus, seminibusque

in ramulis sparsis.
Fucus tenuissimus. Linn. Trans. III. p. 215. t. 19. Wітн. IV. p. 117. Syn. Fuc. I. p.35. Eng. Bot. XXVII. t. 1882.

F. muscoides. Wulfen, Crypt. Aquat. n. 22. (excl. syn. omn.)

Ulva capillaris. Fl. Ang. p.571.

HA B IT AT in lapidibus et saxis sub-marinis in Isthmo Portlandico, necnon in Fucis majoribus, præcipuè $F$. vesiculoso prope Weymouth, sub speculâ Anglicè the Look-out dictâ. Goodenough et Woodward.-In Insulâ Vecti, Fucis majoribus lapidibusque innascens. D. G. R. Leathes,-Supra submarina corpora Tergesti。 Wulfen.

Annua. Jul.--Sept.

RADIX callus exiguus, discoideus, fibris aliquot brevibus crassiusculis repentibus et mox in novas frondes assurgentibus instructus.

FRONDES ex eâdem basi plurimæ, cæspitosæ, teretes, filiformes, longitudine semipedales, vel dodrantales, juxta radicem et ad unius alteriusve pollicis altitudinem merulæ pennæ crassitie, exinde sensim attenuatæ ut in acumen longum producantur, apicesque habeant acutissimos; caule assurgunt plerumque indiviso, rariùs bi- tri-fido, per totam longitudinem obsito ramis sui similibus, sed tenuioribus, ut plurimum alternis, intervallo inter singulos brevi, his pollicaribus, illis palmaribus et ultrà, mediis plerumque longissimis, ipsis quoque aut indivisis, aut bi- tri- fidis atque nunc aliorum minorum simili ratione dispositorum serie instructis, nunc prorsùs simplicibus; rami omnes semper ferunt ramulos (folia si mavis dicas) horizontales, aut horizontalitèr patulos, (nisi per extractionem ex aquâ contrahantur,) laxè et absque ordine positos, sesquilineam duasve lineas longos, utrinque acuminatos, simplices, aliquandd tamen altero breviore proliferos, seque, si plantæ ætas sineret, in novos ramos producturos.

* Fructificatio duplex in diversis individuis, utraque ramulis vel ramis juxta extremitates imposita; hace e tuberculis constans ovatis, sessilibus, papaveris semine aliquantùm minoribus, solitariis confertisve, seminum pyrifornium intensè rubrorum congeriem includentibus; illa e seminibus nudis, sparsis, globosis, sub lente in tres aut plures partes dehiscentibus, in ipsà frondis substantiâ immersis.

+ CoLor dilutè rubens, fusco tinctus, diaphanus; exsiccatce intensior; marcescentis sordidè albicans.

SubSTANTIA inter cartilagineam et gelatinosam quasi media, succosa, tenerrima.

Oвs. Exsiccata chartæ arctè adhæret:-frons tota, præsertìm verò pars superior et ramuli, vitro maximè augenti subjecta, sæpe speciem eandem articulatam quam $\boldsymbol{F}$. dasyphyllus exhibet:- Conferva confervicola non rard hunc Fucum perrepit.

Inter species hactenus detectas nulla est cui planta hìc depicta tam arctè est affinis quam $F$. dasyphyllo, quâcum tot et tantis modis convenit, ut facilè fieri posset ut botanicus aliquis tyro incautusve unam pro alterius varietate præteriret. Crescendi modo, colore, fructu, et ramulis, per quos ab omnibus ferè aliis distinguuntur, consentiunt; sed, sicut jamjam est sub $F$. dasyphyllo observatum, discrepant $F$. tenuissimi staturâ longè tenuiore, et ramulis utrinque paritèr attenuatis. Hasce differentias luculentiùs in vivis quàm in exsiccatis patere, et stirpes ex his habitum quodammodd dissimilem ducere, me olim per literas certiorem fecit b. D. Bryer, cui, vici de Weymouth incolæ, optima diu fuit utramque investigandi facultas. Semina quæ in loc Fuco sparsa et nuda reperiuntur e tribus pluribusve particulis conflari videntur, et ea $F$. dasyphylli referunt : contrà verò res neutiquàm ita se habet cum illis in capsulis inclusis quæ limbo carent. De hoc tamen lectorem monitum volo me dubitantèr admodùm loqui; (quis enim alitèr loqueretur de rebus tam nunutis nec sine summâ microscopii compositi vi distinguendis ?) et præterea seminis limbum parvi modo momenti credo, et qui nequaquam sufficit ad divellendas plantas naturầ tàm arctè connexas quàm $F$. pinnatifidum, $F$. tenuissimum, $F$. dasyphyllum, $F$. òtusum, et $F$. Forsteri. Wulfenii synonymon suprà citatum ad hanc speciem retuli, obtemperans auctoritati Mertensii mei, qui in b. Abbatis herbario specimina hoc nomine suâa ipsius manu notata vidit. Nemo forsàn hoc ex descriptione agnovisset, quippe in quâ desiderantur eloquentiæ nitor et verborum mira felicitas, per quos ille solet auctoribus ferè omnibus in plantis describendis antecellere ; et maximè mirum est virum talem hanc suam stirpem eandem credidisse cum $F$. muscoide Linnæano, præsertim cùm tres illius

icones,

\footnotetext{
* Fateor me mente haud bene capere id quod de hujus Fuci fructu tradunt Goodenovius Woodwardiusque, quum, descriptis tuberculis, in quibus semen unicum pyrifornı includi censent, adjiciunt, preter lax c, "little globular transparent processes resenbling bladders, sòmıtimes are to be found on the sides of the finer branclics, which we havc described as covered with minute tubercles,--sometimes tlicy adhere to the braiches themselves, and appear to contain minute sceds, but this appearance is by no means constant. It is incredible how the plant is disguised, when loaded, as it sometimes is, with thesc vesicles. - These processes, rightly obscrved, might perhaps lielp to elucidate the mode of fructification in Fuci. Perhaps, the tubcrclcs, wlich Rèaumur asserts are capsules, are scattercd in dusty clusters at first along the branclies in an cmbryo state, as is observable in Hypoglossum, alatus, lialiformis, \&ic. \& c., and at length cne or more (the rest proving abortive) become fcrtile, and swell into complete form."-Lim. Trans. 1II. p. 217.

$f$ Duo corpusculorum genera in capsulis includividentur, hæc late pyifornia, illa duplò triplove angustiorâ, quæ tamen forsan niliil sunt nisi semina abortiva.

‡ Vir anicissimus, D. G. R. Leathes, qui hunc Fucum astate prætcritâ copiosè nasccntem lcgit, frondis colorem vorum dilutè lutesccntem credit, qualcm ferc̀ $F$. ligulatus jam flaccidus habcre solct. Suspicor verò hoc eor nm modò excuplaria mi csse preprium, qua per lc cun uatalem soli sunt ohjecta, sicut in multis aliis etiam Fucis accidere solet.
} 
icones, eæque haud pravæ, extent, quarum nullam non citatam reliquit. F. tenuissimi exemplaria multos abhinc annos ad me misit Esperus, nomine tamen adjecto nullo, nec, quantum perspicio, fuit unquam in ejus Iconibus $F_{u-}$ corum delineatus. Primus descripsit Hudsonus, et, vivis fortè tantummodò exemplaribus seminibus nudis donatis, Ulvis associavit, a quibus disjunxerunt - Goodenovius Woodwardius, qui titulum jam inde servatum inposuerunt. Hi Fucorum ordini fronde tereti associant, sed F. dasyphyllum, ob ramulorum formam magis insignem, illi foliis distinctis, sic hạs stirpes longè segregantes, et $F$. témissimum proximum $F$. pedunculato et $F$. asparagoidi ponentes, a quibus exponunt quantum discrepat, de quo tamen haud opus est ut hic aliquid dicam, nisi discrepare ferè in omnibus preter staturam et frondem teretem.
a. F. tenuissimus, magn. nat.
b. ramis cum seminibus sparsis, magn. auct. 5 .
c. semina - - - - - -1 .
d. ramis cum capsulis - - $\quad-\quad-5$.
e. semina - - $-\quad-\quad+1$.

\section{0.-F U G U S T E N U I S S I M U S.}

Fucus tenuissmus, frond sub-gelatinous, filiform, cylindrical, branched in a pinnated manner; branches alternate, between horizontal and patent, mostly simple: ramuli cylindrical, simple, scattered, acuminated at both ends, bearing ovate capsules, and scattered seeds.

Fucus tenuissimus. Linn. Trans. III. p. 215. t. 19. Wгтн. IV. p. 117. Syn. Fuc. I. p. 35. Eng. Bot. XXVII. t. 1882.

F. muscoides. Wulfen, Crypt. Aquat. n. 22. (excl. syn. omn.)

Ulva capillaris. Fl. Ang. p.571.

- On stones and rocks at the Isle of Portland, and on the larger Fuci, particularly $F$. vesiculosus, near Weymouth, under the "Look-out." Goodenough and Woodward.-At the Isle of Wight, upon the larger Fuci and pebbles. Rev. G. R. Leathes.-On submarine bodies at Trieste. Wulfer.

\section{Annual July-September.}

Rоoт, a small callous disk, throwing out a few, short, thickish fibres, which creep, and rise into new fronds.

FrONDS, numerous from the same base, growing in tufts, cylindrical, filiform, from six to nine inches long, as thick as a blackbird's quill near the root, and to the height of an inch or two, thence gradually attenuated, so as to end in long attenuated apices, each of them rises with a single stem, most frequently undivided, but occasionally bifid or trifid, beset throughout its whole length with branches similar to itself, except their smaller size, separated by short intervals, generally alternate, some of them four or five inches, others, not above a single one in length, the middle ones mostly longest; these also are either undivided, or bifid, or trifid, sometimes furnished with a series of smaller ones, disposed in the same manner, and sometimes altogether simple, all the branches are beset with ramuli, or leaves, placed in a horizontal direction, or between horizontal and patent, (unless when they are contracted from being taken out of the water) growing without order at short distances, from a line and half to two lines long, acuminated at each end, simple, or now and then proliferous with another smaller one, and apparently about to lengthen into new branches, if the duration of the plant would permit it.

Fructification, two-fold, in different individuals, each growing on the ramuli, or near the extremities of the branches, the one consisting of ovate sessile tubercles, somewhat smaller than poppy-seed, either solitary, or crowded, containing

\footnotetext{
* I really do not exactly understand the account given by Dr. Goodenough and Mr. Woodward of the fructification of this Fucus, when having mentioned the tubercles, which they describe as containing only a single pyriform seed, they add, that, besides these, "little globular transparent processes resembling bladders, which we have described as covered with minute tubercles, - sometimes they adhere to the branches themselves, "and appear to contain minute seeds, but this appearance is by no means constant. It is incredible how the plant is disgnised, when loaded, as it sometimes is, with these vesicles.-These processes, rightly observed, might perhaps help to elucidate the mode of fructification in Fuci. Perhaps, the tubercles, which Réaumul asserts, are capsules, are scattered in dusty clusters, at first along the branches in an embryo state, as is observable in Hypoglossum, alatus, kaliformis, \&cc, \&c. and at length one or more (the rest proving abortive) become fertile, and swell into complete form."-Linn. Trans, III. p. 217 .
} 


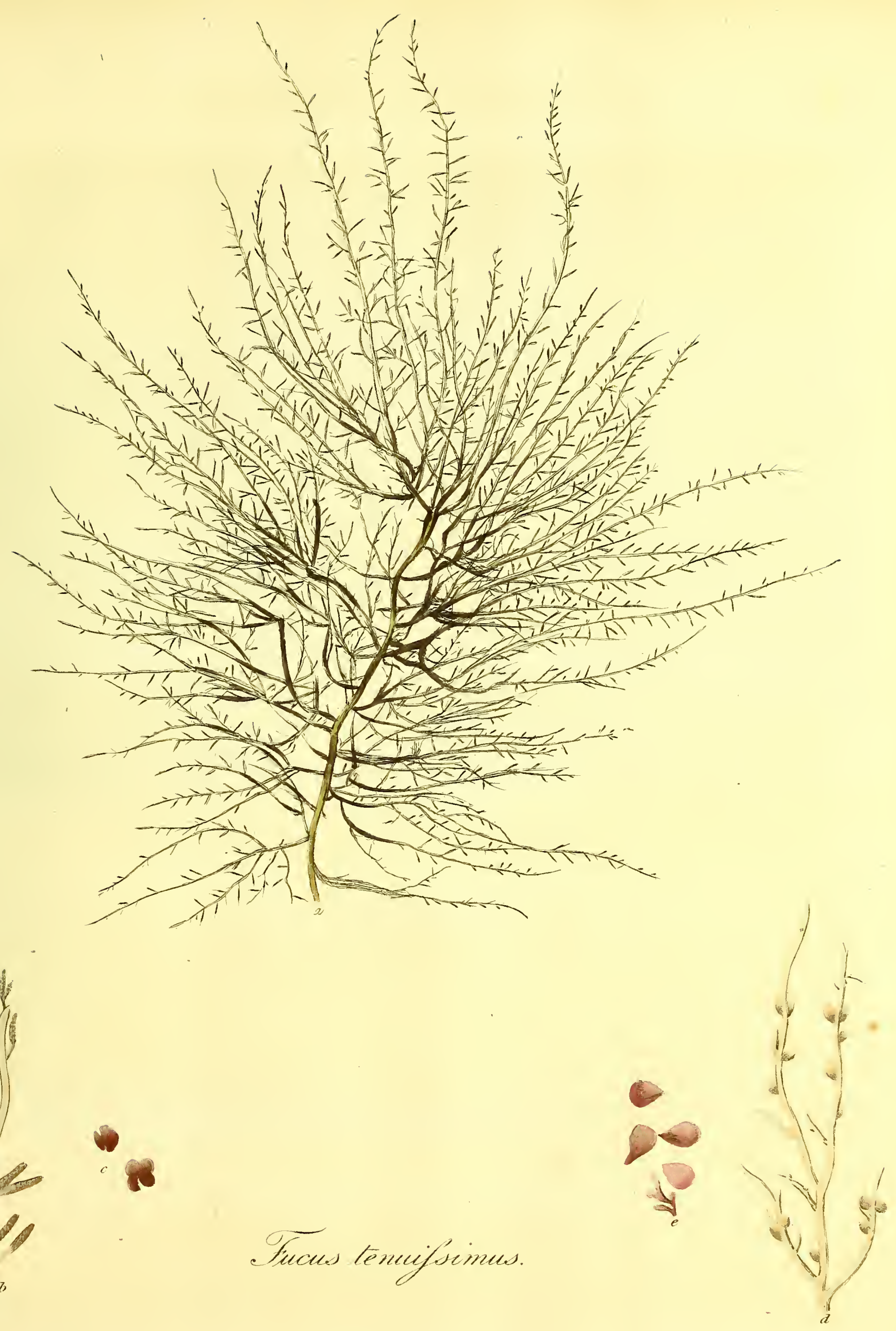



containing a mass of deep-red pyriform * seeds; the other, of naked, scattered, roundish seeds, immersed in the substance of the frond, and appearing under the microscope composed of three or more parts.

+ Co LOR, a pale, brownish red, transparent; darker when dry; and turning to a dirty white in decay.

SUBSTANCE, between cartilaginous and gelatinous, full of moisture, and extremely tender.

Oвs. Conferva confervicola is not unfrequently found upon this Fucus:-in drying it adleres closely to paper :the whole frond, but particularly the upper part and the ranuli, often exhibit under a powerful magnifier the same jointed appearance as $F$. dasyplyyllus.

The nearest affinity of the plant here figured is unquestionably $F$. dasyphyllus, witlı which it has so many particulars in common, that a hasty or inexperienced observer might easily be led to consider them as mere varieties, or to mistake the one for the other. They agree in their mode of growth, their color, their substance, their fructification, and their remakable ramuli; which latter are the strong characteristics of both these species, and serve to distinguish them from all others : but they differ, as has already been observed under $F$. dasypliyllus, in the far more slender size of $F$. tenuissimus, and in its ramuli being equally acuminated at each end ; differences, which, according to the late Mr. Bryer, whose residence at Weymouth afforded him the opportunity of exanining them in a recent state, are still more conspicuous while they are growing, than at any other time, and give a dissimilarity to their general habit. The scattered seeds of the Fucus before us resemble those of $F$. dasyphyllus, in being divided into three or more parts, while those continued in the capsules seem to differ in having no limbus. I speak with hesitation, for it is most easy to fall into error about objects so minute; but $I$ wish to observe, that from all $I$ have seen, I am led to regard the limbus of the seeds as a matter of small moment, the presence and absence of which would by no means induce me to separate into distinct genera, plants so closely allied by nature as $F$. pimnatifidus, F.tenuissimus, F.dasyphyllus, F. obtusus, and F. Forsteri. Wulfen's synonym, above quoted, is referred to this species upon the authority of Professor Mertens, who saw specimens so marked in his own herbarium. His description is by no means drawn up with the happy neatness and precision for which he is remarkable, and his persuasion of his plant being the same as the Limmean $F$. muscoides, is truly extraordinary, particularly since that species is figured by Esper, Gmelin, and the authors of the Flora Danica, to all which he has referred. I received many years ago specimens of $\boldsymbol{F}$. tenuissimus from Professor Esper, gathered in the Adriatic, but without any name, and I find no plate of it in his Icones Fucorum. It was originally described by Hudson, who, having probably seen only individuals with scattered seeds, arranged it among the Ulva, from which genus it was removed by Dr. Goodenough and Mr. Woodward, and received from them the name since preserved to it. 'These gentlemen joined it to the division of Fuci with cylindrical frond, thus keeping it far from $F$. dasyphyllus, which, on account of the more striking shape of the ramuli, they had classed with the species furnished with distinct leaves; and they have carefully pointed out its differences from $F$. pedunculatus and $F$. asparagoides, next to which they liave placed it. Upon this subject, however, it is needless to enlarge, as the most cursory view is sufficient to shew that the three plants are dissimilar in almost every particular, excepting their size and cylindricity.

a. F. tenuissimus, natural size.

b. branch, with scattered seeds, magnified $\quad-5$.

c. seeds - - - - - -1 -

d. branch with capsules - $\quad-\quad-\quad-5$.

e. seeds - - - - - $-\quad-1$.

\footnotetext{
Two kinds of granules appear to be contained in the capsules; the one of a widely pyriform shape, the other twice or thrice as narrow; but these latter are probably only abortive seeds.

t My friend, Rev. G. R. Leathes, who gathered this Fucus plentifully in a growing state last summer, is of opinion that the natural color of the froud is a pale yellow, like that of $F$. ligulatus, when turning to decay. I suspect, however, that such is the case only in those specimens
which have grown in exposed sitnations, as liappens also with other species:
} 
Fucus asparagoides, frond sub-gelatinous, cylindrical, fliform, much and irregularly branched; branches and ramuli between horizontal and patent, the latter simple, setaceous, distichous, opposite, alteruately bearing capsules on their apices: capsules nearly spherical.

Fucus asparagoides. Woobwand, in Linn. Trans. II. p. 29. t.6. Linn. Trans. III. p. 214. Wiтh. IV. p. 117. Eng. Bot. VIII. t. 571. Syn. Fuc. II. p. 364.

Ceramium asparagoides. Rотн, Cat. Bot. III. p. 110.

On rocks and stones at Cromer. Mr. Woodward.-Among the rejectamenta of the sea at Yarmoutl._-Bantry

Bay. Miss Hutchins.-A single specimen found upon the beach at Donaghadee. Mr. Templeton.

Annual. June-September.

Root, a small, almost globular callus.

Frond, either solitary, or rising two or three together from the same base, cylindrical, filiform, from six to nine inches long, about the thickness of packthread, either repeatedly branched in an irregular dichotomous manner, or, as is more commonly the case, furnished with a single undivided stem, beset throughout its whole length with branches disposed in a spirally alternate manner; branches long, between horizontal and patent, flexuose, the lowest generally longest, the rest gradually shortening as they approach the summit of the plant, so as to give the whole frond a subpyramidal outline, but this is uncertain, all of them separated by intervals of a few lines, aud provided with other smaller ones, disposed in the same manner, and these again sonetimes with others; the ultimate branches are from their base to their apices pinnated with distichous ramuli, between horizontal and patent, subulate, scarcely thicker than human hair, *opposite, about a line long, and with the distance of half a line between each, constantly simple, and shewing no tendency to lengthen into branches.

Fructification, ovate capsules, smaller than poppy-seed, placed on the ends of the ramuli, which then perform the office of peduncles, containing a few oblong deep-red seeds :- the capsuliferous ramuli are not above half or a third of the length of the barren ones, and it never happens that two of those with fruit are placed next to each other, but they always stand alternately, a barren one being opposite to a fructified one.

Color, a most beautiful, diaphanous, glossy crimson; becoming more dark after it is dried; turning, from long exposure to the sun, to a dirty white, and in decay taking a purplish tinge.

SUBSTANCE, sub-gelatinous, extremely tender, weak, and flaccid, so that the whole plant is mored by the slightest agitation of the water.

OBs. The surface of the frond appears, under a powerful microscope, elegantly, but faintly, reticulated all over:in drying it adheres very closely to either glass or paper,

For the original discovery of this highly elegant Fucus we are indebted to $\mathrm{Mr}$. Wigg, who found it many years ago among the rejectamenta of the sea upon the beach at Yarmouth, and communicated it to $\mathrm{Mr}$. Woodward, by whom an admirable description and figure of it were published in the second volume of the Linnæan Transactions. This gentleman has since detected it limself in a growing state upon the rocks at Cromer, and is, I believe, the only botanist who has ever been fortunate enough to see it in its locus natalis. It appears to be a species of remarkably unfrequent occurrence, since it is not known to exist beyond the limits of the British Isles, and in the few places where it has been gathered has been far from plentiful; such being the case, even at Yarmouth, where some specimens are generally picked up every summer. When washed by the sea upon the shore, it looks to be a shapeless gelatinous mass, not altogether unlike currant jelly, which may indeed have caused it to be less frequently noticed than it might otherwise have been; but, if seen floating in the water, nothing can be more elegantly feathery and delicate than its general appearance, the exquisite beauty of which those alone can justly appreciate, who have had the opportunity of observing it recent, as, whatever care may have been employed in the preservation of it, the bright glossy tinge will necessarily fade; and though, if well expanded, scarcely any Fucus looks to more advantage on paper, it is never theless in that state far inferior to what it was before it was dried. The peculiar disposition of its barren and fructified ramuli is sufficient to distinguish it at first sight from all its congeners, anong which there is, perhaps, none to which, on a cursory view, it appears to bear more resemblance than to the subject of the following plate.

a. F. asparagoides, natural size.

*a. a very young plant

b. branch, magnified - - - $\quad$ - 5 . 5 .

c. portion of the same - $\quad$ -,$\quad-3$.

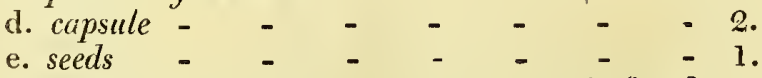

f. part of the frond, to shew the reticulated

structure - - : - - - 1 .

\footnotetext{
* The situation of these does not appear to be regularly opposite, and Roth, in his description of this plant, calls them alternate. I belicve, however, that they are naturally, in general, if not always, opposite, though a snall one is often found opposed to oue much larger, and it is not uncommon to find mally wanting.
} 

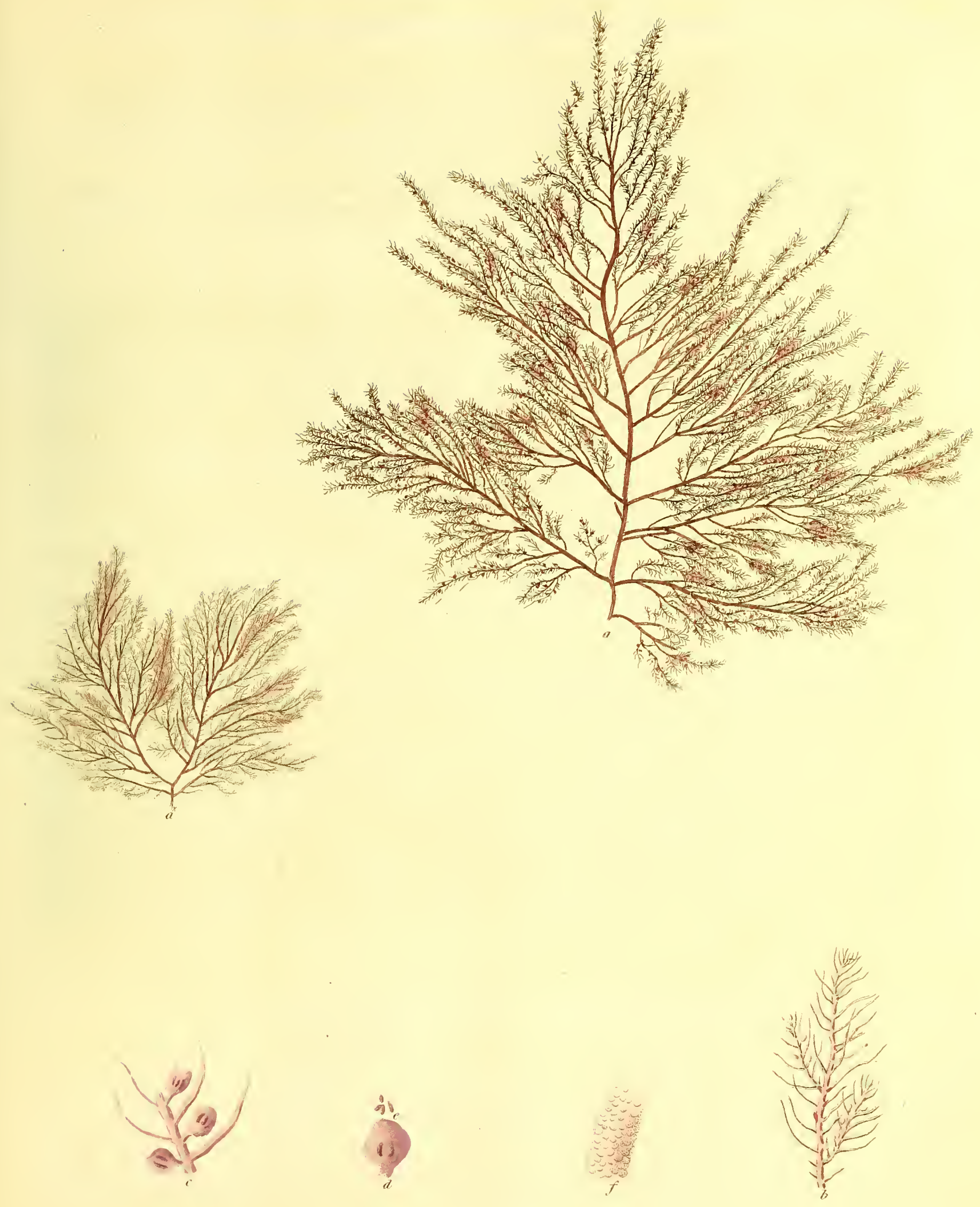

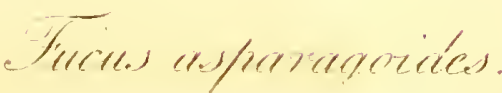



Fucus, fronde sub-gelatinosâ, terete, filiformi, ramosissimâ; ramis ramulisque horizontalitèr patulis, his simplicibus, subulato-setaceis, distichis, oppositis, apice alternatim capsuliferis ; capsulis sub-globosis.

Fucus asparagoides. Woodw A R, in. Limn. Trans. II. p. 29. t. 6. Linn. Trans. III. p. 214. Wxт. IV. p. 117. Eng. Bot. VIII. t. 571 . Syn. Fuc. II. p. 364.

Ceramium asparagoides. Roth. Cat. Bot. III. p. 110.

НА ВітAт in saxis et lapillis marinis apud Cromer in Norfolciâ. D. Woodzard.-Inter rejectamenta maris apud

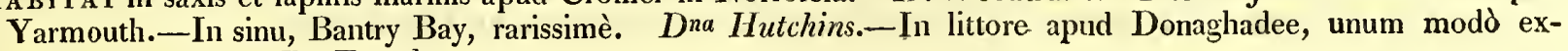
emplar repertum. D. Temipleton.

Annua. Jun.-Sept.

RADıx callus exiguus, sub-globosus.

FrONS nunc solitaria, nunc duæ vel tres ex eâdem basi, teres, filiformis, longitudine semipedalis aut dodrantalis, fili emporetici minoris crassitie, et ubique ferè æqualis, nunc ordine vagè dichotomo ramosissima, nunc, quod sæepiùs accidit caule instructa indiviso, ramis spiralitèr alternis per totam longitudinem obsito; rami elongati, horizontalitèr patuli, flexuosi, inferiores plerumque longissimi, reliqui quo magis plantæ ad apicem appropinquant eo breviores, ut toti stirpi peripheria sit sub-pyramidalis, quod tamen incertum, omnes intervallis aliquot linearum sejuncti, aliisque minoribus simili ratione dispositis instructi, et hi nonnunquàm aliis; ultimi ab ortu ad apices sint pinnati ramulis distichis, horizontalitèr patulis, subulatis, capillo vix crassioribus, * oppositis, circiter lineam longis, et semilineæ inter singulos spatio, semper simplicibus, seque nunquam, ut videtur, in ramos producentibus.

FRUCTIFICATIO capsulæ ovatæ, papaveris semine minores, ramulorum, qui tunc temporis pedunculorum vice funguntur, apicibus impositæ, semina aliquot oblonga intensè rubra includentes:-ramuli capsuliferi sterilibus sunt duplo triplove breviores, et nunquam reperiuntur duo sibi proximi capsulis instructi, sed ordine alterno fructiferi et steriles, hi illis semper oppositi, collocantur.

CoLor amonissimè lætè ruber, diaphanus, nitidus; exsiccata aliquantùm intensior; luci diu objecte sordidè albicans; marcescentis purpureo tinctus.

Substanti a sub-gelatinosa, tenerrima, debilis, flaccida, ut planta levissimo aquæ motu fluctuet.

Oвs. Frondis totius superficies sub lentè acerrimâ pulchrè reticulata apparet:-exsiccata chartæe vel vitro arctê adhæret.

Quòd primùm fuerit hic Fucus perelegans botanicis notus Dno Wigg debetur, qui multos abhìnc annos inter alia maris rejectamenta in littore apud Yarmouth legit, et Dno Woodward impertiit, per quem, icone et descriptione optimâ illustratus, in secundo Sucietatis Linnæanæ Actorum tomo publici demùm juris est factus. Hic quoque nuperiùs rupibus submarinis apud Cromer innascentem detexit, et solus est, nisi fallor, inter botanicos cui in loco natali videre contigit. Paucæ, uti videtur, species infrequentiùs quàm F. asparagoides occurrunt, quæ, nullibi extra Britaunias hucusque reperta, in unâ modo alterâque littorum nostrorum parte, et semper perparcè, est reperta. Ita quoque se res habet apud Yarmouth, ubi plura forsan quàm alibi exemplaria sunt lecta, et singulorum ferè annorum æstate aliquot projiciuıtur. Hæc, dum in arenâ madida jacent, tantımınodò gelatinæ rubicundæ congeriem referunt, illi haud absimilis quæ a Ribis rubri baccis comparatur, sin in aquâ fluitantia videris nihil delicatiùs elegantiùsve plumosum excogitari posse fateberis. Hanc tamen formæ elegantiam ii soli ritè agnoscent, qui stirpem conspexerunt recentem; quantumvis enim cautè explicentur rami, exsiccata nonnihil pulchritudinis unà cum colore nitido necessariè amittit, neque in hoc etiam statu non pulcherrima. Inter Fucos congeneres nulli $F$. asparagoides primo aspectu magis affinis videtur quàm illi in tabulâ insequente depicto, sed, cùm ab hoc, tùm ab omnibus aliis, satis distinguit ramulorum sterilium et fructiferorum singularis dispositio.

a. F. asparagoides, magn. nat.

*a. planta junior.

b. ramus, magn. auct. - - - - $\quad-5$.

c. ejusdem pars - - - - - - 3.

d. capsula - - - - - - -2 .

e. semina - - - - - - $\quad$ - 1 .

f. frondis pars ut structura reticulata appareat 1.

* Horum situs non semper oppositus videtur, et quidem in hujus plantæ descriptione alternos dicit Rothius; credo tamen esse naturâ plerumque, si non semper, oppositos, quamvis non eadem omnibus longitudo, et aliqui non rarò desunt. 
Fucus Wighii, frond sub-gelatinous, cylindrical, filiform, much and irregularly branched, every where beset with setaceous, mostly simple, scattered ramuli, swelling in their centre into lanceolate capsules, and composed of branched jointed fibres.

Fucus Wighii. Turner, in Linn. Trans. VI. p. 135. t. 10. Syn. Fuc. II. p. 362. Eng. Bot. XVII. t. 116.5 .

Among the rejectamenta of the sea at Yarmouth, but very scarce.-At Bantry Bay. Miss IIutchins.-On the beach at Brighton. Mr. Borrer.-One specimen found at Folkstone, by Miss Ezeritt.

Annual. July-September.

Root, a small, blackish, callous disk.

Fron D, cylindrical, filiform, from three to eight inches long, as thick at its origin as a blackbird's quill, and thence graduallý, but almost imperceptibly, attenuated, so as to end in a long acuminated point, furnished with a stem, in general undivided, but sometimes forked, and occasionally dichotomous, beset with branches throughout its whole length; branches scattered without regularity round the stem, some alternate, others opposite, separated by intervals of a few lines, nearly horizontal, flexuose, mostly undivided, of various length, from six or seven inches to not more than half an inch, the middle ones most frequently the longest, the upper ones alivays short, all of them furnished witl other smaller ones, arranged in the same manner, and these not uncommonly with others; around the whole frond grow setiform, horizontal ramuli, thinner than human hair, scattered without order, and separated by short intervals, in general about a line or a line and half long, and simple, but sometimes much longer, and twice or thrice forked, as if about to lengthen into branches: the frond, when old, and approaching to a state of decay, has an appearance extremely different from its general one, loses all its ramuli, so as to look quite naked, and might easily be overlooked by a hasty observer for a fragment of Conferva rubra.

Fructification, situated on the ramuli, which at that time swell in their centre, and have the appearance of lanceolate mucronated capsules, of a darker color than the rest of the frond: these, at the period of fruit, are of an uniform fibrous texture, being destitute of any epidermis, and wholly composed of branclied jointed fibres, in the middle of which lie extremely minute, oblong, dark-red, sessile * seeds.

Color, a pale and very beautiful transparent pink; darker when the plant is dry; but, if kept long in fresh water, or exposed to the air, turning to a dirty yeilowish, and at last to white.

SUBSTANCE, between gelatinous and cartilaginous, slippery, and tender.

OBs. The surface of the frond appears, under a powerful nicroscope, elegantly, but faintly, reticulated with nearly square meshes:-in drying it adheres closely to glass or paper.

There are very few naturalists, indeed, to whom the marine batany of England is under greater obligations than to my friend and original instructor in this department of science, Mr. Lilly Wigg, as a proof of which, it will be sufficient to mention, that $\uparrow$ six of the plants already figured in this work were first brought to light by his industry and acuteness of observation. It was he also who first discovered the subject of the present plate, which I had a particular pleasure in describing under his name. It is an elegant species, both as to form and color, somewhat resembling $F$. asparagoides and $F$. capillaris in general habit; and, like them, confined to the British Isles, and even there of reniarkably unfrequent occurrence. For many years only three specimens, and those gathered at distant intervals, were known to exist, but in the summer of 1804 , it was occasionally thrown in considerable plenty upon the Yarmouth beach, so that there was an opportunity of tracing it in its early state, perfection, and decay; and, since that time, it has been found, though still very sparingly, by Miss Hutchins and Mr. Borrer. Its place of growth, however, remains at present unknown. The extraordinary nature of its formation, which makes it a curious link of connection between the genera of Rivularia and Fucus, was first observed by Mr. Borrer. The structure of the ramuli altogether agrees with the former of these families, except that they want the pellucid hairs observable in the Rivu. laric, but the rest of the frond is formed like that of most other delicate Fuci, being quite cellular, without discovering the least approach to a fibrous texture. The setaceous ramuli render it at first sight distinguishable from its congeners. For the drawing here figured, I am indebted to Rev, G. R. Leathes. .

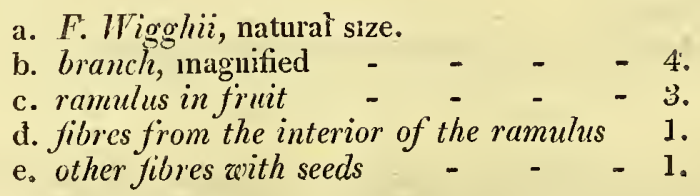

\footnotetext{
* Whether these are in reality seeds or capsules, is a point which their extreme minuteness will probably cause to remain always in donbt. The specimens of them which I have seen, and which are figured in this plate, are so imperfect, that I sliould scarcely have ventured upon regarding them as fruit at all, but for a drawing very kindly communicated by Mr. Sowerby, in which they appear clearly to be sc.

arding them as fruit at all, but for a draw $F$. ruscifolius, $l$. dusyphyllus, $F$, subfuscus, $F$. clavellosus, and $F$. aspuragoides; besides which, he was also the discoverer of Ulia mullifida, Conferva Mertensii, C. rosea, C. stricta, and some other submersed algæ.
} 


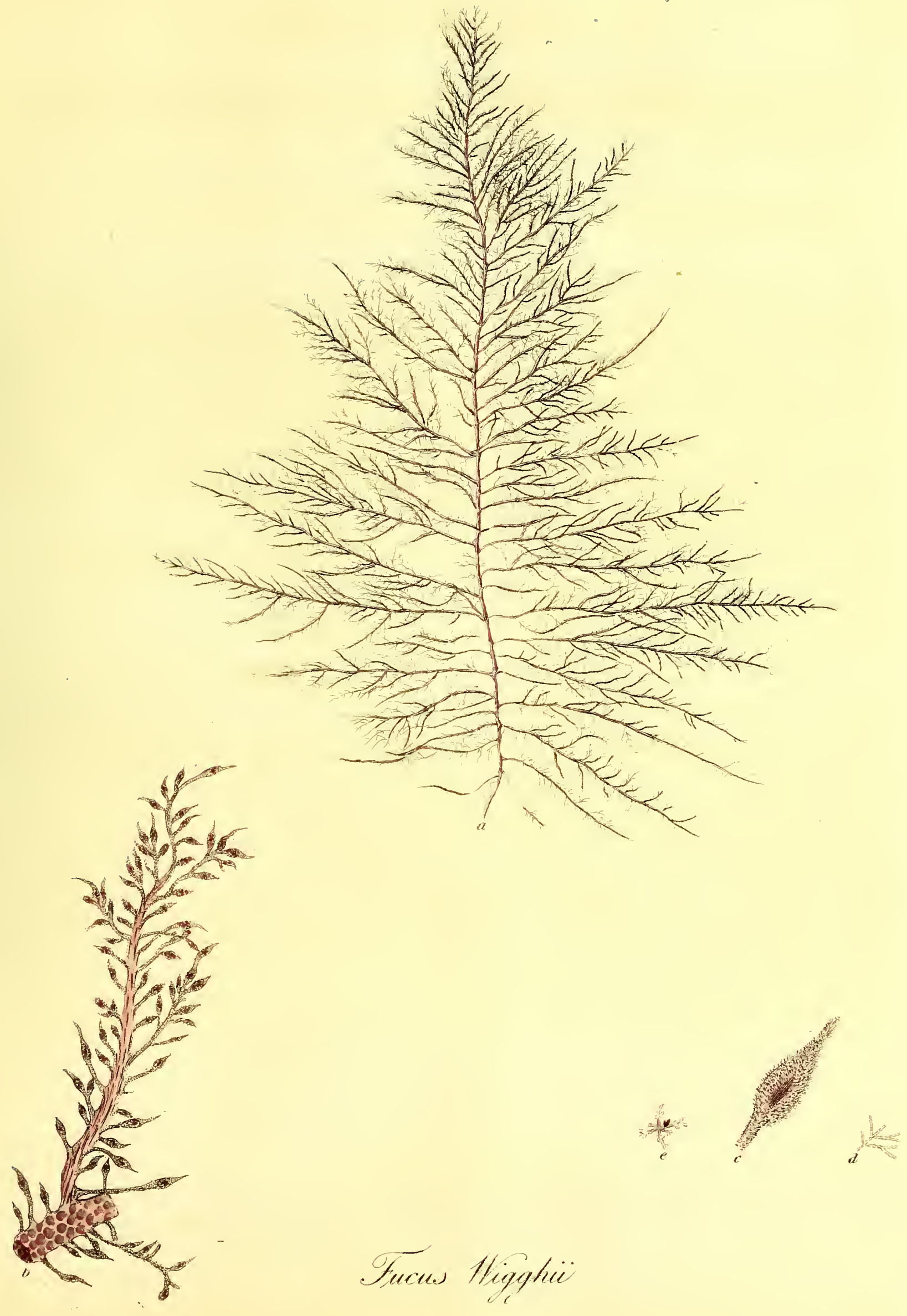



Fucus, fronde sub-gelatinosâ, terete, filiformi, ramosissimâ, ubique obsitâ ramulis setaceis, 'simpliciusculis, sparsis, mediv in capsulas lanceolatas turgidis, e fibris articulatis ramosis constantibus.

Fucks Wigghii. 'TuRner, in Limu. Trans. VI. p. 135. t. 10. Syn. Fuc. II. p. 369. Eng. Bot. XVII. t. 1165 .

Inter rejectamenta maris apud Yarmouth, rarissimè lecta.-In sinu, "Bantry Bay." Dna Hutclinss.-In littore apud Brighton. D. Borrer.-Unum exemplar apıd Folkstone lectum. Dra Everitt.

Annua. Jul.-Sept.

RA DIX callus exiguus, discoideus, nigricans.

Fro Ns teres, filiformis, tri- octo- pollicaris, ortu merulæ peunæ propemodùm crassitie, et exinde sensim attenuata ut in acumen tenuissimum producatur, instructa caule plerumque indiviso, interdùm bifurco, et rariùs dichotomo, ramis per totam longitudinem obsito ; rami circa caulem vagè sparsi, hi alterni, illi oppositi, linearum aliquot intervallis sejuncti, sub-horizontales, flexuosi, ut plurinıùn indivisi, quidam sex septemve pollicum, alii vix unius unguis longitudine, medii sæpiùs reliquis longiores, summi semper abbreviati, omnes aliis minoribus eâdem ratione dispositis instructi, et hi non rarò aliis ; totam frondem obsideıt ramuli setiformes, horizontales, capillo tenuiores, absque normâ sparsi, spatio inter singulos perbrevi, plerunque circiter lineam vel sesquilineam longi et simplices, sed interdùm bitri- furci, quasi sese in ramos producturi :-frons effota et mox peritura faciem a vulgari quàm diversissimam induit, et, ramulis omnibus amissis, mirè denudata videtur, ut minùs cautè intuens facilè pro Conferva rubra fragminibus. prætereat.

FRUCTIFICATIO in ramulis sita, qui tunc in centro intumescentes capsulas lanceolatas mucronatas coloris reliquâ stirpe intelsioris referunt: hi fructûs tempore substantiæ sunt uniformis, texturâ fibrosâ, epidermide nullâ obtecti, sed toti e fibris constantes articulatis ramosis, quorum in medio jacent * semina minutissima, oblonga, atro-rufa, sessilia.

Color dilutè et amœnissimè roseus, diaplıanus; exsiccate intensior; in aquâ dulci diu sertata aut luci objecta sordidè flavescens, et demùm in albicantem evanidus.

SUBSTANTı inter gelatinosanı et cartilagineam, lubrica, tenera.

OBs. Frons, sub lente acerrimâ visa, superficie pulchrè reticulata apparet, maculis sub-quadratis :- exsiccata chartæ vel vitro arctè adhæret.

Perpauci modd sunt botanici quorum majore beneficio Nereis nostra Britamica devincitur quam viri amicissini ejusdemque mihi olìm in hâc re præceptoris Dni Wigg, cujus de meritis satis erit referre + sex e fucis jam in hoc opere evulgatis per ejus industriam et inentis acumen esse patefactos. Hic etiam primus detexit stirpem in hâc tabulâ adumbratam, cui suum nomen in Limmeanæ Societatis Actis magno olim cum gaudio indidi. Species est colore et formâ elegante insignis, cujus habitus, quod aỉunt, generalis ab illo $F$. asparagoidis et $\boldsymbol{F}$. capillaris haud multum abludit, et quæ, illorum instar, nullibi extra Britanuiarum terminos in præsens est lecta, soletque etiam in illis infrequentissimè occurrere. Tria tantummodò exemplaria, omnia in littore apud Yarmouth inventa, intervallo inter utrumque repertum longo, multos per annos innotuermnt, sed demùm A. D. MDCCCIV planta satis copiosè est ibi projecta, aded ut primo ætatis gradu itidèmque effætam observandi facultas diu desiderata sese obtulerit. Legerunt post id tempus Dna Hutchins Dna Everitt et D. Borrer, sed hi quoque parcissimè, et locus natalis hactenus latet. Miram frondis structuram, quæ efficit ut hæc stirps inter Fucos et Rivularias quodammodo ambigat, primus notavit D. Borrer. Ramuli e fibris toti constantes cum lis conveniunt, reliqua autem frons nilil in se simile habet, et cum aliis Fucis minoribus consentit. Ramuli setacei ubique sparsi suppeditant notam certam per quam $F$. Wigh hii a congeneribus dignoscitur. Delineationem in hâc tabulâ exlibitam Dui G. R. Leathes benevolentiæ acceptam refero.

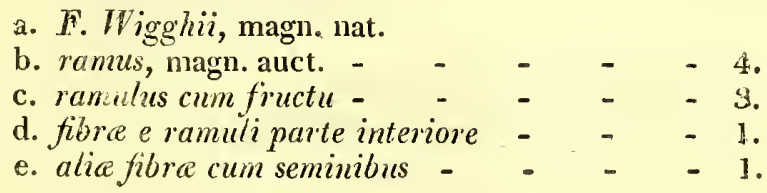

\footnotetext{
* An semina, an capsulæx? - quisnam in tantâ minutie litem dirimet ?-Ipse quidem non sim ausus adeò niti exemplaribus a me visis et in Lậc tabulâ adumbratis ut pro fructu haberem, nisi cl. Sowverbcius delineationem ab ipso factam benevol misisset per quam res liquidò patuit.

+ Ha sex specics sunt $F$. Hypoglossum, $F$.ruscifolius, $F$. dusyphyllus, $F$. subfuscus, F. clavellosus, et $F$. usparagoides, prater quos detexit etiam Ulcum multifidam, Conjercam Nertensii, C. roseam, C. striclam, cum aliquot aliis algis submersis.
} 
Fucus diversifolius, stem compressed, filiform, muricated, pinnated: branches alternate, very short, simple : leaves linear, serrulated, simple, bifid, or pimnatifid : vesicules none: receptacles axillary, racemose.

Fucus serrulatus. ForskiL, Fl. Egypt-Arab. p. 189 ? Linn, Syst. Nat. Ed. Gmel. II. p. 1388?

Shores of Egypt.

\section{Perennial?}

Rоoт, a woody, nearly conical, black disk, about half an inch in diameter.

FroNDs, three, four, or more, from the same base, each furnished with a single, compressed, filiform stem, from a foot to a foot and half long, as thick near the base as a blackbird's quill, towards the apices somewhat attenuated, muricated all over with extremely minute, scattered, homogeneous spines, undivided, but pinnated throughout its whole length with branches, in other respects naked; branches distichous, alternate, horizontal, separated by intervals of about half an inch, simple, and so short, that they appear only to be clusters of leaves; leares placed alternately upon the branches, either solitary, or clustered, crowded, linear, or lineari-lanceolate, from an inch to an inch and half long, and from two to three lines wide, some simple, others twice or thrice forked towards their apices with divaricated segments, and again others more or less pinnatifid, all sessile, provided with a thin blackish midrib, slightly undulated, irregularly serrated at their margins with small teeth, which are in some specimens obsolete; vesicles, apparently, almost always wanting, but in one instance $I$ have seen a single one, which was about the size of the seed of a vetch, and supported upon a short footstalk.

FruCtification, so imperfect in my specimèns tlat I can say little more of it than that it consists of cylindrical receptacles, placed in racemi in the axillæ of the branches: the very young state of these prevented the possibility of examining their interior, but there can be little doubt of their being in this respect similar to those of $F$. natans.

CoLols, of the recent plant, I believe, a bright green; when dry a pale brown; if again moistened, a brownish green, always destitute of gloss.

SUBSTANCE, in the stem cartilaginous, in the leaves between cartilaginous and membranaceous, thin.

Овs. In drying it does not in the least adhere to paper.

The peculiarity already noticed under F. heterophyllus, of the same plant producing two sets of leaves of different size and form, is far from being equally striking in that species as in the one here figured; for, in the former, the difference is little more than that the radical leaves are considerably larger than such as are placed in other parts of the frond, a circumstance common, though in a smaller degree, to many other Fuci, but in the latter, the variation, which is in itself more extraordinary, seems to take place without being subject to any law whatever. The same individual has generally some of its leaves simple, and others bifid, in most uncertain proportions; and of the bifid ones some are scarcely more than emarginate, others deeply divided, or even with a tendency to become dichotomous. This, however, is by no means always the case, for specimens are found, in which the whole of the leaves are bifid, or in which all are simple, and there are others in which a considerable portion of them are more or less regularly pinnatifid. Such among these as have their leaves divided cannot possibly be confounded with any other Fucus at present known : those with simple leaves are distinguished by the stem muricated all over, though so minutely as hardly to be perceptible without a glass, by the peculiar texture, which, when dry, resembles that of a zostera, and by the want of vesicles. This latter character, however, is not altogether constant, as I have already mentioned in the description that in one specimen $I$ have seen a single bladder, and in others, I have noticed a tendency of the leaves to swell into bladders in the same manner as is figured under $F$. Acinaria, but far less strikingly. I am indebted for my specimens of $\boldsymbol{F}$. diversifolius to Sir Joseph Banks, who received a large quantity of it in a collection of Fuci made by some of the French during their residence in Egypt. I had long been in possession of a very young plant, of what $I$ suppose to be a variety of the same species, which was gathered at Teneriffe, and has the whole of its leaves pinnatifid, and deeply serrated. Forskal's synonym is quoted above with a mark of uncertainty, because no specimen of his plant is preserved in his herbarium; his *description, however, is so accurate, that I can scarcely feel a doubt of its being intended for the species before us.

a. $F$. diversifolius, natural size.

b. leaf and fructification, magnified $\quad-6$.

* "F. serrulatus; caulibus teretibus, ramosis; foliis linearibus, serrulatis, simplicibus; vesicis nullis.
"Descr. Totus viridis. Caules angusti, teretes, spith. ramosi. Folia pollicaria, linearia, acute serrata, interdùm simplicia, interdùm medio divisa, in duas tresve lacinias lineares, serratas." 


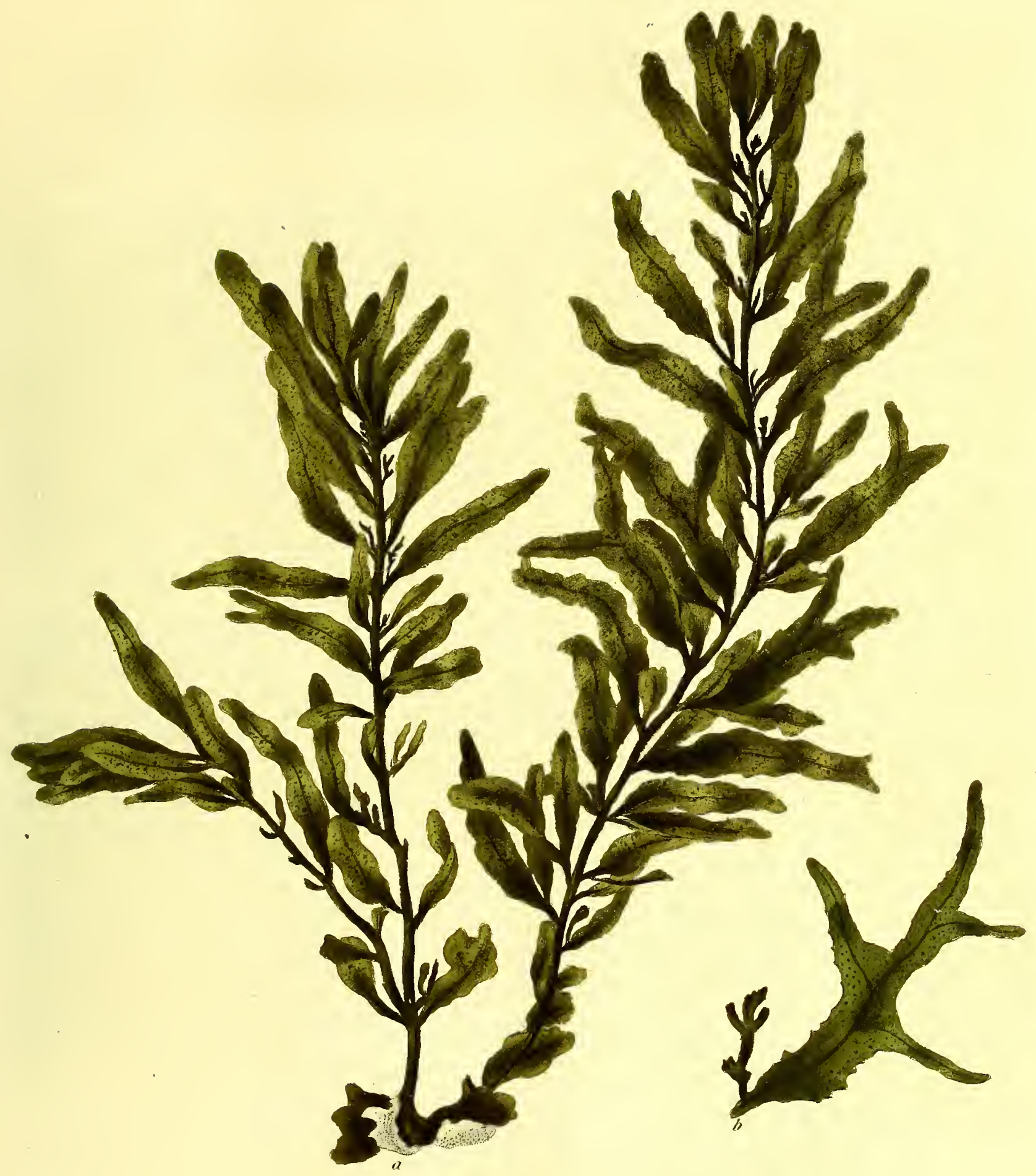

Sucres diversifolius. 

Fucus, caule compresso, filiformi, muriculato, pinnato : ramis alternis, brevissimis, simplicibus: foliis linearibus, serrulatis, simplicibus, bifidis, pimnatifidisque : vesiculis nullis : receptaculis axillaribus, racemosis.

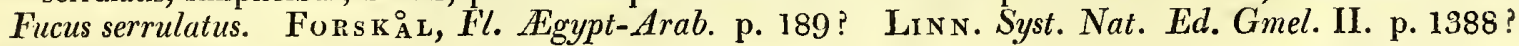

Навіт ат $\mathbb{E}$ gypti ad oras.

Perennis?

$\mathrm{R}_{\mathrm{ADIX}}$ discus lignosus, ferè conicus, ater, diametro circitèr unguicularis.

FRONDEs ex eâdem basi tres, quatuor, vel plures, singulæ caule instructæ unico, compresso, filiformi, longitudiue pedali aut sesquipedali, juxta basin merulæ pennæ crassitie, apices versus aliquantùm attenuato, spinulis minutissimis sparsis homogeneis muriculato, indiviso, sed per totam longitudinen ramis obsito, cætera nudo; rami distichi, alterni, horizontales, intervallis sub-unguicularibus sejuncti, simplices, adedque breves, ut tantummodo foliorum fasciculi videantur; folia in ramis alterna, nunc solitaria, nunc fasciculata, approximata, linearia, vel lineari-lanceolata, pollicem aut sesquipollicem longa, et duas tresve lineas lata, hæc simplicia, illa apices versus bi- tri-furca, segmentis divaricatis, alia sub-pinnatifida, omnia sessilia, nervo tenui nigricante percursa, lenitèr undulata, margine enormitèr serratodentata, dentibus perexiguis, in quibusdam obsoletis; vesicula, ut videtur, plerumque desunt, in umo tamen exemplare unam vidi, quæ Vicia sativa seminis erat magnitudine, et brevitèr petiolata.

FruCTIFICATIO aded est in exemplaribus nostris imperfecta ut nihil ferè de illâ proferre possim: constat e receptaculis teretibus, racemosim foliorum ad alas dispositis, quorum ætas haud satis adulta prohibuit quominus pars interior conspiceretur, neque tamen est dubitandum quin sint ibi eorum F. natantis similia.

CoLor plantæ recentis (uti credo) lætè virens; exsiccata dilutè fuscus; iterum madefacta viridis fusco immixtus, nitoris semper expers.

Su B ST A N т A in caule cartilaginea, in foliis inter cartilagineam et membranaceam, tenuis.

Oвs. Exsiccatione ne minimùm chartæe adhæret.

Si Fucus jam in hoc opere sub $F$. heterophylli nomine delineatus sese spectabilem præstet, quia duplicis formæ duplicisque magnitudinis folia în eâdem stirpe provenire sint solita, ıemo non statìm percipiet idem esse in specie hìc depictâ magis notatione dignum. Prioris quidem folia maximè prima facie inter sese discrepant, sed in eo pracipuè ponitur discrimen, quòd radicalia sint rameis multoties majora, et hoc in aliis quoque Fucis, licet haud paritèr manifestè, conspicitur; inter hujus autem folia insignior est dissimilitudo, et quoad formam nullâ certâ normâ limitata ludunt. Reperiuntur plerumque in eodem individuo quæedam simplicia et alia bifida, et nunc horum nunc illorum major est numerus : bifidorum quoque aliqua sunt tantummodo levitèr alia profundè incisa, aut etiam subdichotoma. Neque tamen se res semper ita habet; dantur enim exemplaria foliis omnibus fissis, dantur quoque non nisi simplicibus, neque desunt alia pluribus, si non cunctis, plùs minus regularitèr pinnatifidis. Ex his talia quibus folia sunt divisa statìm a reliquis omnibus adhuc cognitis Fucorum speciebus dignoscuntur; specimilla vero foliis modo simplicibus gaudentia distinguuntur per caulem ubique, quamvis minutissimè, muriculatım, per texturam admodùm singularem ei Zosterarum haud absimilem, et per vesicularum defectum. Dubito tamen ut sit constans character a vesicularum absentiâ depromptus; quoniam jam suprà in descriptione nıemoravi me unam harum vidịsse, et in aliis individuis folia apices versus bullata, simili modo quo illa $F$. Acinarice sed multo minùs manifestè conspexi. $F$. diversifolii exemplaria nobilissimi Banksii liberalitati debeo. Plurima ille accepit und cum aliis quibusdam Fucis a quodam $e$ Gallis dùm in Egypto comnorarentır lectis. Diu quidem autehac milli fuerat in herbario plantula ex insulâ Teneriffe reportata, sed tenerâ admodùm ætate, quæ ejusdem speciei varietas videtur, quamvis folia habet omnia pinnatifida et margine profunde serrata. Forskalii synonymo suprâ citato dubitationis signum subjeci, quia nullum ille in herbario suæ stirpis exemplar reliquit. * Descriptio tamen, quantumvis brevis, aded onnibus ferè numeris convenit, ut scrupulus mili vix ullus restet quin ad nostriłm plantam pertineat.

a. F. diversifolius, magn. nat.

b. folium et fructificatio, magil. auct. - 6 .

* "Fucus serrulatus; caulibus teretibus, ramosis; foliis linearibus, serrulatis, simplicibus; resicis nullis.

"Descr. Totus viridis. Caules angusti, teretes, spith. ramosi. Folia pollicaria, linearia, acuta, seriata, interdùm simplicia, interdùn medio divisa, in duas tresve lacinias lineares, serratas." 
Fucus longifolius, stem flat, winged, pinnated: branches alternate, simple : leaves linear, petiolate, serrated: vesicles spherical, petiolate: receptacles racemose, with compound racemi, nearly equal in length to the leaves.

Fucus salicifolius. Es PER, Ic. Fuc. 1. p. 57. t. 25. (exclusis synonymis.)

B. tenuifolius; stem near the apices filiform and compressed: substance of the leaves thin, between membranaceous and cartilaginous.

$\gamma$. angustifolius; stem near the apices filiform and compressed: leaves linear, very narrow, serrato-dentate, with teeth reaching down to the midrib.

In the Indian Ocean. Professor Esper. $-\beta$ and $\gamma$ in the Harbour of Nangasaki. Dr. Horner.

\section{Perennial.}

Root, not yet known.

Fron D, furnished with a stem (of what length, and whether divided or not, $I$ am ignorant, but $I$ have seen it above four feet long, and still simple,) thexuose, flat, linear, about a quarter of an inch wide, thickest in the centre, and having there the appearance of a broad midrib, towards its margins thin, and here and there uneven with scattered teeth, which look like the rudiments of leaves, pinnated throughout its whole length with branches, in other respects naked; branches arising from the stem at very uncertain intervals, and exactly like it, excepting their smaller size, distichous, alternate, patent, slightly flexuose, some two or three feet, others scarcely so many inches long, all bearing leaves, vesicles, and fructification; leaves distichous, alternate, separated by spaces of about half an inch each, linear, or between linear and lanceolate, three or four inches long, and the half of one wide, furnished with a dark-coloured midrib not unfrequently almost obsulete, here and there perforated with very minute pores, obtuse at their apices, at their bases attenuated into sub-cylindrical petioli, a line and half long, irregularly seriated at their margins with largish teeth ; vesicles placed at the axillix of the leaves, and often supported upon their petioli, solitary, or in pairs, growing on a petiolus two or three lines long, as large as sloes, externally smooth, internally quite empty, tipped at their apices with a leaf like the rest in shape, but narrower and shorter.

FRUCTIFICATION, which I have never seen, except in a very imperfect state, situated on the same footstalks as the vesicles, and, as far as can be judged from Esper's figure, consisting of compressed, compound, repeatedly divided racemi, as long as, or longer than, the leaves.

CoLor, olive-green, blackish in a dry state.

SUBSTANCE, hard and coriaceous in the stem, in the leaves cartilaginous, flexible and tongh.

The variety $\beta$ differs in its more slender size, in having its stem and branches so attenuated at the apices as to appear filiform, in its leaves being scarcely three lines wide, and, particularly, in the substance of these, which is so thin as to be almost membranaceous, and in their color, which is, even when dry, a pale, transparent, olive-brown.

In $\gamma$, the stem is no where flat, but compressed throughout, and not thicker than a crow's quill; the leaves are scarcely a line wide, serrated with sharp teeth, which extend down even to the midrib.

Овs. In drying it does not adhere to paper.

Never having myself seen a certain specimen of the $F$. salicifolius of Gmelin, which Professor Esper considers the same as the plant here figured, I should scarcely have ventured to dissent from him in opinion upon the subject, had I not been sheltered by the authority of Professor Miertens and * Dr. Mohr, both of whom are acquainted with that species. I may, however, be allowed to add, that it appears from Gmelin's description, that $F$. longifolius differs from his plant in having all its leaves, as well as its vesicles, petiolate, in the much greater size of the latter, and in the lower leaves being equally serrated as the upper. The subject of the present plate is in the Limnaan Herbarium, where it is preserved without any name, remark, or locus natalis attaclied to it. Professor Esper had the advantage of representing an individual infinitely superior with regard to the fructification; for in the Linnæan specimen there are only some rudiments of raceni, so young as to be altogether destitute of seeds, thougl evidently formed for the purpose of hereafter containing them. The fiuit of this species, according to the figure in the Icones Fucorum, differs widely from all others in the size of its receptacles, which equal the length of its leaves, and are repeatedly and variously branched, so as to give the whole frond a singularly elegant appearance. From its mode of growth, its leaves, and its vesicles, there can be no question but it belongs to the same tribe as $F$. natans, nor can I feel a doubt of the fruit agreeing in its internal structure with that species and its affinities; though, unfortunately, no information can be obtained on this subject from Fsper's figure, from its being unaccompanied by any microscopical analysis. Professor Mertens' opinion, already more than once noticed in this work, that the air-bladders of Fuci are

\footnotetext{
* While describing this plant, the mclancholy news has reached me of the death of this excellent young inan, who on the 17th of Angust last fell a victim to his immodcrate zeal and intense application in the prorsuit of natural history, which wore out a frame naturally tender and delicate. I speak feelingly upon the subject of his death, for I lament in him one of the kindest, most liberal, and most instructive of correspondents, and I scarcely fear bcing contradicted in the assertion, that botany has lost, in him, the most ablc and useful cryptogamist of the present day. His remarks upon his nicroscopical dissections of the submerscd algre, continually referred to in these pages, aftord an extraordinary proof of his acquaintance with this fanily, and his cryptogamic Flora Germanica is a work that will be ranked among the wost valuable, so long as that tribe of vegetables continues to bc studicd by naturalists. Hc has also left many other scattered botanical works, the whole of thcm, or ncarly so, written, like those already mentioned, in conjunction with his inseparable fijend Dr. Webcr; and at the tine of his dcath he was engaged with Dr. Swartz in preparing a Spccies Muscorum, of the progress of which I ara at present igno: ant.
} 


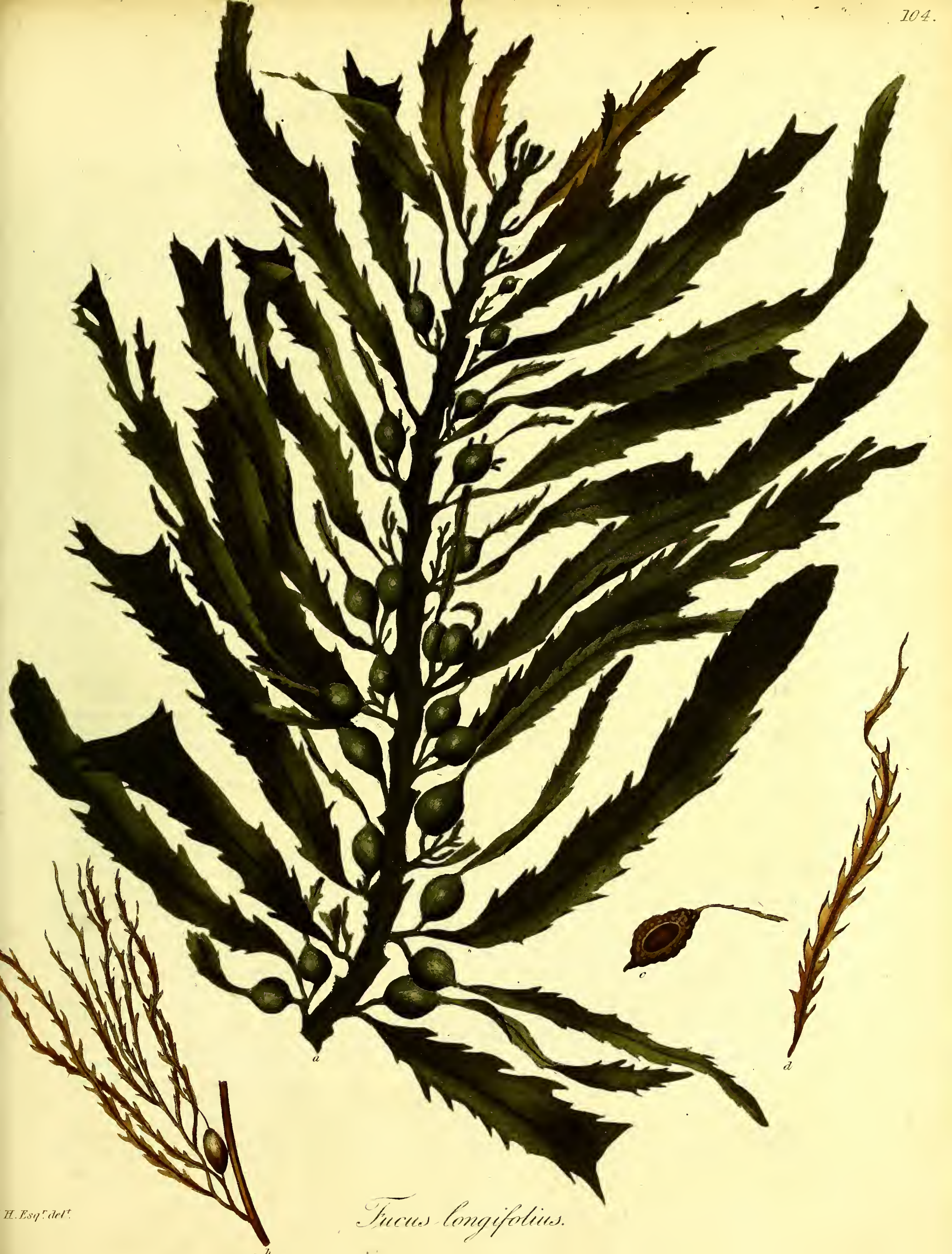



in reality only capsules which have discharged their seeds, appears in this plant, as well as in $F$.turbinatus, and some others, to be improbable, considered as to the size, the number, and the situation of the vesicles, nor does it seem likely that the leaves ever change into branches, although some of those in the Linnæan specimen were torn in such a manner as to have the appearance of so doing. What Dr. Esper means by the observation, that he found minute spherical globules here and there on the ends of the racemi, I am at a loss to imagine. The varieties $\beta$ and $\gamma$ have not yet been seen in fruit, and it is possible that, when their fructification is discovered, they may prove to be distinct species, tlough I can at present detect no reason for regarding them as such, in spite of the extraordinary difference between the appearance of the latter and of the plant here figured.

a. Fucus lonoifolius, natural size.

b. portion of the frond of var. $\gamma$.

c. vesicle of the same cut open, magnified - 6 .

d. leaf of the same - - - 6 .

104.-F U C US L O N G I F O I US.

Fucus, caule plano, alato, pinnato: ramis alternis, simplicibus : foliis linearibus, petiolatis, serratis : vesiculis sphæricis, petiolatis : receptaculis racemosis ; racemis compositis, folia sub-æquantibus.

Fucus salicifolius. EsPER, Ic. Fuc. I. p. 57. t. 25, (exclusis synonymis.)

ß. temuifolius; caule apices versus filiformi, compresso; foliorum substantiâ tenui, membranaceo-cartilagineâ.

$\gamma$. angustifolius; caule apices versus filiformi, compresso; foliis linearibus, angustissimis, ad nervum usque serratodentatis.

Hавіт ат in mari Indico. Esper. $-\beta$ et $\gamma$ in Portu Nangasaki. D. Horner.

Perennis.

RADix nondùm cognita.

Frons instructa caule, (de quo an divisus sit necne nescio, et paritèr ad quantam longitudinem attingat, ipse quadripedalem et ultrà, semper tamen indivisum, vidi,) flexuoso, plano, lineari, latitudine semiunguiculari, in centro incrassato, nervique speciem præbente, margines versus tenuiore, dentibusque sparsis, qui foliorum rudimenta videntur, hìc illìc inæquali, ramis per totam longitudinem pinnato, cæetera nudo ; rami e caule intervallis incertissimis exeuntes, ejusque, magnitudine demptâ, omninò similes, patentes, distichi, alterni, lenitèr flexuosi, hi duorum triumve pedum illi vix totidem pollicum longitudine, folia, vesiculas, fructumque ferentes; folia in ramis disticha, alterna, spatiis subunguicularibus sejuncta, linearia, vel lineari-lanceolata, spithamam longa, et unguem lata, nervo nigricante haud rard obsoleto percursa, superficie poris minutissimis hic illic pertusa, apice obtusa, basi in petiolos sesquilineares teretiusculos attenuata, margine enormitèr serrato-dentata, dentibus majusculis; vesicula foliorum ad alas sitæ, et sæpe eorum petiolis impositæ, solitariæ, vel gemellæ, petiolo bi- tri- lineari fultæ, sphæricæ, Pruni spinosa druparum magnitudine, extrinsecùs læves, intùs onninò vacuæ, apice terminatæ folio reliquorum simili, sed angustiore et breviore.

Fructificatio, a me nunquam nisi in statu perquàm manco visa, ab iisdem quibus vesiculæ petiolis oritur, et, quatenus ex Esperi icone judicare licet, e racemis constat compressis, compositis, iterùm atque iterùm divisis, folia longitudine æquantibus aut superantibus.

Color olivaceus, exsiccate nigricans.

Subst ANT I in caule et ramis dura, coriacea, in foliis cartilaginea, lenta, tenax.

Var. $\beta$. differt staturâ ubique graciliore, caule et ramis ad apices ita attenuatis ut filiformes videantur, foliis vix tres lineas latis, sed præsertìm horum substantiâ aded tenui ut propemodùm sit membranacea, et colore pallidè, etiam in exsiccatâ, olivaceo-fusco, diaphano.

VoL. 1I, 
Var. $\gamma$ caulem habet ubique compressum et nullibi pennâ corvinâ crassiorem, folia vix lineam lata, dentibus acutis, ita magnis ut ad nervum attingant.

Oвs. Planta exsiccata chartæ non adhæret.

Credit cl. Esperus Fucum hìc depictum esse eundem quem sub F. salicifolii nomine descripsit Gmelinus, cujus cùm ego exemplar nullum auctoritate, quod aiunt, ratum viderim, vix secùs sentire sim austis, nisi suaderent viri amicissimi, Mertensius * Mohriusque, quibus utraque planta innotuit. Ex descriptione tamen Gmelinianâ adjicere licet, $\boldsymbol{F}$. longifolium a stirpe suâ in his differre, quod folia habeat omnia, cùm inferiora tùm superiora, serrata, quòd hæc sint non minùs quàm vesiculæ petiolata, et quod vesiculæ eas $F$. salicifolii magnitudine multo exuperent. Exemplar quod hæc tabula delineatum exhibet in Herbario Linnæano servatur, nullo tamen nomine, vel animadversione, vel loco natali adjecto. Illud ab Espero depictum nostro quoad fructum longè antecellit, cujus sunt in Linnæano tantummodò rudimenta quædam racemorum, seminibus omninò carentium, quamvis manifestè ad ea olìm recipienda designatorum. Quantum judicare licet a tabulâ in Iconibus Fucorum datâ, differt hujus Fuci fructificatio ab eâ reliquorum omnium per receptacula foliis haud breviora, varièque et repetito ramosa, unde toti stirpi facies insignitèr elegans. Ad $F$. natant is familiam adjungi debere satis suadent crescendi modus folia et vesiculæ; neque ullus dubito quin fructûs interiore structurâ cum his quoque conveniat; quamvis Esperi icon analysi microscopicâ destituta nihil ad hoc illustrandum suppeditat. Vesicularum molem numerum situmve respicienti non magis verisimilis apparebit in F. lcngifolio quàm in F. turbinato Mertensii sententia, jamjàm plus unâ vice in hoc opere memorata, fucorum vesiculas esse reapse nilil aliud nisi capsulas effoetas; neque magis est probabile folia unquam in ramos immutari, quædam licet ex his in exemplare Linnæano ita lacerentur ut tale quiddam arguere viderentur. Nescio prorsùs quid in animo habuerit Esperus, quum reperisse se memorat tubercula exigua sphærica ramorum apicibus hìc illic insidentia. Neutra varietatum suprà descriptarum hactenus fructifera est detecta. Fieri potest ut, fructu cognito, verè distinctæe reperiantur; quantumvis autem primo aspectu discrepent, nilhil quod ad species distinctas constituendas sufficiat in præsens deprehendi.

a. F. longifolius, magn. nat.

b. pars frondis var. $\gamma$.

c. ejusdem vesicula dissecta, magn. auct. - $\quad-6$.

d. ejusdem folium - $\quad$ - $\quad-6$,

\footnotetext{
* Dum in his scribendis versor, renunciatum est eximium hunc juvenem e vitâ excessisse sexto Calendas Sextiles. Corporis habitus semper, eheu! debilis et in phthisin proclivis mentis fortissimæ laboribus studioque in historiâ naturali investigandâ immenso impar defecit. Luget, hoc extincto, Botanice Cryptogamum sagacissimum eundemque nostri ævi utillimum : lugent amici sodalem carissimum; ipse, alienigena et ignotus, lugens desidero virum literarum commercio suavissimo mecum devinctum, ad docendum peritissimum, ad impertiendum promptissinum. Quantus ille fuerit in algarum submersarum scientiâ satis comprobant animadversiones de adumbrationibus suis microscopicis ab ipso editæ, et jam sæpissimè in hoc opcre citatæ: quantus in reliquis classis cryptogamiæ familiis nemo dubitabit, cui Flora sua Germanica innotuit, liber nunquam sine laude memorandus, et cujus laudes tanto magis clarescent quanto hæ stirpes magis Botanicis erunt in deliciis. Reliquit quoque opera alia ad historiam naturalem pertinentia hic illic sparsa : quæ omnia ferè, sicut ea jam memorata, cum amico conjınctissimo Webero erant communia. Quum mors supervenit, in Muscologia Universali conscribendâ unà cum Swartzio occupabatur.— "Eเ
} 
Fucus, caule triquetro, ramoso ; ramis planis, infernè simplicibus et foliosis, supernè paniculato-divisis aphyllis, vesiculiferis: foliis distichis, linearibus, simplicibus, pinnatifidisque : vesiculis lanceolatis, moniliformibus, terminalibus.

Habitat apud Port Trinidad, in Americæ Septentrionalis oris Occidentalibus. D. Menzies.

Perennis?

RADIX hactenus ignota.

FroN sesquipedalis, et ultrà, forsan etiam multo longior, caule assurgens triquetro, pennæ anserinæ crassitie, cujus de longitudine et an divisus sit necne nihil scio, nudo, apice ramis aliquot instructo ; rami fasciculati, pedales, aut sesquipedales, sub-fastigiati, basi plani et duas tresve lineas lati, exinde lenissinè angustati, ut ad apices fiant e tereti compressi, pennâque merulæ tenuiores, ubique levitèr flexıosi, ad dimidiam et ultrà longitudinem simplices et foliosi, supernè paniculatìm divisi vesiculiferique; folia disticha, horizontalitèr patula, alterna, intervallis sub-unguicularibus sejuncta, plana, linearia, duarum triumve linearum latitudine, summa duos pollices longa et pinnatifida segmentis brevibus, intermedia breviora et enormitèr sinuata, ima vix unguicularia et simplicia, omnia apice rotundata, margine integerrima, et nervo angusto nigricante incrassato qui sese in ramorun quoque parte inferiore conspiciendum præbet percursa ; resicula ramorum superiorum ad apices et latera sitæ, solitariæ, sessiles, vel brevissimè peticlatæ, ellipticolanceolatæ, unguem ferè longæ, pennæ corvinæ majoris crassitie, moniliformes, e 3-5 articulis sphæricis constantes, extrinsecùs læves, intùs fibris aliquot parallelis simplicibus longitudinalitèr percursæ, apice mucronatæ, mucrone brevi setaceo, qui rarissimè in folium parvum oblongum explanatur, et interdùm in vesiculam alteram intervallo exiguo a priore disjunctam producitur.

Fruçtificatio nondùm a me visa.

Color plante madefacta olivaceo-fuscus; exsiccate nigerrimus, opacus.

Su bST ANTIA in caule lignosa, in ramis coriacea, in foliis cartilaginea, at tenuis, lenta, tenax.

OBs. Planta exsiccata chartæ nequaquàm adhæret.

Dolendum est quòd Fuci singularis ejusdemque perpulchri exemplaria omnia quotquot hactenus in Europam reportata scimus insignitèr sint manca; ut non modo radice fructuque, sicut plurimi alii, verùm etiam toto ferè caule careant, unde fit ut de habitu de magnitudine aut de crescendi modo nihil sit certi proferendum. Hanc ob causam voluissem potiùs ad hujus operis distulisse finem quàm in medio delineatum exhabuisse, nisi formâ aded̀ a reliquis abluderet, ut timendum non sit ne cum ullo alio commisceretur. Discrepat in hoc ab affinibus, quorum omnium folia sunt, quod aiunt, unita, quòd ipse distinctis instructus videatur: anne autem se res verè habeat dubito ; superiora enim non modo sunt pinnatifida, sed sensìm angustantur, ut pedetentim et gradatim immutentur in ramos paniculatos qui frondis apicem coronant, stirpique dant faciem non malè illam Osmundarum quarundam referentem. Nomen optimum ab hâc similitudine depromptum indidit Menziesius, cui exemplar hìc delineatum debeo, et qui solus, quod scio, inter botanicos Europeos detexit. Vesiculæ primo aspectu omnind sui generis videntur, et Sophora microphylla siliquis non sunt absimiles; sin attentiùs inspiciantur, structurâ externâ internâque iis $F$. siliquosi congruunt, neque est dubitandum quin quamprimùm patefacta fuerit fructificatio ejus illius stirpis similis reperietur.

2. F. osmundaceus, magn. nat.

b. vesicula longitudinalitèr dissecta.

$c_{9}$ ejusdem pars, magn. auct. - $\quad-\quad 6$. 
Fucus osmundaceus, stem triangular, branched: branches flat, simple, and leafy below; above, divided in a pinnated manner, leafless, and bearing vesicles : leaves distichous, linear, simple, and pinnatifid: vesicles lanceolate, moniliform, terminal.

At Port Trinidad, on the North-west coast of America. Mr. Menzies.

\section{Perennial?}

RooT, at present unknown.

FROND, a foot and half, or more, long, perhaps, even much longer, rising with a three-cornered stem, as thick as a goose quill, (of what length, and whether divided or not, I am quite ignorant) naked, except at its apex, where it is beset with a few branches; branches clustered, a foot or a foot and half long, nearly of equal height, at their base flat, and two or three lines wide, thence very gradually narrowing, so that their extremities are between cylindrical and compressed, and are smaller than a blackbird's quill, they are every where slightly flexuose, for more than half their length they are undivided and leafy, but in the upper part are branched in a panicled manner, and produce vesicles; leaves distichous, between horizontal and patent, alternate, separated by intervals of about half an inch, flat, linear, two or three lines wide, the upper ones two inches long, and pinnatifid with short segments, the intermediate ones shorter and irregularly sinuated, the lowest scarcely half an inch in length, and simple, all of them rounded at their apices, entire at their margins, and furnished with a narrow, blackish, thick midrib, which is also visible in the lower part of the branches; vesicles situated at the extremities and sides of the upper branches, solitary, either sessile, or supported upon very short petioli, between elliptical and lanceolate, nearly half an inch long, and as thick as a large crow's quill, mouiliform, consisting of from three to five spherical joints, externally smooth, internally having a few, white, simple, parallel fibres passing longitudinally through them, tipped at their apices with a short setaceous mucro, which is occasionally, though very rarely, expanded into a small oblong leaf, and sometimes into another vesicle, separated by a short interval from the former.

Fructification, at present unknown.

Co Lor, when moist, an olive-green; when dry, quite black and opaque.

Substance, ligneous in the stem, coriaceous in the branches, in the leaves cartilaginous, thin and flexible, but tough.

OBs. In drying it does not in the least adhere to paper.

It is much to be regretted, that the only specimens yet known to have been received in Europe of this singular and beautiful Fucus, are all in a most imperfect state, wanting, not only the root and fructification, but also nearly the whole of the stem, so that it is impossible to say any thing with certainty, either as to its size or the mode of its growth. I should, on this account, have wished to have delayed the publication of it to the close of this work, but that it is in other respects so distinct and interesting a Fucus, that, though we know but little relative to it, and though it belongs to a tribe more intricate than any other, yet there is no room for apprehension of its being in future mistaken. Its leaves, unlike those of its congeners, have the appearance of being really and essentiaily distinct from the rest of the frond, so as never to grow into new branches, but $\mathbf{I}$ am fearful that this distinctness exists in appearance alone, for the upper ones not only become pimmatifid, but also gradually more and more narrow, till by insensible degrees they lose themselves in the paniculated shoots which crown the extremity of the frond, and give it that resemblance to some species of Osmunda, whence Mr. Menzies, who has alone found it, and to whom I am indebted for my specimens, derived the name. The bladders of this Fucus seem at first sight altogether sui generis, and considerably like the pods of Sophora microplyylla: in structure, however, both without and within, they approach nearly to those of $F$. siliquosus, nor can it be doubted, but that, when the fructification is discovered, it will also be found to be similar to the receptacles of that species.

a. F. osmundaceus, natural size.

b. vesicle, cut open longitudinally.

c. part of the same, magnified - - 6 . 


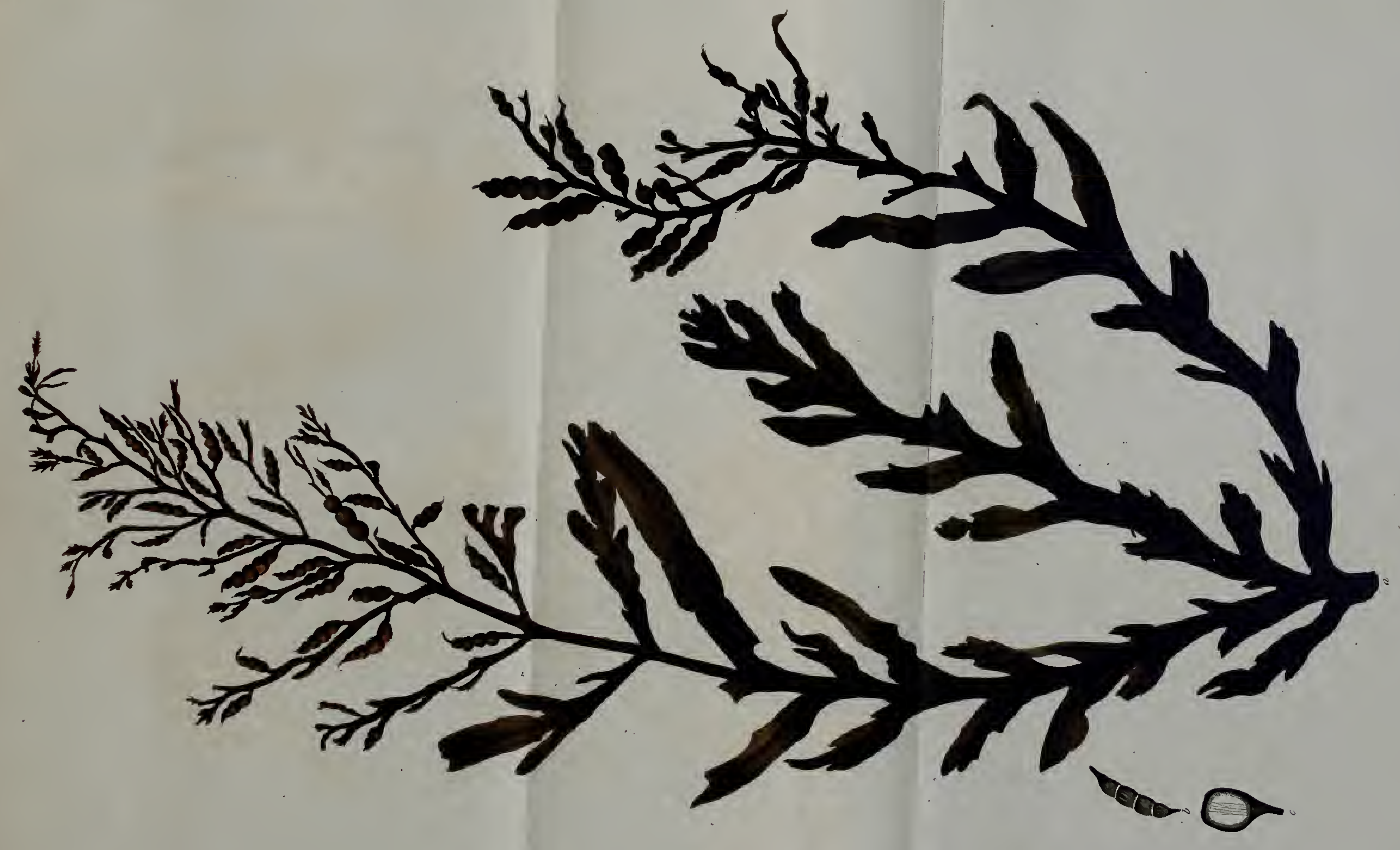



Fucus, fronde terete, filiformi, tubulosâ, ubique articulato-contractâ, ramosâ ; ramis fastigiatis, dichotomis verticillatisque: articulis sub-cylindricis: tuberculis urceolatis, sessilibus, seminibusque in ramulis sparsis.

Fucus articulatus. Fl. Scot. II. p.959. Ner. Brit. p. 28. t. 8. Wiтн. IV. p. 90. Syn. Fuc. II. p. 383. Linn. Trans. III. p. 217. Eng. Bot. XXII. t. 1574.

F. sericeus. var. EsPER, Ic. Fuc. I. p. 158. t. 82.

Ulva articulata. Fl. Ang. p. 569. Fl. Fr. Ed. $2 d a$. II. p. 7.

Ceramium tubulosum. Rотн, Cat. Bot. III. p. 125.

Corallina lenta purpurea compressa. RaII Syn. p. 34. n. 9.

Fucus purpureus humilis tenuiter divisus geniculatus. Moris. Hist. Ox. III. p. 646. s. 15. t. 8. f. 14.

Hавıтат in Britanniarum oris, præsertìm Australibus, haud ita infrequens, rupibus tignisque submarinis Fucisquc grandioribus innascens.-Galliæ in oris Oceano objectis. Decandolle.-Apud Gades. D. S. de Roxas Clemente.-e mari Mediterraneo accepi.

Annua. Æstate.

RADIX latè repens, e fibris constans plurimis, articulatis, densè cæespitosis, sese hìc illic in callos exiguos discoideos dilatantibus, et in novas frondes assurgentibus.

Fro N DES unà plurimæ, teretes, filiformes, tubulosæ, longitudine nunc tri- quadri- pollicares, nunc pedales, merulæ corvive pennæ crassitie, per totam longitudinem intervallis certis, sed in diversis individuis diversis, articulato-contractæ (nequaquàm tamen re ipsâ articulatæ) ut moniliformes evadant, et oculo inermi totæ constare videantur ex articulis subcylindraceis vel ellipticis, his tres quatuorve lineas illis vix duas longis, summis plerumque, sed non semper, brevissimis; frondes ab ipsâ basi sunt ramosissimæ, ramis omnibus fastigiatis, primariis ut plurimùm bis ter vagè dichotomis, furcis patentibus; hi cuncti singulas ad contractiones alios minores emittunt, nunc alternos, nunc oppositos, nunc, quod quidem sæpiùs accidit, præsertìm frondis apices versus, verticillatos, et hi quoque alios minores, illique iterùm minores, omnes eâdem ratione dispositos, ferınt, ultimos perbreves, et non rard propemodùm sphæricos.

Fructificatio duplex in diversis individuis, utraque in ramis ultimis sita; hac e capsulis constans exiguis, * urceolatis, sessilibus, seminum minutissimorum informitèr oblongorum congeriem includentibus; illa e seminibus nudis, sparsis, informitèr ablongis, in ipsâ frondis substantiâ imınersis.

Cosor a pallidè purpareo ad roseum aut læè̀ rubrum variabilis, semper amœenus et diaphanus; exsiccatce intensior; luci diu objecta aut marcescentis in sordidè lutescentem, aut aliquandò in aquosè viridem, et demùm in albicantem evanidus.

SubSTANTIA membranacea, in recente ad gelatinosam accedens, valdè delicata et tenera.

OBs. Frons intùs muco aquoso pellucido referta:-interdùm, sed rariùs, accidit reperiri exemplaria, in quibus, præter ramos e contractionibus ortos, alii minores ex articulis quoque proveniunt, unde toti stirpi facies præter solitum dunıosa:-reperiuntur etiam ubique dichotoma, ramis verticillatis nullis, atque alia insignitèr densè verticillata:exsiccata planta fit membrana tenuissima, et chartæ arctè adhæret.

Fuco elegantissimo in hâc tabulâ depicto sors obtigit, ut, quamvis multis fuerit in locis extra Britanniarum terminos repertus, nullis tamen ferè botanicis, nisi nostratibus, bene innotuerit. Non modd Linnæus Gmeliniusque silentio præterierunt, verùm etiam in novissimâ Systematis Nature editione immemoratus relinquitur; neque inter exteros ullus unquam descripsit priusquàm Rothius tertium Catalectorum Botanicorım tomum et Decandollius Lamarckii Flora Gallicam denuò publici juris fecit. Iconem quidem ejus dedit Esperus, sed, mirè hallucinatus, pro $F$. sui sericei (qui noster $F$. corneus) varietate habuit, adjecto, quod vix minùs est nirum, se credere eandem esse stirpem quam pro $F$. alato juniore depinxit Gmelinus. Hudsonus, qui primus omnium nostræ ætatis botanicorum $F$. articulatum illustravit, Ulvis adjunxit, speciminibus forsàn nullis visis nisi quæ seminibus sparsis sunt instructa. Talia quoque tantummodò reperisse videtur Lightfootius, qui tamen nihilominùs, ob semina in ramulis modò posita, Fucis associandum censuit. Idem auctor etiam animadvertit laanc plantam esse in naturæ catenâ annulum, Fucos Ulvas et Confervas annectentem; quod si dicat credens structurầ verè articılatâ gaudere certè errat, ut cuivis oculo inermi intentiùs observanti statìm patebit. Colore, mole, articulorumque figurâ hic Fucus magnoperè ludit, neque tamen unquam, quantum ego vidi, ita insignitèr aut ita stabilitèr mutatur ut in plures varietates dispescendum crederem. Exemplaria mea ex Hispaniâ accepta altitudine pollicem non superant; Scotica, teste Lightfootio, rarò ad trium longitudinem perveniunt: Anglicis statura plerunque ferè eadem, aut paullùm major; illud in hâc tabulâ depictum, quod Dnæ Hutchins benevolentiæ acceptum refero, mole omnia a me unquàm visa, præeter unum e mari Mediterraneo ad D. Wigg missun, præstat. Arctissimum liabet $F$. articulatus cum specie insequente affinitatem, sub quâ characteres, qui utramque distinguunt, memorati reperientur. Plurimùm etiam accedit quibusdam $\boldsymbol{F}$. kaliformis varietatibus; a quo tamen, præter discrimina jam in illius plantæe historiâ exposita, dignoscitur etiam, sicut in literis nupèr optimè meminit Dna Griffiths, radice repente, et frondis peripheriâ, in hoc semper sub-pyramidatâ, in illo dumosâa

fructicem

\footnotetext{
* Anne semper urceolatis, an potiùs, uti in F. ciuvelloso accidit, primò splaæricis, mox ore elongato aperto ad semina emittenda apto
urceolatis?
} 
fructicem densum ramis fastigiatis referente. Stirps quæ Gmelino $F$. articulatus audit est ab hâc nostrâ quà̀k maximè diversa, et, ut videtur, $F$. natanti affinis.

a. F. articulatus, magn. nat.

b. pars frondis apices versus, seminibus sparsis,

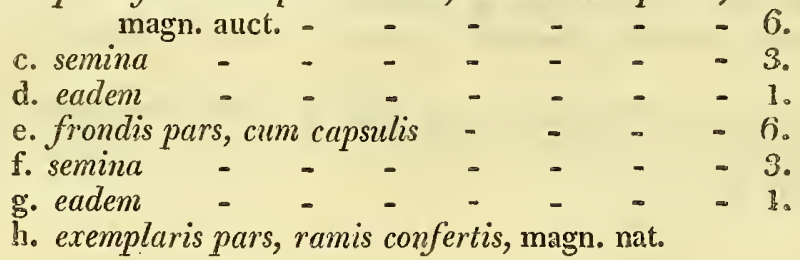

\section{6.-F U G U A R T I U L A T US.}

Fucus articulatus, frond cylindrical, filiform, tubular, contracted throughout, as if jointed, branched: branches of equal height, dichotomous and whirled: joints sub-cylindrical: urceolate, sessile tubercles, and scattered seeds on the ramuli.

Fucus articulatus. Fl. Scot. II. p. 959. Ner. Brit. p. 28. t. 8. Wiтn. IV. p. 90. Syn. Fuc. II. p. 383. Linn. Trans. III. p. 217 . Eng. Bot. XXII. t. 1574.

F. sericeus. var. EsPER, Ic. Fuc. I. p. 158. t. 82.

Ulva articulata. Fl. Ang. p.569. Fl. Fr. Ed. 2 da. II. p. 7.

Ceramium tubulosum. Rотн, Cat. Bot. III. p. 125.

Corallina lenta purpurea compressa. RAII Syn. p. 34. n. 9.

Fucus purpurens humilis temuiter divisus geniculatus. Moris. Hist. Ox. III. p. 646. s. 15. t. 8. f. 14.

On the shores of the Britisl Isles, particularly of the southern counties, not uncommon, growing on rocks, piles, and the larger Fuci.-Coast of France washed by the ocean. Decandolle.-At Cadiz. Don Simon de Roxas Clemente.-I have received it from the Mediterranean.

Annual. In the summer months.

Rоoт, creeping, consisting of many, jointed, thickly entangled fibres, here and there expanding into small callous disks, and rising into new fronds.

Fro Ds numerous, cylindrical, filiform, tubular, from three or four inches to a foot long, as thick as a blackbird's or crow's quill, contracted, as if jointed, but by no means really so, throughout their whole length, at regular intervals, though different in different individuals, (so that they are quite moniliform, and look to the naked eye as if composed of a series of sub-cylindrical or elliptical joints, two, three, or four lines long, the upper ones generally, but not always, shortest; the fronds are much and irregularly branched from the very base, the branches all of equal height, the primary ones mostly twice or thrice irregularly dichotomous, with patent segments; from the contractions of these arise others smaller, some of them alternate, others opposite, and again others, as is most common, especially towards the apices of the frond, verticillated; these too in their turn give rise to a third series, and those not unfrequently to a fourth, each smaller than the preceding one, all disposed in the same manner, the ultimate ones very short, and sometimes almost spherical.

FRUCTIFICATION, two-fold, situated upon different individuals, each on the extreme branches; the one consisting of small, * urceolate, sessile capsules, containing a mass of very minute, irregularly oblong seeds ; the other of naked, scattered, irregularly oblong seeds, immersed in the substance of the frond.

COLOR

\footnotetext{
* Perhaps these are not always urccolate, but, like those of $F$. clavellosus, at first globular, and afterwards becoming urceolate from length-
} ening at the orifice, the more easily to discharge the seeds. 
Cosor, varying from pale purple to pink or bright red, always transparent; darker in a dry state; aud, from decay, or exposure to the light, turning to a faint, dirty yellow, or a light-green, and at last to whitish.

SUBSTANCE, membranaceous, approaching to gelatinous when fresh, very delicate and tender.

Овs. The interior of the frond is filled with a watery transparent mucus:-specimens are occasionally, though not often, found, in which, besides the branches that originate from the contractions, others, still smaller, spring out of the sides of the joints, which gives the plant an unusually bushy appearance :- some individuals are regularly dichotomous, without any verticillate branches, in others the whirled shoots are remarkably numerous :-in drying the plant becomes a very thin membrane, and adheres closely to paper.

It has been the fate of this elegant Fucus to be but little known or understood beyond the limits of the British Isles, to which, however, it is far from being confined. Not only have Linnæus and Gmelin left it altogether unnoticed, but it is omitted in the last edition of the Systema Naturce, and, previously to the publication of the third volume of Dr. Roth's Catalecta Botanica, and of the second edition of the Flore Française, it seems to have escaped the observation of every foreign author whatever upon the subject, excepting only Professor Esper, who, by a most extraordinary error, has figured it as a variety of his F. sericeus, (our F. corneus) observing, at the same time in his description, that he considers it the same as the plant represented by Gmelin as $F$. alatus in an early stage of grovvth. Mr. Hudson, by whom it was first described, has arranged it among the Ulva, having probably seen only specimens with scattered seeds, but Mr. Lightfoot, who seems not to have been in this respect more fortunate, removed it to the Fuci, on account of these seeds being confined to the ramuli alone, at the same time remarking, that the plant serves to shew how nearly related are the three genera of Fucus, Ulva, and Conferva. In this observation, however, he is in error, as far as believing that it has really a jointed structure, for such is by no means the case, as may most easily be seen by the naked eye. In point of color, size, and the shape of the joints, this Fucus is liable to great variations, but none of these have ever appeared to me sufficiently remarkable or permanent to warrant the dividing of the plant into different varieties. The specimens sent me from Spain are not more than an inch in height; those of Scotland are described by Lightfoot as seldom attaining to three inches; the same is also, in general, the size of the British ones : that figured in the present plate, for which I am indebted to Miss Hutchins, is among the largest I ever saw, excepting some received by Mr. Wigg from the Mediterranean. The nearest affinity of $F$. articulatus is with the following species, under which are noticed the characters that distinguish them. It also bears considerable resemblance to some appearances of $F$. lialiformis, as has already been mentioned in the account of that plant; but, in addition to the differences there pointed out, Mrs. Griffiths has observed to me, that the roots of the two are dissimilar, and that they are with no less certainty distinguishable by their form, which in $F$. kaliformis is always nearly pyramidal, while $\boldsymbol{F}$. articulatus resembles a thick bushy shrub, with branches of equal height. Gmelin's $F$. articulatus is a widely different plant from that here figured, and apparently belongs to the family of $F$. natans.

a. F. articulatus, uatural size.

b. upper part of the frond, with scattered seeds,

magnified - - - - - - 6.

c. seeds - $\quad-\quad-\quad-\quad-\quad-\quad-3$.

d. the same - - - - - $\quad$ - $\quad$ - 1 .

e. upper part of the frond, with capsules - $\quad 6$.

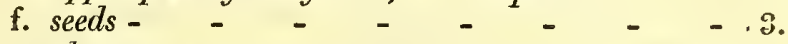

g. the same - - - - - - - - 1 .

h. part of a specimen, with crowded branches, natural size. 
Fucus Opuntia, frond sub-cylindrical, filiform, solid, here and there contracted as if jointed, branched, with a network of fibres internally: branches horizontal, acuminated: joints lanceolate, obsolete : tubercles globular, very minute, scattered.

Fucus Opuntia. Linn. Trans. III. p. 219. Ner. Brit. p. 104. t. 16. Syn. Fuc. II. p. 387.

F. repens. Fl. Scot. II. p. 961. WiтH. IV. p. 91.

F. caspitosus. Ner. Brit. p. 59. t. 12. Fl. Fr. Ed. 2 da. 1I. p. 22.

Rivularia Opuntia. Eng. Bot. XXVI. t. 1868.

Uli:a articulata. $\beta$. Fl. Ang. p. 569.

Tremella marina caspitosa, segmentis tenuibus. DILL. Hist. Musc. p. 50. t. 10. f. 9. A. B. C. D.

On the shores of the British Isles, growing on rocks, piles, and the larger Fuci-C-Cornwall and Devonshire. Mrs. Griffiths.-At Tenby, in South Wales, Stackhouse.-Near Musselburgh, in Scotland. Lightfoot.-Bay of Dublin. Dr. Scott.-Bantry Bay. Miss Hutchins.-Northern coast of France. Decandolle.

\section{Annual?}

Rоот, creeping, fibrous.

Fronds numerous, clustered, thickly matted together, and forming tufts some inclies in diameter, covering the rocks like lichens, furnished with a prostrate or ascending stem, between cylindrical and compressed, from half an inch to an inch long, sometimes not so thick as a sparrow's quill, and of equal size througheut, and sometimes irregularly contracted, so as to have an obsoletely jointed appearance, always much and irregularly branched; branches of the same nature as the stem, erect, about half an inch long, some simple, others forked, and others irregularly beset with smaller ones, similar to themselves, either horizontal or patent; some too are, like the stem, thin and filiform, others twice or thrice as thick, and contracted at uncertain intervals, so as to appear composed of two or three linearilanceolate joints of very different size and thickness, each being, in general, thicker than the one below it, and the upper ones constantly acuminated ; from different parts of the branches, not unfrequently issue short, fibrous, branching radicles, by means of which the several parts of the frond adhere so closely together as not to be separable without injury :- on placing an horizontal section of the frond under a microscope, the interior part is found to consist of a pellucid watery mucus, containing a net-work of white jointed fibres, which, however, appear never to penetrate through the epidermis, so as to reach the surface of the frond, but always to be inclosed under it.

* Fructification, blackish-purple, globular, sessile tubercles, scattered every where about the upper branches, so small as scarcely to be distinguishable to the naked eye:- whether, however, these are capsules, or solitary seeds, or only extraneous bodies accidentally attached to the frond, I have found it impossible, on account of their minuteness, to determine.

CoLOR, dark-purplish, semitransparent, destitute of gloss, turning, from exposure to the sun, or from being kep\& long in fresh water, to a dirty white.

SUBSTANCE, sub-cartilaginous, juicy, soft, tender, brittle,

OBs.- ${ }^{-}$ii drying it scarcely adheres at all to paper,

If, as has been mentioned under $F$. articulatus, it has been the fate of that Fucus to be but little known beyond the limits of the British Isles, it has certainly no less been the lot of the one here figured to be very generally misunderstood, even among the botanists of our own country, and to have been passed over by the greater number of them, either as a variety of the preceding plant, or as the same in an early or imperfect stage of growth. I have, however, received them both from so many different correspondents, without perceiving the least tendency in the one to run into the other, that $I$ cannot suffer myself to entertain a question as to their being perfectly distinct; nor can I doubt but that every naturalist will agree with me upon the subject, who examines the figures and descriptions here given. They differ,-indeed, in almost every respect, but the principal characters appear to be founded upon the tubular structure, delicate substance, bright red color, regular joints, and acute angles of the one, contrasted with the dull purple hue, solid, obsoletely-articulated stem, cartilaginous texture, acuminated apices, and horizontal shoots of the other; in addition to which, their internal formation is altogether dissimilar, $F$. articulatus wholly wanting, as far as I have seen, the curiously reticulated fibres of $F$. Opuntia, on account of which, Dr. Smith has removed it to the genus Rivularia. This extraordinary formation was $\uparrow$ first pointed out to me by my singularly acute friend, Mr. Borrer, and lias since been well figured and illustrated in English Botany. I cannot, however, agree with the excellent author of that work, in the supposition, that the seeds are to be sought for in these fibres, or that the plant ought, on account of them, to be classed with the Rivularia; not only, because it has an epidermis, which is quite contrary to the nature

\footnotetext{
- Upon the subject of the fructification of this Fucus, I nust own that I am in some doubt; for, thongli the tubcrclcs, above described, are most agreeable to analogy, and cannot well be any thing but fruit, yet there is a something in their appearance unlike the capsules of other Fuci, and both Lightfoot, in his Flora Scotica, Goodcnough and Woodward in the Linnain Transactions, and Dr. Smith in English Botany, give different accounts of the fruit. Of thesc, the three former say that the upper joints pcrform the office of capsules, and are full of very minute crowded seeds; the latter, that the extrcnie joints of the internal filaments are short and full of seeds. Perhaps, however, the former of these opinions is not inconsistent with mine, but they have seen the plant ouly with naked seeds, I only with capsules; and certainly any one, judging from its affinities, would look for a two-fold fructification in it.

$\uparrow$ Mr. Borrer's remark, being only conmunicated to me in a letter, was unknown to Mr. Sowerby and Dr. Smith at the time of the publicito tion of this plant in English Bolany.
} 


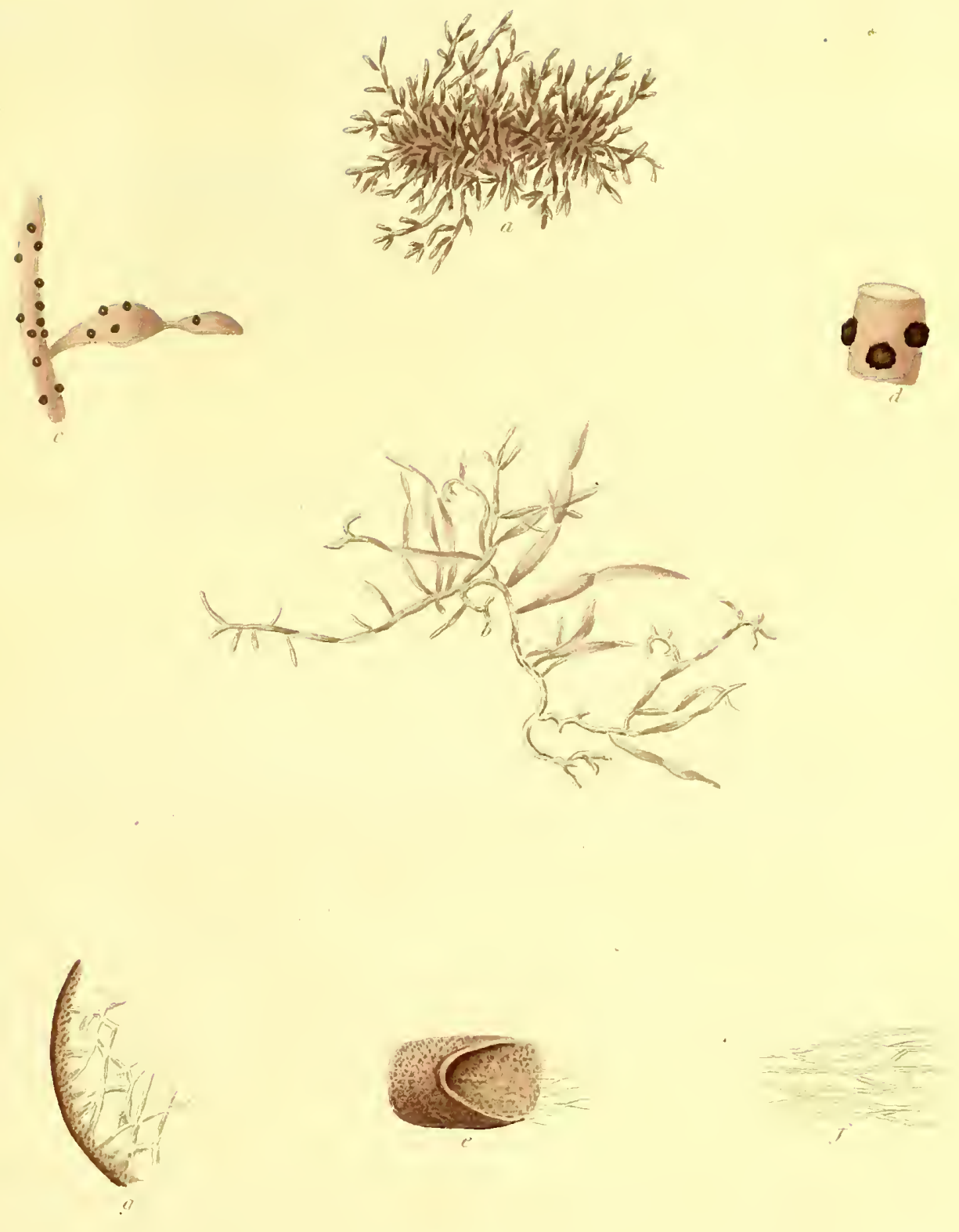

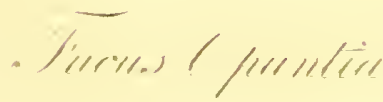



of that family, and would prevent the discharge of the seeds, except upon the decay of the frond, but because it also wants the gelatinous substance and the fine pellucid hairs for which the Rivularia are remarkable. The Ulva rugosa of Linnæus, a plant of a stronger texture than almost any other of the genus it is arranged with, has also internal filaments, but whether placed with the same regularity as those of $F$. Opuntia, I have no means of judging, having never seen it recent. The same is also the case with Ulva furcellata. Lightfoot's description of his F. repens is so characteristic as to leave no doubt of his plant being the same as ours; and his name has consequently a claim to be preferred on the score of priority, though it has appeared best to follow the greater number of writers, in adopting the one here used. The synonym of Dillenius is by no means equally to be depended upon, and, though in his Herbarium are preserved specimens of $F$. Opuntia, yet his figure seems to have been taken from a small variety of $F$. articulatus. Such is also probably the case with the Nereis Britannica. Upon the differences between the Fucus here figured, and the subject of the following plate, remarks will be found under that species.

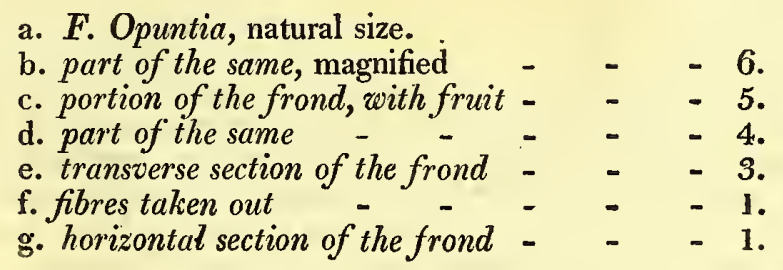

\section{7.-F U G U S O P U T I A.}

Fucus, fronde teretiusculâ, fliformi, solidâ, hìc illìc articulato-contractâ, ramosâ, fibris retiformibus intùs : ramis horizontalibus, acuminatis : articulis lanceolatis, obsoletis : tuberculis globosis, minutissimis, sessilibus, sparsis.

Fucus Opuntia. Linn. Trans. III. p. 219. Ner. Brit. p. 104. t. 16. Syn. Fuc. II. p. 387.

F. repens. Fl. Scot. II. p. 961 . WITH. IV. p. 91.

F. caspitosus. Ner. Brit. p. 59. t. 12. Fl. Fr. Ed. $2 d a$. II. p. 22.

Rivularia Opuntia. Eng. Bot. XXVI. t. 1868.

Ulva articulata. B. Fl. Ang. p. 569 .

Tremella marina caspitosa, segmentis tenuibus. DILL. Hist. Musc. p. 50. t. 10. f. 9. A. B. C. D.

HA BIтA'т Britanniarum ad oras, tignis saxisque submarinis Fucisque majoribus innascens.-In Cornubiâ et Devoniâ. Dna Griffiths.-Apud Tenby in Walliâ Australi. D. Stackhouse.-Prope Musselburgh in Scotiâ. Lightfoot. In Sinu Eblanensi. D. Scott.-In sinu, "Bantry Bay." Dnu Hutchins.-In Galliæ Septentrionalis oris. Decandolle.

Annua?

RADIX repens, fibrosa.

FRO NDES plurimæ, cæspitosæ, densè implicitæ, et in pulvinulos informes aliquot pollicum diametro congestæ, rupes, lichenum instar, velamine denso obducentes, instructæ caule prostrato, vel ascendente, e tereti compresso, unguiculari, vel pollicari, nunc pennâ passerinâ ubique tenuiore et æequali, nunc hìc illìc constricto, ut faciem obsoletè articulatam præ se ferant, semper ramosissimo; rami homogenei, erecti, sub-unguiculares, hi simplices, illi bifurci, alii minoribus sui similibus qui vel horizontales sunt vel patentes vagè obsiti, quidam etiam, caulis instar, tenues et filiformes, alii duplo triplove crassiores et ad intervalla incerta constricti, ut ex articulis duobus aut tribus lineari-lanceolatis longitudinis crassitieique quàm diversissimæ constare videantur, utroque ut plurimum subjacente crassiore, extremis nunquam non acuminatis; rami non rarò hìc illìc radices breves fibrosas ramosas extrudunt, per quas variae frondis partes ita tenacitèr sibi invicem adhærent ut non sint integritate salvâ extricandæ:--si frondis horizontalitèr dissectæ portio lenti subjiciatur, pars interior mucosa fibris pellucidis variè retis in formam anastomosantibus intertexta reperietur, quæ tamen nunquam ipsam frondis superficiem attingere aut epidermidem penetrare videntur, sed semper sub illâ clausæ latent.

Vou. II. 
* Fructificatio tubercula atro-purpurea, globosa, sessilia, per ramos superiores ubique sparsa, aded exigua ut vix sint oculo detegenda inermi :- anne autem hæc sint capsulæ, an semina solitaria, an tantummodd corpuscula plantæ fortuitd innascentia parvitas investigare vetuit.

CoLOR obscurè purpurascens, absque nitore, subdiaphanus; soli diu objecta aut in aquâ dulci servata sordidè albescens.

SUBSTANTra sub-cartilaginea, succosa, mollis, tenera, fragilis.

Oвs. Exsiccatione chartæ laxiusculè adhæret.

$\mathrm{Si}$, sicut sub $F$. articulato memoratur, paullùm ille Fucus extra Britannias innotuerit, nequaquàm ninùs est de specie hìc depictâ inter Botanicos erratum, adeò ut etiam nostratium plurimi vel pro præecedentis varietate vel pro eâdem mancâ nimis aut juniore præterierint. Utrâque tamen a multis iisque dissitis locis acceptâ, nihiloque animadverso quod unam in alteram transituram arguat, ampliùs haud dubitavi pro distinctis recipere; persuasumque mihi habeo tali omnes botanicos sententiæ esse assensuros, qui iconas et descriptiones lì̀c traditas perlustrant. In plurimis quidem dissentiunt, sed præsertìm $F$. articulati structurâ tubulosâ, substantiâ tenerrimâ, colore lætè rubro, ramis patentibus, articulisque figurâ certâ donatis, quæ omnia habet $F$. Opuntia diversa; utpote cui color sordidè purpurascens, textura cartilaginea, caulis obsoletè articulatus, ramique horizontales apicibus acuminatis. Præter hoc structura utriusque interna est dissimillima; semper enim F. articulatus, quantun ego vidi, fibris illis retiformibus caret propter quas F. Opuntiam Rivulariis associavit Smithius. Structuram hanc singularem primus mihi patefecit vir, si quis alius, acutus, D. Borrer, mox bene est in English Botany illustrata. Nequeo tamen in amicissimi hujus operis auctoris sententiam ed usque jurare, ut semina in his quærenda aut stirpem ob hanc causam Rivulariis adjungendam existimarem; cùm quia repugnat epidermis illius generis naturæ contraria, tùm quia Rivulariarum substantiâ gelatinosâ pilisque pellucidis penitùs caret. Ulva Linnæi rugosa, planta substantiâ præ reliquis ferè omnibus Ulvis firmâ prædita, filamenta quoque articulata in se includit; nescio tamen an simili ratione disposita, cùm recentem nondùm viderim. Idem etiam in Ulvâ furcellatâ valet. $F$. suum repentem tam bene, pro more, descripsit Lightfootius, ut omnis tollatur dubitatio an sit idem qui Fucus hic noster, nomenque ab illo datum antiquitatis jure præponendum censerem, nisi omnes ferè botanici Opuntiam appellarent : longè abest ut Dillenii synonymon paritèr sit certum, et quamvis ille in herbario suo $F$. Opuntice exemplaria servavit, videtur tamen iconem ad $F$. articulatum juniorem parvulumve confecisse. Ita quoque verisimilitèr de Nereide Britannicâ accidit. Characteres qui Fucum hìc depictum ab insequente distinguunt sub $E$. pusillo exponuntur.

a. F. Opuntia, magn. nat.

b. ejusdem pars, magn. auct. - $\quad-\quad-\quad-6$.

c. frondis pars, cum fructu - - $\quad-\quad-5$.

d. ejusdem pars - $\quad-\quad-\quad-\quad-4$.

e. frons transversim dissecta - $\quad-\quad-\quad-3$.

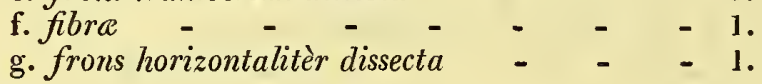

\footnotetext{
* De hujus Fuci fructificatione in dubio quodammodò esse animum fateor. Quantumvis enim tubercula suprà descripta analogiæ maximè respondeant, et vix fieri possit ut sint aliquid nisi fructus, inest tamen in is aliquid quod a Fucorum capsulis abludit; et diversc̀ de fructu statuunt in Florâ Scoticâ Lightfootius, in Societalis Linnceance Actis Goodenovius Woodwardiusque, et in opere suo, English Botany, Smitlius, quorum tres priores, "Articuli ovales, quorum supremi tuberculorum officio funguntur, et seminibus minutissimis congestis fæeti sunt," hic antem refert, "filamentorum internorum articuli ultimi abbreviati, seminibus repleti." Forsan verò illorum sententia non omni ex parte nostræ repugnat, sed illi plantam seminibus modò sparsis, nos modò capsuliferam vidimus, et certè ex affinibus judicanti duplex esset fructificatio in $F$. Opuntia quærenda.
} 
Fucus, fronde cartilagineo-corneâ, planâ, filiformi, hìc illìc articulato-contractâ, ramosissimâ : ramulis horizontalibus, basi attenuatis, apice dilatatis et rotundatis : tuberculis globosis, sessilibus, minutissimis, seminibusque in ramulis sparsis.

Fucus pusillus. Ner. Brit.p. 16. t. 6.

Ulva filiformis. Fl. Dan. t. 949 ?

Ha istat in rupibus arenaceis juxta Sidmouth in Devoniâ. D. Stackhouse.-Apud Brighton, et alibi in Sussexiâ . D. Borrer.

Perennis.

RADIX fibrosa, repens.

FRONDES, plurimæ, cæspitosæ, densè implicitæ, et in pulvinulos formæ magnitudinisque incertissimæ congestæ, rupes, Lichenum more, velamine denso obducentes, instructæ caule plano enervi, prostrato, vel ascendente, unguiculari, pollicari, et ultrà, simplice divisoque, nunc per totan longitudinem filiformi, et setâ porcinâ vix crassiore, nunc sursùm multoties incrassato, et hìc illic constricto, ut obsoletè articulatus appareat, articulis lanceolatis : rami homogenei, flexuosè erecti, unguiculares, caulis instar, vel tenues et filiformes, vel dilatati et articulatim constricti, hi simplices, illi vagè divisi, plerumque sparsìm obsiti ramulis distichis, horizontalibus, brevibus, simplicibus, basi attenuatis, apice dilatatis et rotundatis, aliquandò tamen, sed perrarò, utrinque attenuatis.

Fructificatio, uti videtur, duplex, hac e tuberculis constans atro-purpureis, globosis, sessilibus, undequaque per ramos sparsis, adeò exiguis ut visum inermem propemodùm effugiant, et ut, propter parvitatem, impossibile sit dictu au sint capsulæ an semina, an corpuscula modò extera fortuitò adhærentia; illa e seminibus minutissimis, sanguineis, subrotundis, in ipsâ frondis substantiâ apices versus immersis.

CoLOR pulcherrimè inter roseum et purpureum, exsiccata madefactaque idem, diaphanus.

Su B STANTIA cartilagineo-cormea, tenax.

Oвs. Ob crescendi modum implexum rarò illæsa est extricanda :-Superficies nitida et insignitèr lævis : exsiccata chartæ lax̀̀ admodùm adhæret.

Primus $\boldsymbol{F}$. pusillum detexít et in Nereide Britannicâ pro novâ specie proposuit cl. Stackhousius, quem tamen nemo hactenus inter botanicos, quod scio, est secutus, neque ulla alia ejus icon descriptiove extat; nisi quidem tabula in Florâ Danicâ suprà citata eandem revera plantam exhibeat, de quo neutiquam dubitavissem, nisi obstaret scrupulosque aliquos injiceret character specificus " totum viridem" prædicans. Colore, ramorum dispositione, habituque, quod aiunt, generali, arctissima inter hanc stirpem et $F$. Opuntian affinitas interest, ut quisquis exsiccatas modó viderit facilè unam pro alterâ præteriret. Attentiùs autem lustranti discrepant substantiâ inter se dissimillimâ, et quòd $F$. pusilli frons ubique plana structurâ illâ internâ reticulatâ jamjam sub $F$. Opuntiâ memoratâ necessariè careat. Credebam, dum Fucorum Britannicorum Synopsin scriberem, $\boldsymbol{F}$. pusillum esse tantummodò $\boldsymbol{F}$. corneum, vel in rtate juniore, vel casu aliquo pumilionem redditum, in quâ forsàn perstitissem sententiâ, nisi fructiferum detexisset Borrerus, cui exemplaria hìc delineata debeo. Idem etiam plantam per omnes ætatis suæ gradus cautè observavit, neque unquam in $F$. corneum accrescere vidit; quamobrem pro specie distinctâ agnoscere ampliùs haud dubitavi. Tradit Stackhousius hunc Fucum rupibus nativis innascentem $F$. pygmaum summoperè referre, aded ut botanicis sit cavendum ne pro illo posthabitus intactusque negligatur; quod quidem vix essem suspicatus, toto enim cælo discrepant stirpes juxta positæ et inter se collatæ. Planta ea cui $F$. pusilli nomen Esperus indidit (II. p. 67. t. 142.) est tantummodo $F$. crispi var. $\gamma$. stellata, varietas nullo modo pro distinctâ habenda.
a. F. pusilli caspes, maǵn. nat.
b. ejusdem portio.
c. ejusdem pars, magn. auct. - _ _ - $\quad 6$.
d. frondis apex, seminibus sparsis - $\quad-\quad$ - 3.
e. ramulus - - - - - - - 2.
f. frons cum tuberculis - - - -3.
g. ejusdem pars - - - - -1 . 
Fucus pusillus, frond between cartilaginous and horny, flat, filiform, here and there contracted as if jointed, muclı and irregularly branched: ramuli horizontal, attenuated at their base, dilated and rounded at their apices: very minute globular sessile tubercles, and scattered seeds upon the ramuli.

Fucus pusillus. Ner. Brit. p. 16. t. 6.

Ulva filiformis. Fl. Dan. t. 949 ?

On sand-stone rocks, near Sidmouth. Mr. Stackhouse.-At Brighton, and elsewhere on the Sussex coast. $M r$. Borrer.

\section{Perennial.}

Root, fibrous, creeping.

FroNDS, numerous, clustered, thickly matted together, and collected into tufts of most uncertain size and shape, covering the rocks like Lichens, furnished with a flat, ribless, prostrate, or ascending stem, from half an inch to an inch or more in length, either simple or divided, in some instances filiform throughout its whole length, and not thicker than a hog's bristle, in others thickening as it advances, so that the upper part is many times thicker than the lower, and contracted at intervals, so as to have an obsoletely articulated appearauce, with lanceolate joints; branches about half an inch long, flexuose, erect, of the same nature as the stem, and, like it, either thin and filiform, or dilated upwards, and contracted as if jointed, some simple, others branched, generally beset with smaller ones, which are distichous, horizontal, short, simple, attenuated at their bases, and dilated and rounded at their apices, but sonnetimes, though very rarely, acuminated at both ends.

Fructification, apparently, twofold; the one consisting of blackish purple, spherical, sessile tubercles, scattered all over the branches, so small as to be almost invisible to the naked eye, and to make it almost impossible from their minuteness to determine whether they are single seeds, or capsules, or merely extraneous bodies accidentally adhering to the frond; the other of extremely minute, blood-red, roundish seeds, immersed in the substance of the frond near the apices.

CoLor, a beautiful tint, betiveen purple and pink, transparent, the same dry as moist.

SUBSTANCE, between cartilaginous and horny, tough.

Oвs. From the entangled mode of growth, a single frond can seldom be drawn out whole.-The surface is glossy and renıarkably smooth:- - in drying it adheres very slightly to paper.

This Fucus was originally discovered by Mr. Stackhouse, and has, I believe, been no where hitherto figured or described, except in the Nereis Britannica; unless, indeed, the plant of the Flora Danica, above referred to, be really the same, of which, judging from the plate alone, I should not have the smallest doubt, but the observation in the specific character, that the color is green, renders it in some degree questionable. In point of its size, ramification, and general habit, it agrees in the most striking manner with $\vec{F}$. Opuntia, so that any botanist, who sav them only in a dried state, or did not examine both of them with attention, might easily be led to mistake the one for the other. It differs, however, from it altogether in its substance, and in being completely flat, so as recessarily to be destitute of any tendency to an internally reticulated structure. In the Synopsis of the British Fuci I had regarded it as nothing more than $\boldsymbol{F}$. corneus either in a young or a singularly dwarfish state; and $I$ should probably have continued to hold the same opinion, had not Mr. Borrer, to whom I am indebted for the specimen here figured, detected the fruit, and had an opportunity of watching it in its different stages of existence, during which he has found in it no tendency to grow up into $F$. corneus. It is therefore no longer possible to refuse to regard it as a distinct species. Mr. Stackhouse observes that, when growing, it may easily be mistaken for $F$.pygmaus; a thing I should scarcely have suspected, though, never having myself seen it in that state, I am necessarily uuable to judge upon the subject. The two plants are certainly sufficiently dissimilar when compared together. Professor Esper's F. pusillus, (II. p. 67. t. 142.) is nothing more than $F$. crispus, var. $\gamma$ stellatus.

a. Tuft of F. pusillus, natural size.

b. part of ditto.

c. part of the same, magnified - $\quad-\quad 6$.

d. apex of the frond, with scattered seeds - 3 .

e. part of the same - $\quad$ - $\quad$ - $\quad$ - $\quad$ - 2 .

f. plant with tubercles - - - $\quad-3$.

g. part of the same - - - - $\quad 1$. 


$$
\text { 点斗。 }
$$



Fucus, fronde terete, capillari, bi- tri- pinnatâ: ramis ramulisque horizontalibus, alternis, summis apice involutis : capsulis lanceolatis terminalibus, subrotundisque axillaribus sessilibus.

Fncus amphibius. Fl. Ang. p. 590. Linn. Trans. III. p. 227. Wiтн. IV. p. 116. Ner. Brit. p. 86. t. 14. Syn. Fuc. II. p. 391. Eng. Bot. XX. t. 1428. Fl. Cant. p. 479. Esper, Ic. Fuc. II. p. 84. t. 151.

F. scorpioides. GMeLin, Hist. Fuc. p. 135.

Ceramium scorpioides. Roтн, Cat. Bot. II. p. 173. (excl. syn. F. incurvi Huds.) Cat. Bot. III. p. 158.

Fucoides erectum fructiculi specie, summitatibus infiexis, $\mathrm{R}_{\mathrm{\Lambda I}} \mathrm{I}$ Syn. p. 38. n. 4. t. 2. f. 6.

Ha BIT a T Anglia ad oras, in rupibus, saxis submarinis, et ad radices plantarum in fossis et palustribus maritimis. - In Cambriâ Septentrionali. D. II. Davies.-A pud Shoreham, Atriplici portulacoidi innascens, copiosissimè. D. Borrer.-In fluvio apud Lapurdum, abundantèr. D. S. de Roxas Clemente.

\section{Perennis? Æstate.}

* RA DIX callus minutissimus, ut vix oculo percipiatur.

FroNDES cæspitosæ, teretes, filiformes, setæ porcinæ crassitie, duos tresve pollices longæ, flexuosè erectæ, ab ipso ferè ortu ramosæ; rami sub-distichi, horizontales, aut horizontalitèr patuli, alterni, inferiores pollicem et ultrà longi, et intervallis semiunguicularibus sejuncti, reliqui sensìm breviores, magisque approximati, nunc indivisi, nunc bifurci, omnes pinnati aliis sui similibus, sed minoribus, eâdem ratione dispositis, duas tresve lineas longis, qui quoque vel ramulis brevissimis simplicibus remotiusculis alternis patentibus sunt obsili, vel vagè sunt dichotomi segmentis forcipatis; rami ultimi capillo sunt tenuiores et acuminati; ad summitates frondis rani sunt approximati, apicibus (ut Dillenii verbis utar,) caudæ Scorpii in modum inflexis, quos tamen nunquam $\nmid$ turgidos, aut muco repletos, aut denique $\ddagger$ tuberculatos vidi.

Fructificatio duplex; hac, quam solam ego vidi, terminalis in ramulis, qui tunc intumescentes fiunt capsulæ siliquiformes, lineari-lanceolatæ, seminaque includunt aliquot intensè fusca, sphærica, in duas lineas disposita, limbo tenui sub lente acerrimâ cincta et quasi in tres partes dehiscentia; illa, teste Rothio, e capsulis constans exiguis, et non nisi sub microscopio composito ritè observandis, ad dichotomias plerumque ramorum solitariis, sessilibus, subrotundis, ad lucem subpellucidis.

Color e livido fuscus, diaphanus, exsiccate nigricans, nitoris semper expers.

Su Bst A N I A cartilaginea, tenera, fragilis.

Oвs. Crescendi modus variè implexus:-ob staturam humilem, locumque, quem sibi eligere solet, natalem, in lutosis stirpium majorum ad radices, facilè prætermittitur :- exsiccata chartæ laxe adhæret.

Diu Botanicis innotuit hic parvulus Fucus, quem non modo descripsit verùm etiam icone illustravit in $R a i i ~ S y$ nopsi Dillenius, qui ad stirpen dignoscendam frondis apices involutos jure maximi momenti credidit. Hìnc in primâ Flora Anglice editione F. scorpioidis nomen aptissimum ab his ductum plantæ imposuit Hudsonus, quem in hoc secutus est Gmelinus; ipse tamen postea, cùm denuo id opus ederet, mutationis ratione nullâ redditâ, hoc nomen F. amphibio mutavit, cui quoque titulo nihil est præter mutationem inutilem quod exprobres, in Fuco locos terrestres præ aliis colente. Ramorum forma jam memorata speciei notam certissimam maximèque manifestam certè suppeditat, neque tamen est talis quali unâ ad dignoscendam tutò nitaris; ita enim faciendo in summum errorem incidit Rothius, dum $F$. pinastroidem, nihil ferè aliud cum $F$. amphilio commune habentem, pro ejus synonymo dubiè citavit. Eximius hic naturæ scrutator primus frondis facien obsoletè articulatam perspexit, quam ego etiam nuperrimè in quibusdam, sed neutiquàm in omnibus aut etiam in plurimis, individuis vidi. Obscura sunt genicula, et quæ plantam in articulos, quorum longitudo diametrum vix superat, dividunt, nec formam cylindraceam minimùm lædunt. Stirps præter hæc lineis tenuissimis parallelis nigricantibus sub lente acri notata, et maculis subrotundis fuscis bullata conspicitur, in quibus omnibus mirè consentit cum Confervố polymorph $\hat{a}$, quan habitu quoque et magnitudine multùm refert, et quam, tali deceptus similitudine, sub ejus nomine depinxit Esperus. Ea quidem inter has duas stirpes affinitas interest, ut scrupulus mihi restitisset nullus quin utrique fructificatio esset eadem, etiam si $F$. amphibii capsulæ sphæricæ Rothium latuissent, cujus descriptionem in hoc mutuari non dubitavi; tùm quia viro omni fide dignissimo coecè credendum existimavi, tùm quia, suæ stirpis exemplaribus ab ipso acceptis, cum nostrâ consentire factus sum certior. Gmelini $F$. scorpioides synonymon magis dubium videtur, utpote cui substantiam lignosam ascribit, memoratque Sertulariam pumilam in illo crescere amare.

a. F. amphibius, magn. nat.

b. frons, magn. auct. - $\quad-\quad-\quad-\quad-6$.

c. capsule - - $\quad-\quad-\quad-\quad-3$.

d. semina - - - - - - - .

e. frondis pars, ut textura macnlata appareat 2.

- Hanc in Societatis Linnaana Actis Goodenovius Woodwardiusque atque ego in Fucorum Britannicorum Synopsi fibrosam diximus, sed certè in exemplaribus quæ uunc sub lente obscrvo est, ejus Confervarum instar, callus vix explanatus, qualem etiam descripsit Rothius. Frons per alias quoque partes Atriplici, cui innascitur, agglutinata adhæret, et lujus caulem perrepit.

† Gmelinus contrà tradit, " quo magis maturescunt, eo magis inflantur, maximè turgidi intlectuntur caudæ scorpii in modum, quann tumiditatem afferre videtur mucus, ibi se exoncrans, fructificationis ncgotium pcrficiens."

¥ Ita habent Goodenovius Wood wardiusque, qui " ramulos supremos incurvos, tuberculis mucilaginosis seminiferis involutis" describunt. 
Fucus amphibius, frond cylindrical, capillary, twice or thrice pinnated : branches and ramuli horizontal, alternate, the upper ones involuted at their apices: lanceolate terminal, and roundish axillary sessile capsules.

Fucus amphibius. F\%. Ang. p. 590. Linn. Trans. III. p. 227. W Ітн. IV. p. 116. Ner. Brit. p. 86. t. 14. Syn. Fuc. II. p. 391. Eng. Bot. XX. t. 1428. Fl. Cant. p. 479. EsPER, Ic. Fuc. II. p. 84. t. 151.

F. Scorpioides. GMELIN, Hist. Fuc. p. 135.

Ceramium scorpioides. Rотн, Cat. Bot. II. p. 173. (excl. syn. F. incurvi Huds.) Cat. Bot. III. p. 158.

Fucoides erectum fruticuli specie, summitatibus inflexis. Ra1 I Syn. p. 38. n. 4. t. 2. f. 6.

On the shores of England, adhering to rocks, and to the roots of flowering plants in salt-water ditches and muddy places.-North Wales. Rev. H. Davies.-Very abundant at Shoreham, growing upon Atriplex portulacoides. Mr. Borrer.-River at Bayonne, plentiful. Don Simon de Roxas Clemente.

Perennial? In the summer months.

* Root, a very minute callous disk, so small as to be scarcely perceptible.

Fronds, growing in tufts, cylindrical, filiform, about the thickness of hogs' bristles, two or three inches long, flexuose, erect, branched from their very origin ; branches sub-distichous, horizontal, or between horizontal and patent, alternate, the lowest an inch or more long, and separated by intervals of a quarter of an inch, the rest gradually shorter, and placed nearer to each other, some undivided, others forked, all pinnated with others similar to themselves, but smaller, disposed in the same manner, two or three lines long, which also are either beset with extremely short, simple, rather remote, alternate, patent ramuli, or are irregularly dichotomous, with incurved segments; the extreme branches are thinner than human hair; those at the ends of the frond stand close together, and have their apices (to use the expression of Dillenius) rolled up like the tail of a scorpion, but $I$ have never seen these either $\uparrow$ turgid, or swollen with mucus, or t tubercled.

Fructification, of two kinds; the one (which alone has fallen under my observation) terminal in the ramuli, which then swell, and become lineari-lanceolate pod-shaped capsules, containing a few dark-brown sphærical seeds disposed in two rows, appearing, under a powerful magnifier, to be surrounded by a very thin limbus, and divided into three parts; the other, upon the authority of Roth, consisting of capsules so small as not to be clearly distinguishable without the compound microscope, generally solitary at the axilla of the branches, sessile, roundish, and semitransparent.

CoLOR, livid brown, pellucid, blackish when dry; always destitute of gloss.

Substance, cartilaginous, tender, brittle.

OBs. The mode of growth is much and irregularly entangled:- the small size of this Fucus, and its generally growing in muddy places near the roots of larger plants, cause it to be easily overlooked :-in drying, it adheres loosely to paper.

This little Fucus has long been known to botanists, having been not only described, but figured also, by Dillenius in Ray's Synopsis. The involuted apices, 'which are there particularly noticed, induced Mr. Hudson, in the first edition of his Flora Anglica, to give it the very expressive name of $F$. scorpioides, which was adopted also by Gmelin, but which he himself, in the second edition of that work, changed, without any cause assigned, to $F$. amphibius; a name far less significant, but at the same time, one that also marks a strong peculiarity of the species, no other Fucus, to my knowledge, affecting an equally terrestrial situation. In this formation of the apices lies unquestionably the most obvious character of the plant before us, such as, considered together with its diminutive size and ramification, cannot fail to distinguish it immediately from its congeners; but by relying upon this singly, Dr. Rotls has been led into the remarkable error of supposing $F$. pinastroides, which has no other point in common with F.amphibius, to be probably only a synonym of it. This excellent botanist first noticed the obsoletely jointed appearance of the frond, which I have also latterly seen in some specimens, but by no means in all, or even in the greatest number. The dissepiments are dark-coloured, and divide the plant into joints, of which the length is barely equal to the width, but do not at all injure the cylindricity of the filaments. The frond is also, under a powerful microscope, found to be streaked with faint, longitudinal, parallel lines, and is, moreover, beautifully studded with sub-orbicular brown spots, indicating in all these circumstances a close affinity to Conferva polymorpha, which, in size, and habit, it considerably resembles, and which Professor Esper has mistaken for it, and has §figured under its name. So great indeed is the affinity between these two species, that $I$ should have entertained no doubt of the fructification of both being alike, even if the globular capsules of F. amphibius had not been observed by Dr. Roth, whose description of the fruit $\mathbb{I}$ have feit no scruple in adopting, as well from his unquestionable accuracy, as from knowing, from authentic, though barren, specimens, that his plant is the same as ours. About Gmelin's $H$. scorpioides there is more

room

\footnotetext{
* In the Linnoan Transuctions and in the Symopsis of the British Fuci this root is called fibrous, but in the specimens which $I$ have now under the microscope, it is clearly a minute callous disk, like that of the Conferva, and it is so described by Dr. Roth. The frond adheres also in various other parts without any visible roots to the stem of Atriplcx portulacoides, which it is creeping over.

According to Gnelin, "quo magis maturescunt, eo magis intlantur, maximè turgidi inflectuntur caudæ scorpii in modum, quam tumiditatem adferre videtur mucus, ibe se exonerans, fructificationis negotium perficiens."

‡Dr. Goodenoigh and Mr. Woodward say; " the extremities are rolled spirally, and usually include in their circumvolutions either single or aggregate nucilaginons tubercles."

§ Jcones Fucorum. 1. t. \$2.
} 


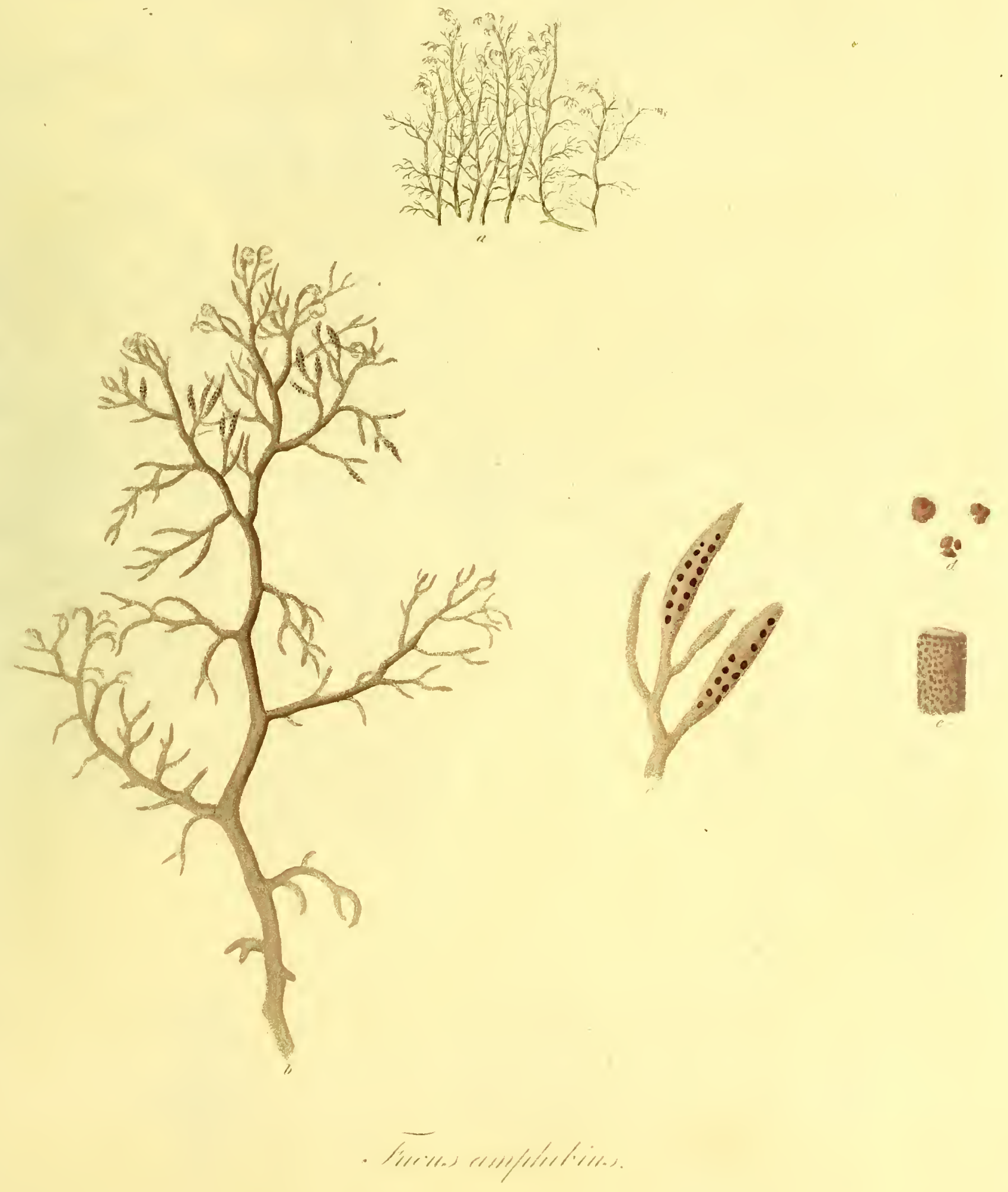





\section{veve}

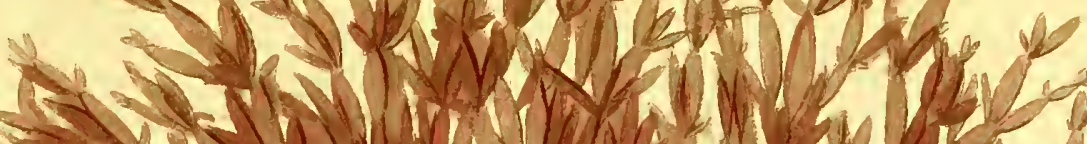

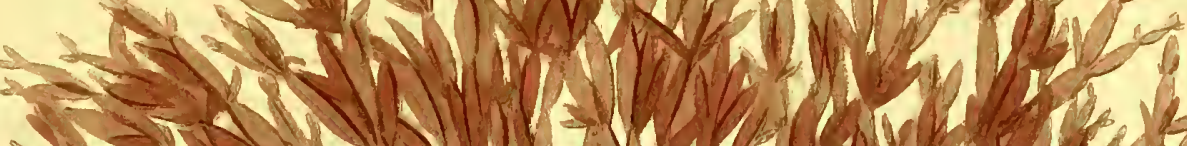

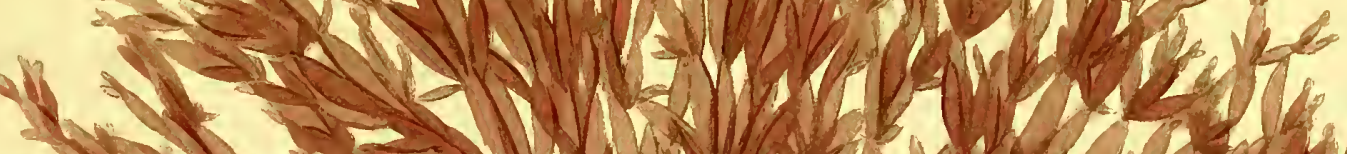

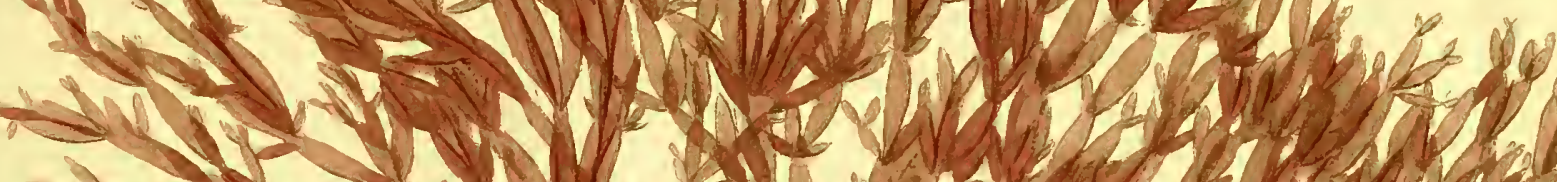

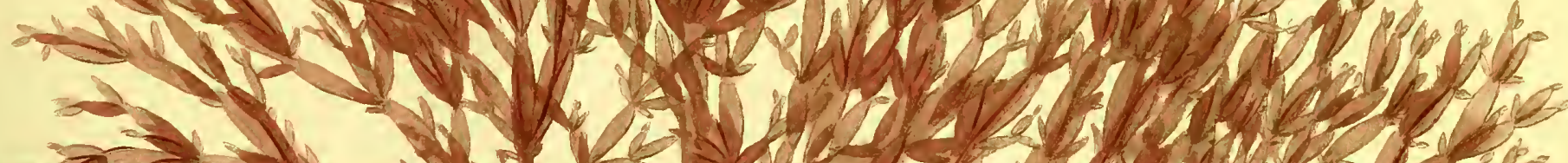

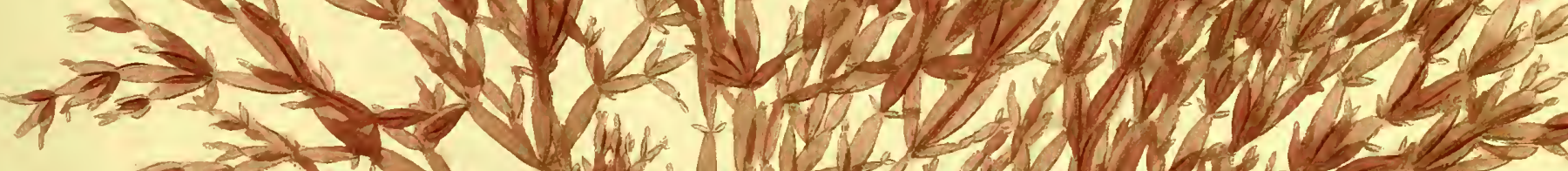

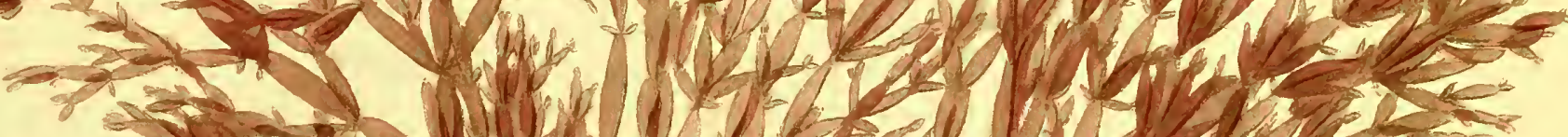

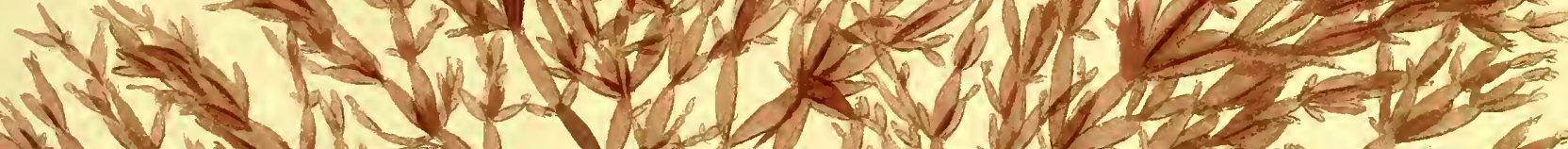

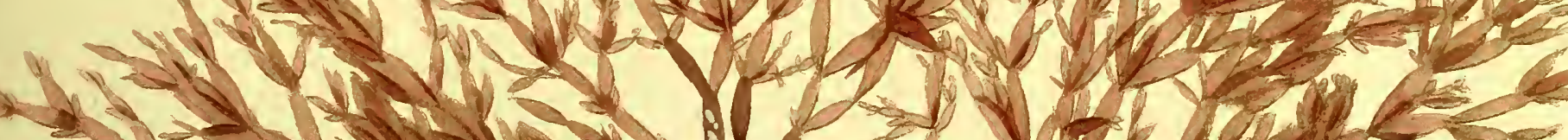

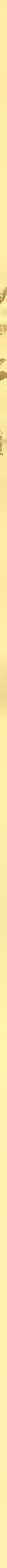



room for doubt, from his describing the substance as woody, and observing that Sertularia pumila is often found upon it.

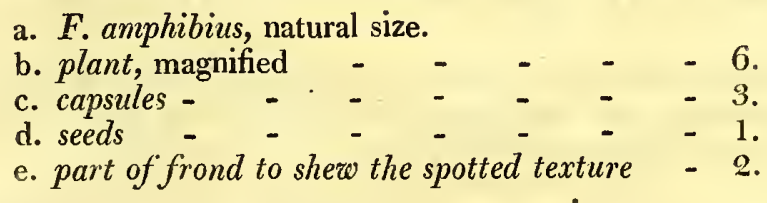

\section{0.-F U G US P Y R I F E R US.}

Fucus, caule terete, filiformi, dichotomo, foliis obsito alternis, remotiusculis, planis, enervibus, ensiformibus, rugosis, serratis, petiolatis; petiolis in vesiculas pyriformes inflatis.

Fucus pyriferus. Linn. Mant. p. 311. Syst. Nat. Ed. Gmel. II. p. 138 I. Es̃ per, Ic. Fuc. 1I. p. 28. t. 124 .

Навітат in Oceano Ethiopico. Linnaus.-In Oceano Americæ Australis, a latitudine australi gr. 40 ad 58, maximâ copiâ prope littora Terræ del Fuego. D. Solander.-Ad Caput Bonæ Spei. D. Brand, in Herb. Banks.

\section{Perennis.}

RADIX nondùm detecta.

FroNs instructa caule * terete, filiformi, glabro, †longissimo, nunc digiti nunc pennæ anserinæ crassitie, supernè attenuato, vagè dichotomo, foliis obsito; folia circa caulem spiralitèr alterna, intervallo inter singula nunc aliquot linearum nunc pollicum, angulum cum caule rectum servantia, petiolata, plana, nervi venarumque prorsùs expertia, sed ubique longitudinalitèr rugosa rugis profundis undulatis sub-labyrinthiformibus, ensiformia, quatuor et ultrà pedes longa, et interdùm quinque pollices lata, summa brevissima et angustissima, omnia margine denticulis subulatis antrorsùm spectantibus remotiusculis obsita, basi prope petiolum attenuata; petioli tri- quadri- pollicares, ortu teretes, et caule aliquantùm angustiores, exinde sensìm ampliati, et in vesiculas tumescentes elongato-pyriformes, supernè pollicis crassitie, extrinsecùs læves, intùs vacuas.- In ipso apice frons est integra planaque, quæ tamen tandem ibi in folia dividitur : a basi ad apicem et non vice versâ denticuli demùm enascuntur, et folia rugosa fiunt.

Fructificatio hactenùs latet.

Co Lo olivaceo-fuscus, illi glutinis communis haud absimilis, subdiaphanus.

SUBSTANTIA in caule coriacea, in foliis membranacea.

Oв S. Tota planta insignitèr lævigata est et glutinosa, ingentemque muci pellucidı copram in aquâ dulci servata effundit; neque tamen exsiccata chartæ adhæret.

Quicquid de hoc Fuco Linnæus tradidit a Koenigio accepit, qui primus, ut videtur, Botanicus ejus mentionem fecit. Hic omnium Fucorum verisimillimè maximum credit, sed simùl in quantam excrescere solet longitudinem silentio præterit; neque hoc ab alio quopiam inter navigatores recentiores traditum reperio, plurimi licet plantam memoraverint, et esse imnensam, insulasque in mari, $\boldsymbol{F}$. natantis instar, referre narraverint. Pauca modo sunt exemplaria, nec nisi stirpium majorum fragmina, quæ observandi hactenùs mihi facultas obtigit; quamobrem eo libentiùs suprà in descriptione multum, alioquìn mihi ignotum, ex Linnæi scriptis sum mutuatus, et longè plus ex Solandri manuscriptis, qui, dum orbem unà cum noblissimo Banksio circumnavigaret, hunc Fucum abundè legit. Memorat hic specimina e fundo maris seu rupibus divulsa diu in mari fluitantia nova folia prope basin emittere, sæpe absque petiolis incrassatis vel vesiculosis; et petiolos abruptos callosos evadere; interdùm etian vesiculas ovales in foliis esse innatas, sed absque ordine, unde conjicere licet eas adventitias esse. Difficile prorsùs foret dictu qualis est verisimillimè $F$. pyriferi fructificatio. Frondis quidem habitus vesiculæque pyriformes eam cum $F$. natante ejusque congeneribus affinitatem innuunt, a quâ similis esset expectandus fructus; sed contrà frons rugosa muco referta $F$. saccharinum potiùs respicit, et in fructu vix ab illo recedere posse suadet.

\section{a. F. pyriferus, magn. nat.}

\footnotetext{
* Compressum dicit Linnæus, et post hunc Esperus, sed in exemplaribus meis est omninò teres, quod etiam in manuscriptis habet cl. Solander, quiquoque semper indivisum vidit.

+ Nihil habeo certi de longitudine compertum; Linnæus enim hoc modò dicit, " caulis omnium longissimus et maximus :" traditq̣ue Soland " specimina sua, quæ tantummodò apices erant, decem duodecimve pedalia esse : nihil magis de crassitie liquet.
} 
Fucus pyriferus, stem cylindrical, dichotomous, beset with alternate, flat, rather remote, nerveless, ensiform, wrinkled, serrated, petiolate leaves; petioli swollen into pyriform vesicles.

"Fucus pyriferus. Lin . Mant. p. 311 . Syst. Nat. Ed. Gmel. II. p. 1381. Es Per, Ic. Fuc. II. p. 28. t. 124 .

In the Ethiopian Ocean. Linnaus.-In the Sea near South America, from the fortieth to the fifty-eighth degree of southern latitude, most plentifully near the shores of Terra del Fuego. Dr. Solander.-At the Cape of Good Hope. Mr. Brand, in the Banksian Herbarium.

\section{Perennial.}

Roот, not yet known.

FroN D, furnished with a *ylindrical, filiform, smooth stem, extending to a very great + length, varying in thickness from that of a finger to that of a goose-quill, most thin towards the apices, irregularly dichotomous, leafy; leaves disposed round the stem in a spirally alternate manner, separated by intervals, in some cases of a few lines, in others of as many inches, standing at right angles with the stem, petiolated, flat, quite destitute of midrib and veins, but full of deep, longitudinal, undulated, sub-labyrinthiform wrinkles, sword shaped, four feet, or more long, and sometimes five inches wide, the upper ones shortest and most narrow, all of them ciliated at their margins with rather remote, subulate, spiniform teeth, which regularly point upwards, and at their bases attenuated; petioli three or four inches long, at their origin cylindrical, and sonewhat narrower than the stens, thence gradually widening, and swelling into pyriform vesicles, an inch wide at top, externally smooth, internally empty:-the summit of the frond is entire and flat, but in time separates into leaves, which afterwards become wrinkled, and produce denticles originating from the base upwards, never in a contrary direction.

Fructification, at present undiscovered.

CoLOR, olive-green, mixed with brown, not very unlike that of common glue, semitransparent.

SubSTANCE, coriaceous in the stem, membranaceous in the leaves.

Ors. The whole plant is remarkably smooth and glutinous, and, if kept in fresh-water, discharges a great quantity of pellucid mucus, but does not in drying adhere to paper.

Dr. Koenig, who communicated to Linnæus the particulars published by him respecting this extraordinary Fucus, appears to have been the first naturalist who ever noticed it. He considers it as being probably the largest of all the Fuci, but, unfortunately, neglects to say what size it attains to, nor do I find that this deficiency has been supplied by subsequent navigators, many of whom have spoken of its immense size, and of the quantity in which it is found, so as, like $F$. natans, to resemble islands in the ocean. The specimens, which $I$ have had an opportunity of seeing, have been but few in number, and all of them merely fragments, and I have therefore the more readily availed myself in my description of the information afforded by Iinuæus, and, still more, of that contained in the manuscripts of Dr. Solander, who gathered the plant abundantly during his voyage with Sir Joseph Banks round the world. He remarks, in addition to what has been above mentioned, that specimens, which have been for some time floating in the water, throw out near the base new leaves, that are often unaccompanied by the inflated pyriform petiolus, that the petioli when broken become callous, and that ovate vesicles are occasionally observable innate in the substance of the leaves, but growing without order, so that they are in all probability only accidental. With regard to the nature of the fructification of $E$. pyriferus, it would be difficult to offer a satisfactory conjecture: its general habit, and pear-shaped vesicles, seem to argue such an affinity to $F$. natans, and its congeners, as might lead to the expectation that its fruit may possibly be found to be not unlike that of those species; but, on the other hand, the wrinkled frond full of mucus would rather induce me to look for such a fructification as obtains in $\mathbb{F}$. saccharinus.

\section{a. F. pyriferus, natural size.}

\footnotetext{
* Linnæus calls the stcm compressed, in which he is followed by Esper, but it is certainly completely cylindrical in my specimens, and Dr. Solander says the same of his : he also never found it divided, on which account, $I$ apprehend the dichotomies are few in number.

+ How great this length is I am quite ignorant ; for Linnæus simply says, that the stem is the longest and largest of all the Fuci, and the specimens, which Solander had an opportunity of observing, and which he says were mere apices, did not extcnd to above ten or twelve feet: -about the thickness to which it may in full grow th attain I am in equal uncertainty.
} 


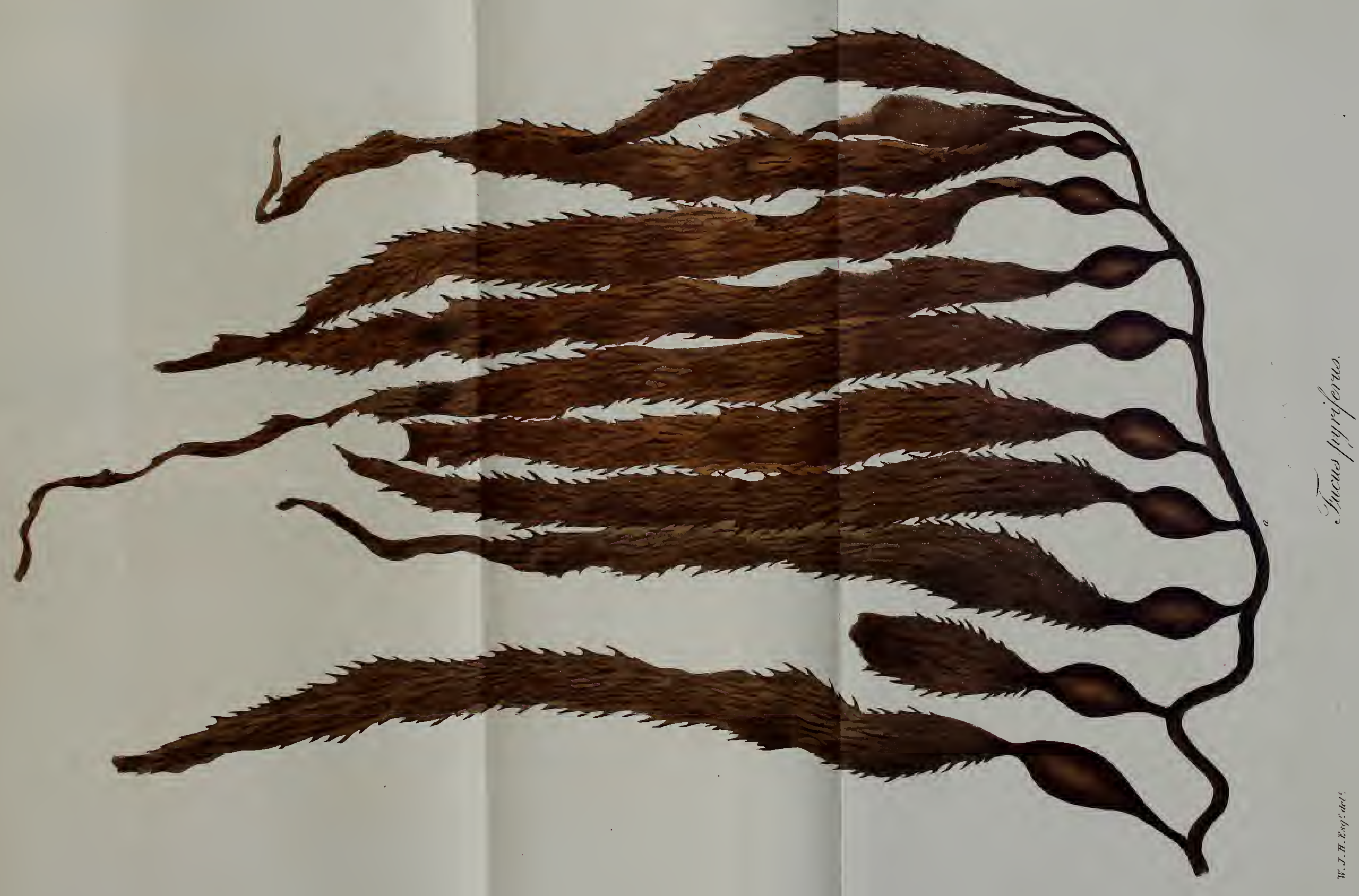



Fucus, caule filiformi, anguloso, indiviso, pinnato : ramis alternis, abbreviatis, simplicibus : foliis linearibus, integerrimis : vesiculis nullis: receptaculis cylindraceis, racemosis.

Habitat in occidentalibus Novæ Hollandiæ oris. D. Menzies.

Perennis.

RADIX nondùm a me visa.

FRONS instructa caule unico, pedali vel sesquipedali, enormitèr triquetro, profundè longitudinalitèr sulcato, pennæ corvinæ crassitie, et ubique ferè æquali, indiviso, ramis per totam longitudinem obsito, cæetera nudo ; rami alterni, intervallis tri- quadri- linearibus vel unguicularibus sejuncti, circa caulem sub-spiralitèr dispositi, angulosi, pennæe passerinææ circitèr crassitie, horizontalitèr patuli, indivisi, longitudine a pollicari ad tripollicarem variabiles, summi brevissimi, omnes foliis fructuque densê obsiti ; folia in ramis numerosa, patentia, sessilia, linearia, obtusa, pollicem longa et lineam lata, nervo valido nigricante percursa, lenitèr undulata, margine integerrima, aliquando, sed rarò, bifurca; vesicula nullæ.

Fructificatio nunc ramis foliorum ad alas, nunc ipsis foliis juxta basin imposita, copiosissima, e receptaculis constans lineari-oblongis, vix sesquilineam longis, his simplicibus, illis divisis, plurimis petiolo perbrevi insidentibus, et in racemum congestis, superficie poris minutissimis undequaque pertusâ, sub quibus latent tubercula subrotunda, singula semen unicum ellipticum nigricans limbo nullo cinctum foventia.

Co Lor, qui recentis verisimillimè est olivaceus, est rursus madefactce niger in caule et receptaculis, intensè fuscus in foliis ; exsiccata ubique est nigerrimus.

Su BST A T T A caulis lignosa, foliorum cartilaginea; ubique lenta et tenax.

Овs. Exsiccatione cliartæ non adhæret.

Nulla hujus Fuci exemplaria hactenus vidi, præter ea a cl. Menziesio in Britanniam reportata, quæ, numero quidem haud ita multa, omnia formâ crescendique modo inter se prorsùs consentiunt. His cunctis folia eadem angusta et integerrima, illis $F$. Acinaria non absimilia, rami abbreviati, vesicularum vestigia nulla, aded ut per hæc planta a congeneribus semper facilè dignoscatur.

a. F. linearifnlius, magn. nat.

b. ramus, magn. auct. - - $\quad$ - $\quad$ - 6 .

c. receptaculorum racemus - $\quad-\quad-3$

$\mathrm{d}$, receptaculum horizontalitèr dissectum - 2 
Fucus linearifolius; stem angular, undivided, pinnated; branches alternate, short, simple: leaves linear, quite entire: vesicles none: receptacles cylindrical, racemose.

On the western coast of New Holland. Mr. Menzies.

\section{Perennial.}

Roот, I have not yet seen.

Fron D, furnished with a single stem, a foot or a foot and half in length, irregularly three-cornered, grooved with deep longitudinal furrows, preserving every where a thickness nearly equal to a crow's quill, undivided, but beset throughout its whole length with branches, in other respects naked; branches alternate, separated by intervals of three or four lines or half an inch each, disposed in a sub-spiral manner round the stem, angular, about as thick as a sparrow's quill, between horizontal and patent, varying in length from one to three inches, the uppermost shortest, all thickly covered with leaves and fruit; leaves numerous upon the branches, patent, sessile, linear, obtuse, an inch long, and a line wide, furnished with a strong blackish midrib, slightly waved, entire at their margins, occasionally, but very seldom, forked; vesicles none.

Fructification, either situated at the axillæ of the leaves, or upon the leaves themselves, near their base, very abundant, composed of receptacles between linear and oblong, scarcely a line and half in length, some simple, others divided, most of them supported upon a very short petiolus, and collected into a racemus, their surface perforated all over with extremely minute pores, under which lie imbedded roundish tubercles, each containing a single, elliptical, blackish seed, destitute of a limbus.

CoLOR, most probably an olive-green in the recent plant; in specimens that have been dried, and are again moistened, black in the stem and receptacles, and dark brown in the leaves; when dried every where an intense black.

Substance, of the stem woody, of the leaves cartilaginous, all over flexible and tough.

OBs. In drying it does not adhere to paper.

I have at present seen no specimens of this Fucus, excepting a few brought home by Mr. Menzies, judging from which, it appears to be subject to little variation in its form or mode of growth, and to be readily distinguishable from all others by its narrow entire leaves, which in shape resemble those of $F$. Acinaria, by its very sliort branches, and by its total want of vesicles.

a. F. linearifolius, natural size.

b. branch, magnified - $\quad-\quad-6$.

c. cluster of receptacles . - - - 3 .

d. horizontal section of a receptacle - 2. 

Fucus, caule terete, abbreviato, ramoso: ramis filiformibus, infernè simplicibus et foliosis, supernè paniculatoramosis aphyllis vesiculiferis, fructiferisque : foliis linearibus, distichis, integerrimis : vesiculis sphæricis, moniliformibus : receptaculis cylindraceis, solitariis, terminalibus.

Нав іт ат in freto Sunda. D. G. Watts.

\section{Perennis.}

RADIX nondùm cognita.

Fro N instructa caule terete, filiformi, pennæ anserinæ crassitie, aliquot modd pollicum longitudine, vagè diviso in ramos plurimos, sui similes, sed minores, a basi ad apicem sensim attenuatos, ut in extremitates setæ porcinæ molem vix exsuperantes desinant, pedales, sesquipedales, et ultrà, lenitèr flexuosos, ad dimidiam circitèr altitudinem simplices et tantummodd foliosos, supernè plerumque aphyllos, at ramis obsitos minoribus distichis, alternis, horizontalitèr patentibus, spatio inter singulos sub-unguiculari, his dodrantem illis vix pollicem longis, summis semper brevissimis, ipsis iterùm pinnatis aliis adhuc minoribus, simili ratione dispositis, vesiculas fructumque ferentibus; folia disticha, sub-alterna, remotiuscula, patentia, sessilia, linearia, sesquipollicem longa, et duas circitèr lineas lata, nervo tenui nigricante percursa, apice rotundata, margine integerrima; vesicule in ramorum minorum substantiâ innatæ, nunc una, nunc duæ vel tres in singulis, semper intervallo aliquo, brevissimo tamen, sejunctæ, ut moniliformes appareant, sub-globosæ Vicia sativa seminum magnitudine, extrinsecùs poris mucifluis pertusæ, intùs cavæ, et vacuæ, nisi quodd filamento tenuissimo percurrantur, apice semper aristatæ ramo ultrà progrediente:-tota frons, cùm caulis, tùm rami, atque etiam ramuli, processubus exiguis, horizontalibus, ramorum seu foliorum primordia referentibus, exasperata evadit, unde stirpi facies insignitèr muricata.

FrUCTIFICATIO terminalis, e receptaculis constans cylindraceis, vix sesquilineam longis, solitariis, superficie ubique inequali et pertusâ poris, sub quibus latent tubercula immersa sphærica, singula semen unicum ellipticum fuscum limbo pellucido cinctum, immixtis granulis plurimis concoloribus multoties minoribus et fibris minutissimis articulatis simplicibus, includentia.

Color in foliis et vesiculis olivaceus et diaphanus, in caule ramisque fuscus et opacus; totius planta exsiccata fusco-nigricans.

SUBSTANT1A in caule et ramis coriacea, in foliis cartilaginea atque tenuis, ubique lenta, tenax.

OBs. Exsiccatione chartæ ne minimùm adhæret.

Interesse crescendi modo summam affinitatem inter Fucum hìc depictum et $F$. osmundaceum quivis statìm percipiet botanicus; talisque est hæc ut non sit dubitandum quin utrique fructificatio sit eadem,'similis ejus Fucorum qui soli Webero Mohrioque Fuci proprii audiunt. F. muricati autem folia nullam, quantum adhuc vidi, in quolibet ætatis stadio formæ mutationem subeunt, neque unquam angustata minuuntur in ramos illos paniculatos qui frondis apicem coronant, sed figuram linearem indivisam non minùs constantèr in summis quàm in imis servant, facieque referunt illa F. natantis affinium; unde fit ut planta sit in Fucorum Systemate annulus, eos foliis distinctis iis quibus sunt unita annectens. Evidentiùs in hujus Fuci quàm in alius ferè cujuspiam tuberculis videre est granula illa seminibus multoties minora et ab illis omnino diversa, (neque tamen, ut sæpiùs accidit, pellucida) fibrasque brevissimas simplices, quas in F. tuberculati fructu speciatìm memorant Weberus Mohriusque; sed hæc utraque, ordine nullo servato, unà cum seminibus immixta jacent. Tria F. muricati exemplaria in Herbario Ellisiano servantur, omnia tamen foliis ramorumque parte inferiore destituta, et quibus neque locus natalis neque animadversio affigitur ulla; majorique igitur mihi fuit gaudio quum demùm specimina accepi perfecta, a D. Watts simul cum $F$. aquifolio et $F$. ilicifolio lecta. Planta est, ut videtur, qua crescendi modo, ramorum longitudinem si excipias, vix ullis mutationibus est obnoxia, et quæ vesicularum dispositione facieque ubique muricatâ, facillimè est a congeneribus distinguenda. Hæc muricata facies, (quam cum Fuco, qui Wulfenio, nequaquàm verò Linnæo, F. Acinaria audit, communem habet) aded est singularis ut nomen specificum inde ducendum existimaverim; quoniam planta, quæ eodem est olim titulo a Gmelino appellata, nunc ita nuncupari desiit, cùm $F$. spinosum esse Linnæanum compertum habemus.

a. pars caulis F. muricati, cum ramo juniore, magn. nat.

b. frondis pars superior.

c. ramus e minoribus, magn. auct. - $\quad-\quad-6$.

d. vesicula, - $-5-5-5$.

e. eadem longitudinalitèr dissecta - $\quad-\quad$ - 4.

f. receptaculum - - - - - $\quad$ - 4.

g. idem horizontalitèr sectum - $\quad-\quad-\quad-3$.

h. semina - - - - - - - 1.

i. granula exigua in tuberculis inclusa - $\quad 1$ - 1 .

k. fibre - - - - - - - 1 . 
Fucus muricatus, stem cylindrical, short, branched; branches filiform, simple and leafy below, above divided in a panicled manner, leafless and bearing vesicles and fructification: leaves linear, distichous, quite entire : vesicles spherical, moniliform : receptacles cylindrical, solitary, terminal.

In the Streights of Sunda. Mr. G. Watts.

Perennial.

Root, at present unknown.

FroND, furnished with a cylindrical, filiform stem, of the thickness of a goose-quill, only a few inches long, irregularly divided into several branches, similar to itself, but smaller, and gradually attenuated from base to summit, so that the extremities are scarcely larger than hogs' bristles, their length is from a foot to a foot and half, or more, they are slightly flexuose, to about the half of their height they remain simple and leafy, but in their upper parts are usually destitute of leaves, and beset with a series of distichous, alternate branches, between horizontal and patent, separated by intervals of about half an incl, varying in length from one to eight or nine inches, the upper ones always shortest ; these also in their turn are again pinnated with others still smaller, disposed in the same manner, and producing vesicles and fruit; leaves distichous, mostly alternate, rather remote, patent, sessile, linear, an inch and half long, and about two lines wide, provided with a thin blackish midrib, rounded at their apices, entire at their margins ; resicles innate in the substance of the lesser branches, sometimes one, sometimes two or three in each, always parted by short intervening spaces, so as to appear moniliform, sub-globose, of the size of the seeds of Vicia sativa, externally perforated with mucifluous pores, internally hollow and empty, except that an extremely thin filament runs through them, always tipped at their summit with a projecting part of the branch:- the whole frond, as well the stem as the branches, both great and small, is rough with minute horizontal processes, resembling the rudiments of leaves or branches, which give the plant a singularly muricated appearance.

Fructification, terminal, consisting of cylindrical receptacles, scarcely a line and half long, solitary, unequal in their surface, and spotted with small pores, under which lie imbedded spherical tubercles, each containing a single, elliptical, brown seed, surrounded with a pellucid limbus, mixed with numerous granules of the same color, but many times smaller, and with exceedingly nimute, jointed, simple fibres.

CoLOR, olive-green and transparent in the leaves and vesicles, in the stem and branches brown and opaque; a brownish black throughout the whole plant when dry.

SUBSTANCE, of the stem and branches coriaceous, of the leaves cartilaginous and thin; every where flexible and tough.

OBs. In drying it does not in the least adhere to paper.

It will immediately be observed how great a resemblance there is, in the mode of their growth, between the subject of the present plate and $F$. osmundaceus already figured in this work; and this circumstance may be regarded as an additional confirmation to the conjecture hazarded under the latter of these species, that its fruit will be found to resemble that of the division of Algc , to which Weber and Mohr have exclusively appropriated the name of Fuci. The leaves, however, of $F$. muricatus, as far as I have at present seen, shew no tendency to change into the paniculated branches that vary the upper part of the frond; but preserve their linear and undivided form no less constantly in the highest than in the lowest; and in appearance greatly resemble those of the tribe of $F$. natans, between which, and the Fuci, with what are termed, united leaves, F. muricatus is an interesting link. In the tubercles of this Fucus, I have seen more clearly than in those of almost any other, the clusters of small bodies quite different from the seeds, but not, as generally happens, colorless, and the short simple fibres particularly described by Weber and Mohr in their account of $F$. tuberculatus, but all these seemed to lie together without any regular order. Three specimens of $\boldsymbol{F}$. muricatus are preserved in Ellis' Herbarium; all of them, however, destitute of the lower part of the stem or of any leaves, and having no remark or locus natalis attached to them. I was therefore the more glad to receive it in a perfect state from Mr. Watts, who collected it together with $F$. aquifolius and $F$. ilicifolius. It seems to be a plant liable to but little variation in its mode of growth, excepting only as to the length of its branches; and to be immediately distinguishable from all its congeners by the disposition of its vesicles, and by its muricated appearance, in which latter circumstance it agrees with the Fucus confounded by many botanists with F. Acinaria of Linnæus. his peculiarity is so striking, even at first sight, that I have been induced to derive from it the specific name; the plant which had been previously called F. muricatus by Gmelin being, as has already been mentioned in this work, the same as the Linnæan $F$. spinosus.

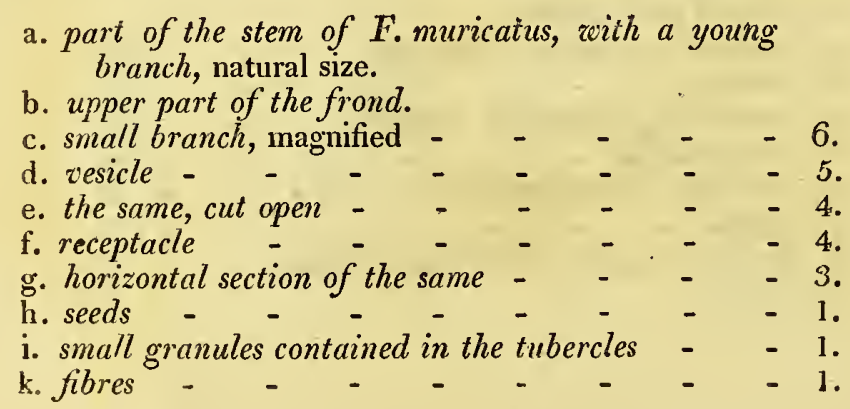



Fucus, caule terete, filiformi, abbreviato, ramoso ; apice expanso in folium cartilagineum, planum, enerve, simplex, reniforme, vel orbiculare, integerrimum, senectute e margine proliferum : tuberculis hemisphæricis, sessilibus, per frondis superficiem sparsis.

B. tenuior; petiolo sursum lenitèr dilatato ; frondis marginibus enormitèr ciliatis ; substantiâ tenui.

Inter rejectamenta maris apud Niton, in Insulâ Vecti. Dna E. Everett.--In littore apud Budleigh. Dna Griffiths.-In Cornubiâ legit D. Rashleigh.— $\beta$ apud Ilfracombe in Devoniâ. Dra Hill.

\section{Perennis.}

RA DIX callus enormitèr discoideus, majusculus, frondi concolor.

FRONDES ex eâdem basi plurimæ, singulæ instructæ caıle terete, filiformi, nunc vix unius lineæ, uunc unguis longitudine, Merulæ pennæ crassitie, variè absque normâ diviso, ramis omnibus ad apicenı usque filiformibus, atque ibi subitò dilatatis in folium unicum simplex, reniforme, vel e reniformi orbiculare, diametro plerumque circitèr unguiculare, interdùm ferè pollicare, planum, nervi venarumque prorsùs expers, margine integerrimum, nisi quòd exemplarium vetustiorum margines haud rarò proliferi evadant foliis aliis primariorum similibus, sed minoribus, petiolo perquàm angusto, plano tamen, brevissimo insidentibus : alia etiam folia, formâ cum reliquis convenientia, petiolis brevissimis teretiusculis fulta, sparsim e ramorum lateribus oriuntur, quæ plurium quoque, ut videtur, diffractorum reliquiis nunquan non rudia apparent.

Fructificatio tubercula hemispherica, aciculæ minoris capitis magnitudine, ubique per folia sparsa, et utrique eorum paginæ imposita, intensè rubra, seminum oblongorum minutissimorum congeriem foventia, unà cum corpusculis aliis quæ fibræ perbreves simplices videntur, sed quæ aded sunt milıuta, ut ad eorum indolem detegendam summa microscopii compositi vis hand satis valuit.

Co Lor amonè, dilutè tamen, sanguineus, sub-diaphanus; soli objecta vel diu in aquâ dulci servata pallidior, et primùm in sordidè fuscescentem mox in albicantem evanidus.

Su BSTANTI A inter cartilagineam et carnosam media, crassiuscula, succo plena.

Var. $\beta$ insignitèr in multis ab $\alpha$ discrepat: folii pars inferior attenuata sensìm in petiolum confluit; substantia tenuior, vix aliquid in se succosi habens; peripheria multo minùs certa; statura duplo major; denique margines hìc illic processubus exiguis inæquales, ut propemodùm dentati appareant.

Oвs. Madefacta odorem violaceum angustum spirat:- exsiccata chartæ non adhæret:- frons naturâ sinplex et integerrima ob substantiam teneram non rarò ita lacerata occurrit, ut ramosam crenatamve facilè crederes.

En tibi, lector botanice, iterùm novum Floræ Britanicæ incrementum; planta, quâ vix ulla, ut videtur infrequentiùs occurrere solet, et quæ, non nisi inter maris rejectamenta lucusque detecta, locum suum natalem hactenus celare pergit. Multi jam anni sunt elapsi ex quo Dna Everett, cui exemplaria in hâc tabulà depicta parvifolia debeo, post procellam aliquot ejus frondes in Insulæ Vectis littore legit. Hæ omnes magnitudine æquè ac figurâ illas hìc depictas referebant, et cùm fructificatione, tùm vi omni proliferấ penitùs carebant. Sæpe postea plures quæsivit, sed semper frustrà. Exemplar, nisi fallor, unum modo est unquam a D. Rashleigh lectum, quod iis Dnæ Everett ad amussim quadrat, neque plus quàm unum legit Dna Griffiths, sed hoc duplo magis, proliferumque, et fructiferum. Per hoc, quod non nisi nuperrimè vidi, talenı similitudinem intercedere reperio inter $F$. reniformem varietatemque $F$. laciniati a D. Scott detectam, et in priore hujus operis tomo descriptam, ut temperare mihi nequeam quin suspicer hanc varietatem esse rectiùs ab $F$. laciniato disjungendam et $F$. reniformi associandam; de quo tamen nihil certi asserere ausim, priusquàm, pluribus speciminibus visis, meliùs judicandi facultas sese obtulerit. Consentiunt hi duo Fuci colore et substantiâ, neque ullus est cui stirps hìc depicta arctiùs naturâ affinis videtur. Foliorum figurâ facilè $a b$ omnibus distinguitur. Exemplar illud (hoc quoque unicum) a Dnâ Hill repertum, et suprà pro var. $\beta$ descriptum, hìc unà cum cæteris delineandum existimavi ; cum saltèm sit varietas summoperè singularis, si non sit specie reverà distinctum, quod ipse, pace fæminæ lectissimæ, suspicor. Texturâ hoc ad F. ciliatum accedit.

i, a. F. reniformis, magn. nat.

b. exemplar vetustum et lasum, cum fructu.

c. frondis pars, cum tuberculis, magn. auct. - 0 .

d. tuberculum dissectum - $\quad$ - $\quad$ - 4.

e. semina - - - - - - -1 .

f. fibra! - - - - - - - 1 .

g. var. $\beta$, magn. nat. 
Fucus reniformis, stem cylindrical, filiform, short, branched; expanded at its summit into a cartilaginous, flat, nerveless, simple, reniform, or orbicular, entire leaf, when old, proliferous from its margin: sessile, hemispherical tubercles scattered over the surface of the frond.

B. tenuior; petiolus slightly dilated upwards; margin irregularly ciliated; substance thin.

Among the rejectamenta of the sea at Niton, in the Isle of Wight. Miss E. Everett.-On the shore at Budleigh. Mrs. Griffiths._Gathered in Cornwall by Mr. Rashleigh.- $\beta$ at Ilfracombe. Miss Hill.

\section{Perennial.}

Root, an irregularly formed, largish, callous disk, of the same color as the frond.

FRONDS, numerous from the same base, each rising with a cylindrical filiform stem, varying in length from a line to half an inch, about the thickness of a blackbird's quill, divided without order into branches which continue filiform to their very apex, where each suddenly expands into a single simple leaf, of a reniform shape, or between reniform and orbicular, in general about half an inch, but sometimes nearly an inch in diameter, quite destitute of midrib and veins, entire at its margin, except that old specimens are there not uncommonly proliferous with a series of other leaves, similar to the primary ones, but smaller, each supported upon an extremely short, and narrow, yet flat, petiolus: other leaves too, of the same shape as the terminal ones, grow on short petioli, in a scattered manner, from the sides of the branches, and these are constantly rough with what appear to be the remains of others that have been broken off.

Fructification, spherical tubercles, about the size of a small pin's head, scattered all over the leaves, and on both sides of them, of a deep red color, containing a mass of very minute oblong seeds, mixed with other bodies which have the appearance of being short simple fibres, but which are so small that I could not satisfy myself as to their nature with the utmost powers of the compound microscope.

CoLOR, a pleasant, but pale, blood-red, semitransparent, soon turning more faint from exposure to the sun, or from being kept in fresh water, and afterwards changing, at first to a dirty light-brown, and then to white.

SUBSTANCE, intermediate between cartilaginous and fleshy, thickish, full of moisture.

The var. $\beta$ differs in many respects from $\alpha$; the lower part of the leaf is attenuated, and loses itself in the petiolus; the substance is more thin, and has scarcely any moisture in it; the circumference is much less regularly defined; the size is twice as great; and, finally, the margin is here and there rough with small processes, so as almost to appear toothed.

OBs. When moistened, it gives out a faint smell of violets:-in drying it does not adhere to paper :- the frond, though naturally quite simple and entire, is from its tender substance not unfrequently so torn as to look branched or crenate.

This Fucus appears to be a species of remarkably unfrequent occurrence, and is one of which the locus natalis remains at present undiscovered. It is many years since Miss Everett, to whom I am indebted for the specimens with the smallest leaves figured in the plate before us, found, after a storm, a few plants of it thrown upon the shore of the Isle of Wight; all of them in size and shape resembling the one here represented, and all barren, and without the least tendency to become proliferous. She afterwards repeatedly sought for it, but always in vain. Mrs. Griffiths and Mr. Raslleigh have also, I believe, never met with more than single specimens: that gathered by the latter, being similar to Miss Everett's, but that by the former much larger, proliferous, and in fruit. In this state, which I have but lately seen, the plant bears a very perplexing resemblance to the variety of $F$. laciniatus, found by Dr. Scott, and described in the first volume of this work, so much so that I am almost tempted to suspect that this variety ought to be separated from $F$. laciniatus and joined to $F$. reniformis, but, without better means of judging, it is impossible to hazard a positive opinion. These two Fuci agree in color and substance; and perhaps there is no other to which the species before us is more naturally allied. The remarkable shape of its leaves seems to keep it sufficiently distinct from all. Of Miss Hill's plant, I have thought it right to give a figure, as being at least a very extraordinary variety. Indeed, I feel rather inclined to differ from this accomplished Lady respecting it, and to suspect that it will hereafter be found to be a distinct species; the differences above mentioned being so numerous and so striking. In texture it rather approaches to $F$. ciliatus.

a, a. F. reniformis, natural size.

b. old, and injured specimen, in fruit.

c. part of the frond, with tubercles, magnified 6.

d. section of a tubercle - - - $\quad 4$.

e. seeds - - - - - - - 1 .

f. fibres? - - - - - - - 1 -

g. plant of var. $\beta$, natural size. 

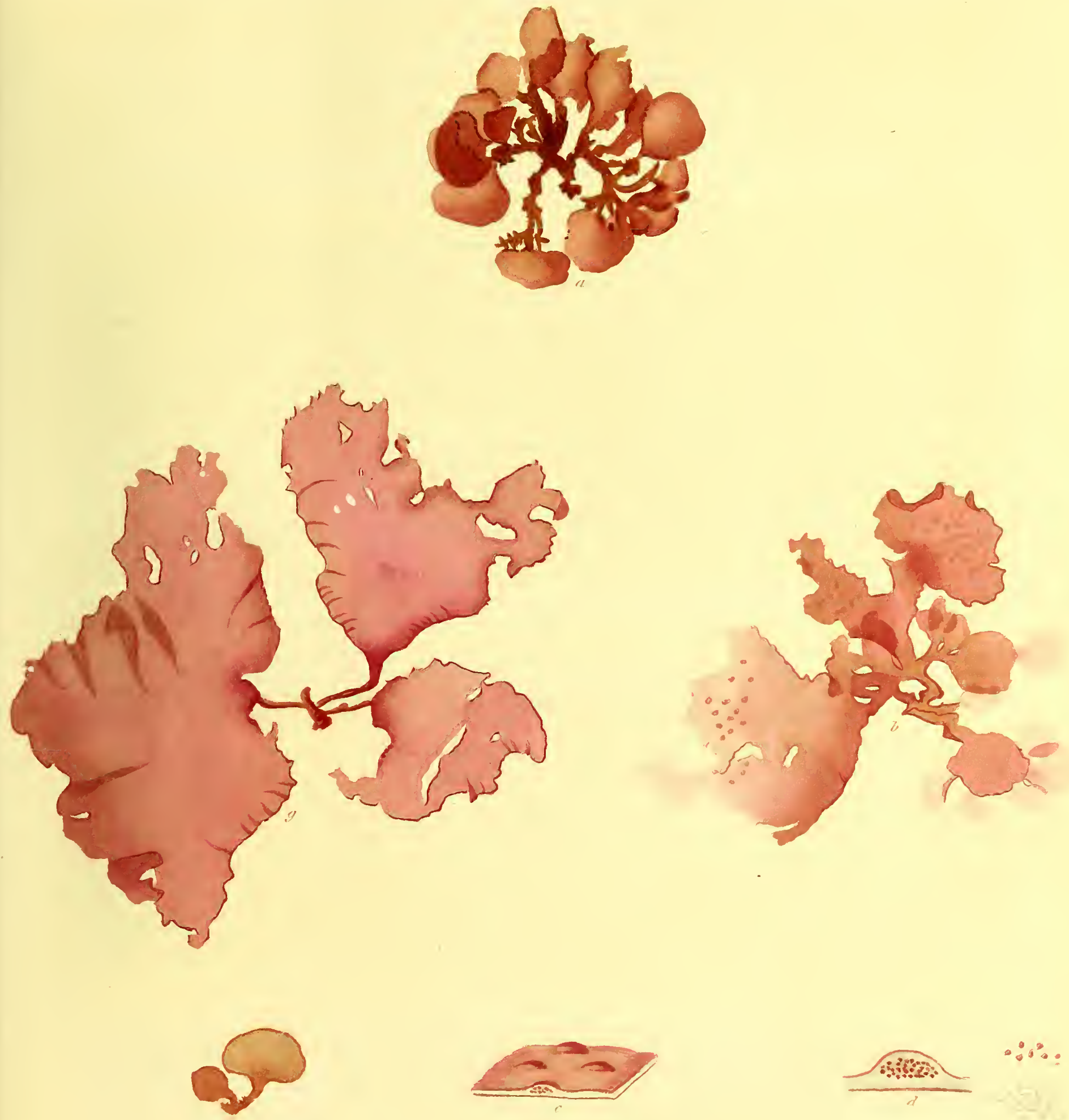

Fucus, fronde carnosâ, planâ, enervi, cuneiformi, simplice, integerrimâ, apice rotundatâ, basi in petiolum brevissimum teretem attenuatâ : seminibus solitariis, ubique per frondem sparsis.

- Fucus edulis. Ner. Brit. p. 57. t. 12. WITH. IV. p. 101. Syn. Fuc. I. p. 180. Eng. Bot. XIX.'t. 1307.

F. dulcis. Gmelin, Hist. Fuc. p. 389. t. 26. (ex icone.)

F. Lactuca. Esper, Ic. Fuc. I. p. 129. t. 64.

F. carnosus. Schmided, Iter. p. 76. ESPER, Ic. Fuc. I. p. 150. t. 76.

F. palmatus. $\beta$. Fl. Scot. II. p. 935 .

Ulva edulis. Fl. Fr. Ed. 2da. II. p. 12.

Haвiтat in Britanniarum oris, præsertim Australibus, haud ita infrequens.-Apud Dieppe, copiosissimè. Schmidel._Gallia in littoribus Oceano objectis. Decandolle.

Perennis? Octobre.

$R_{A}$ DIX callus discoideus, frondi concolor, ejusdemque ferè substantiæ.

FRONDES ex eâdem basi plurimæ, ortu teretes pennæque corvinæ propemodùm crassitie, quæ tamen, quamprimùm ad unius alteriusve lineæ altitıdinem attingunt, fiunt compressæ, et ferè statìm planæ, seque exinde sensìm dilatando mutantur in folium simplex, planum, nervi venarumque prorsùs expers, cuneiforme, longitudine a semipedali ad * pedalem et ultrà, latitudine, ubi maxima, a quadripollicari ad semipedalem variabile; apices rotundati; margines integerrimi, ne minimùm proliferi crispati undulative.- In plantâ, naturâ, si quæ alia, simplice, rarò evenit frondes ullas, nisi juniores, integras indivisasque 'occurrere; de quo optimè habet cl. Stackhousius, "Fucus hic piscibus et vermibus marinis cibus gratissimus tranquillo maris tempore corrosus et semesus, procelloso autem laceratus et divuisus reperitur." Sæpissimè quoque longitudinalitèr in segmenta plurima lineari-cuneiformia enormitèr finditur, quod etiam e casu pendere pro certo habeo :-diversarum ætatum exemplaria semper unà ex eâdem basi proveniunt, observandumque est frondes, quo magis senescunt, eo pro longitudine latiores fieri.

FR UCTIFICATIo semina exigua, sphærica, coccinea, ubique sparsa, in maculas informes congesta, et intra frondem in muco pellucido nidulantia. Vidi exemplaria superficie hìc illic foraminulis, quasi aciculâ factis, pertusa; anne autem hoc aliquid cum fructu commune habuerit nescio.

CoLOR intensè sanguineus, opacus, in plantâ juniore et præsertìm frondis ad basin dilutior: exsiccatce multo intensior, et badius, imò quandòque, nisi luci objiciatur, nigricans : marcescentis lutescens aut virescens, et demùm albicans.

SU BSTANTIA recentis inter coriaceam et carnosam media, crassa, succo plena; per desiccationem dura et cornea ; sin, semel exsiccata, iterùm sit madefacta, ita fit tenera, tantumque aquæ haurit, ut cito marcescat, et, si per radicem inter digitos teneas, raro suum ipsa pondus sustentare valeat,

Ors. Superficies ubique glaberrima et nitida:- tota frons constat e pelliculis duabus tenuibus, quæ inter se includunt gelatinam pellucidam fibris concoloribus anastomosantibus immixtam, et quæ, stirpe pereunte, in frustula solutæ revolvendo aufugiunt, centrum denudatum relinquentes:- planta madida odorem violaceum spirat; et, teste Stackhousio, $\uparrow$ in aquâ salsâ vel fontanâ macerata succum nobilissimi purpurei emittit :- -exsiccata chartæa adhæret.

Difficile sanè foret dictu per quas causas est factum ut Fucus hic depictus, qui nequaquàm infrequentèr in nostris littoribus occurrit, botanicorum notitiam tandiu effugerit; aut, si non penitùs omnes $\ddagger$ latuit, (quod quidem aliquis impossibile crederet,) saltèm sit $\mathbf{a b}$ omnibus eo usque cum $\boldsymbol{F}$. palmato commixtus, ut, priusquàm Stackhousius Nereidem suam ederet, nemo unquam inter auctores nostrates, Lightfootio uno dempto, vel varietatis dignum loco censuerit. Accuratissimus ille Schmidelius primus, ut videtur, rectam de eo sententiam tulit; idemque optimam ejus descriptionem in Itinere per Galliam tradidit, ubi, dum Dieppæ moraretur, recentem nascentemque observandi occasione est fructus. Meliore adhuc usus est Stackhousius, diu Cornubiæ juxta littora incola, qui quoque speciern revera distinctam prædicat, in quo recentiores, nisi fallor; omnes huic uno ore assentiunt. Miror quidem fieri potuisse ut extiterit aliquis qui secùs sentiret; planta enim hæec naturâ habituque aded a $F$. palmato abludit, ut sese primo semper aspectu dignoscendam præstet; attentiùsque inspicienti substantia carnosa et folia cuneiformia nunquam prolifera vel ramosa characteres certissimos per quos utraque ab alterâ facilè distinguitur suppeditant. Hoc licitum sit adjiciam,

me

\footnotetext{
* Persuasum mili labeo lunce Fucum in unolem longè majorem aliquandè accrescere; reperi cnim exemplaria in littore apud Yarmoutl, quæ tantummodo erant fragmenta, sed quæ, si frons figurâ solita est gavisa, duorun triumve pedum longitudiuem certè labuerunt.

+ De hoe Stackhousius, "The most surprizing quality of this plant, and one that will probably render it of service in lying, I discovered by accident. Having placed some of the leaves to macerate in sea-water, in order to procure seeds from it, I perceived on the second day a faint rulby tint, very different from the color of the plant, which is a dill-red, inclining to chocolate color. Being surprized at this, I continued the macerarion, and the tint grew more vivid, till at last it equalled the strongest infusion of cochineal. This liquor was mucilaginous, and had a remarkable property of being of a changeable color; as it appeared a bright ruby, when lield to the light, and a muddy saffion, when viewed in a contrary direction:- This probably arose from a inixture of the substance of the fiond in the liquor. I endeavonred to ascertain its dying powers by the usual process without success, as the quantity of tinging matter was, not sufficient; though, if atteinpted at large, and properly fine lake from an it be niade sufficiently strong." However, an ingenious chemical friend (the Rev. W. Gregor) assures me, he has procured a fine lake from an infusion of it, by means of alum. - Ner. Brit. p. 59 .

‡ Has plantas Hudsonum Lightfootinmque reverà non latuisse me per literas certiorem fecit illıst. D. T. Frankland sie seribendo: “ I never conld persuade Hudson or Lightfoot that $F$. edulis was distinct from $F$. palmatus; when young, it contains a pulp between two membranes, and is quite succulent, and $I$ never could find a single frond that was branched; thongh, when old, it spreads, and becomes rugged and laccrated, which gives it a general appearance of being so."
} 
me paucos cognoscere Fucos qui mutationibus sunt obnoxii minoribus quàm $F$. edulis; illas si excipiảs ab injuriâ aliquâ acceptâ ortas, qua interdùm facit ut exemplaria reperiantur fronde variis in locis, cribri instar, pertusâ; qualia multos botanicos moverunt ut $\boldsymbol{F}$. Clathrum et $\boldsymbol{F}$. Agarum tantummodd hujus synonyma crederent, et ut idem etiam de Sebanâ $F$. bracteati icone existimarent. Tales nunc tolluntur sententize, sed arcta certè interest naturâ inter $F$. bracteatum et $\boldsymbol{F}$. edulem affinitas;. arctissima, si respiciatur substantia, quamvis nulla, si fructus. Hunc in $\boldsymbol{F}$. edulis exemplaribus a Schmidelio lectis primùm detexerunt Weberus Mohriusque, et $a b$ uno eorundem, quod mecum benevolè communicavit illust. Præses de Scheber, hìc ipse delineatum exhibeo. Vix opus est ut dicam $F$. edulem Gmelinianum esse stirpem huic nostræ quàm dissimillimam; et nomen quod illa primitùs acceperat huic nunquam imponi decebat. Restituissem ergo, nisi putarem Gmelini plantam esse eandem, quæ sub $\boldsymbol{F}$. lichenoidis titulo in Herbario Linnæano servatur, sub quo citata in hoc opere reperietur. In errore singulari de $F$. eduli nostro versatur Gmelinus, utpote cujus $\boldsymbol{F}$. dulcis descriptio $\boldsymbol{F}$. palmatum, icones verd $\boldsymbol{F}$. edulem respiciunt; neque ullus de his dubitationi locus datur, nisi quòd frondis margines lenitèr undulatos sistant. Hæ ambæ stirpes paritèr sunt esculentæ; sed, cùm Smithius narret $F$. palmatum frequentissimè Edinæ mandi, quicquid sese de hâc re memorandum offert ejus historiæ subjungendum relinquo.

a. $F$. edulis, magn. nat.

b. frondis portio, in quâ pars epidermidis revolvitur, ut seminum situs appareat, magn, auct. - $\quad 6$.

c. frondis interioris pars - $-\ldots+-4$.

d. semina - - - - - - 1 .

\section{4.-F U C US E D ULIS.}

Fucus edulis, frond fleshy, flat, nerveless, simple, cuneiform, quite entire, rounded at the apex, attenuated at the base into a very short cylindrical petiolus : solitary seeds scattered all over the frond.

Fucus edulis. Ner. Brit. p. 57. t. 12. With. IV. p. 101. Syn. Fuc. I. p, 180. Eng. Bot̀. XIX. t. 1307. F. dulcis. Gmelin, Hist. Fuc. p. 189. t. 26. (ex icone.)

F. Lactuca. Es Per, Ic. Fuc. I. p. 129. t. 64.

F. carnosus. Schmidel, Iter. p. 76. EsPeR, Ic. Fuc. I. p. 150. t. 76.

F. palmatus. B. Fl. Scot. II. p. 935.

Ulva edulis. Fl. Fr. Ed. 2da.1I. p. 12.

Not unfrequent upon the shores of the British Isles, particularly in the Southern counties.-At Dieppe, very abundantly. Schmidel.-Along the coast of France, where exposed to the Ocean. Decandolle.

\section{Perennial? October.}

Rоот, a callous disk, of the same color as the frond, and nearly of the same substance.

FRONDS, numerous from the same base, about as thick as a crow's quill at their origin, but becoming compressed as soon as they attain to the height of a few lines, and almost immediately afterwards flat, when they gradually widen into a simple, flat, cuneiform leaf, quite destitute of midrib or veins, varying in length from half a foot to a * foot, or even more, and in width from four to six inches in its widest part; the apices are rounded; the margins quite entire, never in the least curled or undulated, and still less showing any tendency to become proliferous. No plant can possibly be naturally more simple in its mode of growth than the present, and yet it very seldom happens that specimens are-found with altogether entire and undivided fronds, except in their very earliest stage of existence, for, as Mr. Stackhouse has observed, its tender succulent texture exposes it to the danger of laceration by storms, and its nutritive qualities to the depredations of fishes : it is also very commonly seen perforated in various ways, or divided longitudinally

\footnotetext{
- I am persuaded that this Fucus sometimes grows to a much greater size than is here mentioned; for I have found upon the beach at Yarmontl specimens, which, though mere fragments, must, provided the shape of the frond is regular, as $I$ have reason to suppose, lave belonged to individuals three feet or more long.
} 

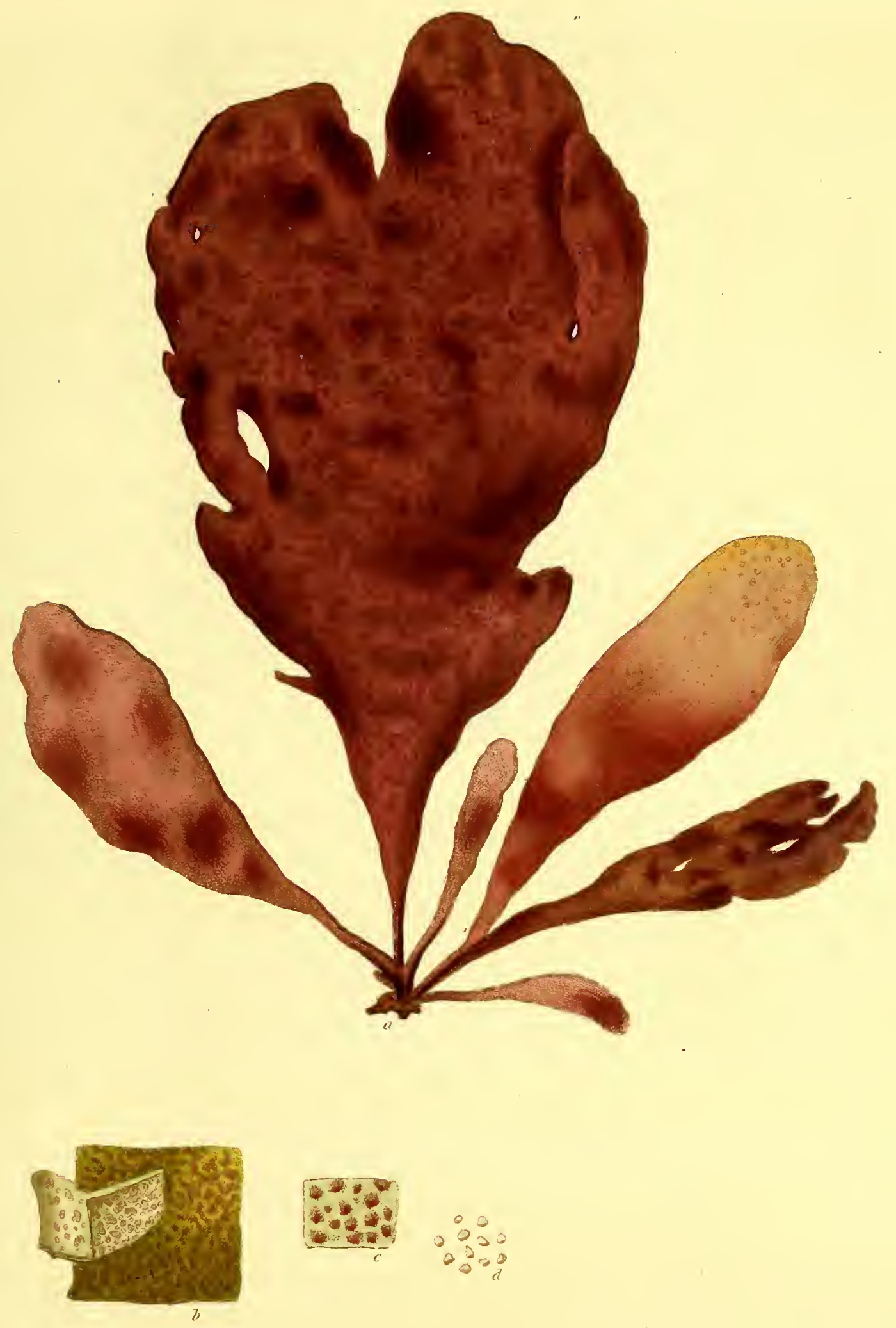

- Herres edritios 

into several irregular lineari-cuneiform segments, so as to appear branched, though $I$ am persuaded that such is merely the effect of accident. Individuals of different ages are constantly observable springing from the same root, and it deserves remark that, the older the plants, the greater is the proportion of their width to their length.

Fructification, minute, spherical, scarlet seeds, scattered all over the frond, placed in small clusters of no certain shape, and situated in the centre of the substance of the plant, in a pellucid mucus:-I have also seen specimens, which were perforated all over, as with minute pin-holes, like the leaves of Hypericum perforatum, but how far these punctures were connected with the fruit I have no means of knowing.

CoLOR, a deep, opaque, blood-red, paler in young plants, and generally so towards the base of the frońd turning much darker by drying, and then approaching to chocolate, or even looking black, unless held to the light: in decay it becomes a dirty light yellow or green, and at last fades to white.

SUBSTANCE, when recent, between coriaceous and fleshy, as thick as neat's leather, and full of noisture; when dry, hard and horny; but, if again moistened, it becomes so tender, and imbibes so much water, that it speedily decays, and can seldom support its own weight, held up by the root.

Oвs. The surface is all over quite smooth and glossy:-the whole frond consists of two very thin pellicles, including a pellucid gelatinous mass, mixed with colorless anastomosing fibres: these pellicles, as the plant decays, break into small pieces, and roll off, leaving the centre naked :- when moist, this Fucus has a strong smell of violets, and, according to Mr. Stackhouse, gives out on maceration either in fresh or salt water a fine purple * dye :-in drying it adheres to paper.

It is difficult to account for the circumstance of this Fucus, which is far from being of unfrequent occurrence, at least upon the shores of the British Isles, having so long $\uparrow$ escaped the notice of all authors upon the subject; or, to speak more correctly, having been so constantly and so entirely confounded with $F$. palmatus, that, previously to the publication of the Nereis Britannica, no British writer, except Lightfoot, ever thought it deserving of being noticed, even as a distinct variety. The accurate and indefatigable Schmidel appears to have been the earliest botanist who well understood it: he has given an excellent account of it in his Tour through France, where, in the neighbourhood of Dieppe, he had an opportunity of observing it abundantly in a recent and growing state. Mr. Stackhouse, whose residence on the coast of Cornwall has given him opportunities in this respect still more favourable, has also declared his opinion in favour of its being completely distinct, and has been followed by most, if not all, the naturalists of the present day. Indeed, it appears to me wonderful how different sentiments could ever be entertained; for, both in its nature and habit, it is so unlike F.palmatus as to be immediately distinguishable at first sight ; and the cuneiform leaves, never either proliferous or branched, as well as the thick flesliy substance, afford characters, which are common to none of the appearances of that Fucus. I may add, that I know of no species liable to fewer variations of shape than $F$. edulis, excepting only such as are the result of injury, among which lias already been reckoned that the frond is occasionally found perforated like a sieve, whence some botanists have entertained the opinion that $F$. clathrus and $F$. Agarum are in reality only synonyms of it. The same has also been thought of Seba's figure of $F$. bracteatus, to which this plant is in its nature very closely allied, though so different in its fructification, which latter was first discovered by Dr. Weber and Dr. Mohr in the specimens gathered by Sclımidel, and is here represented from one of the same, for which I am indebted to the kindness of the President von Schreber. The name, $F$. edulis, having been originally given by Gmelin to a very different species, ought never to have been applied to the present, nor should I have here retained it, had I not reason to believe, that what was first so called belongs to $F$. lichenoides of the Linnæan Herbarium, under which it will be found quoted in this work. The error into which Gmelin has fallen respecting this plant is both singular and unaccountable; for his description of $\boldsymbol{F}$. dulcis evidently belongs, exclusively, to $F$. palmatus, while all his tigures seem to have been designed for $F$. edulis, and admit of no doult, except from being represented with undulated margins. Both these plants appear to be equally esculent, but, as Dr. Snith says, that $F$. palmatus is most commonly eaten in Edinburgh, I have reserved what is to be said upon this subject for my account of that species.
a. F. edulis, natural size.
b. portion of the frond in fruit, with a part of the epidernis rolled back, to shew the position of the seeds, magnified $-\quad-\quad-\quad-6$.
c. part of the interior of the frond - $\quad-\quad-4$.
d. seeds - - - - - - 1.

\footnotetext{
"Upon this subject, Mr. Stacklouse says, " the most suprizing quality of this plant, and one that will probably render it of service in clying, I discovered by accidcut. Having placed some of the leaves to macerate in sea-water, in order to procure seeds from it, I perceived on the second day a faint ruby tint, very different from the color of the plant, which is a dull-red, inclining to chocolate color: Being surprized at this, I continued the maceration, and the tint grew more vivid, till at last it equalled the strongest infusion of cochineal. This liquor was mucilaginous, and had a remarkable property of being of a cliangeable color; as it appeared a bright ruby, when held to the light, and a muddy saffron, when viewed in a contrary direction:- This probably arose from a inixture of the substance of the frond in the liquor: I endeavoured to ascertain its dying powers by the nsual process without snccess, as the quantity of tinging matter was not sufficient ; thougl, if attempted at large, and properly evaporated, it might be niade sufficiently strong. However, an ingenions chemical firicnd (the Rev. W. Gregor) assures me, he has procured a fine lake from an infusion of it, by means of alum."-Ner. Brit. p. 58.

That these plants were not altogether mknown either to Hndson or Lightfoot, I have the autlority of Sir Thomas Frankland for saying; as he writes to me in one of his letters: "I never could persuade Hudson or Lightfoot that $F$. edulis was distinct from $F$. palmatus: when young, it contains a pulp betwcen two membranes, and is quite succulent, and I never could find a single frond that was branclied; though, olien old; it spreads, and becomes rugged and laccrated, which gives it a general appearance of being so."

VOL. II.
} 
Fucus palmatus, frond membranaceous, flat, nerveless, palmated, quite entire at the margin; segments oblong; mostly simple : seeds naked, collected into wide, irregularly shaped spots, scattered all over the frond.

Fucus palmatus. Linn. Sp. Pl. II. p. 1630. Syst. Nat. II. p. 718. Mant. p. 580. Syst. Nat. Ed. Gmel. 1I. p. 1389. Fl. Ang. p. 579. Fl. Scot. II. p. 933. t. 27. Linn. Trans. III. p. 163. Syn. Fuc. I. p. 175. Eng. Bot. XIX. t. 1306. Fl. Norv. II. p. 69. Fl. Ped. II. p. 333. (excl. syn. Raii.)

F. ovinus. Fl. Norv. I. p. 96.

F. caprinus. Fl. Dan. t. 1128 . Esper, Ic. Fuc. I. p. 146. t. 74.

F. rubens. Es PER, Ic. Fuc. I. p. 148. t. 75. (exclusis synonymis.)

F. dulcis. GMELIN, Hist. Fuc. p. 189. t. 26. (ex descriptione.)

F. bulkatus. Fl. Dan. t. 770 ?

F. vel Ulva filipendula. Schnı D L, Iter. p. 76.

F. membranaceus ceranoides. RA11 Syn. p. 46. n. 29.

F. foliaceus humilis palmam humanam referens. MoR1s. Hist. Ox. III. p. 646. s. 15. t. 8. f. 1.

Ulva palmata. Wiтн. IV. p. 123. Fl. Fr. Ed. $2 d a$. II. p. 12.

U. caprina. Fl. Norv. 1I. p. 127. t. 6. f. 4.

Opunzia di membrana finissima, e di color rosso assai vivido. GinanNı. p. 25. t. 25. f. 59 ?

ค. marginifer; frond oblong, mostly simple, margins proliferous.

F. palmatus. $\beta$. Syn. Fuc. I. p. 176.

F. palmatus. Ner. Brit. p. 54. t. 12.

Found abundantly throughout the Northern Ocean, upon the shores of the British 1sles, Norway, Denmark, and France. In the Ocean about Kamtschatka. Gmelin.--Shores of Piedmont. 'Allioni.

\section{Perennial? In the winter months.}

Root, a small, blackish, callous disk.

FroNDS, sometimes solitary, and sometimes clustered, narrow and almost cylindrical at their origin, but becoming compressed as soon as they attain to the height of one or two lines, and thence gradually expanding into a flat leaf, altogether destitute of midrib or veins, varying in length from a quarter of a foot to a foot, and in width from half an inch to two inches; this leaf, with regard to form, is sometimes, and indeed most frequently, elliptical, sometimes linear, and sometimes between linear and cuneifornı ; with regard to ramification, it is either forked, or repeatedly dichotomous, with erect linear branches, or, which is most common, palmated, with three, four, or five segments slightly dilated upwards, and of nearly equal height, which, like the primary ones, vary in being simple, or bifid, or bipartite, or dichotomous, or palmate, of all which, examples are occasionally found upon the same plant: sometimes, too, the frond is altogether undivided: the upper segments are always narrower than the lower ones; the apices, though rather acute, are slightly rounded; the margins are somewhat undulated, generally quite entire, but occasionally proliferous, with small elliptical leaves, mostly simple, though sometimes divided, supported upon extremely short petioli; it sometimes also happens that they are fringed, like $F$. ciliatus, with minute, linear, scattered processes.

*FRUCTIFICATION, seeds scattered all over the frond, but scarcely immersed in its substance, placed in wide irregularly-shaped spots, of a blackish red color, nearly spherical, appearing under the microscope as if composed of two or three parts: mixed with these lie numberless pellucid granules many times smaller than they, indeed so small that the highest power of the compound microscope is insufficient properly to discover their shape.

CoLOR, red, tinged with purplish, turning, from exposure to the light, or from being kept in fresh water, first to a pale dirty green or yellow, and at last to white.

SUBSTANCE, thin, and menibranaceous, but in old specimens thicker, and approaching to coriaceous.

The variety $\beta$ has its frond, in general, either simple, or only bifid at the apex, and has its margins every where proliferous with elliptical leaves, about an inch long, most of them simple, but some forked, attenuated at their bases into extremely short sub-cylindrical petioli.

OBs. The surface of $F$.palmatus is smooth and glossy :- when moistened it has a faint smell of violets :-fructified specimens have, in consequence of the disposition of the seeds in wide spots, a singularly two-colored appearance, those parts of the frond, on which the seeds lie, looking thicker and darker-colored than the rest, which probably arises from the granules above mentioned: the seeds, together with these granules, appear rather to lie upon the surface of the leaf, than to be immersed in the substance of it; for, if touched by a knife, they immediately come off:- tle substance of the frond looks, under a microscope, different from that of $F$. edulis, and is by no means uniform, but every where full of small circular spots, resembling cavities :-in drying it adheres loosely to paper.

Whatever may be the variations of appearance to which the present Fucus is liable, and certainly but few are liable to more, it is a plant of such frequent occurrence, and is so generally known, that it has seldom, if ever, been mistaken

\footnotetext{
* Upon this subject Dr. Goodenough and Mr. Woodward say, "At Weymouth, and elsewhere, we have found $F$. palmatus of a perfectly coriaceous substance, as well as the thinnest membrane. We observed only in these dwarf coriaceous specimens" ( $F$. edulis?) " the true fructification, which is tubercles immersed in the frond, and projecting from it, and opening at the point. In one of our largest specimens, a largish tubercle appears standing upon the surface of the disk, and not immersed: but these tubercles are rarely to be observed. In general the plant shoots out to some length; in this state it has only small seeds like granules (the character of an Ulva) dispersed over the whole frond, 20 that one would conclude it to be an Ulva."
} 


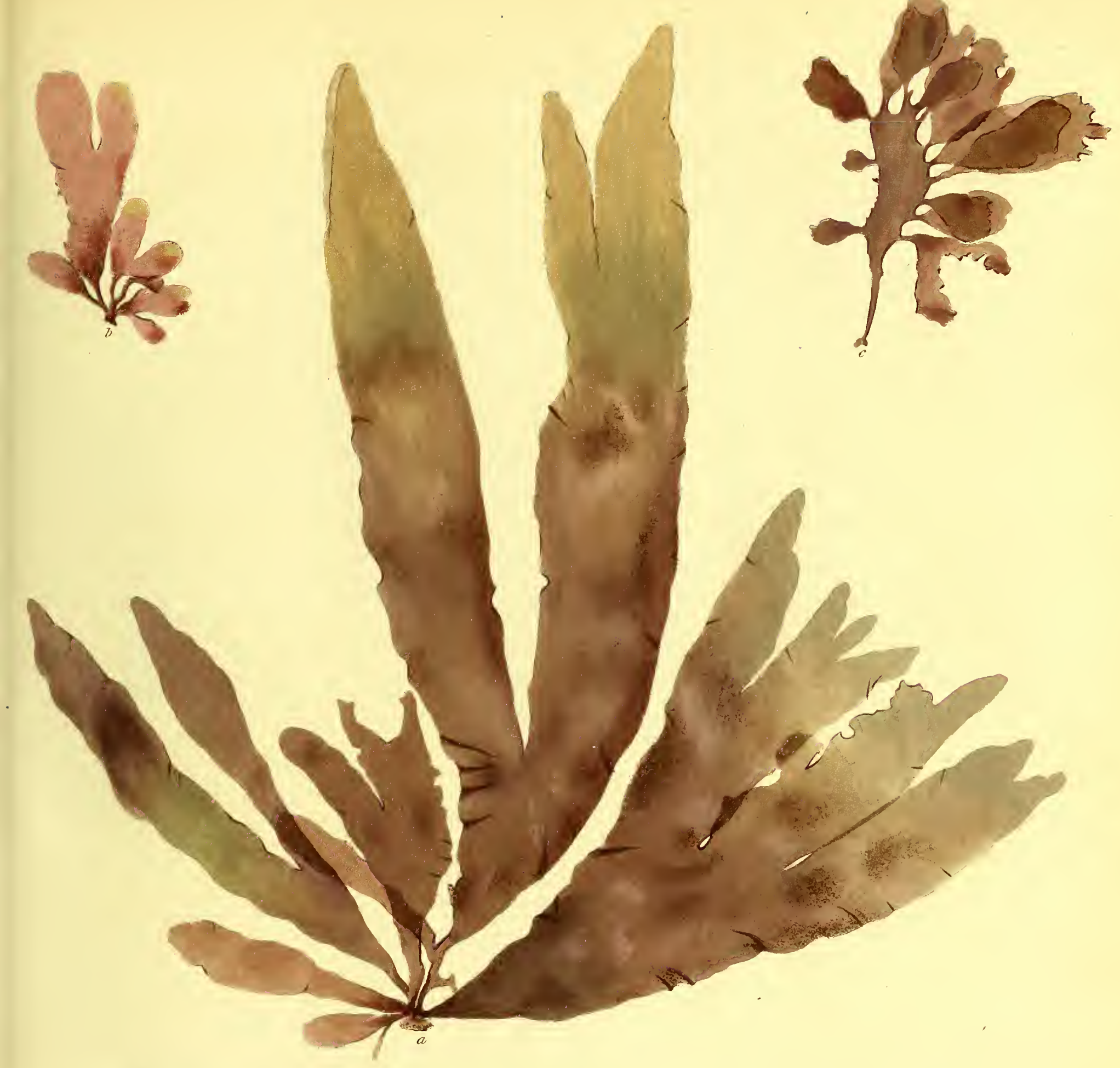



for any other species, * excepting only the subject of the preceding plate, under which are pointed out, and, as I hope, satisfactorily, the characters that separate them from each other. Independently however, of the advantage derived from being thus universally known, there is in $F$. palmatus † something so constant and so peculiar in the form of its segments, as would, in all its changes as to ramification, seldom leave any difficulty in distinguishing it from its congeners, nor did I ever see in it a tendency to run into any other plant, unless, indeed, in some specimens gathered, last summer, by my friends, Mr. Hooker and $\mathrm{Mr}$. Borrer, in Scotland, by the side of Loch Broom, between which and $F$. soboliferus, among which it grew, it seemed impossible to draw a satisfactory line. These specimens, however, did not reach me in a sufficiently perfect state, to enable me to speak with any positiveness respecting them; and I should scarcely have mentioned them, but for the hope of inducing future naturalists, who may visit that part of our island, to ascertain whether they are more properly to be considered a singular small variety of $F$. palmatus, or whether they belong to $F$. soboliferus, or whether they are really intermediate between both. Of the specific difference between these two Fuci $I$ feel it at present impossible to entertain a doubt. There is in the Banksian Herbarium a specimen gathered by Mr. Brand at the Cape of Good Hope, which apparently belongs to $F$. palmatus, but is so covered with small Zoophytes as to be quite disguised, and lias on this account there received the name of F. verrucosus. This specinen agrees in shape with the $F$. bullatus of the Flora Danica, a synonym to which it was scarcely necessary to subjoin a mark of doubt, as $F$. palmatus, when kept in fresh water, often exhibits an appearance of similar tumours upon the frond. Ginanni's figure above referred to is far more questionable. $F$. palmatus is a plant very commonly eaten in different places; with observations upon which subject, extracted from the Flora Scotica, I shall close my account of this species, merely premising that they are at least equally applicable to $F$. edulis. "The inhabitants both of Scotland and Ireland take pleasure in eating this plant; sometimes they feed upon it like a sallad, when fresh taken out of the sea; but the more usual method is first to dry it, then roll it up together, and chew it like a plug of tobacco. And this they do more from the pleasure arising from habit, than from any supposed virtues in the plant itself. The inllabitants also of the islands in the Archipelago, as we learn from Steller, are very fond of this plant. They sometimes eat it raw, but esteem it most when added to ragouts, oglios, and such like dainties, to which it gives a red color, and dissolving, renders them thick and gelatinous, In the Isle of Skye it is sometimes used in fevers, to promote a sweat, being boiled in water with the addition of a little butter. In this manner it also frequently purges." Bishop Gunner states, that in Norway, " it is employed in the fattening of sheep and goats, who betake themselves in great numbers eagerly to the sea-shore at the reflux of the tide to obtain this pleasant food." It is on this account that he has named it $F$. ovinus, about which synonym I am no longer in doubt, having, since the publication of the Synopsis of the British Fuci, had an oppora tunity of consulting the figure in the Acta Nidrosensia.
a. F. palmatus, natural size.
b. young plant
c. small specimen of var. $\beta$.
d. part of the frond in fruit, magnified $\quad-6$.
e. portion of the same - - - - 4 .
f. seeds and granules $\quad-\quad-\quad-2$.
g. seeds - - - - - - - 1 .

\footnotetext{
- It requires to be mentioned that the description of $F$. palmatus in the Linncan Transactions, and in many other works, is purposely drawn up so as to include $F$. edulis also.

+ This holds good to such a degree, that it is difficult, if not impossible, to divide the appearances of $F$. palmatus into distinct varieties; and I eyen doubt whether I have done right in separating the one above described, however different it is from the more common form of the plant.
} 
Fucus, fronde membranaceâ, planâ, enervi, palınatâ, integerrimâ ; segmentis oblongis, simpliciusculis : seminibus nudis, in maculas latas informes congestis, ubique per frondem sparsis.

Fucus palmatus. Linn. Sp. Pl. II. p. 1630. Syst. Nat. II. p. 718. Mant. p. 508. Syst. Nat. Ed. Gmel. II. p. 1389. Fl. Ang. p. 579. Fl. Scot. II. p. 933. t. 27. Linn. Trans. III. p. 163. Syn. Fuc. I. p. 175. Eng. Bot. XIX. t. 1306. Fl. Norv. II. p.69. Fl. Ped. II. p. 333. (excl. syn. Raii.)

F. ovinus. Fl. Norv. I. p. 96.

F. caprinus. Fl. Dan. t. 1128 . Es PER, Ic. Fuc. I. p. 146. t. 74.

F. rubens. EsPe R, Ic. Fuc. I. p. 148. t. 75. (exclusis synonymis.)

F. dulcis. Gatelin, Hist. Fuc. p. 189. t. 26. (ex descriptione.)

F. bullatus. Fl. Dan. t. 770 ?

F. vel Ulva filipendula. Scinidec, Iter. p. 76.

Ulva palmata. Wiтu. IV. p. 123. Fl. Fr. Ed. $2 d a$. II. p. 12.

Ulva caprina. Fl. Norv. II. p. 127. t. 6 . f. 4.

Fucus membranaceus ceranoides. RaII Syn. p. 46. n. 29.

F. foliaceus humilis palmam humanam referens. Mo R1s. Hist. Ox. III. p. 646. s. 15. t. 8. f. 1.

Opunzia di membrana finissima, e di color rosso assai vivido. GinanNI. p. 25. t. 25. f. 59 ?

B. marginifer; fronde oblongâ sub-simplice, marginibus proliferis.

F. palmatus. $\beta$. Syn. Fuc. I. p. 176.

F. palmatus. Ner. Brit. p. 54. t. 12.

Ha вiтat ubique in Oceano Septentrionali, in Britanniarum, Norvegiæ, Daniæ, Galliæ oris, copiosè.-In Oceanø Kamtschatka. Gmelin.-Ad rupes maris Nicæensis. Allioni.

\section{Perennis? Hyeme.}

RADIX callıs discoideus, exiguus, nigricans.

FrondEs nunc solitariæ, nunc ex eâdem basi plurimæ, ortu angustæe et teretiusculæ, sed quamprimùm ad unius alteriusve lineæ altitudinem assurgunt compressæ, seque exinde sensìm dilatantes in folium planum, nervi venarumque expers, longitudine a palınari ad pedalem, latitudine ab unguiculari ad bipollicarem variabile; quoad figuram, nunc, quod quidem sæpiùs accidit, ellipticum, nunc lineare, nunc e lineari cuneiforme; quoad divisionem, nunc bifurcum, nunc iteratis vicibus dichotomum ranis erectis linearibus, nunc, quod maximè vulgare, palmatum segmentis tribus quatuor vel quinque sursùm lenitèr dilatatis sub-fastigiatisque, his quoque, primariorum instar, vel simplicibus, vel bifidis, vel bipartitis, vel dichotomis, vel palmatis, quorum omnium exempla non rarò in unâ eâdemque reperiuntur stirpe: interdùm etiam frons prorsùs est simplex, neque ullâ ratione divisa: segmenta superiora inferioribus semper sunt angustiora; frondis apices acutiusculi, levitèr tamen rotundati ; margines aliquantùm undulati, ut plurimùm integerrimi, sed quandoque proliferi, foliis parvis, ellipticis, simplicibus, vel perraro divisis, brevissimè petiolatis, (quod? insignitèr est in var. $\beta$ conspiciendum) interdùm quoque, $F$. ciliati instar, processubus exiguis linearibus sparsis fimbriati apparent.

* Fructiricatio semina ubique per frondem sparsa, sed vix in ipsius substantiâ immersa, in maculas latas informes disposita, atro-rubentia, enormitèr sphærica, sub lente in duas tresve partes dehiscentia; his immixtæ jacent myriades granulorum pellucidorum, multoties minorum, ad quorum formam ritè dignoscendam summa microscopii compositi vis non satis valet.

Color ruber, purpurascente immixtus, sub-diaphanus, qui tamen, si planta luci objiciatur, vel in aquâ dulci dius servetur, primùm in sordidè virescentem lutescentemve et tandem in album evanescit.

SubSTANTia tenuis et membranacea, in exemplaribus tamen vetustioribus crassior et ad coriaceam accedens.

Var. $\beta$ frondem habet plerumque vel indivisam vel tantummodd apice bifidam, marginibus per totam longitudinem proliferis, foliis ellipticis, circitèr pollicem longis, plerisque simplicibus, quibusdam verò bifurcis, basi in petiolos brevissimos teretiusculos attenuatis.

Oвs. Superficies glabra et nitens:-madefacta odorem angustun violaceum spirat:-exemplaria fructifera ob seminum latas maculas faciem habent insignitèr bicolorem; partes enim eæ quibus semina insident reliquâ fronde sunt crassiores, quod forsan e granulis suprà memoratis pendet, coloremque habent intensiorem :- semina unà cum granulis non in ipsâ frondis substantiâ immersa sed superficiei imposita jacent; si cultri enim acie tangas statìm solvuntur :frondis substantia sub lente ab eâ $F$. edulis diversissima apparet, et nequaquàm est uniformis, sed ubique maculis exiguis pellucidis orbicularibus quasi depressis scatet:- exsiccata chartæ laxè adhæret.

Quales aut quantrecunque sint in crescendi modo mutationes quibus $F$. palmatus ludere solet, non tamen ha obstant quominùs sit species in universum ferè inter botanicos cognita, et quam cum nullâ aliâ commixtam reperio,

\footnotetext{
* De hâc dicunt Goodenovious Woodwardiusque, "Fructificatio etiam variis ludit imaginibus. Modò non Fucum sed Ulvam dieeres, quippe granulis solitariis numerosissimis conspergi videtur. In plantis coriaceis fructificationem Fuci licet detegere, tubercula scilicet in fronde innata, apice dehiscentia.-Hæc perrarò accidunt."
} 
præter * eam in tabulâ præcedente depictam, sub quâ characteres qui utramque distinguunt expositi traduntur. Hoc partìm ex eo pendet quòd vix fieri possit ut planta quæ tam copiosè ubique provenit notitiam effugiat, partìm verò $\mathrm{e}$ formâ segmentorum, in quâ semper inest aliquid sui † proprium, per quod stirps a congeneribus primo statìm aspectu dignoscitur. Viri quidem amicissimi, Hookerus et Borrerus, e Scotiæ Septentrionalis littoribus æestate novissimâ reportaverunt exemplaria quædam prope Loch Broom lecta, quæ mirè inter $\boldsymbol{F}$. palmatum et $\boldsymbol{F}$. soboliferim ambigere sunt visa; sed hæc, utpote non satis adulta nec satis bene servata, silentio hic præteriissem, nisi vellem, aliorum botanicorum in illis regionibus peregrinantium animos isthùc advertere, ut demùm sciamus an sint $F$. palmati varietas exigua, an ad $F$. soboliferum pertineant, an potiùs inter utrumque media hunc cum illo revera conjungendum doceant. Donec hoc fit ipse mihi persuadere nullo modo possum ut dubitem quin hæ stirpes sint toto cælo distinctæ. Servatur in Herbario Banksiano Fuci cujusdam specimen a D. Brand ad Caput Bonæ Spei lectum, quod ab F. palmato nequaquàm diversum videtur, sed adeò est Zoophytis minutis coopertum ut formam prorsùs alienam induerit, et $F$. verrucosi nomen ibidem acceperit. Hoc formâ refert $F$. bullati icon in Florâ Danicâ, quain non sine dubitationis signo adjecto suprà citavi, scrupulosior forsan in hoc quàm quod satis est; quoniam $F$. palmati exemplaria diu in aquâ dulci servata tumores similes per frondem sparsos non rarò ostendunt. Ginannii synonymon longè magis est dubium. F. palmatus in multis locis comeditur, de quo plurima pro more optimè retulit Gmelinus, qua cuncta hic exscribenda existimavi, lectorem modo monens hujusmodi omnia non minùs $F$. edulem quàm $F$. palmatum respicere. " Fucum hunc Hiberni Scotique studiosè siccatum et convolutım assiduò in ore habent et masticant. Masticant antem eum, non quod singularem inesse virtutem illi credant, sed animi causâ, more recepto. Insulas Archipelagi Kurillici inlabitantibus, Stellero oculato teste adnotante, gratissımus est jucundissimusque hujus Fuci cibus, quem sequenti modo præparant. Sumunt rasuram piscis Borsa dictam, coquunt eam satis diu cum exsiccato et minutim concisso Allio ursino, Tscheremscha dicto, post adduut pinguedinem, ultimoque loco, quadrantem horæ antequâm comedunt, Fuci hujus manipulum, qui, præterea quod rubro colore tingat ferculum, totus evanescit, et in pulvis farinaceæ consistentiam jus omne cogit, ita ut baculum ad perpendiculum sustineat, et aeri expositum gelascat. Comedunt etiam recentem plantam. In Insula Skye sudorem excitant violis in sero coctis, vel plantâ marinâ Dulse cum butyro in aquâ bullatâ, quod ultimum simul purgat." Denique cl. Gunnerum auctorem habemus hunc Fucum esse capris ovibusque gratissimum, quamobrem $F$. ovinzm nuncupavit, de quo synonymo non ampliùs dubito, cum iconem in Actis Nidrosensibus datam videndi tandem fuerit oblata facultas.
a. F. palmatus, magn. nat.
b. stirps atate primâ.
c. varietatis $\beta$ parvum exemplar.
d. frondis finctifera pars, magn. auct. - $\quad$ - 6 .
e. ejnsdem portio - - - $\quad$ - $\quad$ - 4 .

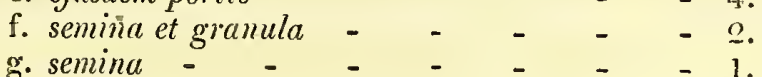

* Nemorandum est plurimas $F$. palmati descriptiones eo ab auctoribus animo esse comparatas ut $F$. edulem simul includant.

$\dagger$ Hoc usque adeo valet ut difficile, imò potiùs impossibile, sit $F$, palmati fornas in varietates distinctas dispertire : dubitemque an rectè fecerim illaw suprà descriptam dividendo, quautumvis longè ał usitatâ plantæa facie abludat. 
Fucus cordatus, frond fleshy, flat, nerveless, simple, between elliptical and roundisa, entire at its margin, rather sharp at the apex, at the base attenuated into a very short compressed petiolus : minute, spherical, immersed, solitary tubercles, scattered all over the frond.

At Banks' Isles, on the North West coast of America. Mr. Menzies.

\section{Perennial?}

Root, a largish, expanded, callous disk, of the same color as the frond.

FRoN Ds, numerous from the same base, narrow and compressed at their origin, thence gradually, but very slowly, widening, till they attain to the height of two or three lines, so as to resemble a stem, then suddenly expanding into a single, simple, flat leaf, altogether destitute of midrib or veins, about a foot long, and six inches vide, of an irregularly cordate shape, or between cordate and elliptical, somewhat acute at its apex, at its margins quite entire and slightly undulated:-in the lower and narrow portion of the frond the margins are remarkably elevated and incurved, and this part consequently looks not only like a stem, but a channeled one.

FRUCTIFICATION, spherical tubercles, smaller than a pin's head, of a tawny color, scattered without order all over the frond, and immersed in the middle of its substance, containing a number of minute, oblong, red seeds, together with pellucid jointed fibres.

Coxor, livid-brown, not without a tinge of purple, transparent, darker when dry, and then looking almost black, unless held to the light.

SubSTANCE, between coriaceous and fleshy, thick, and full of moisture.

Oвs. In drying it adheres slightly to paper, and contracts itself to little more than the half of its original size :if kept in fresh water, it gives out a faint smell of violets :- the specimens which $I$ have seen have in different parts of the frond displayed beautiful bright-blue phosphorescent tints, but whether this is natural to the plant, or proceeds from a tendency to decay, I have no means of judging:- the surface is smootl and glossy.

I have had an opportunity of observing so very few specimens of this Fucus, that $I$ am necessarily unable to speak with any degree of certainty either as to the size it attains to, or to the mode of its growth. Its nearest natural affinity is with $F$. edulis, which it altogether resembles in substance, and in most other essential points, but it differs from it in shape and color, and in these latter respects agrees with Ulva umbilicalis, of which the texture is so completely dissimilar. In its fruit it seems to be unlike both the one and the other, but I can scarcely suffer myself to doubt of the tubercles of $F$. edulis being in reality completely the same, though they have not at present been discovered in an equally perfect state. How far the channeled appearance of the stem-like part of the frond above noticed may not possibly be accidental, must be left to be decided by the observations of future naturalists; and the same with regard to the phosphorescent tints, which I never saw equally brilliant in any other Fucus. If a horizontal section of the frond be placed under the microscope, it is found to be composed of a thin outer coat, including a gelatinous pellucid mass full of anastomosing colorless fibres, such as are represented in the plate lying round the tubercle.

a. F. cordatus, natural size.

b. part of the frond, magnified - - $\quad 6$.

c. the same, with the epidermis thrown back, to shew the situation of the tubercles - $\quad 5$.

d. tubercle, surrounded by the fibres of the frond 3. e. seeds 

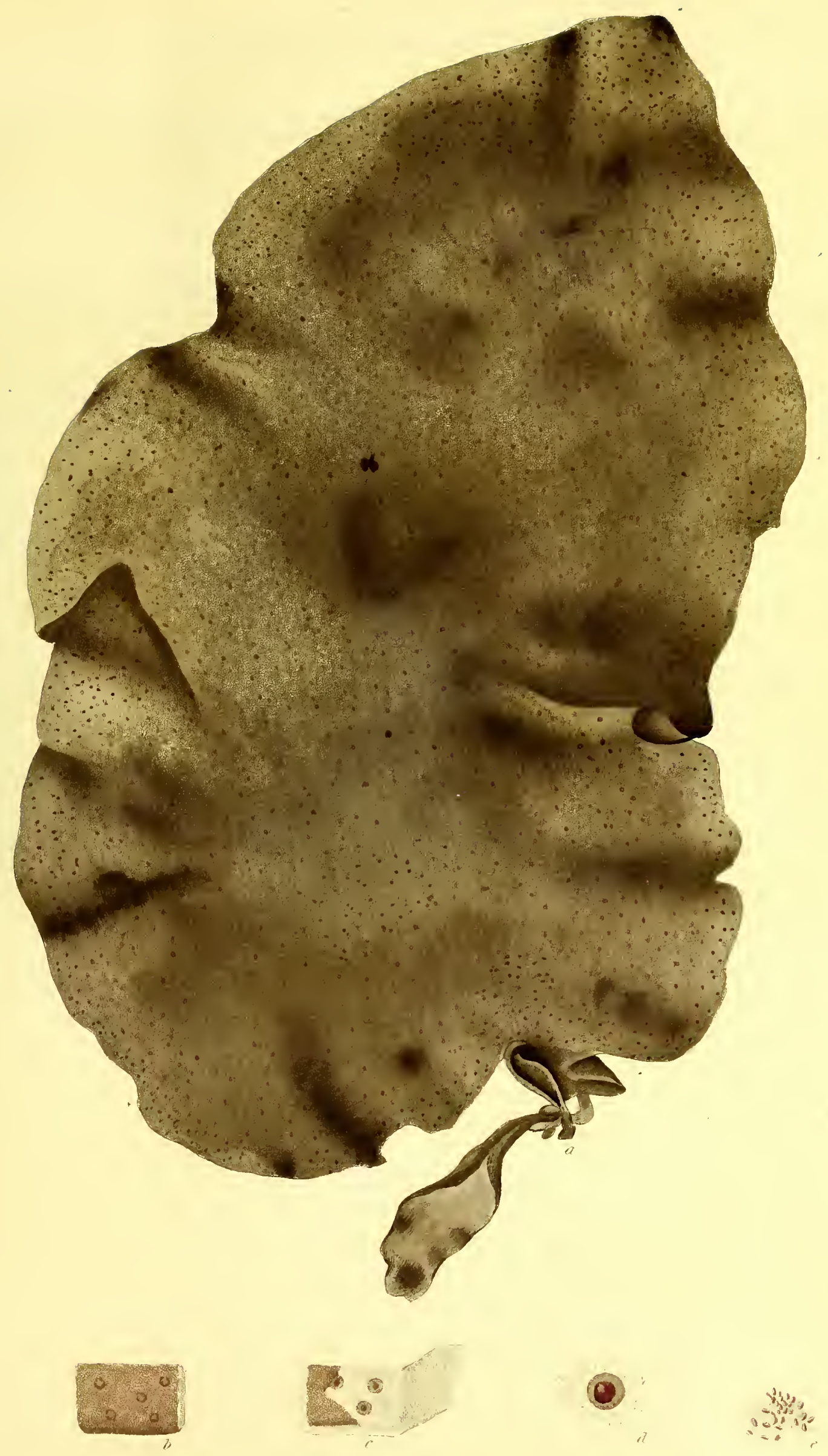

(2): 

Fucus fronde carnosâ, planâ, enervi, simplice, elliptico-subrotundâ, integerrimâ, apice acutiuscula, bải in petiolum brevissimum compressum -attenuatâ : tuberculis exiguis, sphæricis, solitariis, immersis, ubique per frondem sparsis.

Ha Bitat apud “ Banks' Isles," in Americæ Borealis oris Occidentalibus. D. Menzies.

\section{Perennis?}

RADIX callus majusculus, dilatatus, frondi concolor.

FroNDES ex eâdem basi plurimæ, ortu angustæ et compressæ, exinde se sensìm, lenissimè tamen, ad trium quatuorve linearun altitudinem dilatantes, ut stipitem simulent, ibi subitò explanatæ in folium unicum, simplex, planum, nervi venarumque prorsùs expers, pedem circitèr longum, et semipedem latum, formæ enormitèr cordatæ, vel cordato-ellipticæe, apice acutiusculum, margine integerrimum et lenitèr undulatum :-in illâ inferiore frondis parte, ubi angustior est, margines insignitèr sunt elevati et incurvi, unde fit ut folium stipiti concavo insidere videatur.

FructificAt Io tubercula sphærica, aciculæ capite minora, fulva, ubique per frondem sparsa, et in mediâ ejus substantiâ immersa, semina includentia plurima, minutissima, oblonga, rubentia, unà cum fibrillis pellucidis articulatis.

Co Lo R livido-fuscus, non sine purpurascentiâ quâdam, diaphanus, exsiccatæ multo intensior, ut ferè nigrescat.

Substantia inter coriaceam et carnosam, succosa, et crassiuscula.

Oвs. Exsiccata chartæ laxè adhæret, et ad dimidium ferè magnitudinis se contrahit :-in aquâ dulci servata odorem angustum violaceum spirat:- -specimina ea quæ ego vidi hìc illìc colorem pulcherrimè cæruleum iridescentem ostendebant, sed an hoc plantæ sit proprium, an tantummodo in marcescente sit observandum, in dubio relinquere cogor:superficies glabra et nitida.

De Fuco, cujus perpauca modò exemplaria videndi hactenus est data facultas, inane prorsùs foret, si quis aliquid certi quoad crescendi modum vel quoad molem in quam interdùm excrescit proferre conaretur; nihilque amplius nobis licet quam ut ea quæ sunt oculis subjecta fidelibus mente paritèr fidâ referamus. Species hæc naturâ est arctissimè $F$. eduli affinis, cum quo substantiâ suâ aliisque maximi momenti notis convenit, sed discrepat frondis figurâ et colore diversissimo, quæ utraque habet cum Ulvâ umbilicali communia, stirpe cæteroquin toto cælo dissimili. Quoad ad fructificationem attinet, tàm $a b$ hâc quàm ab illo recedere videtur, sed nequeo non suspicari hanc discrepantiam esse in illo modo situm, qudd $F$. edulis tubercula nondùm æquè perfecta sese oculis nostris obtulerint, sed, hoc facto, illorum $F$. cordati omnind similia reperientur. Anne frondis ubi stipitem refert canaliculata facies, quæ suprà memoratur, plantæ sit revera propria, an potiùs a casu quodam pendeat, aliis dijudicandum relinquere cogor, neque magis aliquid ex tripode asserere ausim de coloribus illis iridescentibus, quos in nullo alio Fuco paritèr pulchros splendidosve vidi. Ex hujus stirpis frondis horizontalitèr sectæ assulâ lenti subjectâ liquet totam constare ex epidermide tenuissimâ nembranaceâ gelatinam includente pellucidam, fibris albis anastomosantibus repletam, quales in tabula hâc nostrâ circa tuberculum dispositæe delineantur.

a. F. cordatus, magn. nat.

b. frondis pars, magn. auct. - - - - 6 .

c. eadem, epidermide revolutâ, ut tuberculorum situs in conspectum veniat - - $\quad 5$.

d. tuberculum, fibris e frondis centro desumptis cinctum - - - - - - 3 .

е. semina - - - - - - - 1 . 
Fucus esculentus, frond membranaceous, flat, midribbed, simple, ensiform, entire at its margins, supported upon a short, cylindrical, pinnated stipes ; pinnæ fleshy, distichous, oblong, flat, nerveless, containing numerous, pyriform, immersed seeds.

Fucus esculentus. Linn. Mant. p. 135. Fl. Lápp. p. 364. (excl. syn. Raii.) Syst. Nat. II. p. 718. Syst. Nat. Ed. Gmel. II. p. 1389. Fl. Dan. t. 417. Fl. Scot. II. p. 938. t. 28. Fl. Ang. p. 578. Wiтh. IV. p. 93. Syn. Fuc. I. p. 104. Eng. Bot. XXV. t. 1759. Esper, Ic. Fuc. II. p. 30. t. 126. F. fimbriatus. GMelin, Hist. Fuc. p. 200. t. 29. f. 1.

F. tetragonus. Linn. Trans. III. p. 140.

F. teres. Linn. Trans. III. p. 140.

F. pinnatus. Fl. Norv. I. p. 96.

F. Scoticus latissimus edulis dulcis. RaII Syn. p. 46. n. 30.

In the Northern Ocean, and on the shores of the British Isles.-Coast of Scotland, not uncommon. Lightfoot.Plentiful in Cornwall.-Isle of Anglesea. Rev. H. Davies.-Near Belfast. Mr. Templeton,-Rocks of Bantry Bay. Miss Hutchins.-Sea near Kantschatka. Gmelin.

Perennial. In the Spring.

Rоoт, consisting of numerous, cylindrical fibres, about the thickness of a crow's quill, growing in a radiated manner, horizontal, but slightly incurved at their apices, three or four lines long, hard, nearly ligneous, some simple, others branched.

... FRON D, arising from the centre of the fibres of the root, always solitary, varying in length from * two to twelve feet or more, furnished with a simple undivided stem, as thick as a crow's quill, or a small goose-quill, which in its lowest parts is naked and resembles a stipes, but, when it reaches the height of three inches in some specimens, and of six in others, becomes winged with an ensiform membrane, so that the frond from that part resembles a simple, ensiform leaf, varying in width from two inches to a foot, every where linear, except at the base, which is either cordate, or gradually attenuated in a lanceolate form, and at the apex which is acuminated, but this latter is very seldom found uninjured, perhaps, indeed, never, except in the earliest stage of its growth; the margins are quite entire; the surface of the frond is beautifully undulated, and, what is remarkable, not less so near the midrib than at the margin, frequently also it is spotted all over with very numerous minute perforations, from which issue extremely minute tufts of white fibres :- the naked part of the stem, from a small distance from the base to a still smaller one from the leafy membrane, is beset on both sides with distichous, horizontal +pinna, standing close to each other, flat, quite destitute of midrib or veins, some nearly linear, others oblong, others gradually widening upwards, so as to be of an elongated cuneiform shape, and not less varying in point of length from one to seven inches, and in breadth from a line to an inch and half, always attenuated at their bases in such a manner as to appear as if attached to the stem by a very short petiolus, and there of a thick fleshy substance, but growing gradually more thin as they widen, and ending in rounded membranaceous apices; below these the stem is cylindrical, in the part to which they are attached is compressed, and as soon as it becomes winged becomes also quadrangular, which form it afterwards preserves throughout its whole length, together with an uniform width of about two lines, and a substance considerably greater than that of the leaf.

TFUCTIFICAT1ON, situated in the pinnx, (which at that time are of a darker color than common, and incrassated, but retain their usual shape,) scattered all over them, consisting of small, narrow, pyriform, pellucid seeds, internally dotted, having on their largest extremity a white transparent globule, apparently of a different substance from the rest: they lie in immense quantities immediately under the surface, crowded together, and placed parallel to each other, svith their sharp ends pointing inward, but, as far as I have seen, without any intermixture of fibres, or any pores for them to escape through.

CoLOR, a pale, transparent, olive-green, turning darker from drying; always glossy.

SubSTANCE, in the stem, cartilaginous, thickish, tough, and flexible; in the leaf, thin, and membranaceous; so extremely tender in the young plant, that it can scarcely be handled without injury, but in full grown specimens approaching to cartilaginous, and having a certain degree of elasticity: if kept out of water it is alvays remarkably Haccid.

Ов. In drying it does not adhere to paper.

The excellent authors of Observations upon the British Fuci have, in the Linnaan Transactions, divided F. esculentus into two species, to wlich they have given the names of $F$. teres and $F$. tetragonus; and they have pointed out $\$$ such striking characters of distictiou between them, that, were these only permanent, there could be no question of

dheir

* According to Gmelin it attains to the length of twenty ells.

$\uparrow$ These pinnce are not to be found in the plant in an early stage of its growtil, and they seldom make their appearance till it has attained to the height of two feet, but this varies in different individuals. In the tour which Mr. Sowerby and I made through Cornwall in 1799 , we found a specimen four feet long still unprovided with them, and scarcely exlibiting any rudiments of then.

¥ The figure of this plant in English Botuny, which is excellent, is erroneous in representing the seeds as solitary and separated by short intervals, instead of which they lie so closely crowded together that the whole surface of the pinnælooks, under the microscope, merely like a continued mass of them; if the plant be kept too long in fresh water, the epidermis decays and melts away, and the seeds thus escape, as in $F$. lumbricalis and $F$. Filum, of which latter the fruit, which was only detected last month, exactly resembles that of $F$. esculentus.

$\$$ "In the first place, they are not found in the same place, the tetragonus is met with in the Isle of Man, where teres does not make its appearance : teres is found iu the Isle of Anglesea, and in many places on the uorthern coasts of England and Scotland, both east aud west, where 


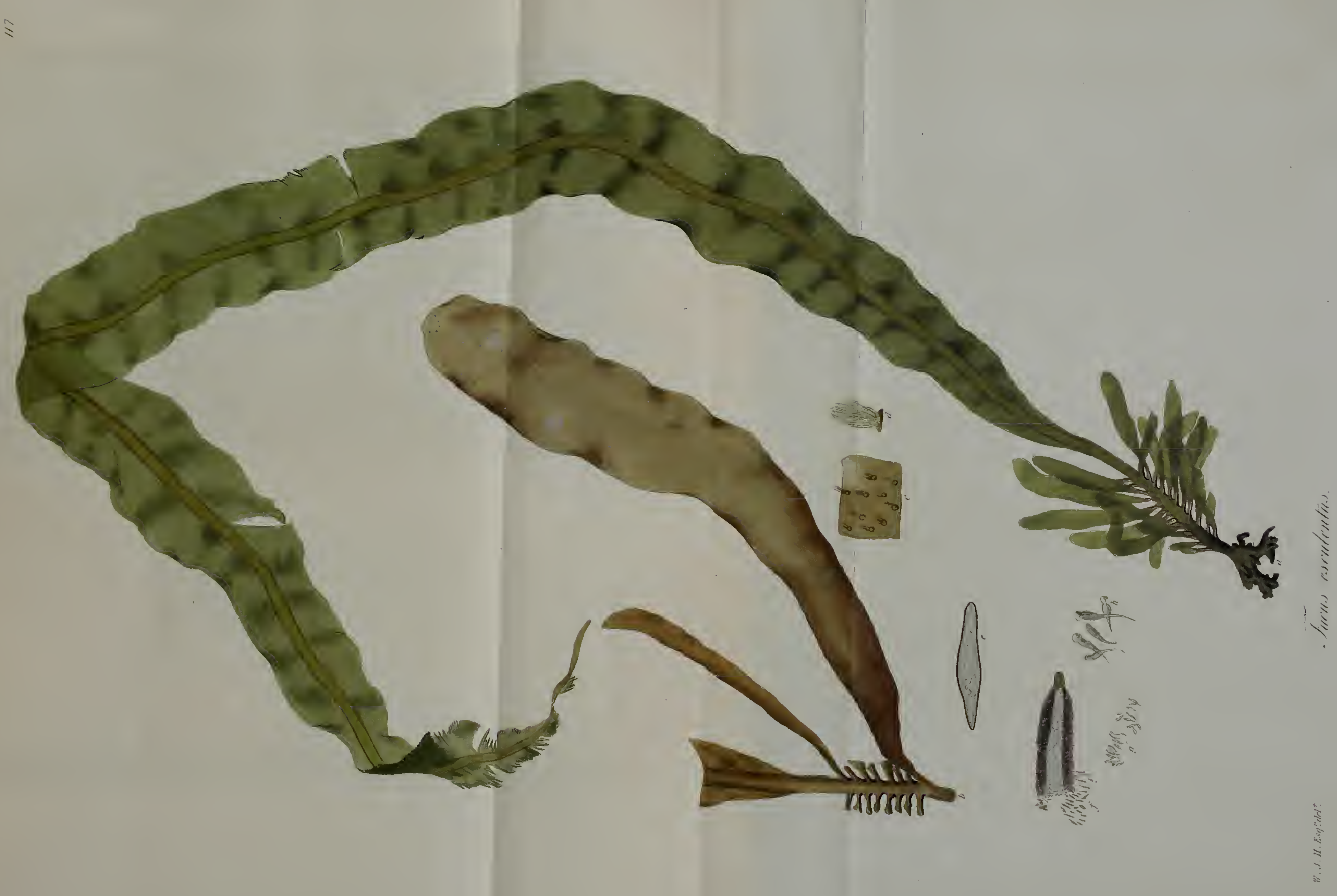



their being sufficient to establish the propriety of this separation in such a manner as could not fail to be satisfactory to the most sceptical naturalist. Unfortunately, however, the remarks, which I have had an opportunity of making upon this plant in its place of growth, will not allow me to coincide with them; nor can I even find any character on which I dare rely for persisting, as in the Synopsis of the British Fuci, in regarding these appearances as distinct varieties; though I am most ready to admit that different specimens differ materially from each other, and that the small ones found by Rev. Hugh Davies in Anglesea, which, without reaching above two or three feet in length, or two inches in width, have thick, horny, nearly linear, pinnæ, and a remarkably cartilaginous texture, are extremely dissimilar to those of the coast of Conwall, in which, notwithstanding their far greater size, the substance is more thin, and the pinnæ are peculiarly dilated and membranaceous at the apices. As, however, in $F$. ovalis, which has by most botanists been divided in the same manner, so in $F$. esculentus the most opposite appearances pass so imperceptibly into each other, that it is impossible to draw a line between them. The fructification of this Fucus, after having long eluded the observation of Naturalists, was at length discovered by my very acute young friend, Mr. James D. Sowerby, who obligingly furnished me with the means of adding it to the present plate. The plant at the time of fruit seems to undergo no cliange that is visible to the naked eye, excepting only the darker color of the pinnæ, which, on dissection, are found not to be of an uniform substance, as when barren, but remarkably thickened towards the surface. There is no species of Fucus at present known with which it is possible that $F$. esculentus should be confounded; its leaf-like midribbed frond and short pinnated stem affording immediate marks of distinction. In Gmelin's figure it is represented as fixed to a rock without any visible root, but, in his description, that learned author justly concludes from analogy, that it must be furnished with a fibrous one. The specimens received by him from Kamtschatka were also destitute of pinnæ, and appear, from what he says, to have had the folds of the leaf much inore conspicuous than in ours. He suggests a question, whether the fruit may not possibly be generated in these, as in F. saccharinus, to which he seems to have been led by an observation of Steller's, that they are wet with a viscid moisture. Mr. C. Fothergill found upon the coast of the Orkney Islands a variety of $F$. esculentus, with the frond twisted spirally throughout its whole length, and Mr. Hooker and Mr. Borrer last summer gathered there a specimen of the same; but it is so much injured, that I can do no more than mention it as an extraordinary appearance. This plant is much eaten in Scotland; the parts employed for that purpose are the midrib, stripped of its membrane, which is extremely sweet, and the thick part of the pinnæ, which are called Keys. These latter, however, are only brought to market when thick and fleshy, never when thin and membranous. It goes by the name of Daberlocks. According to Lightfoot its proper season is September; and he also observes, that it is recommended in the disorder called a pica, to strengthen the stomach and restore an appetite.

a. F. esculentus, natural size

b. part of the stem of a large plant, with a single pinna.

c. portion of the frond, to shew the perforations and tufts of fibres, magnified - $-\quad-6$.

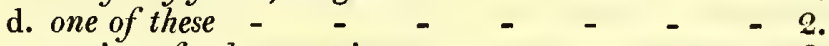

e. section of " barren pinna - - $\quad$ - $\quad-6$.

f. section of a fructified one $\quad-\quad-\quad-6$.

g. seeds - - - - - - - - 4 .

h. some of the same - $\quad-\quad-\quad-\quad-1$.

tetragonus has no place. Tetragomus has a square stalk or rib, teres a roundish one; tetragonus has the base of the frond rounded and sub-cordate, as is expressed in Gmelin's figure, teres has it very much attenuated, as may be seen in Mr. Lightfoot's representation. In tetragonus the little leaves at the base of the froud are tinick and somewhat cartilaginous, in teres they are membranaceous. Tetragonus is found growing above the low-water mark, teres always just within the low-water mark. Tetragonus is by the greater."-Linn. Trans. p. 141. 
Fucus, fronde membranaceâ, planâ, costatâ, simplice, ensiformi, integerrimâ, stipitatâ ; stipite abbreviato, terete, pinnato ; pinnis carnosis, distichis, oblongis, planis, enervibus, semina pyriformia inımersa includentibus.

Fucus esculentus. LinN. Mant. p. 135. Fl. Lapp. p. 364. (excl. syn. Raii.) Syst. Nat. II. p. 718. Syst. Nat. Ed. Gmel. II. p. 1389. Fl. Dan. t. 417. Fl. Scot. II. p. 938. t. 28. Fl. Ang. p. 578. Wrтн. IV. p. 93. Syn. Fuc. I. p. ?04. Eng. Bot. XXV. t. 1759. Esper, Ic. Fuc. II. p. 30. t. 126.

F. fimbriatus. GMELIN, Hist. Fuc. p. 200. t. 29. f. 1.

F. tetragonus. Linn. Trans. III. p. 140.

F. teres. Linn. Trans. III. p. 140.

F. pinnatus. $F l$. Norv. I. p. 96.

F. Scoticus latissimus edulis dulcis. RaII Syn. p. 46. n. 30.

Ha Biт at in Oceano Septentrionali, et Britaniiarum ad oras.-In Scotiæ littoribus, haud infrequens. Lightfoot. -Iu Cornubiâ, copiosè.-In Insulâ Monâ. D. H. Davies.-Prope Belfast. D. Templeton.-In rupibus Sinûs Bantry Bay. Dna Hutchins.-In mari Kamtschatico. Gmelin.

Perennis. Vere.

RADIx fibrosa, e fibris constans plurimis, teretibus, pennæ corvinæ ferè crassitie, radiatìm dispositis, lorizontalibus, apice lenitèr incurvis, tres-quatuor-lineas longis, duris, sub-lignosis, simplicibus ramosisque.

Fross fibrarum radicalium e centro orta, semper solitaria, in *longitudinem nunc duorum nunc duodecim et ultrà pedum porrecta, instructa caule simplice indiviso, pennæ corvinæ aut anserinæ minoris magnitudine, qui basin versus denudatus stipitis faciem præ se fert, sed quandò ad altitudinem in his trium in illis sex a radice pollicum attigit fit alatus membranâ ensiformi, ut frons exinde folium referat simplex, ensiforme, latitudine a bipollicari ad pedalem variabile, ubique lineare, excepto ad basin, quæ nunc cordata, nunc elongato-lanceolata evadit, et quod juxta apicem: sensim attenuetur; hic autem rarissimè, et forsan nunquam nisi in primæ æatatis individuis, illæsus reperitur; margines integerrimi; frondis superficies pulcherrimè undulata, neque hoc minus juxta costam quàm ad margines accidit, sæpe quoque satis copiosè pertusa foraminulis exiguis fibrarum albarum fasciculos perbreves emittentibus:-utrinque caulem obsident, ab exiguo a basi ad minus a membranâ foliaceâ intervallum, †pinna, seu ligula, distichæ, horizontales, approximatæ, planæ, nervi venarumque prorsùs expertes, formæ nunc propemodùm linearis, nunc oblongæ, nunc sensim sursùm dilatatæ ut elongato-cuneiformes sint, quoad longitudinem $a b$ uno ad septem pollices, et quoad latitudinem ab uıâ lineâ ad sesquiunguem incertæ, basin versus semper ita attenuatæ ut per petiolum brevissimum. cauli affigi videantur, atque ibi substantiæ incrassatæ, exinde quo magis dilatantur eo tenuiores fiunt, et in apices rotundatos membranaceos desinuut; caulis infra has teres, ubi collocantur compressus, et quamprimùm fit alatus tetragonus evadit, atque substantiam membranâ multoties crassiorem et latitudinem circitèr bilinearem ad apices usque servat.

† Fructificatio in pinnis, quæe tunc colorem habeit intensè fuscum, et aliquantùm sunt incrassatæ, ita tamen ut formam pristinam semper servent, sita, et ubique per illos sparsa, e seminibus, constat exiguis, elongato-pyriformibus, pellucidis, intùs punctatis, capitulo albo sphærico, substantiæ, ut videtur, diversæ coronatis, sub superficie latentibus, copiosissimis, fibris, quantum vidi, nullis interpositis, porisque per quos effugiant nullis.

CoLOR dilutè olivaceo-viridis, diaphanus; exsiccata intensior; semper nitidus.

Substantia in caule cartilaginea et crassiuscula, lenta, tenax; in folio tenuis; stirpis junioris membranacea atque tenerrima, et vix sine injuriâ tractanda, adultạ ad cartilagineam accedens, et vi quâdam elasticâ dọnata, sẹd extra aquam servate semper flaccida.

OBs. Exsiccata chartæ non adhæret.

Viri optimi, Goodenovius Woodwardiusque, in Socielatis Linnaana Actis F. esculentum in duas species dispertiendum docuerunt, quarum unam $F$. tetragoni alteram $F$. teretis nomine salutaverunt, $\S$ characteribus simul qui has invicem distinguunt ita dilucidè cautèque expositis, ut, dummodò hi semper stabiles manerent, nemo, quantumvis Pyrrhonius, dubitare possit quin summo sint hæ stirpes jure pro diversissimis habendæ. Eo itaque magis piget quodd nequeam amicis in hoc assentire; imò quòd, cautiùs perpensis observationibus de hâc plantâ in loco natali institutis,

necesse

* Ad viginti ulnarum longitudinem protendi perhibet Gmelinus.

+ Hæe pinnce frustra in stirpe juniore quæruntur, et sese rarò monstrant pritusquâm ad dtrorum pedum altitudinem adoleverit; tale autem in diversis individuis variabile; et quum Cornubiæ oras, A. D. 1799, eomitante D. Sowerby, peragrarem, exemplar quadripedale reperimus, his nondum instrictnm, et vix rudimentis pullulans.

$\ddagger$ Icon hujus Fuci in "English Botany," exteroquin optima, in hoc errat, quòd semina solitaria et intervallis brevibus sejuncta exlibeat; sunt au tem é conirario hrec adeò densissinè conferta ut to ta pinnarum superficies nihil aliud quàm horum eongeries sub lente videatur:-si stirps diutiùs æquo in aquâ dulci retineatur, epidermis marcescit et deglubitur, et semina libera evadunt, quod et in $F$. Filo, eujus fiuetus, ejus $F$. esculenti simillimus, est in mense modò proximo detectus, et in $F$. lumbricali aecidere solet.

$\$$ "In the first place, they are not found in the same place, the tetragonus is met with in the Isle of Man, where teres does not make its ap. pearance : teres is found in the Isle of Anglesea, and in many places on the northern coasts of England and Seotland, both east and west, where tetragonus has no place. Tetragonus has a square stalk or rib, teres a roundish one; tetragonus lias the base of the frond rounded and sub-eordate, as is expressed in Gmelin's figure, teres has it very much at tenuated, as may be seen in Mr. Lightfoot's representation. In tetrugonus the little leaves at the base of the frond are thiek and somewhat cartilaginous, in teres they are membranaccous. Tetragonus is found growing above the lo'w-water-maik, tores always just within the low-water-mark, Tetragonus is by fir the greater." Limn. Trans. III. p. 141. 
necesse mihi videatur discedere de sententiâ in Fucorum Britannicorum Synopsi relatâ, faterique me notam reperire nullam, quâ satis niti possum ut $\boldsymbol{F}$. tetragonum et $\boldsymbol{F}$. teretem hìc pro distinctis varietatibus enumerarem. Neque tamen is ego sum qui inficias eam plurimum inter diversa exemplaria interesse discrimen, multùmque discrepare ea quæ apud Insulam Monam legere solet D. H. Davies, quorum longitudo vix duọs tresve pedes, latitudo rarǒ dı̣os pollices exuperat, quorum textura insignitèr est cartilaginea, et quorum pinnæ angustæ linearesque crassæ sunt atque propemodùm corneæ, ab iis Cornubiæ rupium incolis, quibus moles quidem multoties major, substantia vero tenuissima, et pinnarum dilatatarum apices membranacei. Accidit autem in hoc Fuco, sicut in $\boldsymbol{F}$. ovali (ipso quoque in duas species ab auctoribus plerisque diviso) ut facies illæ variorum individuorum discrepantes nullâ certâ definiendæ sint lineâ; sed characteres, in quibus discrimen ponitur, maximè in his manifestos, in illis paullatìm imminutos evanescere. Botanicorum oculos aufugiens diu indetecta latuit $F$. esculenti fructificatio, quam demùm nuperrimè detexit juvenıs acutissimus, J. D. Sowerby, cujus per amicitiam est factum ut in hâc tabulâ delineatam exhibeam. Aded usque hic Fucus primo statim aspectu a congeneribus discrepat ut nullo modo sit timendum ne cum aliis commisceatur; frondis enim ensiformis costatæ stipes brevis pinnatus notam, quæ per se ad distinguendum sufficit, et quæ nulli est, vel tyroni, prætermittenda, suppeditat. Gmelinus, qui nunquam ejus radicem viderat, stirpem sine ullâ basi dilatatâ repenteve rupi affixam in icone suâ depinxit; rectè tamen in descriptione ex analogiâ colligit radice fibrosâ gaudere. Pinnis etiam caruerunt exemplaria ab ipso e Kamtschatka accepta, quibus frons magis quàm in nostris undulata fuisse videtur; quoniam de his refert, " "limbi frondium mirum in modum crispi et plicatiles, fimbriarum ad instar, quibus indusia porrigere solemus nostra, plicis scilicet a costâ versus extrema limborum excurrentibus." Quærit idem de fructificatione; "au generatur snucus prolifer in plicis, ut in saccharino? Stellerus dicit, quod viscositate quâdam madeant." In Orcadum oris legit olim D. C. Fothergill F. esculenti exemplar, fronde per totam, longitudinem spiralitèr tortâ; et simile quoque in iisdem locis æstate proxinâ reperierunt Hookerus Borrerusque, quod mecum amicissimè, pro more, communicaverunt; sed ita læsum mancumque ut nihil sit de illo dicendum, nisi quòd varietas sit summopere singularis. 'Scoti hanc stirpem sæpe comedunt; vescentes costâ, quæ suavissima est, membranâ denudatâ, et pinnarum, quas Keys nominant, parte crassiore. Has autem tum modó, quum crassæ sunt et carnosæ, in foro exponunt. Membranaceas tenuesque spernunt. Planta apud hos Daberlocks audit. Lightfootius tradit maximè tempestivè in Septembri legi, eundemque habemus auctorem adhiberi in morbo quodam, pica dicto, ad stomachum confirmandum cibique appetentiam excitandam.

a. F. esculentus, magn. nat.

b. stirpis majoris stipitis pars, pininâ unâ residuá.

c. pars frondis poris pertuse fibrarum fasciculos emittentibus, magn. auct. $\quad-\quad-\quad 6$.

d. fibrarum fasciculus - $\quad$ - $\quad-\quad$ - $\quad$ - 2 .

e. pinna sterilis horizontalitèr secta - $\quad-\quad-6$.

f. pinna fructifera horizontalitèr secta - $\quad-\quad-6$.

g. semina - - - - - - - - 4 .

h. eadem - - - - - - -5 - 
Fucus lichenoides, frond sub-gelatinous, cylindrical, filiform, much and irregularly branched; branches patent, nearly of equal height, acuminated, generally forked at their apices with short divaricated seginents : tubercles hemispherical, sessile, scattered all over the frond.

Fucus lichenoides. Herb. Linn.

Fucus lichenoides. var. GMELIN, Hist. Fuc. t. 8. f. 2.

B. edulis; frond thin, flexuose, scarcely three inches high.

F. edulis. Gmelin, Hist. Fuc. p. 113. Syst. Nat. Ed. Gmel.II. p. 1382.

In the sea about Ceylon. Herb. Linn.- $\beta$ at $J$ affnapatam. Hon. Frederick North.

Rоoт, a small callous disk.

Fronds, numerous from the same root, cylindrical, filiform, from three to six inches long, about the thickness of a crow's quill, much and irregularly branched from their very base; lower branches long, upper ones gradually shorter and shorter, so that the tops of all are nearly level, slightly curved, some alternate, others growing in alternate clusters, two or three arising together from the same side of the frond, and then as many from the opposite one, all of them beset with others arranged in the same manner, and these again with others, each series being shorter and thinner than the one it succeeds; the whole of the branches are patent, or form at their origin a rounded angle, and are remarkably acuminated at their apices, where they are mostly forked, with very short divaricated segments.

Fructification (which I have seen oniy in the var. $\beta$ ) consisting of roundish, sessile tubercles, scattered all over the frond, smaller than turnip-seed, containing a mass of very minute, oblong, dark-red seeds.

CoLOR, in those specimens which I have seen, a pale semitransparent yellow, but I am quite ignorant what it in the fresh plant, though most probably red.

SUBSTANCE, intermediate between cartilaginous and gelatinous, tender, full of moisture, and slimy.

The variety $\beta$, apparently, does not attain to more than three inches in height, and has a frond remarkably flexuose, more thin than that of $\alpha$, and less branched:- - the color too is quite white :-in other points they agree.

Oвs. This plant, when moistened, imbibes a great deal of moisture, and, consequently, in drying shrinks to but little more than half its proper size, but does not adhere to paper.

The name of $\boldsymbol{F}$. lichenoides has been by different botanists given to four very dissimilar species of Fucus, all of which are connected, though at different points, with the unwieldy genus of Lichen. By Dr. Goodenough and Mr. Woodward it was applied to the $F$. pygmaus of Lightfoot, a plant, which, from its mode of growth, and, still more, from its general appearance, eminently deserves this appellation, and of which the fructification is such that it may almost be considered as doubtful to which of the two families it most properly appertains; insomuch that Micheli has actualiy described it as a Lichen, and Dr. Acharius, in his Methodus Lichenum, has done what is in effect the same; his Stereocaulon confine being in all probability only a variety of it. It must not, howcver, be left unnoticed that that able author, though he has arranged it with the Lichens, candidly avows his doubts how far it properly belongs to that tribe. Dr. Esper, in his Icones Fucorum, (I. t. 50.) has figured a Fucus by the title of $F$. lichenoides, which is so called with scarcely less propriety than the last mentioned, but which, instead of rescmbling the smaller Lichens, is most nearly allied to the section termed by Acharius Physcia, and particularly to L. Prunastri; while the species representcd in the plate before us, the $F$. lichenoides of the Linnean Herbariun, claims its affinity to the Tricharia of the same author, and is far from bcing unlike some specimens of L. usneoides or sarmentosus; and the plant called by Desfontaines $F$. lichenoides in the Flora Atlantica, the $F$. viscidus of Forskal, approaches so closely to the Cladonia, that in a dried state it might be mistaken for one of them. Of these four Fuci I have preferred retaining the appellation of lichenoides to the third; not because it is more applicable to it than to the others, but because the first and last are known among botanists by the names given them by the authors who primarily described them; and, because the second docs not appear to me equally well to answer to the plant so called by Gmelin, upon which the appellation was originally bestowed, and to which it ought, consequently, to be preserved; but, unfortunately, in this, as in many other instances in the work of this excellent naturalist, it is no longer possible to deternine with certainty what he intended. His own figure and description do not exactly accord: the latter speaks of a plant with a frond every where flat, the former seems designed to represent one that is cylindrical, and what he has in the enumeration of his plates called a variety of it, appears to be the same as that which is here delineated. The largest specimen of the present plate, for which I am indebted to Dr. Smith, is preserved in the Linnæan Herbarium : for the smaller one, I have to acknowledge my obligations to the Honourable Frederick North. I cannot entertain a doubt of this being the true $F$. edulis of Gmelin, not only because it agrees with his description, which is by no means written with a happy precision, but because $I$ do not find that any other species of Fucus is eaten in Ceylon, or the neighbouring parts of India. The figure given by Rumphius is too imperfect to be quoted, and might be considered as designed for a fragment of Lichen islandicus: upon the esculent properties of this Fucus, it is recorded by Gmelin, that it is eaten in the East Indies, being merely macerated, or washed in fresh water, and then squeezed, so as to remove a considerable part of its mucilage and saltness, after which it is taken raw with Atsiar or Dabbo Dabbo, or a sauce prepared with lemon-juice and a little ginger. It may also be dried after it has been macerated, and in that state be preserved a long time, and cooked gently at any future opportunity; but, if boiled too violently, or kept too long in lemon-juice, it loses most of its goodness, and nearly melts 


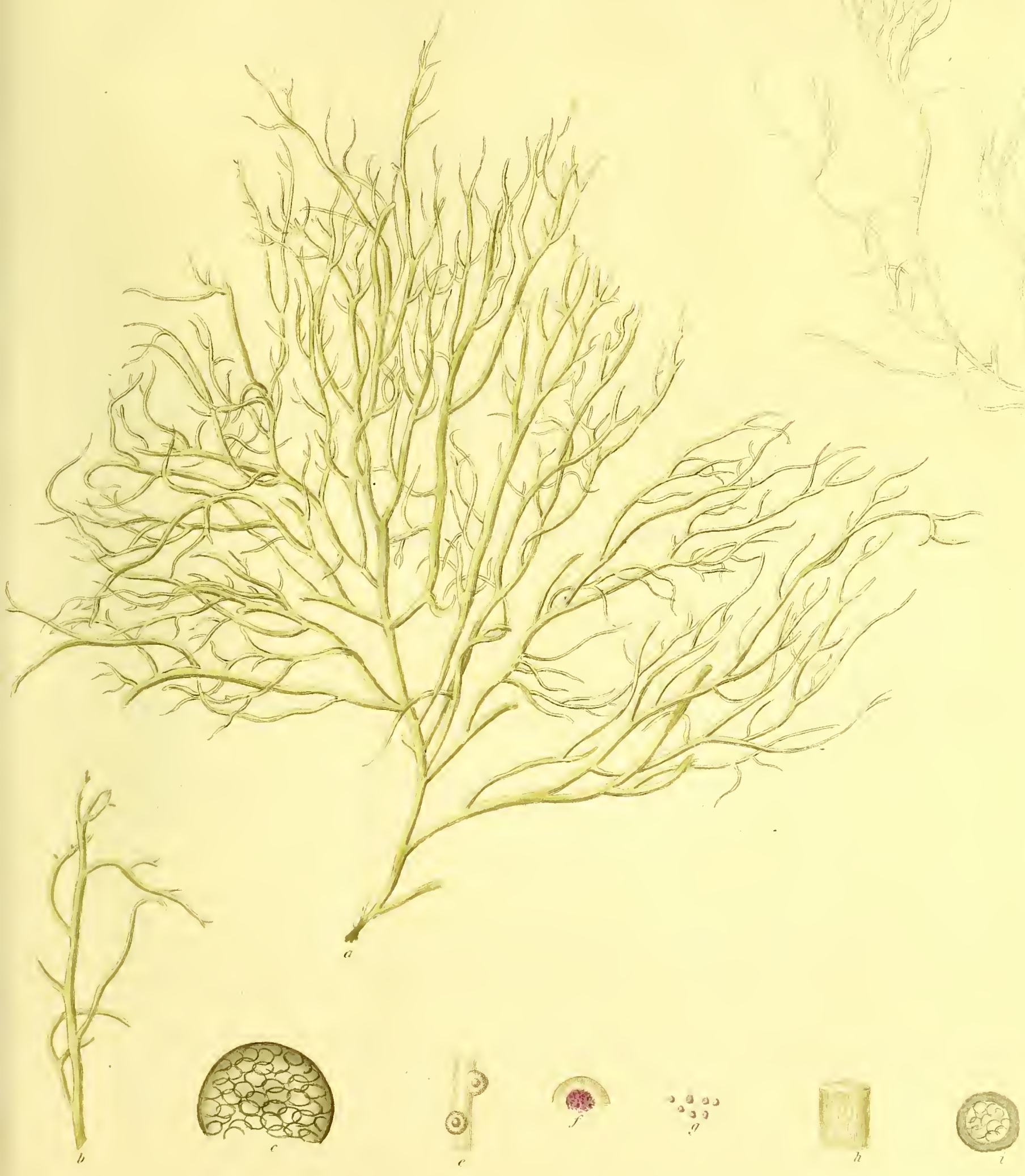

cyerese lirderunerites 

away into a mucus.* The same author observes, that it requires to be investigated how far the famous Hirundines esculente, whose nests the Chinese have taught the Indians and Europeans to esteem such great dainties, take, according to the generally received opinion, the materials for these nests from the present or similar plants, a question to be determined by observations in the places of their growth, and by chemical experiments. The nearest affinity of $F$. lichenoides is with the var. $\varepsilon$ of $F$. confervoides, from which it differs principally in its gelatinous substance, its flexuose branches destitute of short setaceous ramuli, and its bifid apices with divaricated segments.

a. F. lichenoides, natural size.

b. small branch, magnified - $\quad-\quad-6$.

c. horizontal section of the stem - $\quad-\quad 2$.

d. var. $\beta$, natural size.

e. part of the frond, with tubercles, magnified 6.

f. section of a tubercle - - - - 4 .

g. seeds - - $\quad-\quad-\quad-\quad-\quad-1$.

h. part of the stem - $\quad$ - $\quad$ - $\quad$ - $\quad$ - 4 .

i. horizontal section of the same - $\quad-\quad 3$.

* Not having Rumphius's work at hand, I do not know how far any of these observations are copied by Gmelin from it, but I suspect they are. M. Joinville, in a letter to Mr. North, accompanying specimens of this Fucus, says, " en la faisant bouillir dans l'eau on obtint une Gelée que vous vous rappellerés avoir trouvé fort agréable. J'ai oui mettre en avant l'idée qu' elle sert en grande partie au petit Alcyon des Isles de l'Est à faire son nid, dont on fait, comme vous savés, une excellente soupe. J'ai en effet observé dans ces nids des filaments qui ressembloient parfaitement à cette algue qu' on a nommé Mousse de Jafnapatam."

\section{8.-F U C U S L I C H E N O I E S.}

Fucus, fronde sub-gelatinosâ, terete, filiformi, ramosissimâ; ramis patentibus, sub-fastigiatis, acuminatis, apice plerumque bifurcis, segmentis brevibus divaricatis: tuberculis hemisphæricis, sessilibus, ubique per frondem sparsis.

Fucus lichenoides. IIerb. Linn.

F. lichenoides. var. GMEL1N, Hist. Fuc. t. 8. f. 2.

ß. edulis; fronde tenui, flexuosâ, vix tripollicari.

F. edulis. GMrL1N, Hist. Fuc. p. 113.

Ha вiт ar in fundo maris Zeylanici. Herb. Linn.- $\beta$ apud Jaffnapatam. D. F. North.

RADrx callus exiguus, discoideus.

FroNDES ex eâdem radice plurimæ, tcretes, filiformes, palmares, vel sesquipalmares, pennæ corvinæ circitèr crassitie, a basi usque ramosissimæ; rami inferiores elongati, superiores sensìm breviores, sub-fastigiati, lenitèr curvati, nunc alterni, nunc alternatìm subsecundi (scilicet duobus tribusve ex hoc et mox totidem ex illo latere ortis) aliis eodem modo dispositis obsiti, et hi rursùs aliis, utrâque serie præcedente breviore et tenuiore; omnes sunt patuli, vel sinum habent rotundatum, et omnibus apices sunt insignitèr acuminati, plerumque bifurci, segmentis perbrevibus divaricatis.

Fructificat1o (quam in var. $\beta$ modò vidi) e tuberculis constat subrotundis, sessilibus, ubique in fronde sparsis, Brassica Rapa semine minoribus, seminum minutissimorum oblongorum intensè rubrorum congeriem includentibus.

CoLor, quis sit in recente planè nescio, forsan tunc ruber, in iis quæ vidi exemplaribus stramineus fuit et subdiaphanus.

Substant1A inter gelatinosam et cartilagineam media, tenera, succosa, lubrica.

Var. $\beta$, ut videtur, rarò ad majorem quàm trium pollicum altitudinem attingit, et frondem habet insignitêr flexuosam, tenuiorem quàm $\alpha$, et ininùs ramosam :- color quoquè omninò albus:--in cæateris conveniunt.

Oss. Planta madefacta plurimum aquı imbibit, atque idcirco exsiccatione ad dimidium ferè magnitudinis contrahitur, chartæ vero non adhæret. 
Quatuor sunt Fucorum species quæe omnes F. lichenoidis nomen a botanicis acceperunt, et qua omnes immensum, uti nunc constituitur, Lichenis genus diversis in locis attingunt. Inter has ita a Gocdenovio Woodwardioque nuncupatur $F$. pygmaus Lightfootii, planta quæ ob crescendi modum habitumque insignitèr hujus tituli meret, et quæ fructu est instructa tali, qualis efficit ut jure inter utrumque genus ambigere censeatur. Hanc revera pro Iichene descripsit Michelius, atque idem ferè in Methodo Lichenum fecit Acharius, cujus Stereocaulon confine est verisimillimè ejus varietas. Fatetur tamen ipse se dubitare utrum rectè fecerit hoc Plantis Lichenosis associando. Esperus, contrà, in Fucorum Iconibus (I. t. 50.) sub F. lichenoidis nomine depinxit stirpem cui vix minùs aptè quàm $\boldsymbol{F}$. pygmao talis titulus quadrat, sed quæ tantum abest ut Lichenes minores referat ut potiùs Physrias Acharianas, et præsertìn Lichenem Prunastri referat. Longè ab utrâque harum recedit stirps in hâc nostrầ tabulâ delineata, F. lichenoides, Herb. Linn. cui interest summa cum ejusdem auctoris Trichariis affinitas, neque malè refert aliquâ Lichenis usneoidis vel Lichenis sarmentosi exemplaria. Quarta demùm ejusdem nominis planta, in Florâ Atlanticâ a Desfontainesio descripta, est $\boldsymbol{F}$. viscidus Forskalii, Cladoniis facie externâ ita conjunctus ut facilè aliquis exsiccatum pro unâ harum præteriret. His ex omnibus selegi tertiam cui $F$. lichenoidis servaretur nomen, non quia magis est illo quàm reliquæ digna, sed quia prima atque ultima per titulos olìn ab inventoribus inditos jamjàm inter botanicos innotuerunt; neque secunda ita bene respondere videtur $\boldsymbol{F}$. lichenoidi Gmelini, quem, cùm prinus hâc appellatione frueretur, eandem retinere decet. In hoc autem, sicut in aliis quibusdam operis Gmeliniani locis, facultas nulla superest ritè dijudicandi quæ sit planta quam in animo habuerit auctor, descriptio enim et icon nequaquàm inter se conveniunt, illa frondem ubique planam prædicans, hæc teretiusculam exhibens ; quod maximè est in tabulâ suprà citatâ manifestum, ad quam stirps hæc nostra potissimùm accedit. Maximum illud hìc adumbratum exemplar in Herbario Linnæano servatur; alterum viri nob. D. Frederici North benevolentix acceptum refero, de quo nullus dubito quin sit verus $F$. edulis Gmelini, cùm quia congruit ejus descriptioni, quæ concinnitate caret, tùm quia nulla alia, quantum reperio, Fuci species in Zeylonâ vel in Indiæe regionibus vicinis cibi ad locum adhiberi solet. Quicquid igitur de hoc tradidit Gmelinus exscribendum putavi. "Plurima hujus Fuci pars in Indiis Orientalibus cruda editur, ac modò maceratur, vel abluitur in aquâ recente, dein exprimitur, ut maxima pars materiæ mucosæ et salsæ abeat, ac dein cruda editur cum Atsiar vel Dabbo Dabbo seu intinctu præparato e succo Limonum et pauxillo Zingiberis; elegantem præbet inter dentes strepitum. Macerata etiam siccatur, tuncque aliquandiu servari et lenitèr in cibum coqui potest. Si nimis vehementèr coquatur, vel niuis diu in succo Limonum deponatur, plurimam gratiam perdit, et ferè in mucorem deliquescit." Adjungit idem auctor; " accuratiùs * expiscandum est, num celeberrimæ illæ Hirundines esculenta, quarum nidi in tantis deliciis, præeuntibus Sinensibus, apud Indos et Europæos habentur, ipsam niclorum materiam ab hoc Fuco, vel e plantis huic similibus desumunt, prouti putatur; expiscandum id est per experimenta in loco natali instituta, et per chemica."-Arcta intercedit $F$. lichenoidi cuu $F$. confervoidis var. \& affinitas, a quâ præcipuè dignoscitur per substantiam gelatinosam, per ramos flexuosos ramulis brevibus setaceis carentes, et per frondis apices bifidos, segmentis divaricatis.

a. F. lichenoides, magn. nat.
b. ranus, magn. auct.

\footnotetext{
* Cùm Kumphii IJerbarium Amboinense mihi non sit ad manus, nescio an hxe de F. Jichunoilis indole esculentâ ex illo opere partim penitusre der rompserit Gmelinus, sed ita fecisse suspicor. D. Joinville, in epistolâ ad D. North linjıs Fuei, quem Mlousse de Jafnapatam vocat, excmplaria includente sic scribit, " en la faisaut bouillir dans l'ean on obtint une Gelée que vous vous rappellerés avoir trouvé fort agréablc. J'ai oui mettre en avant l'idée qu' elle sert elı grande partie au petit Alcyon des Isles de l'Fst à taire son nid, dont on fait, comme vous sav's, une excellente sompe. J'ai en effet observé dans ces nids des filaments qui resscmlicient paifaitement à cette algue qu' on a nonmié Monsie de Jafnapatam."
} 
Fucus, fronde sub-gelatinosâ, viscidâ, terete, filiformi, dichotomâ, ramisque lateralibus horizontalibus sparsis instructâ; ramis ramulisque fastigiatis, divaricatis, apice bifurcis, segmentis reflexis.

Fucus viscidus. Forsk ̊̊ , Fl. Agypt-Arab. p. 193. Syst. Nat. Ed. Gmel. II. p. 1389.

F. lichenoides. $\quad F l$. Atl. II. p. 427. (exclusis synonymis.)

F. distentus. Rotн, Cat. Bot. III p. 103. t. 2.

Habitat Constantinopoli. Forskal.- In mari prope Porto-Farine apud Tunetanos. Desfontaines. Prope Gades. D. Prof. Mertens.-In Mari Rubro. Vicecomes de Valentia.

RADIX callus explanatus, discoideus.

Fro N s solitaria, teres, filiformis, tres sexve pollices longa, basi pennæ corvinæ crassitie, exinde sensim, lenissimè tamen, ad apices usque attenuata, ipsum prope ortum bifurca, et posted dichotomiis multoties repetitis divisa, intervallo inter singulas incerto, segmentis horizontalibus, vel horizontalitèr patulis; præter quod alii etiam rami hic illic horizontales abbreviati e primariorum lateribus oriuntur, ipsi quoque dichotomi, ipsique aliis minoribus eâdem ratione dispositis instructi; apices omnibus bifidi, furcis perbrevibus, divaricatis, reflexis ; rami plerumque fastigiati.

Fructificatio, a me numquam visa, constat, teste Desfontainesio, globulis terminalibus.

CoLOR, secundum Forskalium et Desfontainesium, totus albus, et talem modd ipse vidi; Rothius verd in radice flavum, in fronde infernè fuscescentem, cæterùm pallidè viridem seu rubicundum perhibet.

SubSTANTI A gelatinosa, viscida, siccate fragilis.

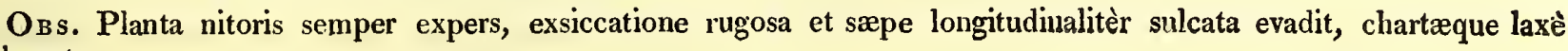
adhæret.

* Perbrevis quidem est descriptio quâ F. viscidum in Florâ EEgyptiaco-Arabicâ designavit Forskalius, neque in plantis cryptogamicis dignoscendis multum prodesse solent breves descriptiones, quæ sæpiùs tenebras quàm lucem Historiæ Naturali prætendunt. Res autem hic alitèr se habet; tollit enim omnem de stirpe Forskalianâ dubitationem notula hæc unica adjecta, " Lichenis rangiferini facies ;" quoniam talis inter has duas plantas intercedit similitudo, ut non modò figura magnitudo ramorumque dispositio utrique sit eadem, verùm etiam, præsertìm $F$. viscidum exsiccatum si spectes, colore insigni glauco-cinerascente absque nitore conveniant. Huic quidem repugnat unicum $F$. distenti Rothiani exemplar olim a Mertensio acceptum, cujus color est per siccitatem in obscurè viridi-fuscum mutatus, in quo ab omnibus aliis a me visis individuis ablusit; hoc autem, cùm nihil ejusmodi memoret Rothius, in descriptione sub silentio transivi, e casu quodam pendere verisimillimum ratus. Quod de $\boldsymbol{F}$. viscidi fructificatione Desfontainesius tradidit non dubitavi suprà exscribere, certior factus per exemplaria ab ipso cum Stackhousio communicata de ejus synonymo, quod, nisi hoc sit factum, pro ancipite habuissem, quoniam F. lichenoidem Esperianum Gmelinianumque citat, quorum neutrum ad hanc nostram stirpem referendum existimo. Ipse quoque Desfontainesius, sicut Forskalius, memorat sui Fuci cum Lichene rangiferino similitudinem, cui adjecisse licuisset, inesse in exsiccato quiddam quod facilè primo aspectu scrupulos injiceret, rectiùsne Fucis Lichenibusve sit annumerandus. Arctissimam habet cum specie in tabulẩ præcedente depictâ affinitatem, a quâ differt substantiâ alienâ, ramis primariis dichotomis, ramulisque e lateribus ortis horizontalibus. Exemplar hìc depictum nobilissimi Vicecomitis de Valentia comitati acceptum xefero.

a. F. viscidus, magn. nat.

b. ramus, magn. auct. $\quad-\quad-\quad-6$.

\footnotetext{
- Quod sequitur est tota hæc descriptio:-

"Fucus viscı Dus; caulibus teretihus, dichotomis, ramosis, fastigiatis, bicornibus."

"Totus albidus. Facie et magnitudine Lich. rangif. Viscidus, etiam intus."
} 
Fucus viscidus, frond sub-gelatinous, viscid, cylindrical, dichotomous, and throwing out lateral, horizontal, scattered branches ; branches and ramuli of equal height, divaricated, forked at their apices, with reflexed segments.

Fucus viscidus. ForsKån, Fl. Egypt-Arab. p. 193. Syst. Nat. Ed. Gmel. II. p. 1389.

F. lichenoides. Fl. Atl. II. p. 427. (exclusis synonymis.)

F. distentus. Rотн, Cat. Bot. III. p. 103. t. 2.

At Constantinople. Forskal. In the sea near Porto-Farine, on the coast of Tunis. Desfontaines.-Near Cadiz. Professor Mertens. - In the Red Sea. Lord Valentia.

Root, an expanded, callous disk.

Fro ND, solitary, cylindrical, filiform, from three to six inches long, about the thickness of a crow's quill at the base, and thence : gradually, but almost imperceptibly, tapering to the apices, forked immediately at its origin, and afterwards repeatedly dichotomous at irregular intervals, with the segments horizontal, or between horizontal and patent; besides this, other short 'horizontal branches grow here and there out of the sides of the primary ones, like which they are themselves dichotomous, and beset with others still smaller, disposed in the same manner; the extremities of all are bifid, with exceedingly short, divaricated, reflexed segments; the branches are mostly of equal height.

Fructification, which I have never seen, consists, according to Desfontaines, of terminal globules.

CoLor, in all the specimens. I have met with, quite white, and so described by Forskal and Desfontaines, but Roth says it is yellow in the root, brownish in the lower part of the frond, and in the rest pale-green or red.

SuBSTANCE, gelatinous and viscid; brittle when dry.

Oss. The plant is always destitute of gloss : in drying it becomes wrinkled, and often longitudinally channelled, and adheres slightly to paper.

* Short and unsatisfactory as is the description given by Forskal of his F. viscidus, the single observation, that it resembles 'Lichen rangiferinus in its appearance, is of itself sufficient to point out the species he intends, so that there is no difficulty in recognizing it. This resemblance is, particularly. in a dried state, more close than will readily be imagined; as then, in addition to the similarity of form and ramification, the substance of the two plants appears to be exactly the same, and the absence of moisture makes the dull lifeless white hue of $F$. viscidus considerably more striking. In respect of color, an authentic specimen of $F$. distentus of Roth, conimunicated to me by Professor Mertens, differed from whatever else I have received of this Fucus, having turned in drying to a dark greenish brown, but this, not being mentioned by Dr. Roth, I have passed by without notice in my description, regarding it as most probably accidental. Of the identity of $M$. Desfontaines' $F$. lichenoides with the species here figured, I am fully assured, having seen specimens given by himself to Mr. Stackhouse; for which reason, I have not scrupled in adopting above his account of the fruit; a thing which I should not otherwise have done, as I should liave felt some doubt as to his plant, from his referring to Gmelin and Esper, the former of whom most probably, and the latter certainly, intended to denote by the same name a very different Fucus. Desfontaines also notices the resemblance that it bears to Lichen rangiferinus, and he might have added, as the strongest proof of the propriety of the appellation used by him, that there is something in the appearance of the plant when dry, that would lead any botanist to take it for a Lichen almost as soon as for a Fucus. Its nearest affinity is with the subject of the preceding plate, from which it differs in its substance, in the dichotomous division of its primary branches, and in the horizontal lateral slioots. For the specimen here figured I am indebted to Lord Valentia.

a. F. viscidus, natural size.

b. branch, magnified - $\quad 6$.

* The following is the whole of this description:-

" Fucus viscidus; caulibus teretibus, dichotomis, ramosis, fustigiatis, bicornibus.

"Totus allidus. Facie et magnitudine Lich, rangif. Viscidus etiam intus." 

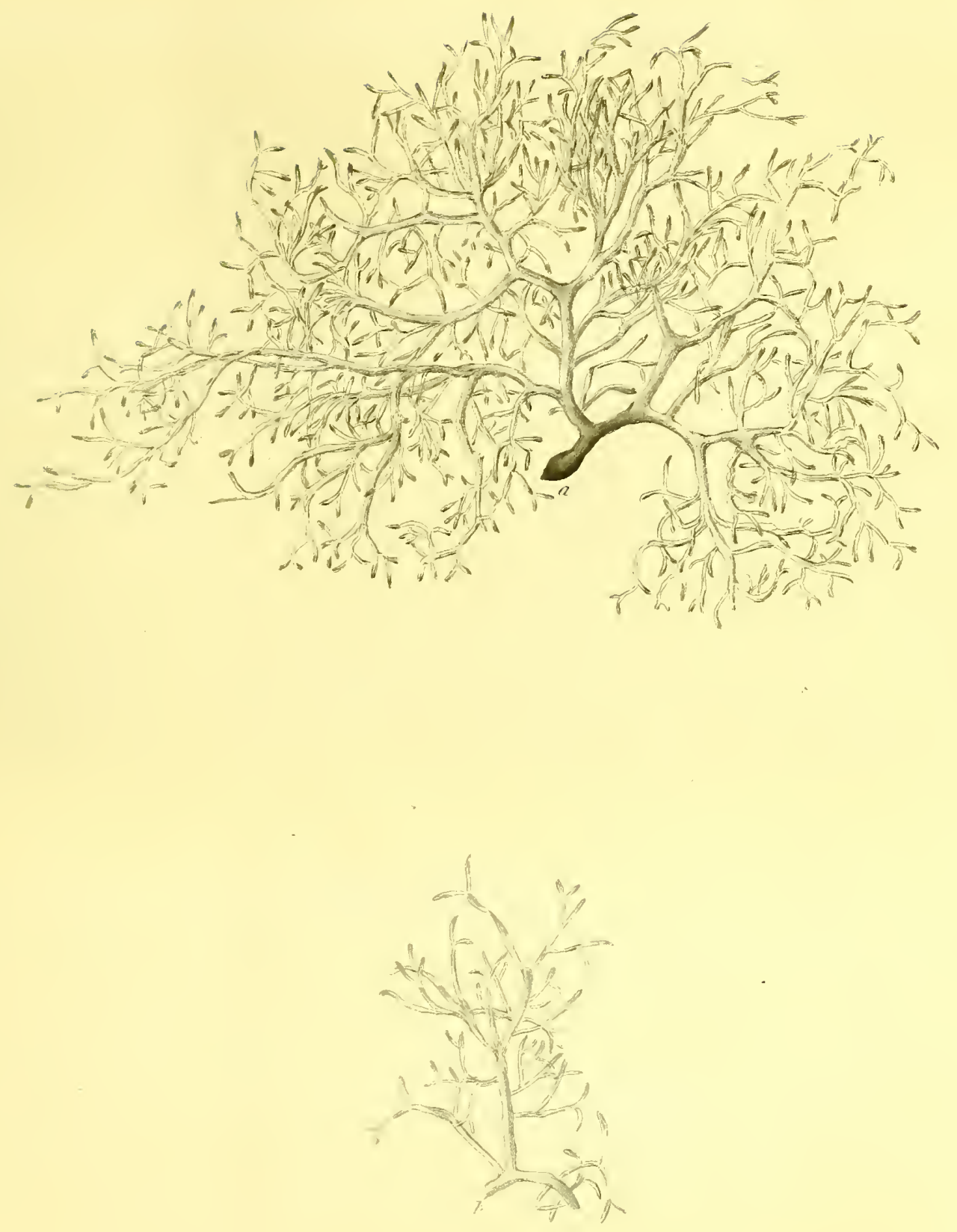

= fireves rencedies 

Fucus, fronde membranaceo-cartilagineâ, planâ, enervi, lineari, sub-dichotomâ, utrinque ramulis distichis, horizontalibus, approximatis, brevibus, multifidis obsitâ.

Ha в гтат in Insulæ Barbadoes littoribus. Baro de Seaforth.

\section{Perennis?}

RADIX callus exiguus, discoideus, nigricans.

Fro s plana, nervi venarumque expers, longitudine spithamam latitudine vix semilineam æquans, a basi ad apices linearis, intervallis incertissimis vagè dichotoma, segmentis erecto-patentibus subfastigiatis, ramos quoque alios sparsos patentes laterales abbreviatos simplices divisosque hìc illìc emittens; frondis latera per totam longitudinem ubique obsident ramuli homogenei, distichi, horizontalitèr patuli, sub-alterni, approximati, ramis duplo angustiores, lineam unam alteramve longi, acuminati, indivisi, sed ipsi utrinque obsiti dentibus perquàm exiguis, homogeneis, distichis, patentibus, alternis, plerumque simplicibus, aliquando tamen bifidis, subulatis, et ita tenuibus ut sint propemodùm capillacei :- hi ramuli interdùm elongati in novos ramos producuntur.

Fructificatio hactenùs latet.

CoLor dilutè ruber, sub-diaphanus; soli diu oljecta aut in aquâ dulci servatce lutescens, et demùm albicans.

Substa NTia membranacea, neque tamen ita tenuis, flaccida, debilis.

Oвs. Frons hìc illìc radiculas emittit elongatas fibrosas, per quas verisimilitèr sese aliis corporibus marinis affigendo sustentat; aut, ut in multis Fucis accidere solet, rami impliciti invicem adhærent:- sub lente ubique obsoletè transversim striata et reticulata apparet :- exsiccata chartæ non adhæret.

Frustrà hujus Fuci descriptionem quærens auctorum botanicorum tomos pervolvi, nequé ulia ejus exemplaria hactenus vidi, : præter ea quæ nobilissimi Baronis de Seaforth benignitati debeo, quorum maximum hæc tabula delineatum exhibet. Hic Insulæ Barbadoes nuper Præfectus, legendo Algas ejus littorum incolas, plurimum in me ipsum et in hoc opus beneficium contulit, quam ob causam lætè illarum pulcherrimam suo nomine sacratam hìc gratâ mente ipsi dedico, testatus simul quàm bene suo ipsius studio aliosque incitando de scientiâ botanicâ semper meruit. Stirps hæc nostra aded usque a reliquis primo statim aspectu abludit, ut difficile prorsùs sit dictu cuinam inter omnes arctissimè accedit. Facie externâ nulli forsan magis est quàm $\boldsymbol{F}$. plumoso vel $\boldsymbol{F}$. asplenioidi affinis, quorum ab utroque structurâ toto cælo discrepat, ut nullo modo fieri possit ut cum hoc vel cum illo unquam commisceatur. Neque sanè verisimile ducerem hos omnes eodem gaudere fructu, sed potiùs capsulas $F$. Seaforthii sphæricas tribuendas putarem. Duceretur facilè aliquis, ex icone modo judicans, ut crederet $F$. confervoidis iconem a Gmelino datam, t. 15. f. 2, et suprà sub $F$. cristato citatam, revera $F$. Seaforthii exemplar exhibere; neque is ego sum qui inficias eam hanc tabulam meliùs hunc quàm illum referre, licet alitèr censuerit $\mathrm{b}$. Mohrius. Sed rem talem quis curet? quis de icone tam pravâ litem non, ut par est, floccifaciet ? præsertìm quoniam satis liquet descriptionem plantam ab utrâvis distinctam respicere. Buxbaumii tabula, Cent. III. t. 65 . f. 4, quam Gmelinus ad sum $F$. confervoidem sine dubio referendum jubet, $\boldsymbol{F}$. pinnatifidi varietatem exprimere videtur.

a. F. Seaforthii, magn. nat.

b. frondis pars, magn, auct. 
Fucus Seaforthii, frond between mentbranaceous and cartilaginous, flat, nerveless, linear, mostly dichotomous, beset on both sides with distichous, horizontal, short, multifid ramuli, placed close to each other.

On the shores of the Island of Barbadoes. Lord Seaforth.

Peremial?

Roor, a small, blackish, callous disk.

FroND, flat, destitute of midrib or veins, about seven inches long, and scarcely half a line wide, linear from base to summit, divided in an irregularly dichotomous manner, at extremely uncertain intervals, with segments between erect and patent, and nearly of equal height, besides which, it also here and there throws out short, patent, scattered, lateral branches, some of them simple, others divided; the sides of the frond are, throughout its whole length, lined with homogeneous distichous ramuli, between horizontal and patent, mostly alternate, placed close to each other, not more than half the thickness of the branches, from one to two lines long, acuminated, undivided, themselves also fringed on both sides with exceedingly minute, distichous, patent, alternate teeth, of the same nature and substance, subulate, and so thin as to appear almost capillary, mostly simple, but sometimes bifid:- these ramuli occasionally lengthen into new branches.

FRUCTIFICATION, hitherto undiscovered.

ColOR, a pale semitransparent red; turning, from exposure to the sun, or from being kept in fresh water, to a light yellow, and at last to white.

SU BSTANCE, membranaceous, yet not very thin, flaccid.

Oвs. The frond throws out here and there long fibrous roots, by means of which it probably supports itself, adhering to other marine bodies; or, as is the case in many Fuci, these radicles serve to attach different parts of the frond to each other:- under the microscope it appears all over obsoletely transversely striated and reticulated :-in drying it does not adhere to paper.

I find no mention of this species in the works of any author, nor did I ever see any specimens of it besides those for which I am indebted to the kindness of Lord Seafortl,, who collected it, together with many others, during his late residence, as Governor, at Barbadoes, where he obligingly exerted himself in procuring materials for this work ; in memorial of which, and of the zeal and liberality with which he has always cultivated and patronized the pursuits of Natural History, I have felt much pleasure in dedicating to him a Fucus that yields to few in elegance or beauty. It is also, even at first sight, a particularly distinct species; insomuch, that it is difficult to say to which it is most closely allied. In point of external appearance it seems to resemble none more nearly than $F$. plumosus or $F$. asplenioides, from both which its structure is so dissimilar, that it is impossible they should ever be confounded; nor should I suppose it likely that the fructification will be found to be the same as in those plants, but should rather be inclined to suspect that it will prove to be globular. Gmelin's figure of his $F$. confervoides, t. 15. f. 2, quoted above, with a mark of doubt under $F$. cristatus, certainly agrees better with $F$. Seaforthii, but is in itself so indifferent, that it is matter of little consequence to which, if either, of the two it is referred, and the description is evidenily intended for a plant distinct from both. As to Buxbaum's plate, Cent. III. t. 65. f. 4, which Gmelin says undoubtedly belongs to the same species, it seems rather to have been designed for $F$. pinnatifidus.

a. F. Seaforthii, natural size.

b. part of the frond, magnified $\quad-\quad 5$. 

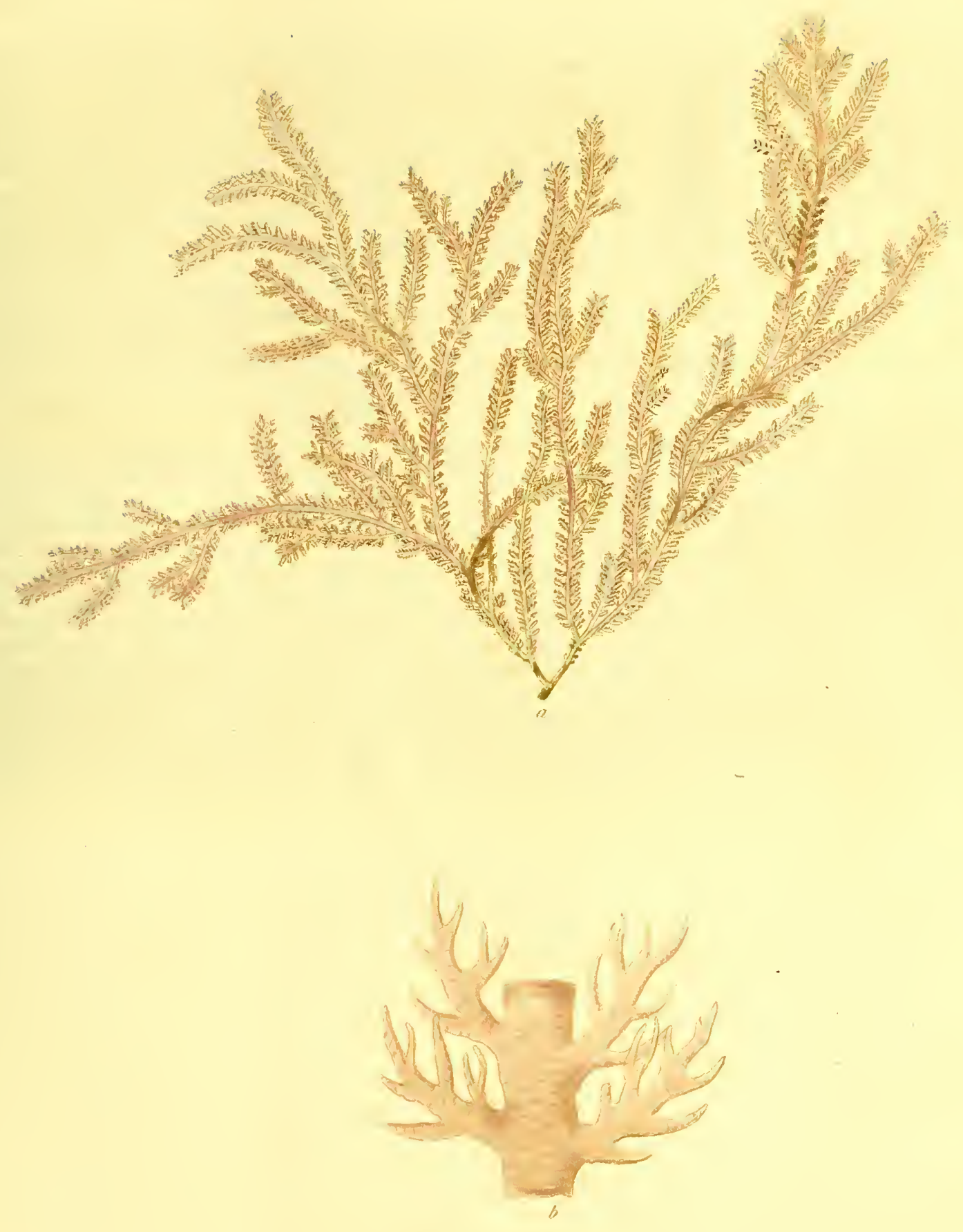

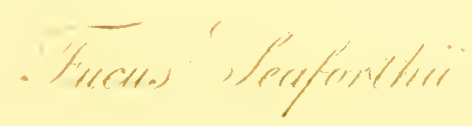



Fucus, fronde cartilagineâ, planâ, enervi, ramosissimâ, ramulis distichis, approximatis, horizontalibus, teretiusculis, abbreviatis, multifidis, acuninatis ubique obsitâ.

H а в т а a in Indiæ Occidentalis oris. D. Wright.

Perennis?

RA DIX callus dilatatus, sub-orbicularis, majusculus.

FRONS plana, nervi venarumque expers, longitudine dodrantalis et ultrà, latitudine in ramis primariis circitèr sesquilinearis, sed apices versus angustior, ipsam juxta radicem plerumque bifurca, atque exinde ordine sub-dichotomo sæpe divisa, spatio inter utramque dichotoniam incertissimo, segmentis patentibus; ex utroque etiam ramorum primariorum latere oriuntur rami alii, eorum similes sed angustiores, horizontales, sparsi, pollicares, vel bipollicares, nunc simplices, nunc dichotomi: frons per totam longitudinem vagè pinnata conspicitur ranıulis distichis, horizontalibus, vel horizontalitèr patentibus, intervallo inter singulos incerto, attamen perbrevi, unguem vel sesquiunguem longis, vix lineæ dimidium latis, ut compressi potiùs quàm plani videantur, his simplicibus, illis dichotomis, aliis indivisis sed dente uno alterove exiguo laterali instructis, plurimorum apicibus bifidis, segmentis perbrevibus acuminatis inflexis : tales quoque ramuli interdùm, sed raro, e mediâ frondis parte pullulant.

Fructificatio hactenus ignota.

Color aquosè ruber purpurascente immixtus, sub-diaphanus; marcescentis vel in aquâ dulci servata sordidè lutescens, et demùm albicans.

Substantia membranaceo-cartilaginea, modicè crassa, exsiccate cornea.

OBs. Per desiccationem chartæ nequaquàm adhæret.

$\mathrm{Si}$ aliquid colligere licet e variis Indiæ Occidentalis littorum partibus e quibus hunc Fucum delatum accepi, certè crederem nequaquàm infrequentèr ibi reperiri, quamvis, præcedentis instar, ipsius earundem quoque orarum incolæ, in hoc usque tempus ab auctoribus indescriptus permansisse videtur. Magnitudine, substantiâ, crescendi modo, et habitu, ita insignitèr cum $F$. coronopifolio convenit, ut, ambobus conspectis, dubitare possit nemo quin utrique fructificatio sit eadem, locosque in systemate sibi proximos hi vindicent. Metuet forsan potiùs aliquis ut verè specie discrepent, de quo quæ mihi præcipuè observanda sese offerunt hæc sunt: color neutiquàm est utrique idem, sed $F$. coronopifolio intensè coccineus, nullo modo in livido-purpurascentem, sicut ille $F$. cervicornis, proclivis; hujusque frons ramulis est per totam ferè longitudinem, non tantùm apices versus, obsita, neque hi unquam ordine alternatìm secundo, quod summâ est in $F$. coronopifolio notatione dignum, disponuntur ; substantiâ quoque rami gaudent ubique æquali, nequaquàm magis in centro quàm ad apices incrassatâ. Inest etiam præter hoc in his stirpibus aliquid, quod, licet non sit ut verbis attingam, satis hæ tabulæ declarabunt, et per quod interdictum videtur ne pro meris varietatibus unquam haberentur. F. cervicornis exemplar hic depictum Dni Gulielmi Wriglit, quem primum detexisse credo, benevolentiæ debeo. Ramuli, si parva licet componere magnis, formâ referunt Cerci Elephantis vel Cervi Tarandè cornua, et ab hâc similitudine nomen speciei impositum deprompsi.

a. F. cervicornis, magn nat.

b. frondis pars, magn. auct. 6. 
Fucus cervicornis, frond cartilaginous, flat, nerveless, much and irregularly branched, every where beset with distichous, horizontal, sub-cylindrical, short, multifid, acuminated ramuli, standing near to each other.

On the shores of the West Indies. Dr. Wright.

\section{Perennial?}

Roor, an expanded, largish, callous disk.

FROND, flat, destitute of midrib or veins, nine inclies or more long, about a line and half wide in the primary branches, and there linear, except that it is narrower at the apices, generally forked immediately near the root, and afterwards repeatedly divided at most uncertain intervals in a sub-dichotomous manner, with patent segments; from each side of the primary branches arise others, similar to them, but narrower, horizontal, scattered, an inch or two long, either simple or dichotomous; the frond throughout its whole length is irregularly pinnated with distichous ramuli, disposed in a direction, either horizontal, or between horizontal and patent, separated by uncertain, but very short, intervals, from half an inch to three quarters of an inch long, and scarcely half a line wide, so that they appear compressed rather than flat, some simple, others dichotomous, and others, though undivided, beset with one or two short lateral teeth, most of them bifid at their apices with extremely short acuminated and incurved teeth : similar ramuli also occasionally, though not often, grow out of the middle, as well as the sides, of the branches.

Fructification, at present unknown.

CoLOR, pale red, with a purplish tinge, semitransparent, turning in decay, or from being kept in fresh-water, at first to a dull dirty yellow, and afterwards to white.

Substance, between membranaceous and cartilaginous, rather thick, horny when dry.

$O_{B}$. In drying it does not in the least adhere to paper.

This Fucus, which, like the preceding, is a native of the West Indies, and at present, apparently, unnoticed by any author upon the subject, seems, from the various channels through which $I$ have received it, to be a plant of far from unfrequent occurrence upon those shores. Botlı in its size, substance, mode of growth, and habit, it is so nearly allied to $F$. coronopifolius that 110 botanist will entertain a doubt but that its fruit, when discovered, will prove to be the same, or will hesitate as to the propriety of placing them next to each other in the system. The question will rather be how far they are really distinct; upon which subject it is to be observed, that their color is different, $F$. coronopifolius being a deep scarlet, and wholly wanting the livid purplish tinge of $\boldsymbol{F}$. cervicornis, in which latter Fucus the frond is far more regularly beset throughout its whole length with short ramuli, and these have 110 tendency to the alternately secund disposition, for which those of the former are remarkable; besides which, its leading branches are, every where of equal thickness, not being, like those of $F$. coronopifolius, thicker in the centre than at the edges, and there is also in the general appearance of the two plants a something which I feel it impossible to describe, but which the figures will illustrate, that seenls to forbid the idea of their being mere varieties of each other. For the specimen of F. cervicornis, here figured, I am indebted to Dr. W. Wright, who appears first to have discovered it. 'The name is derived from the resemblance that the ramuli bear in miniature to the horns of the stag or the rein deer.

a. F. cervicornis, natural size.

b. part of the frond, magnified $\quad=6$. 


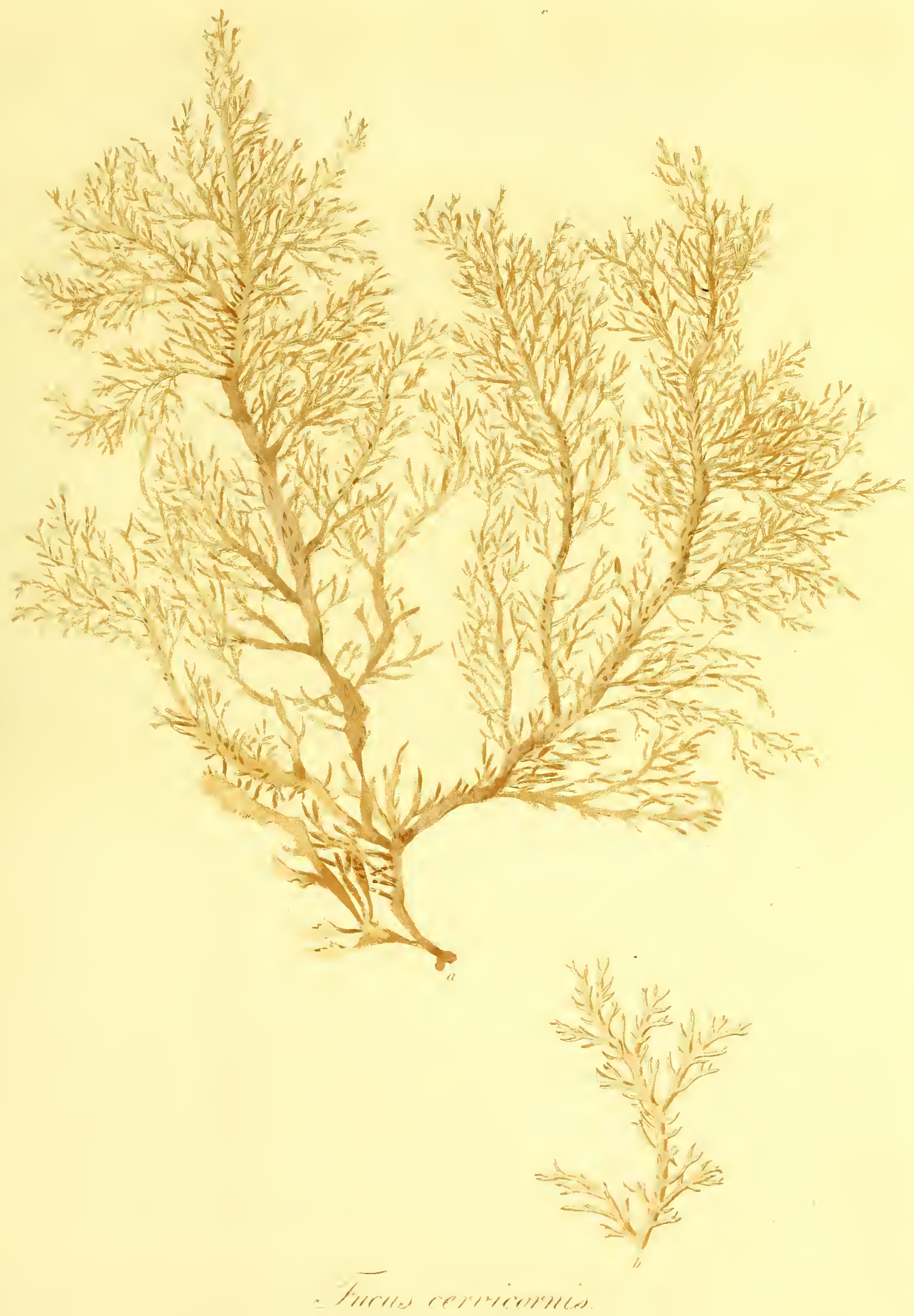



Fucus, fronde cartilagineâ, plano-compressî enervi, ramosissimâ, ramulis disticlis, patentibus, alternatim sub-secundis, teretiusculis, multifidis apices versus obsitâ : capsulis sphæricis, mucronulatis, pedunculatis ; pedunculis distichis, horizontalibus.

Fucus coronopifolius. Linn. Trans. III. p. 185. Ner. Brit. p. 82. t. 14. Syn. Fuc. II. p. $288 . \quad$ Eng. Bot. XXI. t. 1478. Esper, Ic. Fuc. II. p. 60. t. 198. Fl. Fr. Ed. 2da. II. p. 33. Lamouroux, Diss. Fuc. t. 33. (malè.)

F. cartilagineus. Fl. Ang. p. 586 ?

F. coronopi facie. RaII Syn. p. 45. n. 23.

B. angustatus; fronde angustâ, ubique lineari, apicibus elongatis, simpliciusculis, acuminatis.

Habitat Britannia Australis ad oras; apud Insulam Vectem, Dorsetiam, Devoniam, et Cornubiam, haud infrequens.-Hiberniæ ad littora, prope Belfast. D. Templeton.-In sinu, "Bantry Bay," copiosè. Dna Hutchins.-Inter rejectamenta Oceani in Galliæ oris. Decandolle.-Utraque varietas e Zeylonâ est missa ad Linnaum. $\beta$ a Liburni Portu accepi.

\section{Peremis. Aug.-Nov.}

RA DIX callus enormitèr orbicularis, $P$ isi sativi seminis magnitudine, frondi concolor.

Frons plano-compressa, nervi venarumque prorsùs expers, longitudine a dodrantali ad sesquipedalem variabilis, latitudine juxta basin et interdùm ad dimidiam ferè altitudinem sub-bilineari, sed sensìm sursùm angustata, et ad apices triplo quadruplove angustior atque teretiuscula, ipsum prope ortum bi-tri- furca, segmentis patentibus, quæ plerumque sæpe sunt dichotoma, intervallo inter singulas dichotomias incertissimo, aliquandò verò sub-indivisa manent, obsitaque sunt utrinque per totam longitudinem ramis patentibus, distichis, sparsis, primariorum similibus nisi quodd angustiores sint, similique ratione divisis, utrâque serie præcedente angustiore, apicibus multifidis acutis; frons in parte inferiore denudata, in superiore utrinque obsita ramulis distichis, patentibus, intervallis perbrevibus sejunctis, alternatìn sub-secundis, his unguem, illis vix lineam longis, his simplicibus, illis dichotomis, aliis dentem unum alterumve exiguum secundum ferentibus, apicibus plerisque bifidis, segmentis brevissimis incurvis acutis :rami primarii centro incrassati, margines versus tenuiores conspiciuntur, ut nervi lati obsoleti speciem quandam præ se ferant. Non rard evenit frondes ramulis lateralibus omninò vel saltem maximâ ex parte denudatas reperiri, et horum moles in diversis individuis ludit, nunc enim ramis vix sunt angustiores, nunc prorsùs capillacei evadunt.

Fructificatio tubercula sphærica, papaveris semine multoties minora, mucrone aded exiguo ut vix sine lente detegatur aristata, interdùm sessilia, sed plerumque * pedunculo horizontali tereti liaud lineam longo fulta, ad utrumque ramorum summorum latus copiosè disposita, seminum minutissimorum oblongorum congeriem includentia.

† Color saturatè coccineus, in surculis primùm ortis roseus; soli objecta vel in aquâ dulci servata cito in sordidè lutescentem et demùm in album evanidus.

SubSTANTI A cartilaginea, crassiuscula.

Var. $\beta$ insignitèr $\mathbf{a b} \alpha$ in eo discrepat quòd ramos habeat omnes, tàm primarios quàm ultimos, teretiusculos potiùs quàm compressos, et quòd omnibus eadem ferè sit magnitudo pennâ passerinâ tenuior : ramulis quoque lateralibus plurimùm caret, apicibusque gaudet elongatis, acuminatis, rarò divisis : dichotomiarum porrò anguli sunt acuti :quibus ex omnibus faciem ducit tantum ab a diversam ut diu pro distinctâ specie habuerim.

Oвs. Non rarò hunc Fucum perrepit Sertularia anguina:--exsiccatione chartæ laxè admodùm adhæret.

In Australibus Angliæ Hiberniæque littoribus nequaquàm infrequentèr legi solet $F$. coronopifolius, quem nihilominùs botanici nostrates cuncti, dempto uno Raio, vel pro $F$. cartilagineo planè præteriisse, vel cum eodem conjungendum existimavisse videntur, donec in tractatu suo de Fucis Britannicis eximio Goodenovius Woodwardiusque demùm pro novâ specie descriptum summo jure recensuerunt. In hunc quoque errorem, qui quantum a verisimili abhorret facilè omnes judicabunt, non solum Angli inciderunt, sed et $b$. Wulfenius, nti nos certiores fecit anonymus idemque peritissimus $\$$ criticus, in herbario suo $F$. coronopifolii exemplar unicum plurimis $F$. cartilaginci immixtum, eandem putans speciem, servavit; ad quem forsan fontem referendus est error, quo basin huic discoideam ascribit. Habet autem $F$. cartilaginens radicem semper fibrosam, $F$. coronopifolius semper solidam, neque in hoc modd discrepant, sed in multis aliis, et præsertìm illius ramis nunquam non bipinnatis, peripheriâque certâ sub-pyramidatâ, quæ efficiunt ut juxta se collocati primo statim aspectu dissimillimi appareant, et ut $F$. cartilagineus crescendi modo longè propiùs ad F. corneum accedat. E contrario F. coronopifolius, cùm frondis totius formâ, tùm ramorum dispositione, habituque, quod aiunt, generali, similis est fucorum depictorum in tabulis inter quas hic collocatur, sub quibus exponuntur discrimina per quæ invicem dignoscuntur, dum per colorem ramulorumque situm alternatìm secundum $F$. coccineum refert. Fucorun speciosissimorum numero jure insereret aliquis $F$, coronopifolii exemplaria

* Anne li pedunculis, fructificatione peractâ, decidant, an in rả mos ramulosve immutentur, in dubio est animus. Alteri opinioni, cui favet analogia, statim assentirer, nisi repugnarct horum situs semper patens, illorum semper ad amussim liorizontalis.

+ De colore dicit Stackhousius, " variat colore rubro, rosaceo, luteo, viridi, ut frequentèr observavi iu $F$. coccineo, et maximè omniun in $F$. cartilagineo. Specimen perfectissimum olim milì de Acton Castle post prucellam mandatum fuit. Color plantæ istius minimè rosaceus, sed fulvus, qui tamen exsiccatione in coccineum mutatus est.

¥Confer recensionem Wulfenii Cryptogamorum Aquaticorum in opere, cui titulus, Allgemeine Litteratur-Zeitung, 1805. III. p. 450. 
vegeta atque recentia, eademque ramulorum sobole copiosâ pullulantia; frequentiùs tamen reperitur hæc stirps læsa et denudata, ita ut interdùm ægrè agnoscatur; et si semel inter maris rejectamenta tandiu in littore solis radiis objiciatur ut desiccata fuerit, torti omnind evadunt ramuli ramique tenuiores, neque ad ritè explicandos vel ad pristinam revocandam pulcritudinem ulla cura postera satis valet.

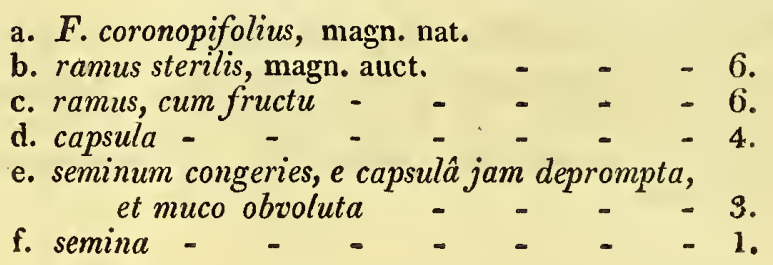

\section{2.-F U C US G O R O N O P I F O L I U S.}

Fucus coronopifolius, frond cartilaginous, between flat and compressed, nerveless, much and irregularly branched, beset towards the apices with distichous, patent, nearly cylindrical ramuli, placed in alternate parcels; capsules splerical, mucronulated, supported on very short, distichous horizontal peduncles.

Fucus coronopifolius. Linn. Trans. III. p. 185. Ner. Brit. p. 82. t. 14. Syn. Fuc. II. p. 288. Eng. Bot. XXI. t. 1478. Esper, Ic. Fuc. II. p. 60. t. 138. Fl. Fr. Ed. 2da. II. p. 33 . I.amouroux, Diss. Fuc. t. 33. (malè.)

F. cartilagineus. Fl. Ang. p. 586?

F. coronopi facie. RaII Syn. p. 45. n. 23.

B. angustatus ; frond narrow, linear throughout ; terminal segments long, mostly simple, acuminated.

On the Southern coast of England, at the Isle of Wight, in Dorsetshire, Devonshire, and Cornwall, not uncommon.-Ireland, near Belfast. Mr. Templeton.-Bantry Bay, abundant. Miss Hutchins.-Among the rejectamenta of the sea on the Northern and Eastern shores of France. Decandolle. Both varieties sent from Ceylon to Linnaus. $-\beta$ I have received from Leghorn.

Perennial. August-November.

Root, callous, irregularly orbicular, as large as a common pea, and of the same color as the frond.

FROND, between that and compressed, wholly destitute of midrib or veins, from nine to eighteen inches long, near the base about two lines wide, and sometimes continuing so to almost half its height, but always gradually decreasing in width upwards, so as at the apices to be three or four times narrower and nearly cylindrical; it is forked almost immediately adjoining the root with two or three patent segments, which are in general repeatedly dichotomous at very irregular intervals, but sometimes are undivided, and beset on both sides throughout their whole length with patent, distichous, scattered branches, similar to the prinary ones, except that they are narrower, and divided in the same manner, each series being smaller than the preceding one; the apices are nultifid and acute; the frond is naked in its lower part, but in the upper is lined on both sides with distichous, patent ramuli, separated by very short intervals, and disposed in alternate parcels, some of them half an inch long, others scarcely exceeding a line, some simple, others dichotomous, and, again, others bearing one or two small secund teeth, the apices of most are bifid, with exceedingly short, incurved, acute segments:--the primary branches are thickest in the centre, and thin at the margins, which gives then the appearance of having a wide obsolete midrib. Specimens are not uncommonly found, which are altogether, or at least principally, destitute of lateral ramuli, and the size of these latter varies exceedingly in different individuals, for in some they are hardly smaller than the branches, so as to appear merely continuations of them, while in others they are quite capillary. 

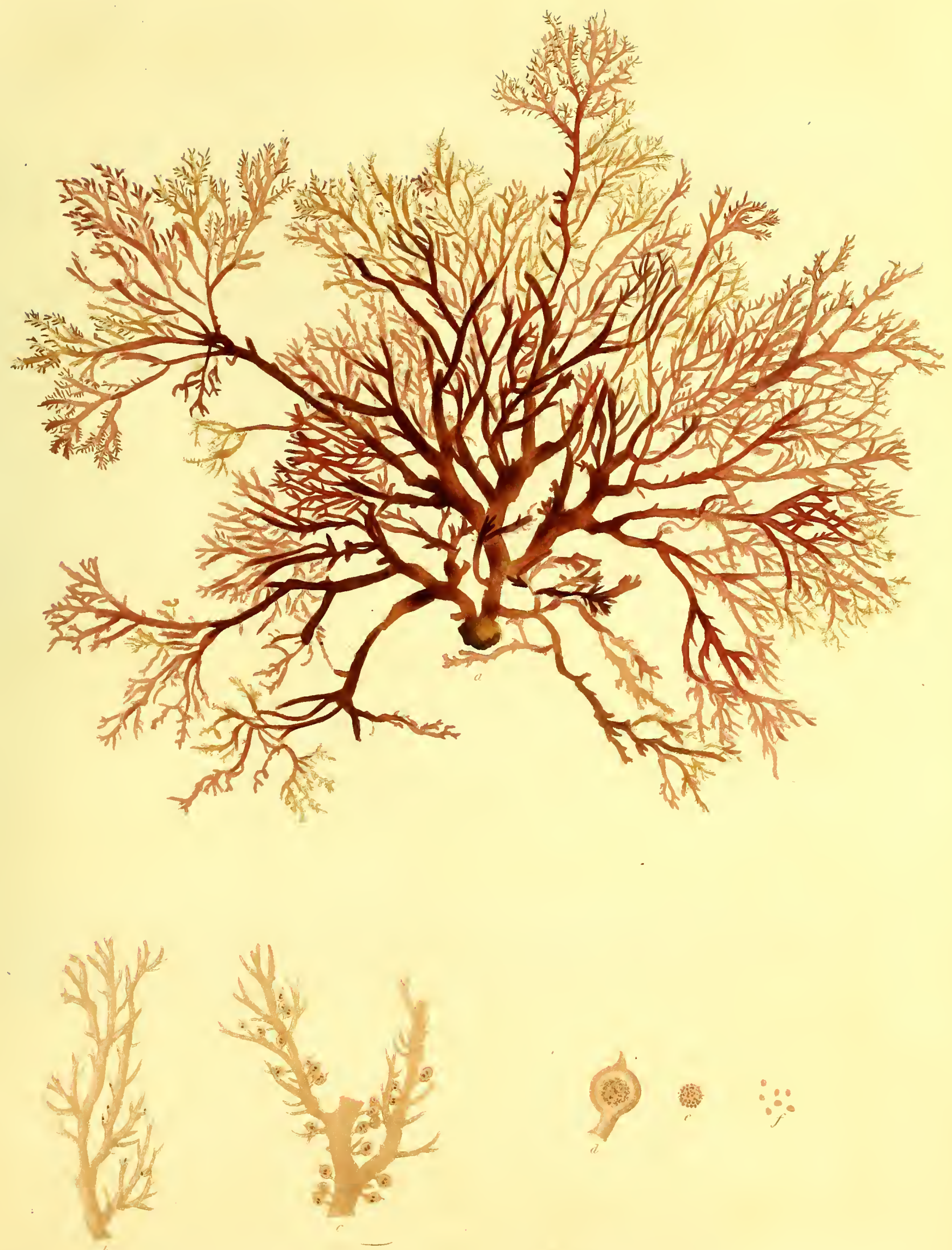

Fructification, spherical tubercles, many times smaller than poppy-seed, tipped with a mucro so minute a scarcely to be distinguishable without a microscope, sometimes sessile, but more frequently supported upon a horizontal, cylindrical * peduncle, not a line long, containing a mass of minute oblong seeds.

†Co Lor deep scarlet, but pink in the very young shoots; soon changing, from exposure to the sun, or from being kept in fresh-water, to a pale dirty yellow, and at last to white.

SU BSTANCE, cartilaginous, rather thick.

The variety $\beta$ differs strikingly from $\alpha$, in having all its branches, as well the primary as the ultimate ones, subcylindrical, rather than compressed, and in the size of them all being nearly the same, scarcely equal to that of a sparrow's quill: it also wants in great measure the lateral ramuli, and has long, acuminated, mostly undivided apices : the angles, too, of its dichotomies are acute; all which circumstances give it an appearance so different from that of $\alpha$, that I long regarded it as a distinct species.

OBs. Sertularia anguina is not uncommonly found upon this Fucus:-in drying it adheres very slightly to paper

This Fucus, which is far from uncommon upon the southern coast of England, appears to have been by all British botanists, except Ray, either confounded with, or mistaken for, $F$. cartilagineus, till Dr. Goodenough and Mr. Woodward published their excellent paper in the Linnaan Transactions, and most justly claimed for it the rank of a distinct species. Nor has this confusion of these two plants, however extraordinary, been altogether confined to the naturalists of Eugland, for $\ddagger$ Baron Wulfen had also in his Herbarium mixed a specimen of $\boldsymbol{F}$. coronopifolius with those of $F$. cartilagineus, and was probably from this error led to ascribe to the latter of them a discoid base. Independently, however, of the dissimilarity of their roots, which is in the one solid and in the other fibrous, they differ in many striking particulars, and, especially, in the regularly bipinnated branches and sub-pyramidal outline of $F$. cartilagineus, the mode of growth of which approaches far more nearly that of $F$. corneus, so that even at first sight they are altogether dissimilar. F. coronopifolius, on the other hand, is most closely allied, both in its form, its ramification, and its habit, to the subjects of the preceding and of the following plates, under which are pointed out the characters that distinguish them from each other; while in its color it considerably resembles $F$. coccineus, to which the alternately secund disposition of its ramuli also indicates an affinity. Fresh and vigorous specimens of this Fucus well covered with ramuli deserve a place among the most elegant of the British species; but it is more commonly found stripped and battered, so that there is not unfrequently a difficulty even in ascertaining the plant ; and when it has once been dried upon the beach, it becomes so curled and twisted that no care can afterwards satisfac. torily recover it.

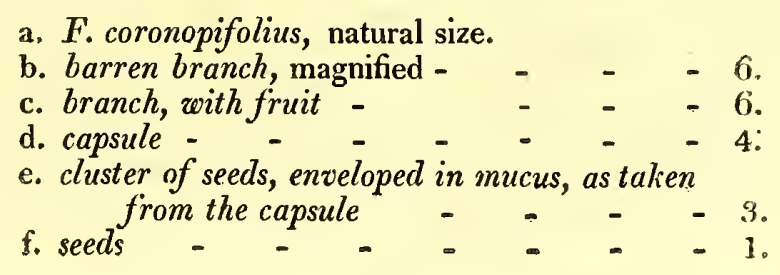

\footnotetext{
* Whether these peduncles fall off when the seeds are discharged, or whether they shoot out into new branches or ramuli, is a point upon which I lave not been able to satisfy myself. The latter opinion is so much more consonant to analogy, that $I$ should have felt no doubt in adopting it, were it not that the situation of the peduncles is always horizontal, while that of the branches is as constantly patent.

$t$ Upon the subject of the color, Mr. Stackhouse says, "I received from Acton Castle an entire plant after a storm, the color of which was yellowish brown, when fresh from the sea, or rather a sorrel, but it dried to a pink."

\$. See the Reyiew of Wulfen's Cryptogama Aquatica in the Allgemeine Litteratur Zeitang' for. Angust 1805. po 450.
} 
Fucus crinitus, frond cartilaginous, flat, nerveless, much and irregularly branched; beset towards the apices with distichous, horizontal, nearly cylindrical, simple, short ramuli, standing near each other.

Fucus crinitus. GmeliN, Hist. Fuc. p. 160. t. 18. f. 2. Syst. Nat. Ed. Gmel. II. p. 1386.

In the Sea of Kamtschatka. Gmelin.

\section{Perennial.}

RooT, largish, solid, irregularly disciform.

FroN D, flat, destitute of midrib or veins, from four to six inches long, about three lines wide in the primary branches, and there nearly linear from base to summit, in the younger ones much narrower, forked almost immediately adjoining the root; and afterwards repeatedly divided at short, but uncertain, intervals, in an *irregularly dichotomous manner, with patent segments, besides which, scattered branches, between horizontal and patent, of most uncertain lengths, some simple, others divided, arise here and there from the sides of the larger ones; the apices of all are obtuse, as if truncated, the margins quite entire, + naked below, but towards the summits fringed on both sides with distichous, horizontal teeth, from one to three lines long, placed close to each other, nearly cylindrical, either filiform, or slightly thickened upwards, and simple, or, what is very uncommon, forked.

Fructification, at present unknown.

CoLOR, blackish red, so dark that, unless held to the light, it looks quite black.

SUBSTANCE, cartilaginous, thick, tough, pliant, every where equal, and not, as in $F$. coronopifolius, incrassated in the centre so as to give the plant the appearance of having a wide obsolete midrib.

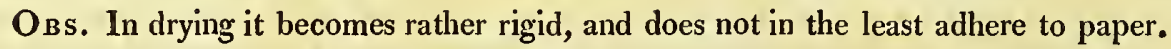

From the figure given by Gmelin of his F. crinitus, there seems no doubt whatever of the plant intended by him being in reality the same as that which is the subject of the present plate, though it must be admitted that there are parts of his description which it is difficult to reconcile with such a supposition, especially where, speaking of the stem, he represents it as somewhat twisted towards the base, to which there is not the slightest tendency in my specimen, nor does it appear probable that there should be in a plant of this nature; and where he points out the color as similar to that of $F$. vesiculosus, but more vivid, whereas it is far from having any olivaceous tinge in it, but; when held to the light, much more resembles that of old plants of $F$. dentatus, to which, in all probability, its affinity is, when growing, still more strong. There is also, in Gmelin's account of this species, another part which is quite unintelligible to me, where he says, that in the substance of the stem are immersed scattered vesicles, either simple; or in pairs, or in a continued series. By the word "vesicles" I presume he means reticulations, but even of these there are no vestiges in my specimen, the substance of which is completely uniform. The Fuci to which $\boldsymbol{F}$. crinitus is most nearly allied are $\boldsymbol{F}$. coronopifolius and $\boldsymbol{F}$.gigartinus, and there can be little doubt of the fructification being similar to that of the one or the other of these species. Indeed, judging from analogy, no one would hesitate to conclude that it consists of spherical tubercles placed upon the ends of the ramuli, and Gmelin's observation, that these swell in such a manner that any one would suppose they perform the office of fructification, probably refers to something of this nature. From $F$.gigartinus $F$. crinitus is immediately distinguishable by its wide flat frond, and by its shorter, linear, regularly distichous ramuli, which are never acuminated, and from $\tilde{F}$. coronopifolius by these latter being constantly simple; fronı both by its color. For the specimen here figured, which was gathered on the shores of Kamtschatka by Dr. Horner, I am indebted to the friendship of Professor Mertens.

a. F. crinitus, natural size.

b. part of the frond, magnified - $\quad-6$.

\footnotetext{
* So far is the ramification of this plant from being properly dichotomous, that Gmelin describes it as furnished with a stem which send: out from the base to the summit sub-alternate, homogeneous, decurrent branches. Instances of tilis sub-dichotomous mode of growth are very common among the Fuci, and occasion no small difficulty in the describing of them.

+ Such is the case in my specimens, but Gmelin both describes and figures his as fringed with ramuli throughout their whole length.-What can he mean by saying that most of these ramuli are terminated by a small linear leaf?
} 


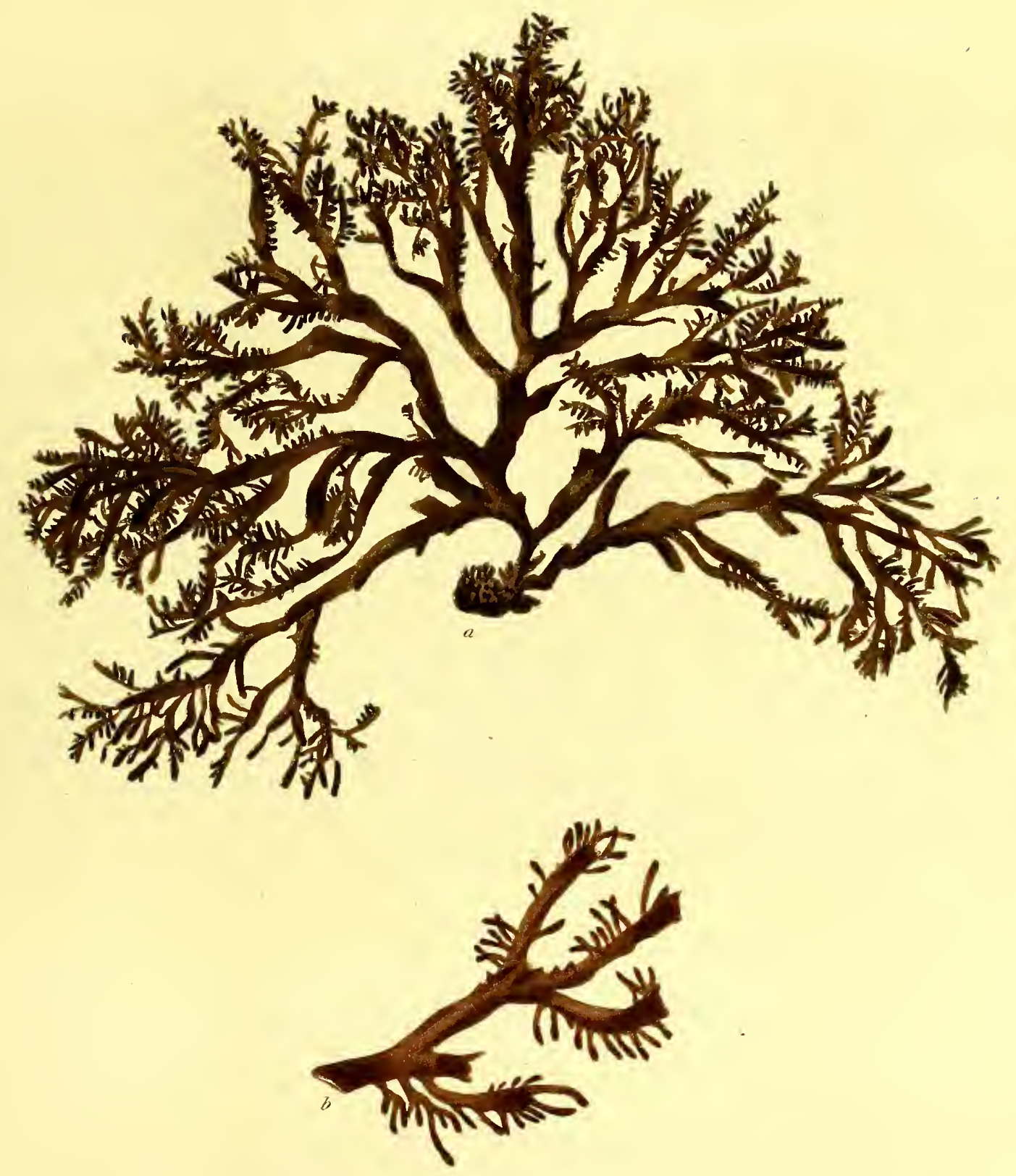

cliectes criniters. 

Fucus, fronde cartilagineâ, planâ, enervi, ramosissimâ, ramulis distichis, approximatis, horizontalibus, teretiusculi simplicibus, abbreviatis, apices versus obsità.

Fucus crinitus. Gmelin, Hist. Fuc. p. 160. t. 18. f. 2. Syst. Nat. Ed. Gmel. II. p. 1386.

Habitat in Mari Kamtschatico. Gmelin.

\section{Perennis.}

RADIX callus enormitèr discoideus, majusculus.

Frons plana, nervi venarumque expers, quatuor sexve pollicum longitudine, latitudine in ramis primariis triun circitèr linearum et a basin ad apices ferè æquali, in junioribus multoties minore, ipsam juxta radicem bifurca, atque exinde ordine *vagè dichotomo pluries divisa, segmentis patentibus, intervallo inter singulas furcas brevi, attamen incerto, alii quoque rami sparsi, horizontaliter patuli, simplices divisique, longitudinis quàm incertissimæ, hìc illic e majorum lateribus oriuntur; apices omnibus obtusi, quasi truncati; frondis nıargines integerrimi, finferne denudati, summitatem versus utrinque fimbriati ramulis, seu dentibus, distichis, horizontalibus, ab unius ad trium linearum longitudinem, plùs minùs approximatis, teretiusculis, filiformibus, vel sursùm lenitèr incrassatis, simplicibus, aut, quod perrard accidit, bifurcis.

Fructificatio hactenus latet.

Color atro-sanguineus, ita intensus ut, nisi luci objiciatur, niger appareat.

SubsT A Nia cartilaginea, crassa, lenta, tenax, ubique æqualis; nec, sicut in F.coronopifolio, in centro incrassata, ut planta obsoletè costata videatur.

OBs. Exsiccatione rigidiuscula evadit, et chartæ nequaquàm adhæret.

Dubitabit, uti credo, nemo botanicus, icone $F$. criniti Gmelinianâ cum hâc nostrâ collatâ, quin eandem omninò speciem exhibeant; sint licet in descriptione a Gmelino datâ quædam, quæ non omnibus numeris stirpi nostræ respondentia scrupulos facilè injicere possint. Talia sunt præcipuè quæ de colore habet et caule, hunc " inferiùs aliquantum contortum" præedicans, quod certè nequaquàm in nostro exemplare ubique planissimo valet, et a verâ plantæ indole toto cælo abludere videtur ; illum verd memorans eundem esse qui $F$. vesiculoso, sed paullo vividiorem, quod contra nihil in se olivacei viridisve includit, sed ei $F$. dentati jam annosi multo meliùs convenit, ut verisimillimum sit utrumque recentem atque vegetum in hoc congruere. Tertium quoque in Gmelini descriptione inest quod non bene capio, scilicet " vesiculas in fronde nidulari sparsas, vel simplices, vel geminatas, vel et continua serie decurrentes," quas per vesiculas quamvis nihil aliud intelligendum autumo, nisi frondem esse reticulatam, maculis pellucidis, hujusmodi tamen nihil in exemplare meo, cui substantia prorsus est uniformis, detegere potui. Fuci ad quos $F$. crinitus arctissimè accedit hi sunt, $F$. coronopifolius et $F$. gigartinus, fructuque esse instructum tali qualis vel hujus vel illius vix est quod dubites. Postulat quidem analogia ut capsulas sphæricas ramulorum ad apices sitas hic quæramus, et fortasse tale quiddam innuit Gmelini animadversio, " turgere suprà, et valde turgidos incrassari, ut fructificationis negotium perficere putares." Distinguitur $F$. crinitus ab $F$. coronopifolio fronde latâ planâ, ramulisque abbreviatis, linearibus, semper distichis, nequaquàm acuminatis; neque minus certè ab $F$. coronopifolio his semper simplicibus; ab ambobus colore. Exemplar hic depictum, quod Kamtschatica ad littora legit D. Hornerus, Mertensii optimi amicitiæ debeo.

a. F. crivitus, magn. nat.

b. frondis pars, magn. auct. - $\quad-\quad 6$.

\footnotetext{
- Frondis divisio tantum a verè dichotomâ abludit ut Gmelinus describàt plantam instructam "caule plano, mox ab origine ad fastigium suum numerosissimos ramos emittente, sibi similes, ordine subalterno decurrentes." Nequaquàm infrequentèr in Fucis occurrere solet hic ereseendi modus, inter dichotomum et cauliferum medius, et hinc multa in describendis difficultas et ambiguitas.

+ Hos margines ramulis per totam longitudinem fimbriatos describit depingitque Gmelinus.
} 
Fucus cartilagineus, frond cartilaginous, between flat and compressed, nerveless, naked below, repeatedly pinnated above ; pinuæ horizontal, mostly alternate, linear, the ultimate ones very short, blunt, and bearing at their apices ovato-lanceolate mucronated tubercles.

Fucus cartilagineus. Lin. Sp. Pl. II. p. 1630. (excl. Syn. Raii.) Syst. Nat. II. p. 719. Syst. Nat. Ed. Gnel. II. p. 1385. (excl. var. B) Fl. Norv. II. p. 108. t. 3. f. 5. Fl. Ped. II. p. 332. Es P E, Ic. Fuc. I. t. I. (exclusis synonymis omnibus quæ ad $F$. gigartinum vel $F$. abrotanifolium pertinent.) WITH. IV..p. 119. Syn. Fuc. II. p. 284. Eng. Bot. XXI. t. 1477. WulfeN, in Jacq. Coll. II. p. 147. WulfeN, Crypt. Aquat. n. 16. Fl. Lus. II. p. 437.

F. capensis. GMELIN, Hist. Fuc. p. 157. t. 17. f. I.

F. versicolor. Gmelin, Hist. Fuc. p. 158. t. 17. f. 2.

F. vindicatus cartilagineus. Fl. Norv. II. p. 123.

Fructices marini arbuscularum formâ multicolores. SF BA, Thes. III. p. 191. t. 102. f. 1, 2. (optimè.)

On the rocks at the Cape of Good Hope, in immense profusion. Seba.-Rocks of the Adriatic, near Ragusa: Wulfen:-In the Northern Ocean, as by Finnark, here and there." Gunner.-Sea by Nice. Allioni.--Mouth of the Tagus. Professor Link.-Sent from Teneriffe to Professor Mertens.

\section{Perennial.}

* Root, fibrous, consisting of numerous, sub-cylindrical, incurved fibres, nearly an inch long, irregularly branched, creeping, and here and there rising into new fronds.

FRONDS, consequently, clustered, each rising with a single stem, which is mostly undivided, but sometimes, though rarely, once or twice furked, from a foot to a foot and half long, between flat and compressed, preserving throughout its whole length a nearly regular width of about a line, generally naked to about half its height, or only rough with the remains of broken scattered branches, but thence upward pinnated with branclies, exactly resembling it, both in form and substance, but more narrow, distichous, either horizontal, or between horizontal and patent, separated by intervals of a qinarter of an inch, or half an inch, mostly, but not always, alternate, the lowest regularly largest, and often reaching to half a foot or more in length, the rest gradually shortening as they approach the summit of the frond, so that the upper ones are not above a quarter of an inch long, and the outline of the plant is pyramidal : all the branches, except the uppermost, which are quite simple, are pinnated, or bipinnated, (though frequently, like the stem, naked in their lower part,) with others similar to themselves, but smaller, distichous, between horizontal and patent, sub-alternate, separated by intervals of one or two lines, the"lowest longest, the rest gradually shorter, so as to give each branch the same outline as the whole frond: these secondary branches are also in their turns pinuated in the same manner as the primary ones, and there is sometimes even a third series, each smaller than the one that precedes it: in the last the pinne are not more than a line long, and either quite horizontal, or slightly incurved: the apices of all are obtuse, and not iucommonly a little dilated, but this is uncertain, for sometimes they are narrower at the end than at their origin, though constantly bluit.

FRUCTIFICATION, situated at the extremities of the ramuli, consisting of solitary, ovato-lanceolate tubercles, as large as poppy-seed, generally tipped with a minute mucro, which is in some instances so much elongated as to swell into a second capsule separated from the former by a very short interval, and the ramulus has a moniliform appearance : the capsules contain a mass of exceedingly minute, oblong seeds, mixed with short simple fibres.

COLOR, in the fresh and perfect plant, I suspect to be red with a purplish tinge, but this, from exposure to the light is very soon changed, and the frond generally appears beautifully party-colored, with a variety of hues from dark purple, through every gradation of purple, red, orange, yellow, and light green to white.

SU BSTANCE, cartilaginous, thickish, flexible, and tough : horny whell dried.

OBs. This Fucus is generally found spotted in various places with a smooth calcareous incrustation, which, according to Pallas, is the first stage of Millepora agaricifornis: Sertularia Pluma too, is frequently observable upon it.In drying it does sot in the the least adhere to paper.

Few species of Fucus are more generally known, or better understood among botanists than the present, which, on account of the elegant regularity of its shape, and the richness, as well as the diversity of its colors, is not unfrequently brought from the Cape of Good Hope to Europe, disposed in various artificial forms. It seems also to be a plant that is liable to renarkably little variation in its mode of growth, excepting only such as may be occasioned by age or casual injury, to one or both of which causes appear to be attributable all the differences that are observable in the $F$. capensis and the $F$. versicolor of Gmelin; the former of these, to judge both from the figure and description, being nothing more than an injured and decaying specimen of the latter. This ill-judged division, however, of the plant, obviously erroneous as it appears upon the first view of the figures, gave rise to no trilling coufusion; for Linnæus, placing too much relimce upon Gmelin, and concluding that he would not have separated what was not really distinct, referred in the Mantissa $F$.capensis as a synonym to $F$.abrotanifolius, and subsequent authors have not been wanting to follow this example, and to add to the errors it occasioned. Dr. Esper, indeed, has gone farther than any; for, not content with joining $F$. cartilagineus and $F$. abrotanifolius, he has added to them $F$. gigartinus, 


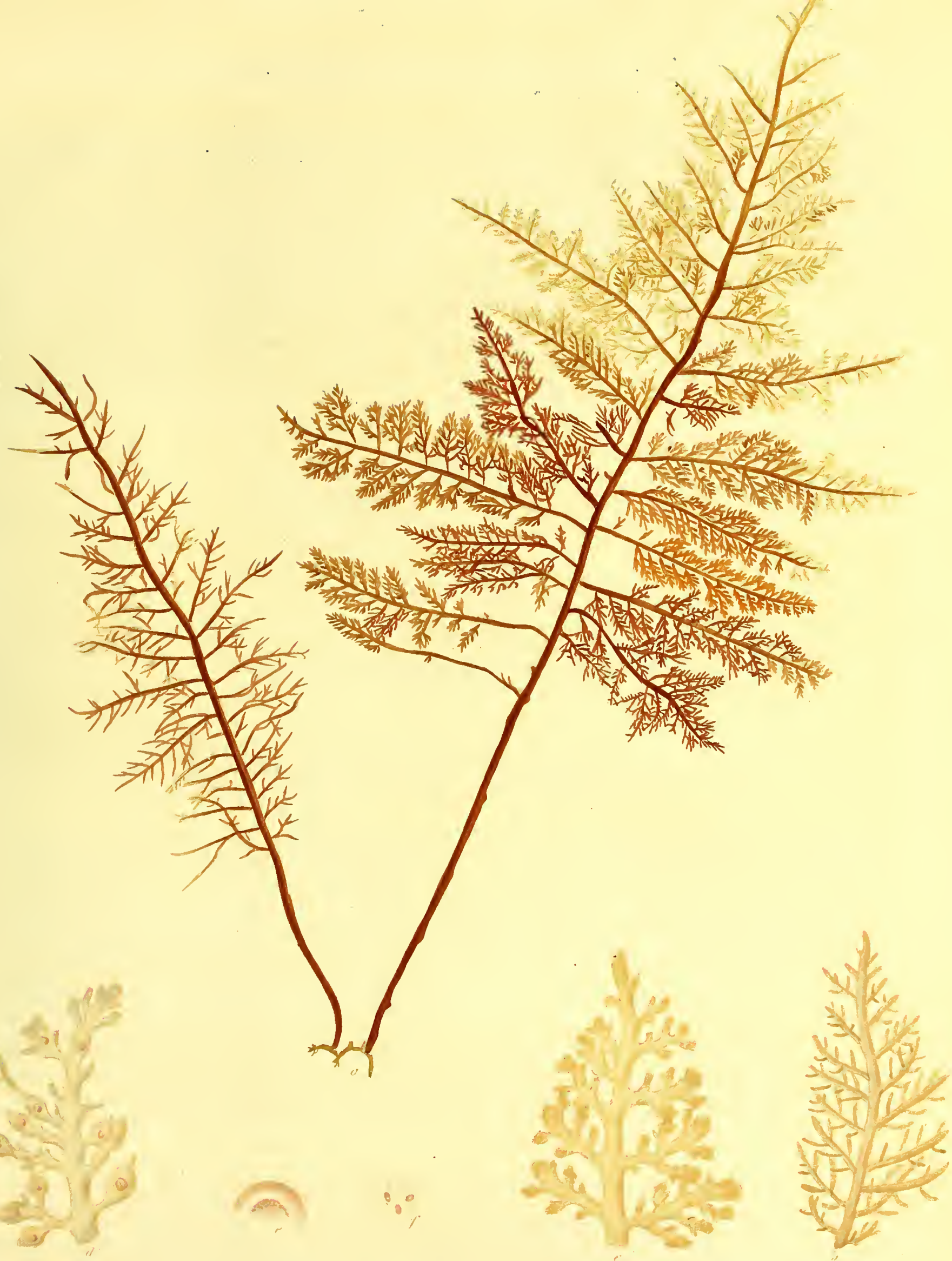



supposing that plant also to be nothing more than the same in a state of fructification. Very different, but scarcely less unaccountable, is the error into which Professor J. F. Gmelin has fallen in his edition of the Systema Natura; who, while he separates $F$. capensis from $F$. cartilagineus, and unites the former to $F$. abrotanifolius, quotes under the latter F. coccineus, as a variety. The circumstance of the Fucus before us, a native of the Southern latitudes, being found also upon the shores of Norway, appears, from the figure given by Gunner, to admit of no doubt, but is a curious fact in the geography of the vegetable kingdom. Its nearest affinity is with $\boldsymbol{F}$. corneus, from all the larger varieties of which proteus-like species it is far from being always easy to distinguish it. Professor Mertens, wlıo has had favourable opportunities of examining them both, is of opinion, that they pass into each other, to which, however, I do not feel myself prepared to accede, though I am willing to adnit that I kuow of no characters of distinction between them, besides the differences in their general liabit, outline, and texture, which, as far as $I$ have seen, are permanent. Linnæus, in his Herbarium, had mixed them under the name of F. cartilagineus, and, indeed, his most authentic specimen there preserved belongs to $F$. corneus; but, as his references to Gmelin, Seba, \&c. leave no doubt as to the plant before us being the one really designed by him, I have followed the example of other botanists in regarding it as such.

a. F. cartilagineus, natural size.
b, c. barren branches, magnified
d. branch in fruit -

\section{4.-F U G U S G A R T I L A G I N E U S.}

Fucus, fronde cartilagineâ, plano-compressâ, enervi, infernè nudâ, supernè decomposito-pinnatâ ; pinnis horizontalibus, sub-alternis, linearibus, extremis brevissimis obtusis apice tuberculiferis; tuberculis ovato-lanceolatis, mucronatis.

Fucus cartilagineus. LIN N. Sp. Pl. II. p. 1630. (excl. syn. Raii.) Syst. Nat. II. p. 719 . Syst. Nat. Ed. Gmel. II. p. 1385. (excl. var. $\beta$.) Fl. Norv. II. p. 108. t. 3. f. 5. Fl. Ped. II. p. 382. EsPER, Ic。 Fuc. I. t. 1. (exclusis synonymis omnibus quæ ad $\boldsymbol{F}$. gigartinum vel $\boldsymbol{F}$.abrotanifolium pertinent.) W ITH. IV. p. 119. Syn. Fuc. Il. p. 284. Eng. Bot. XXI. t. 1477. WulfeN, in Jacq. Coll. III. p. 147. WuLFEN, Crypt. Aquat. n. 16. Fl. Lus. II. p. 437.

F. capensis. GMELIN, Hist. Fuc. p. 157. t. 17. f. 1.

F. versicolor. GMELIN, Hist. Fuc. p. 158. t. 17. f. 2.

F. vindicatus cartilagineus. Fl. Norv. II. p. 123.

Frutices marini arbuscularum formâ multicolores. SE BA, Thes. III. p. 191. t 102. f. 1, 2. (optimè.)

Ha bı r a a Promontorium Bonæ Spei, ubi de rupibus littorum incredibili copiâ germinat. Seba.-Ad rupes maris Ragusani. Wulfen.-In mari Septentrionali, e. g. ad Finmarchiam passim. Gunner.-Ad rupes maris Nicæensis. Allioni.-Ad ostia Tagi. D. P. Link.-Ex Insulâ Teneriffe accepit D. Prof: Mertens.

Perennis.

* RA DIX fibrosa, e fibris constans plurimis, teretiusculis, pollicem ferè longis, incurvis, vagè ramosis, repentibus, et hic illic in novas frondes assurgentibus.

FroNDEs hìnc cæspitosæ, singulæ instructæ caule unico, indiviso, vel, quod rarò accidit, semel iterùmve bifurco, pedem sesquipedem et ultrà longo, plano, vel plano-compresso, unius ferè lineæ latíudinem ubique æqualem servante, plerumque ad dimidam circitèr altitudinem sudo, aut tantummodo ramorum diffractorum sparsorum reliquiis exasperato, exinde sursùm pimıato ramis homogeneis, caulis omnind similibus msi quòd angustiores sint, distichıs, horizontalitèr

\footnotetext{
* Wulfenius contrà dicit hanc plantam, " de more gentis, radicis loco coriaceo-cartilagineâ rupibus conglutinari placcntâ sub-orbiculari,"
de quo conferenda sunt quæe suprá sub $F$. coronopifolio monentur, p. 133 .
} 
zontalitèr patentibus, aut borizontalibus, intervallo semiunguiculari vel unguiculari divisis, plerumque alternis, sed hoc incertum, inferioribus longissimis, et sxpe semipedem aut ultrà longis, reliquis quo magis ad apices appropinquant eo gradatim brevioribus, ut summi semiunguem non exsuperent, et frondis totius peripheria sit pyramidata; rami omnes, suınmis tantummodo, his simplicissimis, exceptis, sunt bi- tri- pinnati, sed parte eâ quæ cauli proxima sæpe, ejus instar, denudati, exinde obsiti aliis, homogeneis, minoribus, distichis, horizontalitèr patulis, sub-al ternis, intervallo inter singulos lineari vel bilineari, inferioribus longissimis, reliquis sensim brevioribus, ut singuli rami eandem habeant quam frons tota formam; raıni quoque hi secundarii pinnati sunt ratione prorsìs simili primariorum, et interdùm tertia etian series utrâque præcedente minor exoritur; in ultimâ pinnulæ haud lineâ sunt longiores, et horizontales, vel lenitèr incurvæ : apices omnibus obtusi, nec rarò etiam aliquantùm dilatati, quod tamen est incertum, interỏùm enim apice angustiores sunt quàm ortu, quamvis semper obtusi.

FrUCTIFICATIo ramulorum ad apices sita, e tuberculis constat solitariis, ovato-lanceolatis, papaveris seminis magnitudine, sæepiùs mucrone exiguo apiculatis, qui autem aliquando ita producitur ut in alteram capsulam brevissimo a præcedente intervallo disjunctam turgeat, ramulusque sub-moniliformis appareat:" capsulæ congeriem includunt seminum minutissimorum, oblongorum, fibris perbrevibus simplicibus immixtis.

CoLOR, nisi fallor, in recente intensè ruber purpurascente tinctus, diaphanus, qui soli objectus citissimè mutatur, et frons hìnc plerumque pulcherrimè versicolor reperitur; et, ut Wulfenii verbis utar, " non uno sed diversis planè speciosissimisque (atro-rubente, dilutè viridi, aquosè flavente, purpurascente, albido, hyacinthino, etc.) varia caloribus."

SU BST A т IA cartilaginea, crassiuscula, lenta, tenax, in exsiccatâ cornea.

Овs. Fucus hic, uti observavit Pallasius, plerumque hìc illìc crustâ vel tartaro quodan obductus apparet, quæ Millepore agariciformis primordia sunt. Anat quoque Sertularia Pluma in eo crescere.-Exsiccatus chartæ neutiquàm adhæret.

Perpaucæ sunt Fucorum species quæ magis universè inter botanicos innotuerunt, vel magis habentur in deliciis inter illos qui algas submersas colligere solent, quàm $F$. cartilagineus, cujus formæ speciosissimè versicoloris præstans elegantia efficit ut non rarò e Bonæ Spei Capite in Europam feratur; varïs modis in tabulas picturam simulantes artificiosè dispositus. Quatenus ex individuis, Ion paucis quiden, hucusque visis judicare licet, stirps est hrec quæ figurâ suâ crescendique modo nullis ferè ludit mutationibus, eas solas si excipias quæ a diversis ætatis stadiis vel ab injuriâ quâdanı acceptâ oriuntur; quales, nisi fallor, Gmelinum moverunt ut ex uno $F$. cartilagineo duas strueret species, $F$. capensem et $F$. versicolorem, quarum illa nihil aliud nisi hujus exemplar mancum exoletumque apparet. Ita saltem innuunt descriptio et icon, quibus tamen prætermissis, Linnæus, Gmelino plus æquo confisus, in Mantissấ suâ $F$. capensem ab $F$. cartilagineo separatum ad $F$. abrotanifolium pro synonymo retulit, neque defuerunt inter auctores recentiores qui tale secuti exemplum errores inde natos stabilirent augerentque. Longiùs quidem Esperus quàm reliqui processit; hic enim non satis ratus $F$. cartilagineum $F$. abrotanifolio conjunxisse, tertium quoque his F. gigartinum, quem eundem fructiferum credit, associavit. In errorem ab hoc diversissimum, sed quem vix minùs mireris, incidit cl. Prof. J. F. Gmelinus, qui in Systematis Natura editione decimâ tertiâ F. capensem ab $F$. cartilagineo divulsit, illi verò $F$. abrotanifolium pro synonymo, huic $F$. coccineum pro varietate ascivit. Fucum hic depictum Australium marium incolam Norvegicas revera reperiri ad oras res est de quâ dubitationem omnem tollit Gunneri icon, et quæ, ut in vegetabilium geographiâ singularis, digna est quæ memoretur. Arctissima inter F. cartilagineum et $F$. corneum affinitas interest, aded ut ab hujus varietatibus grandioribus ille interdùm ægrè dignoscatur, tantumque valet hæc sinilitudo, ut Mertensius cui ad utrumque bene observandum neque summum ingenii acumen neque consummata rei peritia neque exemplarium copia defuit, unum in alterum gradatim transire autumat; cui quamvis sententiæ in præsens assentiri nequeam, invitum tamen fateri cogit veritas me ad distinguendas nulla nıagis certa synonyma afferre posse, quàm quæe utriusque habitus, substantia, frondisque peripheria suppeditant. Ambos in Herbario suo sub $F$. cartilaginei nomine miscuerat Linnæus, quodque ibi servatur exemplar numero designatum summâque idcircò auctoritate ratum ad $F$. corneum pertinet; sed, cùm pro speciei suæ certis synonymis iconas Sebanas Gmelinianasque, utramque optimam, citet, aliorum botanicorum vestigiis insistendum credidi, et stirpem in hâc tabulâ adumbratam pro F. cartilagineo genuino habui.

a. F. cartilagineus, magn. nat.

b, c. rami sieriles, magn. auct.

d. ramus fructifer - -

e. tuberculum dissectum -

f. semina et fibra - - - - 1. 
Ficus, fronde sub-gelatinosâ, lubricâ, terete, filiformi, dichotomâ; segmentis patenti-divaricatis, summis reflexis acuminatis : tuberculis hemisphæricis, sessilibus, ubique sparsis.

Fucus tenax. TURNer, in Annals of Botany. II. p. 376. t. 15.

Habitat in Mari Sinensi.

Annua?

RADIX callus exiguus, discoideus, lutescens.

FRONDES ex eâdem basi plurimæ, cæespitosæ, plerumque omninò teretes, interdùm hic illic modicè et quasi casu compressæ, longitudine circitèr sesquipollicares, filiformes, pennæ nunc merulæ nunc corvi crassitie, utrinque acuminatæ, ipsâ statìm a basi ramosissima ; rami in his vagè dichotomi, intervallis incertissimis, in illis sparsi, patentes, vel divaricati, nec rarò reflexi, summi semper bifurci, segmentis divaricatis et reflexis longitudinis incertæ: - frons, ubicunque læditur, ranıos emittit plurimos, minores, fasciculatos, unde stirpi facies longè a vulgari diversa.

Fructificatio ubique per frondem sparsa e tuberculis constat hemisphæricis, aciculæ minoris capitis magnitudine, subdiaphanis, seminum enormitèr rotundorum minutissimorum lætè rubrorum congeriem foventibus, fibrarum parallelarum arctè stipatarum' albarum serie cinctam.

COLOR aquosè purpurascens, diaphanus, citissimè, si planta in aquâ dulci servetur aut aeri objiciatur, in albofuscum, et tandem in album evanidus.

SU BST ANT I A ténerrima, inter cartilagineam et gelatinosam media, tactu lubrica.

Oвs. Frons horizontalitèr dissecta tota constare reperitur ex epidermide tenui coloratâ, includente pulpam aquosam, viscosam, albam, diaphanam, repletam fibris horizontalibus, articulatis, anastonosantibus:- exsiccata charta adhæret.

Quamvis ad algas submersas colligendas investigandasque multos botanicos alliciant harum formæ elegantia colorumque splendor, ut nulla ferè regni vegetabilis familia majorem admirationem ad se trahat, vix una tamen atque altera hactenus est detecta in tanto specierum numero quæ sese humano generi verè utilem præstat. Has inter paucas eminet Fucus hìc depictus, quem ad omnia Chinæ littora abundantèr repertum Sinenses per immensi sui imperii fines in vulgarem et communem usum adhibent. Maximâ copiâ in provinciis Fokien et Tche-kiang legitur, atque inde circitèr viginti septem millia pondo quotannis in urbem Canton invehuntur, singulæ ubi libræ sestertio ferè veneunt. Lectum Sinenses Soli modò ad desiccandum exponunt, curâque nullâ aliâ adhibitâ aliquot annos servant, per quos ejus vires non modò non minuuntur verùm etiam augentur, dummodò arctè compressum humidulumque servaverint. Siquandò uti volunt, sordes particulasque salinas aquâ dulci cautè abluunt, eâdemque tepidâ mox macerant, in quấ cito liquefit, frigescensque diriget in gelatinam solidam eandemque tenacissimam, quæ, glutinis instar, iterùm calefacta liquescit. Hæc ad omnes ibi adhibetur usus, ad quos Gummi vel gluten nobiscum, sed præcipuè ad roborandas et vernice linendas chartas e quibus laternas suas conficiunt, aut ad incrassandas lævigandasve vestes sericas tenuissimasque lineas. Talia de hâc stirpe memorata unà cum exemplaribus meis viro nob. J. Banks Baroneto et D. H. H. Goodhall accepta refero, quorum ille quinque abhinc anuis ad me misit hunc Fucum, quærens simul annon forsan $e$ nostris aliquandò lectum acceperim oris, aut, si non, annon nos algam quandam haberemus indigenam quæ paritèr ad tales esset apta usus. Hoc si fieret, nos aliquâ saltem ex parte sumptui parsuros, quem in Gummi Arabico invehendo Britannia quotannis impendit. Piguit sanè quod tales ad rogatus responsum quod vellem reddere nequirem; quamvis enim, si texturam, si habitum, si substantiam similem respicias, nulla manet dubitatio quin idem etiam valeant $F$. clavellosus et $F$. asparagoides, unà cum Confervis plerisque gelatinosis, atque Ulvâ rubente, $U$. furcellat $\hat{a}$, et $U$. fliformi, hi tamen omnes tam parcè in littoribus nostris reperiuntur, ut in re inercatoriâ prorsùs forent inutiles. Plurimæ quiden, si non omnes, Algæ submersæ visciditatis in se quiddam includunt, quæ multo magis in his quàm in illis copiosa apparet; nec desunt inter Fucos nostros Britannicos qui satis diu aquâ fervente incocti liquefiunt. Ita præcipuè se res habet in $F$. ciliato et $F$. crispo, qui ambo frigescentes in gelatinam rigent, gluten formâ, nequaquàm tamen tenacitate, quâ prorsùs caret, referentem. Hanc gelatinam ad niliil aliud idoneam hucusque reperi, nisi ad eas Algas, quæ minùs ipsæ sunt glutinosæ, chartæ affigendas. Hoc facit optimè, quonian neque Gummi ad instar nitet, neque sicut gluten papyrum fædat. Magnitudine suâ, figurâ, et ramorum dispositione, $F$. tenax arctissimè Ulva furcellat $a$ accedit: a quâ primo statim aspectu distinguunt fructus diversissimus apicesque acuminati reflexi. Inter Algas, quibuscum fructificatione convenit, nulli est magis quam $F$. aciculari affinis, cujus, sicut sub illâ animadvertitur specie, ramulis lateralibus aculeiformibus caret.

a. F. tenax, sterilis, magn. nat.

b. exemplar aliud, cum fructu.

c. ejusdem apex, magn. auct. - - 6.

d. frondis pars, cum tuberculo - - - 4.

e. tuberculum dissectum - - $\quad$ - $\quad-2$.

f. semina - - - - - - 1 .

g. frons horizontaliter dissecta - $\quad$ - 3.

h. ejusdem vars - $--_{-},-\mathbf{l}$ 
Fucus tenax, frond sub-gelatinous, slippery, cylindrical, filiform, distichous, with segments betrveen patent and divaricated, the upper ones reflexed and acuminated: tubercles hemispherical, sessile, scattered all over the frond.

Fucus tenax. 'Tur ner, in Annals of Botany. II. p. 367. t. 13.

Coast of China.

Annual?

RooT, a small, yellowish, callous disk.

Fronds, numerous from the same base, growing in tufts, mostly quite cylindrical, but sometimes liere and there slightly compressed, though in such a manner as to appear accidental, about an inch and half long, filiform, varying in thickness from that of a blackbird's to that of a crow's quill, acumiuated at both ends, irregularly divided immediately adjoining its base into two or more branches, which are either dichotomous at most uncertain intervals, or are beset with other small scattered ones, patent or divaricated, and not uncommonly reflexed: the apices of all are forked, with divaricated, reflexed segments, of various length: the frond, wherever it is injured, throws out a profusion of small clustered branches, which give the specimens that are so, an appearance very different from the general one of the plant.

FuCTIFICATION, scattered all over the frond, consisting of hemispherical tubercles, as large as a small pin's liead, semitransparent, containing a mass of very minute, deep-red, roundish seeds, surrounded by a close layer of parallel white fibres, which cause the tubercles at first sight to look like large single seeds, with a pellucid limbus.

Color, pale purplish, transparent, very soon turning, from exposure to the sun, or from being kept in freshwater, to a whitish brown, and at last to white.

SUBSTANCE, intermediate between cartilaginous and gelatinous, extremely tender.

Oвs. A horizontal section of the frond shews it to consist wholly of a thin, colored epidermis, containing a coloxless, watery, viscous pulp, full of jointed fibres, lying in a horizontal direction :-in drying it adheres to paper.

Attractive as the submersed Algæ are in general to naturalists, from the beauty of their colors, or the elegance of their forms, there are but few among them which have at present been found to be really serviceable, either in supplying the wants or adınınistering to the comforts of mankind. Among these few, however, the subject of the present plate holds a distinguished place, being in very extensive use in the immense empire of China, upon the coasts of which it is gathered in great abundance. It is found there in almost every part, but is principally collected in the provinces of Fukien and Tche-kiang. The quantity annually imported at Canton is about 27,000 lb., and it is sold in that city at about $6 d$. or $8 d$. per lb. In preparing it, nothing more is done than simply drying it in the sun, after which it may be preserved, like other Fuci, for any length of time, and improves by age, when not exceeding four or five years, if strongly compressed and kept moist. The Chinese, when they have occasion to use it, merely wash off the saline particles and other impurities, and then steep it in warm water, in which, in a short time, it entirely dissolves, stiffening, as it cools, into a perfect gelatine, which, like glue, again liquefies on exposure to heat, and makes an extremely powerful cement. It is employed among them for all those purposes to which gum or glue are here deemed applicable, but chiefly in the manufacture of lanthorns, to strengthell or varnish the paper, and sometimes to thicken or give a gloss to gauze or silks. For this information respecting it, as well as for my specimens, I have to acknowledge my obligations to Sir Joseph Banks, and to Mr. H. H. Goodhall, the former of whom communicated it to me some years ago, inquiring if it was not also found upon the shores of Britain, or if we liad not some other species indigenous in our islands that might be applied to the same purpose, and thus save a part, at least, of the immense expence which the importation of Gum Arabic annually costs the nation. To both these questions, I am sorry to say, that it was necessary to reply in the negative, for thongh, from similarity of habit, texture, and substance, I have not the smallest doubt but this is the case with $F$. kaliformis, $F$. clavellosus, and $F$. asparagoides, as well as with the more gelatinous Confervæ, and Ulva rubens, U. filiformis, and U. furcellata, yet none of these are known to occur on any parts of our shores in sufficient quantity to render the collecting of them otherwise an object than as a matter of curiosity. There are, indeed, few of the. submersed Alga that are not possessed of some degree of viscidity, and many of our British Fuci will in great measure, if not entirely, melt, when boiled in water over a quick fire. Such is particularly the case with $F$. ciliatus and $F$. crispus, both which, on cooling, form into a gelatine resembling glue in appearance, but, unfortunately, by no means in tenacity, of which they are altogether destitute, nor liave $\mathbf{I}$ found them applicable to any purpose, except to the fixing of those sea-weeds on paper, which do not themselves possess a sufficiently adhesive quality. For this purpose they are admirably calculated, as they impart no stain like glue, or glare like gum; nor is any thing farther necessary than to rub over with them the paper on which the specimens are to be preserved, and the delicate membranaceous species will, by pressure, be fixed so firmly, as to be afterwards inseparable. F. tenax, in point of size, shape, and ramification, approaches most nearly to Ulva furcellata, from which it is so different in its fructification, its color, and its acuminated reflexed apices. Among those, with which it agrees in fruit, it is perhaps to none so much allied as to $F$ acicularis, of which, as observed. under that species, it wholly wants the lateral, horizontal, aculeiform ramuli.

a. F. tenux, barren, natural size.
b. fructified specimen.
c. apex of the same, mannified - -
d. small part of the frond, with a tubercle -6.
e. section of a tubercle - -
f. seeds - - - - -
g. horizontal section of the frond -
h. part of the same -



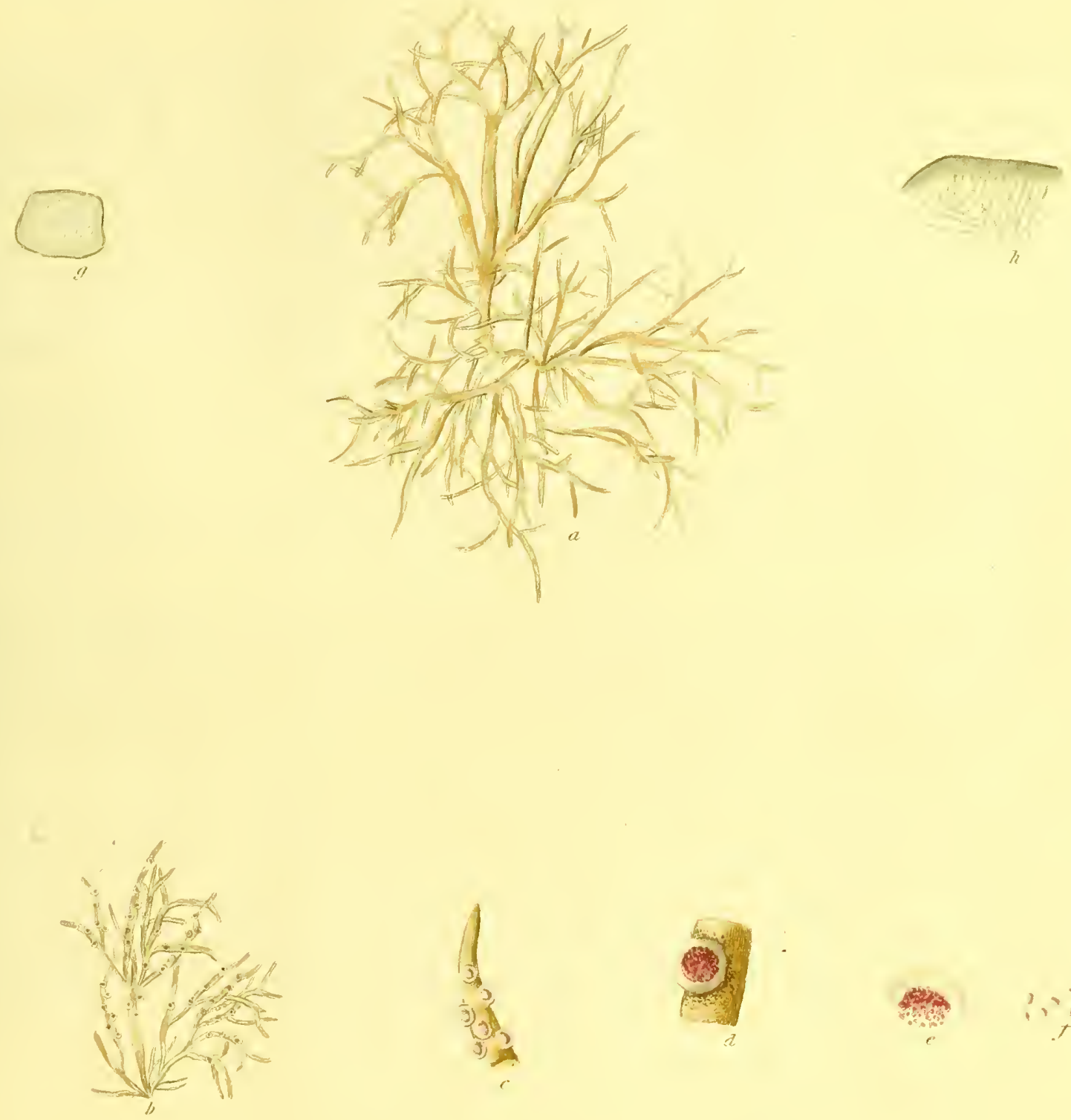

? ? : ?

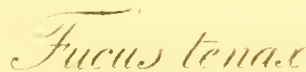



Fucus, fronde sub-cartilagineâ, molli, terete; filiformi, sub-dichotomâ; segmentis patentibus, acuminatis, hìc illìc ramulos laterales horizontales, abbreviatos, aculeiformes ferentibus : tuberculis sphæricis, sessilibus, sparsis.

Fucus acicularis. Wulfen, Crypt. Aquat. n. 50.

B. ustulatus; fronde capillaceâ, vix unguiculari, nigricante.

F. ustulatus. Mertens, MSS.

На вітат in Mari Adriatico. Wulfen.-Lusitaniæ ad oras. D. Link.-Lapurdi. D. Prof. Mertens.-Inter maris rejectamenta prope Belfast, unum modò exemplar repertum. D. Templeton.-In Cornubiâ, perrarò. D. Rashleigh:- $\beta$ apud Gades. D. S. de Roxas Clemente.-In Mari Meditcraneo. D. Mohr.

RADIX callus exiguus, discoideus, quem repentenı nunquam vidi, sed plantæ ex indole repere supicarer.

FRONDES ex eâdem basi plurimæ, teretes, filiformes, longitudine bi-tri- pollicares, Merulæ pennæ ferè crassitie, et ubique propemodùn æquales, laxè diffusæ, ab ipso ortu ramosissimæ; rami sparsi, sub-fastigiati, inferiores sesquipollicares, reliqui sensìm breviores, patentes, vel divaricati, interdùm et reflexi, aliquot linearum intervallis sejuncti, hi simplices, illi aliis minoribus simili ratione dispositis obsiti, aut etiam vagè dichotomi, apicibus omnibus acuminatis; per frondem hìc illic, sæepiùs tamen apices versus, sparguntur ramuli lomogenei, remotiusculi, simplices, unam pluresve promiscuè linean longi, subulati, aculeiformes, sub-horizontales, recti vel incurvi:-frondis dissectæ pars interior e muco albo pellucido fibras plurimas concolores reticulatas includente, ut in $F$. Opuntiâ, constare reperitur.

"Fructificatio tubercula exigua, sphærica, sessilia, frondi concolora, in ramis superioribus sparsa, seminum minutissimorum, subrotundorum, purpurascentium congeriem foventia.

CoLOR rubro-purpurascens, sub-diaphanus, apices versus sæpe e dilutâ rubedine flavescens; sin luci objiciatur, vel in aquâ dulci retineatur, primùm in sordidè lutescentem et demùm in albidum evanescit.

Su BSTA тіi cartilaginea, tenera tamen, exsiccatæ rigidiuscula.

Var. $\beta$ in omnibus est partibus quintuplo sextuplove minor, ut rard ad unguis altitudinem attingat, frondemque habeat propemodùm capillaceam : color, nisi luci objiciatur, niger, facie quâdam deustâ : ramorum dispositio minùs regularitèr dichotoma.

О вs. Planta insigniter lævis et teres exsiccata chartæ non adhæret, sin ita diu in aquâ dulci retineatur ut flaccida sit facta, et mox pressuræ gravi subjiciatur, arctè chartæ adhæret, et apices versus dilatatur, frondisque compressæ planæve omnind faciem præ se ferens $F$. ciliati varietates quasdanı angustiores non nıalè refert. Cavendum est ne tyro exemplaribus exsiccatis plus æquo confisus in errorem inducatur.

Primus et, quantum reperio, solus inter auctores $b$. Wulfenius memoravit hunc fucuin, qui tamen nihilominùs nequaquàm inserendus videtur eorum numero, qui infrequentissimè in Australibus Europæ oris reperiuntur. Floræ quoque Britannicæ civibus annumerari postulat, nostra ad littora nupèr lectus, quamvis ita perparcè ut non revera vernaculum crederem, sed potiùs casu aliquo inter alia maris rejectamenta appulsum. Neque, ut altiùs procedam, Linnæum omnino latuit, quippe cujus in Herbario duo ejus servantur exemplaria, unum $\boldsymbol{F}$. confervoidis alterum $F$. furcellati titulo insignitum. Liceat in transcursu adjicere hujus posterioris sub nomine tria diversarum, uti videtur, specierum, ibi unà videre esse specimina, omnia manca, quibus cunctis præetermissis, Linnæus $F$. suum furcellatum ad Gmelini Oederique iconas descripsit, his solis innixus nisi quòd illi $F$. acicularis colorem rubrum tribuerit. Substantiâ et colore $F$. acicularis $F$. gigartinum multùm refert, cujus ab habitu crescendique modo longè abludit : accedit autem in his ad $F$. tenacem et $F$. musciformem, quorum primus ramulis abbreviatis lateralibus horizontalibus omnind caret, alterius verò frons iis tota cooperta conspicitur, apicesque habet convolutos, non alitèr quàm illos $F$. scorpioidis. In priore hujus operis tomo memoratur Fucum, cui $F^{\prime}$. acicularis nomen indidit Esperus, nihil esse nisi $\boldsymbol{F}$. purpuvascentis exemplar sterile. Varietas $\beta$ suprà descripta distinctam speciem simulat, et forsan est reapse talis, quamvis liactenus frustrà characteres aliquos quæsiverim qui ab $F$. aciculari distinguerent. 'Fructiferam nondùn vidi. Quantum facie externâ dissimilis est $F$. aciculari satis ex hoc liquet, quòd Draparnaudius, qui primus detexisse videtur, $F$. pygmaum crediderit, eoque sub nomine ad Mertensium miserit.

a. F. acicularis, magn. nat.

b. frondis pars, niagn. auct. - $\quad-\quad-6$.

c. ejusden portio, cum tuberculo - - - 4 .

d. tuberculum longitudinalitèr dissectum - $\mathbf{3}$.

e. semina - - - - - - - 1 .

f. frons dissecta, ut fibra internce in conspectum veniant - - - $\quad \bar{\kappa} 2$. 
Fucus acicularis, frond sub-cartilaginous, soft, cylindrical, filiform, irregularly dichotomous, with patent acuminated segments, here and there beset with short, lateral, horizontal, thorn-shaped ramuli ; tubercles spherical, sessile, scattered.

Fucus acicularis. Wulfen, Crypt. Aquat. n. 50.

ß. ustulatus; frond capillary, hardly half an inch long, of a blackish color.

F. ustulatus. Mertens, MSS.

In the Adriatic. Wulfen.-Coast of Portugal. Dr. Link.-Bayonne. Professor Mertens.-A single specimen found among the rejectamenta of the sea near Belfast. Mr. Templeton.-Cornwall, very rare. $M r . W^{T}$. Rashleigh.- $\beta$ at Cadiz. Don Simon de Roxas Clemente.-In the Mediterranean. Dr. Mohr.

Roor, a small, callous disk, in which I have at present seen no tendency to creep, though, from the nature of the plant, I suspect that it sometimes does so.

FrON DS, numerous from the same base, cylindrical, filiform, from two to three inches long, almost as thick as a blackbird's quill, and nearly of equal size throughout, much and irregularly branched from the very base; branches scattered, mostly of equal height, the lower ones an inch and half long, the rest gradually shorter; either patent, or divaricated, or sometimes reflexed, separated from each other by intervals of a few lines, some siniple, others beset with smaller ones disposed in the same uncertain manner, and again others irregularly dichotomous, all of them having acuminated apices; all over the frond, but principally towards the extremities, are scattered ramuli, of the same substance and nature as the branches, rather remote from each other, simple, one or two lines long, subulate, resembling thorns, nearly horizontal, either straight, or incurved:- a section of the frond shews the interior of it to consist of a white transparent mucus, containing a network of colorless tibres, as in F. Opuntia.

Fructification, small, spherical, sessile tubercles, of the same color as the frcnd, scattered about the upper branches, containing a mass of exceedingly minute, roundish, purplish seeds.

COLOR, reddish purple, semitransparent, often yellowish towards the ends, soon turning, from exposure to the light, or from being kept in fresh-water, at first to a dirty, pale yellow, and at last to white.

SU BSTANCE, cartilaginous, but tender, somewhat rigid when dried.

The variety $\beta$ is in all its parts five or six times smaller than the common size of the plant, so that its branches are quite capillary, and it seldom attains to half an inch in height: its color looks quite black, unless it is held to the light, and has a singularly scorched appearance : the ramification too, is less regularly dichotomous.

Ов . In drying it does not adhere at all to paper:- the frond is remarkably smooth and cylindrical, but if, after having been kept so long in fresh-water as to have become flaccid, it is then subjected to a heavy pressure, it sticks to what it is laid upon, and is dilated towards the apices, so as to appear altogether flat or compressed, and greatly to resemble some of the smaller varieties of $\boldsymbol{F}$. ciliatus, for which it may in such case easily be mistaken.

Baron Wulfen appears to be the only botanist who has hitherto described the Fucus here figured, which, nevertheless, seems to be far from uncommon in the more southern seas of Europe, and requires also to be adnitted into the British Flora, though, probably, not really a native of our shores, but only thrown upon them accidentally, with other rejectamenta of the ocean. It was likewise not altogether unknown to Linnæus, though left unnoticed in his works; as in his Herbarium are preserved two specimens of it, the one mixed with $F$. confervoides, the other with two dissimilar, and probably new species, under the name of $F$. furcellatus; from none of which, however, does he appear to have taken lis character of that Fucus, but altogether to have relied for this upon the figures of Gmelin and Oeder, and simply to have borrowed from $F$. acicularis the observation, that the color is generally red. This plant, in point of color and substance, is far from being unlike $\boldsymbol{F}$. gigartinus, from which it differs widely in its habit and mode of growth, and in these latter respects approaches most nearly to $F$. tenax and $F$. musciformis, the former of which is entirely destitute of the short, lateral, horizontal ramuli, and the latter has its frond almost wholly covered with them, instead of their being, as in F. acicularis, only scattered here and there over the branches, and in some of thell wholly wanting: besides which, the ends of its branches are remarkably rolled in, nearly as much so as those of $\boldsymbol{F}$. scorpioides. The Fucus figured by Professor Esper, under the name of $\boldsymbol{F}$.acicularis, is, as has been mentioned in the former volume of this work, nothing more than $F$. purpurascens in a barren state. The variety $\beta$, above described, has wholly the look of a distinct species, and may possibly hereafter prove to be so, though I can at present find no specific character to separate it from $F$.acicularis. I have never seen it in fruit. It appears to have been first noticed by the late M. Draparnaud, who sent it to Professor Mertens as F.pygmeas; a fact, that sufficiently shows how different is its appearance from that of the plant here tigured.

a. F, acicularis, natural size.

b. part of the frond, magnified -. - - 6 .

c. small portion of the sume, with a tubercle - 4 .

d. longitudinal section of the tubercle - - 3.

e. seeds - - - - - - - 1 .

f. frond cut open to shew the internal fibres - ‥ 

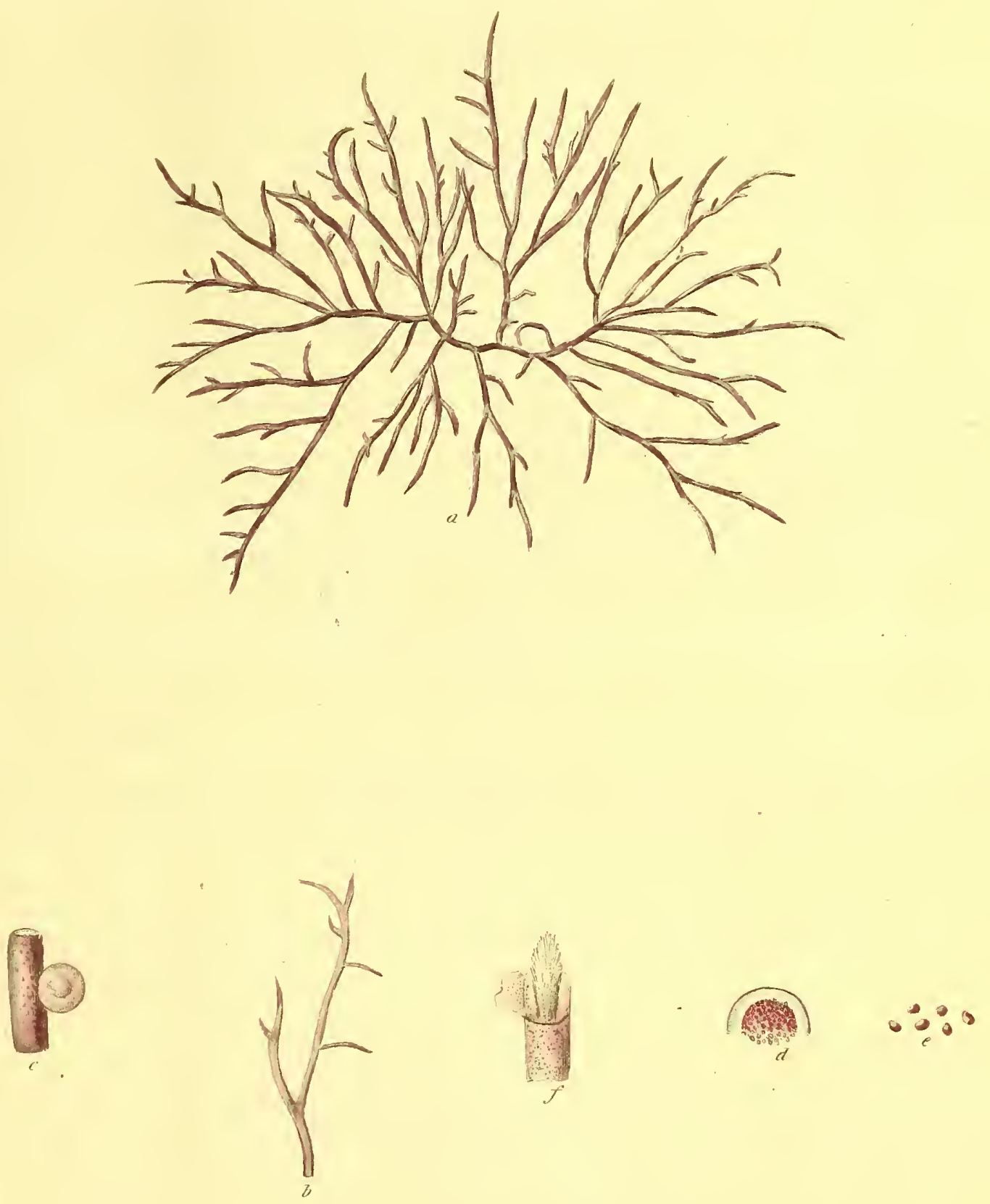

Hecur acicularis. 

Fucus, fronde sub-cartilagineâ, flaccidâ, terete, fliformi, ramosissimâ ; ramis flexuosis, acưminatis, apice uncinatis incrassatis mudiusculisque, alibi obsitis ramulis abbreviatis, approximatis, horizontalibus, setaceis: tuberculis sphæricis, sessilibus, sparsis.

Fucus musciformis. Wu fon, in Jacqu. Coll. III. p. 154. t. 14. f. 3. Crypt. Aquat. n. 23. Linn. Syst. Nat. Ed. Gmel. II. p. 1384. Es PER, Ic. Fuc. I. p. 135. t. 93.

ß. spinulosus; fronde gracili; ramulis patentibus, laxè sparsis. F. spinulosus. ESPER, Ic. Fuc. I. p. 73. t. 34. (exclusis synonymis.)

F. cirrhifolius. V $\mathrm{AH \textrm {L }}$, in Skrivter af Naturhistorie-Selskabet. V. pars $2 d a$. p. 42.

$\gamma$. Nootkanus; ramulis remotiusculis, elongatis, horizontalibus, deflexisque, apice sæpe uncinatis.

F. Nootkanus. Es PER, Ic. Fuc. II. p. 30. t. 125.

8. strictus; frondis apicibus rectiusculis; ramulis erecto-patentibus.

Ha вiтат in Mari Adriatico, Tergesti. Wulfen.-Ex Insulâ Ceylon accepit Linnaus.-In Mari Mediterraneo, ad Insulas Baleares. D. Maimburg.-In Indiæ Occidentalis oris. D. Wright.-In Novâ Selandiâ. $D . J$.

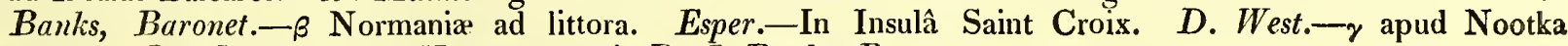
Sound. D. Menzies.- $\delta$ ex Egypto accepit D. J. Banks, Baronet.

RADIx latè repens, fibrosa, fibris elongatis, ramosis, implexis, et, ut Wulfenii verbis utar, musci ad instar cancrorum testas vel alia corpora marina densissimè obsidentibus, hìc illìc in novas frondes assurgentibus.

FRONDES cæspitosæ, plurimæ, diffusæ, palmares vel spithamææ, teretes, basi pennæ passerinæ ferè crassitie, exinde sensìm attenuatæ, ut in apices setâ porcinâ vix crassiores desinant, a basi usque ramosissimæ; rami frequentes, sparsi, patentes, tres et ultrà pollices longi, inferiores plerumque longissimi, aliis ninoribus paritèr vagè sparsis sæpe instructi, qui quoque interdùm alios ferunt: ramos omnes, uti et frondem primariam, obsident ramuli homogenei, sparsi, horizontales, vel horizontalitèr patuli, recti, nunc approximati, nunc remotiusculi, superiores sæpe secundi, simplices, setacei, circiter lineam longi, e quibus tamen hic illic unus alterve conspicitur magis elongatus, seseque in ramum producturus :-frondis apices plerumque nudati vel tantummodo ramulis perpaucis brevissimis instructi lenitèr sunt incrassati et cirrhi in modum revoluti, ut per hos planta sese aliis stirpibus affigat, affigendoque sustentet.

Fructificatro, a me numquam visa, est, teste optimo Vahlio, tubercula sparsa, plerumque solitaria, rarò geminæ vel tria conferta, ad latera etiam ramulorum sessilia, minuta, globosa, pellucida.

* Color obscurè ruber, purpurascente immixtus, sub-diaphanus, nitoris experś, fugacissimus : luci objecte vel in aquâ dulci servalce in sordidè albo-virescentem et demùm in albidum transiens.

Su Bs TA N TI A cartilagineo-membranacea, tenera, succosa, flaccida.

Var. $\beta$ in eo præcipuè $a b \alpha$ discrepat, quòd frondes habeat graciliores, ramulis ubique laxè sparsis, coloremque magis rubrum sine purpurascentiâ.

Var. $\gamma$ ad semipedalem et ultrà longitudinem producitur; fronde flexuosâ, aliquantùm tenuiore quàm $\alpha$, sæpe vagè dichotomâ, dichotomiarum sinubus rotundatis, ubique laxè obsitâ ramulis sparsis, duas tresve lineas longis, simplicibus, tenuissimis, horizontalibus, sed plerumque apice lenitèr uncinatis : frondis color intensè coccineus, attamen hìc illic aurantiacus aut flavescens; apices multo minùs inflectuntur quàm in præcedentibus varietatibus, non rarò recti : fructificatio ignota.

Frondem habet $\delta$ merulæ pennâ crassiorem, et insignitèr strictam, ut apices perrarò sint involuti ; ramuli quoque, qui numero eos a æquant, nequaquàm sunt horizontales, sed potiùs erecto-patentes, ut aculeos referant: color huic intensè brunneus cum purpurascentiâ quâdam.

OBS. Exsiccata chartæ laxè admodùm adhæret.

Iconem hujus Fuci egregiam unà cum descriptione paritèr bonâ tradidit in Jacquini Collectaneis Wulfenius, quå primus hanc stirpem memoravit; ita ut per has diu botanicis innotuerit. Utinam sanè nomen indidisset paritèr aptum; sed hoc, tantummodo depromptum a crescendi modo, quo, Musci instar, Cancrorum testas perrepit, plurimis etiam aliis æaqualitèr convenit Fucis; pigetque igitur quod cogamur tale, utpote janı universè receptum, anteponere optimo illi Vahliano, quod, frondis apices cirrhi in fornam tortos innuens, characterem speciei imprimis proprium denotat. $F$. musciformis est stirps quæ mole sıâ colore et ramulis plùs minùsve copiosis multum ludit; quæ tamen in omnibus suis mutationibus facilè dignoscitur per horum figuram simplicem situmque horizontalem, necnon per ramorum apices, qui vix minùs quàn in $F$. scorpioide insignitèr inflectuntur; eodem, uti videtur, fine quo illi $F$. purpurascentis $\beta$ vel $F$. ciliati $\delta$, nempe ut plantam debilem sustentent. Discrepant autem hi apices ab iis trium jam memoratarum specierum, quòd sint aliquantùm incrassati, et quòd, dum reliqua frons ramulis est obsita, hi nudiusculi appar ant. Fatendum est in dubio quodam esse aninum an var. $\delta$ mea revera an hanc speciem pertineat; habitum enim dissimilem ducit a crescendi modo stricto, faciemque inter $F$. musciformem et $F$. acicularem mediam: sed huic quoque, uti suprà animadvertitur, interdùm non deest ramus unus et alter uncinatus. Hujus varietatis exemplaria benignè mecum communicavit Stackhousius, qui accepit a Decandollio, cujus tamen Floram Atlanticam frustrà VOL. II. 
pervolvi ejus descriptionem quærens; neque minùs seduld in Gmelini Forskaliique operibus aliquas ex $F$. musciformis varietatibus perquisivi ; frustrà ; nihil enim reperi; nisi forsan eandem stirpem sub $F$. muscoidis nomine designavisse in animo habuerit Forskalius; quod, cùm descriptionem in Florấ AEgyptiaco-Arabicâ *brevissimam et nulla in herbario suo exemplaria reliquerit, verisimillimè in æternum latebit. †Varietatem $F$. sui cirrhifolii memorat Vahlius, quam D. West, qui ab Insulâ Sanctæ Crucis misit, pro specie distinctâ habuit: liujus ego nulla specimina vidi, sed ex descriptione suspicor esse primam e meis.

a. F. musciformis, magn. nat.

b. frondis pars, magn. auct. $\quad-\quad-6$.

\footnotetext{
* Tota hæc descriptio est, "Fucus Muscoides; caule tereti, rubro, apice flavido, ramosissimo; spinulis sparsis, mollibus."-Fl. AEgypto Arab. p. 193.

† Hanc varietatem his verbis designat West, "Fucus parasiticus, caule filiformi, angustato, ramosissimo ramulis confertis, capillaribus, foliis subulatis, acutè dentatis, tuberculis singulis axillaribus. Unco in extremiiate ramulorum carnoso, simplici, quo aliis alligatur plantis." Huic adjungit Vahlius, "Habitı quidem aliquid certè differt, at unica differentia mihi obvia in ramulis copiosioribus confertioribusque."
}

\section{7.-F U C U S M U S I F O R M I S.}

Fucus musciformis, frond sub-cartilaginous, flaccid, cylindrical, filiform, much and irregularly branched; branches flexuose, acuminated, with apices incurved, thickened, and mostly naked, in other parts beset with short, lorizoutal, setaceous, simple ramuli, close to each other: tubercles spherical, sessile, scattered.

Fucus musciformis. Wulfen, in Jacq. Coll. III. p. 154. t. 14. f. 3. Wulfen, Crypt. Aquat. n. 23. Lin N. Syst. Nat. Ed. Gmel. II. p. 1384. EsPer, Ic. Fuc. I. p. 135. t. 93.

3. spinulosus; frond slender, ramuli patent, renıte.

F. spinulosus. Esper, Ic. Fuc. I. p. 73. t. 34. (exclusis synonymis.)

F. cirrhifolius. V A L, in Scrivter af Naturhistorie-Selskabet. V. pars 2da. p. 42.

\%. Nootkanus; ramuli rather remote, long, horizontal, or deflexed, often hooked at their apices.

F. Nootkanus. Esper, Ic. Fuc. II. p. 30. t. 125.

S. strictus; apices of the frond mostly straight ; ramuli between erect and patent.

In the Adriatic Sea, at Trieste. Wulfen.-Sent from Ceylon to Linnceus.-Coast of Minorca. Mr. Maimburg。 -Shores of the West Indies. Dr. Wright.-New Zeeland. Sir Joseph Banks. $\beta$ on the coast of Normandy. Esper.-Isle of Saint Croix. West._ $\gamma$ at Nootka Sound. Mr. Menzies.- $\delta$ sent from Egypt to Sir Joseph Banks.

Rоoт, creeping, consisting of numerous, long, branched, matted fibres, which, to borrow the words of Wulfen, like mosses, most thickly cover the shells of crabs and other marine bodies, and here and there rise into new fronds.

FrON DS, numerous, clustered, spreading, from three to seven inches long, cylindrical, about as thick as a sparrow's quill at their base, but thence gradually tapering, so as at their extremities scarcely to be larger than hog's bristles, much and irregularly branched from the very base; branches plentiful, scattered, patent, three inches or more in length, the lowest mostly longest, frequently beset with other smaller ones placed in the same uncertain manner, and these again sometimes with others: the whole of the-branches, as well as the primary shoots, are covered with scattered ramuli of the same nature and texture as themselves, either horizontal, or between horizontal and paitent, straight, some placed close together, others standing at short distances, the upper ones often secund, all simple, setaceous, and mostly about a line long, though here and there one is often observable longer than the rest, and extending into a new branch: the apices of the frond are most commonly naked, or merely beset with one or two extremely 

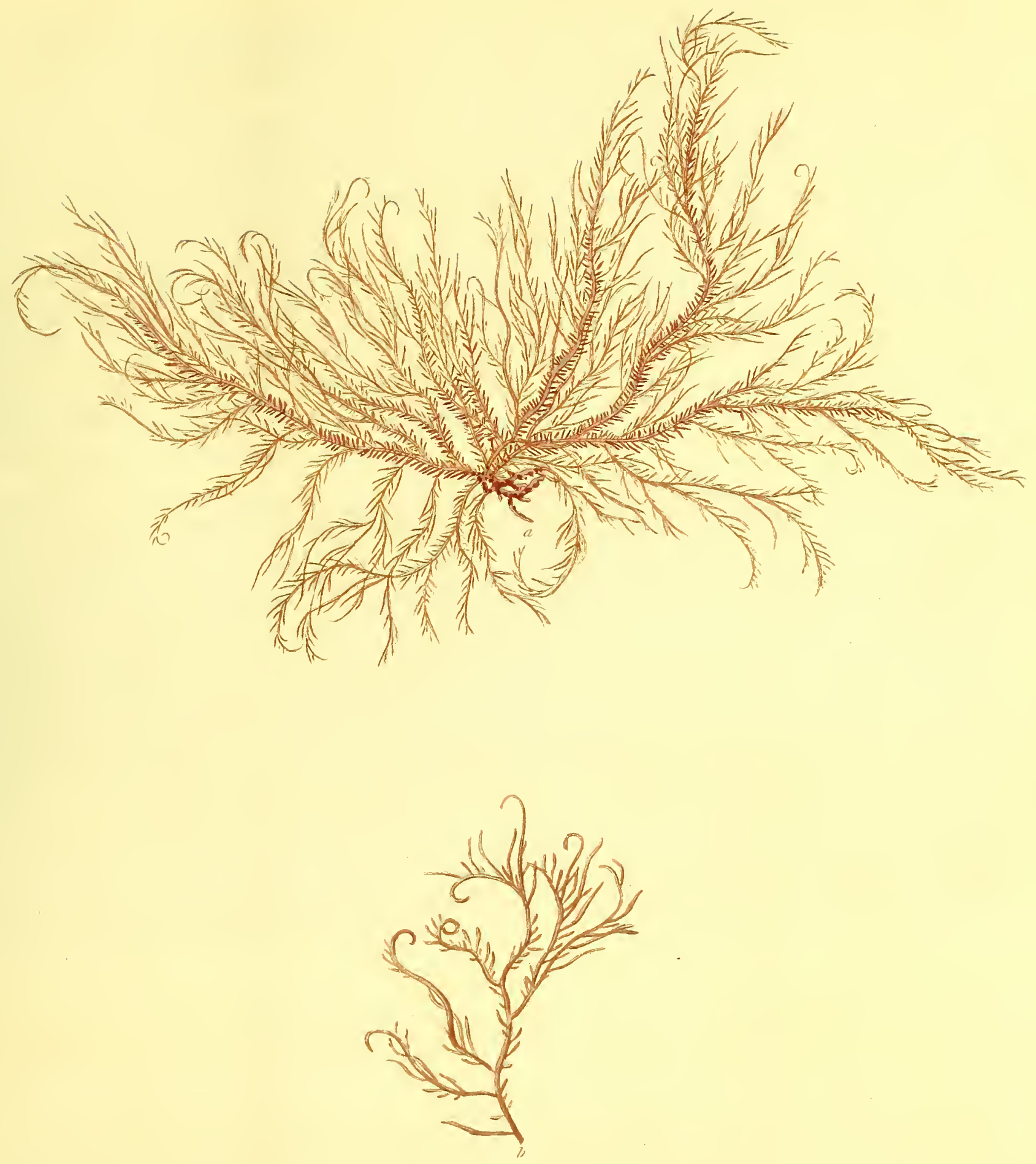

short ramuli, and are slightly swollen, and twisted like tendrils, so that the plant by means of these attaches itself to other substances, and thence derives support.

Fructification, which I have never seen, consists, according to Vahl, of scattered tubercles, mostly solitary, but sometimes, though seldom, growing two or three together, sessile upon the sides of the branches and ramuli, minute, globular, and pellucid.

Co LOR, dark, dull red, with a purplish tinge, quite destitute of gloss, semitransparent, very fugitive, and turning, from exposure to the sun, or from being kept in fresh water, at first to a dirty light green, and afterivards to white.

SUBSTANCE, between membranaceous and cartilaginous, full of moisture, tender, and thaccid.

The variety $\beta$ principally differs from $\alpha$ in being every where more slender, in having its ramuli only scattered at considerable distances over the frond, and its color a pale red, not at all inclining to purple.

$y$ Rises to the height of half a foot or more, with a frond somewhat more slender than that of $\alpha$, flexuose, repeatedly dichotomous in an irregular manner, with the angles of the dichotomies rounded, beset all over with rather remote, scattered ramuli, two or three lines long, simple, very slender, horizontal, or, as is frequently the case, slightly hooked at their points : its color is deep scarlet, but here and there orange, or yellowish; the apices of the branches are far less involuted than those of the preceding varieties, and not uncommonly straight: the fructification is unknown.

In 8 , the frond is as thick as a blackbird's quill, and the appearance of the whole is particularly straight, so that even the apices are but seldom involuted: the ramuli, too, which are as numerous as in $\alpha$, instead of being horizontal, are between erect and patent, so as to look like little spines: the color of this is a deep, brownish purple.

Oвs. In drying it adheres but slightly to paper.

The name of F. cirrhifolius, given to this Fucus by Professor Vahl, who described it in the Copenhagen Transactions, is so admirably expressive of one of the most striking peculiarities of the species, that it is impossible not to regret the necessity of changing it for the comparatively unmeaning appellation which it originally received from Wulfen, by whose excellent figure and description it has long been known among botanists. It is a very sportive plant, with regard both to its size, its color, and the greater or smaller number of its ramuli; but in all its changes it appears to be easily distinguishable by the simple form, and nearly horizontal direction of these latter, and by the incurved ends of the leading shoots, a character no less remarkable in this Fucus than in $\boldsymbol{F}$. scorpioides; though these apices might probably with more propriety be compared to those of $F$. purpurascens $\beta$, or of $F$. ciliatus $\delta$, being, according to all appearances, designed for the same purpose of support. They differ, however, from those of all these species in being slightly swollen, and they have another strong peculiarity, in being mostly the only part of the frond which is not clothed with ramuli. The variety $\delta$ alone seems to me to admit of some degree of doubt, whether it really belongs to the same species, as having, on account of the straightness of the whole frond, a very dissimilar habit, and an intermediate appearance betweem $F$. musciformis and $F$. acicularis; yet even in this, as above observed, some of the branches have a tendency to curl at their extremities. For my specimens of it, I am indebted to Mr. Stackhouse, to whom it was given by M. Decandolle; but I have, nevertheless, sought in vain for a description, either of it, or of the other varieties, in the works both of that author, and of Gmelin, and Forskal, unless, indeed, some of them were intended by the latter as his F. muscoides, which, as he has left no specimens of it in his herbarium, and only a very * short description in his Flora, it is impossible satisfactorily now to determine. There is still another tvariety, described by Vahl, which West, who communicated it to hin from St. Croix, regarded as a distinct species; but I have left it unnoticed above, having seen no specimens of it, and thinking it most probable, from what Vahl says of it, that it is only the $a$ of this work.

a. F. musciformis, natural size.

b. part of the frond, magnified - - 6 .

\footnotetext{
* The whole of this description is, "Fucus Muscordes; caule tereti, rubro, apice flavido, ramosissimo; spinulis sparsis, mollibus."-Fl. Egypt-Arab. p. 193.

$\dagger$ The foilowing is the account given by West of this variety, "Fucus parasiticus caule filiformi, angustato, ramosissimo, ramulis confertis, capillaribus, fol is subulatis, acutè dentatis tuberculis singulis axillaribus. Unco in extremitate ramulorum carnoso, simplici, quo aliis alligatır plantis." To this Vahl adds, "Habitu quidem aliquid certè differt, at unica differentia milti obvia in ramulis copiosioribus confertioribusque."
} 
Fucus squamulosus, frond between coriaceous and cartilaginous, sub-cylindrical, mostly dichotomous, beset here and there with short, scattered, spiniform ramuli, mixed with clusters of branched fibres.

\section{Perennial.}

RoоT, consisting of a few, rather thick, liard, blackish, incurved, branching fibres, disposed in a radiated manner.

Frond, a foot and half, or more, long, * sub-cylindrical, as thick as a goose-quill in the part nearest the base, whence it gradually, but almost imperceptibly, tapers, so as at the extremities not to exceed the size of a sparrow's quill; it rises undivided to the height of four or five inches, where it becomes forked, and is afterwards about eight or nine times dichotomous at most irregular intervals; the upper segments are long, and generally of nearly equal height, the angles of the dichotomies acule : the frond in its lower part is either quite naked, or merely uneven, with the short remains of the broken ramuli, that look like scales; in its upper part it is irregularly beset with ramuli of the same nature and substance as itself, between patent and horizontal, numerous, resembling thorns in their look and shape, a line long, scattered on all sides, some solitary, others growing in pairs, or three together, some simple, others bifid or trifid :- mixed with these ramuli, grow scattered all over the frond, at short intervals, clusters of extremely thin, irregularly branched fibres, twice as long as the ramuli, and of a whitish brown color, which give the whole plant a singularly woolly appearance.

Fructification, unknown.

Tolor, in specimens that have been dried and are again moistened, a very deep and opaque brown near the base, but paler in the upper parts : when dry black all over.

SUBSTANCE, immediately near the root, hard and almost woody; in other parts cartilaginous, tough, and flexible: thickish throughout.

Oвs. This Fucus recovers very imperfectly in fresh-water, and scarcely increases at all in size: the fibres in such case can never be well expanded:--in drying it does not in the least adhere to paper.

It has already, in the course of this work, been repeatedly necessary to request the indulgence of my readers towards those errors which are inseparably connected with descriptions written only from single specimens; and such an indulgence can in no case be more requisite than in the present, which labors under peculiar disadvantages, as I not only find no description of the plant in any preceding author, and never saw a specimen, besides that represented in the plate before us, which is preserved in the Banksian Herbarium, but, in addition to this, it is a species that, as above noticed, after having been once dried, revives most slowly and imperfectly on subsequent immersion. This is the more to be lamented in a Fucus of so singular a nature; for I know of no other that at all resembles it in the strong character of producing all along its branches fibres mixed with the spiniform ramuli, but neither issuing from the apices of these, nor from any visible perforations in the frond, so as not to look as if connected with the fruit, or as if analogous to the pencils of hairs so often spoken of in F. servatus, and others; nor, on the other hand, wearing more the appearance of those fibres that at certain seasons of the year fringe the shoots of $\boldsymbol{F}$. ligulatus, $\boldsymbol{F}$. aculeatus, and their affinities; still less, seeming designed to lengthen into new branches; for this, both from their shape and ramification, appears utterly impossible. It is far from being easy to point out the nearest natural affinity of $F$. squamulosus, but $\mathrm{I}$ am inclined to think that it is more closely allied to none than to $F$. acanthophorus, and that it most probably bears a similar fructification. It might also with great propriety liave received the same name, had not this been previously occupied; which being the case, I have given it another derived from the scaly appearance of the leading stem, especially towards the base, a circumstance particularly striking at the first view of the species. The habitat of this plant is unknown, as Sir Joseph Banks' specimen was taken from Aublet's Herbarium, and no memorandum is attached to it.

a. F. squanıulosus, natural size,

b. upper part of the frond, magnified - -6 .

c. cluster of fibres - - - - - 3.

d. part of the principal shoot near the base -6.

- In Sir Joseph Banks's specimen the frond is compressed, or rather between flat and compressed, and continued so after it had beet soaked for some time in water; but still, from the nature and appearance of the plant, I cannot feel a doubt of its having originally been cylindrical.

$\dagger$ This plant appears in its nature so different from any other, that I am not able to form the least conjecture what the coler is in a recent
cylindrical. state. 


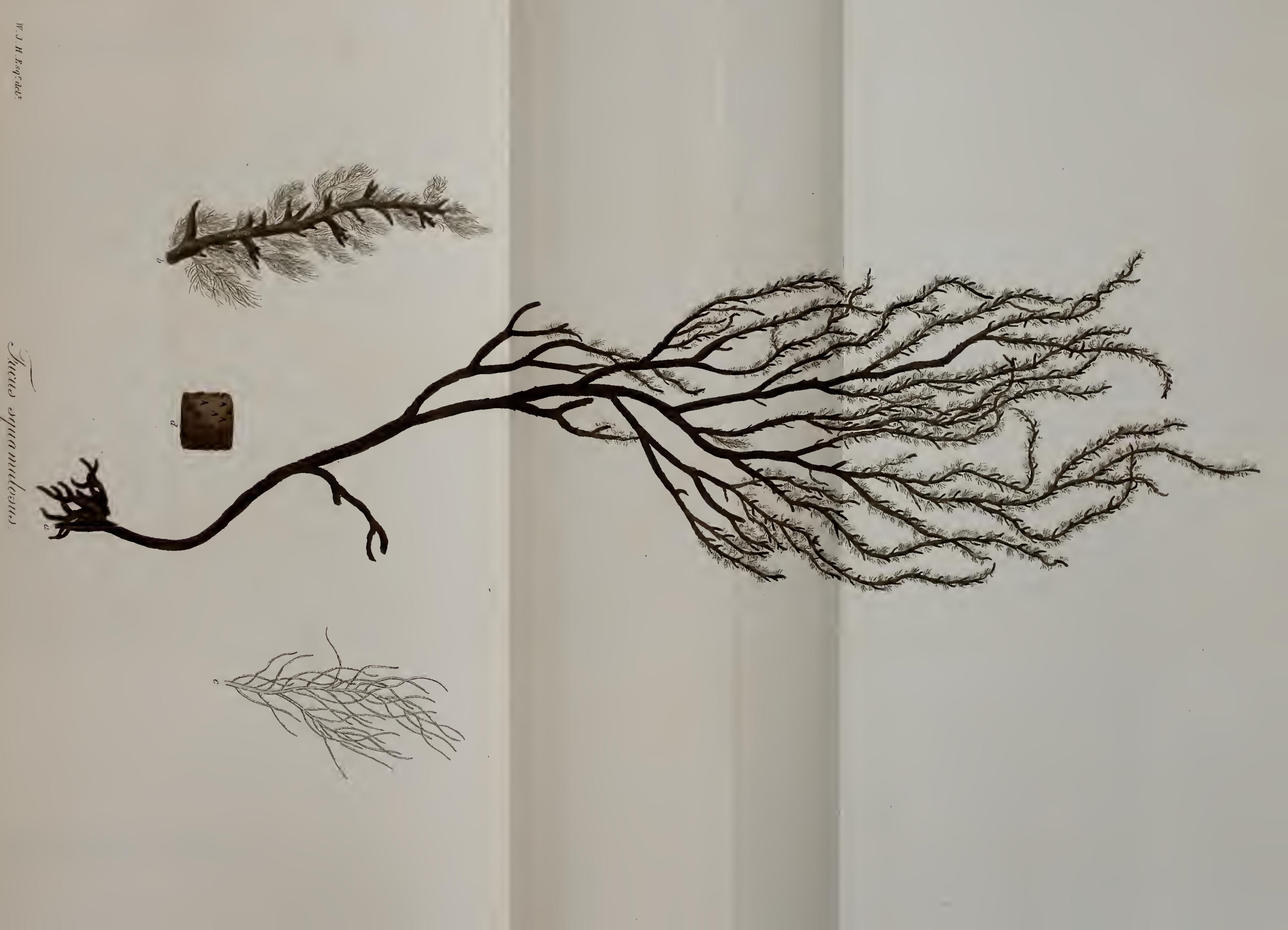



Fucus, fronde coriaceo-cartilagineâ, teretiusculâ, sub-dichotomâ, ramulis sparsis abbreviatis aculeiformibus, fibrarumque ramosarum fasciculis hìc illìc obsitâ.

Habitat ............

Perennis.

RADIX e fibris aliquot constat crassiusculis, duris, nigricantibus, incurvis, ramosis, radiatìm dispositis.

FRoNs sesquipedem et ultrà longa, *teretiuscula, quà basi proxima pennæ anserinæ crassitie, inde sensìm sed lenissimè attenuata ut apices passerinâ sint tenuiores, ad quatuor vel quinque a radice pollicum altitudinem indivisa, ibi bifurca, et postea dichotomiis octies sæpiùsve repetitis ramosa, spatio inter singulas incertissimo, segmentis summis elongatis subfastigiatisque, dichotomiarum angulis acutis: frons infernè denudata aut tantummodò ramulorum diffractorum reliquiis squamas simulantibus inæqualis, supernè vagè obsita ramulis homogeneis, patenti-divaricatis, spiniformibus, frequentibus, undique sparsis, lineam longis, his solitariis, illis binis ternisve, his simplicibus, illis bi-tri-cranis : - ramulis immixtos fert frons fasciculos sparsos, spatiis brevibus sejunctos, fibrarum tenuissimarum, ramosissimarum, ramulis duplo longiorum, fusco-albicantium, quibus frons ubique lanosa apparet.

Fructificatio incognita.

† Color in stirpe rursùs madefactâ prope basin intensè fuscus, supernè dilutior ; exsiccatce ubique nigricans.

Substantia ipsam juxta radicem dura et sub-lignosa; cætera cartilaginea, lenta, atque tehax; ubique crassiuscula.

Овs. Exsiccata chartæ nequaquàm adhæret, et in aquâ iterùm immersa ægrè reviviscit; fibræ nunquam suam veram naturam ita recuperant, ut sese bene extricari sinant.

Quicunque in plantâ quâlibet describendâ unico modò exemplare niti cogitur, hunc descriptiones mancas et quæ hallucinationibus forsan ansam præebeant conscribere necesse est. Quod cùm persuasissimum mihi habeam, et simul operis mei ratio postulet ut tali me discrimini objicerem, sæpe jam a lectore veniam eâ de causâ petii ; sed nullibi veniâ majore est opus quàm de $F$. squamuloso, cujus non modo nullum hactenus vidi specimen præter illud hic depictum quod in Herbario Banksiano servatur, verùm etiam, uti suprà memoratur, stirps est quæ, semel exsiccata, in pristinam ægerrimè formam redit; fucorum reliquorum in hoc dissimillima. A nullo quoque auctore memoratum invenio, ut omnia describenti obstent; quod eo magis doleo quoniam indole ab aliis Fucis abludente gaudere videtur, habetque in se multa sui propria. Inter hæc character qui ad speciem discriminandam maximi est nomenti ponitur in fibris, quæ ramulis aculeiformibus immixtæ totam ramorum longitudinem undique obsident; neque tamen larum ex apicibus nec a poris oculo inerni conspiciendis exoriuntur. Inde fit ut sit nihil de earum naturâ compertum; e fructu enim pendere vel aliquo modo esse cum illo conjunctum nequaquàm videntur; nec referunt fibras illas penicilliformes in $F$. serrato, $F$. esculento, multisque aliis observandas, de quibus tot tantæeque extitere inter botanicos lites: longiùs quoque abest it similes sint fibrarum per quas certis anni tempestatibus $F$. ligulati $F$. aculeati congenerumque frondes ciliatæ apparent; prohibentque omnind earum forma faciesque ramosa quo minus ullo unquam modo in novos ramos produci existimentur. Cuinam inter Fucorum familiam F. squamulosus arctissimè est affinis, et quem sibi in systemate locum vindicat, difficile foret dictu. Longe ab omnibus recedit. Nulli fortasse magis quàm $F$. acanthophoro, huic quoque perquàm dissimili, formâ facieque exterlâ accedit; neque mirarer si eadem in utroque olìn reperiretur fructificatio. Nomen etiam idem non ineptè tulisset $F$. squamulosus; quod cùn priùs alteri sit inditum, aliud huic nostro imposui a facie frondis squamosâ basin versus depromptum, notâ cuivis facillimè manifestâ. Locus hujus Fuci natalis in præsens latet, quod enim nunc in Banksiano, olim fuit in Herbario Aubletiano, animadversione nullâ adjectâ, exemplar servatum.

a. F. squamulosus, magn. nat.

b. frondis pars apicem versus, magn. auct. $=6$.

c. fibrarum fasciculus - - - - - 3 .

d. pars frondis juxta basin - - $\quad-\quad$ - 6 .

\footnotetext{
* In exemplare Banksiano frons est compressa, vel potiùs plano-compressa, neque mutavit suam formam in aquâ emollita: nilailominùs tamen e stirpis facie dubitare nequeo quin olim teres fuerit.

$\uparrow$ Quis sit in recente color planè nescio, et ne suspicari quidem possum.
} 
Fucus sisymbroides, stem filiform, compressed, twice or thrice pinnated with long, flexuose branches, mostly opposite: leaves none: vesicles lanceolate, petiolated, tipped with a long capillary mucro: receptacles terminal and lateral, solitary, cylindrical, pedunculated.

In the Streights of Corea. Dr. Horner,

\section{Perennial.}

Roот, I have not yet seen.

FrOND, furnished with a compressed stem, about half a line wide, and nearly of equal size throughout, but to what length it extends, and whether it is divided or not, I am ignorant, pinnated with branches, in other respects naked; branches distichous, mostly opposite, horizontal, or between horizontal and patent, separated by intervals of about half an inch each, quite like the stem, excepting in their smaller size, some extending to half a foot or more, others, especially the upper ones, to scarce an inch in length, all weak, flexuose, undivided, but pinnated with others still less, disposed in the same manner, and themselves also sometimes pinnated with a third series, the ultimate ones producing vesicles and fructification; vesicles situated upon the lower branches, especially near their base, alternate, solitary, with an interval of a few lines between each, lanceolate, or occasionally slightly swollen upwards, two lines long, and one wide, supported upon a very thin, cylindrical petiolus of about two lines in length, and tipped with a capillary mucro twice as long; leaves, as far as I have seen, none.

Fructification, cylindrical receptacles, placed on the ends of the smaller branches, and generally one or two others standing on the sides near them, and growing upon very short peduncles, all of them about half an inch, or three quarters of an inch, long, as thick as a sparrow's quill, externally quite smooth, and not perforated with any pores, internally having a row of small, round tubercles, placed immediately under the epidermis, but these, in my specimens, contained no seeds.

CoLOR, dark-brown in the stem and branches, much paler in the vesicles, and inclining to yellow.

SUBSTANCE, cartilaginous, flexible, and tough, though weak.

OBs. In drying it shrinks considerably, but does not adhere to paper.

The affinity which there exists, in almost every respect, both as to habit, mode of growth, texture, color, vesicles, and fructification, between the Fucus here figured, and F. Horneri, F. fulvellus, and F. pallescens, makes it not a little extraordinary that the present plant should differ from these in so important a particular as the being destitute of leaves, and naturally creates a suspicion that my specimens are either injured or imperfect. At the same time, however, $\mathbb{I}$ cannot but think that, if such were really the case, some vestiges, at least, of footstalks could scarcely fail to be observable on different parts of the frond, and yet even of these there is not the slightest appearance. 'This plant was communicated to me by Professor Mertens, under the appropriate name here attached to it, together with the other species just mentioned, from all which it is immediately distinguishable, not merely, as above noticed, by the want of leaves, but, if even those should be found upon it, by the shape of its vesicles.

a. $\boldsymbol{F}$. sisymbroides, natural size.

b. apex of the frond, magnified - - - 6 .

c, horizontal section of a receptacle - $\quad 3$. 


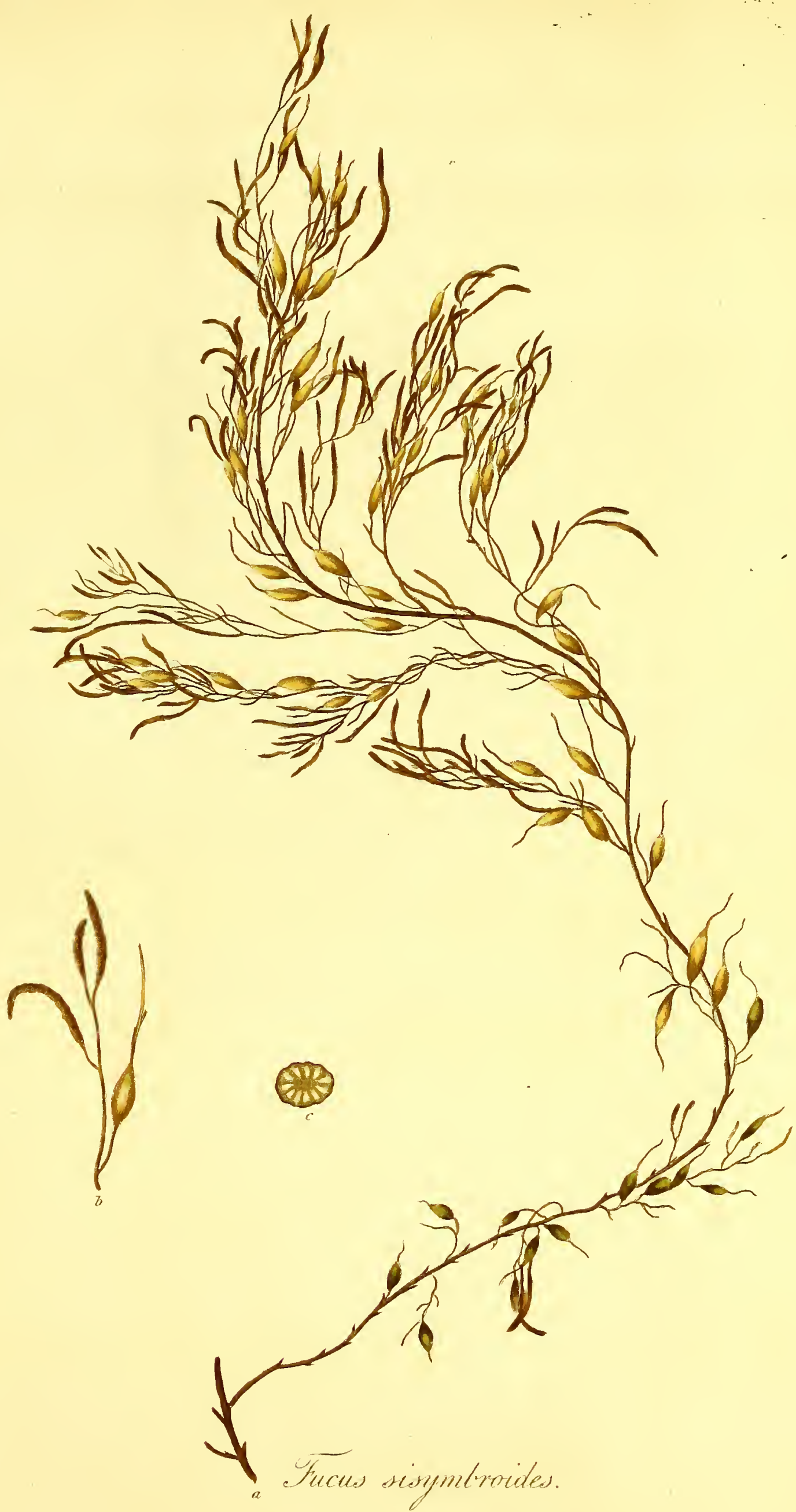



Fucus, caule filiformi, compresso, bi-tri-pinnato ; ramis sub-oppositis, elongatis, flexuosis: foliis nullis : vesiculis lanceolatis, petiolatis, mucronatis; mucrone elongato, capillaceo: receptaculis terminalibus lateralibusque, solitariis, cylindraceis, pedunculatis.

Habitat in Mari Coreano. D. Horner.

Perennis.

RADIX nondùm a me visa.

Frons instructa caule compresso, semilineam lato, et ubique ferè æquali, de cujus autem longitudine et an divisus sit necne nihil scio, flexuoso, ranis pinnato, cætera nudo ; rami distichi, plerun:que oppositi, horizontales, vel horizontalitèr patuli, spatiis subunguicularibus sejuncti, caulis omnind similes nisi quod tenuiores sint, hi semipedales et ultrà, illi, præsertim summi, vix pollicares, debiles, flexuosi, indivisi, sed ipsi pinnati aliis minoribus, simili ratione dispositis, vesiculas fructumque ferentibus; vesicula in ramis minoribus, præsertimı eorum basin versus, sitæ, solitariæ, intervallo inter singulas aliquot linearum, lanceolatæ, vel rariùs aliquantùm sursùm incrassaræ, duas lineas longæ, et unam latæ, petiolo tenuissimo tereti bilineariffultæ, et nucrcne capillaceo duplo longiore aristatæ: folia, quantum vidi, nulla.

Fructificatio receptacula cylindracea, ramos minores terminantia, et plerumque unum alterumve quoque prope ramorum apices situn, et pedunculis brevissimis insidens, omnia unguem vel sesquiunguem longa, pennæ passerinæ crassitie, extrinsecùs lævia et poris nullis pertusa, intùs tuberculormm exiguorum rotundorum seriem ipsâ sub epidernide sitam foventia, quæ vero nostris in exemplaribus seminibus caruerunt.

CoLOR in caule et ramis intensè in vesiculis dilutè fuscus, ad lutescentem proclivis.

Substantı a cartilaginea, lenta, atque tenax, attamen debilis.

OBs. Exsiccatione se multum contrahit, sed chartæ nequaquàm adhæret.

Crescendi mødo, habitu, texturâ, colore, vesiculis, atque fructificatione, affinitas maxima, ut primo statìm aspectu cuivis facillimè patebit, inter Fucum hì depictum et $F$. Horneri $F$. fulvellum et $F$. pallescentem intercedit; qui cùm omnes foliis, quæ dicuntur, distinctis, nunquam ill ramos transituris præditi conspiciantur, vix fieri potest quin mirentur botanici hunc prorsùs aphyllum videntes. Dubitabit quoque verisimilitèr aliquis, (neque, ut verum fateor, tali ipse dubitatione vacavi,) annon exemplaria mea in hoc essent nianca vel læsa; cui quidem suspicioni repugnant horum rami omnind læves, nec ulla vel minima petiolorum diffractorum vestigia prodentes, qualia, si planta unquam foliosa fuerit, vel hìc vel illìc, me judice, certè deprehenderentur. Hanc stirpen sub $F$. sisymbroidis aptissimo nomine primus ad me misit Mertensius, unà cum aliis supradictis speciebus, quibus ab omnibus non modo foliorum absentiâ, ut jam memoratur, differt, verùm etiam, hæc si adessent, sese per vesicularum quoque formam distinguendam præstaret.

a. F. sisymbroides, magn. nat.

b. frondis apex, magn. auct. - $\quad-\quad-\quad-6$.

c. receptaculum horizontalitèr dissectum - - 3 . 
Fucus microceratius, stem cylindrical, filiform, pinnated with alternate, flexuose branches: leaves none: vesicles spherical, on very short petioli: branches, vesicles, and petioli here and there muricated : receptacles terminal and lateral, solitary, cylindrical.

In the Streights of Corea. Dr. Horner.

\section{Perennial.}

RooT, at present unknown.

Fro N D, furnished with a cylindrical, filiform stem, of the thickness of a blackbird's quill, a foot and a half, or more, long, flexuose, undivided, but pinnated throughout its whole length with branches of the same nature and substance as itself, in other respects naked; branches disposed in an alternately spiral manner, separated by intervals of scarcely half an inch each, horizontal, or between horizontal and patent, flexuose, the lowest about three inches long, the rest gradually shortening as they approach the summit of the frond, all simple, and bearing vesicles and fructification; vesicles placed upon the lower part of the branches, alternate, with a space of two or three lines between each, spherical, smaller than vetch-seed, supported on cylindrical petioli, which are about a line long, and not uncommonly forked, externally smooth, except that they are here and there muricated with small, black, prominent dots, some of which are often observable upon the petioli also, internally empty:-leaves, as far as I have seen, none; but I still suspect that the plant laturally produces them, and that my specimens are imperfect, because the lower part of the branches is rough, as if with the remains of broken petioli : at the same time, however, I must confess my doubts whether this roughness is really occasioned by broken footstalks, or by processes similar to those just mentioned on the vesicles and their petioli, and whether all these are not of the same nature as those for which $\boldsymbol{F}$. muricatus is so conspicuous : such an opinion is by far most consonant to analogy, but the smoothness of the stem appears to contradict it.

FRUCTIFICATION, both terminal and lateral upon the branches, consisting of cylindrical receptacles, two lines long, of the thickness of a sparrow's quill, blackish, nearly sessile, externally uneven all over, and perforated with extremely minute pores, under which lie imbedded spherical tubercles, each containing numerous, oblong, pale-brown seeds, without any apparent pellucid limbus.

CoLOR, a pleasant pale-brown, even in the stem; only blackish in the receptacles.

SubstancE, cartilaginous, full of moisture, weak and flaccid, yet tough.

Oвs. The mode of growth of this plant is irregularly twisted :-in drying it does not adhere to paper.

In the present Fucus, no less than in $F$. sisymbroides, the apparently total want of leaves fornis a strong and extraordinary character, being directly opposite to all that might be expected from analogy, which would naturally lead to the classing of both these plants with the foliaceous families of F.natans, and F. Horneri. In F. microceratius, how vever, there is far more reason than in the other to believe that leaves do really exist; for, as above observed, the roughness of the branches at regular intervals certainly makes them look as if they had once borne petioli; or, even supposing these small protuberances to be of the same nature as those of $F$. muricatus, it is still possible that, as in that species, this also may be provided with leaves in the part of the stem immediately adjoining the base, or in the young and barren branches, neither of which I have yet seen. The circumstance also of the footstalks of the vesicles being not uncommonly branched, is another remarkable character, and one indeed which I know of no other Fucus having in common with it. It is an elegant little species, more succulent, and of a more pleasant color than most of its congeners, from which it is easily distinguishable. The name of $F$. microceratius is the same under which it was sent me by Professor Mertens, from whom alone $I$ ever received it.

a. F. microceratius, natural size.

b. summit of the frond, magnified - - 6.

c. horizontal section of a receptacle - - 3 .

d. seeds is - - - - - 1. 


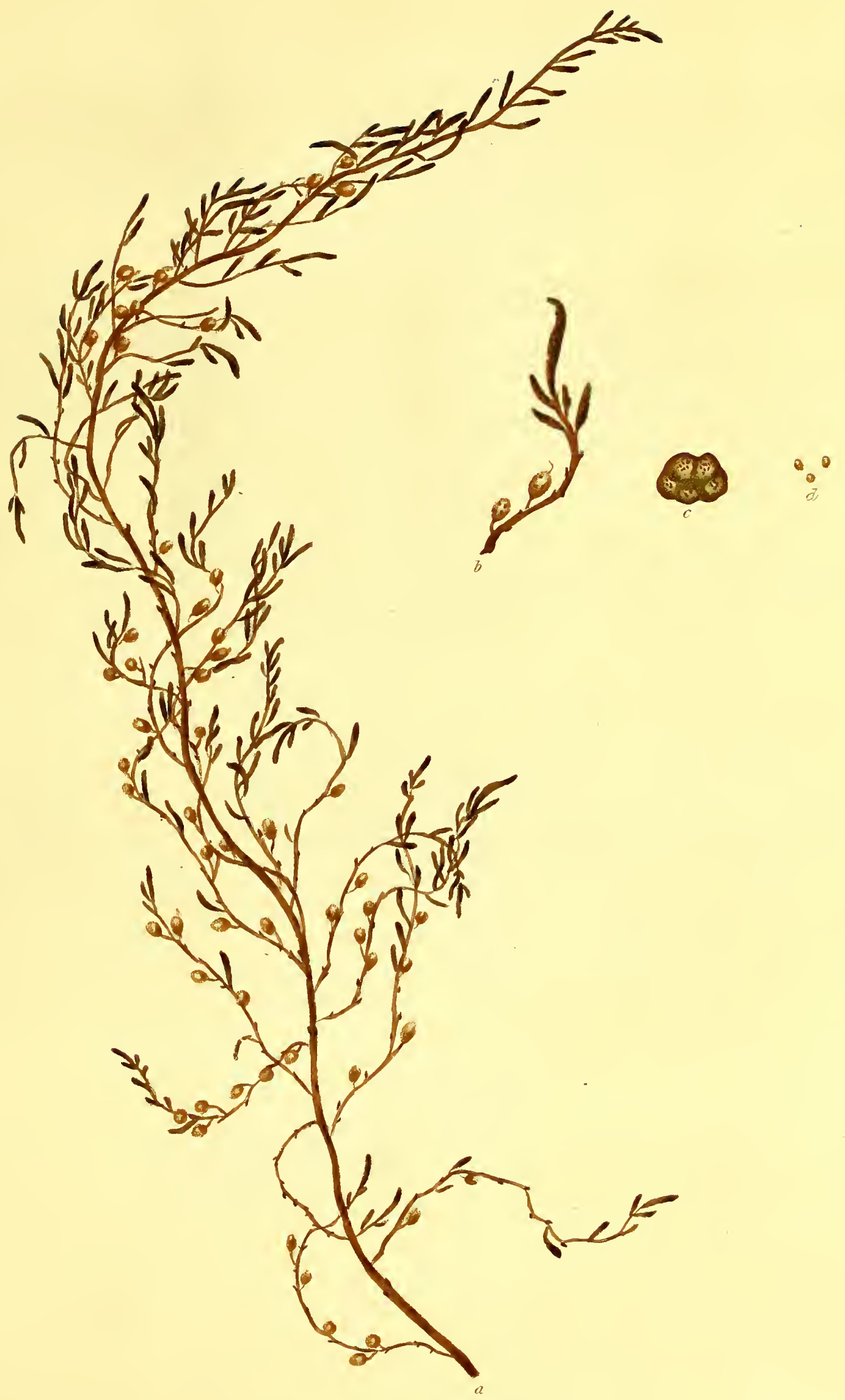

sucus micreceratius. 

Fucus, caule terete, filiformi, pinnato ; ramis alternis, flexuosis: foliis nullis : vesiculis sphæricis brevissimè petiolatis: ramis vesiculis petiolisque hìc illìc muriculatis: receptaculis terminalibus lateralibusque, solitariis, cylindraceis.

Haвiтат in Mari Coreano. D. Horner.

Perennis.

RADIX hactenus ignota.

Frons instructa cale terete, filiformi, merulæ pennæ crassitie, sesquipedem et ultrà longo, flexuoso, indiviso, sed ramis homogeneis per totam longitudinem obsito, cætera nudo; rami circa caulem spiralitèr alterni, ejus omnind similes præter crassitiem minorem, intervallis vix unguicularibus sejuncti, horizontales, vel horizontalitèr patuli, flexuosi, inferiores tripollicares, reliqui quo magis frondis ad apicem appropinquant ed gradatim breviores, omnes simplices, vesiculiferi, et fructiferi; vesicula in ramorum parte inferiore dispositæ, alternæ, spatio inter singulas bitri-lineari, sphæricæ, Vicia sativa seminibus minores, petiolis teretibus non rarò bifurcis unam circiter lineam longis fultæ, extrinsecùs læves, nisi quòd sint punctis nigris prominentibus hic illic muricatæ, qualia etiam interdùm petiolis non desunt, intùs cavæ et vacuæ:-folia, quantum vidi, nulla; sed, ob ramorum partem inferiorem exasperatam, quasi petiolorum diffractorum reliquiis, hæc plantæ esse propria et specimina mea manca suspicor; fateor tamen in dubio esse animum an hæc exasperata facies ortum ducat a petiolis diffractis, an a processubus similibus eorum jam in vesiculis harumque petiolis memoratorum, et annon hi omnes sint iidem per quos F. muricatus est insignis : tali quidem sententiæ favet analogia, sed repugnat caulis lævissimus.

FRUCTIFICATIo ipsos ad apices ramorum et juxta apices ad latera alternatìn sita, e receptaculis constans cylindraceis, duas lineas longis, pennæ passerinæ crassitie, nigricantibus, brevissimè pedunculatis, extrinsecùs ubique inǽqualibus et poris minutissimis pertusis, sub quibus latent tubercula immersa, sphærica, singula includentia semina plurima, oblonga, dilutè fusca, limbo, ut videtur, nullo pellucido cincta.

Color, etiam in caule, amœnè dilutè fuscus; in receptaculis modo nigricans.

Substantia cartilaginea, succosa, lenta, tenax.

Oвs. Stirps debilis, flaccida, variè torta, et quæ exsiccata chartæ non adhæret.

Huic quoque Fuco, sicut $F$. sisymbroidi, desunt, quantum adhuc vidi, folia, quod vix minùs est in uno quàm in altero mirum, et nobis naturæ leges cæcissimè per vitrum inspicientibus ab analogiâ prorsùs dissidere videtur; hæc enim postulat ut utramque speciem familiis Fucorum foliosis inseramus, et F. microceratium F. natanti affinibus, $F$. sisymbroidem illis $F$. Horneri adjungamus. Facies verd $F$. microceratii magis quàm ea $F$. sisymbroidis suadet se folia olim revera habuisse; quoniam rami hìc illìc intervallis certis scabriusculi, quasi foliorum rudimentis abortivis, vel petiolorum diffractorum reliquiis, tale quiddam verisimilitèr innuunt; et, si res alitèr-se habeat, sintque hæc tubercula eorum $F$. muricati similia, nihilo tamen minus fieri potest ut hæc quoque stirps, illius instar, foliis sit prædita, vel in caulis parte basi proximâ, vel in ramis junioribus sterilibusque, quibus omnibus exemplaria mea paritèr caruerunt. Vesicularum quoque petioli non rarò ramosi alterum summoperè manifestum characterem suppeditant, hujus Fuci proprium, et vix, quod scio, in alio quopiam detegendum. F. microceratius pulchella est stirps, cujus frons est magis plena succi, et colorem habet amœeniùs fuscum quàm eæ plerorımque e congeneribus. Sub nomine hic dato Mertensius misit, et ab eo solo in præsens accepi.

a. F. microceratius, magn. nat.

b. frondis apex, magn. auct. - - - - 6.

c. receptaculum horizontalitèr dissectum - - $\quad$ S.

d. semina - - - - - - - 1 . 
Fucus crassipes, stem quadrangular, short, branched; branches quadrangular, filiform, swollen at the base, pinnated with alternate ramuli, the lowest bearing leaves, the rest vesicles: leaves linear, very narrow ${ }_{2}$ entire; vesicles elliptical, immersed, placed in a moniliform manner.

In the sea near Japan. Dr. Horner.

\section{Perennial.}

Root, I have not yet seell.

FRON D, furnished with a quadrangular stem, of the length of which I am ignorant, about the thickness of a small goose-quill, irregularly beset towards its apex with branches of the same nature and substance as itself; branches a foot and more long, thickened at their base to the height of about an inch, with subcylindrical tumors of the size of a goose-quill in their centres but attenuated at each extremity, afterwards preserving to their apices a nearly equal thickness, inferior to that of a crow's quill, slightly flexuose, undivided, but pinnated throughout their whole length with a series of smaller branches, in other respects naked; secundary branches exactly similar to the primary ones, except that they are twice as slender, between erect and patent, alternate, separated by intervals of about half an inch each, the upper ones extremely short and simple, the others two or three inches long, and pinnated with a third series disposed in the same manner as themselves, but almost capillary, and often again divided ; the lowest branches produce leaves, the rest only vesicles; leaves sessile, alternate, rather remote, between erect and patent, twisted, flat, linear, an inch long, and about half a line wide, having a very obsolete midrib pass through them, blunt at their apices, and quite entire at their margins; vesicles placed in the smaller branches, principally in the central ones, and towards the center of them, immersed in their substance, between elliptical and spherical, of the size of vetch-seed, generally two or three in each branch, arranged in a moniliform manner, each separated from the other by an interval of a line or two, the ultimate one constantly mucronated by the end of the branch extending beyond it.

Fructification, at present unknown.

CoLor, most probably an olive-brown in the recent plant, but black when dried, and equally so if again moistened.

SUBSTANCE, coriaceous in the stem and branches, cartilaginous and thin in the leaves and vesicles.

Ов. In drying it does not adhere to paper.

The name of $F$.crassipes having been attached to the specimens of this Fucus, given me by Professor Mertens, who has had the best opportunity of examining a great number of individuals, I have felt no hesitation in here retaining it, trusting that the peculiarity from which it is derived will prove a constant, as well as a striking character of the species. At the same time, however, I must not dissemble my suspicions that it may possibly be merely accidental; and I should scarcely have ventured even to have mentioned it in my description of the plant, had I not known it to exist in other specimens besides the few that I lave myself seen. $F$. crassipes evidently belongs to the family of those whose leaves are situated only in the lower part of the frond, and imperceptibly lose themselves in the branches; nor can there be any doubt but that its fructification, like that of its congeners, is contained in cylindrical receptacles disposed at the ends of the smaller shoots. I have never seen a tendency in the leaves to become divided, as is common in this tribe, and their extreme narrowness appears to afford a strong mark of the species.

a. $F$. crassipes, natural size.

b. branch, magnified - - 6 . 


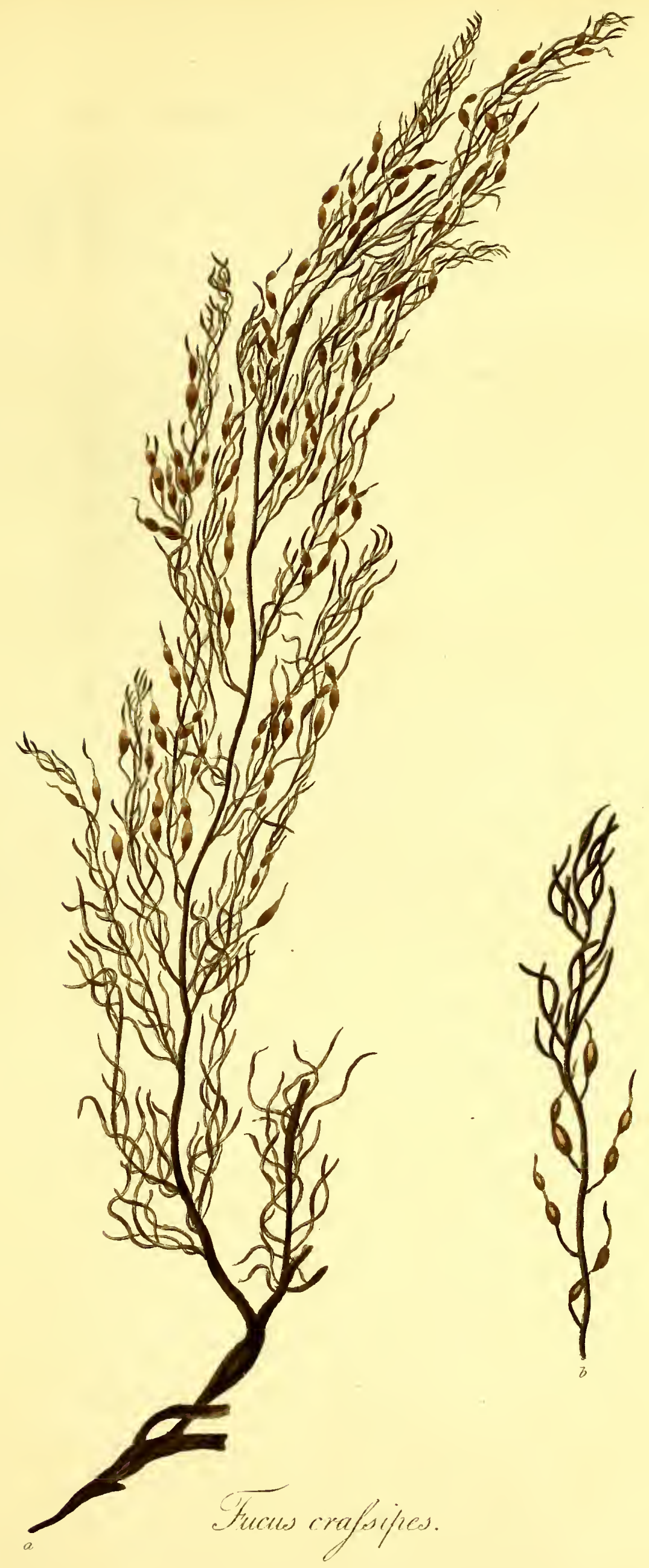



Fucus, caule quadrangulo, abbreviato, ramoso: ramis quadrangulis, filiformibus, basi incrassatis, pinnatis : ramulis alternis, inferioribus foliosis, superioribus vesiculiferis; foliis linearibus, angustissimis, integerrimis; vesiculis ellipticis, immersis, moniliformibus.

\section{Ha bitat in Mari Japanensi. D. Horner.}

\section{Perennis.}

RADIX nondùm a me visa.

FroNs instructa caule quadrangulo, cujus de longitudine nihil est quod dicam, pennæe anserinæ minoris crassitie, apice vagè obsito ramis homogeneis, pedalibus, et ultrà, basi ad pollicis ferè altitudinem incrassatis, tumore teretiusculo pennæ anserinæ crassitie utrinque attenuato, exinde sub-filiformibus, pennâque tenuioribus corvinâ, lenitèr flexuosis, indivisis, sed ramorum minorum serie per totam longitudinem obsitis, cætera nudis; rami secundarii primariorum omnino similes, nisi quòd duplo sint tenuiores, erecto-patuli, alterni, spatiis sub-unguicularibus sejuncti, duos tresve pollices longi, aliis propemodùm capillaceis eâdem ratione dispositis nec rarò iterùm divisis ob̆siti, summi brevissini, et simplices, inferiores folia ferentes, reliqui vesiculas; folia sessilia, alterna, remotiuscula, erecto-patula, variè tortilia, plana, linearia, pollicem longa, et circiter semilineam lata, nervoque obsoletissimo: percursa, apice obtusa, margine integerrima; vesicula in ramis minoribus præsertìm mediis eorumque medium versus sitæ, in ipsâ eorum substantiâ immersæ, elliptico-sphæricæ, Vicia sativa seminum magnitudine, extrinsecùs læves, intùs vacuæ, plerumque duæ vel tres in singulis ramis, moniliformitèr collocatæ, utraque a præcedente sejuncta intervallo unius alteriusve lineæ, ultima ramo longiùs procedente nunquam non aristata.

Fructificatio hactenus latet.

COLOR in recente verisimillimè olivaceo-fuscus; sed in exsiccatâ et paritèr in rursùs madefactâ niger.

SuBSTANTIA caulis ramorumque coriacca, foliorum et vesicularum cartilaginea tenuis.

OBs. Exsiccata chartæ non adhæret.

In nullo unquam herbario hactenus hunc Fucum vidi, neque ejus exemplaria a botanico quoquam accepi, præter Mertensium, cui maxima in manibus speciminum fuit copia, atque idcirco optima contigit observandi facultas. Hanc ob causam nullus dubitavi hìc retinere $F$. crassipedis nomen ab jpso individuis ad me missis inditum; speroque ramos basi incrassatos, unde hoc deducitur nomen, speciei notam non minùs stabilem quàm insignem suppeditaturos. Diffidentèr tamen spero; fatebor enim tantam huic characteri dubitationem inesse mihi videri, ut, si iis modò paucis a me visis individuis esset fidendum, vix sim ausus hunc in descriptione perstrinxisse, nedùm pro tituli specifici basi adhibuisse. F. crassipes liquidd ad illam Fucorum familiam attinet cui folia sunt, quæ dicuntur, unita, non nisi in frondis parte inferâ quærenda, et sese sensìm in ramos immutantia. Dubitabit quoque nemo quin fructu sit eodem, quo congeneres, præditus, in receptaculis cylindraceis ramorum minorum ad apices sitis incluso. In hoc a plerisque ex affinibus differt, qudd folia semper integra manere - videaltur, et angusta horum forma speciei notam manifestam præbet.

a. F.crassipes, magn. nat.

b. ramus, magn. auct. $\quad-\quad 6$. 
Fucus scoparius, stem quadrangular, bipinnate; branches mostly alternate; leaves linear, very narrow, entire, some simple, others pinnatifid: vesicles elliptical, petiolated, tipped with a setaceous mucro: receptacles cylindrical, compressed, solitary, nearly sessile, terminal and axillary.

In the Straights of Corea. Dr. Horner.

\section{Perennial.}

Rоот, I have not yet seen.

FroND, rising with a quadrangular stem, two feet or more long, as thick as a small crow's quill, filiform, slightly flexuose, undivided, but beset throughout its whole length with branches, in other respects naked; branches mostly. alternate, separated by intervals of about a quarter of an inch each, between horizontal and patent, three or four inches in length, smaller than the stem, but in other respects quite similar to it, the lower ones longest, and naked, like the stem, except that they are pinnated with a series of smaller ones disposed in the same manner, the upper ones producing leaves, vesicles, and fructification; leaves alternate, rather remote, so narrow as to be almost setaceous, flat, some simple and quite entire, others, especially towards the base of the branches, pinnatifid with short, alternate segments ; vesicles, mostly situated in the lower part of the branches, and seldom more than one or two on each, solitary, elliptical, as large as the seeds of a yellow Lupine, externally smooth, internally hollow and empty, each supported. upon a compressed petiolus, two or three lines long, and tipped with a capillary mucro of more than double that length.

FrUCTIFICATION, consisting of nearly linear, compressed receptacles, situated at the extremities of the branches, and upon the sides near the extremities, two or three lines long, and scarcely half a line wide, nearly sessile, solitary, alternate, rather remote, externally rough all over, and perforated with very minute pores, under which lie imbedded spherical tubercles:-in these, however, [ have seen no seeds.

CoLOR, most probably an olive-green in the recent plant, blackish when dried, and not changing from subsequent immersion.

SUBSTANCE, coriaceous in the stem, in the leaves and vesicles cartilaginous, flexible and tough.

Oв. In drying it does not adhere to paper.

This Fucus, which was received at the same time with the other two last, from Professor Mertens, seems to differ from most others, yet sent from the same seas, in the greater size of its vesicles, and in this respect agrees with F. Siliquastrum, to which it is also in its shape and mode of growth more closely allied than to any other. Its leaves. also are no less narrow than those of that species, from which it is immediately distinguishable by the very remarkable circumstance of its producing upon the same shoot both simple and pinnatifid leaves, neither of which appear to shew any tendency to change their form and swell into branches.

a. F. scoparius, natural size.

b. branch, magnified - - - - - 6 .

c. horizontal section of a receptacle - - 3 . 


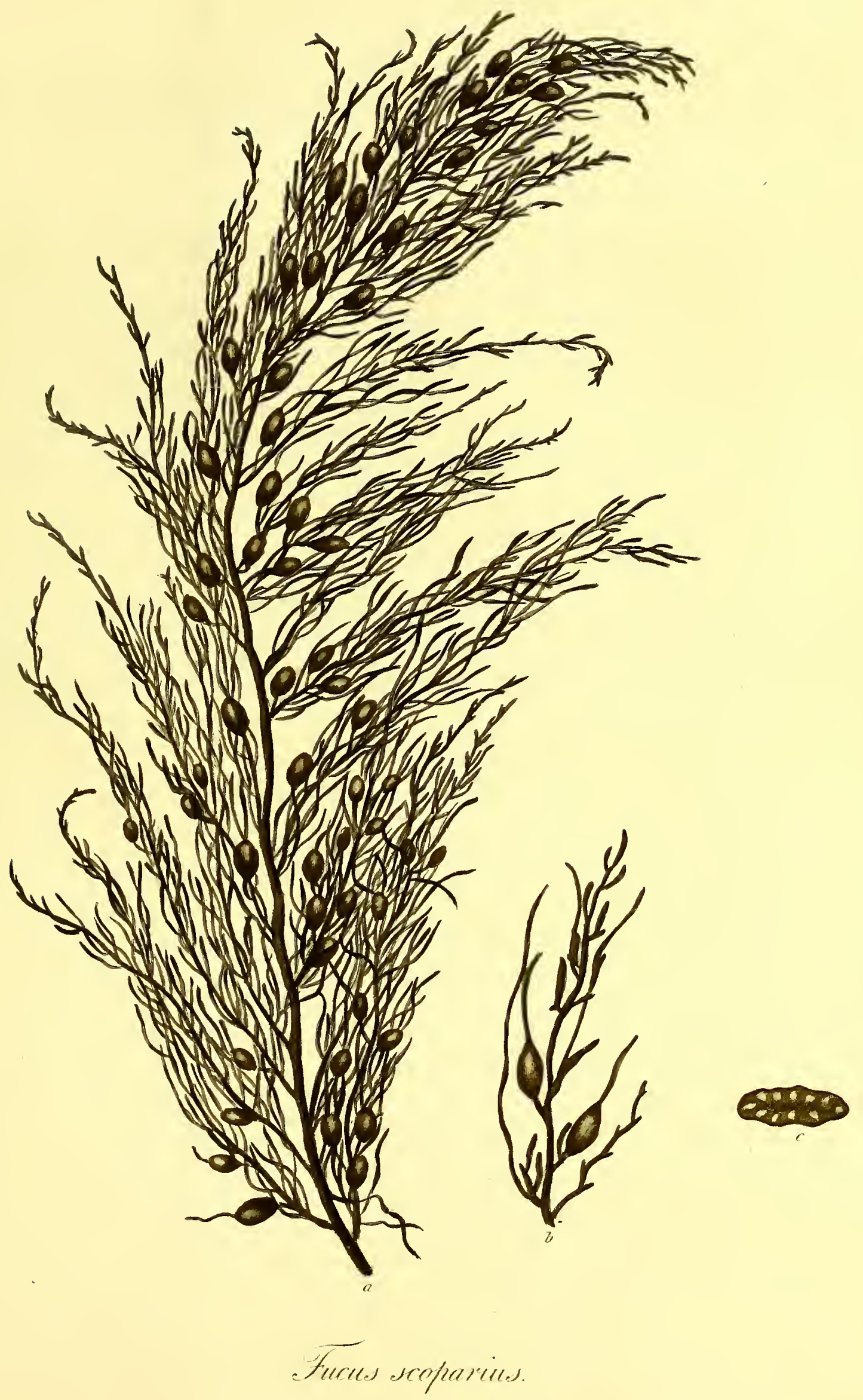



Fucus, caule quadrangulo, bipinnato; ramis sub-alternis: foliis linearibus, angustissimis, integerrimis, his simplicibus, illis pinnatifidis : vesiculis ellipticis, petiolatis, mucrone setaceo aristatis : receptaculis cylindraceis, compressis, solitariis, subsessilibus, terminalibus axillaribusque.

Haв it at in Mari Coreano. D. Horner.

Perennis.

RADIX nondùm a me visa.

FRONS instructa caule acutè quadrangulo, bipedali, et ultrà, pennæ corvinæ minoris crassitie, filiformi, lenitèr flexuoso, indiviso, sed ramis per totam longitudinem obsito, cætera nudo; rami sub-alterni, spatiis semiunguicularibus sejuncti, horizontalitèr patuli, tres quatuor pluresve pollices longi, caulis omnind similes, sed tenuiores, indivisi, inferiores longissimi, et, caulis instar, nudi, nisi quodd aliorum minorum simili ratione dispositorum seriem ferant, superiores simplices, et foliis vesiculis fructuque obsiti ; folia alterna, remotiuscula, ita angusta ut sint propemodùm setacea, plana, hæc simplicia atque integerrima, illa, quod præsertim ramorum basin versus accidit, pinnatifida, segmentis brevibus alternis; vesicula plerumque juxta ramorum basin sitæ, et rarò plures quàm una duæve in singulis, solitariæ, ellipticæ, Lupini lutei seminum magnitudine, extrinsecùs læves, intùs cavæ et vacuæ, petiolo bi-tri-lineari compresso insidentes, et mucrone setaceo longiore aristatæ.

FrUCTIFICATIO e receptaculis constans sub-linearibus, compressis, ramorum ad apices, et juxta apices ad latera sitis, duas tresve lineas longis, et vix semilineam latis, sub-sessilibus, solitariis, alternis, remotiusculis, extrinsecùs ubique torulosis, et poris minutissimis pertusis, sub quibus latent tubercula immersa spherica; in his autem semina nulla vidi.

COLOR, qui recentis verisimillimè olivaceus, exsiccate nigrescit, et rursùs madefacta non mutatur.

SuBSTANTA in caule coriacea, in foliis vesiculisque cartilaginea, lenta, tenax.

Oвs. Exsiccatione chartæ non adhæret.

Videtur hic Fucus, quem eodem quo antecedentes duos tempore benevolè ad me misit Mertensius, a congeneribus plerisque ex iisdem maribus missis per vesicularum molem majorem differre. In hoc convenit cum F. Siliquastro, cui formâ etiam crescendique modo magis est quàm alii cuipiam affinis, foliaque habet îs non minùs angusta quibus illa species gaudet. Dignoscitur autem cùm ab hoc tùm a reliquis omnibus in præesens detectis Fucis, quòd iidem rami folia aliqua simplicia alia pinnatifida gerat, quorum neque hæc neque illa unquam ita tumere ut sese in ramos immutent videntur.

a. F. scoparius magn. nat.

b. ramus, magn. auct. - - - - - 6 .

c. receptaculum horizontalitèr dissectum - - 5. 
Fucus Thunbergii, frond simple, or branched, swollen and leafy at its base, then cylindrical, filiform, and beset throughout its whole length with vesicles and fruit: leaves very minute, flat; lanceolate, imbricated: vesicles small, clustered, verticillate, lanceolate, acuminated at each end; receptacles cylindrical, mixed with the vesicles.

Fucus Thunbergii. Rotн. Cat. Bot. III. p. 104. t.3.

In the seas of China and Japan. Thunberg.-In the Streights of Corea. Dr. Horner.-Sent from Teneriffe to Mr. Dickson.

\section{Perennial.}

RooT, not yet known.

FRON D, apparently, rising with numerous stems, or with a single one immediately divided into many, each of them, to the height of three or four lines from the base, clothed on all sides with small, lanceolate, concave leaves, most thickly imbricated, and of a substance between cartilaginous and membranaceous, but afterwards leafless, so that the frond looks as if it were beset at the base with several cylindrical knobs about the thickness of a goose-quill, each of them giving rise at its apex to a single stem, a foot or two feet in length, cylindrical, filiform, of the size of a dove's quill, undivided, some beset with branches, others destitute of them, some furnished with vesicles or fructification, others completely naked; branches similar to the stem, but less thick, patent, scattered, either opposite or alternate, or, as is most common, sub-verticillate, varying in length from half an inch to a span, long and short irregularly mixed together, constantly, as far as I have seen, undivided, but, like the stem, sometimes bearing vesicles and fruit, and sometimes naked; vesicles situated both upon the stem and branches, mostly scattered and solitary towards the base of the frond, but afterwards growing in whirls, many being together in the same whirl, and the whirls separated from each other by short intervals; in young plants, or at the extremities of full-grown cnes, they are closely imbricated; they are about a line and half long, lanceolate, narrowed at their base into a very short and narrow footstalk, and at their apex into an equally short and somewhat crooked beak; *xternally they are smoo!h, internally quite einpty; the younger ones are so narrow as to be almost setaceous.

FRUCTIFICATION, consisting of receptacles scattered all over the stem and branches, either alternate or opposite, rather remote, cylindrical, two lines long, externally uneven all over, and perforated with extremely small pores:the advanced age of my specimens prevented me from observing any thing of their internal structure.

Color, most probably an olive-brown in the recent plant, but turning in drying to an inteñse dull black, and continuing equally so if again moistened.

SUBSTANCE, between coriaceous and cartilaginous, flexible, tough.

OBs. In drying it does not at all adhere to paper.

The name of F. Thunberzii was given to this Focus, in honor of the illustrious Swedish naturalist who now fills the chair of the immortal Linuæus at Upsal, by my exicellent friend, Professor Mertens, to whom we are indebted for having first described and tigured the plant in the third volume of Dr. Roth's Catalecta Botanica. I have also to express my obligations to lim for the branched specimen here represented, which he received but lately through the kindness of Dr. Horuer; but which, I am satisfied, had it arrived earlier, would have induced him, not only to make considerable changes in his description, but also to alter his opinion respecting the fruit of the species, and no longer to look for it in the vesicles, but in the receptacles, which it produces abundantly, and which are altogether similar to those of such other Fuci as appear, from their texture and color, to be its most natural affinities. In these receptacles I have mentioned above that I have not been fortunate enough to meet with either tubercles or seeds, nor indeed have I seen any appearance of the latter in the vesicles, from which Professor Mertens has figured them issuing, a circumstance probably to be accounted for upon the supposition that the seed-vessels of this plant are in course of time changed into air-bladders, and that those which he observed were undergoing such a metamorphosis. I am very sorry that the specimens I have seen do not seem to me to justify the dividing of $F$. Thunbergii into two varieties, the one simple, the other branched, as is done in Dr. Roth's Calalecta, where figures of both are given, and the latter, from being young, with narrow and closely imbricated vesicles, has so widely different an appearance from what is usual, that it looks like a completely distinct species. The branched specimen in this plate, on the other hand, produces the same effect from an opposite cause, that of being old and nearly stripped of its vesicles. These circumstances naturally lead to the conclusion, that $F$. Thunbergii is a particularly variable Fucus; but under every change of form, however great, there can be no difficulty in recognizing any speciniens that retain their vesicles, which in their shape are quite unlike those of every other species at present known, and are so extraordinary, that it is impossible to avoid regretting that some other Fucus was not dignified with the name of Thunberg, and the highly characteristic appellation of $F$. pulicaris, marking its resemblance to the Carex of the same name, reserved to the present. The short, knob-like shoots at the base of the frond, on which alone it appears that leaves are to be seen, afford another strong character, and mark an affinity between this plant and $F$. ericoides, which, at certain periods

* Such is the case with all I have seen; but Roth says they are perforated with scattered, whitish pores, out of which is sue minute, scarlet granules. 

of its growth, shows the same appearance. Specimens of this Fucus, brought from China by Sir George Staunton, are preserved in the Banksian Herbarium.

a. F. Thunbergii, natural size.

b. another specimen, branched, and nearly stripped of vesicles.

c. part of the same, magnified - $\quad-\quad-\quad 6$.

d. horizontal section of a receptacle - $\quad-\quad-4$.

e. section of a vesicle - $\quad-\quad+\quad-\quad 4$.

\section{3.-F U G U S TH U N E R GII.}

Fucus, fronde simplice vel ramosâ, basi incrassatâ foliosâque, exinde terete, filiformi, et per totam longitudineın vesiculiferâ fructiferâque : foliis minutissimis, planis, lanceolatis, imbricatis : vesiculis exiguis, confertis, verticillatis, lanceolatis, utrinque acuminatis, sessilibus : receptaculis cylindraceis, vesiculis immixtis.

Fucus Thunbergii. Rотн, Cat. Bot. III. p. 104. t. 3.

Haвıтат in Chinæ et Japoniæ maribus. D. Thunberg.-In mari Coreano. D. Horner.-Ex Insula Teneriffe accepit D. Dickson.

Perennis.

RADIX nondum cognita.

FRONS caulibus, ut videtur, assurgens plurimis, vel unico statim in plures diviso, singulis basi ad duarum et ultrì linearum altitudinem undique obsitis foliis exiguis cartilagineo-membranaceis lanceolatis concavis densissimè imbricatis, exinde aphyllis, ut ibi tubera referant cylindracea pennæ anserinæ crassitie, quorum singulorum ex apice caulis exurgit unicus, pedalis, vel bipedalis, teres, filiformis, columbæ pennæ ferè magnitudine, indivisus, nunc ramis obsitus, nunc horum expers, nunc vesiculis fructuve instructus, et interdùm omnino denudatus; rami caulis similes, sed tenuiores, patentes, sparsi, hi alterni, illi oppositi, alii, (quod sæpiùs quiden accidit) sub-verticillati, longitudine quoque quàm diversissimâ ab unguiculari ad spithamæam ludentes, longiores brevibus immixti, semper, quantum vidi, indivisi et simplices, et, sicut caulis, nunc vesiculiferi aut fructiferi, nunc nudi; vesicula in caule et ramis sitæ, plerumque frondis basin versus sparsæ atque solitariæ, exinde verticillatæ, plurimis in unâquâque verticillâ, intervallo inter verticillas brevi, in fronde tantummodo juniore aut adultioris ad apices arctè imbricatæ, sesquilineam circitèr longæ, lanceolatæ, basi in petiolum tenuissimum brevissimumque, apice in mucronem perbrevem curvulum attenuatæ, *extrinsecus læves, intùs omnino vacuæ; juniores adultis multo angustiores, et ferè setaceæ.

Fructificatio e receptaculis constat per caulem ramosque sparsis, oppositis, alternisve, remotiusculis, cylindraceis, duas lineas longis, extrinsecùs ubique torulosis, et poris minutissinis pertusis :- de horum autem structurâ. interná ætas meorum specininum nimis provecta prohibet ne aliquid dicam.

Colon recentis vcrisinillimè olivaceus vel olivaceo-fuscus; exsiccatee æquè ac rursùs madefacte nigerrimus, et nitoris omnind expers.

SubstanTia inter coriaceam et cartilagineam media, lenta, tenax.

Oвs. Exsiccatione chartæ nequaquàm adheret.

* Ita ego semper vidi, sed alitèr de his Rothius; quo teste "vesiculæ e poris albidis sparsis demùm granula minıta coccinea fundunt." 
Primus huuc Fucum, Japoniæ Chinæque ad littora a Thunbergio repertum, in tertio Rothii Catalectorum Bota nicorum tomo descripsit depinxitque Mertensius; qui etiam illustrissini inventoris nomen speciei impositum voluit. Hujus quoque amicitiæ acceptum refero exemplar ramosum in hâc tabulâ adumbratum, idem ipsi nuperrimè a $D$. Hornero missum. Infaustum id quidem quodd non aliquot anted̀ annis acceperit; si enim ita fuisset, persuasissimum mihi habeo non modò quædam in descriptione sibi minùs arrisisse, verùm etiam se mutavisse suam de fructu sententiam, neque ampliùs censuisse hunc esse in vesiculis quærendum, sed potiùs, mecum faciens, situm credidisset in illis partibus, ipsi tunc temporis nondùm visis, quæ facie externâ Fucorum, qui dicuntur, propriorum, quibus hæc species colore texturâque summoperè est affinis, receptacula ita referunt, ut dubitare nequeam quin ad eundem sint finem a naturâ comparatæ. Tali quidem sententiæ obstat quod semina in his, uti suprà monui, nulla hactenus repererim, poros quoque per quos semina effugerent nullos, tubercula nulla; neque e contrario ego aliqua ex his deprehendi in vesiculis, e quibus profluentia semina delineat Mertensius. Virum optimum fortè fefellerunt granula quædam extranea, sicut etiam cautissimis accidere solet; aut, si non ita sit, verisimile est receptacula effæta in vesiculas mutari, et stirpem ab ipso depictam in tali jam versari metamorphosi. Neque de fructificatione solâ cogor a Mertensio dissidere, assentiri enim nequeo dispertienti hunc Fucum in duas varietates. Harum utriusque descriptionem iconemque adjecit, hanc prædicans sinılicem, nec multum simpliciusculo illi in hâc tabulâ exhibito exemplari absimilem, illam ramosam, et, ob ætatem minùs provectam, vesiculis aded angustis et tam densè imbricatis obsitam, ut speciem distinctam simulet. Prohibent autem exemplaria a me accepta quo minùs illum in hoc sequar; præsertìm cùm ramosa nostra vesiculis propemodùm carentia faciem paritèr a vulgari abludentem e causâ oppositâ capiant. Adducor igitur potiùs ut credam $F$. Thunbergii esse stirpem, quâ, crescendi modo et formâ, paucæ magis mutationibus sunt obnoxiæ, sed has varietates nullis certis finiri limitibus, aut saltem limites nobis nondum innotescere. Quantum quidem cunque varietur, dummodò vesicula supersit unica, nullus unquam dabitur in specie dignoscendâ labor ; similis enim figuræ vesiculas non ullus est alius qui jactat Fucus. Hæ Caricis pulicaris vesiculas ita referunt, ut dolendum sit quòd titulum eundem specificum ambæ non acceperint plantæ, et quod non alii cuipiam ex algis a Thunbergio detectis ejus fuerit inditum nomen. Alterum etiam speciei characterem summoperè insignem suppeditant surculi frondis ad basin abbreviati tuberiformes, quibus in solis, uti videtur, conspicienda sunt folia. Hi affinitatem quandam indicant inter hanc stirpem et $F$. ericoidem, qui quoque certis ætatis suæ stadiis surculis similibus pullulare conspicitur. Servantur in Herbario Banksiano hujus Fuci exemplaria a nob. G. Staunton Baroneto e Chinâa reportata.
a. F. Thunbergii, magn. nat.
b. exemplar aliud, ramosum, et vesiculis maximâ ex parte spoliatum.
c. ejusdem par's, magn. auct. = - - - 6 .
d. receptaculum horizontalitèr dissectum - $\quad$ - 4.
e. wesicula dissecta - $\quad \ldots \quad-\quad 4$. 
Fucus, stipite terete, lignoso, indiviso, apice expanso in folium unicum, membranaceum, planum; enerve, subrotundum, profundè lobatum; lobis sub-linearibus, sinuatis, margine dentatis.

ß. exasperatus; frondis superficie ubique ligulis brevibus homogeneis pullulante.

Ha Bıт a utraque varietas in Novæ Hollandiæ oris. D. Hunter, et D. Brown.

Perennis.

RADIX e fibris plurimis constans nigricantibus, lignosis, duris, pollicem sesquipollicemve longis, teretiusculis, pennæ anserinæ minoris crassitie, incurvis, ramosis.

Frons stipite assurgens simplice, terete, pennâ olorinâ crassiore, sub-palmari, apicem versus compresso, seque ibi sensim dilatante in folium unicum, sub-orbiculare, diametro bipedale et ultrà, basi latè cuneiforme, et ad unius alteriusve pollicis altitudinem indivisum, mox undique profundè incisum lobis numerosissimis, ut expansorum margines sibi invicem incumbant, radiatim dispositis, sub-linearibus, pollicem circitèr latis, his simplicibus, illis, bi- tri-fidis, aliis margine vagè et variè sinuatis, sinubus plùs minùs profundis; apices omnibus lenitèr angustati, attamen obtusiusculi ; margines dentibus exiguis remotis sparsis per totam longitudinem spinosi ; superficies rugosa et undulata :frondis ad basin, ubi est indivisa, margines ligulis minutissimis linearibus homogeneis sunt fimbriati.

Fructificatio ignota.

CoLOR in stipite nigricans; folii ad basin fuscus; cæetera dilutè et amœene herbaceus, atque subdiaphanus.

SuBstantia stipitis lignosa, folii ad basin ubi est indivisum cartilaginea et crassiuscula, cætera membranacea tenuis.

Var. $\beta$ insignitèr $a b a$ discrepat quòd utraque folii superficies ubique est obsita ligulis homogeneis, erectis, exiguis, triangularibus, lineam unam alteramque longis, copiosioribus in his quàm in illis: margines quoque dentibus longè majoribus sunt armati, magisque profundè sinuati lobis acuminatis.

Ов . Exsiccatione chartæ non adhæret.

Duas hujus Fuci suprà descripsi varietates, sed unicum modò utriusque exemplar hactenus vidi ; hoc multis ablinc annis acceptum a b. Velleio, cui e Novæ Hollandiæe oris, unà cum Confervâ suâ umbilicatâ, misit D. Hunter; illud eadem ad littora prope portum, qui “Dalrymple” audit, a D. Brown lectum, et in ejusdem phytophylacio nunc servatum, adjectâ animadversione, in primo tantùm esse æatatis suæ stadio. Hìnc adducor ut suspicarer hanc stirpem, instar $F$. digitati et $F$ bulbosi, quibus naturâ arctissimè est affinis, in molem longè majorem excrescere, quàm quæe in hâc nostrâ delineatur tabulâ ; in dubioque est animus annon varietates illæ duæ suprâ memoratæ revera specie sint distinctæ, aut e contrario annon e diversis modo ætatis gradibus pendeant. In posteriorem sine dubio discessissem sententiam, nisi repugnaret utriusque statura æqualis; priorique ita obstat frondis forma atque textura in utrâque eadem, ut, donec plura videndi exemplaria facultas fuerit data, nemo, ut opinor, auderet pro speciebus venditare diversis. Rem igitur hanc in medio, sicut plurimas alias, botanicis posteris dijudicandam relinquere invitus cogor. Prohibent hujus Fuci substantia membranacea marginesque dentati quo minus cum $F$. digitato commisceretur, et ab omnibus aliis formâ satis recedit. Radice duriore magisque lignosa quàm alia quælibet quæ mihi hucusque innotuit species gaudet. F. radiati nomen huic stirpi inditum olim $F$. rotundo impositum voluerunt Goodenovius Woodwardiusque, quos tamen in hoc pauci modd sunt secuti botanici, quare ablegatum occupando me nullam confusioni ansam suppeditaturum et spero et arbitror.

a. F. radiatus, magn, nat.

Yor. II. 
Fucus radiatus, stipes cylindrical, woody, undivided, expanded at its apex into a single, membranaceous, flat, nerveless, sub-orbicular leaf, deeply cleft into numerous, nearly linear, sinuated, and toothed lobes.

B. exasperatus; surface of the frond beset all over on both sides with small, flat, triangular processes of the same nature and substance as itself.

Both varieties found on the coast of New Holland. Governor Hunter and Mr. Brown.

\section{Perennial.}

Rоот, consisting of numerous, blackish, woody, hard fibres, from an inch to an inch and half high, sub-cylindrical, as thick as a small goose-quill, incurved, branched.

Fro N, rising with a simple, cylindrical stipes, thicker than a swan's quill, four or five inches long, compressed towards the apex, and there gradually expanding into a single sub-orbicular leaf, two feet and more in diameter, widely cuneiform at its base, and rising undivided to the height of one or two inches, when it is on all sides deeply cleft into lobes, so numerous that, if expanded, their margins lie upon each other, disposed in a radiated form, nearly linear, about an inch wide, some simple, others bifid or trifid, and again others irregularly and variously sinuated at their margins, more deeply in some individuals than in others: the apices of all are slightly narrowed, but rather blunt; the margins are throughout their whole length spinous, with small, remote, scattered teeth; the surface is wrinkled and undulated :- at the base of the frond, where it is undivided, the margins are fringed on both sides with very minute, linear processes of the same texture as themselves.

Fructification, unknown.

CoLor, blackish and opaque in the stèm; brown at the base of the leaf; in other parts a pale, pleasant, and semitransparent grass-green.

SUBSTANCE, of the stem woody; of the undivided part of the leaf nearest the stem cartilaginous and rather thick; of the leaves thin and membranous.

The variety $\beta$ differs remarkably in having both sides of the leaf more or less copiously beset with small, erect, triangular processes, of the same nature and substance as itself, a line or two long:- the margins, too, are armed with far larger teeth, and more deeply sinuated with acuminated lobes.

OвS. In drying it does not adhere to paper.

Of the two varieties of this Fucus, above described, I liave at present seen only single specimens, the one communicated to me many years ago by the late Col. Velley, to whom it was sent from New Holland, together with Conferva umbilicata, by Governor Hunter, the other collected upon the same coast, near Port Dalrymple, by $\mathbf{M r}$. Brown, in whose Herbarium it is preserved, with a remark, that it is only in an early stage of its growth. 1 an from this led to suppose, that, like our $F$. digitatus and F. bulbosus, which are its most natural affinities, it attains to much greater size than is represented in the present plate; and I am necessarily in doubt whether what are here described as varying appearances of the same, may not, on the one hand, be distinct species, or, on the other, be merely the natural result of different periods of existence. To the latter of these opinious I should have been prepared to accede, had not both specimens been nearly of equal size; and the circumstance of their resembling each other in texture and form seemed to me to forbid the adopting of the former without being furnished with more satisfactory means of judging. The thin membranous texture of the leaf, and the toothed margins, preclude all possibility of this Fucus being confounded with $F$. digitatus, which alone it so far resembles as to admit any fear on this head. Its root is more hard and woody than that of any otler Fucus with which $I$ am acquainted. The name of F. radiatus here given to this plant, was formerly assigned by Dr. Goodenough and Mr. Woodward to F. rotundus, to which species, however, it was never generally applied among botanists, so that its being now attached to the present cannot give rise to confusion.

3. F. radiatus, natural size. 


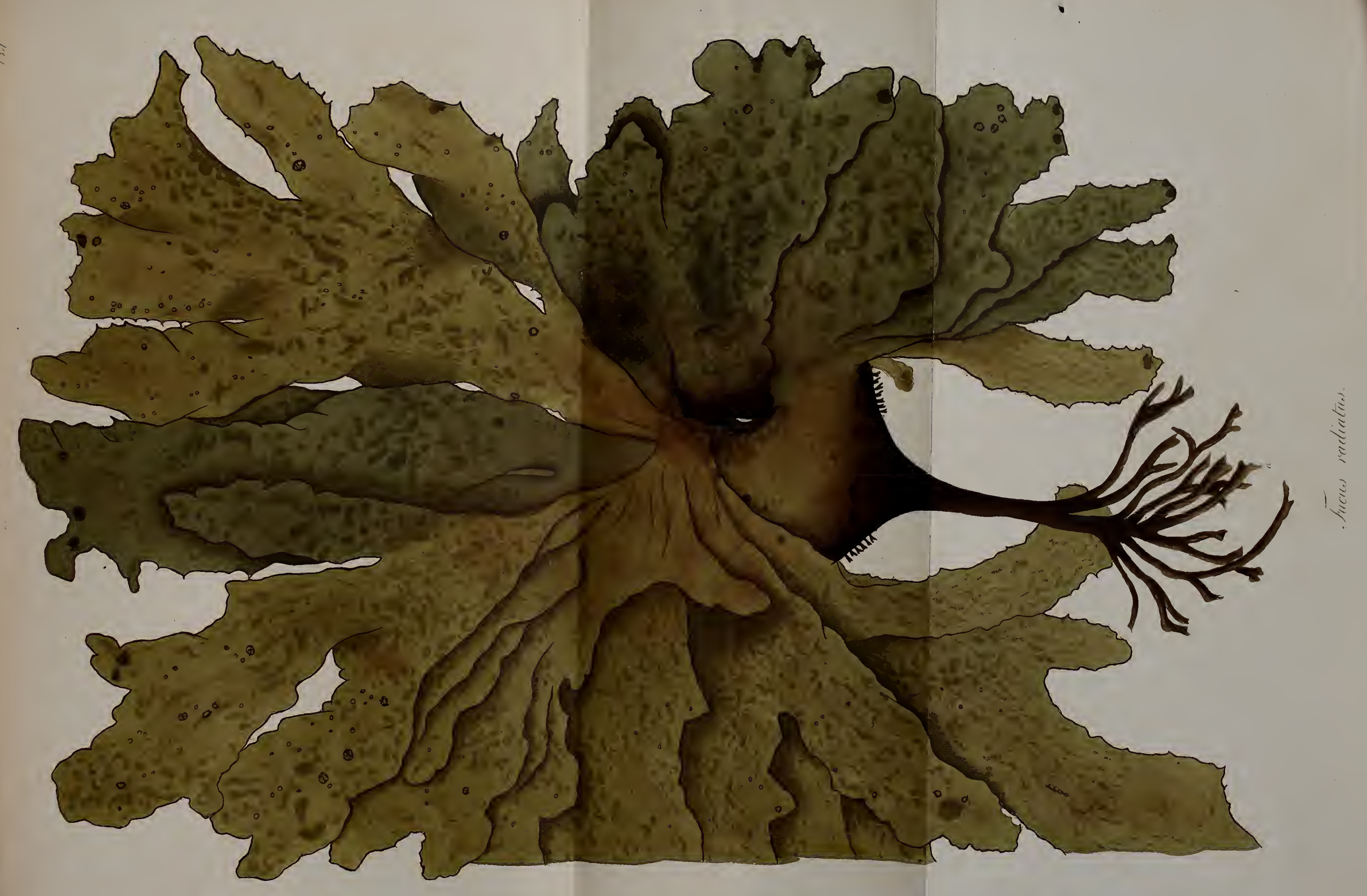





\section{N $\mathbf{D} \quad \mathrm{E} \quad \mathrm{X}$.}

The Names printed in Italics are Synonyms.

The first Number refers to the Plate, the second to the Page.

AL GA, sive Fucus 2uercus marina dictus. $\mathrm{BA}=$ STER. Ceramiantemo ramosissimo basso, \&c. Danat. Ceramium asparagoides. Rотн. :...... 101 C. Filum. Rotн. ............ 86

C. longissimum. Rотн. : ......... 84

C. longissimum. $\beta$. Rотн. ........... 84

C. scorpioides.' Rotн. . . . . . . . . 109

C. spermophorum. Rотн. .......... 76

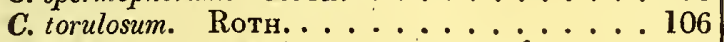

Conferva dichotoma. Fi. Dan. . . . . . . 84

Corallina lenta purpurea, \&c. $\mathrm{R}_{\mathrm{Ax}} . . . . . .106$

Frutices marini, \&c. SЕва. . . . . . . . 124

Fucoides erectum fruticuli specie. RaY. . . . 109

Fucus acicularis. Wulf. ......... 126

F. Agarum. Gmel. . . . . . . . . . . 75

F. albidus. Huds. ........... 84

F. albus. WULF. .......... 84

F. amphibius. Huds. . . . . . . . . . 109

F. angustifolius. Wıтн. .......... 88

F. articulatus. LIGHTF. . . . . . . . . 106

F. asparagoides. Woodw. ......... 101

F. bifidus. Huds. .................. 73

F. botryoides. WuLF. ........... 81

F. Brodiæi. Tunn. ............ 72

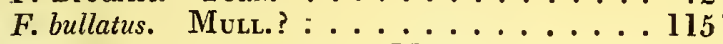

F. bullatus fruticescens, \&c. Mokss. . . . . 88

F. caspitosus. Sтаскн. . . . . . . . 107

F. capensis. GMEL. . . . . . . . . 124

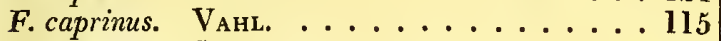

F. carnosus. Schmid. . . . . . . . 114

F. cartilagineus. Linn. . . . . . . . . . 124

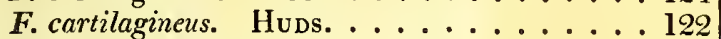

F. ceranoides, Llinn. .......... 89

F. ceranoides. Esp. ............. 88

F. ceranoides. \&. Huds. ........... 88

F. ceranoides. 8. LightF. ........... 74

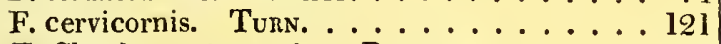

F. Chordam referens, \&c. RAY. ....... 86

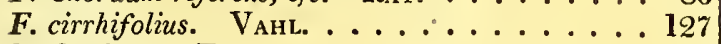

F. Clathrus Esp. ............ 75

F. conferroides Linn. .......... 84

F. confervoides. $\beta$. Syn. Fuc. . . . . . . 84

F. confervoides. $\gamma$. Syn. Fuc. . . . . . . 84

F. confervoides. 8. Syn. Fuc. ........ 84

F. confervoides. є. Syn. Fuc. . . . . . . . 84

F. Corallorhiza. Turn. ........... 96

F. cordatus. Tunn. ............. 116

F. coronopi fucie. RAY. . . . . . . . . 122

F. coronopifolius. Good. et Woodw. . . . . 122

F. crinitus. Gmet. . . . . . . . . 123

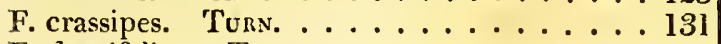

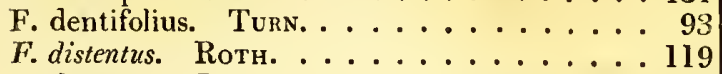

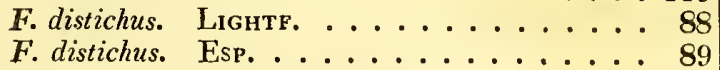

F. divaricatus. Lrns. . . . . . . . . . . 88

F. diversifolius. Tunn. . . . . . . . . 103

F. dulcis. GMEL. . . . . . . . . . . 115

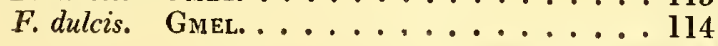

Page
F. edulis. Sт Aскн.

F. edulis. GMEL. .................... 118

F. esculentus. Linn. . . . . . . . . 117

F. filiformis. LaMaRK. . . . . . . . 86

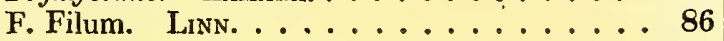

F. fimbriatus. Huds. ............ 74

F. fimbriatus. GMEL. . . . . . . . . . . 117

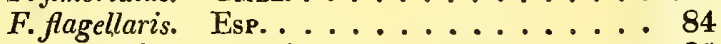

F. flagelliformis. $F l . D a n . \ldots \ldots . . . . .85$

F. foliaceus humilis palmam humanam referens.

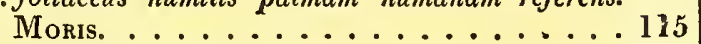

F. Forsteri. MERTEns . ........... 77

F. frutescens, folits angustis, \&c. Mins. . . . 74

F. gracilis. Sтаскн. ........... 84

F. hamulosus. Esp. ........... 79

F. herbaceus. Tuns. ........... 99

F. herbaceus. Huds. . . . . . . . . . 98

F. heterophyllus. Turs. .............. 92

F. inflatus. Linn. . . . . . . . . . . 88

F. Lactuca. Esp. . . . . . . . . . 114

F. latifolius. Turn. . . . . . . . . 94

F. lichenoides. Linn. . . . . . . . . 118

F. lichenoides. Desfont. . . . . . . 119

F. lichenoides. var. Gmé. .............. 118

F. ligulatus. LightF. ................ 98

F. linearifolius. TuRn, .................. 111

F. linearis. Huns...................... 88

F. longifolius. TunN. . . . . . . . . . 104

F. longifructus. DEcand. .......... 88

F. longissimus. WuLF. . . . . . . . . . 84

F. longissimus. GMEL. . . . . . . . . 84

F. mamillaris. EsP. ............ 88

F. marinus purpurascens, \&c. Ray....... 84

F. marinus vulgatissimus latifolius, \&c. Moris. 88

F. maritimus nodosus. Reaumur . . . . . . 91

F. maritimus vesiculis majoribus singularibus, \&c.

Moris. ..................... 91

F. membranaceus. Stackн. ........ 87

F. membranaceus ceranoides. $\mathrm{R}_{\mathrm{AY}} . \ldots \ldots \ldots 115$

F. membranifolius. Good. et Woodw_.... 74

F. membranifolius. Lamouroux ...... 72

F. membranifolius. $\beta$. Syn. Fuc. . . . . . . 74

F. membranifolius $\gamma$ Syn. Fuc. . . . . . . 74

F. membranifolius. $\gamma$. Linn. Trans. . . . . . . 74

F. membranifolius. ¿. Linn. Trans. . . . . . . 74

F. microceratius. Turs. ......... 130

F. mollis candicans, \&c. Reaumur ..... 81

F. muricatus. Turn. ............112

F. musciformis, Wulf. ............... 127

F. muscoides. Wulf. ..................... 100

F. myagroides. Turn. . . . . . . . . . 83

F. nodosus. Lins. .................. 91

F. nodosus. var. GMeL. ................ 91

F. nodosus. var. Esp. . . . . . ....... 91

F. nodosus. B. Syn. Fuc. .......... 91

F. nodosus. $\beta$. Rотн. ................. 91

F. nodosus. $\gamma$. Syn. Fuc.................. 91

F. Nootkanus. Esp. ................. 127

F. Opuntia. Good et Woodw. . . . . . . 107

F. Osmundaceus. Turn. ........... 105
Page

112

124

120

39

39
6

120

30

36

114

16

6

30

20

78

74

62

45

112

66

128

124

74

106

45
88

45

30

30

44

30

44
58

58

42

114

6

2

6

6

6.

$152^{\circ}$

108

146

80

28
58

58

53 
F. ovalis. Huds. . . . . . . . . . 81 Plate $^{\text {Page }}$

F. ovinus. Guns. ............ 115

F. palmaris latioribus foliis, \&c. MoRIs. . . . $88 \quad 45$

F. palmaris platyphyllus, \&c. Moris. . . . . 8845

F. palmatus. Lins. . . . . . . . . . 115114

F. palmatus. SтаскH. ......... 115

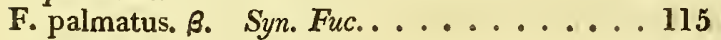

F. palmatus. $\beta$. LightF. . . . . . . . . . 114

F. Palmetta. Turn. . . . . . . . . . 73

F. Palmetta. Lamouroux . . . . . . . . 73

F. Palmetta. Fl. Dan. . . . . . . . 74

F. Palnetta. GMEL. . . . . . . . . . 74

F. Palmetta. var. B. Lamouroux. … . 73

F. Palmetta. var. C. Lanouroux. . . . . . 74

F. parvus cauliculis teretibus, \&c. Morss. . . 7 74

F. pinnatus. Guns. . . . . . . . 117

F. polypodioides. GMEL. . . . . . . . 81

F. polypodioides. Desfont. . . . . . . . 87

F. procerrimus. Esp. . . . . . . . . 84

F. pseudo-cerancides. GMEL. . . . . . . . 74

F. purpureus humilis tenuitèr divisus geniculatus. Moris.

F. pusillus. STACKH. $\ldots \ldots \ldots \ldots$

F. pyriferus. Lisn. . . . . . . . . . 110

F. 2uercus marina. GMEL. . . . . . . . 88

F. 2uercus marina. \&. GMEL. . . . . . . 88

F. 2uercus marina. ६. GMEL. . . . . . . . 88

F. 2uercus marina. n. GMEL. . . . . . . . 88

F. 2uercus marina. 9. GMEL. . . . . . . . 88 88

F. 2uercus marina. ‘. GMEL. . . . . . . . . 88

F. 2uercus marina herbacea et varietas. PARKINs. 89

F. radiatus. Turn. . . . . . . . . 134

F. reniformis. TuRn. . . . . . . . 113

F. repens, LightF. . . . . . . . 107

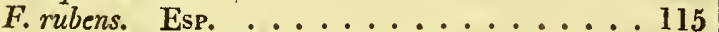

F. salicifolius. Esr. . . . . . . . . 104

F. scoparius. Turn. . . . . . . . . . 132

F. scorpioides. OEDER? . . . . . . . 84

F. scorpioides. GMeL. . . . . . . . . . . 109

F. Scoticus latissimus edulis dulcis. $\mathrm{R}_{\mathrm{AY}} \ldots \ldots 117$

F. Seaforthii. Turn. . . . . . . . . . . 120

F. sedoides. Good. et Woopw. . . . . . . .81

F. sericeus. var. Esp. . . . . . . . . 106

F. serratus. Lins. . . . . . . . . . . 90

F. serratus. $\beta$. Huds. . . . . . . . . . . 90

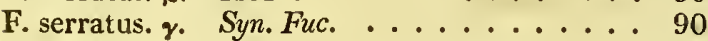

F. serrulatus. Forsk? . . . . . . . . . . 103

F. setaceus niger longissimus, \&c. Mor1s. . . . 86

F. seu 2uercus marina angustiore folio, \&c. MoRIs. 88

F. Sherardi. Sтаскн. . . . . . . . 88

F. siliquastrum. 'I'Urn. . . . . . . . 82

F. sisymbroides. Tunn. . . . . . . . . 129

F. sive Alga latifolia major dentata. Reaunur. 90

F. sive Alga lenta capillacea 8 c. Moris. . . 84

F. sive Alga marina latifolia vulgatissima. $R_{A Y} 88$

F. sive 2uercus marina minima angustifolia. Mo-

Ris. . . . . . . . . . . . . 88

F. spermophorus. Lins. . . . . . . . 76

F. spinulosus. Esp. . . . . . . . . 127

F. spiralis. Lens. . . . . . . . . . 88

F. spiralis. Esp. . . . . . . . . 88

F. spiralis. var. Eз3. . . . . . . . . 88

F. spiralis maritimus major. $\mathrm{R}_{\mathrm{AY}} \ldots \ldots . . .88$

\section{E X.}

\begin{tabular}{r|r} 
Piate & Page
\end{tabular}

F. spiralis maritimus minor. $\mathbf{R}_{\mathrm{AY}} \ldots \ldots \ldots .88 \quad 45$

F. squamulosus. Turn. . . . . . . . . . $128 \quad 148$

F. telephifolius. Turn. . . . . . . . . 956

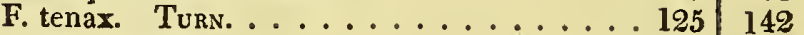

F. Tendo. Ess............ $86 \quad 39$

F. tenuissimus. Good. et Woodw. . . . . 10080

F. teres. Good. et Woodw. . . . . . . . 117

F. teres ramosissimus. REAUMUR $\ldots \ldots \ldots .840$

F. teres rubens minus ramosus. $\mathrm{R}_{\mathrm{AY}} \ldots \ldots \ldots .84$

F. tetragonus. Good. et Woodw. . . . . . 117 120

F. Thunbergii. Rотн ......... 133

* F. ulvoides. Turn. . . . . . . . . 80

F. undulatus. SтаскH. . . . . . . . 88

F. uniformis. Esp. ? . . . . . . . 84

F. ustulatus. MERTENs. . . . . . . 126144

F. uvarius. WULFEN. ........ $81{ }_{24}$

F. uvarius. Esp. . . . . . . . . . 81 24

F. Valentiæ. Tunn. .......... 78

F. vel Ulva filipendula. Schmid. . . . . I15 114

F. vermicularis. Gмец. . ... . . . . . . . 81 24

F. verrucosus. GMEL. . . . . . . . 84

F. verrucosus. Huds. . . . . . . . . 84

F. versicolor. GMEL. . . . . . . . . 124

F. vesiculosus. LinN. . . . . . . . . 8 8844

F. vesiculosus. WuLFEN. ........ $88 \quad 45$

F. vesiculosus. $\beta$. Syn. Fuc. . . . . . . . $88 \quad 45$

F. vesiculosus. $\beta$. Linn. Trans. . . . . . 88

F. vesiculosus. $\beta$. Sтаскн. . . . . . . . 8 $88 \quad 45$

F. vesiculosus. $\gamma$. Syn. Fuc. . . . . . . . 88

F. vesiculosus. $\gamma$. Huds. . . . . . . . 88

F. vesiculosus. $\%$. Rотн ......... 88

F. vesiculosus. $\%$. Limn. Trans. . . . . . . . . 8845

F. vesiculosus. 8. Linn. Trans. . . . . . . . 88 88

F. vesiculosus. d. Sym. Fuc. . . . . . . . 8845

F. vesiculosus. \&. Syn. Fuc. . . . . . . . $88{ }_{45}^{45}$

F. vesiculosus. є. Linn. Trans. . . . . . . 88 88

F. vesiculosus. $\zeta$ Linn. Trans. . . . . . 88 8845

F. vesiculosus. n. Syn. Fuc. . . . . . . 88 45

F. vesiculosus. 9. Syn. Fuc. . . . . . . . 88

F. vesiculosus. .. Syn: Fuc. . . . . . . . $88 \quad 45$

F. vesiculosi varietates. Esp. . . . . . . . 88 44

F. vindicatus cartilagineus. GunN. . . . . . 124138

F. viridis. Muller . . . . . . . . . 97 72

F. viscidus. Forsk. . . . . . . . . 119

F. volubilis. Huds. . . . . . . . $88{ }^{45}$

F. Wigghii. Tunn. . . . . . . . 1028

Opunzila di membrana finissima, \&c. GinaNN1. . $115 \quad 114$

2uercia marina che ha vesiche. Ginannı. . . . 8845

Quercia marina di foglie anguste e florida. G1-

NanN1 . . . . . . . . . . . . . . 88

2uercus marina humilis latifolia serrate similis.

$R_{a y} \ldots \ldots \ldots \ldots \ldots \ldots \ldots$

Rivularia Opuntia. Хммтн . . . . . . . 107

Tremella marina caspitosa, \&c. Dillen. . . . 107

Ulva articulata. Huds. . . . . . . . . 106

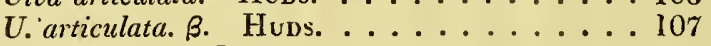

U. capillaris. Huds. . . . . . . . . 100

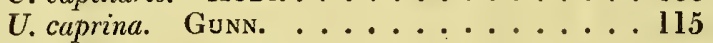

U. edulis. DECAND. . . . . . . . . 114

U. fliformis. Fl. Dan. . . . . . . . 108

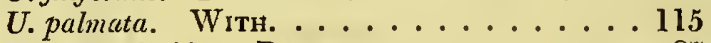

U. polypodioides. DECAND. . . . . . . 87

Virsoide con caule terete, \& $\&$. Donatı. . . . 88

\section{5}

54

96

96

94

96

80

114

100

$\mathrm{J} 14$

42

45

- This plant is by mistake included in the Index of the 1st volume. 





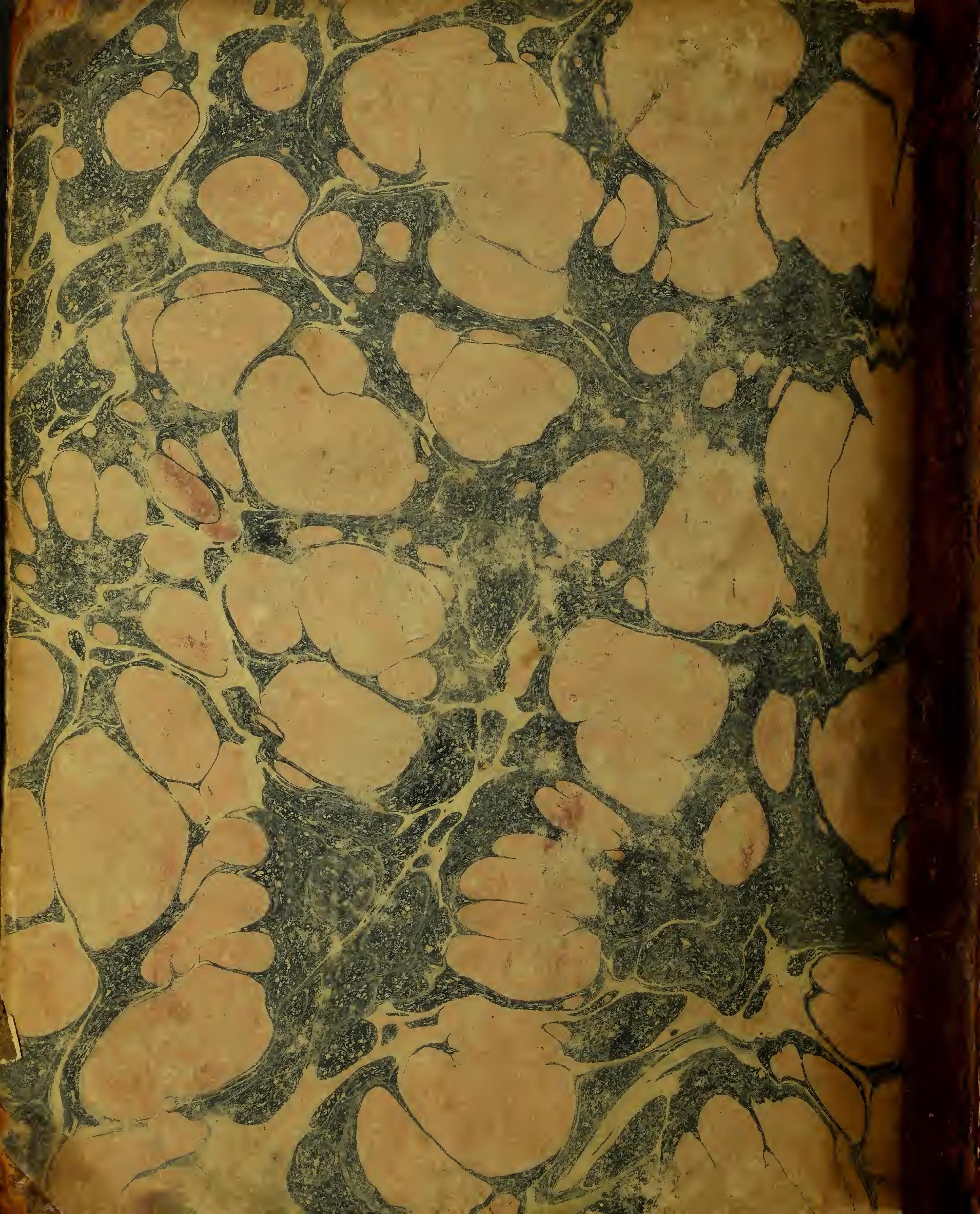

